\title{
CARACTERIZACIÓN DE LINAJES MATERNOS EN LA POBLACIÓN ACTUAL DEL NOROESTE Y CENTRO-OESTE ARGENTINOS
}

Josefina María Brenda Motti

2012

Director: Claudio M. Bravi

Co-Director: Graciela Bailliet

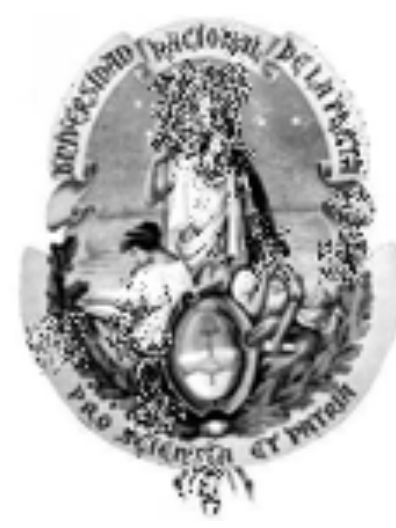

Universidad Nacional de La Plata

Facultad de Ciencias Naturales y Museo 
A mi linaje materno 


\section{AGRADECIMIENTOS}

A las autoridades del IMBICE que permitieron el desarrollo de este trabajo. A la Universidad Nacional de La Plata por mantener una educación pública y gratuita. A los encargados de generar las secuencias Michael Coble, Rebecca Just, Jodi Irwin, Jessica Saunier y Melissa Scheible.

Al personal de los hospitales y centros de salud donde fuimos a muestrear, no sólo colaboraron con nuestro trabajo, sino que realmente nos ofrecieron su hospitalidad, desde el punto de vista humano. Con el riesgo de olvidar algunos nombres, quiero recordar especialmente a Nicolasa, Marisa, Miguel, María José, a la Dra Lobos, Mario, Norma y Valeria. A quienes participaron de las campañas Virginia Ramallo, Marina Muzzio, Angelina García, María Emilia Pérez, Felicitas Fonseca, Mercedes Santos, Luciana Carreras, Cecilia Castro y Emma Alfaro. A Angélica Rave y Santiago Chiarullo que colaboraron con la digitalización de las encuestas genealógicas.

A mi papá que permaneció siempre con esa imagen de naturalista viajero decimonónico a quien todos llamaban —-eprofesor" y creo que heredé de él la curiosidad por ta ciencia". A mi mamá que introdujo un poco de historia entre tanta biología y me sembró las ganas de ir a estudiar a La Plata. A mi hermana que nos dio asilo en la pensión, sin una queja. A las tres tías Marisol, Lorena y Guadalupe que me ayudan a cuidar a Martina, si no fuera por ellas no habría podido ir a congresos ni cursos ni a dar clases.

A Marina que me abrió las puertas del IMBICE. A Graciela por interesarse siempre preguntando: - Y.. ¿Cómo vas?”, pregunta que da pie a contestar acerca de todo tipo de problemas: existenciales, familiares o académicos. A Claudio por permitirme compartir su pasión por los linajes mitocondriales americanos. A Virginia por haber hecho huella para los antropólogos en el IMBICE y por ser siempre el buen ejemplo a seguir, también por solucionar problemas inmobiliarios. A Rita, por compartir incertidumbres (no es fácil encontrar a alguien dispuesto a reconocerlas). A Laura por tener fe en mí. A Mariela, Julieta S, Julieta B, Marisol, Javier, Anita, Julia, Lorena, Cecilia, Luisina y Guillermina, por compartir mates y esta cosa de ser becario (mal de muchos...). A la gente del IMBICE.

A mis amigas platenses Mara, Felicitas, Silvina C, Silvina A, Analía, Jessi y Mariel por haberme acompañado en distintos momentos de la carrera y de la vida. A Feli también por ser mi compañera de oficina virtual. A mis amigos necochenses Itatí, Lorena, Belén, Richard, el Gato y Ximena por recordarme que hay vida fuera del mundo de la investigación. A quienes me recibieron académicamente en Necochea: Ricardo, Pamela y Nora.

A Pablo que permanentemente me alentó a seguir con la demoledora pregunta: -ysi no... ¿qué vas a hacer?” A Martu por ser mi compañera. 


\section{INDICE}

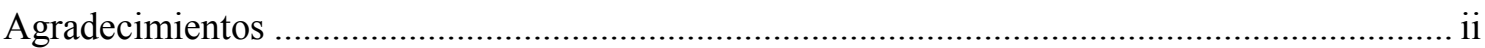

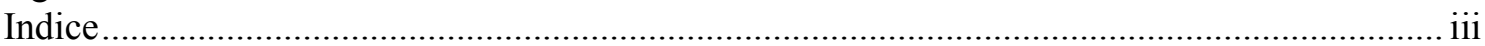

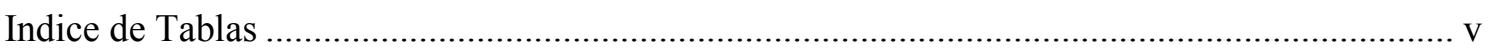

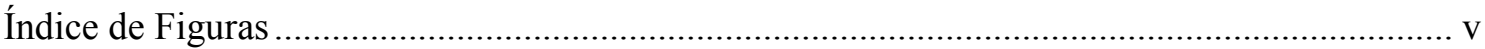

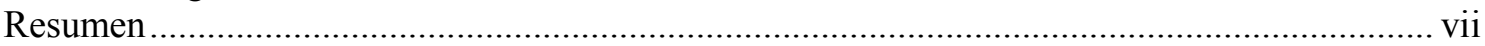

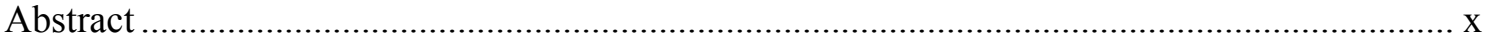

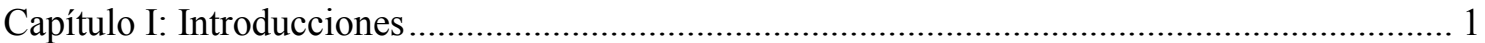

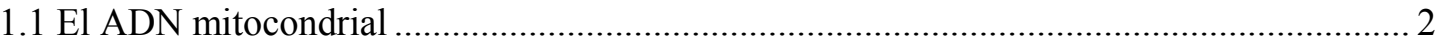

1.2 El uso del ADNmt en antropología ............................................................................ 7

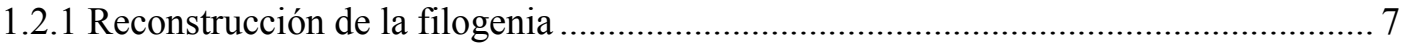

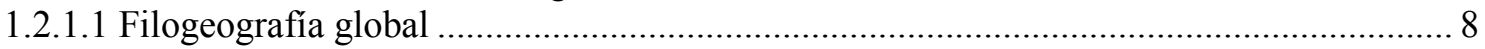

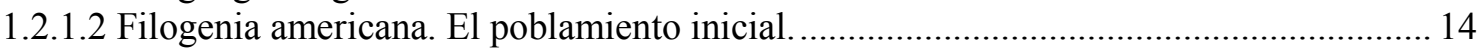

1.2.2 La población americana actual. ADNmt y mestizaje............................................... 15

1.3 Noroeste y Centro-oeste argentinos (NOA y COA), distintas miradas sobre el territorio 16

1.3.1 Doce mil años de ocupación humana. Apuntes desde la Arqueología........................ 16

1.3.2 El mosaico étnico del siglo XVI. Apuntes desde la Etnohistoria y la Lingüística ..... 22

1.3.3 Conflictos e identidades. Desde la conquista española a la conformación del Estado

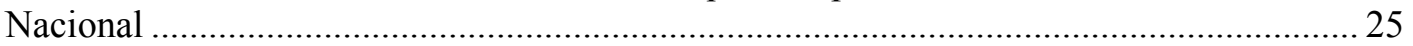

1.3.4 La sociedad argentina actual. Las desigualdades regionales.................................. 26

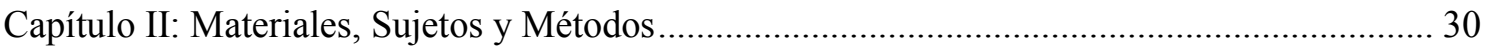

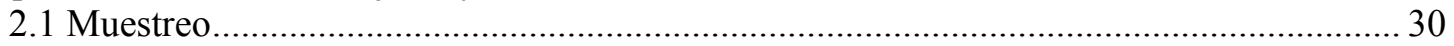

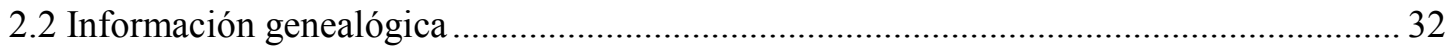

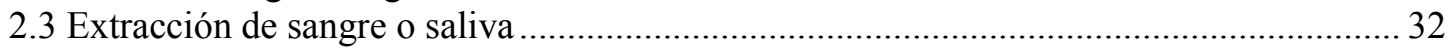

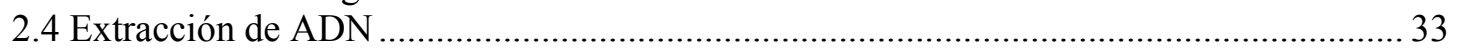

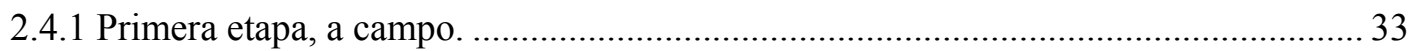

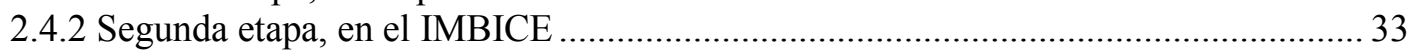

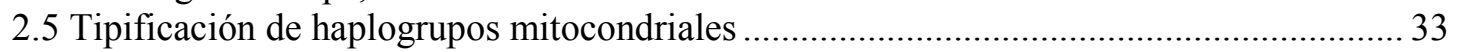

2.5.1 Tipificación mediante análisis de polimorfismos de longitud de los amplicones y de

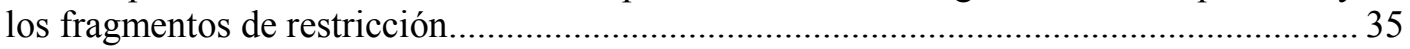

2.5.2 Tipificación mediante polimorfismos de longitud de los productos de amplificación

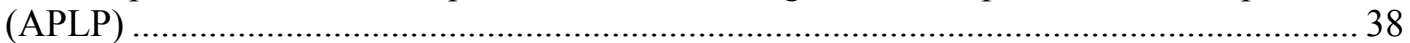

2.5.3 Asignación mediante secuenciación de la región control ....................................... 40

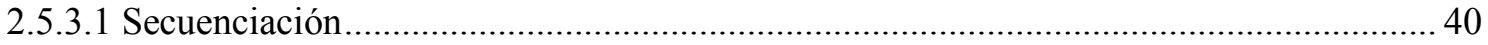

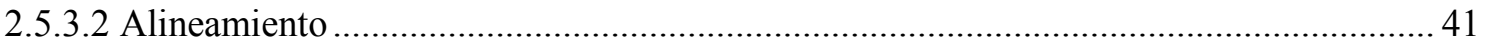

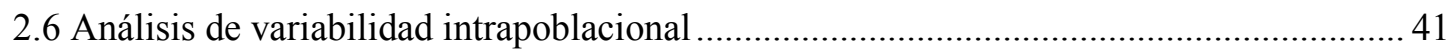

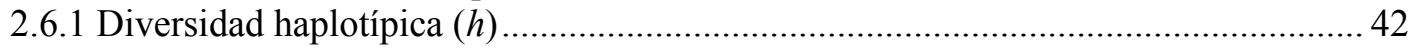

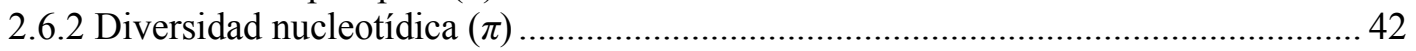

2.6.3 Número medio de diferencias nucleotídicas entre pares de haplotipos (Nei, 1987) 42

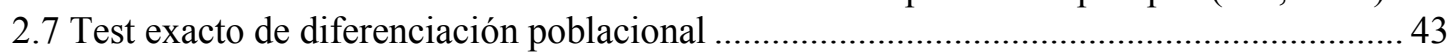

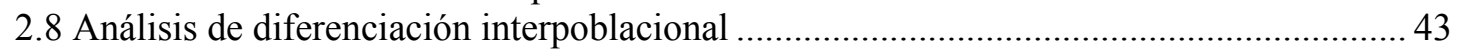

2.8.1 Construcción de hipótesis filogenéticas: definición de linajes................................. 43

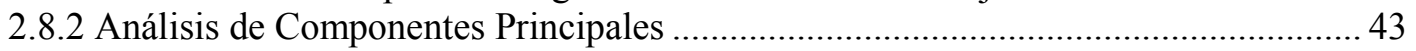

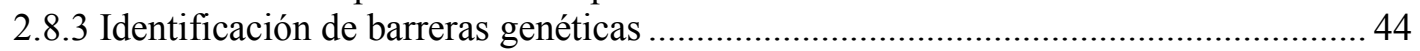

2.8.4 Análisis de distribución de linajes a nivel sudamericano ........................................... 44

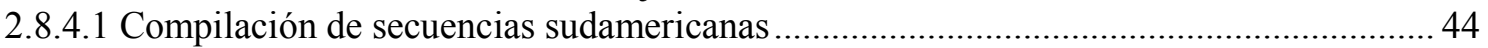

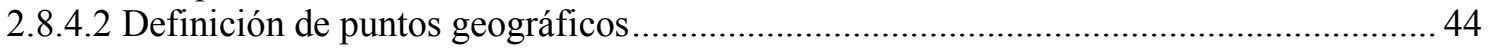

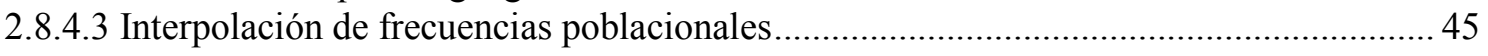

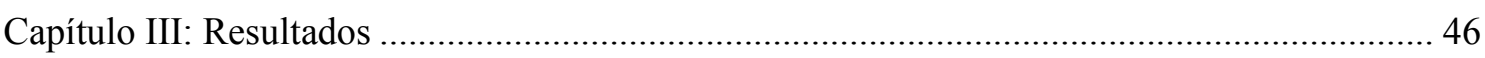

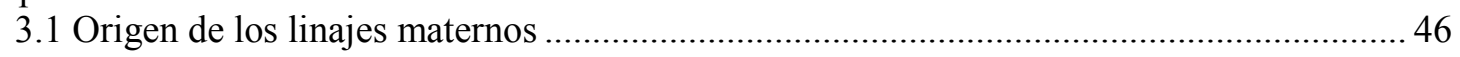




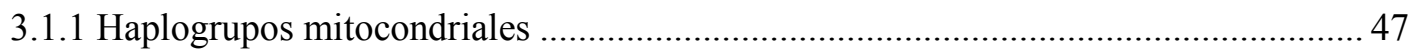

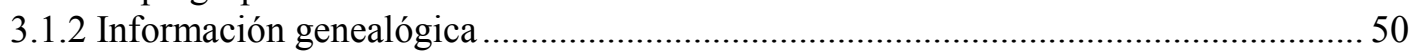

3.1.3 Correspondencia entre ambas fuentes de información.......................................... 53

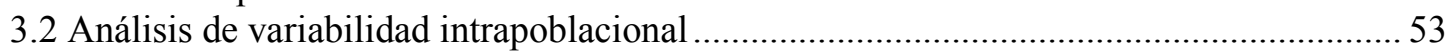

3.3 Distribución regional de los linajes maternos nativos ........................................................ 55

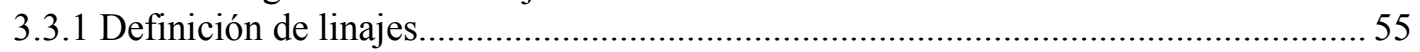

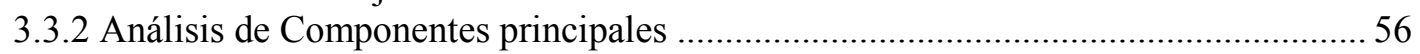

3.3.3 Identificación de barreras genéticas ........................................................................ 57

3.3.4 Análisis geográfico de la distribución de frecuencias de linajes ...............................58

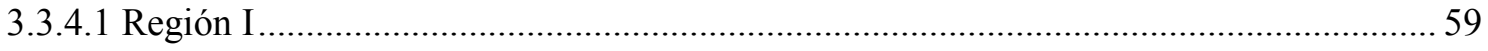

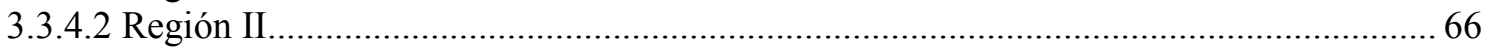

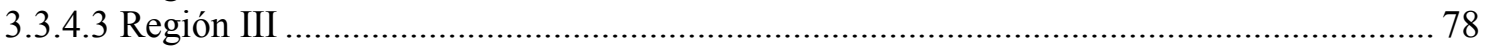

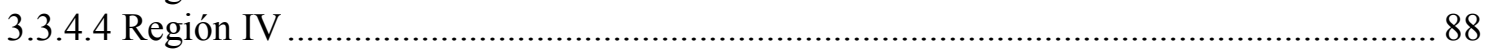

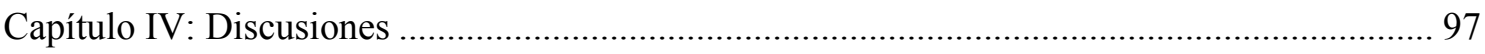

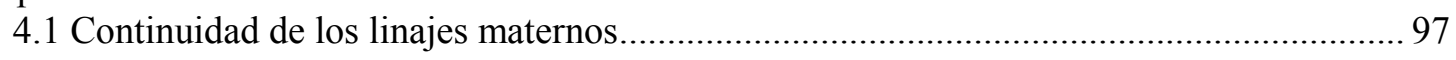

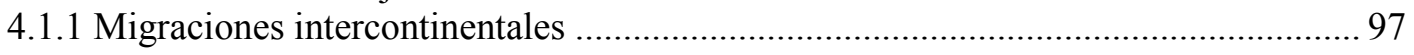

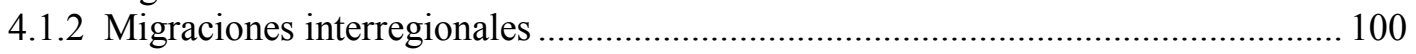

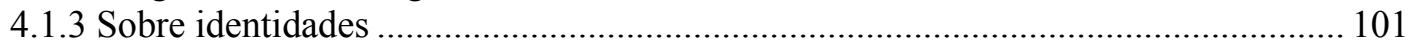

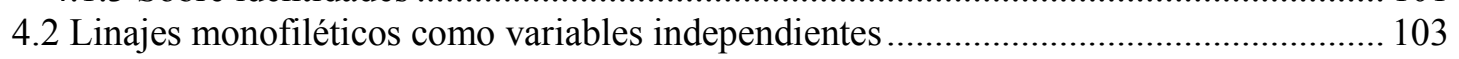

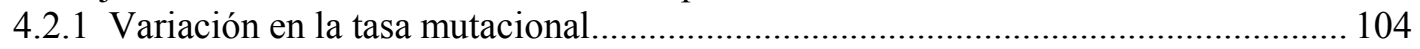

4.2.2 De cómo un único evento mutacional puede afectar a más de una base ................... 106

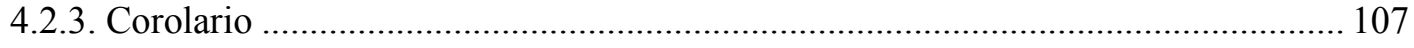

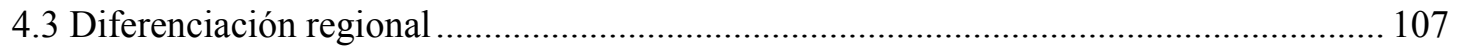

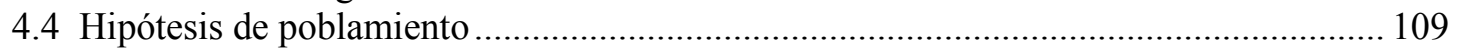

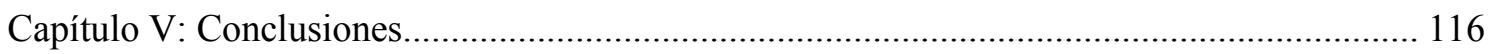

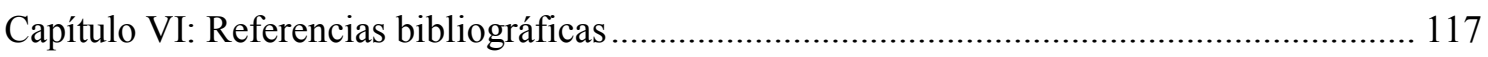

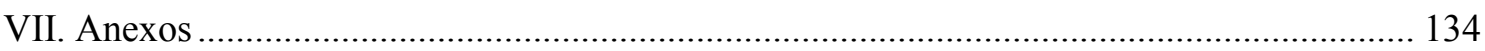

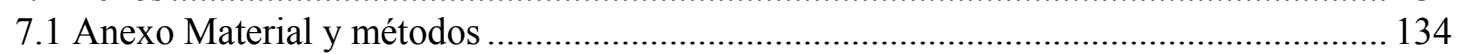

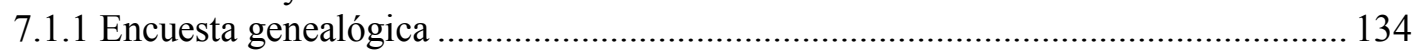

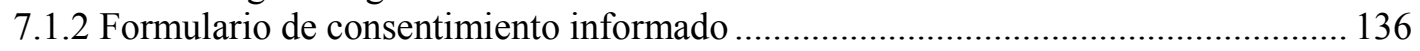

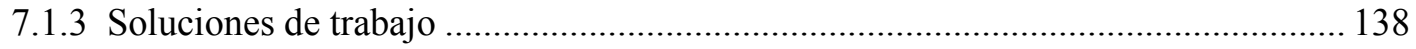

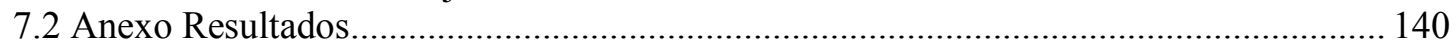

7.2.1 Lista de muestras por localidad, indicando el haplogrupo, el método de asignación y

el lugar de nacimiento del último ancestro materno conocido........................................ 140

7.2.2 Lista de muestras secuenciadas por localidad, indicando las mutaciones con respecto

a la Secuencia de Referencia de Cambridge (SRC revisada), el rango de lectura y la

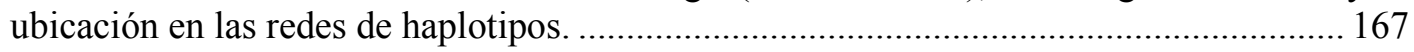

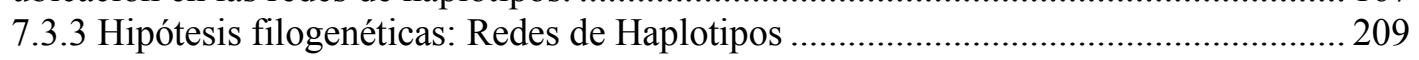

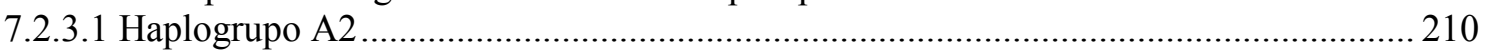

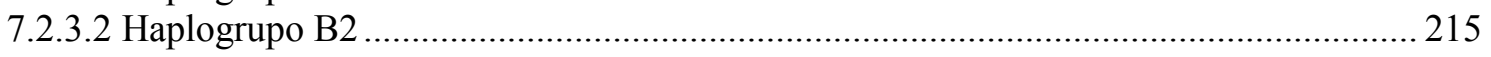

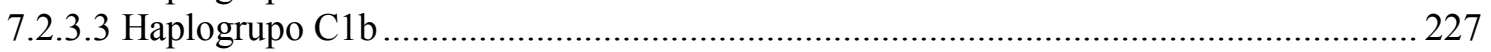

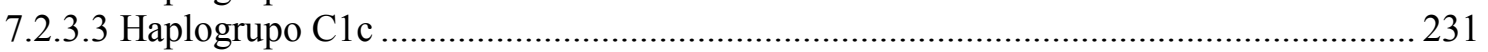

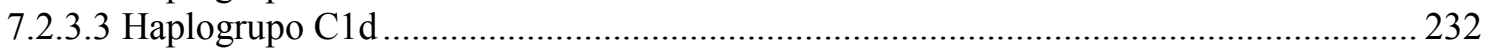

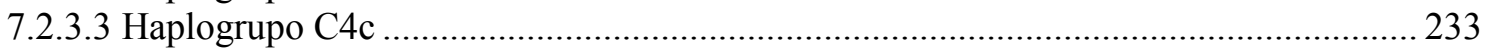

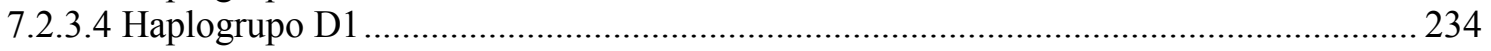

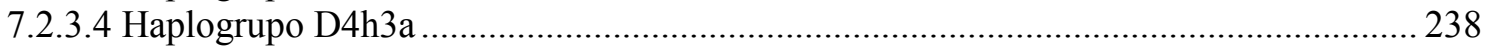

7.2.4. Frecuencia de clados por población. ...................................................................... 239

7.2.5 Puntos geográficos definidos para la interpolación de frecuencias de clados ........... 244

7.2.5.1 Puntos geográficos definidos para polimorfismos en la RHVI ....................................2. 244

7.2.5.2 Puntos geográficos para polimorfismos en la RHVI y RHVII ...................................... 252

7.2.5.3 Puntos geográficos para polimorfismos en la Región Control (por fuera de las RHVI y 
7.2.6 Frecuencias poblacionales utilizadas para confeccionar los mapas de distribución

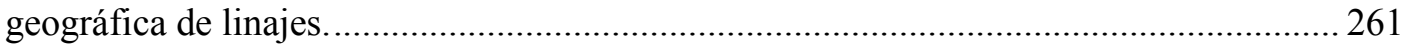

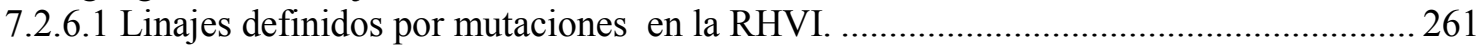

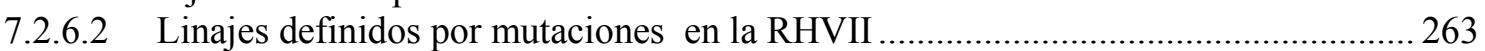

7.2.6.3 Linajes definidos por mutaciones en la Región Control (por fuera de las RHV I y II). 266

7.3 Lista de Abreviaturas 268

\section{INDICE DE TABLAS}

Tabla 1.1. Sitios arqueológicos tempranos de Argentina y áreas vecinas ..........................19

Tabla 1.2. Cantidad de habitantes por localidad, Censo Nacional de Población, INDEC 2001_.......27

Tabla 1.3. Composición de la población por provincia según lugar de nacimiento en $1914 \ldots \ldots \ldots \ldots .28$

Tabla 2.1. Localidades muestreadas, institución donde se realizó el muestreo y número de muestras..31

Tabla 2.2. Enzimas de restricción y polimorfismos utilizados para asignar el origen continental.......36

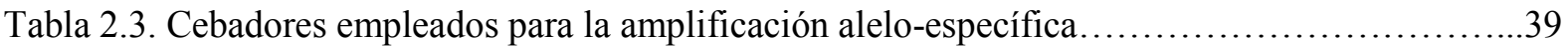

Tabla 2.4. Mutaciones de la Región Control asociadas a los haplogrupos americanos................40

Tabla 3.1. Origen continental de los haplogrupos mitocondriales, en porcentaje por localidad........47

Tabla 3.2. Test exacto de diferenciación poblacional entre pares de poblaciones.....................48

Tabla 3.3. Lugar de origen declarado del último ancestro conocido por vía materna, por localidad de

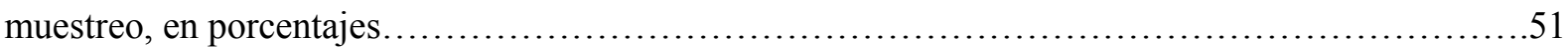

Tabla 3.4. Lugar de origen declarado del último ancestro conocido por vía paterna, por localidad de

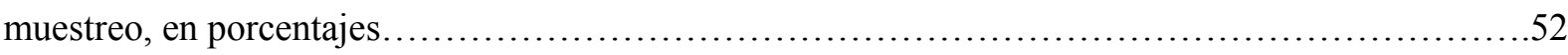

Tabla 3.5. Número de hombres cada 100 mujeres a través de los últimos 7 censos nacionales........52

Tabla 3.6. Medidas de diversidad intrapoblacional........................................... 54

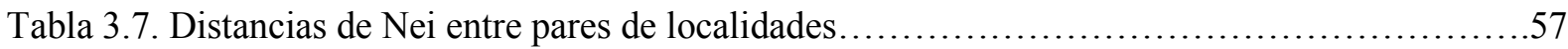

\section{ÍNDICE DE FIGURAS}

Figura 1.1. Árbol mitocondrial humano con énfasis en los linajes extra-africanos; reproducido de van

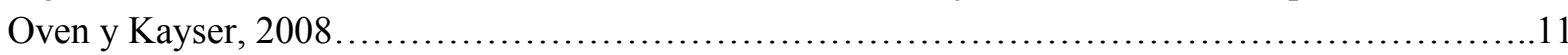

Figura 1.2. Árbol mitocondrial humano con énfasis en los linajes africanos; reproducido de Behar y col. 2008.

Figura 1.3. Árbol mitocondrial humano mostrando la distribución geográfica de los haplogrupos, reproducido de Olivieri y col. 2006........................................................... 13

Figura 1.4. Árbol mitocondrial de los haplogrupos americanos basado en Perego y col. 2010 .......15

Figura 1.5. Mapa con los sitios con fechados radiocarbónicos sin calibrar $>$ a 10.000 ap.............18

Figura 1.6. Mapa esquemático de las regiones fitogeográficas y los grupos indígenas del siglo XVI..25

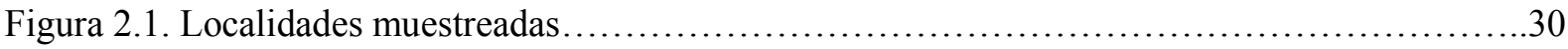

Figura 2.2. Visualización de los fragmentos co-amplificados para determinar los haplogrupos C y D.36

Figura 2.3. Visualización del fragmento amplificado para determinar el haplogrupo A..................36

Figura 2.4. Visualización del fragmento amplificado para detectar la deleción de $9 \mathrm{pb}$ en región $\mathrm{V}$

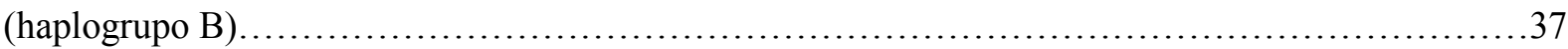

Figura 2.5. Visualización de los fragmentos resultantes luego de la digestión con AluI. ..............37

Figura 2.6. Visualización de los fragmentos resultantes luego de la digestión con HaeIII.................37

Figura 2.7. Co-amplificación alelo específica, indicando la determinación de haplogrupos.............39

Figura 3.1. Comparación de las localidades en base al porcentaje de linajes alóctonos................49 
Figura 3.2. Correlación entre la latitud y el porcentaje de haplogrupos $\mathrm{Nx}(\mathrm{A}, \mathrm{B}) \ldots \ldots \ldots \ldots \ldots \ldots \ldots . . . . . .49$

Figura 3.3. Correlación entre la latitud y el porcentaje de haplogrupos $\operatorname{Lx}(\mathrm{M}, \mathrm{N}) \ldots \ldots \ldots \ldots \ldots \ldots \ldots \ldots$

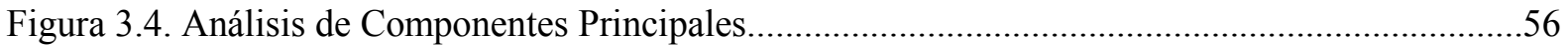

Figura 3.5. Barreras genéticas identificadas con el programa Barrier 2.2 .........................58

Figura 3.6. Regiones geográficas concordantes con los patrones de distribución de linajes............59

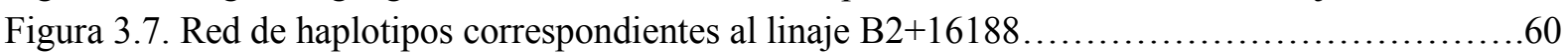

Figura 3.8. Distribución geográfica del linaje B2+16188......................................61

Figura 3.9. Distribución geográfica de linajes propios de la Región I (a-d) .......................63

Figura 3.10. Distribución geográfica de linajes propios de la Región I (e-h) ......................64

Figura 3.11. Distribución geográfica de linajes propios de la Región I (i-1) .........................65

Figura 3.12. Distribución geográfica del linaje D1+16293 ..................................66

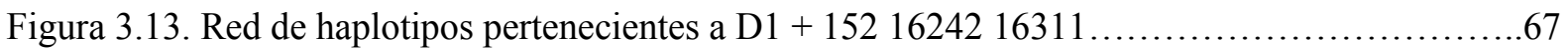

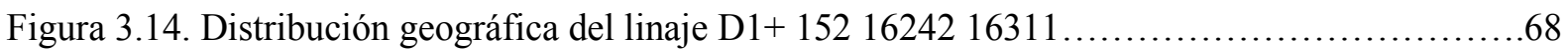

Figura 3.15. Distribución geográfica del linaje $\mathrm{C} 1 \mathrm{~b}+146$ y sus linajes derivados.....................70

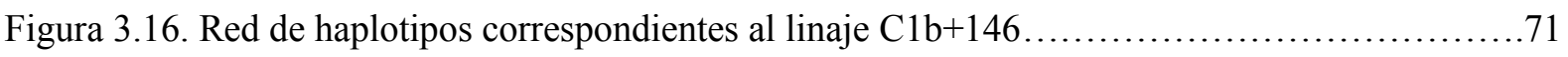

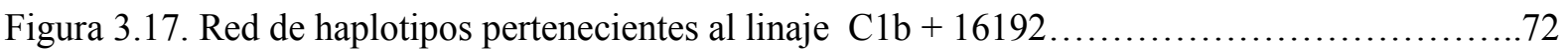

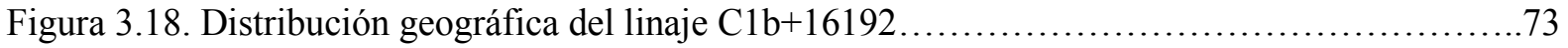

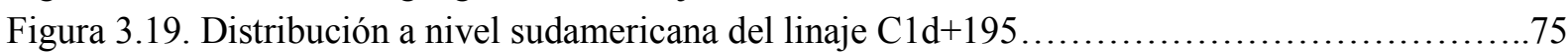

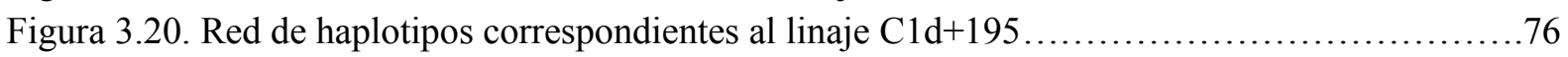

Figura 3.21. Distribución geográfica del linaje B2+16142 .................................. 77

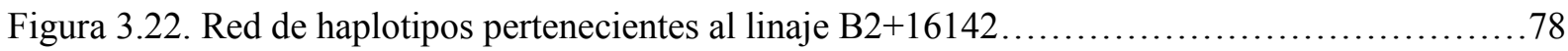

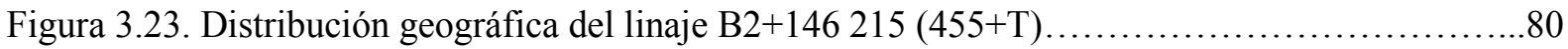

Figura 3.24. Red de haplotipos pertenecientes a B2 + 146215 455+T ............................ 81

Figura 3.25. Distribución geográfica de linajes con centro de distribución en la Región III (a-d).....82

Figura 3.26. Distribución geográfica de linajes propios de la Región III (a-d) ....................... 84

Figura 3.27. Distribución geográfica de linajes propios de la Región III (e-g).......................85

Figura 3.28. Distribución geográfica de linajes propios de Andes Centrales en la Región III...........86

Figura 3.29. Distribución geográfica de sub-linajes derivados de B2+103 (a-d) ....................87

Figura 3.30. Distribución geográfica de sub-linajes derivados de B2+103 (e-f)..................... 88

Figura 3.31. Red de haplotipos pertenecientes a A2+150 .................................... 89

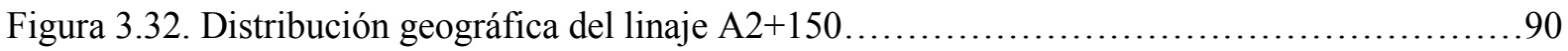

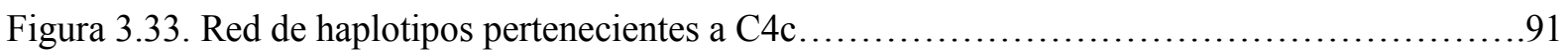

Figura 3.34. Distribución geográfica del linaje linajes C sin la mutación $16325 \ldots \ldots \ldots \ldots \ldots \ldots \ldots \ldots . . . . . . . . .92$

Figura 3.35. Distribución geográfica de linajes identificados en la región IV .......................93

Figura 3.36. Mapas de distribución geográfica de linajes patagónicos...............................95

Figura 3.37. Redes de haplotipos de los linajes propios de Patagonia.............................96

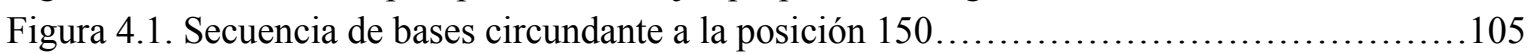

Figura 4.2. Estructuras I (izquierda) y J (derecha) identificadas por Pereira y col. (2008), indicando la

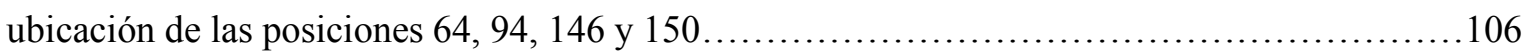

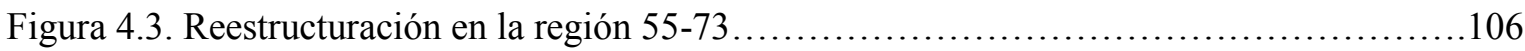

Figura 4.4. Modelo de poblamiento sudamericano propuesto en esta tesis. Se señalan los focos de poblamiento discutidos en el texto. 


\section{RESUMEN}

\section{Introducción y Objetivos}

El estudio de la variabilidad humana en América ha sido abordado aplicando técnicas de la antropometría, la lingüística, la etnografía y la historia. Otra técnica para evaluar similitudes y diferencias entre grupos humanos proviene de la biología molecular. El ADN mitocondrial (ADNmt) debido a su herencia exclusivamente materna no sufre recombinación y por ello permite la reconstrucción de filogenias a nivel subespecífico. Los estudios de ADNmt en poblaciones humanas han apoyado la hipótesis del origen africano de los humanos modernos y han contribuido a reconstruir las rutas migratorias de poblamiento.

Los datos referidos a América confirman el origen asiático de sus primeros pobladores y contribuyen a discutir el tiempo y modo de dispersión. Sin embargo en este continente, la población actual incluye no sólo a los descendientes de los primeros pobladores, sino también a quienes arribaron al continente como consecuencia del — dscubrimiento" por parte de marinos europeos. Además de conquistadores y colonos europeos, en América se introdujo una gran cantidad de población proveniente de África subsahareana, traída como mano de obra esclava. En algunos países como la Argentina, la composición de la población se vio fuertemente alterada por el impulso de la inmigración europea durante los siglos XIX y XX. En virtud del balance desigual entre migrantes varones y mujeres, tanto en tiempos coloniales como estatales, tuvo lugar un mestizaje de tipo sexoasimétrico entre mujeres locales y hombres foráneos, que resultó en la persistencia de linajes maternos nativos tanto en comunidades rurales como urbanas.

Teniendo en cuenta estos antecedentes, esta tesis tiene como objetivo determinar el origen continental de los linajes maternos de la población actual del Noroeste y Centro-Oeste de Argentina (NOA y COA) y analizar desde una perspectiva filogeográfica la distribución de aquellos propios de América, tanto al interior de la región analizada como en un contexto sudamericano.

\section{Material y Métodos}

Por medio de campañas de muestreo en distintos hospitales y centros de salud de las provincias de Mendoza, San Juan, La Rioja, Catamarca, Salta y Jujuy; se obtuvieron muestras biológicas acompañadas de información genealógica correspondientes a 1.787 individuos, quienes manifestaron su consentimiento por escrito. La información genealógica fue codificada para establecer el lugar de nacimiento del último ancestro por vía materna del que se tuviera conocimiento (UACM) y así diferenciar a aquellos individuos de origen -dcal" (UACM nacido en la misma provincia o en provincia limítrofe o en país limítrofe a la provincia), versus los de origen —ndocal" (UACM nacido en provincia no limítrofe o en país no limítrofe a la provincia). A partir de las muestras biológicas se extrajo el ADN y se determinó el origen continental a través de la tipificación de los clados $\mathrm{L}(\mathrm{xM}, \mathrm{N})$ propio de África subsahareana, N(xA,B) propio de Europa y Medio Oriente y ABCD americanos. La 
tipificación se realizó mediante análisis de polimorfismos de fragmentos de restricción o de amplificación, por amplificación alelo específica y/o por secuenciación de la Región Control (RC) completa. Con los datos de polimorfismos en RC, se construyeron manualmente redes de haplotipos por haplogrupo a modo de hipótesis filogenéticas. Se tuvieron en cuenta tanto criterios internos (consistencia geográfica, mayor parsimonia), como criterios externos (escala de sitios altamente variables, información publicada basada en secuencias completas). De esta manera se definieron clados o linajes potencialmente monofiléticos en base a la presencia compartida de mutacion(es) que se consideraron diagnósticas de ancestralidad común. Los análisis subsiguientes se basaron en la distribución de frecuencias de estos clados por localidad. Se realizó un Análisis de componentes Principales (ACP) y estimación de barreras para el flujo génico con el programa BARRIER 2.2, a partir de distancias de Nei entre pares de localidades y se diagramó el patrón geográfico de distribución de frecuencias de cada clado a nivel sudamericano teniendo en cuenta los datos generados en esta tesis y la compilación de más de 6.000 secuencias publicadas de haplotipos A-D. Para ello se hizo una interpolación de frecuencias con el algoritmo de krigin en el programa Surfer 8.0.

\section{Resultados}

En cuanto a la información molecular referida al origen continental, se comprobó que del total de las muestras, un $90 \%$ de los linajes maternos tiene un origen nativo americano, con un rango que va desde $71 \%$ para la ciudad de Mendoza, hasta $99 \%$ para Maimará. Los linajes africanos están mayormente representados en la ciudad de Mendoza con un 7\% y decrecen gradualmente hacia el norte. Del mismo modo, los linajes de Europa y Oriente Medio alcanzan su mayor frecuencia en la ciudad de Mendoza (21\%) y decrecen hacia el norte. Los datos referidos al lugar de nacimiento del UACM revelan que un $91 \%$ de los entrevistados tiene un origen tocal" en el sentido mencionado anteriormente; se observa a su vez la mayor presencia de linajes —a locales" en la ciudad de Mendoza $(28 \%)$. Estos datos son consistentes tanto con la información molecular como con los testimonios históricos que marcan a la capital mendocina como un polo atrayente de población. Ninguno de los entrevistados declaró tener un ancestro de origen africano, lo cual obedece a la profundidad temporal del arribo de africanos al continente, que escapa a los alcances de la memoria individual. La inmigración europea, por otra parte, tuvo lugar hace unas 3 o 4 generaciones atrás, por lo cual en la mayoría de los casos aún persiste un recuerdo fidedigno de la misma.

En conjunto, el ACP y las barreras genéticas identificadas, permiten definir cuatro regiones de acuerdo a la variabilidad mitocondrial presente. En primer lugar la Región I que comprende a las localidades de Maimará y La Quiaca, indicando una fuerte diferenciación respecto de las restantes localidades que conforman un segundo grupo, Región II. Esta última se caracteriza por ser el centro de distribución de al menos cuatro clados que alcanzan su mayor frecuencia a la altura de la provincia de La Rioja. La segunda barrera marca el límite de expansión de los linajes que tienen mayor frecuencia en la región circumpuneña, queda así definida la Región III, que incluye a la Región I y a un 
subconjunto de la Región II que comprende a las localidades de Tartagal, Jujuy, Santa María y Belén. Esta región se caracteriza también por la presencia de linajes propios de las tierras bajas (Chaco y Amazonía). La Región IV, al sur de la segunda barrera, está integrada por las localidades de las provincias de La Rioja, San Juan y Mendoza; la misma cuenta con algunos linajes propios, pero también marca el límite de la influencia de linajes propios de Patagonia.

\section{Discusión y Conclusiones}

El elevado porcentaje de linajes maternos nativos hallado en este trabajo puede estar relacionado con el tipo de muestreo que por realizarse en centros de salud y hospitales públicos, tiene un sesgo hacia los sectores de la población con menor poder adquisitivo que suelen estar asociados a un mayor componente de ancestría indígena. También se debe a la menor influencia de la inmigración transatlántica de los siglos XIX y XX que resultó en la preservación de una sociedad formada mayormente por descendientes de uniones entre hombres españoles y mujeres nativas. A pesar de la existencia de movimientos migratorios interregionales, la información genealógica recabada, permite manejar como hipótesis la persistencia de linajes nativos, no sólo a nivel continental sino también a nivel regional, justificando de este modo la aproximación metodológica aquí empleada que intenta analizar la distribución de linajes maternos nativos a partir del estudio de la población actual. Este análisis demostró que existe una estructuración regional de los linajes y que si bien en cada región existen múltiples linajes, producto de diferentes procesos de movilidad poblacional a lo largo del tiempo, es posible identificar linajes que por su frecuencia y variabilidad interna, podrían estar relacionados con momentos tempranos del poblamiento. 


\section{ABSTRACT}

\section{Introduction}

The study of human variability in America has been carried out using techniques from anthropometry, ethnography, linguistics and history. Another way to investigate similarities and differences between human groups comes from molecular biology. Mitochondrial DNA (mtDNA) has strictly maternal inheritance and so, it does not suffer recombination. This feature allows the reconstruction of intraspecific phylogenies. MtDNA studies in human populations have supported the African origin of modern humans and contributed to describe migratory routes.

American data upholds the Asian origin of first settlers and takes part in the debate about time and mode of dispersion. Nevertheless, the contemporary American population includes not only the descendants of first settlers, but also those who arrive after the European - dicovery". Conquerors and colonizers from Europe were not the only ones that arrived; also many sub- Saharan people were brought as slaves. In some countries like Argentina, the population composition was strongly altered by an ultramarine immigration of XIX and XX centuries. Due to the unequal sex distribution between immigrants, an asymmetrical miscegenation took place; it involved local women and foreign men. This results in the persistence of native maternal lineages in the extant populations.

In this context, the objective of this thesis consists in determining the continental origin of maternal lineages in the present population of Northwest and Center-West of Argentina (NWA and CWA). Then, the aim is to analyze the distribution of Native American lineages from a phylogeographical perspective.

\section{Materials and methods}

1.787 biological samples and genealogical information were collected in hospitals and sanitary centers in the provinces of Mendoza, San Juan, La Rioja, Catamarca, Salta and Jujuy. All donors gave their informed consent. Genealogical information was encoded to establish the place of birth of the last known maternal ancestor (LKMA). Two categories were generated -dcal" and fon local". The first included LKMA that were born in the same province, in an adjacent one or in an adjoining country. The second involved LKMA that were born in a distant province or in a non-adjacent country. DNA was extracted from biological samples and continental origin was estimated considering $L(x M, N)$ as indicator of African sub-Saharan origin; $\mathrm{N}(\mathrm{xA}, \mathrm{B})$ as indicator of West Eurasian origin and $\mathrm{ABCD}$ as indicator of Native American origin. Typing was made by Restriction Fragment Length Polymorphisms (RFLP), Amplification Fragment Length Polymorphisms (AFLP) and full Control Region (CR) sequencing. Phylogenetic networks were made by hand with sequence data of 1.108 individuals, using internal criteria (geographic support and most parsimonious) and external criteria (ranking of mutational hot spots in mtDNA and published information regarding full sequence). 
Potential monophyletic clusters or lineages were defined considering shared presence of mutation(s). Subsequent analyses were made taking into account the cluster frequency by locality. Principal Component Analysis (PCA) and identification of genetic barriers through BARRIER 2.2 software were performed. The geographical distribution of cluster frequency was drawn using our own data plus a compilation of more than 6.000 published sequences of A-D haplotypes applying the kriggin algorithm in Surfer 8.0 software.

\section{Results}

Regarding molecular data, $90 \%$ of samples have Native American origin from the maternal side. The range includes values between $71 \%$ for Mendoza city and $99 \%$ for Maimará. African lineages are most represented in Mendoza with a 7\% frequency and they decline gradually towards the North. In the same way, West Eurasian lineages reach its highest frequency in Mendoza (21\%) and diminish towards the North. Data concerning the place of birth of LKMA reveals that the $91 \%$ of interviewed have a tocal" origin. The largest presence of —noflocal lineages" takes place in Mendoza city $(28 \%)$. These numbers are consistent with molecular information and with historical data, which show Mendoza as an important pole of population attraction. None of the interviewed declared an African ancestry, in consistence with time depth of the slave trade in Argentina, nobody remember it. On the contrary, European migration took place three or four generations ago, so it is present in individual memory.

Together, PCA and genetic barriers allow the identification of four regions based in mitochondrial variability. Region I includes La Quiaca and Maimará, with strong differences regarding the remaining localities that conform a second group, Region II. This last one is the center of distribution of at least four clusters that reach their highest frequency in La Rioja province. The second barrier traces the limit of expansion of lineages that have their maximum frequencies around the Puna region, thus defining Region III, which comprises Region I and a subset of Region II including Tartagal, Jujuy, Santa María and Belén. In this region we found lineages typical from the lowlands (Chaco and Amazonia). Southern to the second barrier, the provinces of La Rioja, San Juan and Mendoza form Region IV. This final one has some distinctive lineages, but also consist the influence limit of Patagonian lineages.

\section{Discussion and conclusions}

The high percentage of native maternal lineages found in this study may be related to the sampling strategy conducted in health centers and public hospitals, bearing in mind that it is known that public services have a bias towards population sectors with lower purchasing power, which are usually associated with a higher Native American ancestry. Another factor involved is the lower influence in the NWA and CWA of transatlantic migration in the $19^{\text {th }}$ and $20^{\text {th }}$ centuries. Despite the existence of inter-regional migration, the data concerning genealogical information allows us to 
sustain the hypothesis of persistence of native lineages, not just at continental level but also at regional level, thus justifying the methodological approach used here. The analyses of lineage distribution have demonstrated that there is a geographical pattern of structuring. While in each region there are multiple lineages due to different processes of population mobility over time, it is possible to identify lineages related with the early settlement inferred by their frequency and internal variability. 


\section{CAPÍTULO I: INTRODUCCIONES}

Mucho de esta tesis trata sobre el ADN mitocondrial, de hecho, necesitamos conocer las características básicas de esta molécula, para comprender el método empleado y los resultados obtenidos. Sin embargo, los objetivos de la tesis no se limitan a alcanzar un mayor conocimiento acerca de la variabilidad de linajes maternos en el área, sino que pretende emplear las herramientas generadas, para abordar desde una nueva perspectiva, la historia poblacional de la región.

Para contar la historia de los pueblos, algunos estudian los restos materiales que sobrevivieron el paso del tiempo. Un resumen desde esta perspectiva puede encontrarse en la sección 1.3.1 Đoce mil años de ocupación humana. Apuntes desde la Arqueología”. Este enfoque nos ofrece la mayor profundidad temporal y constituye la única fuente de información de que disponemos acerca de los primeros 12.000 años de historia.

Recién con la llegada de los españoles, la introducción del lenguaje escrito nos ofrece otra perspectiva de estudio denominada etnohistoria. Sección 1.3.2 Đl mosaico étnico del siglo XVI. Apuntes desde la Etnohistoria y la Lingüística". Con la debilidad de mostrar sólo la mirada de los conquistadores, este enfoque es el primero en proporcionarnos nombres propios para estos pueblos y además se centra en un momento particularmente sensible de la historia de esta región: la irrupción incaica relativamente reciente y el profundo impacto provocado por la conquista y colonización europeas. De la mano de la capacidad de nombrar, surge la necesidad de clasificar. La lingüística nos ofrece un criterio independiente para agrupar a los pueblos de la región y establecer probables relaciones de ancestralidad común.

Por último, no por su proximidad temporal, se ha de negar la historia reciente de la región, los movimientos poblacionales no se congelaron en el siglo XVI y las desigualdades económicas regionales constituyen hoy el motor de migraciones cuya continuidad temporal genera efectos evidentes en la distribución de linajes maternos actuales. Estos aspectos serán tratados en las secciones 1.3.3 Conflictos e identidades. Desde la conquista española a la conformación del Estado Nacional” y 1.3.4 ta sociedad argentina actual. Las desigualdades regionales". 


\subsection{EL ADN MITOCONDRIAL}

Las mitocondrias son organelas intracelulares generadores de energía, llevan a cabo el proceso de fosforilación oxidativa que consiste en transformar la energía química potencial almacenada en las uniones covalentes de moléculas como la glucosa o ácidos grasos en energía química almacenada en las uniones covalentes entre fosfatos del trifosfato de adenosina (ATP). Según la teoría endosimbionte las mitocondrias fueron alguna vez organismos de vida independiente, ya que la célula eucariota evolucionó mediante un proceso de fagocitosis en el cual organismos de vida libre pasaron a vivir en forma simbionte en el interior del citoplasma de otra célula (Margulis, 1967). Una prueba de esta teoría es el hecho de que las mitocondrias portan su propio material genético y éste es de tipo procarionte. Se ha demostrado que las mitocondrias tienen afinidades genéticas con las proteobacterias, previamente llamadas bacterias purpúreas (Yang y col. 1985).

El ácido desoxirribonucleico mitocondrial (ADNmt) se presenta como una doble cadena circular cerrada. En el caso de Homo sapiens tiene una longitud de 16569 pares de bases (pb). Fue secuenciado en forma completa por primera vez en 1981 en la Universidad de Cambridge (Anderson y col. 1981), siendo ésta la secuencia de referencia, llamada Secuencia de Referencia de Cambridge (SRC). Posteriormente, en 1999 se publicó una revisión de dicha secuencia en donde se corrigen algunos errores (Andrews y col. 1999). Esta secuencia corregida recibe el nombre de SRC revisada ( $\mathrm{SRCr}$ ) y es por contraste con ella que se definen las mutaciones de las nuevas secuencias descriptas. Las dos cadenas que forman el ADNmt se distinguen por una asimetría en el contenido de las bases nitrogenadas Guanina $(\mathrm{G})$ y Citosina $(\mathrm{C})$, de modo que la cadena con mayor contenido de $\mathrm{G}$ tiene mayor peso molecular y recibe el nombre de cadena pesada o cadena $\mathrm{H}$ por la inicial de Heavy en inglés. La cadena complementaria, con mayor contenido de $\mathrm{C}$, se denomina cadena liviana o cadena $\mathrm{L}$ por la inicial de Light en inglés. En la publicación original de 1981, los autores argumentan que eligieron presentar la secuencia de la cadena L porque esta es la que expresa el sentido de la mayoría de los ARN, que son transcriptos con la cadena $\mathrm{H}$ como molde.

Como todo ADN bacteriano, el ADNmt carece de intrones, es decir que prácticamente todas las bases son codificantes, con sólo algunas bases intercaladas no codificantes. De los 16569 pb que componen el ADNmt, sólo un segmento continuo de gran tamaño (1121 pb), es no codificante; este segmento se extiende entre las posiciones 16024-16569 y 001-576 y se denomina Región Control (RC) porque contiene sitios de unión de factores codificados en el núcleo que regulan la expresión del ADNmt. Entre ellos se encuentran el origen de replicación de la cadena $\mathrm{H}(\mathrm{OH})$, sitios de iniciación de la transcripción y regiones promotoras.

Por las funciones metabólicas de la mitocondria, el ADNmt se encuentra en un medio rico en mutágenos. Ello, sumado a que como todo ADN procarionte carece de proteínas histonas asociadas y su enzima polimerasa no posee actividad reparadora de errores, resulta en una tasa de mutación que 
supera por varios órdenes de magnitud a la del ADN nuclear. Sin embargo, las tasas de mutación no son uniformes al interior de la molécula. Constricciones selectivas imponen una menor tasa de mutación en la región codificante con respecto a la $\mathrm{RC}$; y aún dentro de la $\mathrm{RC}$, existen zonas ampliamente conservadas y zonas con mayor tasa mutacional. Estas últimas reciben el nombre de Regiones Hipervariables (RHV) y son tres; la RHV I comprende los sitios entre las posiciones 16024 16365, la RHV II se expande entre las posiciones 73 y 340; y la RHV III entre 438 y 576. (Brandstätter y col. 2004).

Existe un gran debate en torno a la tasa de mutación del ADNmt. Una de las tasas más utilizadas es la de Mishmar y col. (2003) que tiene en cuenta sólo a la región codificante (entre 577 y 16023) y estiman una tasa de $1,26 \times 10^{-8}$ sustituciones de base por nucleótido por año, o sea una mutación cada 5137 años. El problema de esta tasa es que no tiene en cuenta a la RC, la cual, por acumular mayor cantidad de mutaciones, puede ser mucho más informativa; y tampoco tiene en cuenta la acción de la selección. Recordemos que el ADNmt codifica para 13 subunidades de la cadena de fosforilación oxidativa, $2 \mathrm{ARN}$ ribosómicos (ARNr) y $22 \mathrm{ARN}$ de transferencia (ARNt). Una prueba de la acción de la selección fue el descubrimiento de una mayor proporción de mutaciones no silenciosas en ciertas ramas del árbol mitocondrial. En un principio este patrón se planteó como evidencia de una posible adaptación a climas fríos, ya que estas mutaciones podrían estar asociadas al desacoplamiento de la formación de ATP durante la fosforilación oxidativa, lo cual genera calor (Mishmar y col. 2003). Posteriormente se demostró que la mayor proporción de mutaciones no silenciosas es una característica de las ramas más jóvenes del árbol, independientemente de cuál sea el clima de la región donde viven las poblaciones que las poseen (Kivisild y col. 2006). Este patrón indica la acción de la selección purificadora que ha tenido tiempo para actuar en las ramas más profundas del árbol, sobre mutaciones levemente deletéreas; o también puede deberse a una relajación de las presiones selectivas en tiempos recientes. Como consecuencia de ello, con una tasa de mutación lineal, la edad de los clados más jóvenes puede ser sobreestimada. Para corregir este defecto, Kivisild y col. (2006) proponen distintas tasas para distintos tipos de mutación, una para las transversiones sinónimas $\left(2,13 \times 10^{-9}\right)$, otra para las posiciones que codifican $\operatorname{ARNr}\left(4,13 \times 10^{-10}\right)$ y otra para las transiciones sinónimas $\left(3,53 \times 10^{-8}\right)$. Soares y col. (2009), en cambio, calcularon una tasa de mutación teniendo en cuenta a la molécula completa, tanto en su región codificante como no codificante y estiman una tasa de $1,665 \times 10^{-8}$ sustituciones de base por nucleótido por año, o sea una mutación cada 3624 años. Luego realizan una corrección temporal, para adaptar el reloj molecular a cualquier profundidad temporal, al suplantar la diversidad total observada, por una diversidad teórica calculada mediante la remoción de los linajes portadores de mutaciones deletéreas que serían eliminados por acción de la selección purificadora. Para la RC la tasa estimada por Soares y col. es de $9,883 \times 10^{-8}$ sustituciones de base por nucleótido por año, o sea una mutación cada 9058 años. 
Por otra parte, las estimaciones basadas en estudios familiares de eventos de trasmisión madrehijo, estiman tasas de mutación que superan por un orden de magnitud a las propuestas mediante una aproximación filogenética. El trabajo pionero en estimar la tasa mutacional mediante el método genealógico fue el de Howell y col. (1996). Posteriormente, en 2003 el mismo grupo calcula una tasa de mutación para la $\mathrm{RC}$ de $4,75 \times 10^{-6}$ por sitio por año, lo que equivale a una mutación cada 1980 años (Howell y col. 2003). Según estos autores la disparidad entre las tasas mutacionales calculadas por el método filogenético y el genealógico no puede explicarse por un único factor, sino que se debe a la presencia de sitios altamente variables, al efecto de la deriva, de la selección y a la imposibilidad de detección de las mutaciones recurrentes en los estudios filogenéticos. Según Macaulay y col. (1997), debido a que un número significativo de las mutaciones observadas en estudios genealógicos han surgido recientemente y probablemente no lleguen a fijarse, la tasa filogenética (que contempla a las mutaciones que han alcanzado una frecuencia apreciable a nivel poblacional) es preferible para estudios de gran profundidad temporal, mientras que sería recomendable usar la tasa estimada mediante el método genealógico para estudios de fenómenos más próximos a nivel temporal. Svante Paäbo (1996) también sostiene el mismo argumento y señala que las mutaciones detectadas en estudios genealógicos son las que presentan una tasa mutacional sumamente elevada y por tanto no puede extrapolarse la tasa calculada en base a ellas para todo el genoma mitocondrial.

Recién en 2005, Santos y col. realizan un estudio de aproximación genealógica donde por primera vez se incluye una corrección por sexo, por la obvia razón de que las nuevas mutaciones cuyos portadores sean del sexo masculino tienen una probabilidad de fijación nula, ya que no serán trasmitidas a la descendencia. También corrigen la tasa mutacional en función de la probabilidad de fijación intra-individual, ya que las nuevas mutaciones detectadas están presentes sólo en un porcentaje del total de las mitocondrias del individuo y la probabilidad de que sean trasmitidas a la descendencia depende de su frecuencia inicial. Con estas correcciones, la tasa mutacional estimada para las RHV I y II es de 2,415 x 10 ${ }^{-7}$, equivalente a una mutación cada 6593 años en esas regiones. Este valor, cae dentro del rango contemplado por las estimaciones mediante el método filogenético y de esta manera se comprueba empíricamente la posibilidad de una reconciliación entre ambos métodos de estimación de tasas mutacionales.

Todo lo expuesto indica que existe una gran variabilidad entre sitios en cuanto a la tasa de mutación. Ya en 1991, Kocher y Wilson demostraron que la distribución del número de sustituciones por sitio no se ajusta a una distribución de Poisson sino a una distribución binomial negativa. Ésta se genera cuando el parámetro $\lambda$ de la distribución de Poisson varía de acuerdo a una distribución gamma. Para establecer esta distribución gamma es necesario definir el parámetro $\alpha$. Cuanto menor es $\alpha$, mayor es la variabilidad de la tasa mutacional entre sitios. Aris-Brosou y Excoffier (1996) consideran que un valor de $\alpha=0,4$ equivale a decir que 200 de 300 loci tienen igual probabilidad de sufrir una mutación; mientras que con un valor de $\alpha=0,1$ la cantidad de loci potencialmente variables 
se reduce a 100 y con $\alpha=0,01$, el número es de 20 . En ese trabajo concluyen que la variabilidad intersitio en cuanto a la tasa de mutación es mayor en la RHV II que en la RHV I. Al mismo resultado llegan Meyer y col. (1999), quienes definen un $\alpha=0,26$ para la RHV I y este es el valor más usado en la actualidad. En tanto que para la RHV II es de $\alpha=0,13$.

Diversas causas explican la disparidad inter-sitio en cuanto a la tasa mutacional; por un lado, las transiciones son más frecuentes que las transversiones y dentro de las transiciones, son más frecuentes las que involucran a pirimidinas que las correspondientes a purinas (Tamura y Nei, 1993). Pero más allá de estas tendencias, existen posiciones denominadas hotspots (puntos calientes) que exhiben una tasa mutacional excepcionalmente alta. De acuerdo a Soares y col. (2009), por ejemplo, las diez primeras posiciones son ocupadas por las bases 16519, 152, 16311, 146, 195, 16189, 16129, 16093, 16362 y 150. Algunas de estos puntos calientes pueden explicarse por la secuencia de bases que flanquean a la posición en cuestión, por ejemplo, la transición en la posición 16189, constituye un cambio de Timina (T) por $\mathrm{C}$ en medio de una secuencia de nueve $\mathrm{C}$. En ocasiones, la presencia de una mutación trae aparejada otra, como en el caso de la transición ya mencionada en la posición $\mathrm{C}$, que suele estar asociada a una transversión en la posición 16183, generando una $\mathrm{C}$ adicional en el homopolímero. Estos cambios están asociados a una mayor tasa de error de la ADN polimerasa en regiones con homopolímeros. Así como también son comunes las mutaciones de tipo indels (deleciones o inserciones) en los homopolímeros y en regiones denominadas microsatélites, que consisten en la repetición sucesiva de dos o más pares de bases. En la RC, éstas ocurren en torno a las posiciones 16193, 310, 523 y 573. Ante este panorama, resulta difícil de aceptar una tasa de mutación uniforme para la RC.

Análisis de mutaciones en tumores y del daño en el ADN que se observa en muestras antiguas, también apuntan a los mismos sitios como los más propensos a sufrir mutaciones (Stoneking, 2000, Gilbert y col. 2003), indicando que los hotspots podrían ser hipermutables debido a una mayor exposición al daño. Siguiendo esta línea de razonamiento, Pereira y col. (2008) proponen que la mayor propensión al cambio que sufren algunos sitios estaría determinada por la formación de estructuras secundarias intracatenarias que tendrían oportunidad de generarse por el retardo en el inicio de la replicación de la cadena liviana. Mediante simulaciones informáticas, identificaron trece estructuras secundarias con posibilidad de formarse en la Región Control. Para ocho de ellas encuentran que son más frecuentes las mutaciones en las bases no apareadas, que en las que forman el tallo de la estructura. Respecto de la estructura formada por las bases comprendidas entre las posiciones 1602816120 presentan también evidencia de la acción de la selección positiva ya que al comparar la RC humana con secuencias de Pan troglodytes y Pan pygmaeus detectan la ocurrencia de mutaciones compensatorias en el tallo.

Más allá de las discusiones en torno a la tasa de mutación, el ADNmt presenta claras ventajas a la hora de encarar un estudio filogenético. Por empezar, existen muchas copias de ADNmt en las 
células humanas mientras que sólo existen dos copias de cada gen o segmento de ADN nuclear, pueden encontrarse cientos de copias de ADNmt ya que cada célula, dependiendo del tipo, puede contener desde una a cientos de mitocondrias y a su vez cada mitocondria contiene varias copias de ADN. Esta propiedad constituye una ventaja en cuanto a la extracción del ADNmt, pudiéndose recobrar muestras incluso en restos antiguos o degradados. Por eso el ADNmt es el marcador elegido en estudios paleontológicos, arqueológicos y forenses.

No necesariamente todas las copias de ADNmt que porta un individuo son idénticas. La existencia de distintos tipos de ADNmt en un mismo individuo se llama heteroplasmia. La frecuencia observada de heteroplasmia en humanos depende del nivel de sensibilidad con que se mida. Las estimaciones iniciales indicaban poca o ninguna heteroplasmia porque se basaban en métodos poco sensibles. Actualmente se estima que aproximadamente un $14 \%$ de la población tiene un segundo tipo de ADNmt presente en una frecuencia de al menos 1\% (Tully y col. 2000). Sin embargo, la homogeneidad general del ADNmt a nivel individual indica que en estadios tempranos de la ovogénesis existe un cuello de botella que reduce el número de mitocondrias. En la práctica la existencia en bajísimas proporciones de un segundo tipo de ADNmt no resulta en un problema metodológico en el campo de la antropología molecular, ya que pocas veces es detectado. Y cuando sí lo es, se reporta como una ambigüedad en un sitio, lo cual en general no afecta la asignación a un determinado linaje. La heteroplasmia puede sí tener otras implicancias en el campo forense (Ivanov y col. 1996).

Aunque la herencia paterna del ADNmt ocurre en mejillones y ha sido reportada en híbridos de Drosophila, ratones y aves, no es un fenómeno común en humanos. Existe un único reporte de un hombre con una patología causante de severa intolerancia al ejercicio, cuyo ADNmt muscular resultó ser principalmente de herencia paterna (Schwartz y Vissing, 2002). Posteriores investigaciones en otros pacientes con miopatías mitocondriales, no pudieron en demostrar nuevos casos de trasmisión paterna. Se ha demostrado además que en el ovocito, las mitocondrias del espermatozoide son destruidas y el ADNmt paterno es marcado por la ubiquitina para su destrucción (Sutovsky y col. 1999). De modo que la trasmisión paterna puede considerarse un fenómeno extremadamente raro, y es poco probable que haya contribuido al acervo genético mitocondrial actual.

El modo uniparental de trasmisión es una de las grandes ventajas del ADNmt ya que ante la ausencia de recombinación, las diferencias entre secuencias pueden ser atribuidas sólo al efecto de la mutación. Asumiendo un carácter homólogo para estas mutaciones, pueden reconstruirse filogenias: árboles evolutivos donde los individuos y no las especies son las unidades taxonómicas operativas. Esto permite trabajar a nivel intraespecífico sin la necesidad de definir poblaciones a priori. 


\subsection{El uso DEL ADNMT EN ANTROPOLOGÍA}

\subsubsection{RECONSTRUCCIÓN DE LA FILOGENIA}

A pesar del rechazo posmoderno a las tipologías, clasificar y nombrar ha sido desde el comienzo una de las actividades principales del quehacer científico. Para poder explicar los fenómenos del mundo que nos rodea, un primer paso consiste en desarrollar términos para nombrarlo y clasificarlo. Más allá de las clasificaciones intuitivas, basadas en agrupar lo semejante, existen métodos sistemáticos para construir conjuntos jerárquicos sustentados por una teoría. El método más difundido es el de la sistemática filogenética o cladística que tiene la virtud de que las agrupaciones jerárquicas construidas se fundan en una hipótesis evolutiva, ya que los grupos se definen por la presencia de caracteres compartidos que han sido heredados de un ancestro común. El entomólogo alemán Willi Hennig fue quien expuso con claridad los principios de la sistemática filogenética (Hennig, 1968). Uno de los principios rectores es el de la parsimonia, según el cual, ante dos modelos explicativos alternativos igualmente aceptables, se recomienda optar por el que requiera menor número de supuestos. En el caso de las reconstrucciones filogenéticas, el desafío consiste en minimizar los cambios o número de pasos necesarios para lograr la transformación de un estado al siguiente. Si se considera a cada cambio como una hipótesis de que ese cambio efectivamente ocurrió, el modelo más adecuado será aquel que requiera menor número de hipótesis ad-hoc.

El principio de parsimonia es el más simple y permite dirimir entre diferentes hipótesis propuestas, sin embargo, existe la posibilidad de que la ocurrencia de un tipo de cambio sea mucho más probable que la de otro. Por ejemplo, en el caso de las mutaciones en el ADN, son más probables las transiciones que las transversiones. Cuando esto ocurre, resulta más apropiado el método de Máxima Verosimilitud (Maximun Likelihood) que no sólo cuenta el número de pasos sino que estima la probabilidad de ocurrencia de cada uno de ellos. Este método tiene el inconveniente de que es necesario un conocimiento previo e independiente del fenómeno en estudio y muchas veces surge disparidad de criterios entre investigadores, generándose debates en torno a cuál es el evento más probable.

Tradicionalmente la sistemática filogenética ha sido aplicada en niveles supra-específicos, ya que por debajo del nivel de especie, las relaciones de reproducción entre los individuos producen un patrón reticulado o red de linajes anastomosados, en vez de un patrón jerárquico ramificado. Sin embargo, en caracteres con herencia uniparental, la ausencia de recombinación permite la aplicación de los principios de la sistemática filogenética a nivel infra-específico.

En el caso del ADNmt, los caracteres a comparar son las bases nitrogenadas que por su repetición sucesiva determinan una secuencia. Como ya se dijo anteriormente, cada individuo posee una única versión de esta secuencia, heredada únicamente por vía materna y por lo tanto en condición 
haploide. Por eso una determinada secuencia de bases recibe el nombre de haplotipo. Un haplotipo puede diferenciarse de otro por una sola base que equivale a un evento mutacional, o por muchos de ellos. La tarea en la reconstrucción de la filogenia consiste en agrupar los haplotipos más parecidos, y por ello más cercanamente emparentados. Un conjunto de haplotipos que comparten una serie de mutaciones que habrían estado presentes en un ancestro común se denomina haplogrupo. Los haplogrupos se nombran con letras mayúsculas del alfabeto latino o mediante la combinación de letras y números.

\subsubsection{Filogeografía global}

La reconstrucción de la filogenia del ADNmt a nivel mundial ha estado regida por el principio de prioridad, es decir que los nombres que se asignaron a los haplogrupos no se corresponden con un orden lógico o con una organización jerárquica sino que han sido otorgados a medida que fueron descriptos. Los haplogrupos americanos, por ejemplo recibieron las cuatro primeras letras A-D (Torroni y col, 1993), a pesar de que investigaciones posteriores determinaron que los dos primeros forman parte de un conjunto mayor o súperhaplogrupo denominado $\mathrm{N}$ y los dos últimos corresponden al súperhaplogrupo M. Otra incongruencia resulta de que una sola letra es utilizada para nombrar a conjuntos de diferente jerarquía siendo imposible, sin un conocimiento previo, deducir cuáles son las categorías inclusivas. Así mismo, algunos haplogrupos incluyen mucha más variabilidad que otros. Al punto de que para la mayor variabilidad presente en la especie humana que se encuentra en el continente africano, se ha reservado una sola letra - L El clado L, es en realidad un parahaplogrupo debido a que no incluye a todos los descendientes de un mismo ancestro, ya que los súperhaplogrupos $\mathrm{M}$ y $\mathrm{N}$ constituyen ramas derivadas de L. Algunas denominaciones van incluso en contra de cualquier lógica, por ejemplo el haplogrupo D1 que fuera descripto inicialmente, constituye un subconjunto dentro de D4. De modo que D4h tiene la misma jerarquía que D1. Luego de la irregularidad inicial, generada por la descripción en primer término de linajes derivados, los principios de nomenclatura se han normalizado y consisten en la sucesión intercalada de letras y números para cada nuevo nivel jerárquico, como por ejemplo Cld1b.

Hechas estas advertencias previas, pasemos a describir brevemente lo que se conoce hasta el momento de la filogenia global mitocondrial.

En el 2008 van Oven y Kayser publicaron una reconstrucción del árbol mitocondrial humano, basada en 4198 secuencias completas. La publicación fue acompañada de una versión en línea que se actualiza constantemente, a la que se accede a través de http://www.phylotree.org En dicha publicación presentan un esquema simplificado, necesario para comprender la nomenclatura de los haplogrupos (Figura 1.1). Sin embargo, para poder apreciar la dimensión de la variabilidad existente a nivel mundial, nos son más útiles las imágenes publicadas por Behar y col. (2008) (Figura 1.2) y por Olivieri y col. (2006) (Figura 1.3). 
EL verdadero poder de reconstrucción histórica de la filogenia emerge cuando los datos referentes a la variabilidad son yuxtapuestos con los de la distribución geográfica de dicha variabilidad, dando lugar a una disciplina llamada filogeografía (Avise, 1987). Algunas de las propuestas teóricas de esta disciplina serán ejemplificados con los datos de la distribución de la variabilidad humana.

-La región que presenta mayor variedad de linajes se postula como el lugar de origen del clado.

En la figura 1.2 puede apreciarse que a partir de la raíz se genera una dicotomía que separa a los linajes L0 del resto de los linajes L1'2'3 $3^{\prime} 4^{\prime} 5^{\prime} 6$; de todos éstos, sólo dos ramas diferenciadas dentro de L3 ( $\mathrm{M}$ y N), se distribuyen fuera de África. De este esquema se desprende que la mayor variabilidad de linajes mitocondriales presente en la especie humana se encuentra en el continente africano apoyando la teoría de un origen africano de los humanos modernos, en concordancia con los datos paleontológicos. Dentro de África, Behar y col. (2006) emplean también este concepto cuando señalan como evidencia del origen Khoisan (sur de África) de los linajes L0d y L0k, la mayor frecuencia y variación interna de dichos linajes entre estos pueblos. Mientras que la alta frecuencia y variación interna de los linajes L1'5 en los no khoisan indicaría que la presencia de estos linajes entre los Khoisan es producto de flujo génico reciente.

-Los nodos internos son los más antiguos, mientras que los nodos externos son más recientes.

Continuando con el ejemplo anterior, podemos observar que los nodos correspondientes a los linajes extra africanos tienen una ubicación externa, indicando una expansión reciente fuera de África en contraposición a la mayor antigüedad de la presencia humana en el continente africano.

Este principio también se aplica para el caso del poblamiento temprano de Asia. Metspalu y col. (2006) proponen un poblamiento rápido inicial a lo largo de la costa sur asiática y presentan como evidencia el hecho de que en el sur y sudeste de Asia y Sahul, se encuentran haplogrupos que divergen directamente de las ramas troncales de M, N y R (Figura 1.3). La ubicación interna de estos linajes es interpretada como evidencia de una antigüedad semejante para todos ellos, indicando un proceso de poblamiento rápido en vez de uno lento, que hubiera resultado en una ubicación más externa y una consiguiente menor antigüedad, de los linajes del extremo oriental de la región (Sahul). Como contrapartida, señalan al poblamiento de América que es claramente posterior, y cuyos haplogrupos fundadores constituyen nodos externos de los linajes asiáticos (Figura 1.4).

-Cuando linajes con grandes discontinuidades genéticas se encuentran en simpatría, se debe al contacto secundario de linajes previamente diferenciados en alopatría.

Este concepto está implícito en la interpretación acerca del origen de los linajes M1 y U6 que se encuentran en el norte y este de África. Éstos presentan una clara discontinuidad genética respecto 
de los linajes L(xM,N) (Figura 1.3). Olivieri y col. (2006) analizan la variabilidad y distribución de estos linajes y concluyen que los haplogrupos M1 y U6 representan una migración en sentido inverso, desde Asia hacia África, que habría tenido lugar cuando un cambio en las condiciones climáticas fragmentó y redujo las áreas desérticas de Medio Oriente, permitiendo a los humanos modernos que habían emigrado fuera de África, reingresar al continente a través del Levante.

-Los linajes que han sufrido una expansión reciente, tienden a tener redes de haplotipos con forma de estrella. Es decir que un haplotipo común ancestral se encuentra en el centro y los haplotipos derivados se unen en forma independiente al haplotipo central.

En la población europea actual, las redes de haplotipos se caracterizan por presentar gran cantidad de ramas que parten del nodo central, con pocas ramificaciones posteriores. Este patrón ya lo habían señalado Bandelt y col. (1995) para la población europea en general y fue confirmado mediante estudios de mayor resolución respecto del haplogrupo H (Achilli y col. 2004) y el haplogrupo V (Torroni y col. 2001). Estos haplogrupos habrían sufrido una expansión reciente hace unos 10.000 años, coincidente con el inicio del Holoceno y el repoblamiento post-glacial de Europa a partir del refugio ubicado en la región franco-cantábrica.

-Cuando la interrupción del flujo génico entre dos poblaciones es reciente, los alelos de una población pueden estar más emparentados con los de la otra población que con los de la propia, en este punto se dice que las poblaciones no han alcanzado el estado de "monofilia reciproca" (Avise, 2000).

En el caso del poblamiento de América los linajes que ingresaron constituyen un subconjunto de los que en ese momento estaban presentes en Asia. Del cuello de botella ocurrido resultó que tres de los haplogrupos ( $\mathrm{A}, \mathrm{B}$ y $\mathrm{X}$ ) pertenecen al súperhaplogrupo $\mathrm{N}$, mientras que los dos restantes $(\mathrm{C}$ y D) corresponden al súperhaplogrupo M. De modo que desde el punto de vista de la filogenia mitocondrial un individuo americano portador de un linaje A, está más emparentado con un europeo portador de un linaje $\mathrm{H}$ que con un miembro de su propia comunidad con linaje C (Figura 1.1). Este ejemplo esquemático nos introduce en las dificultades que reviste pasar de un análisis a nivel de linajes a una interpretación poblacional.

Los casos presentados constituyen un ejercicio de aplicación de algunos de los conceptos teóricos de la Filogeografía y de ningún modo pretenden ser una imagen acabada de la información actual acerca de la distribución mundial de linajes mitocondriales. En la sección posterior, se expondrá con más detalle el caso americano. 
Introducciones

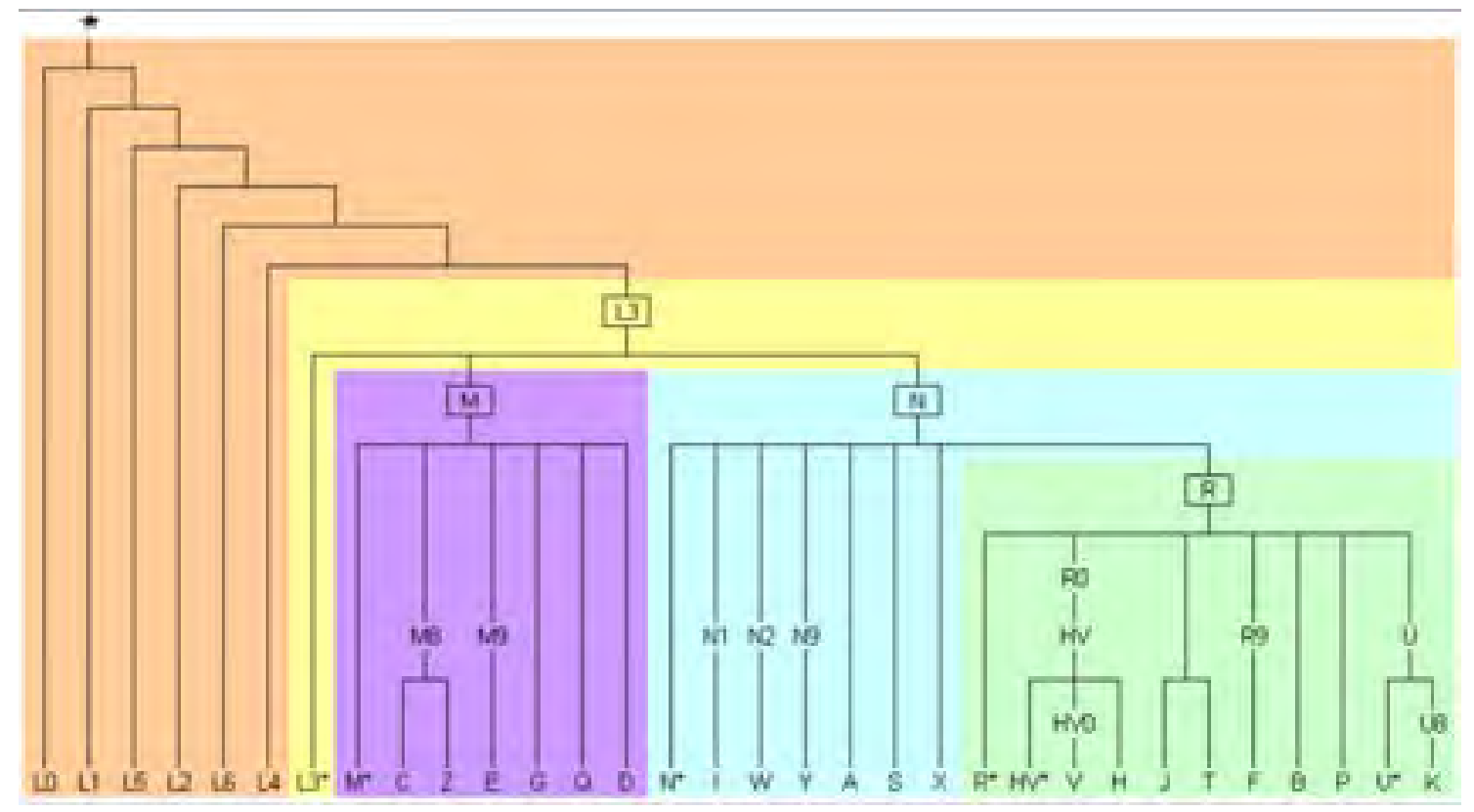

Figura 1.1. Árbol mitocondrial humano con énfasis en los linajes extra-africanos; reproducido de van Oven y Kayser, 2008.

La raíz está indicada con una estrella que representa al ancestro común más reciente. Los haplogrupos que están señalados con una estrella representan al resto de los linajes descendientes del clado, para el cual no se han reservado letras. 
Introducciones

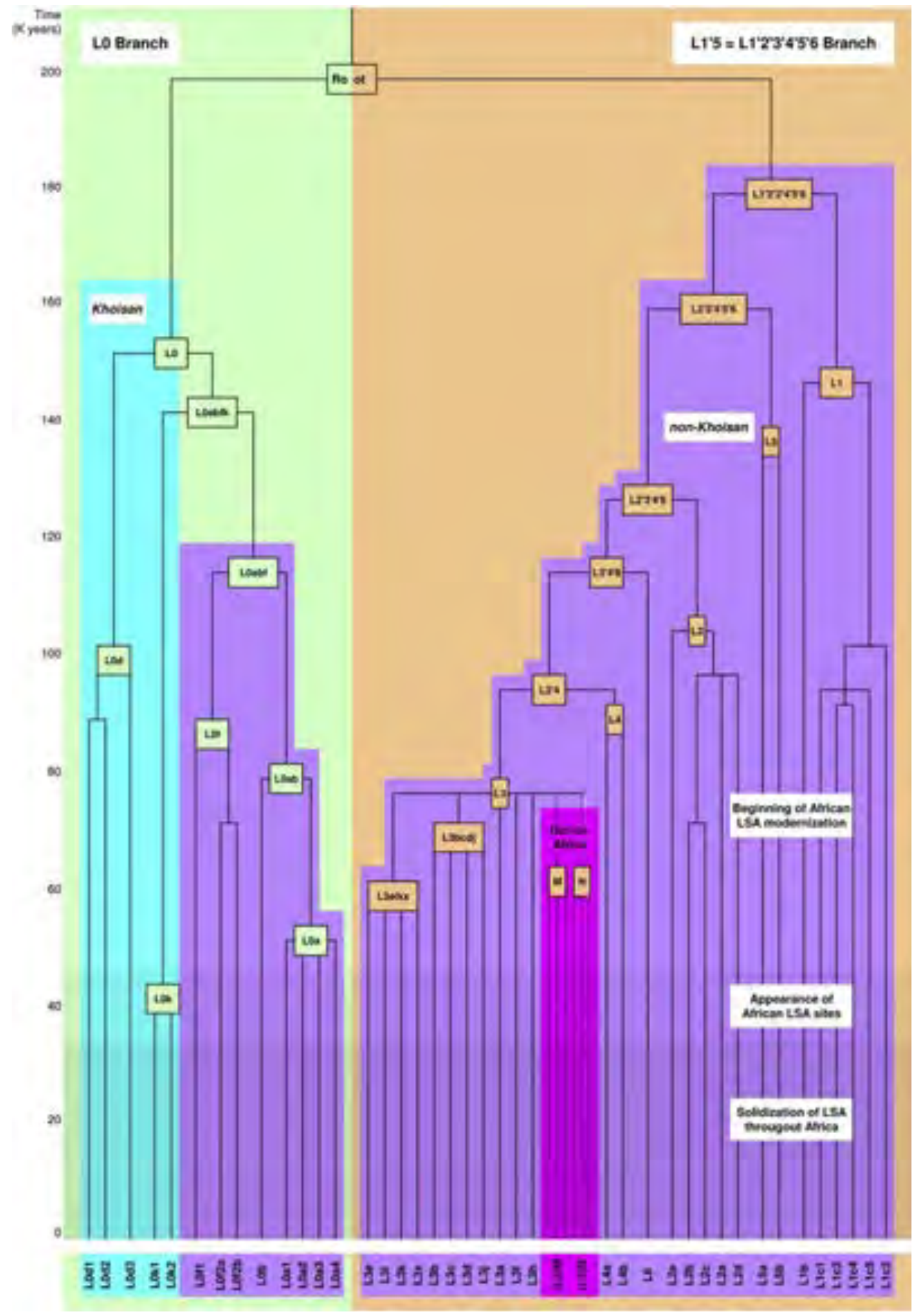

Figura 1.2. Árbol mitocondrial humano con énfasis en los linajes africanos( reproducido de Behar y col. 2008).

Se indican los tiempos aproximados del progreso de la etapa industrial africana llamada Edad de la piedra tardía, en inglés Late Stone Age (LSA). 
Introducciones

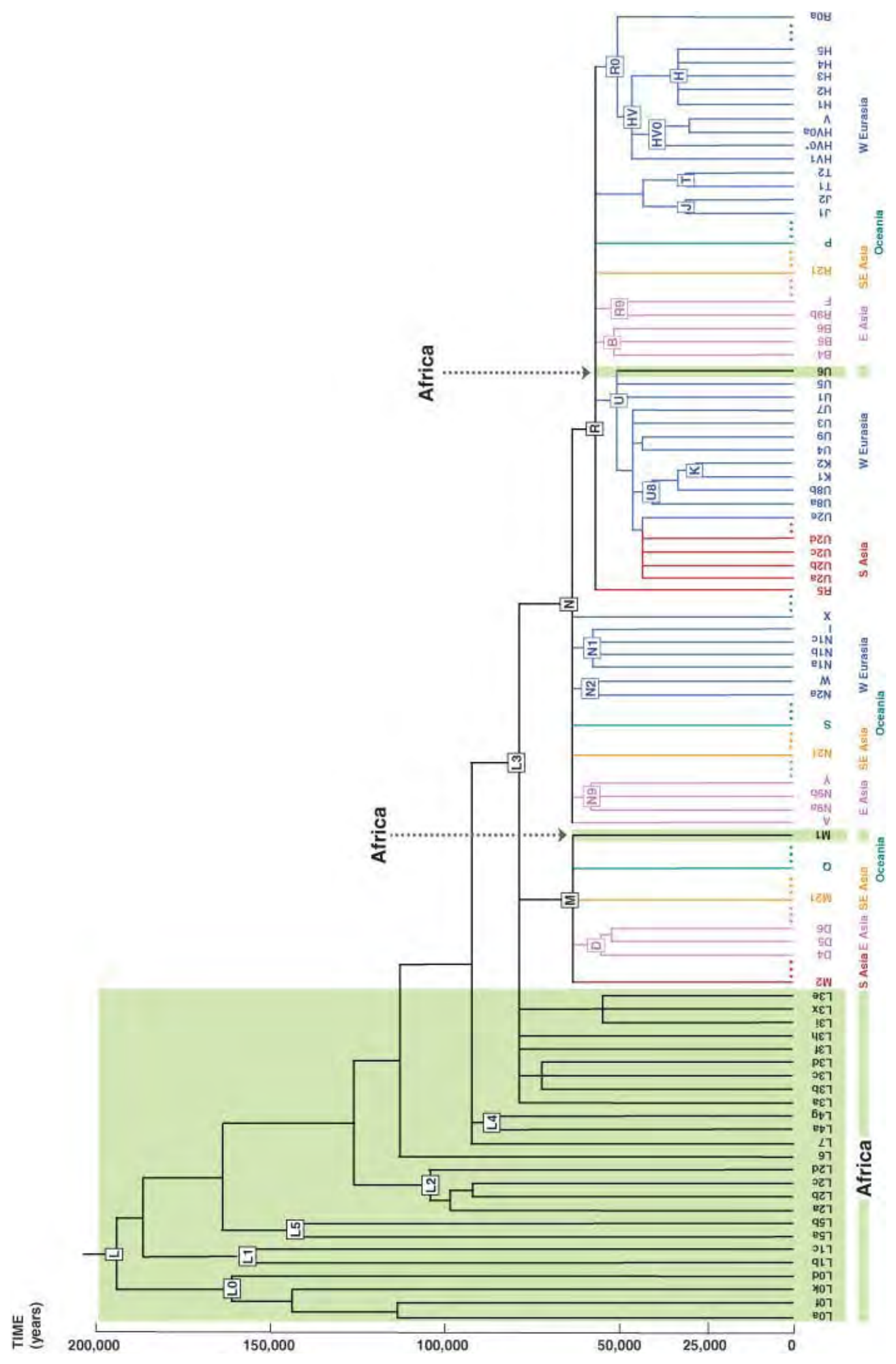

Figura 1.3. Árbol mitocondrial humano mostrando la distribución geográfica de los haplogrupos, reproducido de Olivieri y col. 2006. 


\subsubsection{Filogenia americana. El poblamiento inicial.}

El privilegio de haber recibido las cuatro primeras letras del abecedario para nombrar a los haplogrupos mitocondriales le fue otorgado al continente americano. En un estudio pionero Torroni y col. (1993) definen a los haplogrupos $\mathrm{ABCD}$ en base a la detección de mutaciones en la región codificante por medio de enzimas de restricción. Posteriormente se define un quinto haplogrupo denominado X, cuya distribución está restringida a América del Norte (Forster y col. 1996). Sin embargo, el colosal aumento en el poder de resolución otorgado por la secuenciación del genoma mitocondrial completo, llevó al número de linajes fundadores de $5 \mathrm{a}$ al menos 13 (A2, B2, C1b, C1d, C1c, C4c, D1, D2a, D3, D4h3a, D4e1c, X2a y X2g) (Figura 1.4), (Tamm y col. 2007; Achilli y col. 2008; Perego y col. 2009; Perego y col. 2010; Malhi y col. 2010; Kumar y col. 2011). A pesar del incremento en el número de linajes, los haplogrupos americanos continúan siendo apenas un subconjunto de los linajes asiáticos, indicando la ocurrencia de un cuello de botella antes o durante el poblamiento. Los modelos actuales, plantean un tiempo de pausa, donde una población habría permanecido en un refugio situado en Beringia, el tiempo suficiente para dar lugar a la aparición de nuevos alelos de distribución exclusiva en América (Tamm y col. 2007).

Dos subhaplogrupos dentro de A2 (A2a y A2b), junto con D2a y D3 son exclusivos del norte de Norteamérica y se encuentran también presentes en el Ártico asiático. Con tiempos de coalescencia posteriores al último máximo glacial, son interpretados como evidencia de flujo génico reciente (hace al menos 1000 años) entre los grupos esquimales de ambos continentes (Helgason y col. 2006).

A diferencia de los haplogrupos $\mathrm{ABCD}$, que claramente derivan de linajes asiáticos, para el haplogrupo $\mathrm{X}$ no se ha descripto una población portadora de linajes cercanamente emparentados; si bien el haplogrupo X se encuentra ampliamente distribuido en el norte de África, Europa, Asia central y Siberia, ninguno de los linajes del viejo mundo (X1, X2b-X2f), puede ser planteado como ancestro de los linajes americanos (X2a y X2g). Los linajes X que dieron origen a los americanos parecen haberse extinguido (Reidla y col. 2003). Otra característica particular del haplogrupo X es que sólo se encuentra en América del Norte y su distribución presenta mayor frecuencia en el centro del subcontinente. Perego y col. (2009) interpretaron esta evidencia como el rastro de una ruta migratoria que habría atravesado el corredor libre de hielo entre los casquetes cordillerano y lauréntico, permitiendo a la población expandirse ampliamente en la región de los Grandes Lagos. En el mismo trabajo analizan la distribución del linaje D4h3a que se caracteriza por una restricción a lo largo de la costa pacífica, tanto en América del Norte como del Sur y sería el rastro de otra ruta migratoria seguida por los primeros pobladores americanos. Esta ruta costera explicaría el rápido avance de los inmigrantes, que habrían alcanzado el extremo sur del continente poco tiempo después del ingreso por Beringia. Como señalan los mismos autores, estos haplogrupos no se localizan en forma aislada sino que las poblaciones que los portan, cargan también con otros haplogrupos de distribución pan- 
americana. Por eso es necesario afinar las filogenias del resto de los haplogrupos para poder confirmar estos patrones de distribución y/o plantear otros nuevos.

Nueve de los haplogrupos fundadores alcanzan América del sur, sin embargo, debido su reciente descripción, los haplogrupos C1b, C1c, C1d*, C1d1, C4c y D4h3a, aún no han sido caracterizados masivamente a nivel poblacional por lo que las interpretaciones respecto a su distribución continúan siendo parciales. Así mismo, la variabilidad existente dentro de A2, B2 y D1 tampoco ha sido analizada a nivel poblacional y la tarea de definir subhaplogrupos capaces de aumentar el poder de discriminación, en especial en Sudamérica, continúa en marcha.

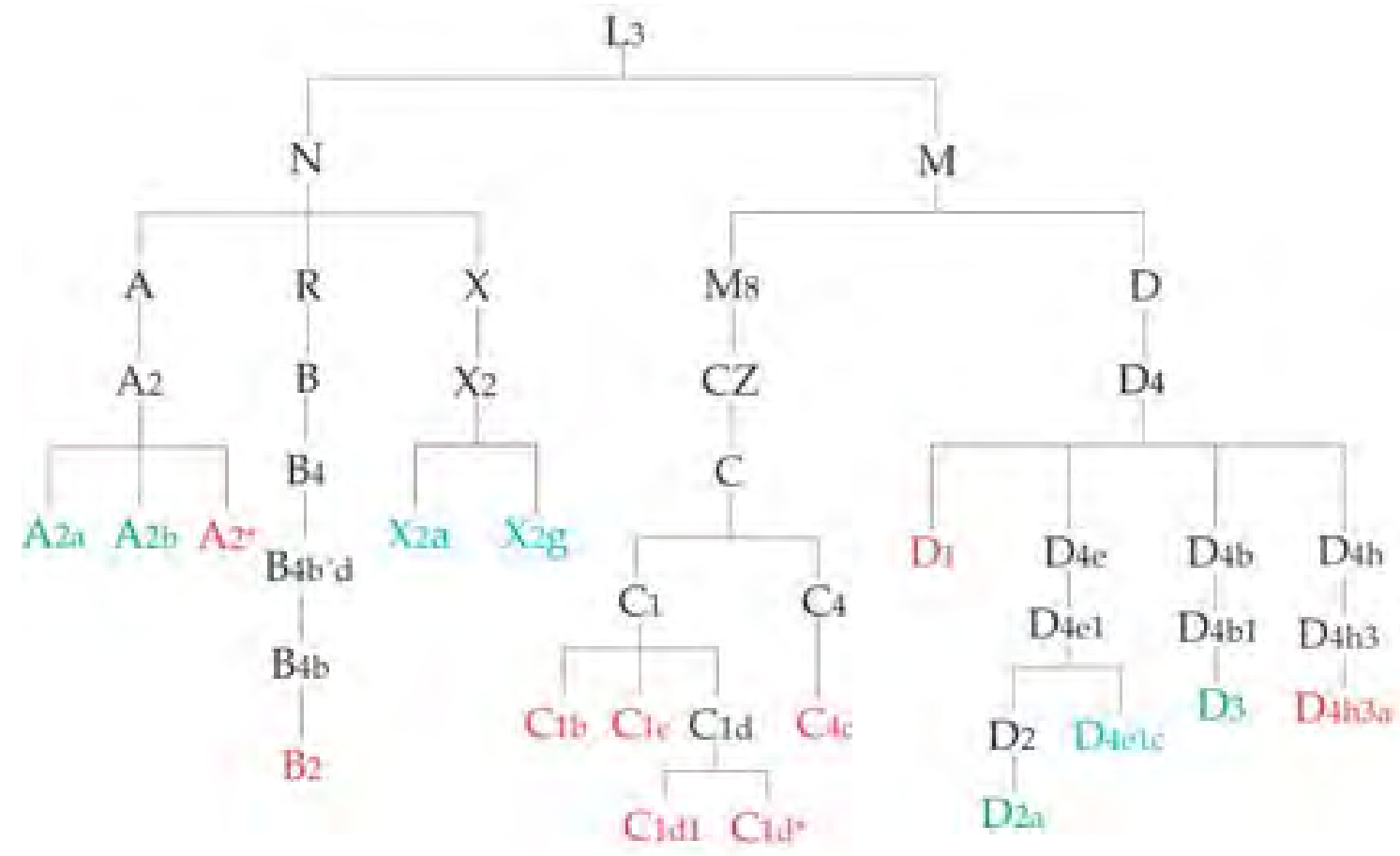

Figura 1.4. Árbol mitocondrial de los haplogrupos americanos basado en Perego y col. 2010. Y Kumar y col. 2011.

Los haplogrupos en verde se distribuyen en el norte de Norteamérica y en la región circumpolar, los indicados en azul se encuentran sólo en América del norte, mientras que los señalados en rojo son de distribución pan-americana. El asterisco representa al resto de los linajes descendientes del clado.

\subsubsection{LA POBLACIÓN AMERICANA ACTUAL. ADNMT Y MESTIZAJE.}

Uno de los principales problemas en torno al estudio de los linajes nativos americanos proviene del profundo impacto de la llegada masiva de contingentes europeos y africanos llegados al continente luego de la conquista española. Como resultado, algunos pueblos originarios fueron desplazados, reducidos o aniquilados. En otras regiones, sin embargo el contacto propició el mestizaje sexo-asimétrico que resultó en la preservación de los linajes maternos nativos en elevadas proporciones dentro de la población actual. 
Como se mencionó anteriormente, cuando los linajes se han diferenciado en alopatría, la discontinuidad genética resultante, permite diferenciarlos cuando se encuentran en simpatría. El continente americano es hoy el lugar de encuentro de linajes originados en África y en el oeste de Eurasia, que pueden distinguirse claramente a nivel molecular, por lo que muchos trabajos en América latina han utilizado al ADNmt como herramienta para caracterizar los procesos regionales de mestizaje (Dipierri y col. 1998; Martínez-Marignac y col. 1999; Alves-Silva y col. 2000; CarvajalCarmona y col. 2000; Sans y col. 2006; Bonilla y col. 2004; Salas y col. 2008; García y Demarchi, 2009; Avena y col. 2007, 2009, 2010; Marrero y col. 2007; Bobillo y col. 2010).

Como resultado de más de diez años de investigación, queda claro que aún en poblaciones sin un reconocimiento indígena desde el punto de vista cultural, se encuentra gran porcentaje de linajes maternos nativos. Esta situación dio lugar a la elaboración del concepto de homopatría, que refiere al hecho de que las poblaciones actualmente asentadas en la región donde habitó determinado grupo étnico, conservarían linajes propios de dicho grupo y que por lo tanto el estudio de la población actual, es válido para hacer interpretaciones respecto de la distribución geográfica de linajes indígenas (Gonçalves y col. 2010).

\subsection{Noroeste y CENTRO-OESTE ARGEntinos (NOA y COA), Distintas MIRADAS SOBRE EL TERRITORIO}

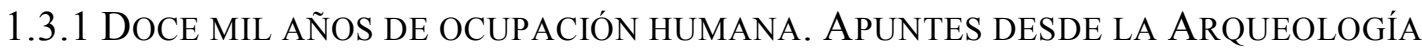

La escala espacial con que trabajan los arqueólogos suele ser de menores dimensiones que la que aquí se maneja. Algunas regiones se han estudiado en mayor profundidad, mientras que para otras existe poca información; del mismo modo ocurre con los períodos temporales, para los cuales la información es variable, ya sea por razones técnicas o académicas. Para escribir las líneas siguientes se han tenido en cuenta trabajos de compilación que son debidamente citados. Los trabajos originales de descripción de cada sitio deberán buscarse en la bibliografía del trabajo citado.

En Sudamérica, se han hallado restos arqueológicos con una antigüedad que supera los 11.000 años antes del presente (AP). Esta misma fecha era la propuesta para el momento de ingreso de los primeros americanos en América del norte, dada la abundancia de sitios con las características puntas de proyectil estilo Clovis. El modelo - Covis, los primeros" fue sostenido en especial por investigadores norteamericanos que no daban crédito a los hallazgos en América del Sur. Sin embargo, el continuo hallazgo de sitios en el extremo sur de Sudamérica con una antigüedad de entre 10.000 y 12.000 años, es un indicio de que para ese momento ya existía una ocupación humana estable, capaz de dejar claros signos arqueológicos y que por lo tanto la llegada a estas tierras debió ser ligeramente 
anterior (Steele y Politis, 2009). Los hallazgos tempranos en América del sur obligan a retrotraer la fecha de ingreso de los primeros americanos.

Para poder explicar la presencia tan temprana en el extremo sur del continente se propone una ruta costera de ingreso, apoyada en la localización de los sitios más tempranos y en modelos de desplazamiento humano que demuestran que los movimientos siguiendo la línea de costas son más rápidos que los intracontinentales. En la Figura 1.5, se indica la ubicación de los sitios sudamericanos con antigüedades mayores a 10.000-AP.

Rothhammer y Dillehay (2009) señalan que al contrario de lo que ocurre con la expansión de la industria lítica Clovis en América del Norte, en Sudamérica no se encuentra una industria lítica homogénea y expandida por todo el subcontinente. Por el contrario, los sitios tempranos sudamericanos muestran evidencia de adaptaciones a los recursos locales sin presencia de material transportado largas distancias. A su vez, la evidencia paleoclimática registra oscilaciones de las condiciones ambientales a fines del Pleistoceno (circa 10.000-AP) que pudieron haber fragmentado los hábitats humanos por la expansión de zonas áridas. La adaptación a los recursos locales, sumado al posible aislamiento de estos primeros grupos habría tenido como consecuencia la gran diversidad lingüística y cultural que se encuentra hoy en el último confín de la tierra en ser habitado por el hombre.

En el Holoceno temprano (entre los 10.000 y 7.000 años-AP), la cantidad de comunidades de cazadores-recolectores aumentó. Su modo de vida básico no se modificó demasiado, aunque tras la desaparición de la megafauna el guanaco se transformó en el recurso esencial. En la región que nos ocupa, la presencia de esas comunidades se extendió al actual territorio de la provincia de San Juan, donde se hallaron restos de la industria lítica denominada La Fortuna, fechada en unos 8.500-AP. Y a las Sierras Centrales (Córdoba y San Luis), donde se desarrolla la fase Ayampitín caracterizada por las puntas del mismo nombre que fueron halladas inicialmente en un sitio a cielo abierto en la Pampa de Olaen (Córdoba) sin un contexto estratigráfico. Posteriormente fueron halladas en la Gruta de Intihuasi (San Luis) en los estratos inferiores con una datación de 8.000-AP (González, 1960). Un sitio recientemente descripto en Pampa de Achala, Córdoba, denominado El Alto 3 posee un fechado radiocarbónico de $11.010 \mathrm{bp}$, sin embargo el material fechado se encuentra ligeramente por debajo de los restos arqueológicos (Rivero y Roldán, 2005). En la puna de Catamarca el sitio Quebrada Seca 3 posee fechados de 9.790-AP. Por tanto, hace 8.000 años grupos de cazadores recolectores estaban bien afirmados en los bordes de la puna, en San Juan y Mendoza y en las Sierras Centrales. 


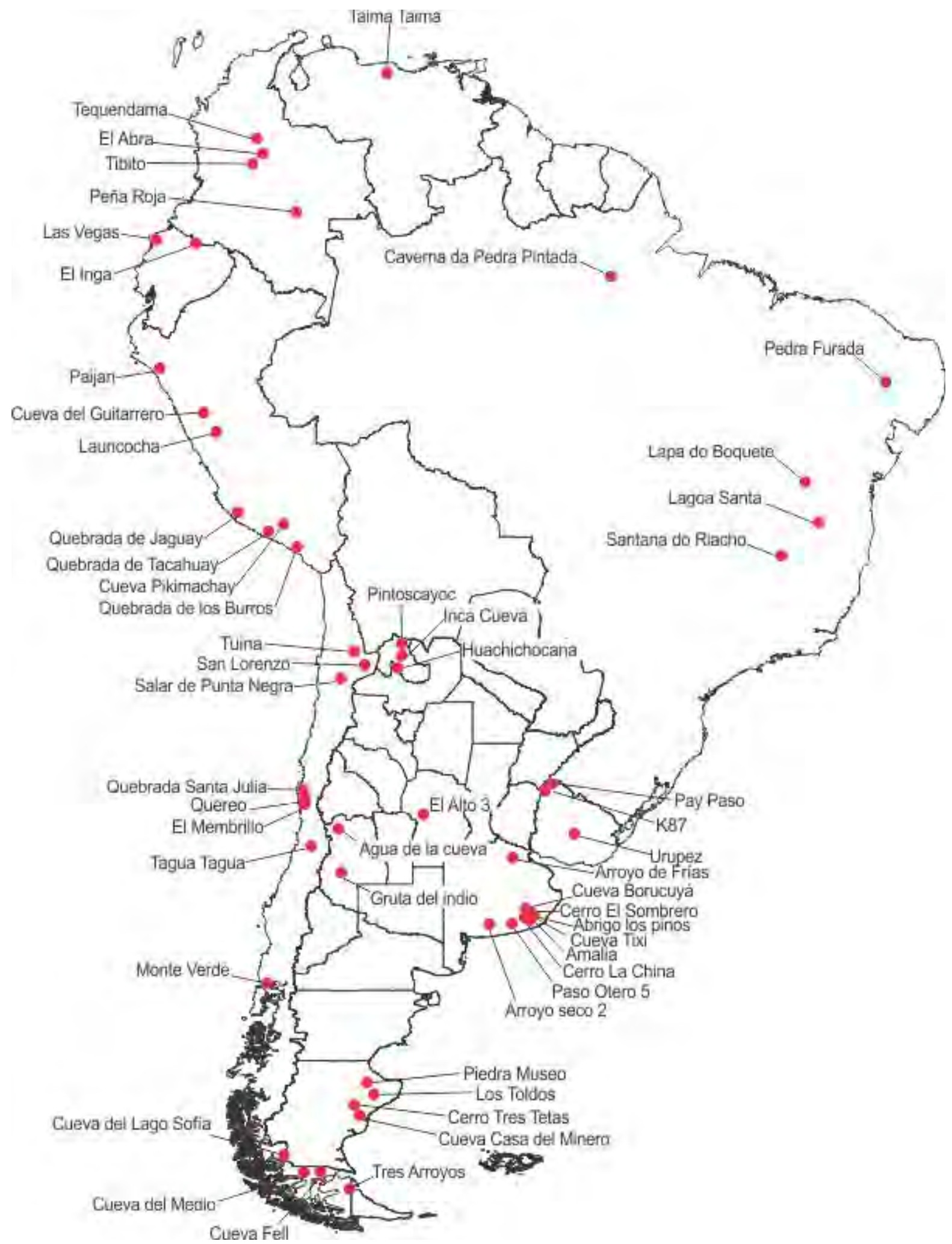

Figura 1.5. Mapa con los sitios con fechados radiocarbónicos sin calibrar > a 10.000-AP. Basado en Politis y col. 2004; Rivero y Berberian, 2007; Steele y Politis, 2008 y Rothhammer y Dillehay, 2009. 


\begin{tabular}{|c|c|c|c|c|}
\hline País & Región & Nombre del Sitio & $\begin{array}{c}\text { Fechados } \\
\text { radiocarbónicos } \\
\text { sin calibrar }\end{array}$ & Fuente (compilación) \\
\hline Chile & Centro-Norte & Tagua Tagua & 11.000 & Rivero y Berberián 2007 \\
\hline Chile & Centro-Norte & Tuina & 10.820 & Rivero y Berberián 2007 \\
\hline Chile & Centro-Norte & San Lorenzo & 10.400 & Rivero y Berberián 2007 \\
\hline Chile & Centro-Norte & $\begin{array}{l}\text { Salar de Punta } \\
\text { Negra }\end{array}$ & 10.470 & Rivero y Berberián 2007 \\
\hline Chile & Centro-Norte & El Membrillo & 13.500 & Rivero y Berberián 2007 \\
\hline Chile & Centro-Norte & Quereo 1 & 12.000 & Rivero y Berberián 2007 \\
\hline Chile & Centro-Norte & $\begin{array}{l}\text { Quebrada de Santa } \\
\text { Julia }\end{array}$ & 11.090 & Jackson y col. 2007 \\
\hline Argentina & Jujuy & Inca Cueva 4 & 10.620 & Rivero y Berberián 2007 \\
\hline Argentina & Jujuy & Huachichocana & 10.200 & Rivero y Berberián 2007 \\
\hline Argentina & Jujuy & Pintoscayoc & 10.720 & Rivero y Berberián 2007 \\
\hline Argentina & Mendoza & Agua de la Cueva & 10.950 & Rivero y Berberián 2007 \\
\hline Argentina & Mendoza & Gruta del Indio & 10.350 & Rivero y Berberián 2007 \\
\hline Argentina & Buenos Aires & Cerro el Sombrero & 10.725 & Politis y col. 2004 \\
\hline Argentina & Córdoba & El Alto 3 & 11.010 & Rivero y Roldan, 2005 \\
\hline Argentina & Buenos Aires & Cerro la China & 11.150 & Politis y col. 2004 \\
\hline Argentina & Buenos Aires & Arroyo Seco 2 & 12.240 & Politis y col. 2004 \\
\hline Argentina & Buenos Aires & Paso Otero 5 & 10.440 & Politis y col. 2004 \\
\hline Argentina & Buenos Aires & Cueva Tixi & 10.375 & Politis y col. 2004 \\
\hline Argentina & Buenos Aires & Abrigo los Pinos & 10.465 & Politis y col. 2004 \\
\hline Argentina & Buenos Aires & Cueva Burucuyá & 10.000 & Politis y col. 2004 \\
\hline Argentina & Buenos Aires & Amalia & 10.400 & Politis y col. 2004 \\
\hline Argentina & Buenos Aires & Arroyo de Frías & 10.300 & Politis y Bonomo, 2011 \\
\hline Uruguay & & K87 & 10.400 & Politis y col. 2004 \\
\hline Uruguay & & Urupez & 10.690 & Rivero y Berberián 2007 \\
\hline Uruguay & & Pay Paso & 10.930 & Suarez, 2011 \\
\hline Chile & Sur & Monte Verde & 12.740 & Rivero y Berberián 2007 \\
\hline Chile & Sur & Cueva del Medio & 12.390 & Rivero y Berberián 2007 \\
\hline Chile & Sur & Tres Arroyos & 11.880 & Rivero y Berberián 2007 \\
\hline Chile & Sur & Cueva Sofía 1 & 11.570 & Rivero y Berberián 2007 \\
\hline Chile & Sur & Cueva Fell & 11.000 & Rivero y Berberián 2007 \\
\hline Argentina & Santa Cruz & Los Toldos 3 & 12.600 & Rivero y Berberián 2007 \\
\hline Argentina & Santa Cruz & Piedra Museo & 12.890 & Rivero y Berberián 2007 \\
\hline Argentina & Santa Cruz & Cerro Tres Tetas & 11.560 & Rivero y Berberián 2007 \\
\hline Argentina & Santa Cruz & Casa del Minero & 10.999 & Rivero y Berberián 2007 \\
\hline
\end{tabular}

Tabla 1.1. Sitios arqueológicos tempranos de Argentina y áreas vecinas.

Resaltado en gris, los sitios chilenos próximos al NOA y COA con edades más antiguas.

Durante el Holoceno medio (7.000 a 5.000-AP) hubo fluctuaciones climáticas que aumentaron las condiciones de aridez en la región. Si bien estos cambios no se dieron en forma simultánea, se observa una reducción en el número, e incluso la ausencia de sitios en los ambientes más frágiles, produciéndose un -idencio arqueológico” en algunas áreas (Gil y col. 2005 y bibliografía allí citada). 
En la región circumpuneña, el aumento de la aridez modificó la distribución de sitios, provocando la concentración en torno a los lugares con agua disponible. Hace unos 5.000 años en la cuenca de Antofagasta de la Sierra (sitio Quebrada Seca), los sitios muestran mayor densidad y variedad de vestigios que reflejan ocupaciones más intensas. El aumento de la densidad de población puede haber sido uno de los factores que propiciaran los comienzos de la domesticación de plantas y animales. En algunas quebradas de acceso a la Puna (Inca Cueva, Huachichocana) y en las cabeceras del Valle Calchaquí (Puente del Diablo) hay indicios arqueológicos del inicio de la domesticación de unos 4.000 años de antigüedad.

En la región occidental de cuyo, entre el 7.000 y el 4.000-AP se desarrolló la cultura de Los Morrillos, denominada en forma homónima al sitio donde primero se la describió, en el valle de Calingasta. Los indicios de cultivos incipientes tempranos provienen de algunos abrigos y cuevas de los valles de Iglesia y Calingasta, en el oeste de San Juan, como Punta de Barro, Los Morrillos y Ansilta, donde se encontraron indicios de un núcleo de agricultura incipiente que se conoce con el nombre del último de los sitios mencionados. También en el valle mendocino de Uspallata y en la Gruta del Indio, se encontraron indicios del cultivo de quinua y calabazas. Se cree que el inicio de la domesticación pudo haber estado influenciado por la llegada de grupos desde el actual territorio chileno ya que al oeste de los Andes los testimonios de prácticas de cultivo y domesticación de animales son mucho más tempranos. En Tiviliche, una aldea situada a $41 \mathrm{~km}$ de la costa, se recuperaron las primeras evidencias de cultivo de maíz y la crianza de Cavia sp., con fechados de entre 7.800 y $6.600-\mathrm{AP}$.

Hacia el 2.500-AP comenzaron a desarrollarse sociedades aldeanas, basadas en el cultivo y el pastoreo. También se dio el desarrollo de la tecnología cerámica y metalúrgica. Los asentamientos de los tempranos agricultores sedentarios se distribuyen en los distintos ambientes andinos; se los encuentra en el norte y el sur de la puna, las quebradas de Humahuaca y del Toro, en los valles principales de Salta, Tucumán, Catamarca, La Rioja, San Juan y norte de Mendoza. En las yungas orientales, grupos aldeanos vivieron en el oriente de Jujuy y Salta y el norte de Tucumán, destacándose los valles de San Francisco y Bermejo. Con la incorporación de la cerámica, los arqueólogos cuentan con un elemento poderoso para la identificación de estilos regionales. A diferencia de la tecnología lítica que está limitada por las características de la materia prima, la tecnología cerámica es mucho más plástica, permitiendo mayor variedad de expresiones artísticas. Estas expresiones son el correlato arqueológico de una cultura o grupo humano y su permanencia temporal o dispersión espacial es interpretada como la continuidad de un espacio social y/o político.

En base a la secuencia descripta para el Valle de Hualfín en Catamarca, Rex González (1979) elaboró la periodificación que es utilizada como referencia de trabajo en las investigaciones arqueológicas en el NOA. Para la etapa agro alfarera consideró tres períodos, temprano, medio y tardío. El período temprano se caracteriza por la diferenciación de estilos regionales, mientras que el 
período medio está definido por la expansión del estilo Aguada; por su amplia distribución, desde el norte de San Juan hasta los Valles Calchaquíes de Salta, éste consiste en un momento de integración regional que tiene lugar entre el 600 y el 900 de nuestra era, aproximadamente. El período Aguada se da en simultáneo con el Horizonte Tiahuanaco-Wari en los Andes Centrales y posee algunas de sus características como la importancia del complejo mágico-religioso asociado al consumo de alucinógenos. Si bien se discute hasta qué punto la difusión de un estilo cerámico implica la unidad del área donde se lo encuentra, o si se trata de la adopción de un sistema simbólico por parte de las elites para legitimar su poder, un mismo estilo cerámico implica necesariamente la interacción fluida dentro de un sistema de intercambio. Al mismo tiempo, en la región de la Puna se identifica otro circuito de interacción denominado Yavi-Isla, por el nombre de sus principales sitios arqueológicos. Este circuito, fuertemente vinculado con el norte del actual Chile y suroeste de la actual Bolivia, habría funcionado de manera independiente del sistema Aguada ubicado más al sur. Mientras tanto en el sur de San Juan y norte de Mendoza, a los registros del período medio se los aglutina, en general, dentro de la -Clrura de Agrelo".

En el período tardío, en el área de expansión Aguada, vuelven a surgir diferentes estilos cerámicos en áreas más acotadas. Paralelamente, los lugares preferenciales de residencia se trasladan de los valles a zonas más elevadas e inaccesibles, construyéndose fortalezas defensivas o pukaras. Todo esto es evidencia de que hubo una desintegración del sistema Aguada, surgiendo o agravándose los conflictos entre distintas entidades regionales. El período tardío es también llamado de —Desarollos Regionales" y en cada área se identifican estilos cerámicos que, en algunos casos, son asociados con los pueblos asentados en el momento de contacto hispano-indígena. La cerámica Belén en el valle de Belén y la cerámica Santa María en el valle homónimo, ambos en Catamarca, son consideradas los antecedentes arqueológicos de grupos diaguitas. La cerámica Angualasto de La Rioja y San Juan es asociada a los Capayanes, la cultura Viluco del sur de San Juan y norte de Mendoza con los grupos huarpes (Lagiglia, 1976) y la cerámica Yavi del norte jujeño a los Chichas (Ávila, 2005 y bibliografía allí citada).

Esta asociación de las culturas arqueológicas del período tardío con los grupos descriptos por la etnohistoria, es una prueba del escaso impacto que tuvo la ocupación incaica iniciada por la expansión territorial del imperio en 1476. Si bien los signos de la expansión incaica a nivel arqueológico son evidentes por la presencia de tambos, caminos y cerámica. Los sitios que ocuparon suelen ser diferentes a los de los grupos locales, todo indica que el poco tiempo que pasó desde la ocupación incaica hasta la llegada de los españoles, no fue suficiente para alterar las tradiciones locales. El mayor impacto de la expansión incaica fue la relocalización de pueblos enteros que eran trasladados ya sea como castigo, o como estrategia política para afianzar el control territorial. 


\subsubsection{El MOSAICo ÉtNiCo DEL Siglo XVI. APUNTES DESDE LA ETNOHISTORIA Y LA LINGÜÍSTICA}

Los nombres con que se identifica a los grupos humanos no corresponden ya a los de un estilo cerámico sino que, con la introducción de las fuentes escritas, surge una pluralidad de denominaciones que resulta difícil de interpretar. Muchas veces se hace referencia a un mismo grupo con distintos nombres: aquel con el que ellos mismos se identifican, aquel con el que otros grupos los nombran o el topónimo de la región que ocupan. Otras veces se identifican parcialidades a las que se puede agrupar bajo un mismo nombre, o un mismo nombre encierra entidades culturales diferentes. Se intentará aclarar el panorama étnico de la región siguiendo a Lorandi (1998), Albeck y Ruiz (2003), Michieli (1996) y Censabella (1999). La ubicación geográfica de las áreas y los pueblos indígenas mencionados en el texto, se ilustran en la Figura 1.6.

La prolongación meridional del altiplano, llamada Puna, se extiende en la Argentina en el oeste de las provincias de Jujuy, Salta y Catamarca. La información procedente de los documentos etnohistóricos ha dado lugar a planteos contradictorios sobre la adscripción étnica de los grupos que habitaban esta región. La parte de Puna árida compartida por los actuales países de Bolivia, Chile y Argentina se percibe como un mosaico de etnías e identidades. Para el territorio correspondiente a la Puna argentina se ha hablado de la presencia de Chichas en el extremo norte, Atacamas al oeste y sur, además de otros grupos como los Apatamas, los Casabindo y los Cochinoca en Jujuy. Los Apatamas aparentemente fueron un subgrupo de los Chichas y los Casabindo y Cochinoca han sido adscriptos alternadamente como etnía chicha, atacameña y aún se los ha considerado Diaguitas. En la actualidad se percibe a los Casabindo y a los Cochinoca como grupos con una identidad distintiva que los diferenciaría de grupos aledaños.

El área Valliserrana Central comprende diversos valles, quebradas y pampas, abiertos entre cadenas montañosas que se escalonan a lo largo de las provincias de Salta, Catamarca y La Rioja y el oeste de Tucumán. Podemos incluir aquí también a los valles del norte de San Juan. Toda el área fue ocupada por una gran unidad étnico-lingüística denominada Diaguita, de habla cacana. Dentro de este amplio territorio y del conjunto diaguita se pueden distinguir diversos grupos étnicos o parcialidades. Si bien en los primeros escritos todos estos indios fueron designados como Diaguitas, con el tiempo los pueblos que ocupaban los actuales Valles de Calchaquí y Santa María (o Valles Calchaquíes como denominación general) empezaron a ser identificados como Calchaquí. Este apelativo es una hispanización proveniente de la extensión del "apellido" de un líder de la resistencia indígena llamado Juan Calchaquí. Las investigaciones etnohistóricas demuestran que más tarde, a medida que los diversos grupos que habitaban estos valles pudieron ser individualizados con mayor precisión, el gentilicio Calchaquí no aparece como autodesignación de ningún grupo étnico en particular. No obstante, se generalizó su uso para señalar en general a todos los habitantes de los Valles Calchaquíes. 
Las parcialidades más importantes de habla cacana se distribuyeron de norte a sur de la siguiente manera: el extremo sur del Valle Calchaquí y norte del actual Santa María fue habitado por los Tolombón, Colalao y Paccioca; el centro del Valle de Santa María los Quilmes; en el sur del valle se hallaban los Yocabil, la mayoría recostados en las laderas del Aconquija; hacia el sur, en los actuales Valles de Hualfín y en Andalgalá, los Malfin en el primero y éstos y los Andalgalá en el segundo; en el Valle de Abaucán, próximo a la cordillera que nos separa de Chile, a los Abaucán; en el norte de La Rioja hallamos a los Sanagasta y en el sur de La Rioja y norte de San Juan a los Capayanes y Yacampis. Los historiadores que basan sus investigaciones en fuentes documentales de la administración colonial de la gobernación del Tucumán no suelen tener en cuenta al territorio de San Juan, ya que éste perteneció administrativamente a la Capitanía General de Chile, sin embargo en los trabajos de Michieli $(1983,1996)$ pueden hallarse pruebas de que los pueblos del norte de San Juan pertenecían también a la confederación Diaguita. En especial, la autora señala la participación activa que tuvieron los Capayanes y los Yacampis durante los alzamientos indígenas ocurridos entre 1630 y 1633.

Hacia el este, ocupando las pampas altas y las vertientes orientales de las cadenas que forman el límite del noroeste argentino, se encuentra la antigua provincia prehispánica del Tucumán. El Tucumán Prehispánico fue habitado por diversos grupos con menor coherencia política que los del área diaguita y, en general, presentan características culturales mixtas, entre andinas y chaqueñas. En las primeras épocas de la ocupación hispana, esta región fue identificada como la tierra del cacique Tucma o Tucuman, pero nunca se logra una identificación étnica precisa de los vasallos del dicho cacique. Compartiendo el territorio con ellos se hallaban los Lule, Vilelas, Solco y Tonocoté que fueron llamados por conquistadores con el nombre genérico de juríes", que significa "los que se visten con plumas de avestruz", éstos se distinguen del resto de los pueblos nombrados, por ser de hábitos semisedentarios.

En el seno del área diaguita se identifican ciertos grupos que eran reconocidos en las crónicas como pueblos extranjeros o advenedizos. Se trata de los contingentes que fueron trasladados por el imperio incaico para hacer efectivo el control de la región. Existen varias evidencias que apuntan a que los Diaguitas no acataron el dominio incaico y por ello la explotación económica, así como la defensa militar de los nuevos territorios, fue llevada a cabo por mano de obra traslada desde otras regiones del imperio. En el Valle Calchaquí propiamente dicho en sus sectores alto y medio se encontraban los Pulares, el territorio que ocupaban también fue llamado "provincia de Chicoana" en referencia a la patria natal de sus habitantes que fueron traídos desde el Chicoana cercano a Cuzco. En el sur del valle de Santa María, se encontraban los Ingamana, más allá de su nombre, una señal de su carácter extranjero quedó en evidencia cuando entre 1658 y 1659, mantuvieron una conducta ambigua en la guerra contra los españoles y finalizaron por colaborar con ellos, perjudicando a las restantes poblaciones del valle. Otro indicio del traslado de pueblos por parte de los Incas proviene de la 
arqueología: en todos los asentamientos estatales ubicados dentro del área diaguita siempre está presente la cerámica que proviene del territorio que hoy consideramos el Tucumán Prehispánico. Si se descarta que esta alfarería, extraña a la región diaguita, provenga de intercambios, lo más probable es que dicha cerámica haya sido elaborada in situ por mitmakuna traídos a esa frontera oriental. Lorandi (op. cit.) plantea la hipótesis de que los indios del Tucumán, acosados por los Lule nómadas, se protegieran bajo el "paraguas" imperial y que estos nativos fieles fueran también instalados en la zona de los valles centrales como mitmakuna, una de cuyas funciones fue la de contener a los "bárbaros" del este. Más tarde, habiendo regresado estos mitmakuna a su antiguo natural luego de la caída del Cuzco, fueron los que expandieron el quichua en los llanos de Tucumán y Santiago del Estero, subregión que nunca fue incorporada al Tawantinsuyu pero que en tiempos preincaicos había sido su hábitat como lo muestra la arqueología.

En la frontera sur del área diaguita, en el mapa de distribución étnica del siglo XVI, encontramos a los Huarpes. Éstos también eran sedentarios y tenían prácticas agrícolas que incluían el riego artificial. Sin embargo se diferencian desde un punto de vista lingüístico de los Diaguitas, ya que sus dialectos Allentiac (al norte) y Millcayac (al sur) no se relacionaban con el cacan. La frontera este, en cambio, presenta un marcado contraste ecológico y cultural. En el este de las actuales provincias de Salta y Jujuy, el paisaje serrano da lugar al de la yunga tropical. Este territorio fue ocupado por grupos de las denominadas tierras bajas", caracterizado por un modo de vida seminómade con agricultura extensiva.

Más allá de la unidad lingüística aceptada para los miembros de la confederación Diaguita, las relaciones entre las distintas lenguas de los grupos descriptos, permanecen en terreno especulativo, sin existir un consenso en cuanto a una probable relación genética (en el sentido de origen común) entre ellas. En cambio, los grupos de las tierras bajas de Salta y Jujuy pertenecen a familias lingüísticas bien definidas. A ello contribuye el hecho de que son lenguas habladas en la actualidad y que han podido ser mejor estudiadas. A la familia Tupí-guaraní pertenecen los Chiriguanos; a la familia Mataco-mataguaya, los Wichi, los Chorotes y Chulupís o Nivaclés; al tronco lingüístico Guaycurú, los Tobas; y a la familia Arawak, los Chané. Algunos de estos grupos como los Tobas y los Chiriguanos, por su característica belicosidad, impusieron el límite oriental de la expansión incaica, del mismo modo que los Mapuches lo hicieron en el extremo sur. En algunos casos el asentamiento en territorio argentino es mucho más reciente y fue como consecuencia de la Guerra del Chaco que involucró a Bolivia y Paraguay y tuvo lugar entre 1932 y 1935, que motivó los desplazamientos hacia un lugar más seguro. También la Argentina se convirtió en lugar atractivo por la oferta de trabajo en los ingenios azucareros El Tabacal, en Salta y San Pedro y Ledesma, en Jujuy. 


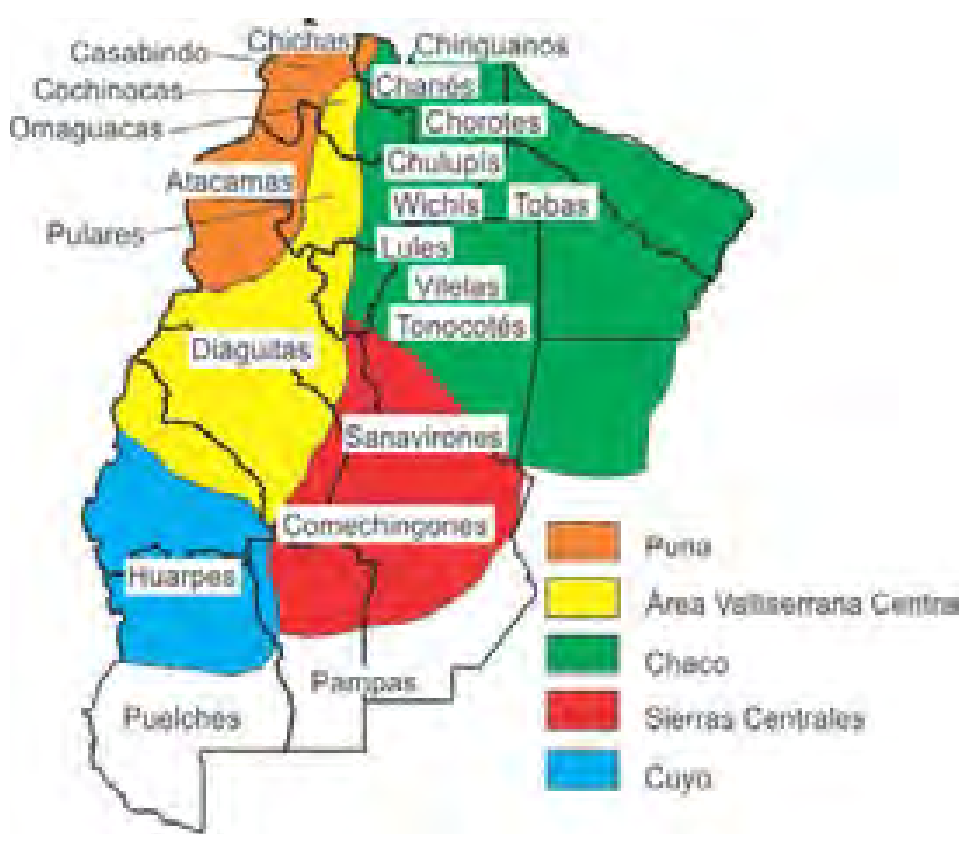

Figura 1.6. Mapa esquemático de las regiones fitogeográficas y los grupos indígenas del siglo XVI.

\subsubsection{CONFLICTOS E IDENTIDADES. DESDE LA CONQUISTA ESPAÑOLA A LA CONFORMACIÓN DEL ESTADO NACIONAL}

Para pensar el territorio en tiempos de la conquista española, debemos dejar de lado nuestra actual visión que tiene como centro a Buenos Aires y recordar que hasta 1776, los núcleos del control colonial se hallaban en Lima y en Santiago de Chile, de modo que NOA y COA fueron objetivos de conquista tempranos, fundándose las principales ciudades en la segunda mitad del siglo XVI.

El modo de vida sedentario y la previa experiencia del dominio incaico en la región se plantean como factores coadyuvantes en la rápida incorporación al estado colonial. Pero ésta no estuvo libre de rebeliones y luchas, las más conocidas son las guerras Calchaquíes que se iniciaron en 1562 con la destrucción de las primeras ciudades fundadas y continuaron hasta la derrota definitiva de los Quilmes en 1667.

A pesar de que los pueblos sublevados fueron trasladados en forma compulsiva o reducidos a la esclavitud, los colonizadores no tenían como objetivo el exterminio de los pueblos originarios, sino su incorporación como mano de obra. Así, los grupos sometidos fueron organizados en encomiendas, institución colonial que pretendía una actitud paternalista de protección y educación, principalmente religiosa.

En síntesis, los pueblos del territorio que nos ocupa ya habían sido incorporados en tiempos coloniales. Sus identidades indígenas se fueron desdibujando, tanto desde lo individual por el desprestigio social de la casta, como desde el sistema estatal que sustituyó la categoría de indio" por la de —ampesino". 
Por razones tanto geográficas como históricas, la localidad de Tartagal se distingue del resto de las incluidas en este trabajo. Si bien administrativamente pertenece a la provincia de Salta y este es el justificativo para su incorporación, se encuentra en la región fitogeográfica del Chaco, el paisaje cambia sustancialmente y también las características de los pueblos que la habitan. Lo dicho anteriormente acerca de la incorporación colonial es válido para la región de Tartagal, este territorio se mantuvo bajo control indígena hasta fines del siglo XIX, la presencia actual y el reconocimiento propio y ajeno de los pueblos originarios es indiscutible. Los grupos han mantenido su lengua y la vida en comunidad, constituyéndose en localidades cercanas o barrios dentro de la ciudad.

\subsubsection{LA SOCIEDAD ARGENTINA ACTUAL. LAS DESIGUALDADES REGIONALES.}

Algunos efectos de la migración postconquista son fácilmente identificables, debido a la gran distancia espacial que separa a los inmigrantes de los locales; cuando se trata de europeos o africanos, sus linajes maternos se distinguen claramente por la acumulación de numerosas mutaciones distintivas. Pero cuando los inmigrantes son intracontinentales, como el caso de la inmigración desde países limítrofes o el fenómeno de concentración poblacional en torno a la Capital Federal, no es tan clara la distinción molecular entre migrantes y locales, y se hace necesaria una diferenciación al interior de los haplogrupos. División que está en proceso de construcción y a la que esperamos aportar con este trabajo.

Como punto de partida, consideraremos la información de la historia reciente, sobre todo en lo referido a censos poblacionales, para establecer un cuadro aproximado de los principales centros atractores de población según la conformación geopolítica actual.

Una medida que nos da rápidamente una idea de la importancia de cada una de las localidades muestreadas es el número de habitantes. Debido a que los muestreos se realizaron durante los años 2007 y 2008, se tomaron como referencia los datos correspondientes al canso nacional de 2001 publicados por el INDEC. En la tabla 1.2 se ordenan las localidades en forma decreciente según la cantidad de habitantes del área de influencia. Las capitales provinciales se ubican en los primeros lugares, seguidas de la localidad de Tartagal.

El área del gran Mendoza corresponde a la región muestreada con mayor cantidad de habitantes, con el doble de población que la localidad que le sigue en orden de magnitud. A nivel nacional, constituye el cuarto aglomerado urbano, luego de Buenos Aires, Córdoba y Rosario. La importancia económica de la localidad, situada en la principal ruta de comercio con Chile y centro del desarrollo industrial vitivinícola, la convierte en un polo atractor de población. Esta tendencia se refleja ya en el censo de 1914 cuando queda registrado que un 28\% de los habitantes eran nacidos en Europa o Medio Oriente, constituyendo Mendoza la provincia andina con mayor afluencia de inmigrantes (Tabla 1.3). La especialización agrícola centrada en la producción de frutos implica una 
cosecha manual que requiere gran cantidad de mano de obra estacional. Esta condición provoca la afluencia de inmigrantes tanto nacionales como internacionales y entre estos últimos se destacan los procedentes de Chile y Bolivia (Paredes, 2004).

La importancia de las localidades de San Juan, Jujuy y La Rioja radica en que constituyen las capitales de sus respectivas provincias. La afluencia de inmigrantes proviene principalmente del territorio provincial. A nivel provincial, la inmigración ultramarina registrada en 1914 representa un $12 \%$ para San Juan, un 5\% en Jujuy y sólo un 2\% en La Rioja. En un estudio intercensal realizado por Lattes (1976), queda en evidencia la escasa influencia de la migración como fuente de crecimiento para estas provincias.

\begin{tabular}{|c|c|c|c|}
\hline Localidad & $\begin{array}{c}\text { Cantidad de } \\
\text { Habitantes } \\
\text { de la } \\
\text { localidad }\end{array}$ & Área de influencia & $\begin{array}{c}\text { Cantidad de } \\
\text { Habitantes de la } \\
\text { localidad más el } \\
\text { área de } \\
\text { influencia }\end{array}$ \\
\hline Mendoza & 110.993 & $\begin{array}{l}\text { Gran Mendoza (Capital, Godoy Cruz, } \\
\text { Guaymallén, Las Heras, Luján de Cuyo y } \\
\text { Maipú.) }\end{array}$ & 848.660 \\
\hline San Juan & 112.778 & $\begin{array}{l}\text { Gran San Juan (Capital, Rawson, } \\
\text { Rivadavia, Santa Lucía, Chimbas, Nueve } \\
\text { de Julio y Pocito) }\end{array}$ & 421.640 \\
\hline $\begin{array}{l}\text { S. S. de } \\
\text { Jujuy }\end{array}$ & 231.229 & $\begin{array}{l}\text { Gran Jujuy (Dr. Manuel Belgrano y } \\
\text { Palpalá) }\end{array}$ & 278.336 \\
\hline La Rioja & 143.684 & Departamento Capital & 146.648 \\
\hline Tartagal & 56.308 & Departamento Gral. José de San Martín & 139.204 \\
\hline V. Tulumaya & 7.005 & Departamento Lavalle & 32.129 \\
\hline Belén & 11.003 & Departamento Belén & 25.475 \\
\hline Santa María & 10.800 & Departamento Santa María & 22.127 \\
\hline La Quiaca & 13.761 & Departamento Yavi & 18.160 \\
\hline Chepes & 9.781 & Departamento Rosario Vera Peñaloza & 13.299 \\
\hline Maimará & 2.740 & Departamento Tilcara & 10.403 \\
\hline Calingasta & 2.039 & Departamento Calingasta & 8.176 \\
\hline
\end{tabular}

Tabla 1.2. Cantidad de habitantes por localidad, Censo Nacional de Población, INDEC 2001. 


\begin{tabular}{|c|l|r|r|r|r|r|}
\hline \multirow{5}{*}{ Mendoza } & Argentinos & $\begin{array}{c}\text { Europa y } \\
\text { Oriente } \\
\text { Medio }\end{array}$ & \multicolumn{1}{c|}{$\begin{array}{c}\text { País } \\
\text { limítrofe }\end{array}$} & \multicolumn{1}{c|}{ Otros } & \multicolumn{1}{c|}{ N } \\
\hline \multirow{3}{*}{ San Juan } & Varones & 63,15 & 33,11 & 3,55 & 0,20 & 148.227 \\
\cline { 2 - 8 } & Mujeres & 73,92 & 23,30 & 2,66 & 0,12 & 129.308 \\
\cline { 2 - 8 } & Total & 68,16 & 28,54 & 3,14 & 0,16 & 277.535 \\
\cline { 2 - 8 } & Varones & 83,34 & 14,66 & 1,91 & 0,08 & 59.142 \\
\cline { 2 - 8 } & Lujeres & 89,07 & 9,49 & 1,39 & 0,05 & 60.110 \\
\hline \multirow{4}{*}{ Latamarca Rioja } & Total & 86,23 & 12,06 & 1,65 & 0,07 & 119.252 \\
\cline { 2 - 8 } & Varones & 96,99 & 2,37 & 0,61 & 0,03 & 36.592 \\
\cline { 2 - 8 } & Total & 98,83 & 0,77 & 0,38 & 0,01 & 43.162 \\
\hline \multirow{3}{*}{ Salta } & Varones & 97,99 & 1,50 & 0,49 & 0,02 & 79.754 \\
\cline { 2 - 8 } & Mujeres & 96,48 & 3,12 & 0,38 & 0,01 & 46.717 \\
\cline { 2 - 8 } & Total & 98,81 & 0,85 & 0,33 & 0,02 & 53.674 \\
\cline { 2 - 8 } & Varones & 97,73 & 1,91 & 0,35 & 0,01 & 100.391 \\
\cline { 2 - 8 } & Mujeres & 89,18 & 7,15 & 3,57 & 0,11 & 73.578 \\
\cline { 2 - 8 } & Total & 94,26 & 3,31 & 2,38 & 0,04 & 67.349 \\
\hline \multirow{3}{*}{ Jujuy } & Varones & 91,61 & 5,31 & 3,00 & 0,08 & 140.927 \\
\cline { 2 - 8 } & Mujeres & 85,05 & 3,11 & 11,72 & 0,12 & 34.621 \\
\cline { 2 - 8 } & Total & 77,72 & 5,14 & 16,84 & 0,31 & 76.631 \\
\hline
\end{tabular}

Tabla 1.3. Composición de la población por provincia, según lugar de nacimiento. Fuente: Tercer Censo Nacional, 1914. Elaboración propia.

Luego de las capitales provinciales sigue en importancia la localidad de Tartagal, ubicada en el noreste de la provincia de Salta, cabecera del departamento de General San Martín que limita al norte con Bolivia. A diferencia de la mayor parte del territorio incluido en esta tesis, cuya incorporación como parte del sistema occidental se remonta al siglo XVI con el establecimiento del poder colonial español, el territorio correspondiente a la localidad de Tartagal fue despojado del control indígena recién luego de 1884 cuando el gobierno nacional inició la conquista definitiva del Chaco. El trazado del límite con Bolivia se estableció en 1889, incorporándose así el territorio correspondiente a Tartagal como parte de Argentina. La historia de esta ciudad está fuertemente vinculada al desarrollo de las industrias tabacalera, azucarera y petrolera. Esta característica económica convierte a Tartagal en la tercera localidad en importancia de la provincia de Salta, luego de la capital y de Orán, y se ve traducida en un incremento poblacional asociado a la atracción de mano de obra (Benclowicz, 2011).

La localidad de Villa Tulumaya merece una atención especial ya que es la cabecera del departamento de Lavalle, ubicado en el noreste de la provincia de Mendoza, una región caracterizada por su gran aridez. Esta aridez se ve compensada por la formación de lagunas como producto de la pérdida de pendiente de los ríos de la cordillera. El complejo de lagunas de Guanacache y del Rosario 
constituyó un área de asentamiento huarpe, donde se dio la especialización en el aprovechamiento de los recursos acuáticos. Durante la colonización, esta región permaneció al margen del dominio español y se constituyó en una especia de refugio para aquellos que escapaban del traslado compulsivo hacia Chile. Este traslado que afectó especialmente a los hombres, fue llevado a cabo debido a que los primeros encomenderos cuyanos no pretendían colonizar la zona, sino obtener la abundante mano de obra que se encontraba al este de la cordillera para sacar mayor provecho de sus haciendas ya establecidas al oeste (Lobos, 2004). La persistencia de la comunidad huarpe en esta región queda en evidencia en la actualidad como se expuso en la sección anterior y, por tanto la localidad de Villa Tulumaya, como cabecera del departamento de Lavalle, se distingue sustancialmente por su composición poblacional respecto de la ciudad de Mendoza, a pesar de estar separadas tan sólo por 30 $\mathrm{km}$.

Las restantes localidades, al igual que Tartagal y Villa Tulumaya, constituyen cabeceras de departamentos, de ahí la presencia de centros de salud donde tuvo lugar el muestreo. Se destacan por su carácter de localidades de frontera, Calingasta y La Quiaca. La Quiaca, ubicada a 1 km de Villazón (Bolivia) se encuentra sobre la ruta nacional $\mathrm{N}^{\circ} 40$ y consiste un importante punto de tráfico internacional. Esta característica le otorga un cierto dinamismo en cuanto a la movilidad de sus habitantes. Calingasta, en cambio, se encuentra aislada geográficamente, rodeada por la cordillera de los Andes al oeste y la sierra del Tontal al este. Un único acceso pavimentado se da a través de la ruta provincial $\mathrm{N}^{\circ} 436$, la cual es un derrotero sinuoso que sigue las curvas del río San Juan. Y no cuenta ni contó nuca con servicio de ferrocarril.

Los determinantes geopolíticos actuales generan zonas de expulsión y de atracción de población que deben ser tenidos en cuenta a la hora de analizar los patrones de distribución de linajes maternos. 


\section{CAPÍTUlo II: MATERIALES, SuJETOS Y MÉTODOS}

\subsection{Muestreo}

En cuanto a las localidades...

Inútil sería pretender un muestreo aleatorio, lujo de los biólogos, casi una utopía para los antropólogos. La elección de las localidades incluidas en el presente estudio aspira a una representatividad provincial ya que en la mayoría de los casos incluye a la ciudad capital, al tiempo que comprende también una localidad pequeña donde se presupone una continuidad local con mayor profundidad temporal. Sin embargo estos criterios también se vieron afectados por cuestiones de logística y organización: obtención de los permisos, empatía con el personal directivo de los centros de salud, accesibilidad y disponibilidad de tiempo de los integrantes del equipo de campaña (ver agradecimientos). Como resultante de esta combinación de factores, se obtuvieron 1787 muestras en doce localidades de seis provincias del centro-oeste y noroeste de Argentina (Figura 2.1). En algunos de los puntos de muestreo se incluyeron muestras de parajes cercanos (Tabla 2.1). Una mirada introspectiva del proceso de muestreo puede encontrarse en Motti (2010).

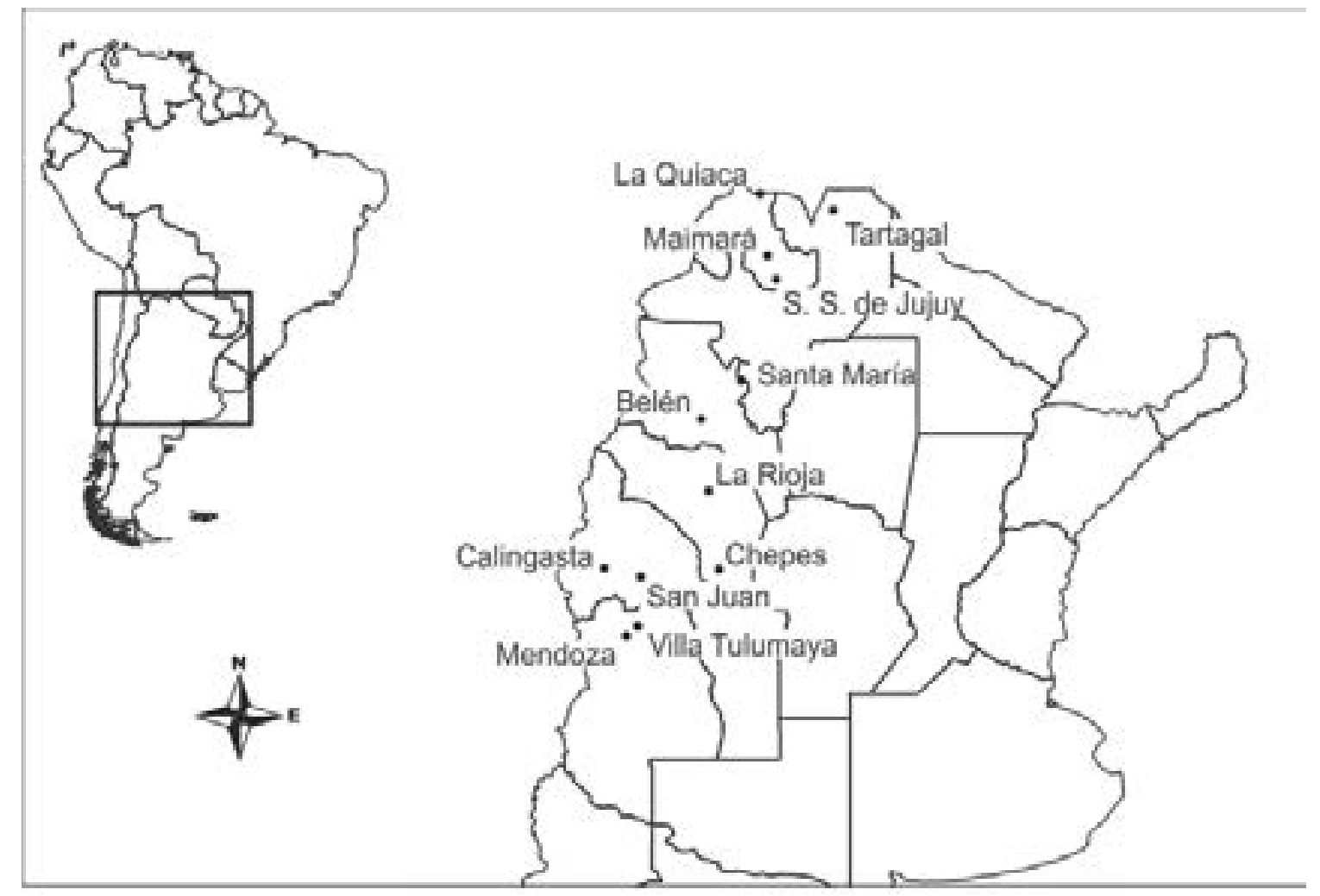

Figura 2.1. Localidades muestreadas. 


\begin{tabular}{|c|c|c|c|c|}
\hline Provincia & Localidad & $\mathrm{N}$ & Lugares de colecta (localidad) & $\mathrm{N}$ \\
\hline \multirow{3}{*}{ Salta } & \multirow{3}{*}{ Tartagal } & \multirow{3}{*}{258} & Hospital Juan Domingo Perón", (Tartagal) & 191 \\
\hline & & & Hospital —Dr. Lis Adolfo Güemes" (Aguaray) & 43 \\
\hline & & & Regimiento de Infantería de Monte 28, (Tartagal) & 24 \\
\hline \multirow{8}{*}{ Jujuy } & S.S. de Jujuy & 42 & Hospital —Pab Soria" (San Salvador de Jujuy) & 42 \\
\hline & \multirow{4}{*}{ La Quiaca } & \multirow{4}{*}{222} & Puesto de Salud (Santa Catalina) & 3 \\
\hline & & & Laboratorio Privado (La Quiaca) & 41 \\
\hline & & & Puesto de Salud (La Ciénaga) & 9 \\
\hline & & & Hospital —DrJorge Uro" (La Quiaca) & 169 \\
\hline & \multirow{3}{*}{ Maimará } & \multirow{3}{*}{192} & Hospital -DrJulio F. Campero" (Maimará) & 140 \\
\hline & & & Puesto de Salud(Purmamarca) & 35 \\
\hline & & & Puesto de Salud (Tumbaya) & 17 \\
\hline \multirow{4}{*}{ Catamarca } & \multirow{2}{*}{ Santa María } & \multirow{2}{*}{170} & Hospital Zonal -Lis A. Vargas" (Santa María) & 148 \\
\hline & & & Hospital de San José (San José) & 22 \\
\hline & \multirow{2}{*}{ Belén } & \multirow{2}{*}{161} & Hospital Zonal "Dr. Segundo Muñiz" (Belén) & 107 \\
\hline & & & Laboratorio Privado (Belén) & 54 \\
\hline \multirow{2}{*}{ La Rioja } & La Rioja & 236 & Hospital Regional -Dr. Erique Vera Barros" (La Rioja) & 236 \\
\hline & Chepes & 73 & Hospital -Lusi Pasteu”r (Chepes) & 73 \\
\hline \multirow{4}{*}{ San Juan } & \multirow{2}{*}{ San Juan } & \multirow{2}{*}{119} & Instituto de Hemoterapia del Hospital Rawson (San Juan) & 106 \\
\hline & & & Hospital San Roque (Jáchal) & 13 \\
\hline & \multirow{2}{*}{ Calingasta } & \multirow{2}{*}{71} & Hospital -Dr. Ado Cantoni” (Calingasta) & 66 \\
\hline & & & Centro de Salud (Tamberías) & 5 \\
\hline \multirow{3}{*}{ Mendoza } & Mendoza & 141 & Hospital -Lisi Carlos Lagomaggiore" (Mendoza) & 141 \\
\hline & Villa Tulumaya & 102 & Hospital —Dr. Dmingo Sícoli” (Villa Tulumaya) & 102 \\
\hline & Total & 1787 & & \\
\hline
\end{tabular}

Tabla 2.1. Localidades muestreadas, institución donde se realizó el muestreo y número de muestras.

En cuanto a los individuos...

Ya en el título de esta tesis se manifiesta la amplitud en cuanto al criterio de inclusión de muestras, efectuando un único recorte que excluye a las poblaciones extintas. Elegí el término —atual" y no el de -eosmopolita" ya que considero que la universalidad que pretende este último no es tal en la realidad. Los fenómenos migratorios propios de la región en estudio que fueron descriptos en la introducción, circunscriben los componentes poblacionales y es en tal sentido que se interpreta el origen continental de los haplogrupos, descartando por ejemplo un origen asiático reciente. El término actual posee otras ventajas adicionales: —atual" no niega aborigen ni niega europeo, ya que no faltaron casos en que los entrevistados se autorreconocieron tanto como pertenecientes a un pueblo originario como descendientes de europeos; —atual" elude las polisemias de los términos criollo o mestizo; a saber, al comienzo de la conquista criollo se decía de aquel de padres españoles, nacido en América, mientras que el mestizo era el resultante de la unión de español y nativo. Pero el devenir del 
tiempo y las sucesivas generaciones desdibujaron las delimitaciones. La categoría criollo recobró significado a partir del fenómeno de inmigración masiva europea de los siglos XIX y XX, distinguiendo a aquellos nacidos en América de los recién llegados y sus descendientes. Esta demarcación que resultaba útil unas tres generaciones atrás, hoy se vuelve confusa ya que muchos de los entrevistados declararon tener tanto abuelos criollos como inmigrantes de ultramar. Por lo tanto, puede ser difícil distinguir entre individuos de ascendencia criolla y/o europea. Sí es posible hacer esa diferenciación respecto de los linajes maternos y/o paternos. En esta tesis los linajes maternos serán considerados - dollos", cuando la información referida al último ancestro conocido por vía materna no dé cuenta de un origen europeo.

\subsection{INFORMACIÓN GENEALÓGICA}

En todas las localidades, excepto San Salvador de Jujuy, se realizó, junto con la toma de muestra biológica, una encuesta genealógica. Reuniéndose en total, 1.734 perfiles. A cada donante se le preguntó por nombres, apellido y lugar de nacimiento de los ascendientes hasta dos generaciones atrás. El cuestionario empleado puede leerse en el Anexo 7.1.1, y el formulario de consentimiento informado en el Anexo 7.1.2. La información obtenida se volcó en planillas Excel, y toda localidad de nacimiento informada fue codificada empleando un sistema jerárquico de tres letras para designar cada

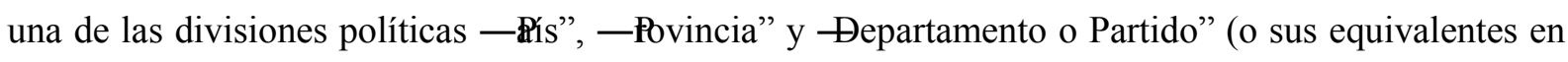
otros países). Una persona nacida en Tartagal, por ejemplo, tendría codificada esa información como —AR SAL GSM, Tartagal”. Esta codificación permitió agilizar la búsqueda centrada en el lugar de nacimiento del último ancestro materno conocido. Éste fue, en la mayoría de los casos la abuela materna, pero en caso de desconocimiento, se apeló al lugar de nacimiento de la madre o del donante mismo. Así se generó una tabla en la que cada muestra es asociada a una localidad correspondiente al lugar de procedencia de su linaje materno, y en base a eso se elaboró un criterio para considerar a cada muestra como -dcal" o no local". Este criterio es relativo a la localidad de toma de la muestra y considera a una muestra de origen local cuando el lugar de nacimiento del último ancestro por vía materna fue dentro de la misma provincia a la que pertenece la localidad muestreada, o dentro de cualquier provincia limítrofe, o bien en un país limítrofe a la provincia en que se encuentra la localidad muestreada.

\subsection{EXTRACCIÓN DE SANGRE O SALIVA}

La extracción de sangre fue realizada por el personal de cada hospital o centro de salud donde se llevara a cabo el muestreo. En el caso de que se tratara de pacientes ambulatorios que concurrieran a hacerse un análisis de sangre o de donantes voluntarios de sangre, procedíamos a la entrega de un tubo de $15 \mathrm{~mL}$ conteniendo $200 \mu 1$ de EDTA $0,5 \mathrm{M}$, donde el técnico colocaba una fracción de la sangre 
extraída. En los casos en que se acercaron personas interesadas en participar del proyecto pero que no necesitaban realizarse un análisis de sangre, pudieron optar por una extracción ad hoc o la toma de una muestra de saliva mediante un enjuague bocal con alto contenido de alcohol. Este último procedimiento resultó en menores cantidades de ADN obtenido y menor tiempo de preservación a campo, implicando en algunos casos la imposibilidad de obtener resultados durante el análisis de las muestras.

\subsection{EXTRACCIÓN DE ADN}

\subsubsection{PRIMERA ETAPA, A CAMPO.}

Entre 5 y $15 \mathrm{~mL}$ de sangre total fueron centrifugados a 4000 revoluciones por minuto, durante unos 20 minutos para lograr la separación de los componentes sanguíneos. De este modo se logra la conformación de una capa de linfocitos (buffy coat) que puede ser separada mecánicamente con una pipeta automática. Para eliminar los hematíes que eventualmente se co-extraen, el buffy coat es resuspendido en $10 \mathrm{~mL}$ de solución de lisis de glóbulos rojos (ver anexo 7.1.3 Soluciones de trabajo). Luego se precipitan los glóbulos blancos por centrifugado y de ser necesario, se repite la operación de lavado, previa resuspensión por pipeteo. Una vez eliminada la mayor proporción de glóbulos rojos, la fracción nucleada se conserva en $3 \mathrm{~mL}$ de solución de lisis de glóbulos blancos (anexo 7.1.3), condición en que las muestras son conservadas a campo y trasladadas hasta el IMBICE para su posterior procesamiento.

\subsubsection{SEGUNDA ETAPA, EN EL IMBICE}

A cada una de las muestras se agregó solución de lisis de glóbulos blancos hasta alcanzar un volumen final de $6 \mathrm{~mL}$. En este estado, las muestras fueron colocadas en un rotor durante 24 hs para homogeneizar el lisado. Posteriormente, se procedió a la precipitación de las proteínas con el agregado de $3 \mathrm{~mL}$ de $\mathrm{NaCl}$ 5,4 M. El precipitado de proteínas fue descartado y el sobrenadante transvasado a otro tubo donde los ácidos nucleicos fueron precipitados con 1 volumen de alcohol isopropílico. Se descartó el sobrenadante y el ADN fue lavado con etanol $70 \%$ y rehidratado en $1 \mathrm{~mL}$ de Tris-EDTA (TE).

\subsection{TIPIFICACIÓN DE HAPLOGRUPOS MITOCONDRIALES}

A lo largo del desarrollo de esta tesis fueron empleadas distintas estrategias metodológicas para diagnosticar haplogrupos. En primera instancia se recurrió a la técnica de PCR-RFLP que consiste en la amplificación de un segmento determinado del ADN por medio de la Reacción en 
Cadena de la Polimerasa (PCR por sus siglas en inglés) y la posterior digestión con enzimas de restricción que resulta en un polimorfismo en el largo de los fragmentos de restricción (RFLP por sus siglas en inglés) siguiendo un protocolo modificado a partir de Bailliet y col. (1994). Posteriormente se ensayó y comprobó la eficacia de las amplificaciones alelo-específicas, que no requieren del uso de enzimas. El protocolo desarrollado por Umetsu (2005) fue acondicionado para adaptarse a las características de nuestra población, cuyos resultados fueron presentados en Motti y col. (2009). Por último, se secuenció la Región Control en muestras que no habían sido previamente tipificadas para la región codificante. En estos casos, la asignación de haplogrupo está dada por la asociación comprobada de una serie de polimorfismos en la Región Control con los haplogrupos de interés (Bandelt y col. 2003; Tamm y col. 2007; Achilli y col. 2008; Perego y col. 2010).

Teniendo en cuenta la historia demográfica de la región en estudio, consideramos que la población actual es la resultante del encuentro de tres componentes continentales mayoritarios: la población originaria nativa americana, la población proveniente de Europa y Medio Oriente y también la población africana que fuera traída compulsivamente como mano de obra esclava. Es por esto que el análisis de los polimorfismos en el ADN mitocondrial se centró en la búsqueda de mutaciones diagnósticas de los clados propios de dichos continentes. Los linajes asignados a los haplogrupos A-D fueron considerados de origen nativo, mientras que aquellos asignados a los para-haplogrupos $\mathrm{L}(\mathrm{xM}, \mathrm{N})$ y $\mathrm{N}(\mathrm{xA}, \mathrm{B})$ fueron interpretados como aportes provenientes de África y de Eurasia occidental (Europa y Medio Oriente), respectivamente. Somos conscientes que este enfoque experimental entraña el riesgo de asignar un origen continental erróneo para algunos linajes, a saber:

- considerar como nativos aquellos linajes A-D que en realidad derivan de inmigrantes del este asiático, o incluso de países europeos y de Medio Oriente donde algunos de estos haplogrupos han sido descriptos esporádicamente en muy baja frecuencia (entre otros, véase los ejemplos de AlvesSilva y col. 2000, Brandstätter y col. 2007, Grzybowski y col. 2007, Haber y col. 2011);

-considerar como africanos a aquellos linajes $\mathrm{L}(\mathrm{xM}, \mathrm{N})$ que son genuinamente europeos (Cerezo y col. 2012);

-considerar como europeos o de Medio Oriente algunos clados de haplogrupo U6 que podrían en efecto haber ingresado desde el Africa sub-sahareana en tiempos coloniales.

La evidencia obtenida en el marco de esta tesis (encuestas genealógicas y secuencias de la Región Control), así como publicaciones de otros autores sobre poblaciones argentinas (Bobillo y col. 2010, Catelli y col. 2011), nos permiten aseverar que esos errores, de haber ocurrido, habrían tenido un impacto menor en las estimaciones de origen continental. A modo de ejemplo, nótese que Bobillo y col. (2010) detectaron sólo un linaje A-D de origen no americano en su muestra de 338 argentinos, de los cuales 189 fueron A-D. Del mismo modo, Catelli y col. (2011) hallaron dos casos de linajes A-D que en principio no parecen ser de origen americano en una muestra de 384 individuos. Al menos dos 
de estos casos parecen estar relacionados con ancestría reciente del este asiático, un hecho que hubiera sido fácilmente detectado en la encuesta genealógica.

\subsubsection{TIPIFICACIÓN MEDIANTE ANÁLISIS DE POLIMORFISMOS DE LONGITUD DE LOS}

\section{AMPLICONES Y DE LOS FRAGMENTOS DE RESTRICCIÓN}

Esta estrategia consistió en la amplificación secuencial de las muestras en busca de mutaciones diagnósticas de los haplogrupos en la región codificante. Esta metodología implica que una vez que fuera descubierta una de las mutaciones no se continuara con la búsqueda de las siguientes, ya que se las considera excluyentes. Inicialmente se analizaron las muestras para los polimorfismos diagnósticos de los haplogrupos A-D, y aquellas muestras no asignadas a un clado nativo fueron entonces analizadas para C10873T, una de las cinco transiciones que definen al súper-haplogrupo N. Los linajes no atribuidos a ninguno de estos haplogrupos fueron considerados en forma preliminar como pertenecientes al para-haplogrupo $\mathrm{L}(\mathrm{xM}, \mathrm{N})$, dada la baja probabilidad de la otra interpretación posible, esto es que fueran otros clados anidados dentro de M. La distribución de M se restringe a Oceanía y las porciones central, sureña y oriental de Asia, estando además presente bajo la forma del haplogrupo M1 en Europa, Medio Oriente y Norte de África (Olivieri et al. 2006). Las muestras inicialmente consideradas como miembros del clado $\mathrm{L}(\mathrm{xM}, \mathrm{N})$ fueron secuenciadas entre las posiciones $16024 \mathrm{y}$ 576 para confirmar y refinar su asignación (ver sección 2.6 Secuenciación).

El detalle de los cebadores y enzimas de restricción empleadas para determinar los haplogrupos se encuentra en la Tabla 2.2. Nótese que en algunos casos la digestión positiva es señal de la presencia de la mutación diagnóstica (ejemplo $+A l u \mathrm{I}$ para el haplogrupo $\mathrm{C}$ ), mientras que en otros casos es la ausencia de digestión la que indica la presencia de la mutación (-AluI para el haplogrupo D). Los cebadores empleados para generar los amplicones para diagnosticar A y B son aquellos descriptos en Bailliet y col. (1994), mientras que los restantes fueron diseñados para esta tesis utilizando Primer3 (http://frodo.wi.mit.edu/). El nuevo diseño de los fragmentos para analizar C y D tuvo en consideración la conveniencia de generar productos co-amplificables y co-digeribles de modo tal que tanto los amplicones como los fragmentos de digestión fueran fácilmente analizables en geles de agarosa.

Para los fragmentos correspondientes a los haplogrupos A, B, C y D se aplicaron las siguientes condiciones de amplificación: 2 minutos de desnaturalización inicial a $94^{\circ} \mathrm{C}$ y 35 ciclos de desnaturalización a $94^{\circ} \mathrm{C}$ por 1 minuto, hibridación a $55^{\circ} \mathrm{C}$ por 1 minuto y extensión a $72^{\circ} \mathrm{C}$ durante dos minutos, seguidos por una extensión final de 5 minutos. Para el fragmento correspondiente a $\mathrm{N}$ se mantienen iguales condiciones, excepto la temperatura de hibridación que fue de $60^{\circ} \mathrm{C}$.

Los fragmentos correspondientes a C y D fueron co-amplificados y co-digeridos ya que requieren de la misma enzima y el tamaño de los fragmentos permite una fácil resolución. Los fragmentos correspondientes a los haplogrupos A y B fueron amplificados en forma independiente. En todos los casos se incluyó un control negativo, conteniendo todos los reactivos necesarios para la PCR 
pero sin $\mathrm{ADN}$. Los productos de amplificación para los haplogrupos $\mathrm{A}, \mathrm{C}$ y $\mathrm{D}$ fueron verificados junto con un marcador de peso molecular en geles de agarosa al $2 \%$, teñidos con Bromuro de Etidio (Figuras 2.2 y 2.3). En el caso del haplogrupo B, el producto de amplificación fue corrido en geles de acrilamida al $6 \%$ (Figura 2.4).

\begin{tabular}{|l|l|l|l|l|l|}
\hline Hg & $\begin{array}{l}\text { Mutación } \\
\text { diagnóstica }\end{array}$ & Cebadores 5'-3' & $\begin{array}{l}\text { Enzima de } \\
\text { restricción }\end{array}$ & $\begin{array}{l}\text { Tamaño del } \\
\text { fragmento } \\
\text { amplificado }\end{array}$ & $\begin{array}{l}\text { Tamaño de } \\
\text { los } \\
\text { fragmentos } \\
\text { digeridos }\end{array}$ \\
\hline A & $663^{*} \mathrm{G}$ & $\begin{array}{l}\text { L-582 TGTAGCTTACCTCCTCAAAGC } \\
\text { H-745 TTGATCGTGGTGATTTAGAGG }\end{array}$ & HaeIII & $163 \mathrm{pb}$ & $81 / 82$ \\
\hline $\mathrm{B}$ & $\begin{array}{l}\text { Deleción } \\
9 \mathrm{pb} \text { Región } \\
\mathrm{V}\end{array}$ & $\begin{array}{l}\text { L-8209 CATCGTCCTAGAATTAATTCC } \\
\text { H-8304 CTTTACAGTGGGCTCTAGAGG }\end{array}$ & - & $87 \mathrm{o} 96 \mathrm{pb}$ & - \\
\hline $\mathrm{C}$ & $13263^{*} \mathrm{G}$ & $\begin{array}{l}\text { L-13128 CCCCCTAGCAGAAAATAGCC } \\
\text { H-13526 TCGATGATGTGGTCTTTGGA }\end{array}$ & AluI & $398 \mathrm{pb}$ & $135 / 263$ \\
\hline $\mathrm{D}$ & $5178^{*} \mathrm{~A}$ & $\begin{array}{l}\text { L-4983 CAAACCCAGCTACGCAAAATL } \\
\text { H-5325 TGATGGTGGCTATGATGGTG }\end{array}$ & AluI & $342 \mathrm{pb}$ & $147 / 195$ \\
\hline $\mathrm{N}$ & $10873^{*} \mathrm{~T}$ & $\begin{array}{l}\text { L-10621 CCCACTCCCTCTTAGCCAAT } \\
\text { H-10987 TGTGAGGGGTAGGAGTCAGG }\end{array}$ & MnlI & $366 \mathrm{pb}$ & $114 / 252$ \\
\hline
\end{tabular}

Tabla 2.2. Enzimas de restricción y polimorfismos utilizados para asignar el origen continental.

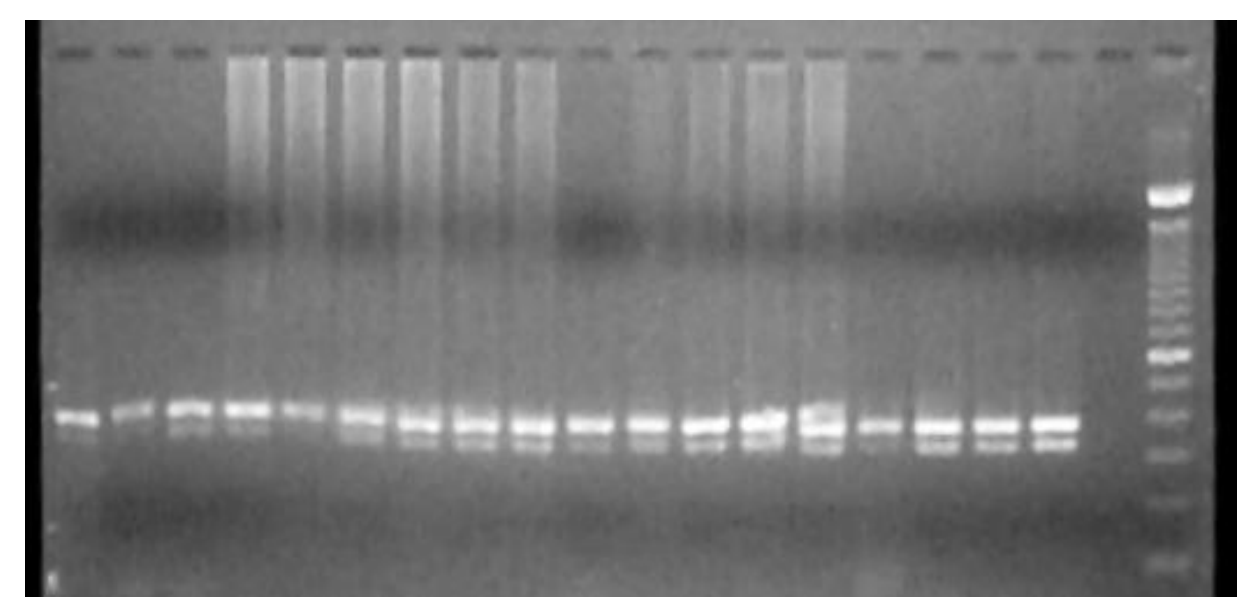

Figura 2.2. Visualización de los fragmentos co-amplificados para determinar los haplogrupos $C$ y D.

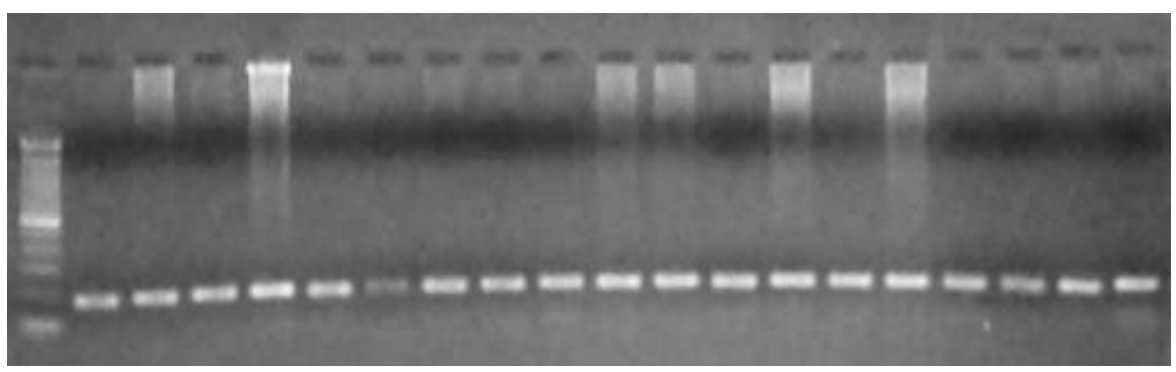

Figura 2.3. Visualización del fragmento amplificado para determinar el haplogrupo A. 


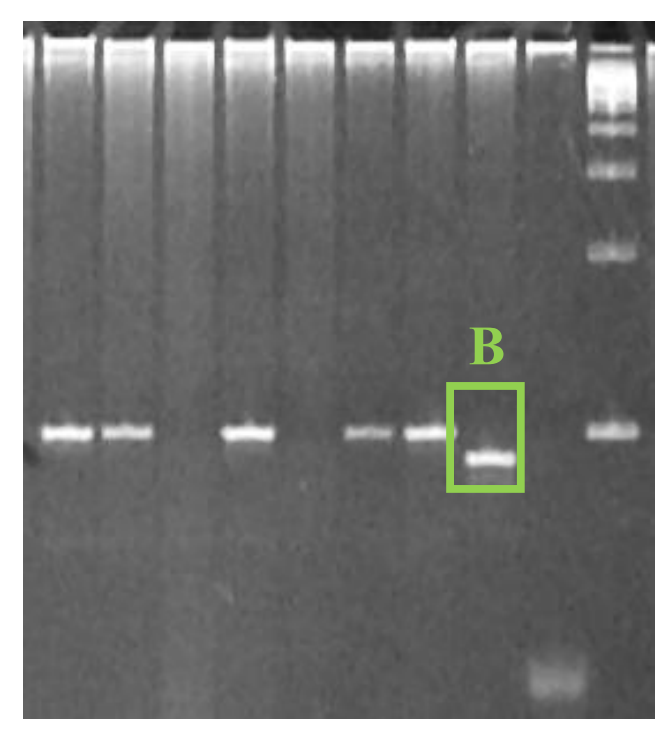

Figura 2.4. Visualización del fragmento amplificado para detectar la deleción de 9 pb en región $V$ (haplogrupo B).

Para el proceso de digestión se siguieron las indicaciones provistas por el proveedor de la enzima, empleando una unidad de enzima por muestra en un volumen final de $30 \mu \mathrm{L}$. Los productos de la digestión fueron sometidos a corridas electroforéticas en geles de agarosa al 2,5\% empleando un $0,5 \%$ de agarosa de bajo punto de fusión para aumentar el poder de resolución (Figuras 2.5 y 2.6).

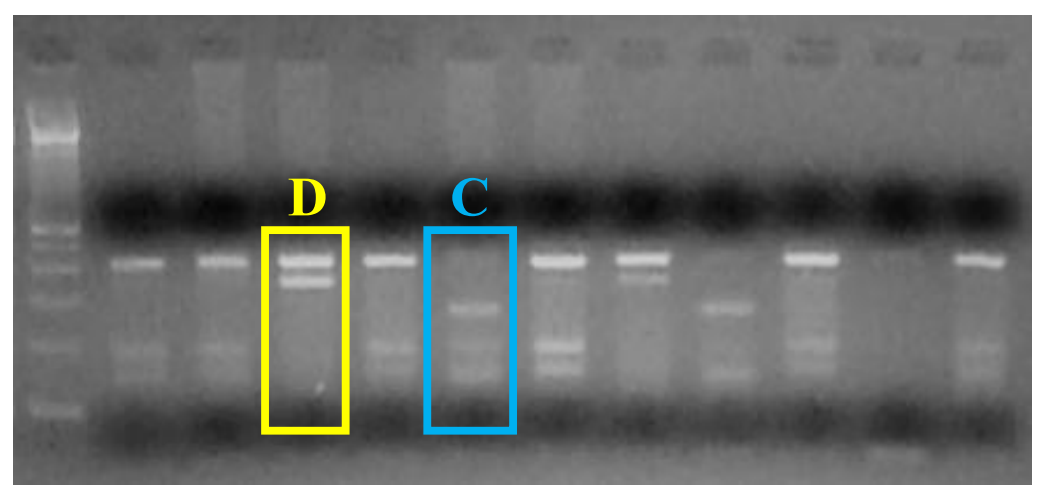

Figura 2.5. Visualización de los fragmentos resultantes luego de la digestión con AluI.

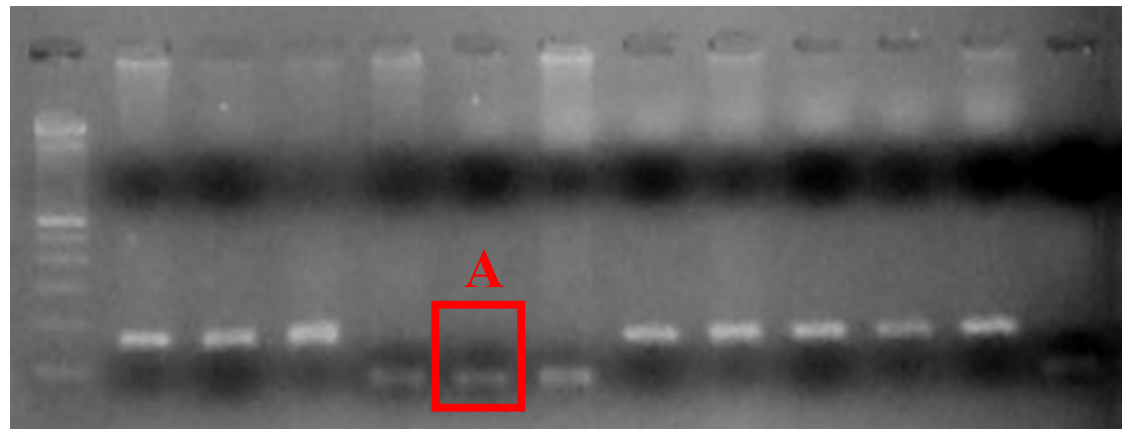

Figura 2.6. Visualización de los fragmentos resultantes luego de la digestión con HaeIII. 


\subsubsection{TIPIFICACIÓN MEDIANTE POLIMORFISMOS DE LONGITUD DE LOS PRODUCTOS DE} AMPLIFICACIÓN (APLP)

En esta estrategia cada polimorfismo es investigado mediante el empleo de tres cebadores, dos de los cuales son alelo-específicos y difieren fundamentalmente en su base del extremo 3', cuya posición coincide con la de la mutación investigada. Además de otras diferencias menores en su secuencia, uno de los cebadores posee una extensión variable de 1-7 nucleótidos en el extremo $5^{\prime}$ de modo que el producto de amplificación varía en su longitud según cuál de los dos cebadores haya intervenido.

Para esta tesis se seleccionaron, de entre los publicados por Umetsu y col. (2005), cinco tríos de cebadores cuyo análisis simultáneo permite analizar los clados de interés. Tres tríos interrogan mutaciones diagnósticas de los haplogrupos A, D y M8 (al que pertenecen los haplogrupos C y Z), mientras que los dos restantes caracterizan los macro-haplogrupos $\mathrm{M}$ y N. El haplogrupo B fue analizado independientemente tal como se describe en el apartado 2.5.1.

Dado que todas las amplificaciones de mutaciones de punto se generan en una única reacción de PCR múltiplex, este enfoque experimental tiene la virtud de economizar trabajo, reactivos y ADN, al tiempo que minimiza errores de asignación. Toda muestra asignable al haplogrupo A deberá también ser asignable al clado $\mathrm{N}$, mientras que aquellas pertenecientes a $\mathrm{C}$ o $\mathrm{D}$ deberán asimismo llevar el patrón de amplicones esperados para miembros del clado M. Esta técnica también tiene el potencial de detectar clados alóctonos de $\mathrm{M}$, así como de poner en evidencia la presencia de linajes asignables a $\mathrm{L}(\mathrm{xM}, \mathrm{N})$.

En la Tabla 2.3 se detallan las secuencias de los cebadores, indicando con letra minúscula las bases que generan una región de no apareamiento. Estas regiones son necesarias para homogeneizar la afinidad de ambos cebadores, en iguales condiciones de temperatura. Para lograr la co-amplificación de estas cinco regiones en una única reacción de PCR se ajustó la concentración de cada cebador mediante el método de prueba y error. Las condiciones de amplificación fueron: 2 minutos de desnaturalización inicial a $94^{\circ} \mathrm{C}$ y 35 ciclos de desnaturalización a $94^{\circ} \mathrm{C}$ por 1 minuto, hibridación a $52^{\circ} \mathrm{C}$ por 1 minuto y extensión a $72^{\circ} \mathrm{C}$ durante dos minutos, seguidos por una extensión final de 5 minutos.

El producto de amplificación fue visualizado en geles de poliacrilamida al $10 \%$. Se corrieron $4 \mathrm{uL}$ del producto de amplificación durante 3,5 horas a 163 voltios, y el gel fue luego teñido en solución de TBE 1x con Bromuro de Etidio o con Gel Red® (Figura 2.7). 


\begin{tabular}{|c|c|c|c|c|}
\hline & Cebadores & Secuencia & Concentración & $\begin{array}{l}\text { Tamaño } \\
\text { (Haplogrupo } \\
\text { detectado) }\end{array}$ \\
\hline \multirow{3}{*}{ M } & $\mathrm{F}-10400 * \mathrm{~T}$ & taattaTACAAAAAGGATTAGACTGtgC & $47 \mu \mathrm{M}$ & $149 \mathrm{pb}(\mathrm{M})$ \\
\hline & $\mathrm{F}-10400 * \mathrm{C}$ & & $47 \mu \mathrm{M}$ & $142 \mathrm{pb}$ \\
\hline & R-10400 & GAAGTGAGATGGTAAATGCTAG & $47 \mu \mathrm{M}$ & \\
\hline \multirow{3}{*}{$\mathrm{N}$} & F-10873*T & aatataCCTAATTATTAGCATCAaCССТ & $51 \mu \mathrm{M}$ & $136 \mathrm{pb}(\mathrm{N})$ \\
\hline & F-10873*C & CCTAATTATTAGCATCATtCCC & $64 \mu \mathrm{M}$ & $130 \mathrm{pb}$ \\
\hline & R-10873 & tGGTAtGAGTCAGGTAGTTAG & $64 \mu \mathrm{M}$ & \\
\hline \multirow{3}{*}{$\mathrm{D}$} & F-5178*A & tgatcaaCGCACCTGAAACAAGA & $44 \mu \mathrm{M}$ & $107 \mathrm{pb}(\mathrm{D})$ \\
\hline & $\mathrm{F}-5178 * \mathrm{C}$ & gTCGCACCTGAAgCAAGC & $32 \mu \mathrm{M}$ & $102 \mathrm{pb}$ \\
\hline & R-5178 & CCCATTTGaGCAAAAAGCC & $32 \mu \mathrm{M}$ & \\
\hline \multirow{3}{*}{ M8 } & $\mathrm{R}-15487 * \mathrm{~T}$ & gtcttGGTCGCCTAGGAaGTCA & $25 \mu \mathrm{M}$ & $70 \mathrm{pb}(\mathrm{M} 8)$ \\
\hline & $\mathrm{R}-15487 * \mathrm{~A}$ & tGGTCGCCTAGGAGtTCT & $45 \mu \mathrm{M}$ & $66 \mathrm{pb}$ \\
\hline & F-15487 & СТТАСТТСТСТТССТТСТСТСС & $25 \mu \mathrm{M}$ & \\
\hline \multirow{3}{*}{ A } & F-1736*A & taaAGCCAAACCATTTtCCCAA & $28 \mu \mathrm{M}$ & $55 \mathrm{pb}$ \\
\hline & $\mathrm{F}-1736^{*} \mathrm{G}$ & AGCCAAACCATTTAtCCAG & $28 \mu \mathrm{M}$ & $52 \mathrm{pb}(\mathrm{A})$ \\
\hline & R-1736 & aCCAGGTTTCAATTTCTATCG & $28 \mu \mathrm{M}$ & \\
\hline
\end{tabular}

Tabla 2.3. Cebadores empleados para la amplificación alelo-específica.

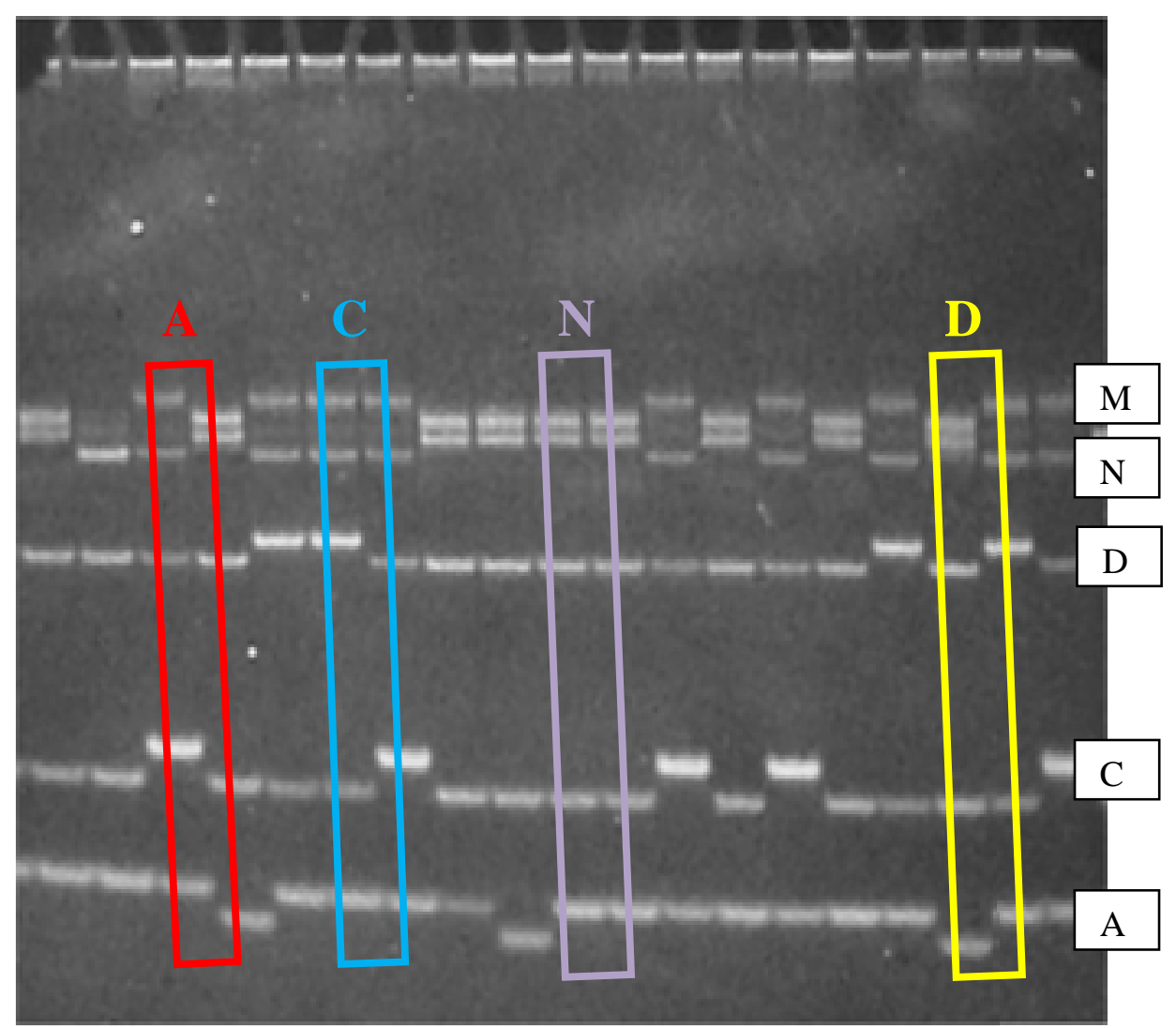

Figura 2.7. Co-amplificación alelo específica, indicando la determinación de haplogrupos. 


\subsubsection{ASIGNACIÓN MEDIANTE SECUENCIACIÓN DE LA REGIÓN CONTROL}

La asociación entre mutaciones en la región codificante que definen a los haplogrupos americanos y haplotipos en la Región Control fue descripta en el trabajo de Torroni y col. (1993). En algunas muestras que no fueron analizadas mediante PCR-RFLP ni mediante APLP, se estableció el haplogrupo de pertenencia siguiendo a Bandelt y col. (2003) y Tamm y col. (2007) para los haplogrupos americanos (Tabla 2.4), y se empleo Haplogrep (Kloss-Brandstaetter y col. 2010) y Phylotree (van Oven y Kayser, 2008) para los linajes alóctonos.

\begin{tabular}{|l|l|l|}
\hline \multirow{2}{*}{ Haplogrupo } & \multicolumn{2}{|l|}{ Diferencias respecto de la SRCr } \\
\cline { 2 - 3 } & Porción 5' Región Control & Porción 3' Región Control \\
\hline A2 & $(16111) 16223162901631916362$ & $(64) 73146153235263315+C$ 522-523d \\
\hline B2 & 16183 C 1618916217 & $73263315+C$ C 499 \\
\hline C1b & 16223162981632516327 & $73249 d 263290-291 d$ 315+C 489 493 522-523d \\
\hline C1c & 1593016223162981632516327 & $73249 d 263290-291 d$ 315+C 489 \\
\hline C1d & 1605116223162981632516327 & $73194249 d 263290-291 d$ 315+C 489 522-523d \\
\hline C4c & 162231629816327 & $73249 d 263315+C 489$ \\
\hline D1 & 162231632516362 & $73263315+C 489$ \\
\hline D4h3a & 1622316241163011634216362 & $73152263315+C 489$ \\
\hline
\end{tabular}

Tabla 2.4. Mutaciones de la Región Control asociadas a los haplogrupos americanos.

No se indican las variantes de longitud alrededor de posición SCRr 309. Las variantes entre paréntesis pueden no estar presentes.

\subsubsection{Secuenciación}

Un subconjunto de muestras de cada población fue secuenciado. En todos los casos se obtuvo información de la Región Control completa (posiciones 16024 y 576). En la mayoría de los casos, la lectura se extendió más allá de ambos extremos, incluyendo las bases entre las posiciones 15898 y 628. Esta extensión del rango permitió la identificación del subhaplogrupo $\mathrm{C} 1 \mathrm{c}$, definido por una transición en la posición 15930. La información detallada del rango de lectura correspondiente a cada muestra puede encontrarse en el anexo 7.2.2 Secuencias.

Esta labor fue realizada por investigadores colaboradores de un laboratorio estatal de EE.UU. como parte de un convenio de colaboración, según las condiciones descriptas en el trabajo de Brandstatter y col. (2004), que se transcriben a continuación.

Las amplificaciones fueron llevadas a cabo usando los cebadores F15878 (AAA TGG GCC TGT CCT TGT AG) y R649 (TTT GTT TAT GGG GTG ATG TGA) o F15971 (TTA ACT CCA CCA TTA GCA CC) y R599 (TTG AGG AGG TAA GCT ACA TA). La Reacción en Cadena de la 
Polimerasa automatizada fue realizada en la estación de trabajo robótica MWG RoboAmp 4200. Cada reacción fue llevada a cabo en $50 \mu \mathrm{l}$ de volumen final, que incluyó: $1 \times$ de buffer de reacción AmpliTaq Gold (Applied Biosystems), $200 \mu \mathrm{M}$ de cada dNTP, $200 \mathrm{nM}$ de cada cebador y, ya sea 5 unidades de los cebadores F15878 y R649 o 2,5 unidades de F15971 y R599. Las condiciones de ciclado para los cebadores $\mathrm{F} 15878 / \mathrm{R} 649$ fueron de $95^{\circ} \mathrm{C}$ durante 10 minutos y luego 36 ciclos de $94^{\circ} \mathrm{C}$ por 1 minuto, $56^{\circ} \mathrm{C}$ por 1 minuto y $72^{\circ} \mathrm{C}$ por 2 minutos, mientras que para los cebadores F15971/R599 fueron de $95^{\circ} \mathrm{C}$ durante 10 minutos y luego 36 ciclos de $94^{\circ} \mathrm{C}$ por 30 segundos, $56^{\circ} \mathrm{C}$ por 30 segundos y $72^{\circ} \mathrm{C}$ durante 1 minuto. Los productos del PCR fueron purificados con exonucleasa I ( 2.5 unidades) y fosfatasa alcalina de camarón (5 unidades) y luego secuenciados con el kit de secuenciación Big Dye Terminator Cycle (Applied Biosystems, Foster City, CA) en el MWG RoboAmp 4200. Las reacciones de secuenciación fueron analizadas con Applied Biosystems 377 o con Applied Biosystems 3100 DNA Analyzer, llevando a cabo purificaciones con columnas AGTC (Edge Biosystems, Gaithersburg, $\mathrm{MD})$. Los cebadores empleados para la secuenciación, en adición a los utilizados para la amplificación fueron: F16190 (CCC CAT GCT TAC AAG CAA GT), F16450 (GCT CCG GGC CCA TAA CAC TTG), F15 (CAC CCT ATT AAC CAC TCA CG), F314 (CCG CTT CTG GCC ACA GCA CT), R274 (TGT GTG GAA AGT GGC TGT GC), R16400 (GTC AAG GGA CCC CTATCT GA) y R16175 (TGG ATT GGG TTT TTA TGT A).

\subsubsection{Alineamiento}

Las secuencias fueron alineadas con el programa MEGA 4.0 (Tamura y col. 2007), mediante el algoritmo ClustalW y luego corregidas manualmente siguiendo el criterio filogenético de Bandelt y Parson (2008). Para uniformizar el tamaño de las secuencias, se efectuó un corte para incluir sólo el fragmento comprendido entre las posiciones 16024 y 576 (Región Control completa). Se descartaron los polimorfismos de longitud en los segmentos poli-C en torno a las posiciones 16193, 310 y 573, así como también las variaciones correspondientes al microsatélite AC en la Región Hipervariable III.

\subsection{ANÁLISIS DE VARIABILIDAD INTRAPOBLACIONAL}

Teniendo en cuenta la secuencia de nucleótidos entre las posiciones 16024 y 576, se generó un archivo en formato FASTA con el programa MEGA4. Este archivo fue luego modificado con un procesador de texto para reemplazar los caracteres ambiguos $M, N$, R e Y, por el signo -? ya que éste es un requisito para que los datos puedan ser procesados por el programa DNAsp (Rozas y col. 2003). Este programa permite la definición de múltiples conjuntos de secuencias y se utilizó para generar los conjuntos poblacionales así como también conjuntos que incluyeron sólo a las muestras A-D dentro de cada población. Los datos así organizados fueron exportados en formato acorde al programa Arlequín versión 3.5.1.2 (Excoffier y col. 2005), con el que se llevaron a cabo los test estadísticos que se 
describen a continuación. Para todos ellos la probabilidad de cada valor se calculó por remuestreo por permutación en base a 100.000 permutaciones, estableciéndose el valor de significancia en $\mathrm{p}<0,05$.

\subsubsection{DIVERSIDAD HAPLOTÍPICA $(H)$}

La diversidad haplotípica se define como la probabilidad de que dos haplotipos, seleccionados al azar en una muestra, sean diferentes entre sí. Mientras mayor sea esta probabilidad, más diversa será la muestra y, por ende, también la población de la que fue tomada. Se utilizó la fórmula de Nei (1987):

$$
\hat{H}=\frac{n}{n-1}\left(1-\sum_{i=1}^{k} p_{i}^{2}\right)
$$

siendo $n$ el número de alelos en la muestra, $k$ el número de haplotipos y $p_{i}$ la frecuencia de los $i$ haplotipos.

\subsubsection{DiVERSIDAD NUCLEOTÍDICA $(\Pi)$}

Debido a que un haplotipo puede diferir de otro ya sea por una sola mutación o por muchas de ellas, una medida de la variabilidad con mayor poder de resolución es la Diversidad Nucleotídica, definida como la probabilidad de que dos nucleótidos homólogos elegidos al azar sean diferentes.

La diversidad nucleotídica fue calculada en base al algoritmo de Tamura-Nei (1993) que tiene en cuenta una tasa de sustitución diferencial para transiciones y transversiones así como también según se trate de purinas o pirimidinas. Se utilizó, tal como sugieren los autores en el mencionado trabajo, un parámetro gamma de corrección de 0,11. Esta corrección se aplica cuando no se asume una tasa mutacional uniforme para todos los sitios, como es el caso de la Región Control del ADN mitocondrial.

\subsubsection{NÚMERO MEDIO DE DIFERENCIAS NUCLEOTÍDICAS ENTRE PARES DE HAPLOTIPOS (NEI,} 1987)

Consiste en el promedio de diferencias nucleotídicas entre todos los pares posibles de haplotipos de una muestra, según la fórmula:

$$
\hat{\pi}=\frac{n}{n-1} \sum_{i=1}^{k} \sum_{j=1}^{k} p_{i} p_{j} \hat{d}_{i j}
$$

donde $d_{i j}$ es una estimación del número de mutaciones ocurridas desde la divergencia entre los haplotipos $i$ y $j, k$ es el número de haplotipos, $p_{i}$ es la frecuencia del haplotipo $i$, y $n$ es el tamaño muestral. 


\subsection{TEST EXACTO DE DIFERENCIACIÓN POBLACIONAL}

Para evaluar estadísticamente la existencia de diferencias significativas entre pares de poblaciones se empleó el Test exacto de diferenciación poblacional, desarrollado por Raymond y Rousset (1995) y Goudet et al. (1996), que consiste en probar la hipótesis de distribución de los individuos al azar entre pares de poblaciones.

\subsection{ANÁLISIS DE DIFERENCIACIÓN INTERPOBLACIONAL}

\subsubsection{CONSTRUCCIÓN DE HIPÓTESIS FILOGENÉTICAS: DEFINICIÓN DE LINAJES}

Cada haplogrupo americano puede ser subdividido en sublinajes monofiléticos o clados. Debido a que los datos para esta tesis se restringen a la Región Control, el carácter monofilético de los linajes es una hipótesis basada en la presencia compartida de una o varias mutaciones. Para definirlos se construyeron manualmente redes medianas de haplotipos por haplogrupo, teniendo en cuenta a las secuencias generadas en esta tesis cuyo rango de lectura cubre a toda la Región Control. Los cubos e hipercubos generados por las mutaciones recurrentes fueron resueltos teniendo en cuenta criterios globales como la escala de sitios calientes publicada por Soares y colaboradores (2009), así como también criterios específicos para cada haplogrupo, en base a observaciones de datos publicados y propios. Los polimorfismos de longitud de los segmentos poli-C y del microsatélite AC fueron considerados, indicándolos como paralelismos o reversiones cuando fue necesario. Un linaje es definido toda vez que una mutación es compartida por al menos dos individuos y dicha mutación no reviste carácter homoplásico al interior del haplogrupo, o cuando las mutaciones compartidas son dos o más, desestimando en este último caso la condición homoplásica si la hubiere. También se consideraron linajes válidos a aquellos con evidente coherencia geográfica, aún cuando se diera la posibilidad de recurrencia aislada de la o las mutaciones que lo definen.

\subsubsection{ANÁlisis De COMPONENTES PRinCiPALES}

Una vez definidos los linajes potencialmente monofiléticos, éstos fueron considerados como variables independientes cuyos valores de frecuencia caracterizan a cada localidad. Se desestimaron los haplotipos que no pudieron ser identificados como pertenecientes a alguno de dichos linajes (haplotipos no asignados) debido a que en ellos no es posible constatar un vínculo filogenético más allá del que corresponde a cada linaje fundador. Luego, se realizó un Análisis de Componentes Principales con el programa NTSYSpc Versión 2.11S (Rohlf, 2000), a fin de generar un ordenamiento capaz de representar en dos dimensiones las relaciones de similitud y diferenciación entre las localidades analizadas. 


\subsubsection{IDENTIFICACIÓN DE BARRERAS GENÉTICAS}

Teniendo en cuenta a las frecuencias de linajes definidos como variables, se estimaron las distancias de Nei entre pares de localidades con el programa NTSYSpc y en base a esa matriz se identificaron barreras genéticas mediante el programa Barriers 2.2 (Manni y col. 2004). Este programa realiza una aproximación geométrica computacional que fracciona el área geográfica en cuestión atribuyendo un área específica a cada punto de muestreo, de esta manera quedan definidos los límites de cada localidad y se definen a aquellas localidades que comparten un límite como adyacentes. A continuación se identifican los pares de localidades adyacentes que presentan mayor diferenciación y comienzan a trazarse las barreras genéticas. Una vez iniciada, la barrera continúa por la línea de mayor debilidad, es decir por aquel límite continuo que ostente la mayor diferenciación entre las localidades que separa. De esta manera, el orden de importancia de las barreras identificadas radica en la diferenciación entre el par de localidades que lo inició y no necesariamente entre cada par de localidades a uno y otro lado de la barrera.

\subsubsection{ANÁLISIS DE DISTRIBUCIÓN DE LINAJES A NIVEL SUDAMERICANO}

\subsubsection{Compilación de secuencias sudamericanas}

Las secuencias de ADN mitocondrial publicadas al 20/04/2011 fueron compiladas en una base de datos Excel en donde constó la localidad de pertenencia, el número de muestras A-D y el rango de lectura. También se incluyeron datos inéditos generados por el Laboratorio de Genética Molecular Poblacional del IMBICE. Se excluyeron aquellas secuencias publicadas cuya referencia geográfica resultaba extremadamente vaga como por ejemplo —aorígenes de Brasil”, así como aquellas cuyo punto de muestreo acusaba un $\mathrm{N}$ muy bajo (menor a 20) y cuando dicho punto no podía ser reunido con otro por encontrarse en una zona con mayor resolución en la definición de puntos de referencia [por ejemplo Tucumán $n=9$ de Tamm y col. (2007)]. Tampoco se tuvieron en cuenta secuencias descriptas por características especiales que no contaban con una referencia del total de muestras que fue necesario analizar para su hallazgo, por ejemplo en el caso de trabajos de genética médica que informan casos patológicos o cuando el trabajo versa en linajes específicos como las secuencias con 16178 en Dornelles y col. (2005) o el linaje C1d en Perego y col. (2010). Estas secuencias no fueron tenidas en cuenta porque no es posible establecer su frecuencia a nivel poblacional.

\subsubsection{Definición de puntos geográficos}

A partir de la base de datos generada, las secuencias fueron ordenadas por región. Se privilegió un criterio geográfico y no étnico para el agrupamiento de las muestras, ya que éste permite incluir a todas las muestras con linaje materno nativo, más allá de la identificación étnica de los 
individuos. Las localidades correspondientes al muestreo se consideraron como puntos independientes, mientras que otras localidades fueron agrupadas, generándose un punto de referencia artificial de ubicación intermedia. Esta decisión metodológica se tomó en base a la necesidad de mantener un número de muestras elevado para cada punto y también debido a que en algunos de los trabajos tomados como fuente no hay precisión respecto del punto de muestreo.

Fue necesario definir distintos conjuntos de puntos geográficos para analizar la distribución de linajes definidos por mutaciones en la RHVI, RHVII y la Región Control no comprendida por estas regiones, respectivamente. Esto es debido a que existe menor número de muestras con mayor rango de secuenciación y fue necesario en algunos casos considerar regiones geográficas más amplias para poder mantener un $\mathrm{N}$ superior a 20. Las coordenadas correspondientes a los puntos geográficos fueron establecidas mediante la digitalización de puntos en el mapa base, mediante el programa Surfer 8 (Golden Software, 2002).

\subsubsection{Interpolación de frecuencias poblacionales}

Para cada punto geográfico se determinó el número de muestras A-D correspondiente y en base al mismo, se calcularon las frecuencias de cada linaje. La interpolación de las frecuencias se realizó con el algoritmo de Kriging en el programa Surfer 8. 


\section{CAPÍTULO III: RESULTADOS}

Los resultados se presentan articulados en dos ejes que se corresponden con los principales objetivos de esta tesis, a saber:

-Probar que es posible acceder al conocimiento de los linajes maternos nativos, a través del estudio de la población actual, al menos para el territorio que abarca el estudio.

-Analizar la distribución geográfica de linajes nativos.

Para alcanzar el primer objetivo, analizamos dos fuentes independientes de información que ofrecen distintos niveles de aproximación a la problemática: por un lado la tipificación de mutaciones diagnósticas en el ADN mitocondrial permite asignar un origen continental a los linajes discriminando entre los componentes provenientes de América, África subsahariana y el oeste de Eurasia. Pero para acceder al segundo objetivo es necesario no sólo probar el carácter local a nivel continental, sino regional. Con una menor profundidad temporal y un menor nivel de confiabilidad ya que apela a la memoria individual, contamos con la información genealógica suministrada por cada donante acerca del lugar de nacimiento del último ancestro conocido por vía materna (UACM). Como contrapartida también analizo el lugar de nacimiento del último ancestro conocido por vía paterna (UACP).

El segundo ítem supone un paso metodológico previo que consiste en la definición de linajes en base a la presencia de mutaciones diagnósticas en la Región Control. Luego, se analiza en contexto sudamericano, la distribución espacial de las frecuencias de los linajes definidos.

\subsection{ORIGEN DE LOS LINAJES MATERNOS}

Los seres humanos nos desplazamos, pertenecemos a una especie que ha colonizado todos los continentes y ambientes a excepción de la Antártida. Por eso, si nos preguntamos acerca de la continuidad local de un pueblo, debemos precisar a qué nivel de profundidad temporal queremos acceder. En el nivel más profundo, todos los linajes humanos se remiten al continente africano, por lo que fuera de éste todos serían necesariamente alóctonos. Sin llegar a tal extremo y atendiendo a la diferenciación de linajes a nivel continental, podemos distinguir con suficiente claridad, movimientos migratorios recientes intercontinentales. Conociendo la información histórica sobre los procesos de poblamiento de la Argentina, este punto no genera mayor controversia y es abordado a través de la identificación de mutaciones diagnósticas para los haplogrupos propios de América, África subsahariana y el oeste de Eurasia.

Ahora bien, América es un continente muy amplio, con conocidas variaciones climáticas, ecológicas y culturales, por lo que no basta con una definición continental de lo local. Surge la cuestión de distinguir regionalmente el origen de las muestras americanas. Distinguir diferencias regionales a nivel genético constituye el segundo objetivo principal de esta tesis, por lo que a priori, el 
origen local de las muestras debe ser abordado desde otras fuentes de información. Del siglo XVI a esta parte existen fuentes escritas, con mayor o menor precisión, que documentan el volumen y el sentido de los desplazamientos humanos. Contamos además con una fuente directa de información proporcionada por cada donante, referida al lugar de nacimiento propio y de sus ancestros, la cual se analiza bajo el ítem fnformación genealógica". La lista completa de muestras analizadas, asociada al haplogrupo mitocondrial definido y al lugar de nacimiento del último ancestro materno conocido se encuentra en el Anexo 7.2.1.

\subsubsection{HAPLOGRUPOS MITOCONDRIALES}

A nivel global, la mayor frecuencia corresponde a linajes nativos de América (90, 2\%). Dentro de la fracción alóctona un cuarto está constituido por linajes africanos y el resto por los linajes euroasiáticos (Tabla 3.1). En líneas generales la tendencia es similar en todas las localidades, sin embargo, un test exacto de diferenciación poblacional (Raymond y Rousset, 1995) muestra que existen diferencias significativas en cuanto a los aportes relativos continentales entre pares de poblaciones (Tabla 3.2).

\begin{tabular}{|c|c|c|c|c|}
\hline & \multirow[b]{4}{*}{$\mathbf{N}$} & \multicolumn{3}{|c|}{ Origen continental } \\
\hline & & América & $\begin{array}{c}\text { Europa y Medio } \\
\text { Oriente }\end{array}$ & $\begin{array}{c}\text { África } \\
\text { Subsahariana }\end{array}$ \\
\hline & & \multicolumn{3}{|c|}{ Clados } \\
\hline & & A, B, C y D & $\mathbf{N x}(A, B)$ & $\operatorname{Lx}(\mathbf{M}, \mathbf{N})$ \\
\hline Mendoza & 141 & 71,63 & 21,28 & 7,09 \\
\hline Villa Tulumaya & 102 & 79,41 & 14,71 & 5,88 \\
\hline San Juan & 119 & 83,19 & 13,45 & 3,36 \\
\hline Calingasta & 71 & 92,96 & 2,82 & 4,23 \\
\hline Chepes & 73 & 86,30 & 13,70 & 0,00 \\
\hline La Rioja & 236 & 82,20 & 13,98 & 3,81 \\
\hline Belén & 161 & 92,55 & 3,73 & 3,73 \\
\hline Santa María & 170 & 94,12 & 4,71 & 1,18 \\
\hline Jujuy & 42 & 97,62 & 0,00 & 2,38 \\
\hline Maimará & 191 & 98,95 & 1,05 & 0,00 \\
\hline Tartagal & 258 & 97,29 & 1,94 & 0,78 \\
\hline La Quiaca & 222 & 98,20 & 1,35 & 0,45 \\
\hline TOTAL & 1.787 & 90,26 & 7,28 & 2,46 \\
\hline
\end{tabular}

Tabla 3.1. Origen continental de los haplogrupos mitocondriales, en porcentaje por localidad. 


\begin{tabular}{|l|c|c|c|c|c|c|c|c|c|c|c|c|}
\cline { 2 - 13 } \multicolumn{1}{c|}{} & MZA & VT & SJN & CAL & CHE & LRJ & BEL & SMA & JUJ & MM & TTG & LQ \\
\hline MZA & & - & - & + & + & + & + & + & + & + & + & + \\
\hline VT & - & & - & + & - & - & + & + & + & + & + & + \\
\hline SJN & - & - & & + & - & - & + & + & + & + & + & + \\
\hline CAL & + & + & + & & + & + & - & - & - & + & - & - \\
\hline CHE & + & - & - & + & & - & + & + & + & + & + & + \\
\hline LRJ & + & - & - & + & - & & + & + & + & + & + & + \\
\hline BEL & + & + & + & - & + & + & & - & - & + & - & + \\
\hline SMA & + & + & + & - & + & + & - & & - & + & - & - \\
\hline JUJ & + & + & + & - & + & + & - & - & & - & - & - \\
\hline MM & + & + & + & + & + & + & + & + & - & & - & - \\
\hline TTG & + & + & + & - & + & + & - & - & - & - & & - \\
\hline LQ & + & + & + & - & + & + & + & - & - & - & - & \\
\hline
\end{tabular}

Tabla 3.2. Test exacto de diferenciación poblacional entre pares de poblaciones según el origen continental de los linajes $-=p>0,05 ; \quad+=p<0,05$.

En un espacio de dos dimensiones donde las abscisas representan a la fracción europea y las ordenadas a la fracción africana, puede apreciarse la dispersión de las localidades (Figura 3.1). Las localidades de Jujuy, La Quiaca, Maimará, Santa María y Tartagal presentan niveles bajos en ambas categorías, mientras que Belén y Calingasta mantienen bajos porcentajes de linajes europeos pero aumenta la contribución relativa de linajes africanos, que superan el $3 \%$. La localidad de Chepes presenta el caso contrario, ya que no se observan linajes africanos, pero la fracción europea asciende a 13,7 \%. La Rioja y San Juan se sitúan en el centro de la distribución con porcentajes de europeos similares a Chepes (entre 10 y $15 \%$ ) y porcentajes de africanos similares a Belén y Calingasta (entre 3 y 5 \%). Villa Tulumaya se reúne con La Rioja, San Juan y Chepes en cuanto a los linajes europeos, pero se distingue por un mayor porcentaje de linajes africanos que superan el $5 \%$. Por último, Mendoza es la localidad con mayor porcentaje de linajes alóctonos; en cuanto a los africanos es similar a Villa Tulumaya pero es en el porcentaje de linajes de Europa y Oriente Medio, donde ésta localidad se diferencia sustancialmente del resto, superando el $20 \%$, en coincidencia con lo esperado según los datos históricos referidos a la distribución diferencial por regiones de la inmigración europea de fines del siglo XIX y principios del XX. 


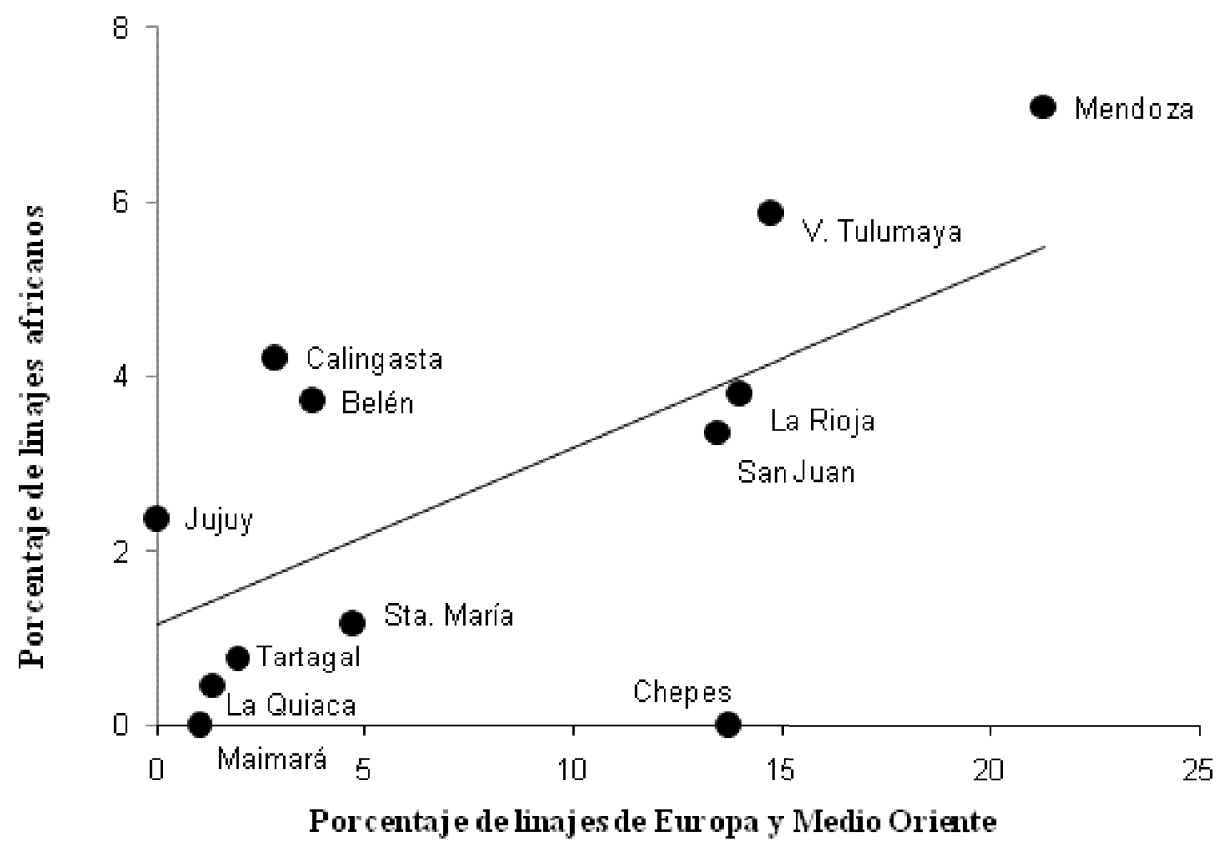

Figura 3.1. Comparación de las localidades en base al porcentaje de linajes alóctonos.

La conformación de estos grupos no se ajusta estrictamente a demarcaciones provinciales ni tampoco puede generalizarse que las diferencias obedecen a la oposición ciudad capital vs. localidad del interior, ya que Jujuy no se agrupa con ninguna otra ciudad capital. La asociación entre el porcentaje de linajes africanos y euroasiáticos es muy baja (coeficiente de correlación = 0,62), pero sí puede encontrarse una asociación entre cada una de estas variables y la latitud en que se ubican las poblaciones (coeficiente de correlación entre el porcentaje de haplogrupos N(xA,B) y la latitud= 0,82**, Figura 3.2; coeficiente de correlación entre el porcentaje de haplogrupos L(xM,N) y la latitud= 0,71**, Figura 3.3).

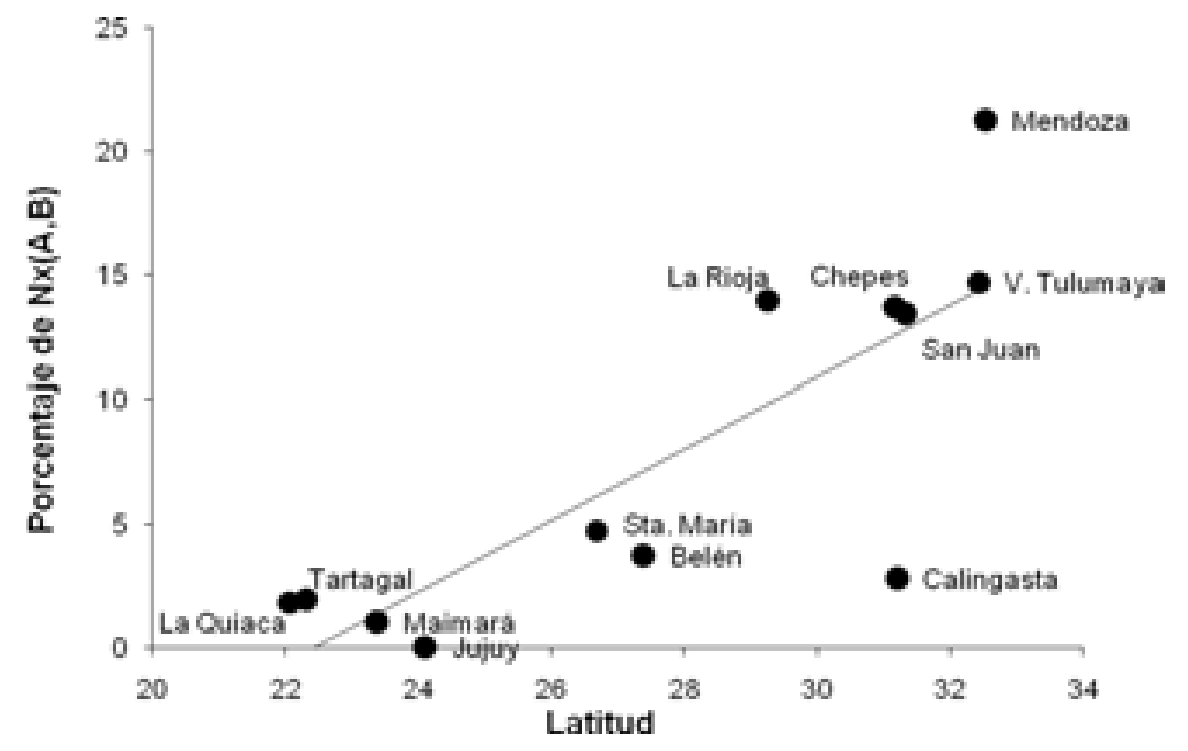

Figura 3.2. Correlación entre la latitud y el porcentaje de haplogrupos $N x(A, B)$ 


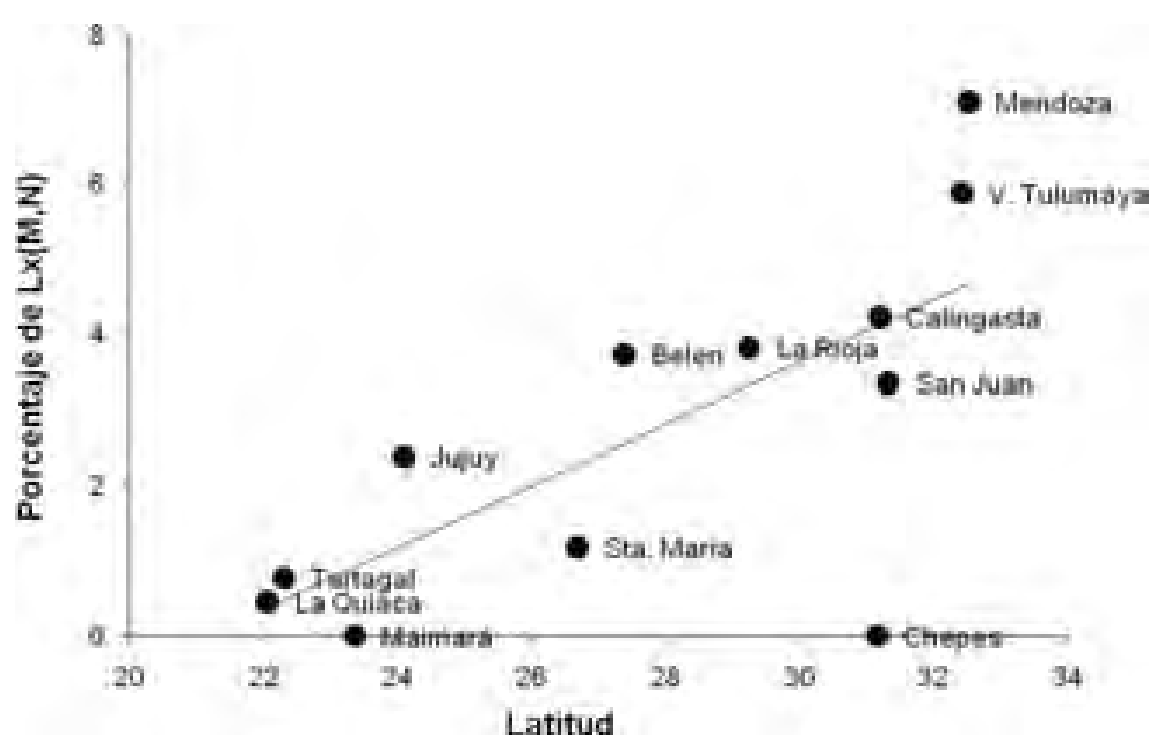

Figura 3.3. Correlación entre la latitud y el porcentaje de haplogrupos $L x(M, N)$

De modo que el criterio más apropiado para explicar los datos observados es la diferenciación Norte-Sur que señala, para los linajes europeos, el asiento preferencial de inmigrantes ultramarinos entre finales del siglo XIX y principios del XX. Y en el caso de los linajes africanos, la ubicación estratégica de las rutas de paso de los esclavos ingresados por el puerto de Buenos Aires, hacia Chile.

En relación al objetivo inicial que consiste en probar la continuidad local (en este caso a nivel continental) de los linajes maternos, en todas las localidades el porcentaje más alto corresponde a los linajes nativos, aún la ciudad de Mendoza, con un $70 \%$ de linajes A-D, constituye una prueba de que en la población actual persisten en altas proporciones los haplogrupos mitocondriales nativos.

\subsubsection{INFORMACIÓN GENEALÓGICA}

La información proporcionada por los donantes entrevistados rara vez se extiende más allá de la tercera generación, es decir los abuelos de los mismos. Y en los casos en que se nombra una generación anterior, los bisabuelos, las referencias suelen ser vagas tanto en cuanto al lugar preciso del nacimiento como a cuál de los progenitores se está haciendo referencia. Por tal razón, tomamos como dato el lugar de nacimiento de los abuelos, ya sea por vía materna o paterna. Cuando el dato era desconocido o carecía de la precisión suficiente como para diferenciar entre las categorías que hemos dado en llamar -dcal" y —ndocal", consideramos a la generación parental o al donante mismo. En un $77 \%$ de los casos, la información se refiere a la tercera generación. 
Los resultados correspondientes al lugar de nacimiento del último ancestro conocido por vía materna (Tabla 3.3) se comparan con los equivalentes para la vía paterna (Tabla 3.4). En ambos casos la categoría tocal" engloba a la mayor parte del universo considerado. Pero se observa una diferencia de seis puntos que confirma el patrón esperado de una mayor tendencia local en los linajes maternos con respecto a los paternos. Esta diferencia está dada principalmente por la categoría — Utramar" en donde se observan cinco puntos de diferencia entre las líneas materna y paterna de ancestros. Este hecho concuerda con lo conocido a través de los datos censales correspondientes a los elevados índices de masculinidad entre la población migrante de los siglos XIX y XX (Tabla 3.5).

\begin{tabular}{|c|c|c|c|c|c|c|c|}
\hline & \multirow[b]{3}{*}{$\mathrm{N}$} & \\
\hline & & \multicolumn{6}{|c|}{ Línea materna } \\
\hline & & $\begin{array}{c}\text { Misma } \\
\text { Provincia }\end{array}$ & $\begin{array}{l}\text { Provincia } \\
\text { limítrofe }\end{array}$ & \begin{tabular}{|c|} 
País \\
limítrofe a \\
la provincia
\end{tabular} & $\begin{array}{c}\text { Resto de } \\
\text { Argentina }\end{array}$ & \begin{tabular}{|c} 
Resto de \\
Sudamérica
\end{tabular} & $\begin{array}{c}\text { Europa y } \\
\text { Asia Menor }\end{array}$ \\
\hline Mendoza & 139 & 50,36 & 18,71 & 3,60 & 10,07 & 7,91 & 9,35 \\
\hline V. Tulumaya & 102 & 50,00 & 25,49 & 1,96 & 10,78 & 7,84 & 3,92 \\
\hline San Juan & 119 & 80,67 & 9,24 & 2,52 & 4,20 & 0,00 & 3,36 \\
\hline Calingasta & 71 & 61,97 & 2,82 & 33,80 & 0,00 & 0,00 & 1,41 \\
\hline Chepes & 73 & 69,86 & 24,66 & 0,00 & 4,11 & 0,00 & 1,37 \\
\hline La Rioja & 234 & 62,82 & 23,93 & 0,43 & 11,11 & 0,85 & 0,85 \\
\hline Belén & 159 & 89,94 & 4,40 & 0,63 & 2,52 & 1,26 & 1,26 \\
\hline Sta. María & 170 & 72,94 & 20,59 & 0,00 & 3,53 & 0,59 & 2,35 \\
\hline Tartagal & 253 & 49,01 & 15,42 & 30,43 & 4,35 & 0,00 & 0,79 \\
\hline Maimará & 192 & 75,00 & 7,81 & 14,06 & 0,52 & 1,56 & 1,04 \\
\hline La Quiaca & 222 & 47,30 & 9,91 & 39,64 & 1,80 & 0,45 & 0,90 \\
\hline Subtotal & & 63,38 & 14,82 & 13,15 & 4,90 & 1,61 & 2,13 \\
\hline Total & 1.734 & & 91,35 & & & 8,65 & \\
\hline
\end{tabular}

Tabla 3.3. Lugar de origen declarado del último ancestro conocido por vía materna, por localidad de muestreo, en porcentajes

Podemos afirmar, en base a estos resultados que en más del $90 \%$ de los casos los linajes maternos tienen una continuidad local al menos en el corto plazo que puede abordarse a través de la historia oral. Como medida precautoria, decidimos no eliminar ni redistribuir las muestras de acuerdo al origen declarado, no por falta de confianza en la veracidad, sino por no intervenir en lo que efectivamente consiste en la distribución actual de los linajes maternos. A su vez, los casos conocidos de migración reciente servirán para ilustrar ejemplos de afinidad biológica con muestras correspondientes al lugar de origen. 


\begin{tabular}{|c|c|c|c|c|c|c|c|}
\hline & \multirow[b]{3}{*}{$\mathrm{N}$} & \multicolumn{6}{|c|}{ Línea paterna } \\
\hline & & \multicolumn{3}{|c|}{ Local } & \multicolumn{3}{|c|}{ No Local } \\
\hline & & $\begin{array}{c}\text { Misma } \\
\text { Provincia }\end{array}$ & $\begin{array}{l}\text { Provincia } \\
\text { limítrofe }\end{array}$ & \begin{tabular}{|c|} 
País \\
limítrofe a \\
la provincia
\end{tabular} & $\begin{array}{c}\text { Resto de } \\
\text { Argentina }\end{array}$ & $\begin{array}{c}\text { Resto de } \\
\text { Sudamérica }\end{array}$ & $\begin{array}{c}\text { Europa y } \\
\text { Asia Menor }\end{array}$ \\
\hline Mendoza & 139 & 41,01 & 12,23 & 3,60 & 13,67 & 5,76 & \begin{tabular}{|l}
23,74 \\
\end{tabular} \\
\hline V. Tulumaya & 102 & 44,12 & 17,65 & 5,88 & 17,65 & 4,90 & 9,80 \\
\hline San Juan & 119 & 75,63 & 4,20 & 4,20 & 6,72 & 0,00 & 9,24 \\
\hline Calingasta & 71 & 54,93 & 4,23 & 30,99 & 4,23 & 0,00 & 5,63 \\
\hline Chepes & 73 & 71,23 & 17,81 & 0,00 & 0,00 & 1,37 & 9,59 \\
\hline La Rioja & 234 & 59,40 & 16,67 & 1,28 & 14,10 & 1,71 & 6,84 \\
\hline Belén & 159 & 84,91 & 7,55 & 0,00 & 3,77 & 0,00 & 3,77 \\
\hline Sta. María & 170 & 69,41 & 20,59 & 0,00 & 4,71 & 1,18 & 4,12 \\
\hline Maimará & 192 & 77,08 & 7,29 & 11,98 & 1,04 & 1,04 & 1,56 \\
\hline Tartagal & 253 & 47,04 & 18,58 & 22,92 & 3,95 & 0,40 & 7,11 \\
\hline La Quiaca & 222 & 50,00 & 9,91 & 31,08 & 4,95 & 0,45 & 3,60 \\
\hline Subtotal & 1.734 & 60,73 & 12,98 & 11,01 & 6,81 & 1,38 & 7,09 \\
\hline Total & & & 84,72 & & & 15,28 & \\
\hline
\end{tabular}

Tabla 3.4. Lugar de origen declarado del último ancestro conocido por vía paterna, por localidad de muestreo, en porcentajes.

\begin{tabular}{|c|c|}
\hline Censo & $\begin{array}{c}\text { Índice de masculinidad en } \\
\text { población extranjera }\end{array}$ \\
\hline 1869 & 251 \\
\hline 1895 & 173 \\
\hline 1914 & 167 \\
\hline 1947 & 139 \\
\hline 1960 & 120 \\
\hline 1970 & 111 \\
\hline
\end{tabular}

Tabla 3.5. Número de hombres cada 100 mujeres entre la población extranjera, a través de los primeros seis censos nacionales. (Otero, 2006)

Otros puntos a destacar son la elevada proporción de ancestros con origen en los países limítrofes en las ciudades de frontera como Calingasta (33,8 \%), La Quiaca (39,29\%) y Tartagal $(31,40 \%)$. Y el hecho de que en los casos de ancestros nacidos en países no limítrofes a la provincia, las localidades donde esta categoría alcanza valores más elevados son Mendoza y Villa Tulumaya ( $>8 \%)$ y corresponden en un $79 \%$ a ancestros oriundos de Bolivia. Esta conexión está registrada históricamente y se debe a la capacidad atrayente, en términos del mercado laboral, propio de estas ciudades. 


\subsubsection{CORRESPONDENCIA ENTRE AMBAS FUENTES DE INFORMACIÓN}

En este punto sólo podemos hacer una comparación entre el porcentaje de quienes declararon un ancestro por vía materna de origen ultramarino y el porcentaje de linajes mitocondriales pertenecientes al suprahaplogrupo $\mathrm{N}$, ya que no se registraron casos en que se declarara un origen africano y que las restantes categorías en que se discrimina la información genealógica no pueden ser abordadas desde la genética molecular.

En el caso de las localidades de Mendoza, Villa Tulumaya y San Juan, es coincidente el mayor porcentaje de linajes mitocondriales de Europa y Medio Oriente con un mayor porcentaje de ancestros nacidos en el Viejo Mundo. Por el contrario, llama la atención la falta de registro a través de la historia oral de un origen ultramarino en las localidades de La Rioja y Chepes; en estas localidades los haplogrupos mitocondriales provenientes de Europa y Medio Oriente alcanzan un porcentaje relativamente alto (13\%) pero el porcentaje de donantes que declararon tener conocimiento de que su abuela fuera inmigrante fue bajo $(\sim 1 \%)$, similar al del resto de las localidades, en las cuales la información molecular registra porcentajes de linajes alóctonos mucho más bajos.

\subsection{ANÁLISIS DE VARIABILIDAD INTRAPOBLACIONAL}

Teniendo en cuenta la secuencia de nucleótidos entre las posiciones 16024-16569 y 001-573, y sin considerar las variaciones en el número de residuos citosina en los homoplímeros en torno a las posiciones 16189 y 309 ni las variaciones en el número de repetidos del microsatélite AC en 573, se estimaron las medidas de diversidad intrapoblacional que se presentan en la Tabla 3.6. Para estimar estas medidas, se tuvieron en cuenta sólo las secuencias correspondientes a los haplogrupos nativos AD. La lista completa de las secuencias obtenidas se encuentra en el Anexo 7.2.2.

Todas las medidas señalan a La Rioja como la localidad menos diversa, este dato es sorprendente teniendo en cuenta que se trata de una capital provincial. Luego de La Rioja, le siguen en orden ascendente en cuanto a la diversidad haplotípica, las localidades de Calingasta, Belén, Chepes y Santa María, estos datos se corresponden con su condición de localidades pequeñas. Luego siguen San Juan y Villa Tulumaya, alterándose el orden esperado de acuerdo al tamaño poblacional de las mencionadas ciudades, e indicando una diversidad nucleotídica menor a la esperada para la ciudad de San Juan, por tratarse de una capital provincial. 


\begin{tabular}{|c|c|c|c|c|c|c|c|c|c|c|c|c|}
\hline 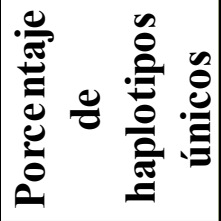 & $\frac{\infty}{\infty}$ & $\begin{array}{l}2 \\
2 \\
\infty \\
0\end{array}$ & $\frac{8}{n}$ & $\begin{array}{c}\infty \\
n \\
n \\
n\end{array}$ & $\begin{array}{l}8 \\
8 \\
8\end{array}$ & $\begin{array}{l}8 \\
n \\
\text { ñ }\end{array}$ & $\begin{array}{l}\mathcal{O} \\
\mathcal{f} \\
\mathcal{f}\end{array}$ & $\frac{\Xi}{n}$ & \begin{tabular}{l}
\multirow{\sim}{\sim}{} \\
$\infty$ \\
$\infty$
\end{tabular} & $\begin{array}{l}0 \\
\text { jn } \\
\text { f }\end{array}$ & శ్ & \\
\hline 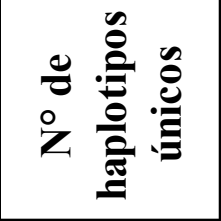 & $\stackrel{\mathscr{F}}{\forall}$ & $\stackrel{m}{\vartheta}$ & $\bar{n}$ & $\hat{\sim}$ & $\widetilde{N}$ & $\stackrel{\infty}{\sim}$ & 구 & iे & পి & $\stackrel{n}{2}$ & 8 & \\
\hline 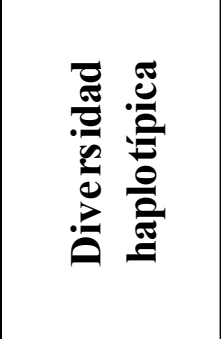 & $\begin{array}{l}\bar{n} \\
\delta \\
\dot{\delta} \\
1 \\
+ \\
\dot{+} \\
\tilde{\sigma} \\
\tilde{\sigma} \\
\dot{0}\end{array}$ & $\begin{array}{l}n \\
\tilde{\delta} \\
0 \\
0 \\
1 \\
+ \\
+ \\
\infty \\
\infty \\
\infty \\
0 \\
0\end{array}$ & $\begin{array}{l}0 \\
\tilde{8} \\
8 \\
0 \\
1 \\
+ \\
+ \\
\tilde{+} \\
\infty \\
0 \\
\vdots \\
0\end{array}$ & 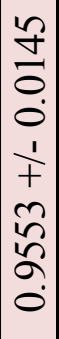 & $\begin{array}{l}8 \\
8 \\
8 \\
0 \\
1 \\
+ \\
+ \\
2 \\
\frac{5}{2} \\
0\end{array}$ & $\begin{array}{c}\tilde{J} \\
\tilde{D} \\
0 \\
0 \\
1 \\
+ \\
+ \\
\tilde{2} \\
\tilde{2} \\
\vdots \\
0\end{array}$ & 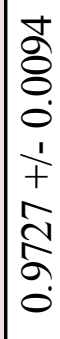 & $\begin{array}{l}0 \\
0 \\
8 \\
0 \\
0 \\
1 \\
+ \\
+ \\
0 \\
0 \\
0 \\
0 \\
0\end{array}$ & $\begin{array}{l}\tilde{N} \\
0 \\
\delta \\
0 \\
0 \\
1 \\
+ \\
+ \\
0 \\
\delta \\
\vdots \\
0\end{array}$ & 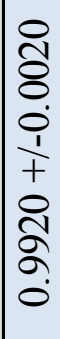 & 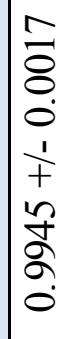 & \\
\hline 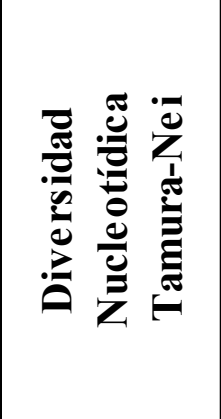 & $\begin{array}{l}20 \\
2 \\
2 \\
\mathscr{8} \\
\dot{0} \\
1 \\
+ \\
+ \\
\infty \\
\frac{\infty}{0} \\
0 \\
0\end{array}$ & 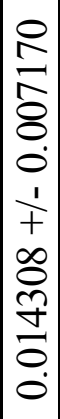 & 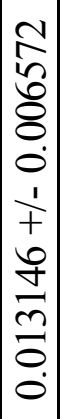 & 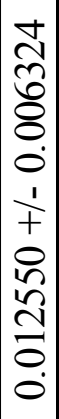 & 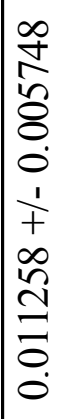 & $\begin{array}{l}0 \\
0 \\
+ \\
2 \\
8 \\
0 \\
0 \\
1 \\
+ \\
+ \\
\hat{o} \\
0 \\
0 \\
0 \\
0 \\
0\end{array}$ & 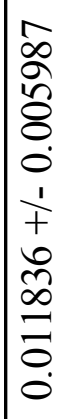 & 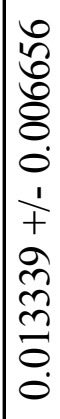 & 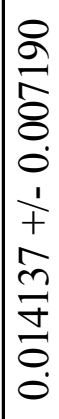 & $\begin{array}{l}\hat{n} \\
\hat{n} \\
\delta \\
0 \\
0 \\
1 \\
+ \\
+ \\
\tilde{\delta} \\
\delta \\
0 \\
0 \\
0 \\
0\end{array}$ & 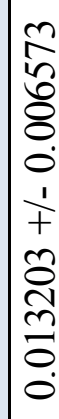 & \\
\hline$\simeq$ & 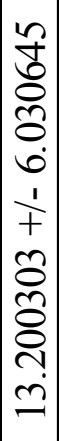 & 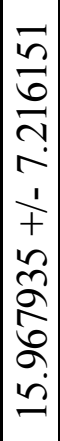 & 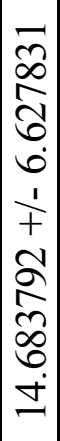 & 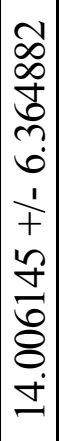 & 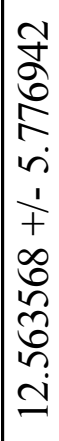 & 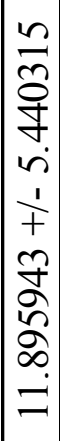 & 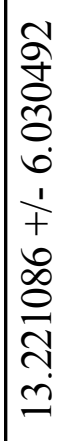 & 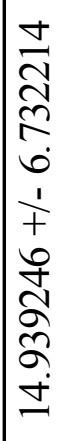 & 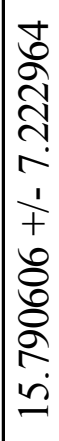 & 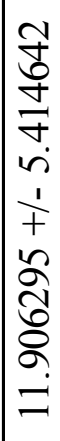 & 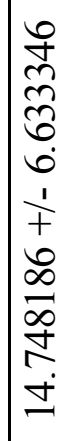 & \\
\hline n & $\infty$ & 2 & 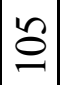 & ホ & $\infty$ & 6 & 6 & $\stackrel{\infty}{\stackrel{0}{0}}$ & $\infty$ & $\bar{\Xi}$ & $\Omega$ & \\
\hline$=$ & $\stackrel{\infty}{q}$ & in & 6 & $m$ & $\bar{m}$ & \& & $\bar{m}$ & $\widetilde{\sigma}$ & $\tilde{N}$ & 0 & $\widehat{\simeq}$ & \\
\hline Z & $n$ & $\hat{\sigma}$ & $\Xi$ & 6 & 寸 & $\stackrel{\infty}{\sim}$ & $\overline{6}$ & 三 & $\underset{m}{+}$ & 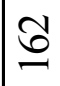 & 6 & \\
\hline 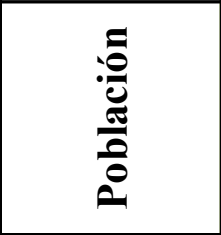 & 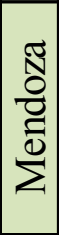 & 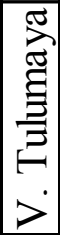 & 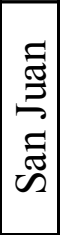 & 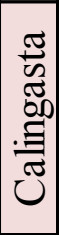 & $\frac{\tilde{d}}{\tilde{d}}$ & 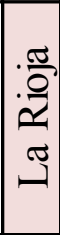 & 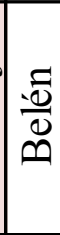 & 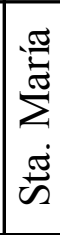 & 兺 & 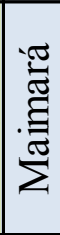 & 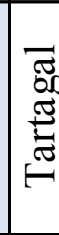 & \\
\hline
\end{tabular}

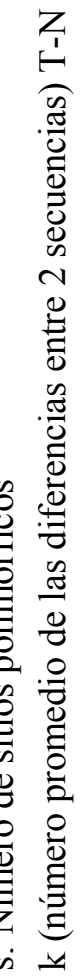


Las restantes localidades cuentan con un valor de más de 0,99 en cuanto a la diversidad nucleotídica, siendo el valor más alto el correspondiente a Jujuy, sin embargo, cabe señalar que en esta localidad el número de muestras es bajo y esto puede estar afectando los valores de diversidad. En las localidades de Maimará y La Quiaca la diversidad nucleotídica es relativamente baja, a pesar de su gran diversidad haplotípica, este patrón se corresponde con la existencia de numerosos haplotipos, pero en su gran mayoría correspondientes al haplogrupo B, lo cual disminuye la diversidad nucleotídica.

\subsection{DiSTRIBUCIÓN REGIONAL DE LOS LINAJES MATERNOS NATIVOS}

\subsubsection{DEFINICIÓN DE LINAJES}

En base a 1108 secuencias de la Región Control completa (16024- 16569 y 001-576) que corresponden a los haplogrupos nativos A2, B2, C1b, C1c, C1d, C4c, D1 y D4h3a, se construyeron por cada haplogrupo redes de haplotipos que representan una hipótesis filogenética. El total de redes construidas se encuentra en el Anexo 7.2.3. Hipótesis filogenéticas.

La construcción de dichas redes fue hecha en forma manual ya que además del criterio de parsimonia, se tuvieron en cuenta criterios de coherencia geográfica y en algunos casos información inédita de la región codificante que se obtuvo en el IMBICE durante la redacción de esta tesis. Otra razón para la no utilización de un programa informático para la construcción de redes fue la observación de la dependencia de la frecuencia de mutación de ciertas posiciones respecto de las mutaciones circundantes. Es sabido que al seno de cada haplogrupo existen posiciones que se mantienen relativamente estables, como es el caso de 16519 que está —ongelada" en el haplogrupo B2; mientras que otras presentan gran inestabilidad, como por ejemplo 64 dentro de A2. Es por eso que el pesado de los caracteres es el producto de la combinación de criterios externos como la escala de posiciones variables publicada por Soares y col. (2009) y también de criterios internos definidos en base a la observación de la inesperada estabilidad de ciertas posiciones conocidas por su alta tasa mutacional, al interior de un haplogrupo, como es el caso de la mutación 150 en A2 que según postulamos aquí, puede ser utilizada como mutación diagnóstica de un linaje de distribución local.

La inclusión de los datos de la RHV-II, que presenta sitios con gran inestabilidad, dificultaba en grado extremo la interpretación de las redes generadas mediante el programa Network. La construcción manual de las redes permitió mantener la información de todas las posiciones mutadas, incluso de sitios hipervariables, al mismo tiempo que se mantiene un esquema de clara representación gráfica, manteniendo sólo los ciclos y cubos que no pudieron resolverse por criterios tales como el de parsimonia, la coherencia geográfica, la información de secuencias completas o el pesado de caracteres. De todos modos, recalcamos la idea de que se trata de hipótesis filogenéticas que sólo podrán ser contrastadas cuando se incremente el número de secuencias completas disponibles. 
En base a las redes construidas se definieron linajes potencialmente monofiléticos teniendo en cuenta la presencia compartida de una o más mutaciones, la coherencia geográfica y en algunos casos, información de región codificante generada en el IMBICE. Las mutaciones diagnósticas de cada linaje y su frecuencia poblacional se exponen en el Anexo 7.2.4.

\subsubsection{ANÁLISIS DE COMPONENTES PRINCIPALES}

De la tabla anterior, se desprende la definición de 97 variables, que comprenden al $90 \%$ de la muestra (todos los linajes definidos excepto los haplotipos no asignados). Estas variables, al ser resumidas en dos componentes principales, representan el $40 \%$ de la variabilidad. En la Figura 3.4 puede observarse que el componente 1 , el cual representa $26 \%$ de la variabilidad, separa claramente a las localidades de La Quiaca y Maimará por un lado, luego a la localidad de Tartagal y finalmente al resto de las localidades que se disponen en un cline desde Santa María a Calingasta. El componente 2 reúne el $14 \%$ de la variabilidad y señala de manera contundente la particularidad de la localidad de Tartagal.

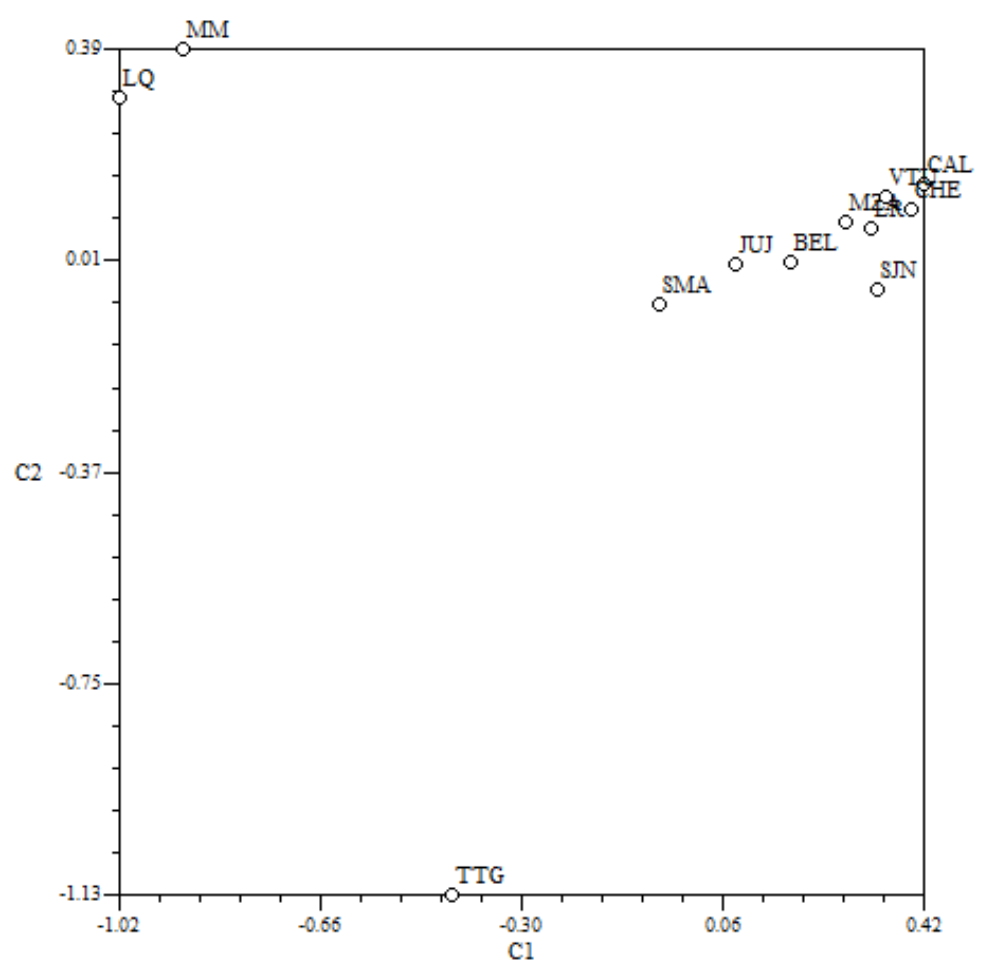

Figura 3.4. Análisis de Componentes Principales.

Componente $1=26 \%$. Componente $2=14 \%$. 


\subsubsection{IDENTIFICACIÓN DE BARRERAS GENÉTICAS}

A partir de las frecuencias de los 97 linajes definidos, se calcularon las distancias de Nei entre pares de localidades (Tabla 3.7) y esa matriz fue utilizada para la identificación de barreras genéticas, que coinciden con las mayores distancias entre pares de localidades adyacentes. En la tabla 3.7 se señalan en rojo las distancias que generan el inicio de las barreras.

La primera barrera identificada, corresponde a la separación de las localidades de Maimará y La Quiaca del resto de las localidades. La segunda barrera está ubicada a la altura del límite entre las provincias de La Rioja y Catamarca, separando las localidades al norte y al sur de la misma. Una tercera barrera separa a Mendoza y a Villa Tulumaya de sus vecinas. Y recién con una cuarta barrera se aísla a la localidad de Tartagal del resto (Figura 3.5). El orden de prioridad de las barreras responde a las mayores distancias genéticas encontradas entre pares de localidades adyacentes. En el caso de la barrera - $\mathfrak{c}$, la distancia mayor que da inicio a la misma, ocurre entre Villa Tulumaya y Chepes $(0,8284)$, sin embargo las distancias entre las localidades que separa la continuación de la barrera son muy bajas: entre Villa Tulumaya y San Juan, 0,5077 y entre Mendoza y Calingasta 0,5991. En cambio la distancia que genera la barrera - dentre Jujuy y Tartagal es de 0,7261, de modo que en términos regionales no se justifica separar a las localidades de las provincias de Mendoza y de San Juan.

\begin{tabular}{|l|r|r|r|r|r|r|r|r|r|r|r|r|}
\hline & MZA & VTU & SJN & CAL & CHE & LR & BEL & SMA & JUJ & MM & TTG & LQ \\
\hline MZA & 0 & & & & & & & & & & & \\
\hline VTU & 0,4347 & 0 & & & & & & & & & & \\
\hline SJN & 0,3938 & 0,5077 & 0 & & & & & & & & & \\
\hline CAL & 0,5991 & 0,6751 & 0,3008 & 0 & & & & & & & & \\
\hline CHE & 0,6184 & 0,8284 & 0,3337 & 0,7887 & 0 & & & & & & & \\
\hline LR & 0,4794 & 1,0678 & 0,4277 & 1,0508 & 0,1689 & 0 & & & & & & \\
\hline BEL & 1,2355 & 1,8156 & 1,259 & 1,9981 & 1,0645 & 0,9743 & 0 & & & & & \\
\hline SMA & 0,7921 & 1,3472 & 0,5157 & 0,9308 & 0,6671 & 0,4922 & 0,2791 & 0 & & & & \\
\hline JUJ & 0,9103 & 1,3206 & 0,8287 & 1,6764 & 0,7883 & 0,6425 & 1,0649 & 0,7164 & 0 & & & \\
\hline MM & 1,7962 & 1,9775 & 1,8035 & 2,3865 & 2,3388 & 2,4907 & 0,6701 & 0,7066 & 0,8 & 0 & & \\
\hline TTG & 1,066 & 1,3399 & 0,8109 & 1,6976 & 1,0087 & 1,023 & 1,3724 & 0,8954 & 0,7261 & 1,1492 & & 0 \\
\hline LQ & 1,9972 & 2,1206 & 2,0553 & 2,5834 & 2,8597 & 2,9412 & 0,9468 & 0,9071 & 0,6791 & 0,1923 & 1,154 & 0 \\
\hline
\end{tabular}

Tabla 3.7. Distancias de Nei entre pares de localidades.

Destacados en rojo, los valores que dan origen a las principales barreras genéticas. 


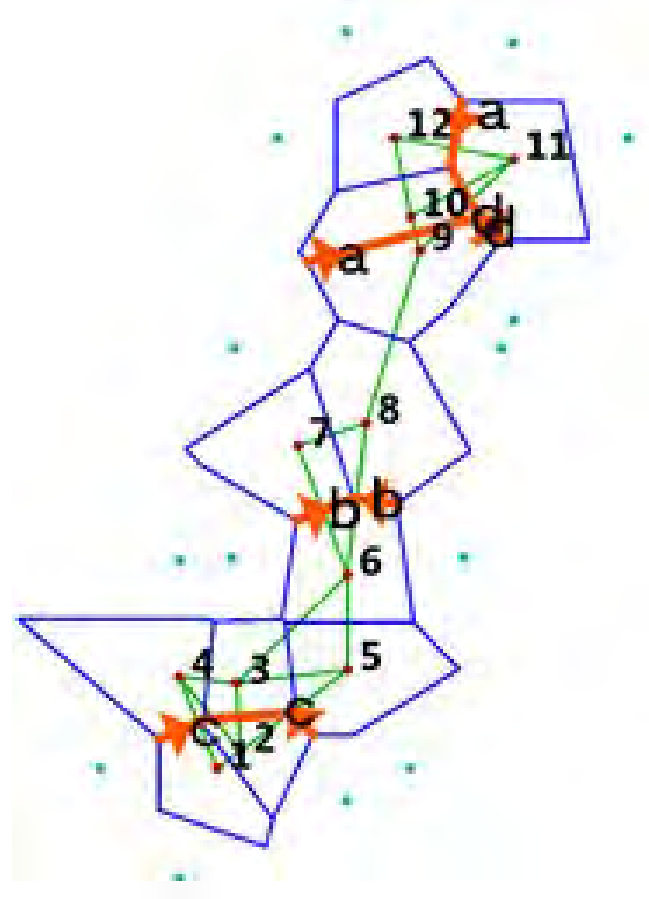

Figura 3.5. Barreras genéticas identificadas con el programa Barrier 2.2.

Localidades: $1=$ Mendoza, $2=$ Villa Tulumaya, $3=$ San Juan, 4= Calingasta, $5=$ Chepes, $6=$ La Rioja $7=$ Belén, $8=$ Santa María 9=SS de Jujuy, 10= Maimará, 11= Tartagal, 12= La Quiaca. Las letras del alfabeto indican el orden de prioridad de las barreras.

\subsubsection{ANÁLISIS GEOGRÁFICO DE LA DISTRIBUCIÓN DE FRECUENCIAS DE LINAJES}

Los métodos empleados supra permiten analizar en forma conjunta toda la información disponible y de esta manera nos acercan un panorama general de la variabilidad genética actual. Un análisis más fino teniendo en cuenta la variabilidad y distribución particular de cada uno de los linajes es sin embargo necesario para comprender a qué responden estos patrones generales. La sección siguiente se ocupará de describir e interpretar la frecuencia, variabilidad y distribución de los linajes más conspicuos, que explican en gran medida el agrupamiento de las poblaciones y las barreras definidas. La presencia compartida de linajes permite diferenciar cuatro regiones limitadas por dichas barreras (Figura 3.6). Estas cuatro regiones no son necesariamente excluyentes sino que representan conjuntos cuya relación mutua puede ser de exclusión (regiones I y II; III y IV) de pertenencia (la Región I pertenece a la región III) o de intersección (la Región III comparte con la Región II algunas localidades). En el Anexo 7.2.5 se listan los puntos geográficos definidos para la interpolación de frecuencias a nivel sudamericano, se indican las poblaciones incluidas dentro de cada uno y la fuente bibliográfica.

En el Anexo 7.2.6 se expresan las frecuencias poblacionales utilizadas para confeccionar los mapas de distribución de linajes. 


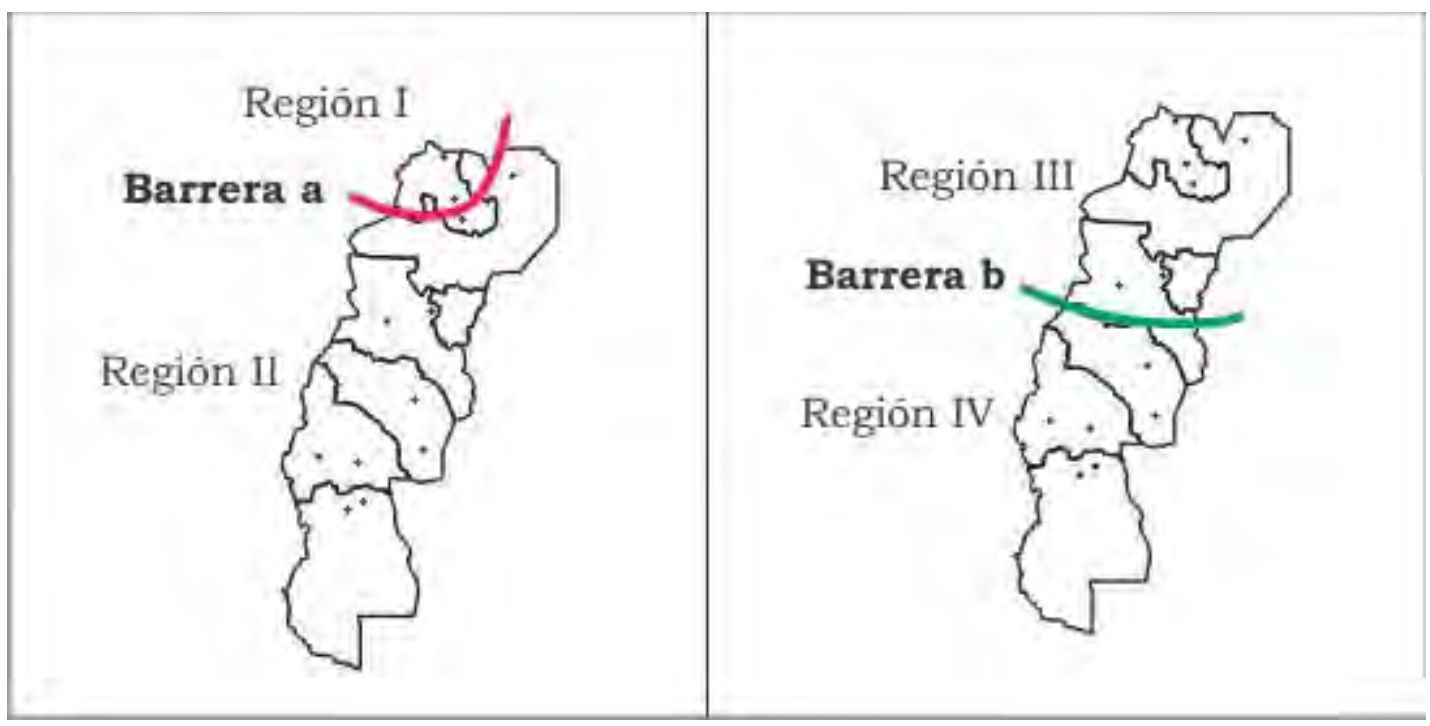

Figura 3.6. Regiones geográficas concordantes con los patrones de distribución de linajes.

\subsubsection{Región I}

Tanto el Análisis de Componentes Principales como las barreras para el flujo génico identificadas, concuerdan en señalar la particularidad de las localidades de Maimará y La Quiaca. En esta sección presentamos la distribución a nivel sudamericano de los linajes que confieren una distinción a estas dos localidades.

\section{$\underline{\mathrm{B} 2+16188}$}

El linaje definido por la mutación 16188 dentro del haplogrupo B2 incluye a 66 muestras (6\% de un total de 1108 muestras analizadas) que representa el 17\% de las muestras de La Quiaca y 12\% de las muestras de Maimará, seguido de cerca por un 9\% para la ciudad de San Salvador de Jujuy. La red de haplotipos del linaje (Figura 3.7) refuerza su preponderancia en las localidades de Maimará y La Quiaca ya que en éstas, no sólo la frecuencia es mayor, sino también la variabilidad. Se observa una gran diversidad, con numerosas ramificaciones y haplotipos alejados del nodal por hasta cinco mutaciones, señal de una cierta profundidad temporal. Resulta interesante destacar que son muy pocos los haplotipos faltantes, indicando que la diferenciación del haplotipo se habría dado in situ, es decir que este linaje tiene una gran antigüedad en la provincia de Jujuy.

El mapa de la distribución sudamericana de este linaje (Figura 3.8) muestra que la mayor frecuencia se encuentra en La Paz, Bolivia (Afonso y col. 2010; Gaya-Vidal y col. 2011); sin embargo la red de haplotipos presentes en la Argentina no se corresponde con la de un área marginal, sino que la diversidad y la presencia de haplotipos intermedios apuntan a considerar este territorio como parte del área central de origen y diversificación del linaje. En el mismo sentido apunta la presencia 
geográficamente restringida y en relativamente alta frecuencia de un haplotipo privado en Santa María.

En el territorio argentino la frecuencia es alta en la provincia de Jujuy y se observa también el efecto de las migraciones hacia los centros de atracción económica en términos de la configuración geopolítica actual, es decir hacia las provincias de Mendoza y Buenos Aires que ofrecen mayores y mejores oportunidades de trabajo y atraen población de las provincias menos favorecidas del NOA.

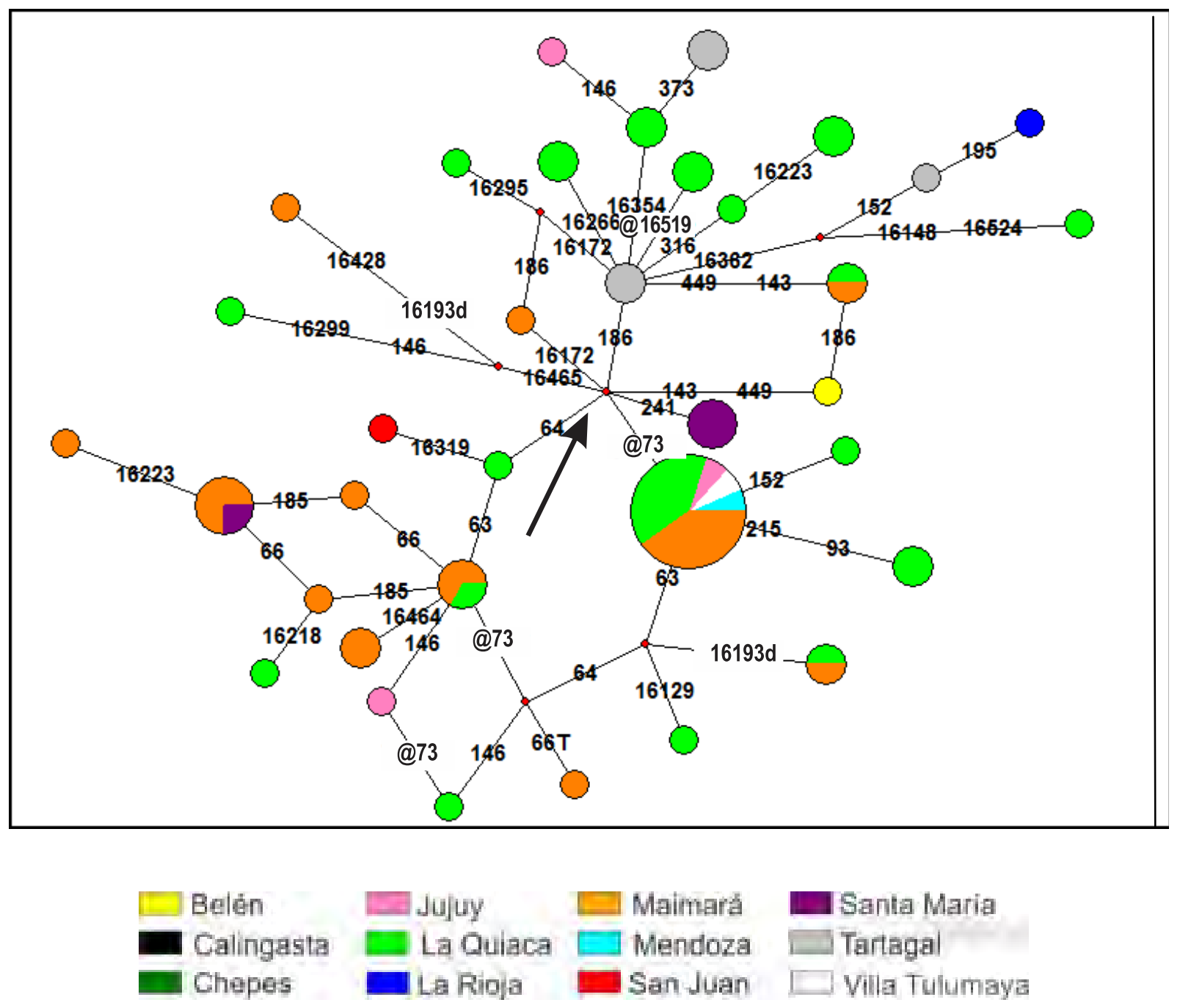

Figura 3.7. Red de haplotipos correspondientes al linaje B2+16188.

La flecha señala al haplotipo nodal del clado. 


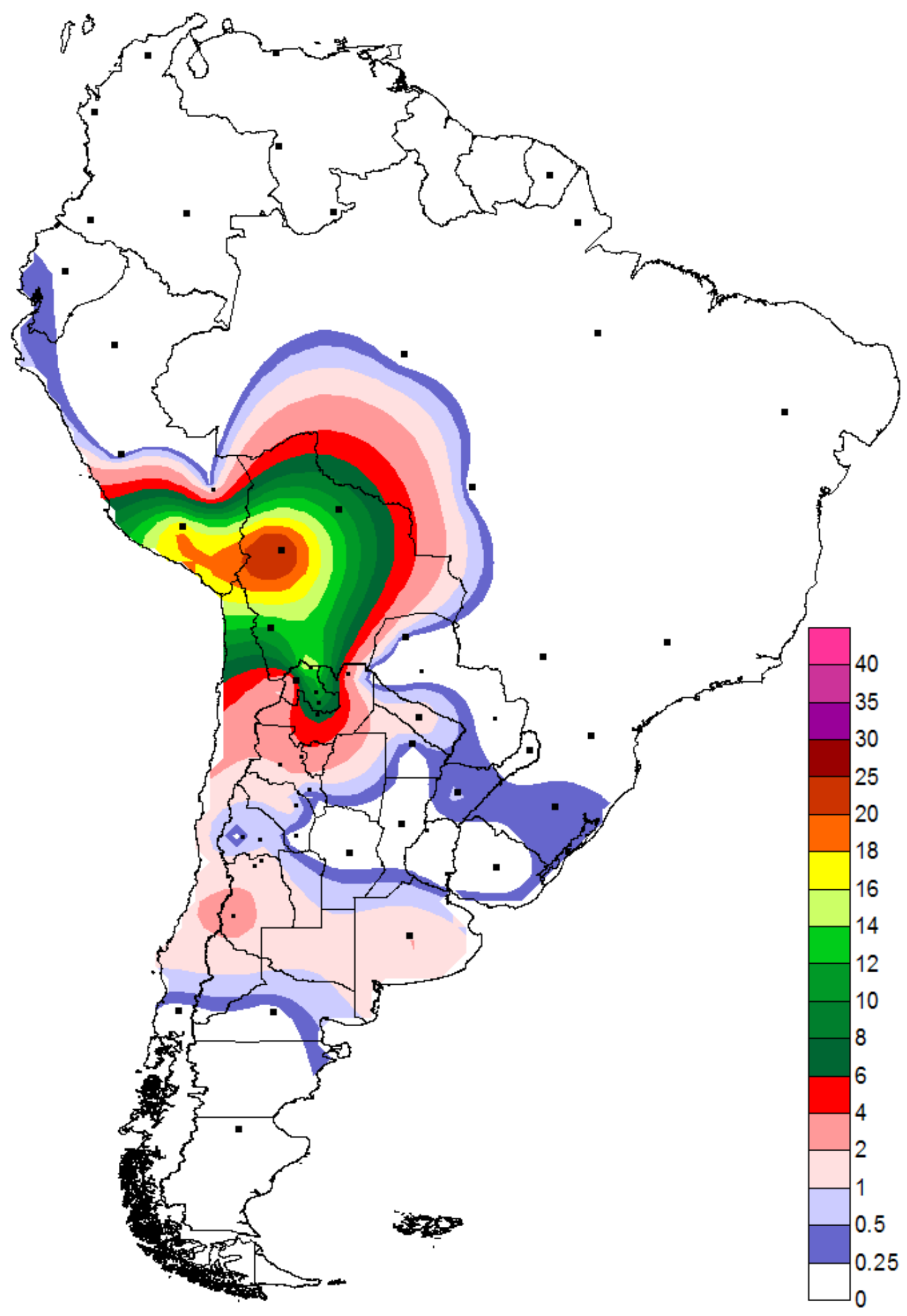

Figura 3.8. Distribución geográfica del linaje B2+16188. 
Acompañando al linaje B2+16188, se distinguen una serie de linajes cuya distribución es similar, en general se trata de linajes correspondientes a B2, pero también los hay dentro de A2, C1c, C1d y D1 (Figuras 3.9, 3.10 y 3.11). Cada uno de estos 13 linajes se encuentra en baja frecuencia, en general representado únicamente por dos o tres muestras en cada localidad, pero en conjunto suman $16 \%$ de las muestras correspondientes a La Quiaca y 20\% de las muestras de Maimará. Cabe señalar que algunos de estos linajes también se encuentran representados en las localidades de Mendoza y Villa Tulumaya donde alcanzan un 2\% y 3\% respectivamente. Este patrón es atribuible al efecto de las migraciones recientes hacia los centros de atracción económica. La presencia de estos linajes en Mendoza y Villa Tulumaya y no así en San Juan y Calingasta, podría contribuir a la explicación de la presencia de una barrera genética (barrera c) entre las localidades mendocinas y sanjuaninas, esta diferencia no sería atribuible a la diversidad genética prehispánica sino al efecto de las desigualdades regionales en el desarrollo económico actual.

A nivel sudamericano, la mayoría de estos linajes muestran un vínculo claro con el norte de Chile y el oeste boliviano, en especial con la ciudad de La Paz, del mismo modo como ocurría con B2+16188. En algunos casos el vínculo se extiende hasta Perú o incluso Colombia, Venezuela y Brasil. Sin embargo, en los casos en que la distribución es disyunta y el linaje está definido por una mutación altamente recurrente como 16111, lo más probable es que se trate de la ocurrencia independiente de la misma mutación en distintos linajes. 


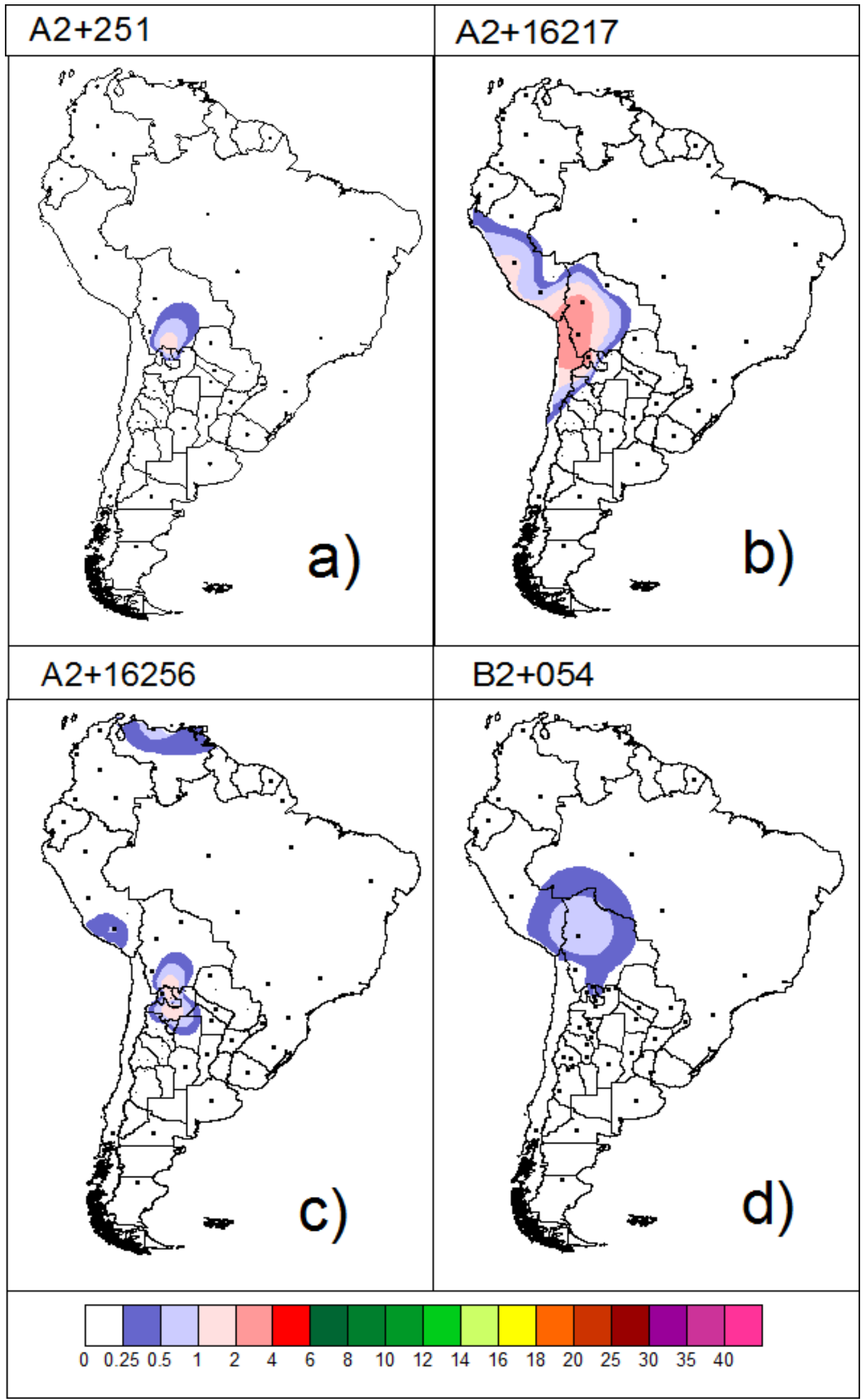

Figura 3.9. Distribución geográfica de linajes propios de la Región I (a-d). 


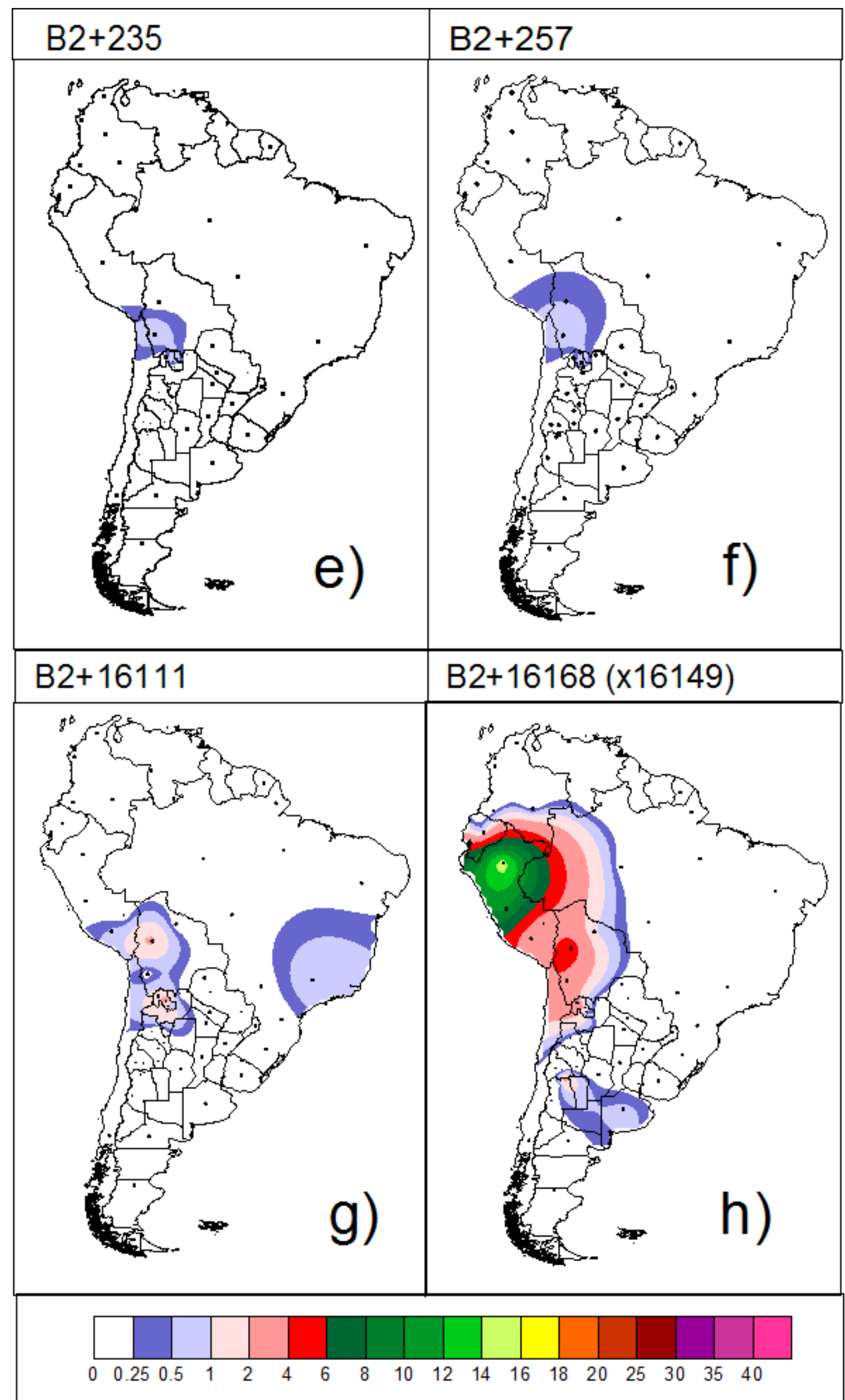

Figura 3.10. Distribución geográfica de linajes propios de la Región I (e-h). 


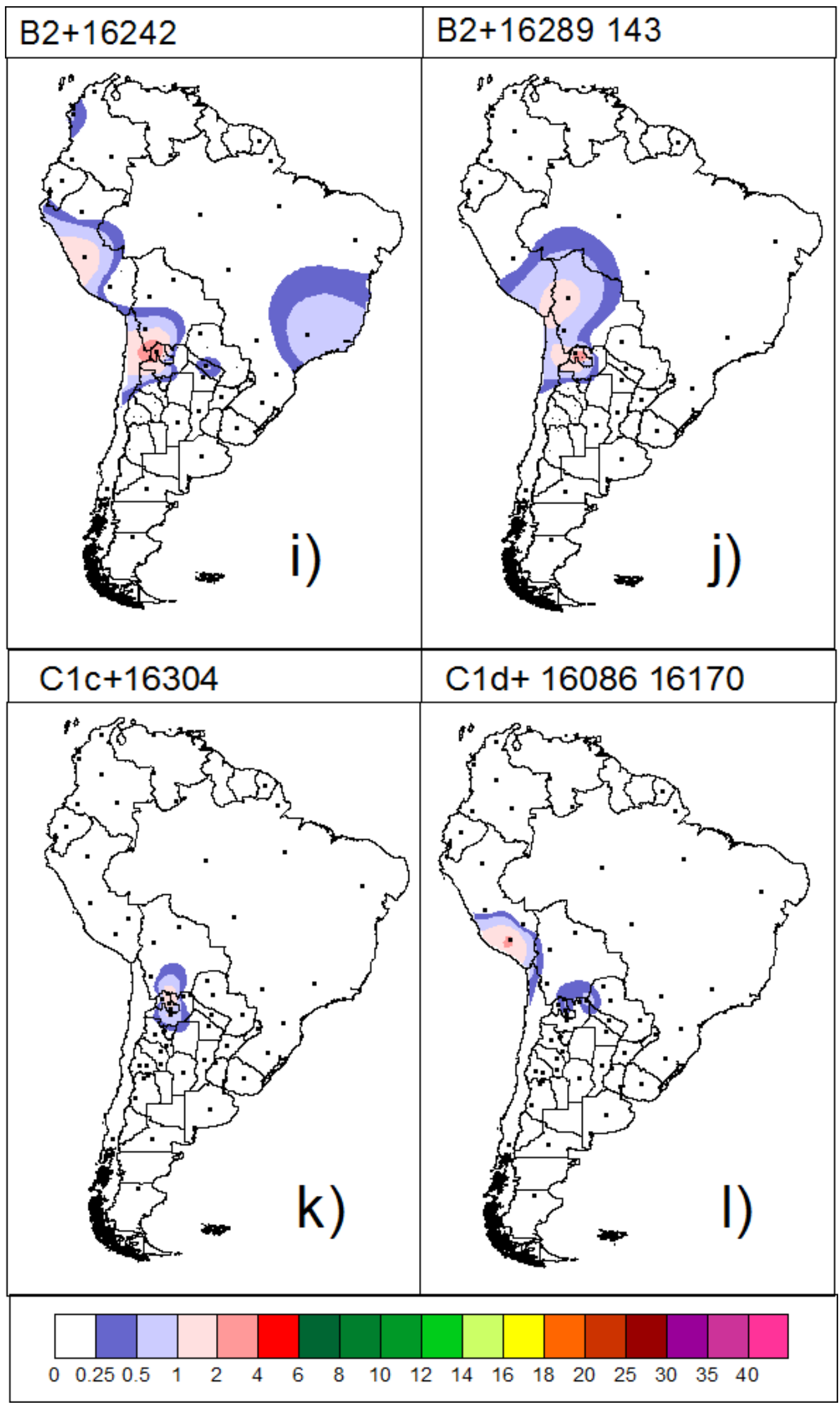

Figura 3.11. Distribución geográfica de linajes propios de la Región I (i-l). 


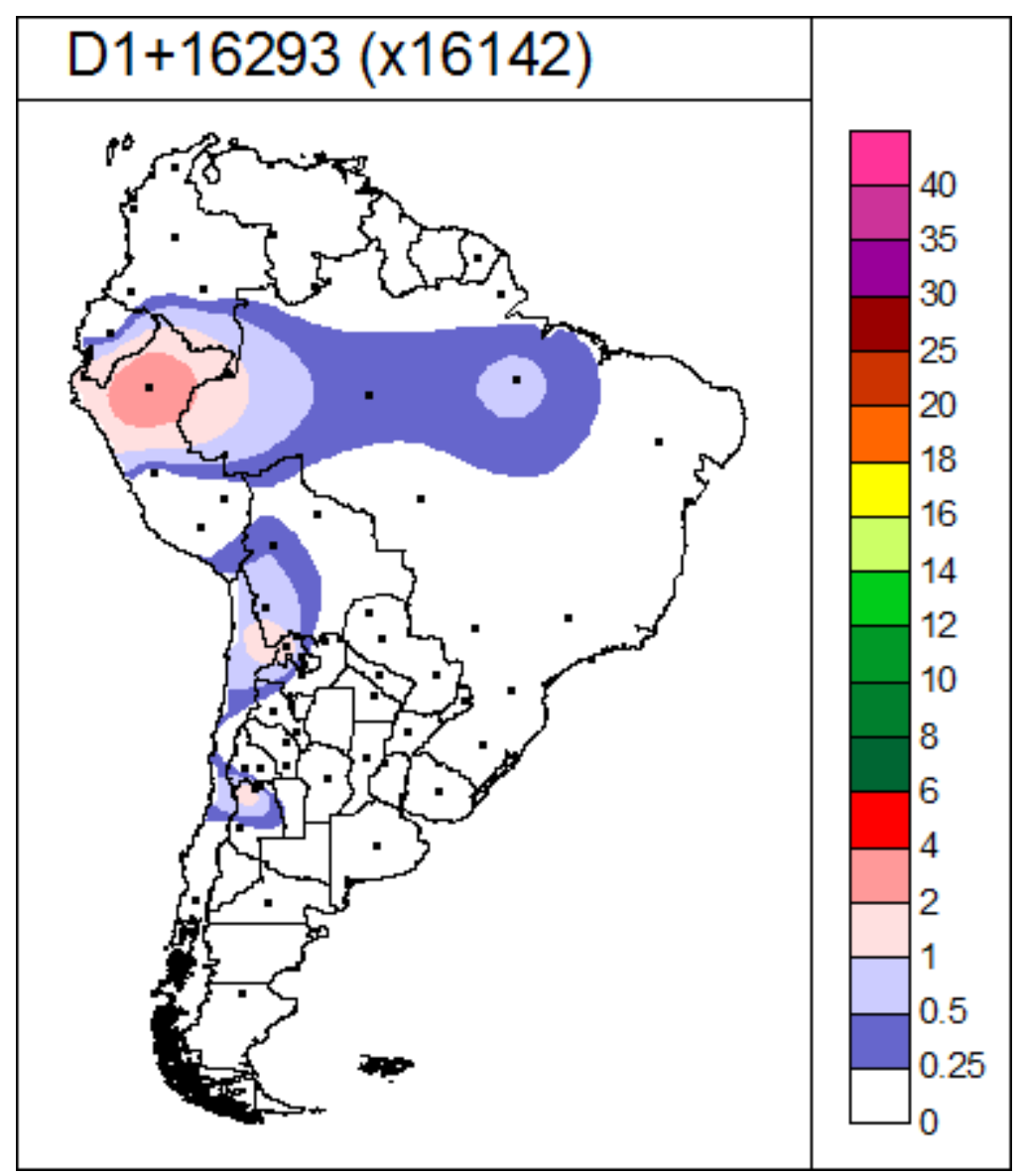

Figura 3.12. Distribución geográfica del linaje D1+16293 (x16142).

\subsubsection{Región II}

Esta región queda definida por la exclusión de las localidades de Maimará y La Quiaca. Esto no implica, por ejemplo, que las localidades de Jujuy y Villa Tulumaya sean más semejantes entre sí, que Jujuy y Maimará, pero sí pueden identificarse linajes cuya distribución unifica a localidades de ambos extremos de la región. Cinco de los diez linajes con mayor frecuencia analizados en esta tesis, corresponden a esta región.

\section{$\underline{D} 1+152-16242-16311(\mathrm{D} 1 \mathrm{j})$}

Con 106 muestras éste linaje constituye el más abundante entre las muestras analizadas, comprendiendo al $9 \%$ de las 1108 muestras con ADNmt nativo americano. Alcanza la máxima frecuencia en la localidad de La Rioja donde representa $45 \%$ de los linajes nativos.

La red de haplotipos (Figura 3.13) presenta forma de estrella, con gran cantidad de muestras correspondientes al haplotipo nodal y las ramas separadas por pocas mutaciones y, en la mayoría de los casos, una sola mutación. Nótese que el microsatélite AC en la posición 524 es la mutación que separa a los dos fodales". La característica rapidez de mutación de los microsatélites permite 
mantener la consideración de una configuración en estrella para esta red. Por otra parte, la ocurrencia de 3 deleciones y tres inserciones en la región comprendida entre las posiciones 55 y 77 es considerada un único evento, manteniendo así la coherencia respecto de los pocos eventos mutacionales que separan a los haplotipos que se desprenden del nodal. La casi total ausencia de haplotipos faltantes y la gran cantidad de haplotipos nodales, indica que estamos abarcando el rango de distribución del linaje en el área de muestreo y que este linaje no ha sufrido un cuello de botella desde su origen. Debido a la variabilidad de la tasa mutacional intersitio en las regiones hipervariables, no creemos pertinente arriesgar una antigüedad en años para este linaje, pero las ramas cortas que separan a los haplotipos que se desprenden del nodal, indican que se trata de un linaje relativamente reciente. Las muestras pertenecientes a este linaje, secuenciadas en forma completa por Tamm y col. (2007), comparten la una transición en la posición 5004. A nivel sudamericano se distribuye en forma casi exclusiva en el centro de Argentina con muy baja frecuencia en zonas aledañas (Figura 3.14).

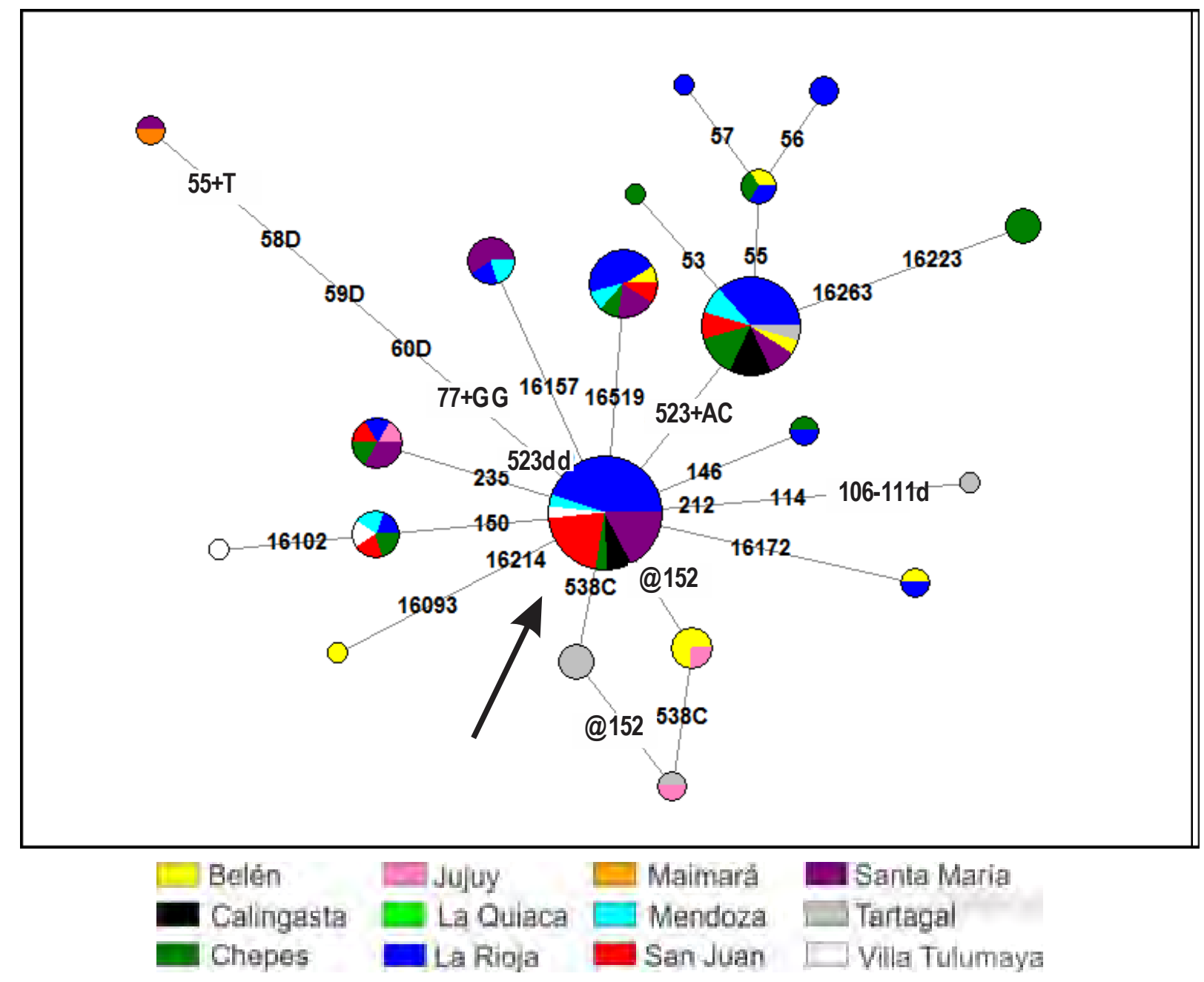

Figura 3.13. Red de haplotipos pertenecientes a D1 + 1521624216311 (Dlj).

La flecha señala al haplotipo nodal del clado. 


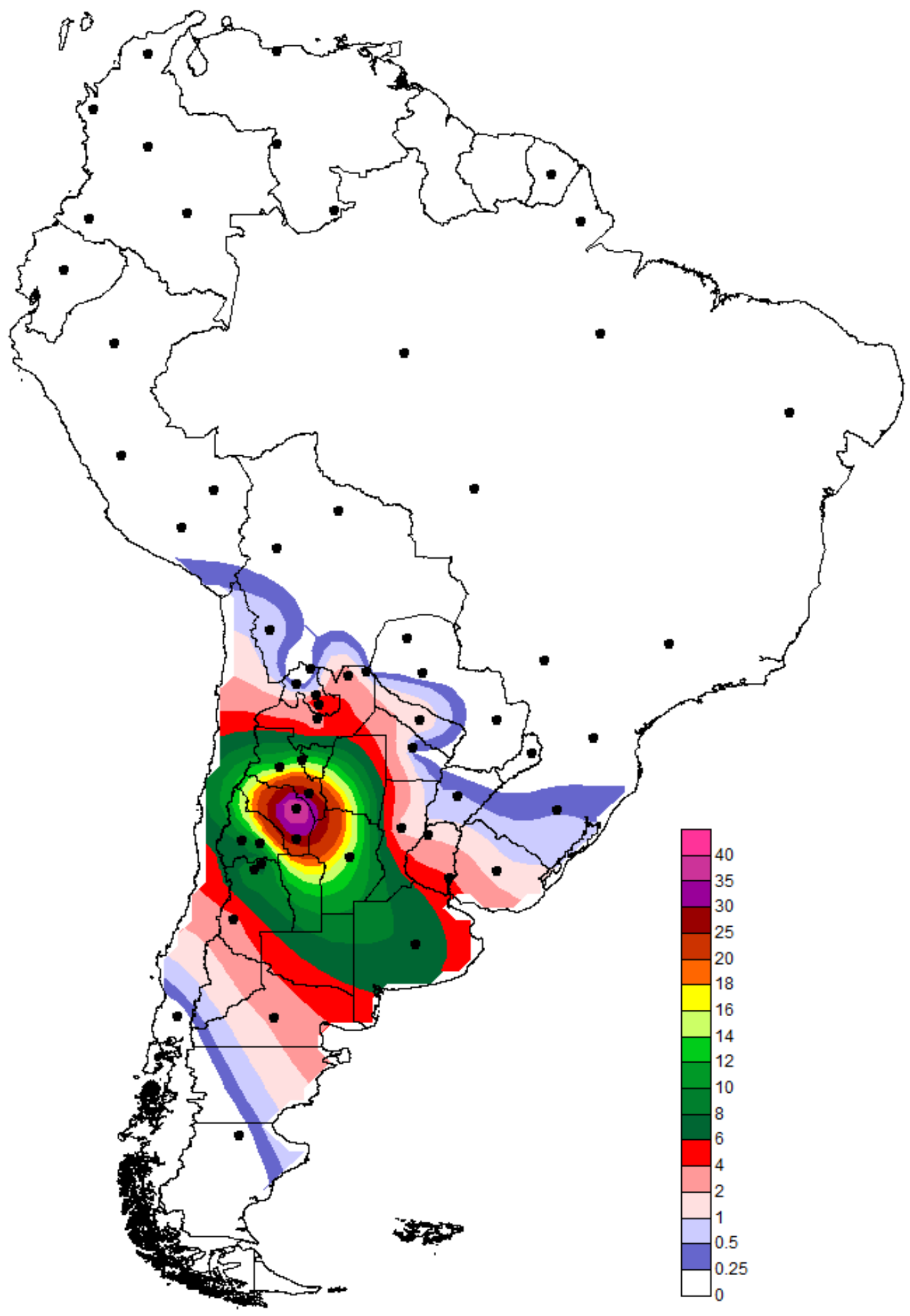

Figura 3.13. Distribución geográfica del linaje D1+ 1521624216311 (Dlj). 


\section{$\underline{\mathrm{C} 1 \mathrm{~b}+146}$}

A pesar de que la posición 146 es un sitio identificado como altamente variable, la coherencia geográfica que presenta en el territorio argentino, permite sustentar la hipótesis de que existe un linaje monofilético dentro de $\mathrm{C} 1 \mathrm{~b}$, identificado en la Región Control únicamente por una transición en la posición 146. Sin embargo, es necesario mantener la precaución de excluir de este linaje a aquellos haplotipos que presenten alguna de las otras mutaciones señaladas como diagnósticas dentro de $\mathrm{C} 1 \mathrm{~b}$ (16092, 16192, 258). Por información de secuencias completas publicadas en Tamm y col. (2007) se conoce que las muestras $\mathrm{C} 1 \mathrm{~b}$ con 146 en Argentina (Salta, Catamarca y Tucumán) presentan una transición en la posición 12813, lo cuál apoya la hipótesis de monofilia extendida a las muestras que no han sido secuenciadas en forma completa. En el territorio que nos ocupa, este linaje está representado por 47 muestras y constituye el cuarto linaje en importancia alcanzando el $4 \%$ del total de las muestras. Las frecuencias más altas se encuentran en Chepes, San Juan y La Rioja con 11\%, $10 \%$ y $9 \%$ respectivamente.

A nivel sudamericano las muestras de Colombia y Argentina $\mathrm{C} 1 \mathrm{~b}+146$ no comparten mutaciones en la región codificante. Sobre los linajes de Perú y el norte de Bolivia no hay información adicional, de manera que no es posible, por el momento, discernir si están emparentados con los de Colombia o con los de Argentina. Los linajes de Potosí (Bolivia) y los del sur patagonico comparten con los del centro-norte de Argentina, además de 146, la mutación 16519. En el centro y norte de Argentina se diferencia además un sub grupo que comparte la mutación 16136. En caso de tratarse efectivamente de un mismo linaje, los mapas de distribución sudamericana (Figura 3.15) muestran cómo los linajes derivados tienen una distribución espacial más acotada que los linajes ancestrales, esto permite proponer un modelo de amplia distribución inicial de un linaje que luego se habría diferenciado en forma local con la aparición de linajes derivados que adquirieron mayor frecuencia en determinadas regiones. A pesar de que las mayores frecuencias se concentran en el centro-oeste del territorio argentino, la red de haplotipos (Figura 3.16) muestra la existencia de gran variedad de haplotipos en la ciudad de Tartagal, contrariamente a lo que sería esperado para un área periférica de expansión de un linaje. Por lo tanto, este linaje refuerza la idea de unidad territorial para la denominada Región II, vinculando a las localidades más distanciadas desde un puto de vista geográfico. 


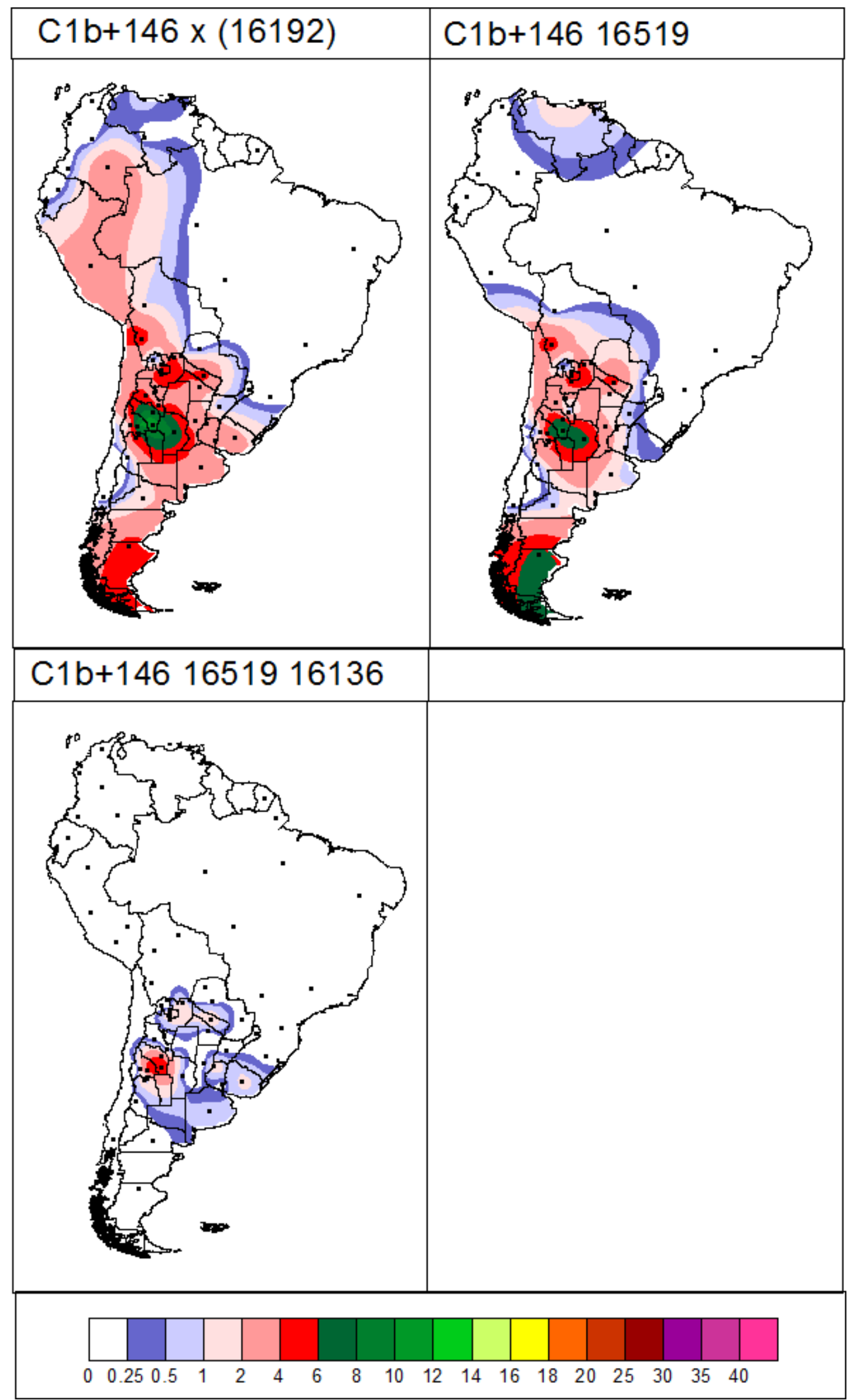

Figura 3.15. Distribución geográfica del linaje C1b+146 y sus linajes derivados. 

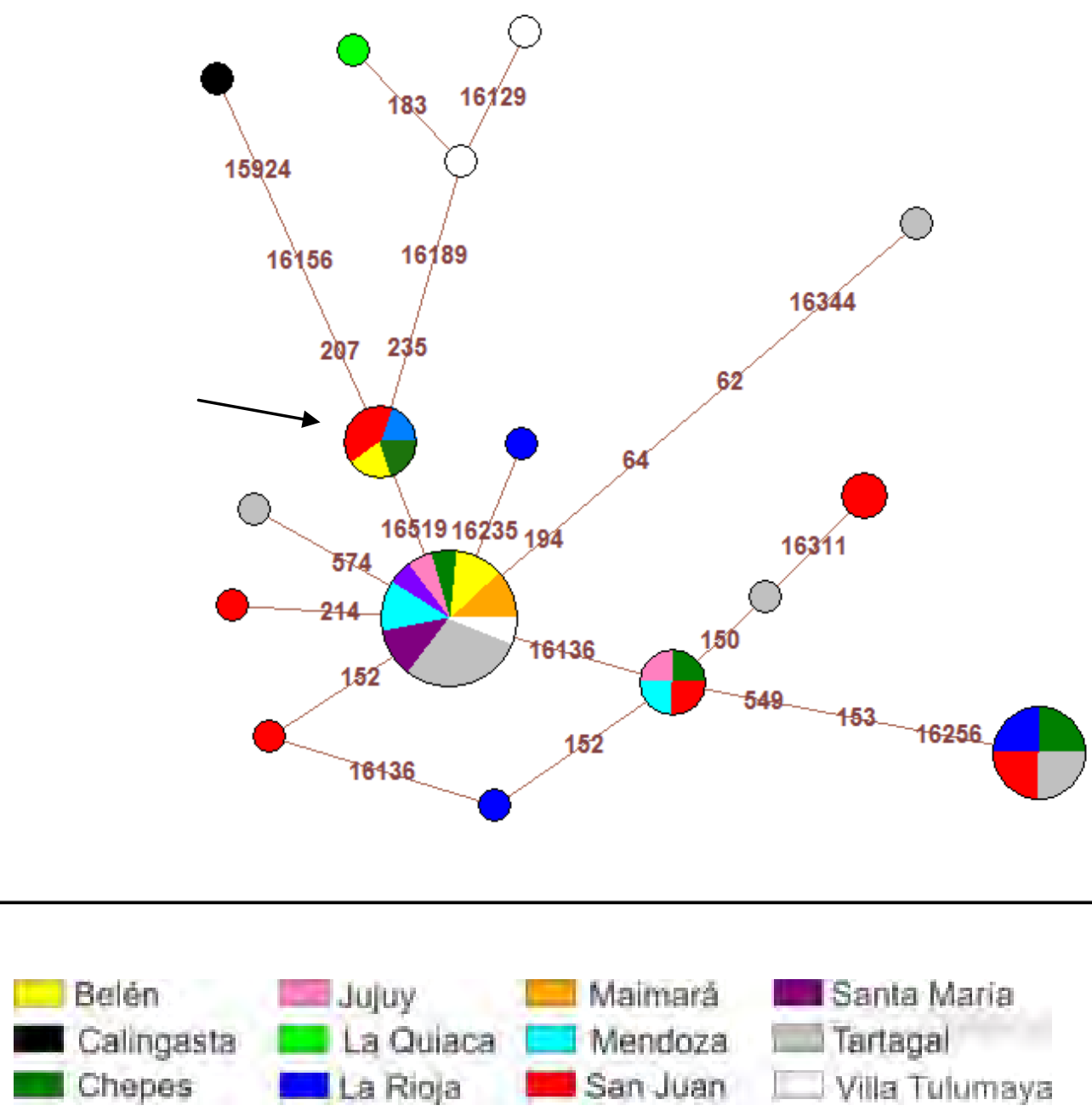

Figura 3.16. Red de haplotipos correspondientes al linaje $C 1 b+146$.

La flecha señala al haplotipo nodal del clado.

$\underline{\mathrm{C} 1 \mathrm{~b}+16192}$

Con 47 muestras, $\mathrm{C} 1 \mathrm{~b}+16192$ comparte con el linaje $\mathrm{C} 1 \mathrm{~b}+146$, el cuarto lugar en importancia entre las muestras analizadas en esta tesis. Se distribuye en toda la porción norte de Argentina con mayor frecuencia en el oeste, también se lo encuentra en el norte de Bolivia, centro de Perú y Norte de Colombia (Figura 3.18). Alcanza el pico más elevado de frecuencia en la localidad de Calingasta, donde representa $20 \%$ de las muestras. En este caso la mayor frecuencia no se corresponde con la mayor variabilidad, ya que las 13 muestras de Calingasta pertenecientes a este linaje, corresponden al mismo haplotipo (Figura 3.17). De modo que no puede proponerse a la región del oeste de San Juan como lugar de origen del linaje, sino que la alta frecuencia debe ser atribuida a un fenómeno de aislamiento propio de una localidad pequeña. Por otra parte, el sublinaje C1b+1619216093 tiene una amplia distribución que incluye a Perú. En Colombia, las muestras C1b con la 
mutación 16192 aparecen asociadas en la mayoría de los casos a otras dos mutaciones en la RHV-I: 16066 y 16311, en la RHVII a 146 y 275, y en la Región Codificante presentan las mutaciones 5600 y 6872. En este caso no se trataría del mismo linaje monofilético ya que hay muchas secuencias colombianas con dichos polimorfismos en Región Codificante pero sin la mutación en la posición 16192. Por el contrario, las muestras de Perú, Bolivia y Argentina comparten las mutaciones 16093, 16145 o 16362 reafirmando la hipótesis de monofilia.
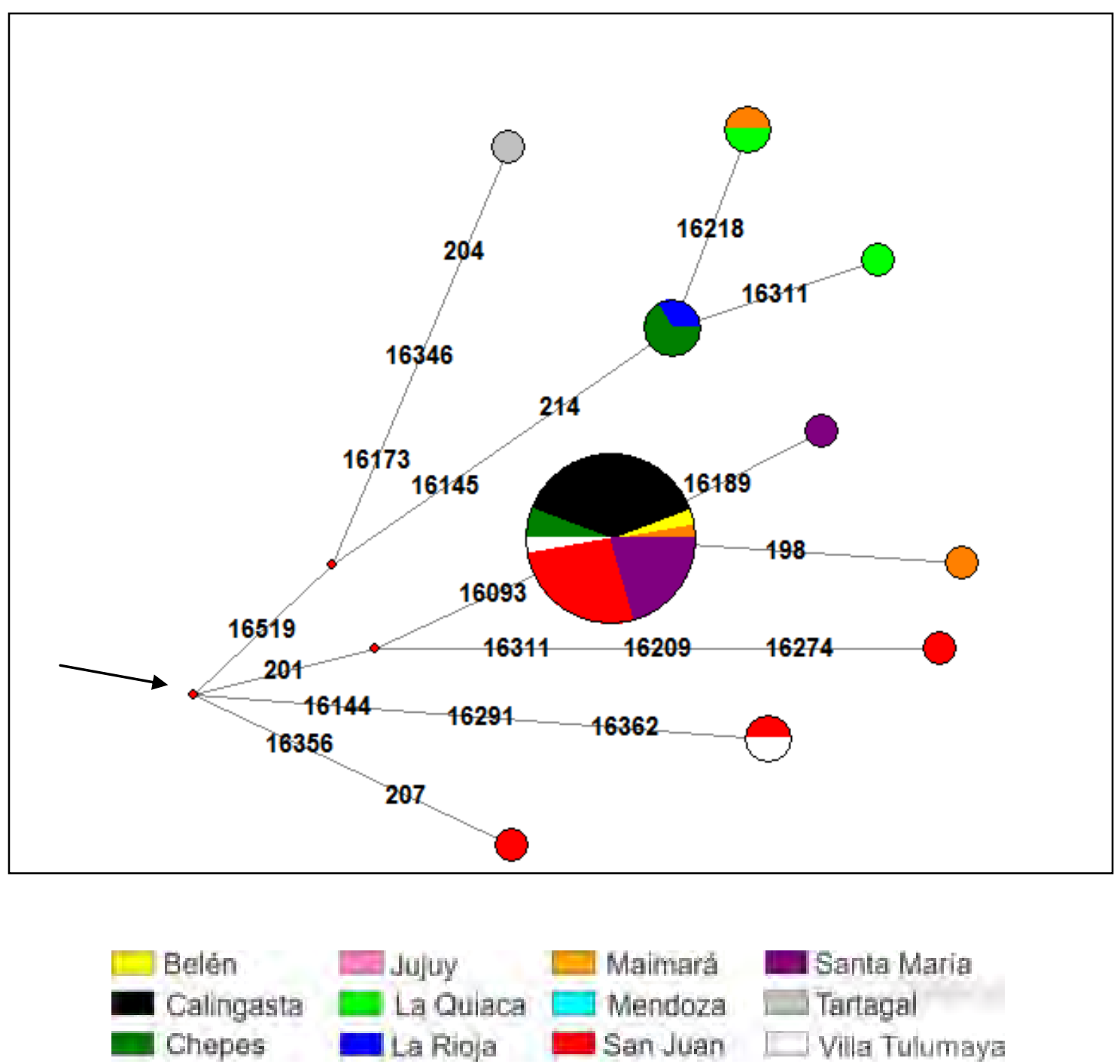

Figura 3.17. Red de haplotipos pertenecientes al linaje $C 1 b+16192$.

La flecha señala al haplotipo nodal del clado. 


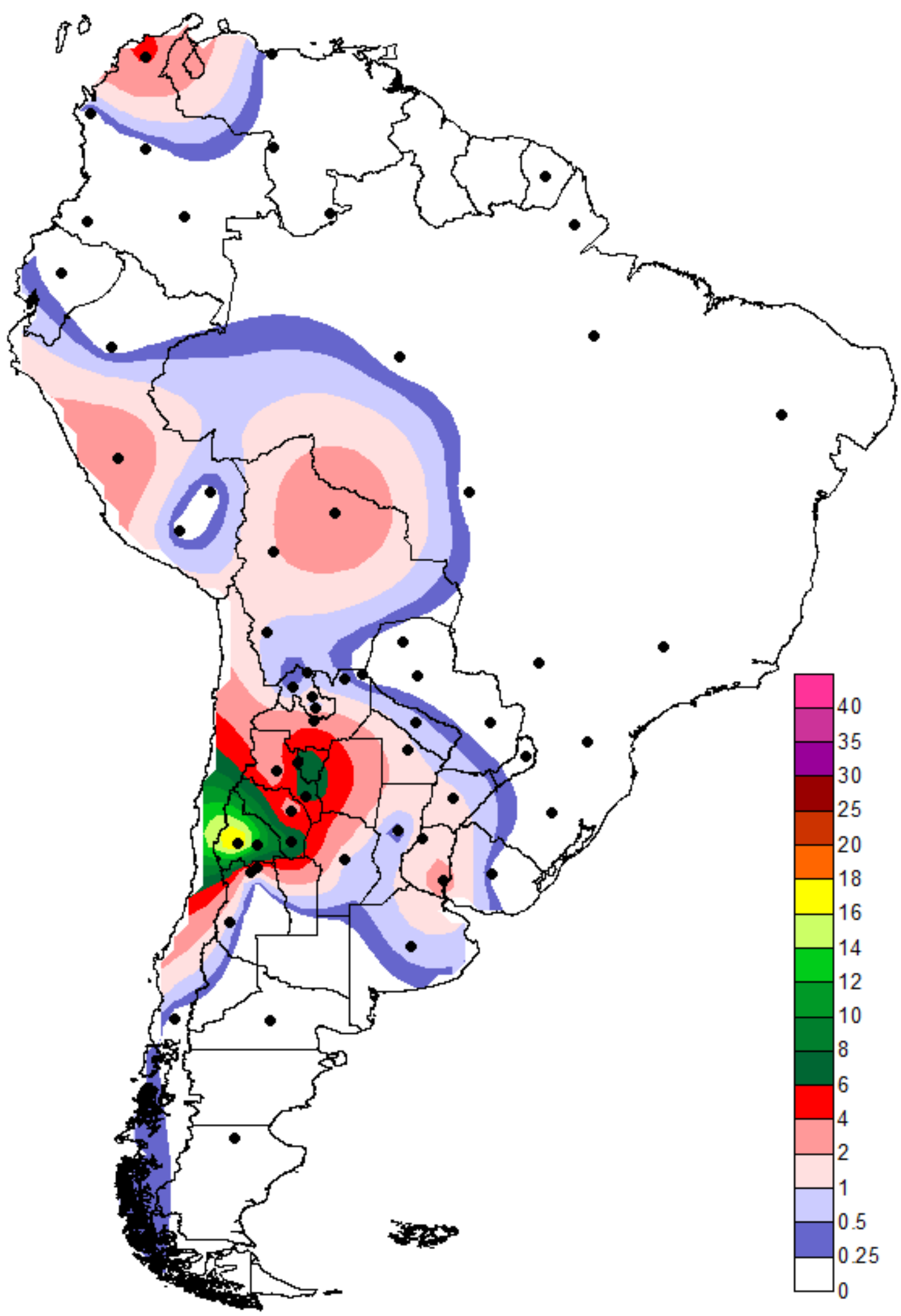

Figura 3.18. Distribución geográfica del linaje C1b+16192. 


\section{$\underline{\mathrm{C} 1 \mathrm{~d}+195(\mathrm{C} 1 \mathrm{~d} 1 \mathrm{~b})}$}

A pesar de que 195 constituye un sitio altamente variable, contamos con elementos para afirmar que, al menos al interior de la región en estudio, las muestras que presentan dicho polimorfismo forman parte de un linaje monofilético. Por un lado, la coherencia geográfica en la distribución del mismo y por otro, la existencia de un clado definido en base a secuencias completas correspondientes al linaje C1d (Perego y col. 2010) que queda definido por los polimorfismos 928 y 195. Este clado recibe el nombre de $\mathrm{C} 1 \mathrm{~d} 1 \mathrm{~b}$ y en el citado trabajo fue reportado únicamente en muestras del sur de Sudamérica. Así mismo, otros polimorfismos en RC descriptos en las muestras correspondientes a este linaje, también fueron reportados en el trabajo citado: la reversión de 16223 y 204 dentro de C1d1b1 y la co-ocurrencia de 16271 y 16259 por un lado y de 16519 y $573+$ CC por otro, dentro de C1d1b.

Entre las muestras analizadas $\mathrm{C} 1 \mathrm{~d} 1 \mathrm{~b}$ representa $3 \%$ del total y se encuentra mayormente representado en las ciudades de La Rioja, Santa María y San Juan (9\%, 8\% y 7\%, respectivamente).

A nivel sudamericano, existe una distribución continua con foco en el centro de Argentina y una disminución gradual de la frecuencia hacia el norte y el sur, con valores menores al 1\% en el norte de la Patagonia y el Litoral. Entre los países limítrofes sólo se lo ha descripto en Uruguay, donde alcanza 1\% (Figueiro y col. 2010 y Figueiro comunicación personal). También se han identificado muestras C1d con una transición en 195 en Caracas, Venezuela (Castro de Guerra y col. 2011) (Figura 3.19). Dada la gran distancia geográfica, no puede descartarse la ocurrencia de un paralelismo, sin embargo, es interesante señalar que son varios los linajes que presentan este patrón de distribución disyunta entre el centro de Argentina y la costa atlántica del Caribe, dejando abierta la posibilidad de que efectivamente se trate de un mismo grupo monofilético.

La red de haplotipos (Figura 3.20) muestra una mayor frecuencia de los haplotipos nodales respecto de los derivados. Las localidades que representan el núcleo central de la distribución comparten haplotipos que incluyen al nodal y a los separados por un paso mutacional, mientras que las localidades de la periferia (San Salvador de Jujuy, La Quiaca, Maimará, Mendoza y Villa Tulumaya) presentan haplotipos externos y alejados del nodal por hasta tres pasos mutacionales. 


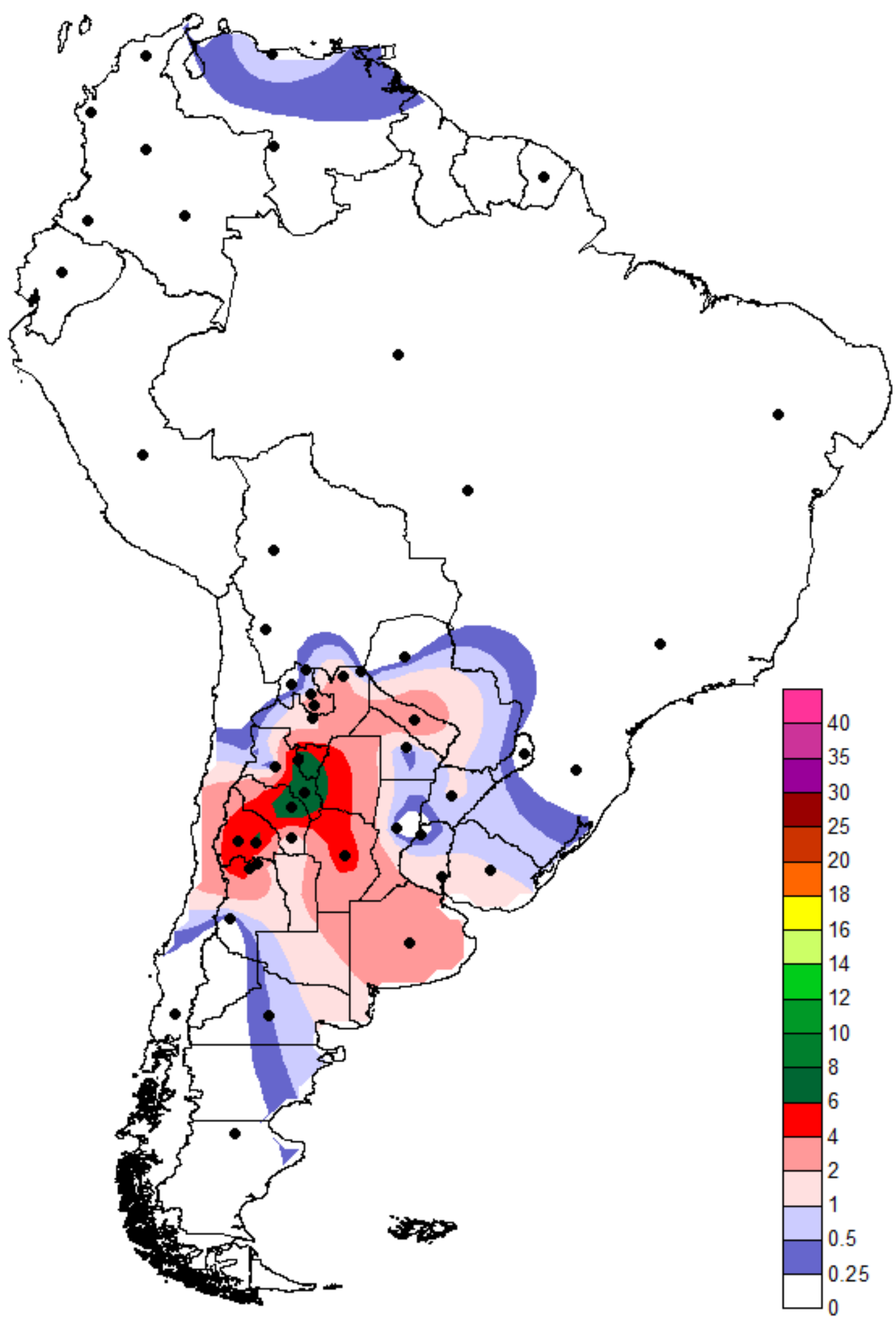

Figura 3.19. Distribución a nivel sudamericana del linaje Cld+195 (Cld1b). 


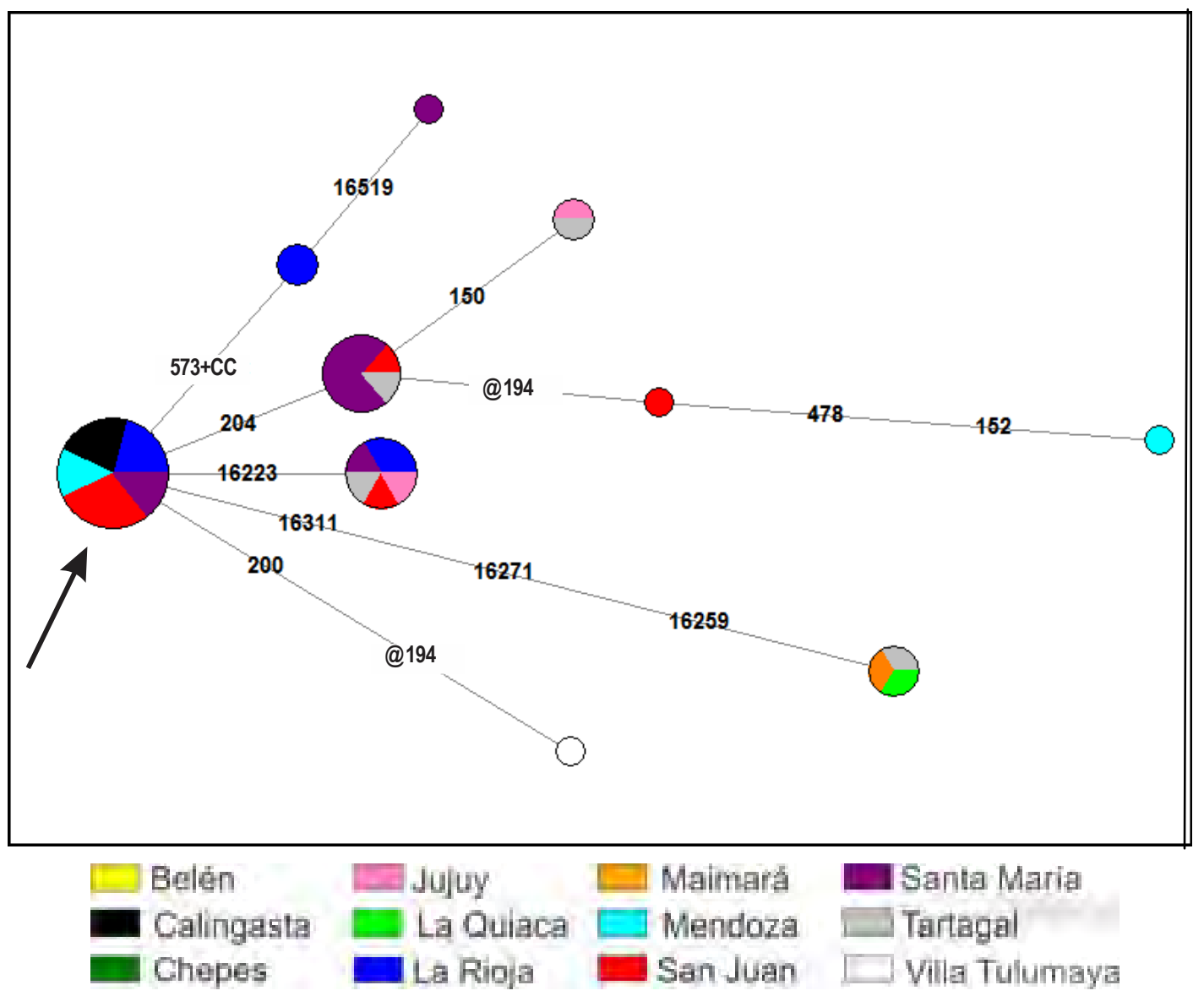

Figura 3.20. Red de haplotipos correspondientes al linaje C1d+195 (C1d1b).

La flecha señala al haplotipo nodal del clado.

\section{$\underline{\mathrm{B} 2+16142}$}

Resulta particularmente interesante puesto que se trata de un linaje dentro del haplogrupo B, cuya mayor frecuencia no se encuentra en el área andina central. Por el contrario, el centro de distribución del mismo parece ubicarse en el centro-oeste del territorio argentino con frecuencias de $7 \%$, 6\% y 5\% en San Juan, La Rioja y Santa María, respectivamente. No se encuentra representado ni en San Salvador de Jujuy ni en Maimará pero sí en Tartagal y en La Quiaca. No se lo identifica en Bolivia, pero sí en el centro de Perú. Tampoco se extiende hacia la región chaqueña, con excepción de una muestra en Formosa (Bobillo y col. 2010), mientras que hacia el sur alcanza el norte de la Patagonia con una frecuencia del 1\% (Figura 3.21).

La red de haplotipos (Figura 3.22) es atípica ya que no está representado el haplotipo nodal, a su vez, presenta un conjunto de haplotipos con alta frecuencia pero poca variabilidad, separados del nodal por cinco pasos mutacionales. Estos haplotipos coexisten en las mismas localidades con los haplotipos que se desprenden directamente del nodal, sin poder apelar a la distancia geográfica para justificar la separación a nivel molecular. 


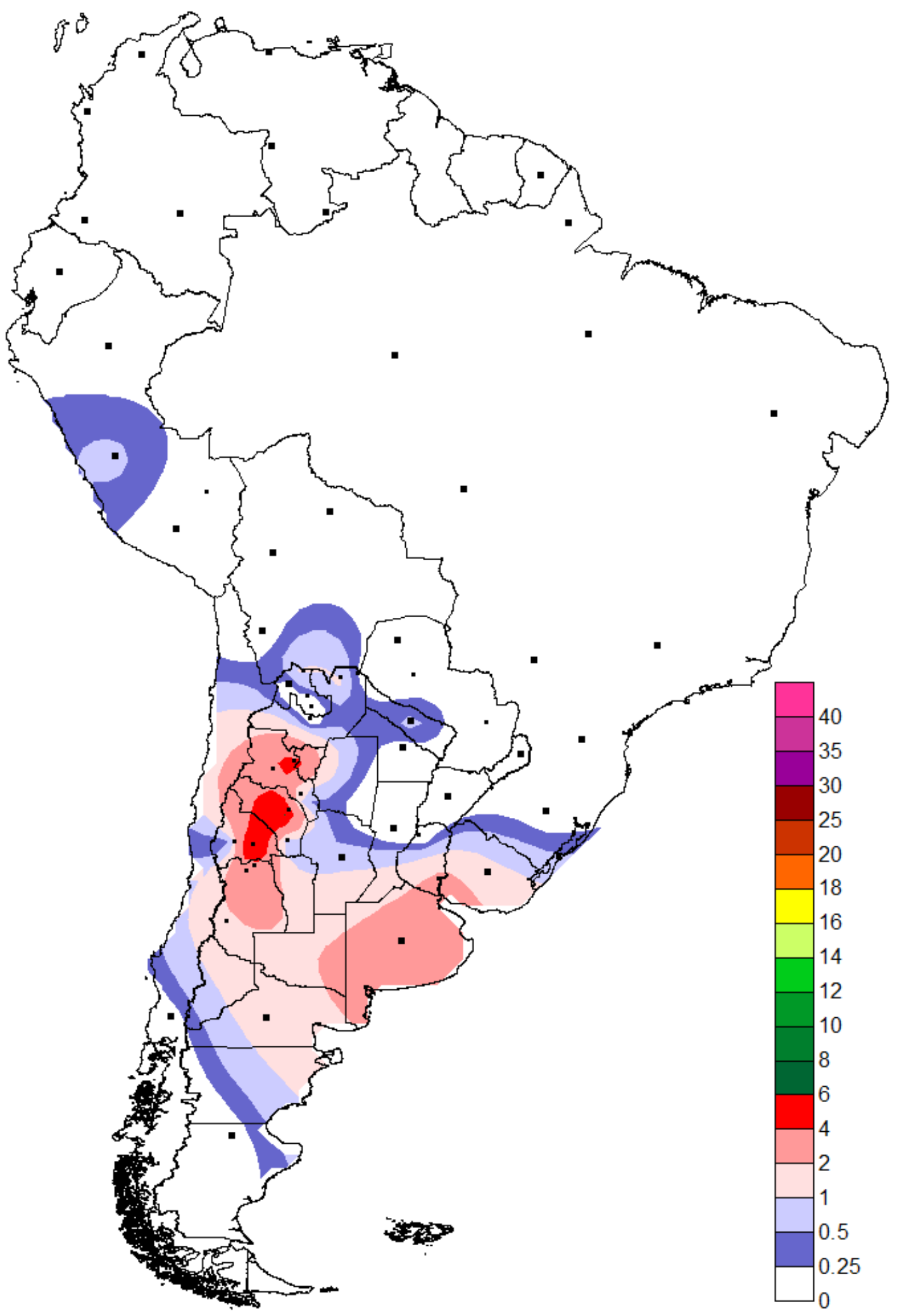

Figura 3.21. Distribución geográfica del linaje B2+16142. 

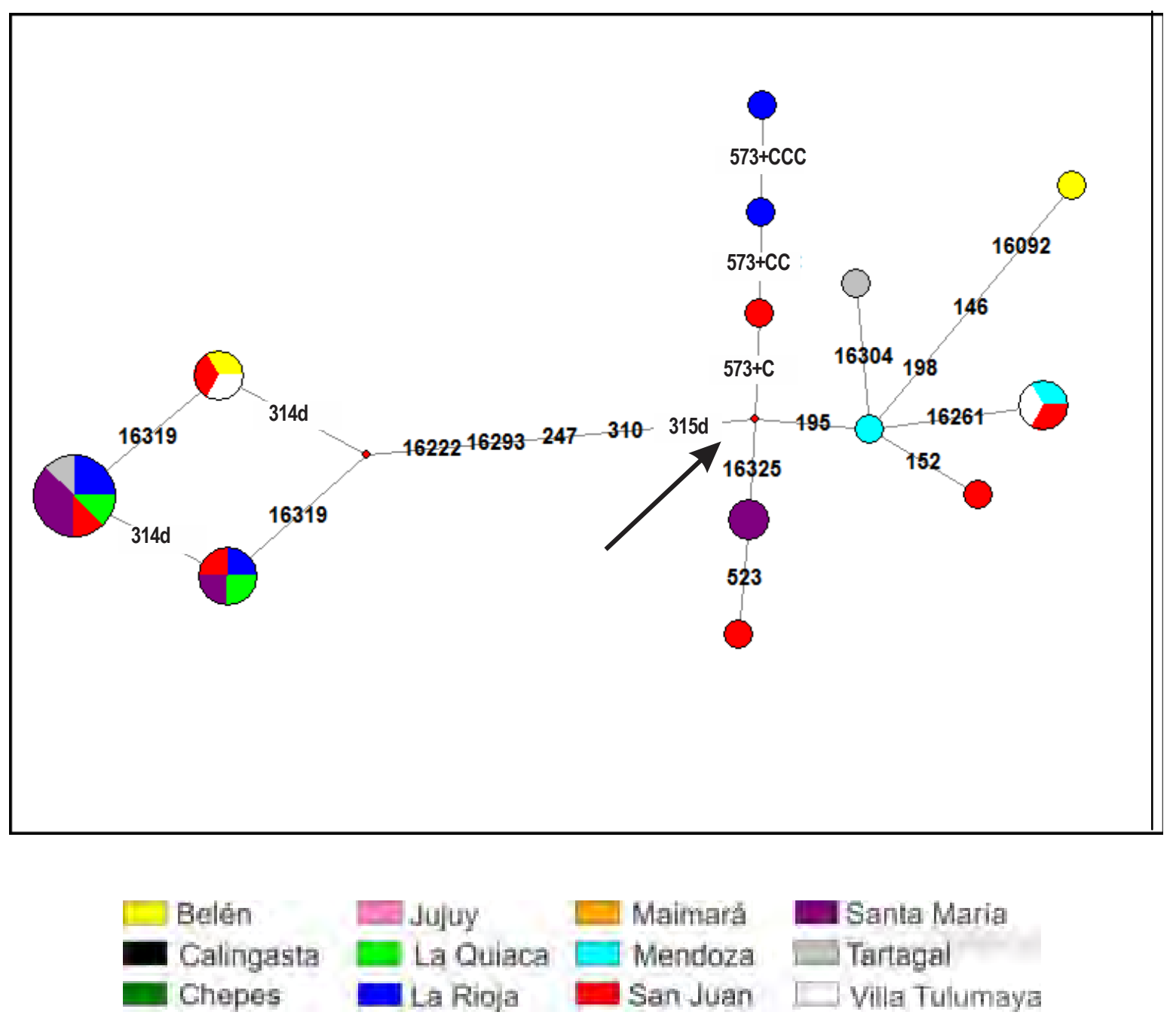

Figura 3.22. Red de haplotipos pertenecientes al linaje B2+16142.

La flecha señala al haplotipo nodal del clado.

\subsubsection{Región III}

La Región III tiene como característica saliente al linaje B2+146-215-455+T, otros linajes con baja frecuencia comparten con el mismo una distribución central en la Región III. Por otra parte esta región constituye la extensión natural de la Región I, encontrándose linajes cuyo centro de distribución se encuentra en los Andes centrales tal como sucede con el linaje B2+16188 descripto supra y con $\mathrm{B} 2+103$ y D1+16527. Otra característica destacada es la penetración de linajes propios de las tierras bajas como A2+16051, A2+16266, B2+16051, B2+16140, B2+16316, C1c+16169 y D1+16142 (D1f). En conjunto, estos linajes representan $38 \%$ de las muestras de Belén, $18 \%$ de las de Jujuy, 22,5 \% de La Quiaca, $22 \%$ de Maimará, 35 \% de Santa María y $20 \%$ de Tartagal. 


\section{$\underline{\mathrm{B} 2+146-215-455+\mathrm{T}}$}

Con 70 muestras pertenecientes a este linaje, B2+ 146215 455+T representa el segundo linaje en orden de importancia en la región en estudio. Su mayor frecuencia corresponde a la localidad de Belén (33\%), ubicada en el valle homónimo de la provincia de Catamarca. A nivel sudamericano, el mapa de distribución del linaje se construyó tomando como referencia la presencia conjunta de las mutaciones 146 y 215 , ya que son muy pocas las muestras que han sido secuenciadas más allá de la RHV-II. De esta manera se identifica su presencia en elevada frecuencia en el norte de Chile y oeste de Bolivia. La presencia en Buenos Aires, Mendoza, Santa Fe y Río Negro refleja la atracción de los polos económicos actuales (Figura 3.23).

Al observar la red de haplotipos (Figura 3.24), queda en evidencia que la frecuencia alcanzada en Belén es producto del aislamiento local ya que en allí se encuentran pocos haplotipos con altas frecuencias, por el contrario el mayor número de haplotipos se encuentra en las localidades de La Quiaca y Maimará indicando que esta podría ser la región de origen del linaje. La red de haplotipos de este linaje se caracteriza por la inestabilidad en la posición 66. El haplotipo más frecuente no es el nodal, sino el que porta dos mutaciones adicionales en las posiciones 63 y 64 . Se observan pocos haplotipos faltantes.

En el trabajo de Tamm y col. (2007) se describen dos muestras con las mutaciones características de este linaje que en región codificante comparten las mutaciones 3483 y 3591. 


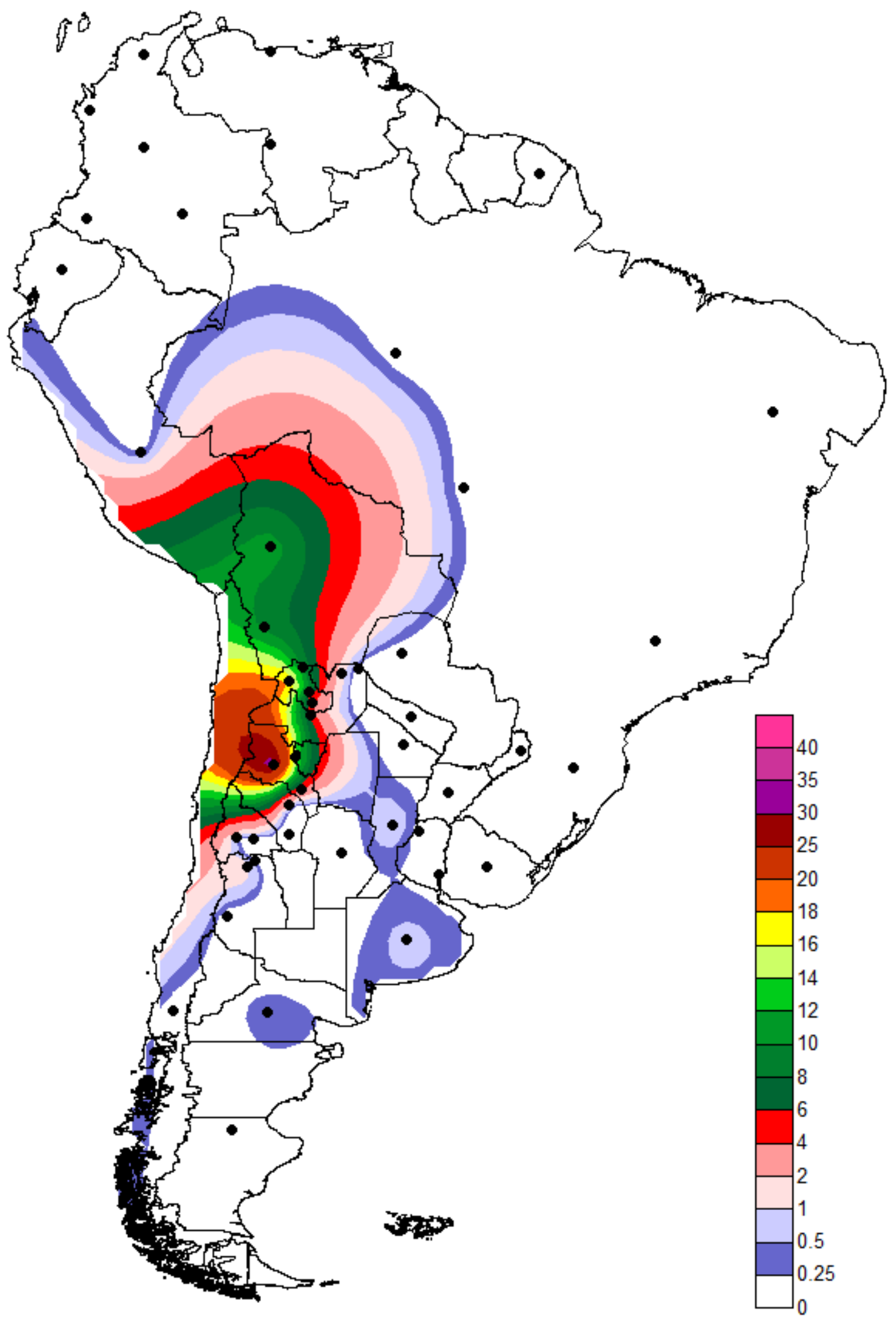

Figura 3.23. Distribución geográfica del linaje B2+146 $215(455+T)$. 


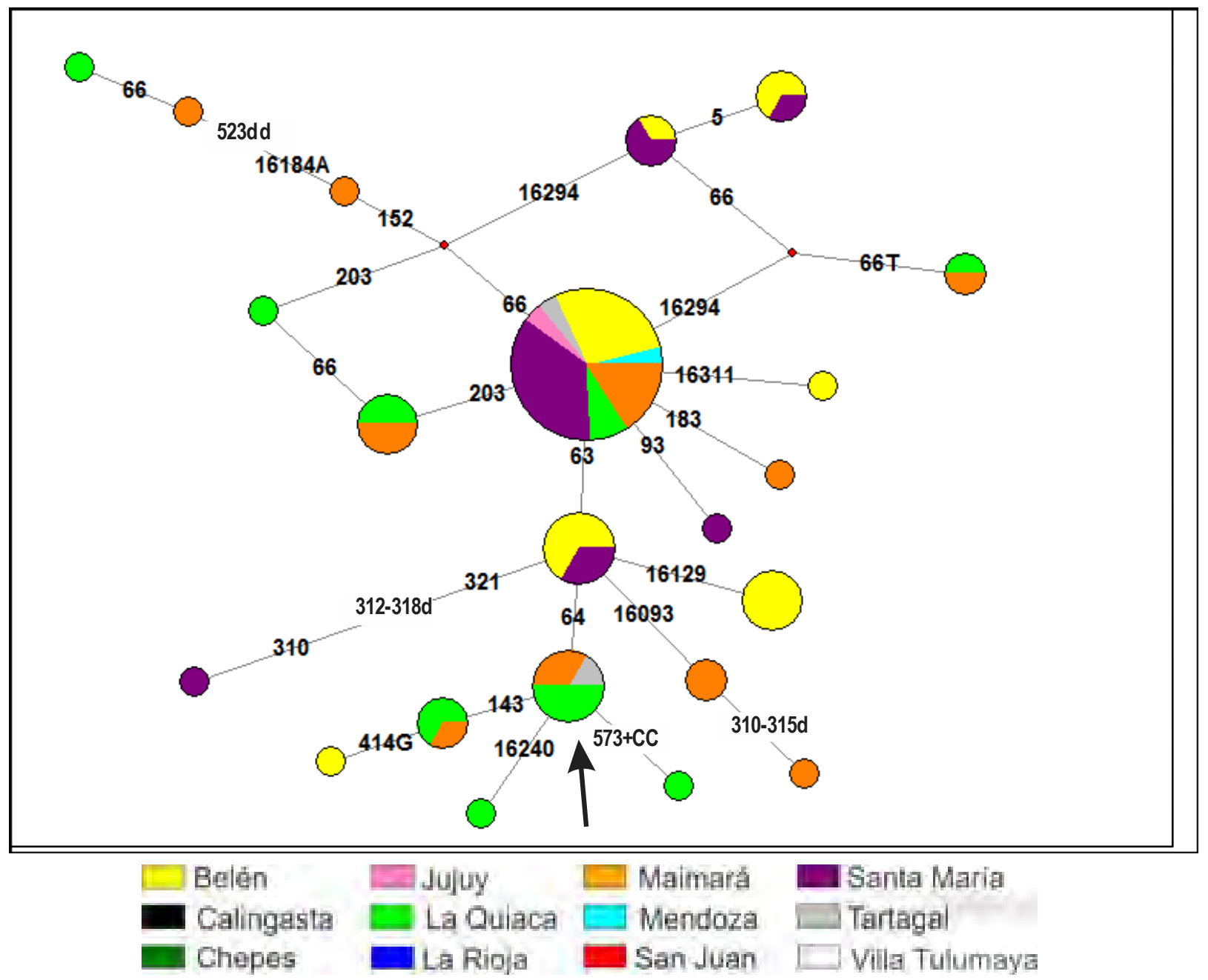

Figura 3.24. Red de haplotipos pertenecientes a B2 + $146215455+T$.

La flecha señala al haplotipo nodal del clado.

Linajes con centro de distribución en la Región III

Se trata en general de linajes con mayor frecuencia en Santa María (13\% en total) y baja frecuencia en las localidades aledañas; $5 \%$ en Maimará, $3 \%$ en Belén y en Tartagal y $2 \%$ en La Quiaca. La conjunción de las mutaciones 203 y 204 dentro del haplogrupo B2 define a un linaje que está restringido a la Región III (Figura 3.25a), mientras que los restantes linajes señalados se encuentran presentes en las provincias de Mendoza, Buenos Aires y Río Negro, distribución que es interpretada como resultado de migraciones actuales (Figura 3.25 b, c y d). La presencia de B2+16309 y de $\mathrm{C} 1 \mathrm{~b}+16189-16311$ en regiones disyuntas de Brasil y Venezuela (Figura 3.25 c y d) plantea la posibilidad de la recurrencia de la mutación y que no se trate de un único linaje, ya que se trata de posiciones altamente variables. Por otra parte D4h3a+16294 está altamente representado en los Santa María (5 \%), en con menor frecuencia en el sur de Perú, en La Paz (Bolivia) y en migrantes quechuas asentados en el Beni boliviano (Corella y col. 2007; Sandoval y col. 2008; Afonso y col. 2010), (Figura $3.25 \mathrm{~d}$ ). 


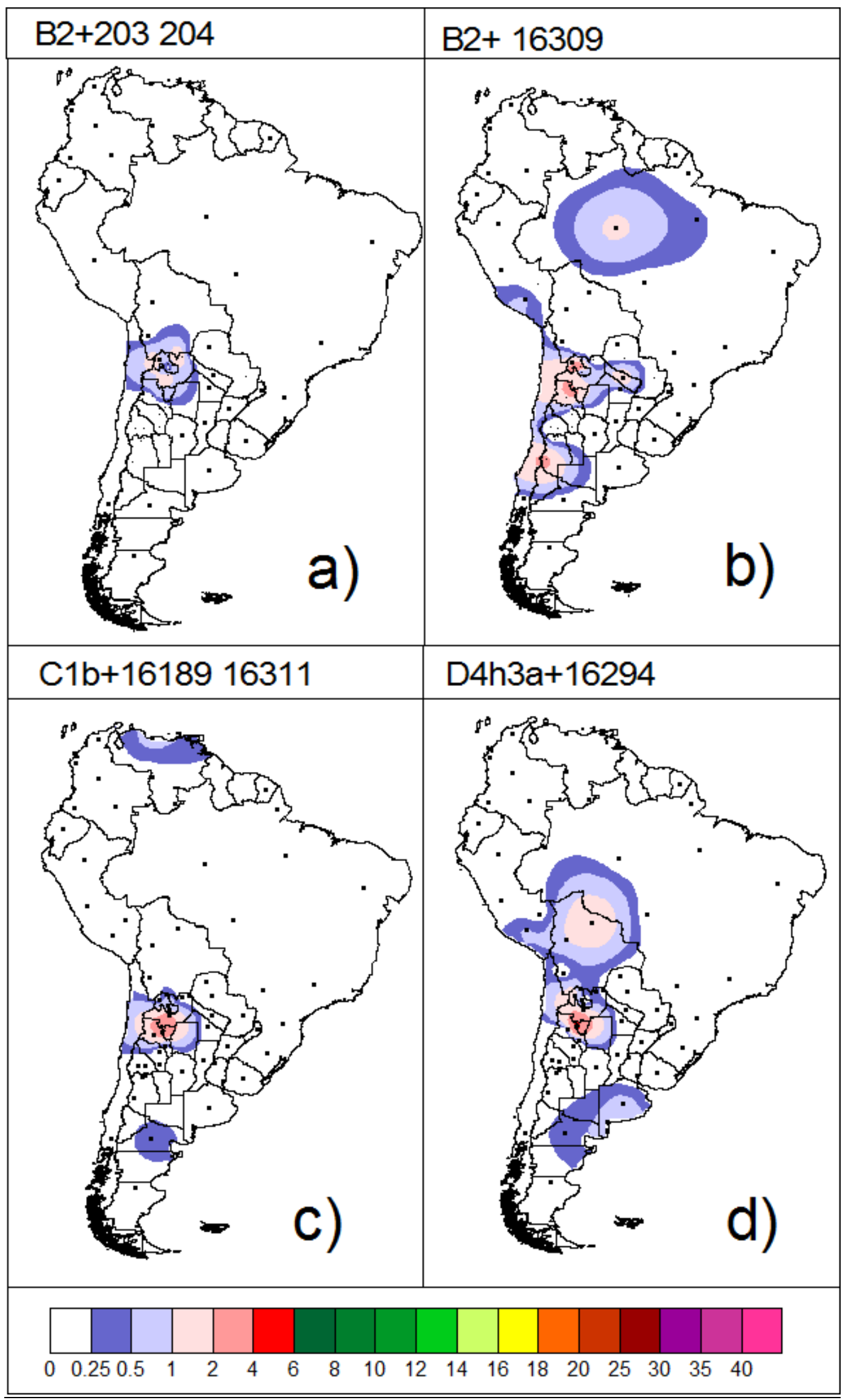

Figura 3.25. Distribución geográfica de linajes con centro de distribución en la Región III (a-d). 


\section{Linajes propios de tierras bajas}

En las Figuras 3.26 y 3.27, se observan linajes cuyas mayores frecuencias se encuentran en las regiones del Chaco o del Litoral. Éstas han sido denominadas tradicionalmente Tierras Bajas por oposición a aquellas de los Andes Centrales. En la región que nos ocupa se observa la presencia de estos linajes en especial en las localidades de Tartagal y Jujuy (13\% y $12 \%$ respectivamente).

Todos estos linajes son compartidos con las provincias del Noreste de Argentina. Algunos de ellos, a pesar de estar representados por pocas muestras en el territorio que es objeto de esta tesis, merecen especial atención por su particular distribución geográfica.

A2+ 16051 es un linaje característico del Chaco austral, con una extensión continua que alcanza la provincia de Rio Negro y el sur de Perú. Por otra parte también se lo identifica en el norte del subcontinente, en la Guyana Francesa y norte de Venezuela.

B2+16140 y B2+16316 constituyen linajes al interior de B2 que no coinciden con el patrón general de este haplogrupo que ostenta mayor frecuencia en los Andes Centrales. Éstos y otros como el mencionado B2+ 16142 en Región II, constituyen un ejemplo de la necesidad de refinar el nivel de análisis a la hora de realizar interpretaciones a nivel regional. 


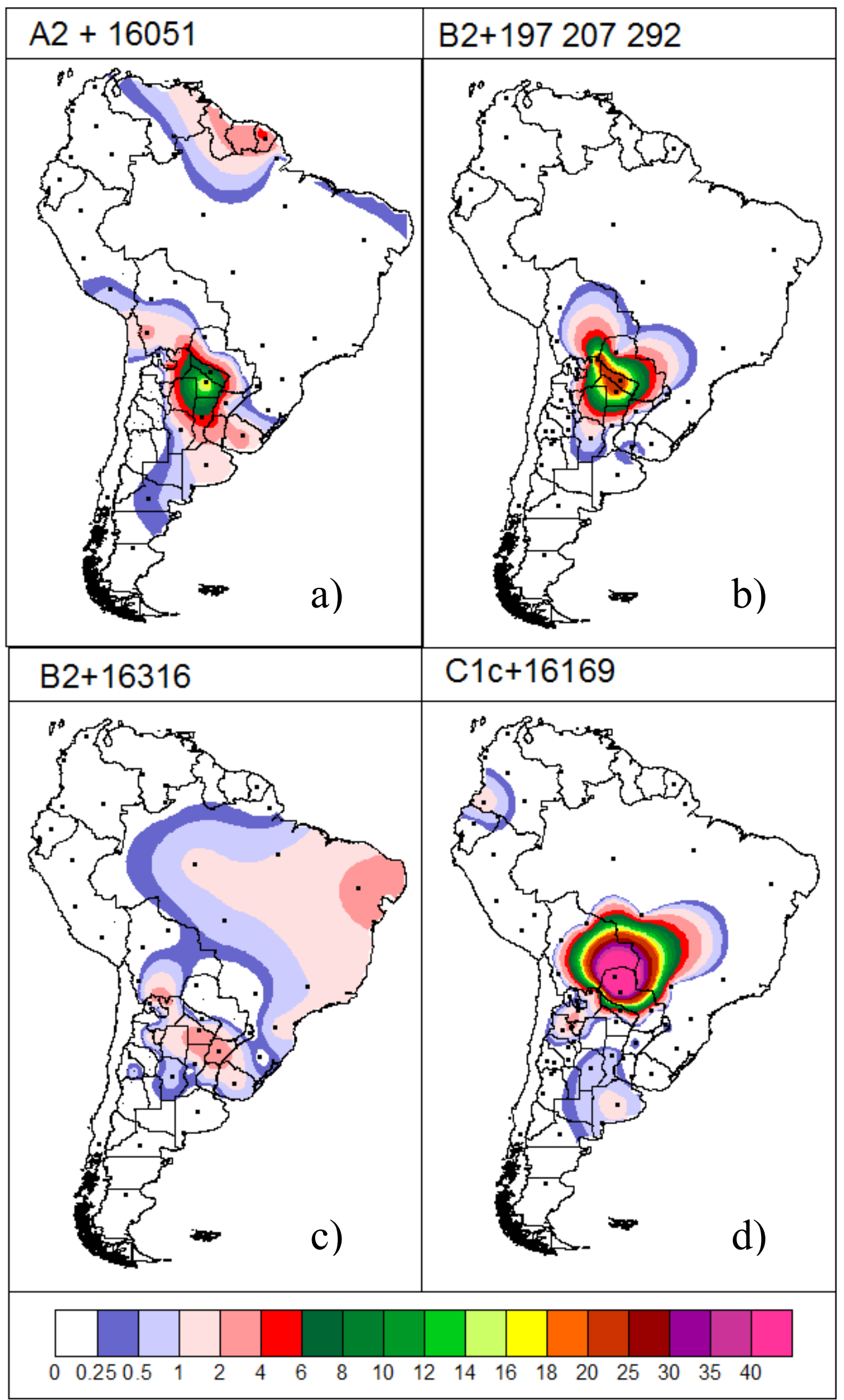

Figura 3.26. Distribución geográfica de linajes propios de la Región III (a-d). 


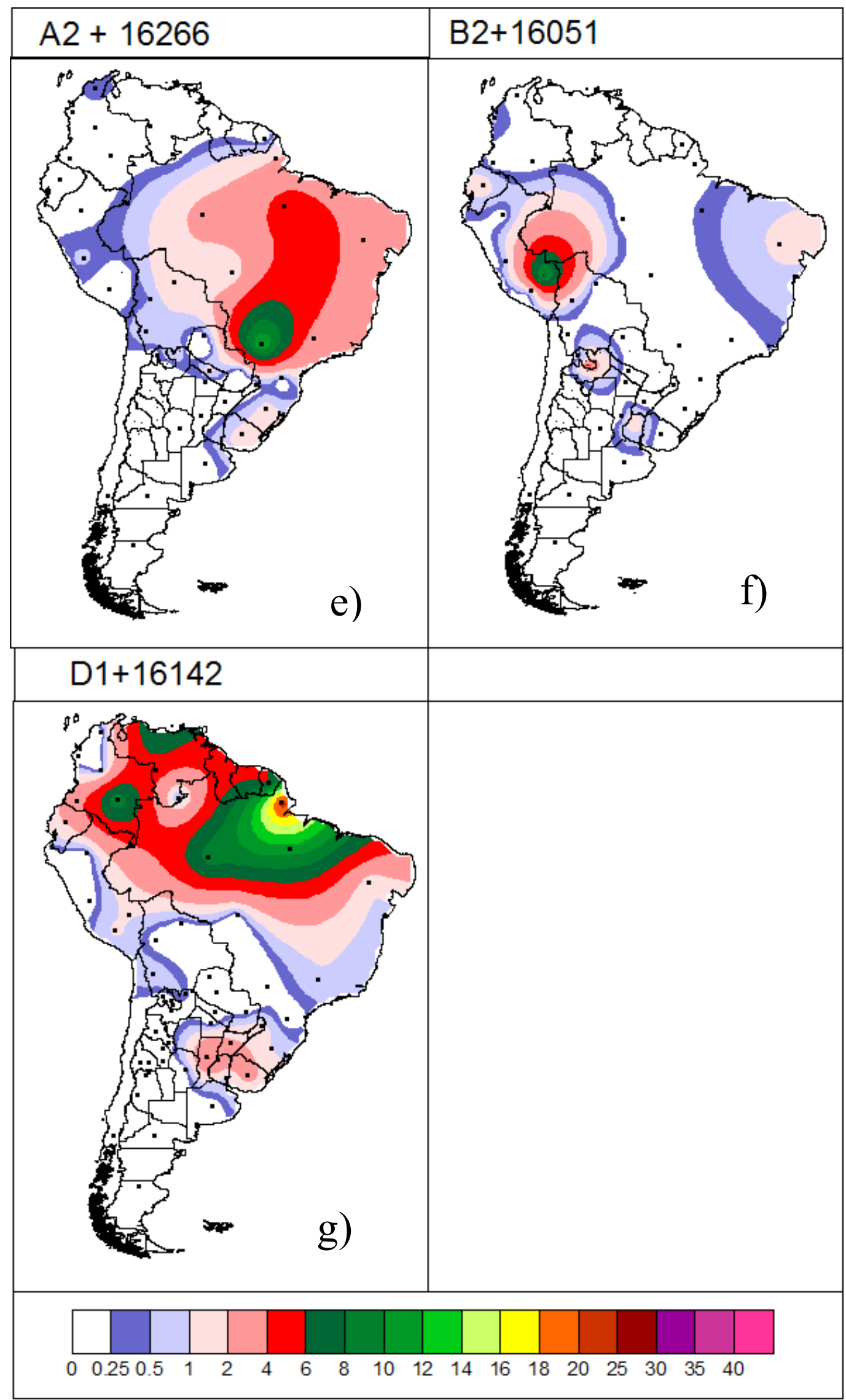

Figura 3.27. Distribución geográfica de linajes propios de la Región III (e-g). 


\section{Linajes propios de Andes Centrales}

La distribución a nivel sudamericano de D1+16527 no deja dudas respecto de su filiación andina, siempre y cuando se acepte la hipótesis de que la presencia en Mendoza y Buenos Aires y en menor medida en San Juan es debida a migración reciente (Figura 3.28 a). La distribución de B2 +103 (Figura 3.28 b), por el contrario, merece un análisis más detallado, ya que se extiende tanto en el este como en el oeste de Sudamérica. Puede hacerse una subdivisión dentro de este linaje que muestra la diferenciación de dichas regiones (Figuras 3.29 y 3.30). La hipótesis de la monofilia se mantiene, puesto que la mutación en la posición 103 se presenta como previa a la aparición de las mutaciones con especificidad regional, ya que existen haplotipos con la mutación 103 que carecen de las mutaciones diagnósticas de los linajes derivados tanto en el litoral como en el área andina.

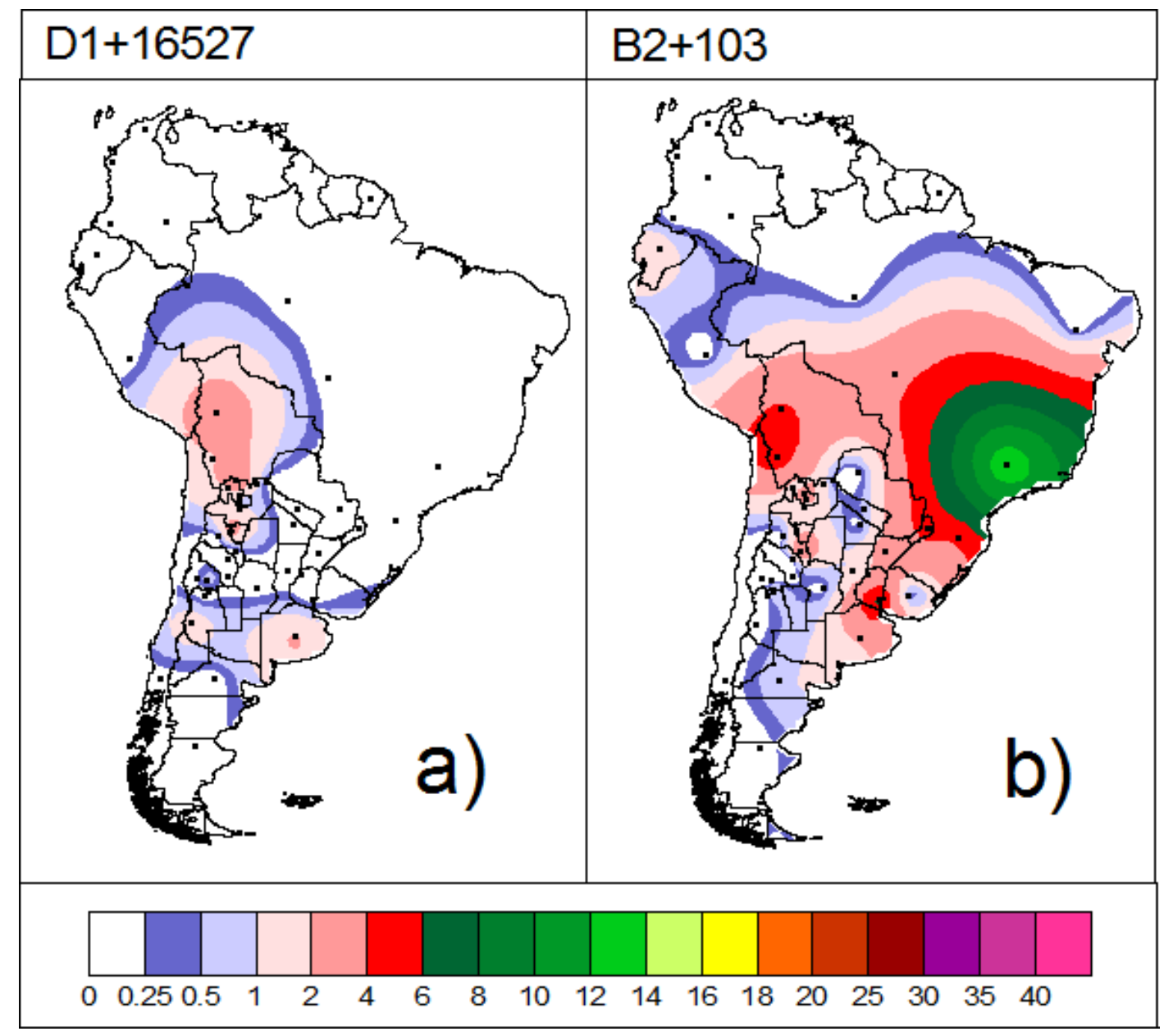

Figura 3.28. Distribución geográfica de linajes propios de Andes Centrales en la Región III. 


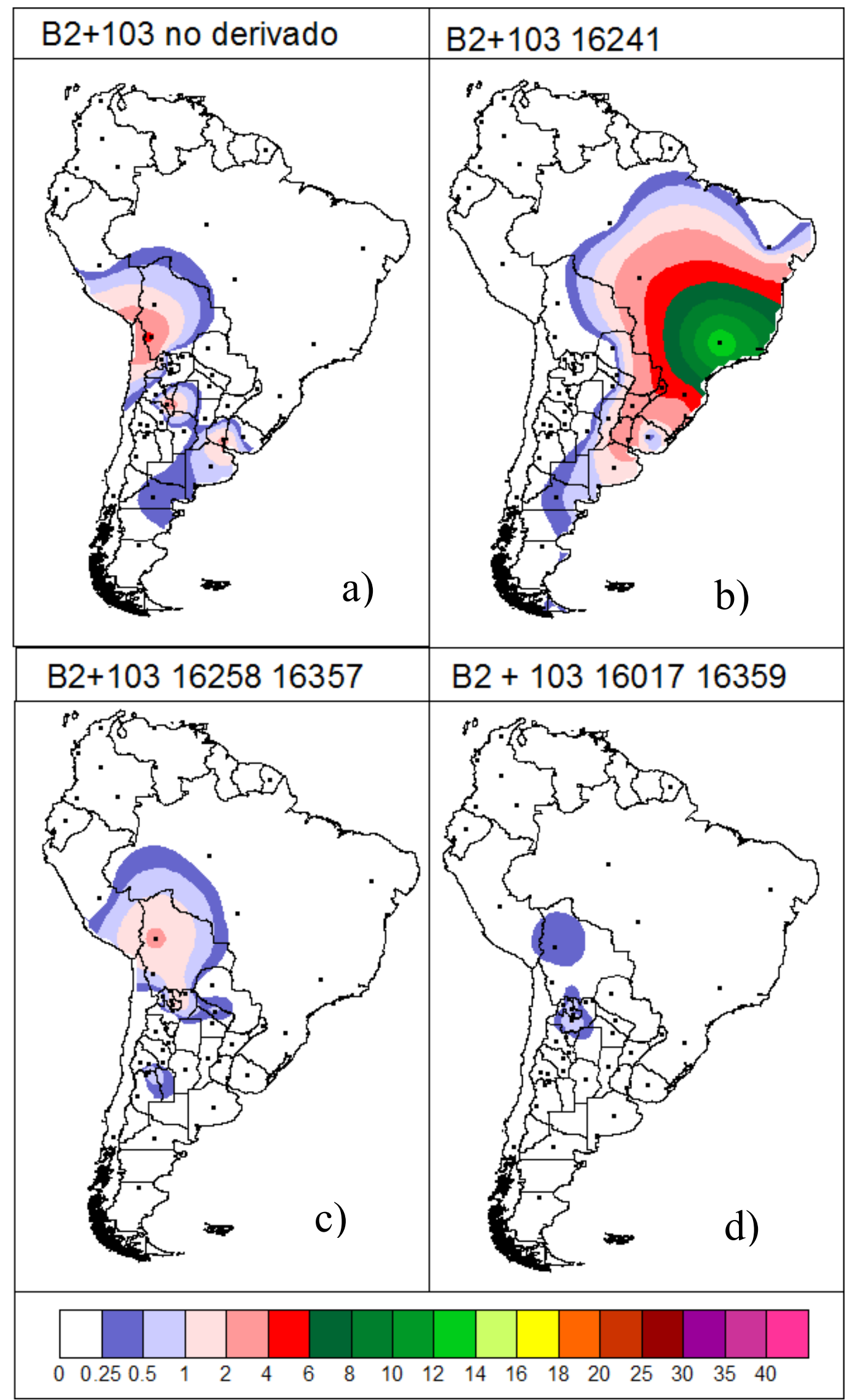

Figura 3.29. Distribución geográfica de sub-linajes derivados de B2+103 (a-d). 


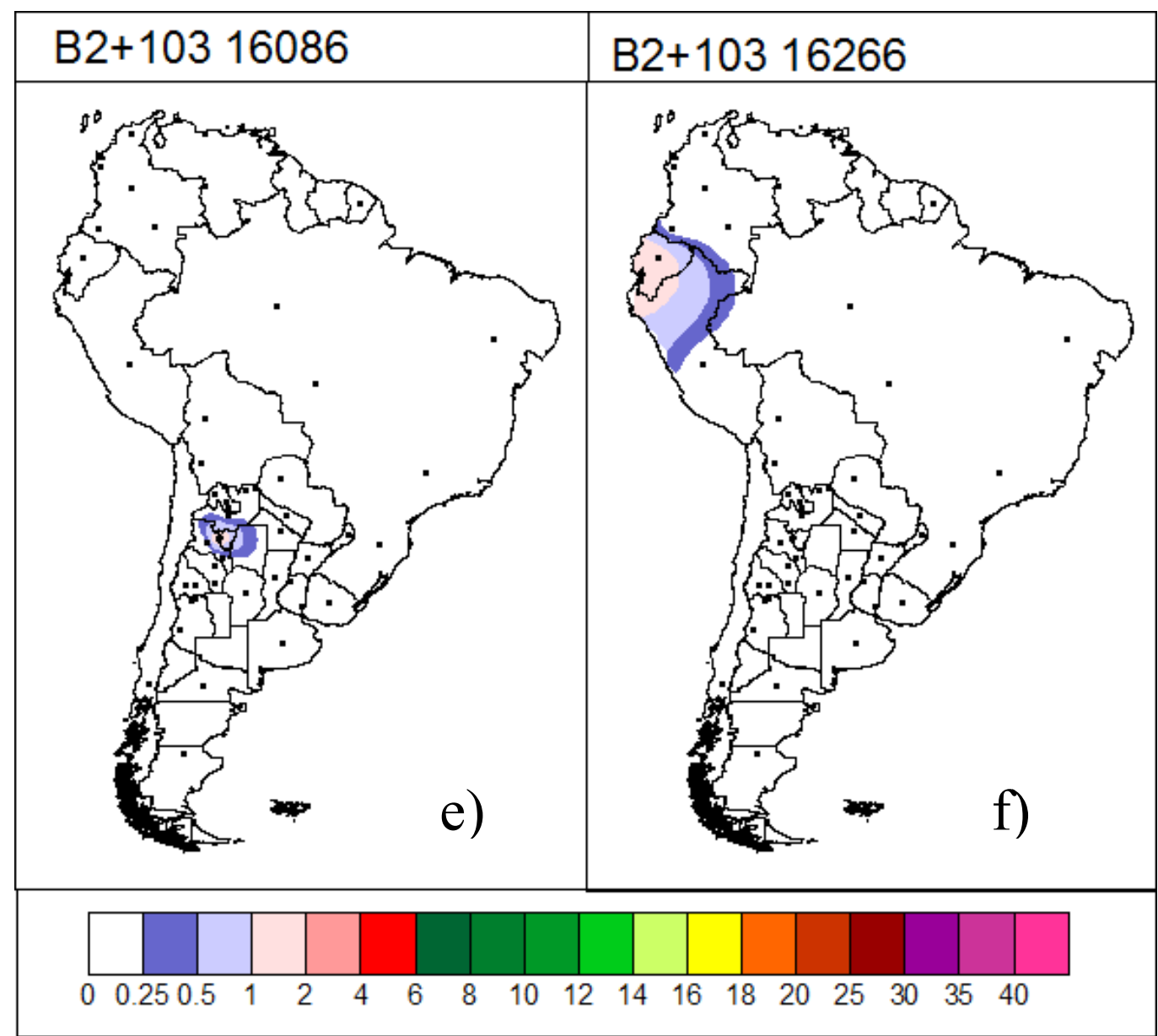

Figura 3.30. Distribución geográfica de sub-linajes derivados de B2+103 (e-f).

\subsubsection{Región IV}

La región IV está conformada por las provincias de La Rioja, San Juan y el norte de Mendoza. De los linajes que se distribuyen en esta región, A2+150 es el más representativo, lo acompañan A2+16129 195 y C1b+194. Y también se encuentra en esta región uno de los últimos linajes fundadores en ser descriptos, $\mathrm{C} 4 \mathrm{c}$, previamente reportado únicamente en América del Norte (Malhi y col. 2010) y en Colombia (Tamm y col. 2007). Respecto de la distribución a nivel sudamericano de los linajes propios de la Región IV, llama la atención un probable vínculo con poblaciones del extremo noroeste de Sudamérica. La monofilia está confirmada para C4c y restaría constatarla para los linajes definidos en base a la Región Control A2+16129 195 y C1b+194. Por otra parte, en esta región se extienden los linajes propios de la Patagonia D1+16187 (D1g), B2+470 y $\mathrm{C} 1 \mathrm{~b}+258$, reforzando el límite señalado entre las regiones III y IV. 
Con centro en la localidad de Villa Tulumaya, donde reúne 17\% de las muestras, se extiende hacia el centro y el sur de la Argentina y no se encuentra al norte de Catamarca, con la excepción de una muestra aislada en La Quiaca (Figura 3.32). En Villa Tulumaya también se identifica el mayor número de haplotipos, señalando a esta localidad como centro de origen y dispersión del linaje. La red de haplotipos presenta varios haplotipos faltantes y haplotipos separados del nodal por hasta 6 pasos mutacionales, indicando que se trata de un haplotipo con considerable profundidad temporal (Figura $3.31)$.

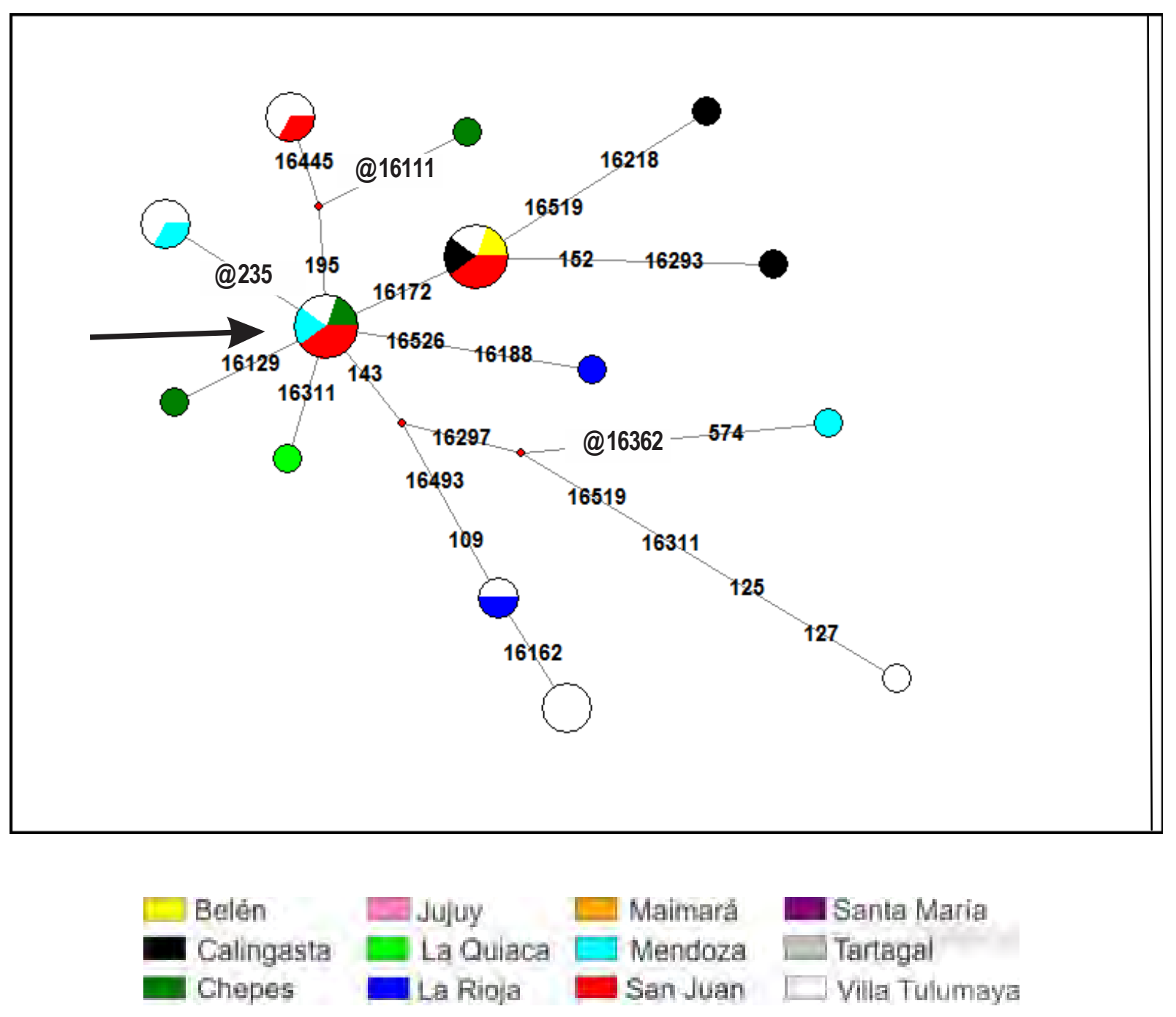

Figura 3.31. Red de haplotipos pertenecientes a A2+150.

La flecha señala al haplotipo nodal del clado. 


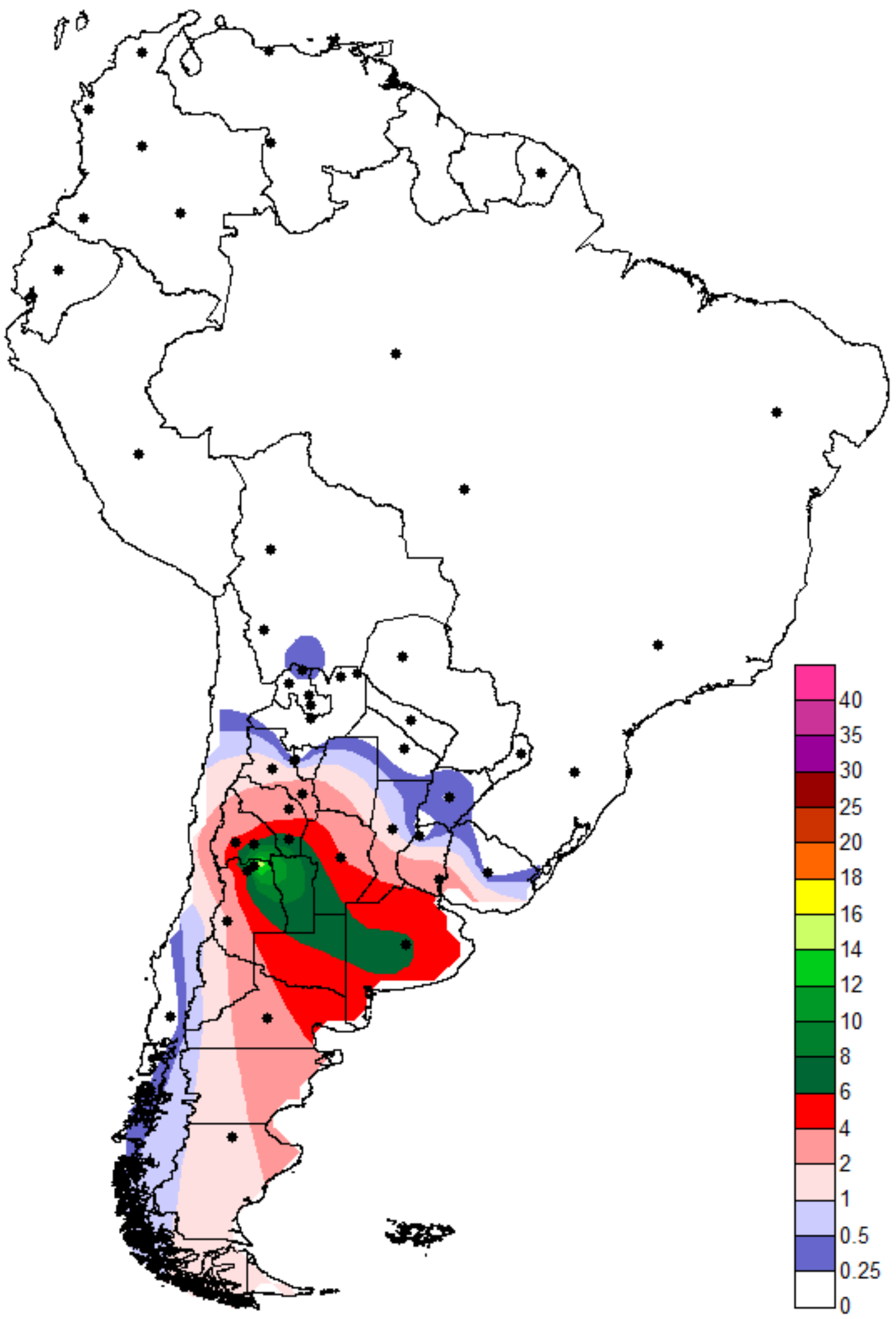

Figura 3.32. Distribución geográfica del linaje A2+150. 
La información de secuencias completas ha confirmado la presencia de $\mathrm{C} 4 \mathrm{c}$ en dos áreas disyuntas: el norte de Colombia y el centro de Argentina. Esta distribución es interpretada como la persistencia en estas regiones de poblaciones relicto, donde habrían perdurado linajes presentes en una expansión poblacional inicial que, tras ingresar en Sudamérica vía el istmo de Panamá, se habría dispersado hacia el este y el sur, alcanzando la región central de Argentina.

Los linajes $\mathrm{C} 4 \mathrm{c}$ correspondientes al centro de Argentina comparten cinco mutaciones que los separan del nodal para el haplogrupo (Figura 3.33). Mientras que los linajes colombianos no presentan ninguna de ellas sino que comparten entre sí una transición en 16245. Este patrón indica el gran tiempo de separación entre ambos linajes correspondientes a $\mathrm{C} 4 \mathrm{c}$.

Con respecto al mapa de distribución en sudamérica (Figura 3.34), a nivel de la Región Control, los linajes C4c pueden distinguirse de los C1 por la ausencia de las mutaciones 16325 y 290291d, diagnósticas del último clado. Toda secuencia americana potencialmente asignable al haplogrupo $\mathrm{C}$ pero que no sea portadora de las mutaciones $\mathrm{C} 1$-específicas puede entonces provisoriamente ser atribuída a C4c. En las muestras de Venezuela, Brasil y Chile su asignación al haplogrupo $\mathrm{C} 4 \mathrm{c}$ es tentativa, ya que está basada únicamente en la ausencia de la mutación 16325 porque no se dispone de información referida a la región codificante ni a la RHV-II.
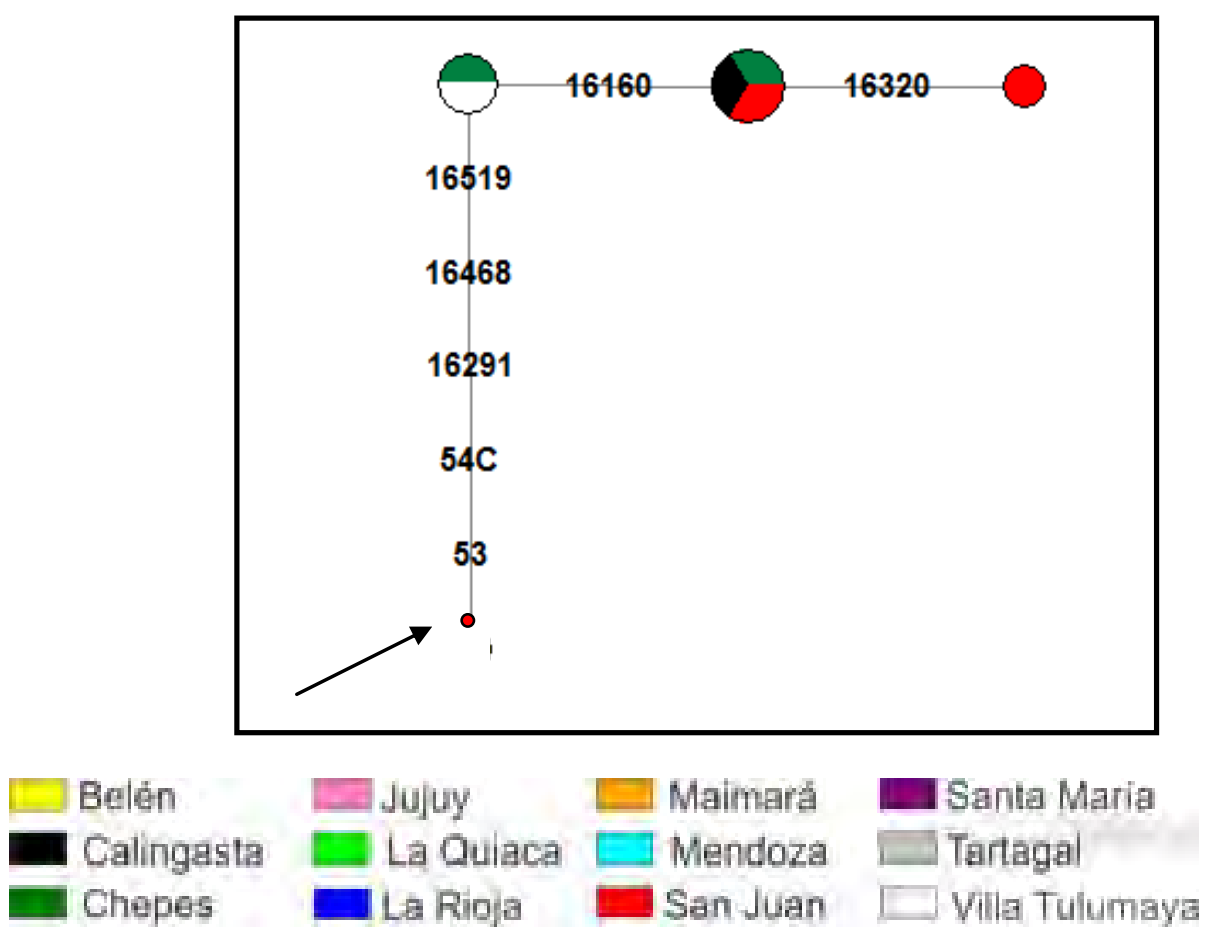

Figura 3.33. Red de haplotipos pertenecientes a C4c.

La flecha señala al haplotipo nodal del clado. 


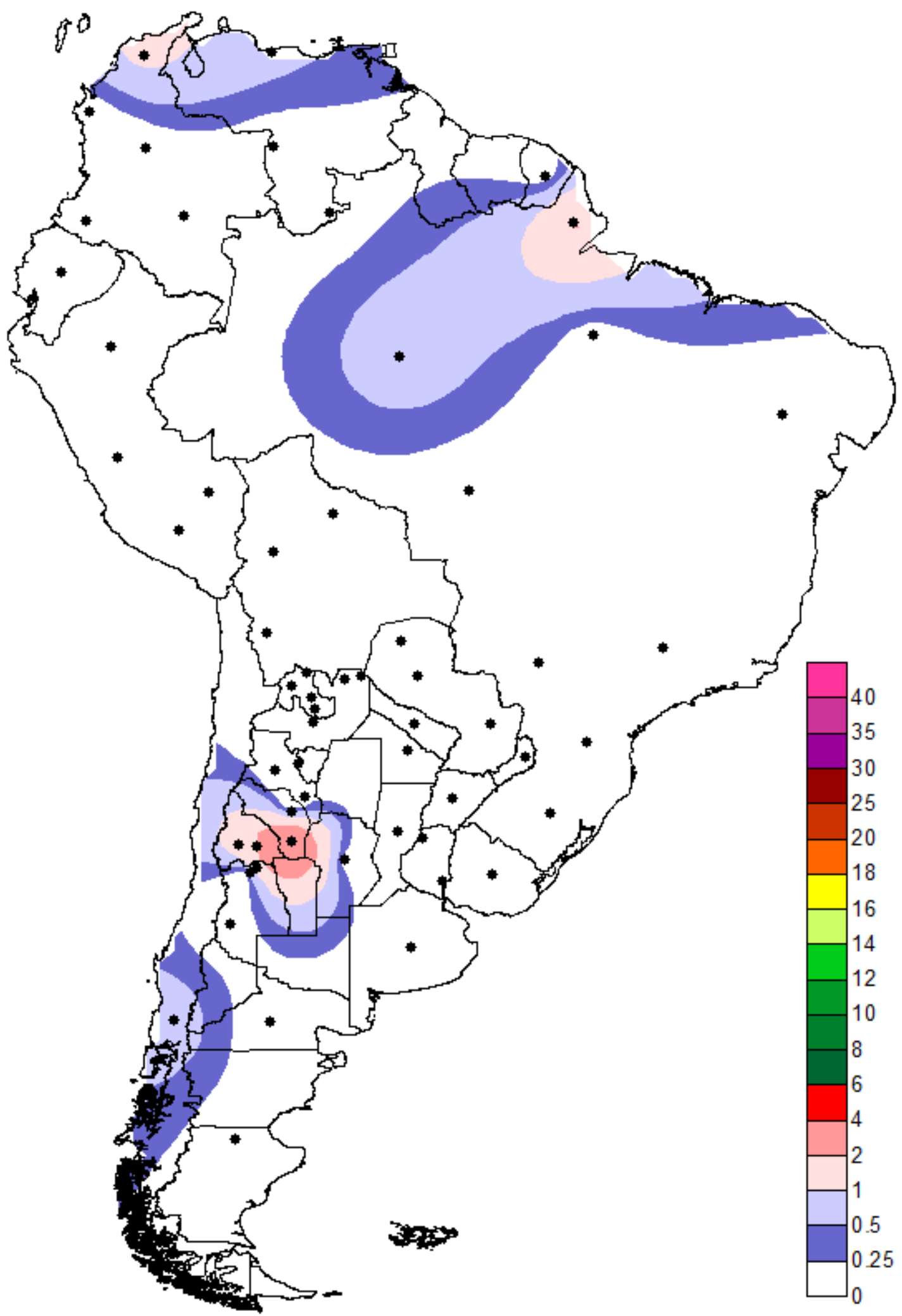

Figura 3.34. Distribución geográfica del linaje linajes C sin la mutación 16325. 


\section{Otros linajes propios de la Región IV}

Se detectan otros dos linajes con centro de distribución en la Región IV (Figura 3.35), uno correspondiente a $\mathrm{C} 1 \mathrm{~b}$ con una transición en la posición 194 y otro dentro de A2 con dos transiciones en las posiciones 16129 y 195. Estos dos últimos constituyes sitios hipervariables y sólo la ocurrencia conjunta de ambos y la coherencia geográfica de la distribución del linaje permiten proponerlo como tal. Sin embargo, la presencia de una muestra con ambas mutaciones en el norte de Colombia plantea la posibilidad de que ambas mutaciones hayan aparecido en forma conjunta como producto de eventos independientes y que se trate de un paralelismo. La presencia de la mutación 194 dentro de C1b en Ecuador y el oeste de Colombia plantea los mismos interrogantes.

Ambos linajes se encuentran altamente representados en Chepes donde en conjunto, reúnen el $13 \%$ de las muestras, le siguen 4\% en La Rioja, 3\% en Villa Tulumaya, 2\% en Mendoza y 1\% en San juan. Ninguno de estos linajes se encuentra representado en Calingasta.

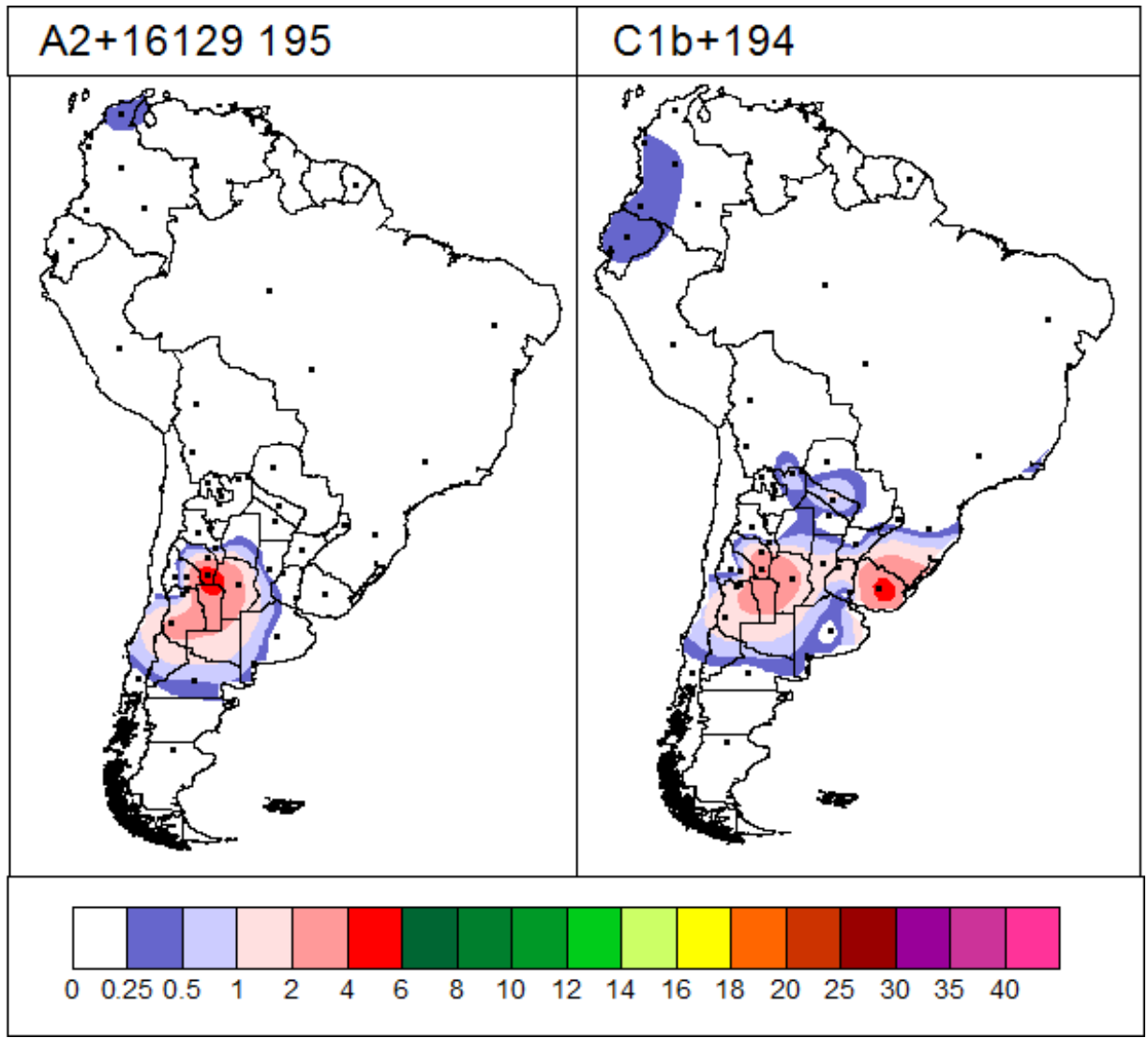

Figura 3.35. Distribución geográfica de otros linajes propios de Región IV. 


\section{Linajes propios de la Patagonia}

En la Región IV se identifican linajes que son propios de la Patagonia, tales son D1+16187 (D1g), C1b+258 y B2+470 (Figura 3.36). De las localidades muestreadas, es Calingasta la que presenta mayor frecuencia de los mismos ( $11 \%, 9 \%$ y $11 \%$ de los linajes nativos, respectivamente). Y en menor medida las localidades de San Juan, Mendoza y Villa Tulumaya. La semejanza de estas localidades en cuanto a la frecuencia de los linajes patagónicos no concuerda con la marcación de las barreras identificadas por el programa Barriers 2.2, ya que según las distancias de Nei entre pares de localidades, existe una barrera (tercera en orden de importancia) que separa a las localidades sanjuaninas de las mendocinas. Analizando el por qué de esta situación queda en evidencia que esta barrera se origina por las diferencias existentes entre Chepes y Villa Tulumaya (nótese que los linajes patagónicos no se encuentran representados en Chepes) y se continúa entre Mendoza y San Juan a pesar de que las diferencias entre ambas son menores.

Las redes de haplotipos de los linajes $\mathrm{C} 1 \mathrm{~b}+258$ y $\mathrm{B} 2+470$ (Figura 3.37 a y b) presentan poca diversidad y haplotipos poco apartados del nodal, indicando escasa profundidad temporal. El linaje D1+16187 (D1g), por el contrario está altamente diversificado, con haplotipos que se separan del nodal por numerosos pasos mutacionales. En la red de haplotipos de este linaje se observa gran cantidad de haplotipos faltantes (Figura $3.37 \mathrm{c}$ ). Este patrón puede deberse a que el área muestreada es un área periférica en cuanto a la distribución del linaje o también puede ser el resultado de una disminución de la diversidad haplotípica como consecuencia de un cuello de botella en el tamaño poblacional. 


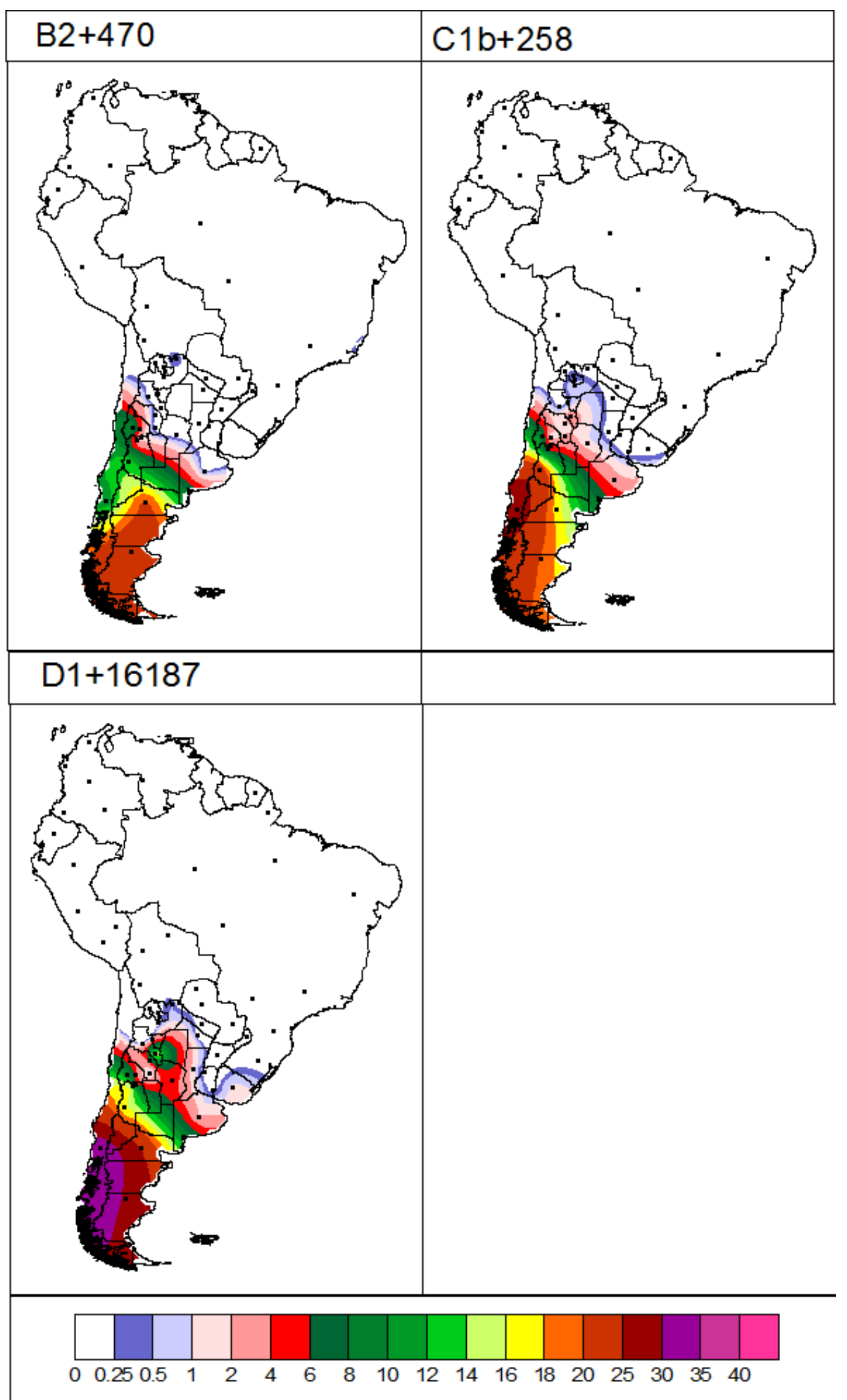

Figura 3.36. Mapas de distribución geográfica de linajes patagónicos 

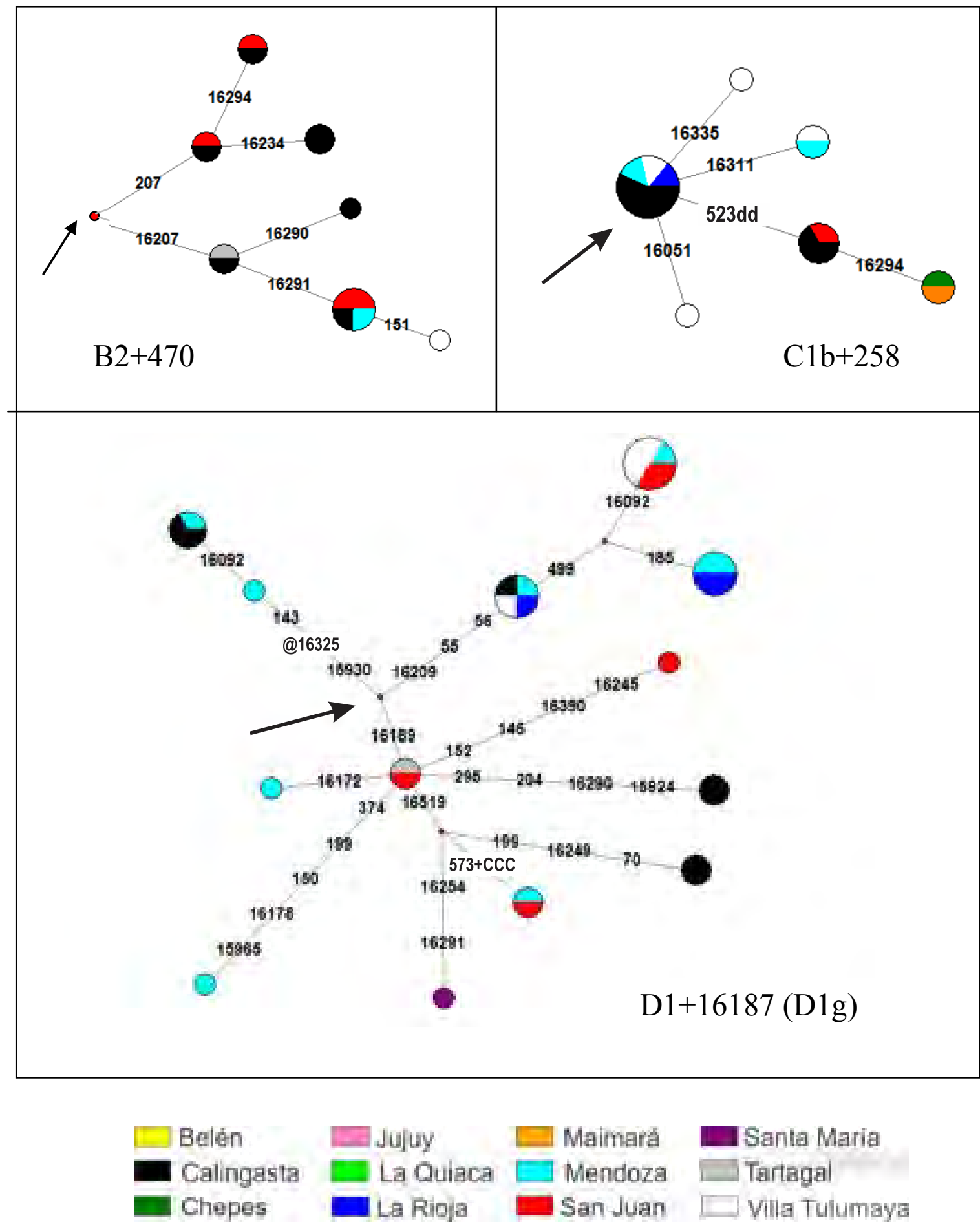

Figura 3.37. Redes de haplotipos de los linajes propios de Patagonia.

La flecha señala al haplotipo nodal del clado. 


\section{CAPÍTULO IV: DiscuSIONES}

Nos referiremos aquí a cuestiones metodológicas e interpretativas. En cuanto a la cuestión metodológica trataremos específicamente dos temas; por un lado, se plantea el debate en torno al estudio de la población actual como estrategia de abordaje al conocimiento de los linajes maternos nativos y las implicancias respecto de la cuestión identitaria. Por otro, se discute la estrategia empleada, basada en la definición de linajes, como alternativa a los métodos tradicionales de estimación de distancias basados en comparación directa de secuencias.

En cuanto a la interpretación de los nuevos datos aportados por este trabajo, se discutirán las diferencias interregionales en la distribución y frecuencia de linajes maternos nativos y los aportes en cuanto a las hipótesis de poblamiento de la región.

\subsection{CONTINUIDAD DE LOS LINAJES MATERNOS}

La estrategia metodológica utilizada en este trabajo presupone un cierto grado de continuidad en términos biológicos entre las poblaciones actuales de una determinada región y sus predecesoras. Hablar de continuidad regional implica establecer límites temporales arbitrarios ya que en última instancia todos los grupos humanos han alcanzado su ubicación actual al desplazarse desde la —ana" africana. Del mismo modo, los desplazamientos y los contactos intrerétnicos han constituido la regla antes que la excepción. No obstante, desde este enfoque metodológico se propone la posibilidad de identificar linajes diferenciados en forma local capaces de dar cuenta de la historia poblacional de la región. Algunos fenómenos tales como la introducción de linajes que, por su profunda separación temporal, son claramente diferentes de los locales, son fáciles de detectar; mientras que los movimientos migratorios entre regiones cercanas requieren de un análisis más minucioso. Ambos casos son analizados en las secciones siguientes.

\subsubsection{MigRACIONES INTERCONTINENTALES}

Desde el punto de vista molecular, en todas las localidades estudiadas el porcentaje de linajes maternos nativos de América superó $70 \%$, representando en total $90 \%$ de las muestras. El aumento hacia el sur de los linajes provenientes de Europa y Medio Oriente concuerda con la información histórica referida a los lugares preferenciales de instalación de los migrantes ultramarinos de los siglos XIX y XX. Según el censo de 1914, por ejemplo, el porcentaje de inmigrantes provenientes de Europa y Oriente Medio respecto del total de la población en Mendoza representaba más del doble (28 \%) que en San Juan (12\%), mientras que en Salta y Jujuy los inmigrantes ultramarinos constituían $5 \%$ de la 
población y en La Rioja y Catamarca menos de 2 \% (elaboración propia a partir del Tercer Censo Nacional, 1914). Los porcentajes más altos de linajes africanos fueron hallados en localidades de las provincias de Mendoza y San Juan, coincidiendo con las rutas de paso del tráfico de esclavos que ingresaban al puerto de Buenos Aires con dirección a Chile y Perú (Guzmán, 2006). A la ciudad de Mendoza corresponde el valor más alto (7\%), seguida de Villa Tulumaya (6\%).

Calingasta presenta muy bajo porcentaje de linajes europeos, en relación a su ubicación en altas latitudes, caso particular que puede explicarse por el difícil acceso que caracteriza a esta localidad de frontera, ya que se ubica en un valle entre la cordillera y la precordillera. Es esperable que esta situación geográfica, sumada a la ubicación periférica respecto de los centros de atracción económica, haya desalentado la llegada de inmigrantes. Podría pensarse que lo mismo sería aplicable también para el caso de los linajes africanos, sin embargo el territorio dentro del cual se ubica Calingasta constituyó un lugar tradicional de paso entre la Argentina y Chile, conocido por ser un centro de contrabando de todo tipo de mercancías, inclusive de esclavos (Escolar, 2001). Así se podría explicar la relativamente alta proporción de linajes africanos (4\%). En sintonía con los resultados alcanzados en este trabajo, Campaña y col. (2010) detectaron en Cuyo y Córdoba una mayor frecuencia de una anomalía congénita, la polidactilia postaxial, cuya prevalencia es 10 veces mayor en poblaciones afro-descendientes que en poblaciones de ancestría europea (Frazier, 1960).

Cuatro de las poblaciones aquí informadas fueron analizadas previamente para establecer los haplogrupos de 368 linajes paternos (Ramallo y col. 2009), hallándose que en promedio un cuarto de los varones analizados son portadores de linajes indígenas, aunque con notables variaciones regionales: mientras que las ciudades de Tartagal y San Salvador de Jujuy presentaron frecuencias relativamente altas de entre 33 y $45 \%$, la fracción nativa se reduce a valores de 7-10 \% en La Rioja y Mendoza. Estos valores, junto al elevado porcentaje de linajes maternos nativos encontrados en este trabajo, concuerdan con el patrón de mestizaje sexo-asimétrico que ya ha sido demostrado en distintos países latinoamericanos (Dipierri y col. 1998; Alves-Silva y col. 2000; Caravajal-Carmona y col. 2000; Sans y col. 2002; Bonilla y col. 2004; Marrero y col. 2007; Salas y col. 2008).

Otros autores han analizado la contribución continental de los linajes maternos en distintas regiones de la Argentina. En el trabajo de Bobillo y col. (2010), las frecuencias de haplogrupos mitocondriales nativos correspondientes a las regiones del Nordeste y del Sur (cerca de $66 \%$ ), son más bajas que las aquí presentadas para el NOA y COA, no pudiéndose concluir si estas diferencias reflejan desigualdades regionales o son el resultado de una distinta estrategia de muestreo. En el trabajo de Salas y col. (2008), dicha frecuencia para la provincia de Córdoba asciende sólo al 57 \%, contrastando claramente con el trabajo de García y Demarchi (2009), orientado explícitamente a la población criolla, donde la fracción nativa representa $80 \%$. El trabajo de Martínez-Marignac y col. (1999) en La Plata analiza una muestra hospitalaria y otra de trabajadores universitarios, poniendo en evidencia las notables diferencias en frecuencia de linajes nativos -72 vs. $32 \%$, respectivamente- en 
diferentes grupos socio-económicos de una misma localidad. Los trabajos de Avena y col. en el Área Metropolitana de Buenos Aires (2006), Bahía Blanca (2007), Comodoro Rivadavia (2009) y Esquel (2010) corresponden a muestreos hospitalarios y los porcentajes de linajes maternos nativos son de $46 \%, 45 \%, 70 \%$ y $80 \%$, respectivamente. En el trabajo del 2010 analizan además una submuestra del Área Metropolitana correspondiente a migrantes provenientes del Noroeste y Cuyo, obteniendo resultados que se acercan a los presentados aquí $(80 \%$ y $63 \%$ de linajes maternos nativos respectivamente). En todos los casos, los datos concuerdan con la información genealógica e histórica disponible para cada localidad o región que reflejan tanto el efecto de las diferencias regionales en el impacto de la migración ultramarina de los siglos XIX y XX, como el efecto de las migraciones internas hacia los centros con mayor oferta de trabajo.

Un estudio llevado a cabo en Caracas, Venezuela, resulta ilustrativo ya que pone de manifiesto las diferencias en cuanto a los patrones de mestizaje entre muestras de distintos niveles socioeconómicos (Martínez y col. 2007). En el trabajo citado se comprueba que quienes acuden a los centros de atención públicos poseen un mayor componente africano y nativo americano que quienes asisten a clínicas privadas. Los autores enfatizan la importancia de conocer la procedencia de las muestras con las que se trabaja y en particular el origen geográfico de los abuelos, y lo señalan como un aspecto metodológico fundamental a la hora de intentar reconstruir eventos históricos por medio de estudios genéticos.

La cuestión del mestizaje sexo-asimétrico puede ser abordada también desde otras perspectivas. Desde un enfoque etnohistórico, Michielli (2000) expone un caso judicial en el que la india Ana de Asaguate se presenta ante las autoridades a fin de solicitar permiso para residir en la ciudad de San Juan, alegando que su pueblo natal, donde debería de permanecer encomendada, se encuentra desierto; el mismo se desarrolla en el año 1693 y, si bien se trata de un caso particular, puede ser representativo de la situación sufrida por las mujeres indígenas de la región de Cuyo, que quedaban solas con sus hijos, cuando los hombres eran trasladados al oeste de la cordillera como mano de obra.

Desde una perspectiva etnográfica, rescatamos del trabajo de Escolar entre los Huarpes, en el que sostiene:

“...la afirmación de ascendencia indígena en casi todos los autoadscriptos como indios o descendientes remite en la mayoría de los casos a matrilinajes donde la ascendencia es construida por línea materna por varias generaciones. La 'sangre' indigena es portada por abuelas o madres, quienes son definidas como indias. Esta representación uterina de la ascendencia huarpe coincide notoriamente con la mitología básica del mestizaje provincial que asocia lo indígena a las líneas maternas y lo español/blanco a líneas paternas" (Escolar, 2007 p.87). 


\subsubsection{MigRaCiOnES INTERREGiONALES}

A diferencia de lo que ocurre con las migraciones intercontinentales, las migraciones entre distintas regiones de América no son fácilmente identificables a nivel molecular. La definición de linajes con distribución regional acotada está en proceso de construcción y esta tesis pretende ser un avance en ese sentido. Por otro lado, la evaluación de las tendencias migratorias interregionales puede enriquecerse con el apoyo de otras fuentes de información, tales como el registro histórico, tanto en su forma escrita como oral.

A este último tipo de registro hemos podido acceder a través de las entrevistas genealógicas, dónde se recuperó información referida al lugar de nacimiento de los ancestros. La información genealógica permite constatar que para cada localidad, al menos en el $69 \%$ de los casos, la línea femenina de ancestría corresponde a un origen local, en sentido regional, y en promedio para todas las localidades constituye $90 \%$. En los casos en que se registran porcentajes considerables de un origen no local de la línea materna en la información genealógica, éstos coinciden con la información histórica que señala a los centros económicos como atractores de población de otras regiones, como sucede en Mendoza tanto con los migrantes ultramarinos como con los trabajadores temporarios de la cosecha (Paredes, 2004). Es decir que desde una perspectiva de la historia oral, se puede proponer una continuidad local para la mayoría de los linajes maternos en la región considerada, al tiempo que se constata que los fenómenos migratorios regionales son fácilmente identificables tanto desde una perspectiva histórica como genealógica.

Volviendo a la información molecular, encontramos casos en los que la distribución actual de un determinado linaje puede ser explicada por migraciones interregionales. El caso más conspicuo es el de linajes con alta frecuencia en el norte de Argentina y Bolivia, que se presentan en menor frecuencia en las provincias de Mendoza, San Juan, Buenos Aires y/o Río Negro (figuras 3.10, 3.12, 3.25 y 3.28a). Algunos de estos casos son confirmados por la información genealógica disponible.

Otra vía de aproximación para evaluar la continuidad a nivel regional de los linajes maternos, consiste en comparar los datos actuales con los disponibles para ADN antiguo. Esta línea de evidencia aún es sumamente escasa, sin embargo expondremos aquí algunos casos de relaciones entre las muestras antiguas y actuales.

El linaje B2 con la mutación 16142 fue descripto en una muestra antigua de Pampa Grande, provincia de Salta, con una antigüedad de más de 1300 años (Carnese y col. 2010). La localidad de Pampa Grande se encuentra próxima a Santa María, donde este linaje alcanza el 5\% en la actualidad. Sin embargo, las muestras de Santa María presentan polimorfismos derivados que no están presentes en la muestra de Pampa Grande. Este haplotipo, por el contrario es idéntico a algunos hallados en Mendoza, San Juan y La Rioja, indicando la conexión de los valles Calchaquíes con el centro-oeste. Por otra parte, la persistencia del clado en términos regionales, refuerza la hipótesis de continuidad. 
El linaje D1+16293 pertenece a una de las momias halladas en el volcán Llullaillaco en la provincia de Salta, que formaban parte de una ofrenda incaica (Wilson y col. 2007). La —iña del rayo" comparte con muestras de Maimará, La Quiaca, Mendoza, La Paz (Bolivia) y Rinconada (provincia de Jujuy) una transición en la posición 97 y una deleción de seis pares de bases entre las posiciones 106 y 111.

El linaje C1b + 1619216093 ha sido registrado en muestras antiguas de Perú; en el valle de Ica se hallaron diez muestras C con la mutación 16192, la mayoría pertenecientes al Período Intermedio Temprano (cultura Nasca 200 AC- 600 DC), incluídas dos que poseen también la mutación 16093 y una correspondiente al Horizonte Medio Temprano (cultura Wari 600-800 años DC) que presenta la mutación 16145 (Fehren-Schmitz y col. 2009). Esta mutación ha sido reportada también entre las muestras actuales de Argentina y sur de Bolivia. Del mismo modo, en la región de Ayacucho, Perú, se ha reportado una muestra C con las mutaciones 16192 y 19093 perteneciente al período postWari (1100-1400 DC) (Kemp y col. 2009). Llama poderosamente la atención que este linaje se encuentre altamente representado entre las muestras de Calingasta en particular (20\%) y en la región del centro-oeste argentino en general, quedando en evidencia la existencia de un vínculo entre el COA y el área Andina Central. En base a la información disponible basada en la distribución de linajes en la población actual y en los datos provenientes del análisis de ADN antigüo, esta linaje parece haberse distribuido a lo largo de la costa pacífica, habiendo alcanzado una mayor frecuencia en la región del centro-oeste de Argentina.

Con respecto al linaje B2+ 146215 455+T, característico de la Región IV, se ha reportado la presencia conjunta de transiciones en las posiciones 146 y 215 en muestras antiguas del Valle de Urubamba, Perú (Shinoda y col. 2006).

La presencia de una muestra C1b con la mutación 16311 y otra posible mutación en 16189 (16189Y) fue hallada en el sitio arqueológico de Los Amarillos en la provincia de Jujuy. Este linaje actualmente está presente en la denominada Región III, por lo que es probable que la conjunción de ambas mutaciones, de por sí conocidas por ser altamente variables, pueda constituir un indicio de monofilia. De modo que este linaje, con una distribución local tendría una antigüedad en el área que se remonta al menos al Período de Desarrollos Regionales II (Siglos XI a XV) (Mendisco y col. 2011).

\subsubsection{SOBRE IDENTIDADES}

La cuestión de la identidad, desde luego, no puede ser dirimida en el terreno biológico, pero tampoco se puede negar que los rasgos físicos pueden ser significados culturalmente como expresión de la identidad. Al mismo tiempo la noción de una herencia común ya sea cultural o biológica está presente en la conformación de la identidad. La apelación a los ancestros constituye también una estrategia de cohesión grupal. Estas categorías no deben ser pensadas en términos individuales ya que un sujeto que reclame identidad no será excluido de la misma por no reunir todos estos requisitos. 
Existe una construcción colectiva de la identidad que evidentemente tiene en cuenta también a aspectos biológicos como la fisonomía y la herencia.

En estos tiempos, se incorpora una nueva entidad reconocida popularmente como asociada a la identidad, que es el ADN. El ADN está en boca de todos, se lo nombra como sinónimo de identidad, de individualidad y tiene ese halo de veracidad del que gozan las entidades presentadas como -ientíficas". Se constituye también como una demanda por parte de quienes se auto-identifican como indígenas y reclaman el reconocimiento por parte de otros de esa identidad; es por eso que como investigadores debemos afrontar el desafío de debatir estos temas, aunque sepamos de antemano que la respuesta no será unívoca y no será permanente.

¿Cuál es el aporte desde el ADNmt? Recordemos una vez más que las características particulares del ADNmt lo convierten en una herramienta especialmente útil para abordar el componente indígena ya que registra sólo la línea materna de ascendencia. Fundamental para los objetivos de esta tesis, pero decididamente parcial si queremos hablar de identidad. Lo interesante del abordaje mitocondrial es que rescata la historia de las mujeres indígenas, tradicionalmente olvidadas por una historia patriarcal y europeizante. Si bien es una mirada parcial, su valor radica en que se contrapone a la mirada, también parcial, instituida como única verdad hasta hace muy poco tiempo atrás.

Ahora bien, nos encontramos inmersos en un momento donde surgen fenómenos de reetnización. Además del reclamo sostenido de comunidades indígenas reconocidas históricamente, surgen en diversas provincias, reclamos de identidad por parte de comunidades consideradas -xtintas". El reconocimiento constitucional que adquirieron los reclamos indígenas a partir de la reforma de la Constitución en 1994, es parte de la explicación, pero también la coyuntura política de la última década en pos de la hermandad latinoamericana, revaloriza aspectos culturales anteriormente negados. El tema ha sido tratado, a mi entender de manera exquisita, por Diego Escolar (2007), en referencia a los movimientos de reetnización huarpe en las provincias de San Juan y Mendoza. Me permito citarlo textualmente:

"Más allá de la imposibilidad de establecer un peso demográfico masivo europeo en los primeros siglos de conquista, el argumento del mestizaje racial "blanqueador" sugiere la biológicamente discutible preponderancia de la sangre europea en la medida en que se asume como única ascendencia significativa de la población regional. [...] en una matriz claramente evolucionista y esencialista, se afirma que la cultura indigena (imaginada como estática) fue "aculturada" en favor de la cultura española, cuyos cambios no son vistos como una pérdida de sustancia. [...] "La transformación de pautas culturales originarias es vista hasta hoy en día, al igual que en las teorías sobre la mezcla de sangre, como fatal transición a una homogeneidad étnica unidireccional. Habrían sido los huarpes quienes a raiz del contacto con los europeos "perdieron" su cultura y su 
raza y adoptaron la de los españoles y no a la inversa. No se conciben como una pérdida étnica las transformaciones de la cultura originaria española-europea desde la época de la conquista ni la posibilidad de un intercambio cultural entre indígenas y españoles."

Con estos argumentos queda claro que son legítimos los reclamos de identidad. Ahora pasemos a discutir, en qué medida resultados como los obtenidos en esta tesis y en numerosos trabajos de colegas en distintos puntos de Argentina (v.g. Avena y col. 2007, 2009, 2010; García y Demarchi, 2009; Bobillo y col. 2009) contribuyen a repensar los discursos dominantes sobre la identidad nacional. Una vez más, sostenemos la futilidad de discutir estas cuestiones a nivel individual, ya que cada sujeto es atravesado por innumerables circunstancias particulares que influirán en la interpretación de un resultado biológico. Volvamos a la identidad colectiva, ya no podemos sostener la visión tradicional de la Argentina como país de ascendencia exclusivamente europea. No puede negarse el pasado indígena y el africano. Y rescatar ese pasado contribuye a re significar el presente. Las evidencias moleculares contribuyen de esta manera a reivindicar una identidad digna de ser reclamada, no actúan de manera aislada, sino en el contexto actual de repensar la historia. Tampoco conducen necesariamente al reclamo de la identidad plenamente indígena sino a la toma de conciencia de que lo indígena también es parte de nuestro ser nacional, tal como lo ha sido la inmigración.

\subsection{LINAJES MONOFILÉTICOS COMO VARIABLES INDEPENDIENTES}

En las aproximaciones metodológicas tradicionales, las medidas de distancia poblacional son estimadas por comparación directa de las secuencias. Esta metodología, no tiene en cuenta el caso particular asociado al poblamiento de América y la segregación particular de linajes ocurrida al momento de ingreso. Los haplogrupos nativos americanos, previamente diferenciados en el viejo continente, arrastran consigo la historia, traducida en diferencias nucleotídicas, ocurrida en otros territorios y en otros tiempos. Por dar un ejemplo concreto, los haplogrupos A y B (pertenecientes al macrohaplogrupo $\mathrm{N}$ ) se diferenciaron de los haplogrupos $\mathrm{C}$ y D (pertenecientes al macrohaplogrupo M) hace más de 40.000 años, en momentos inmediatos a la salida del continente africano. De este modo, por poner un ejemplo, cuando cada nucleótido es considerado como una variable independiente, se incurre en el error de considerar a una población con alta frecuencia de D más emparentada con otra población con alta frecuencia de $\mathrm{C}$, que con una tercera con alta frecuencia de $\mathrm{A}$; siendo que, en el contexto americano, esas diferencias son irrelevantes. Un ejemplo extremo de cómo este tipo de análisis puede llevar a conclusiones erróneas, puede hallarse en el trabajo de Afonso y col. (2010), donde los autores, en base al análisis de las RHVI y II, concluyen que los linajes maternos nativos de Bolivia están estrechamente emparentados con los de Corea. Ciertamente, ambas poblaciones ostentan altos porcentajes del haplogrupo $\mathrm{B}$ y por lo tanto comparten las mutaciones propias de dicho haplogrupo; sin embargo la historia común de ambas poblaciones se remonta a algún lugar de Asia, 
desde donde luego siguieron trayectorias evolutivas independientes, atravesando unos el estrecho de Bering y arribando otros a Corea. Consideramos que, para un adecuado estudio de las afinidades interregionales americanas, las variables operativas deben consistir en linajes monofiléticos de menor jerarquía, de modo que las relaciones de afinidad no se remonten a momentos anteriores a la ocupación humana de América. Por eso, proponemos una opción alternativa que consiste en la definición de linajes, cuyas frecuencias relativas constituyan una medida más ajustada de las afinidades interregionales. Otra falencia que trae aparejada la comparación directa de secuencias radica en que supone la independencia de cada cambio de nucleótido, y en que no tiene en cuenta la posible dependencia de la tasa mutacional de ciertas bases en relación a las bases circundantes. A continuación se ilustran ejemplos en los linajes nativos americanos que dan cuenta de ambos fenómenos y se discuten las causas posibles.

\subsubsection{VARIACIÓN EN LA TASA MUTACIONAL}

A lo largo del trabajo de investigación en ADNmt, el conocimiento de las mutaciones recurrentes ha llevado a la observación, ya registrada en trabajos previos (Achilli y col. 2008; Forster y col. 1996), de que la estabilidad o inestabilidad de ciertos sitios no es la misma según el haplogrupo del que se trate. Esto lleva a la ineficacia de un pesado de caracteres uniforme basado en criterios externos, y a la posibilidad de considerar a sitios que en ciertos contextos son inestables, como indicio de monofilia, teniendo en cuenta un criterio geográfico y de coherencia interna, como es el caso de la posición 150 al interior del haplogrupo A2.

La posición 150 ocupa el décimo lugar en la escala de sitios altamente variables, elaborada por Soares y col. (2009), sin embargo hemos observado que no es un sitio que presente homoplasia al interior del haplogrupo A2 y que la distribución geográfica del linaje definido por la misma es continua, identificándose claramente el centro y la periferia (Figura 3.31). Esta relativa estabilidad podría estar asociada a las sustituciones de base en sitios circundantes que son propias del haplogrupo A2, ya que en éste, las mutaciones en las posiciones 146 y 153, reemplazan uniones A-T por uniones G-C (figura 4.1); éstas últimas al estar formadas por tres puentes de hidrógeno otorgan mayor estabilidad a la unión de la doble cadena en esta región, lo cual podría explicar la menor tasa mutacional de la posición 150 al interior de A2.

El caso opuesto ocurre cuando una posición para la que se esperaría un comportamiento estable, adquiere inusual inestabilidad, como es el caso de la posición 64 al interior del haplogrupo A2. Tomando como referencia a las secuencias analizadas en esta tesis, de las cuales 174 pertenecen al haplogrupo A2, se registra la ocurrencia independiente de mutaciones en la posición 64 en cinco oportunidades, del mismo modo por tomar una referencia externa, pueden citarse las secuencias publicadas por Achilli y col. (2008), en donde dicha mutación ocurre seis veces en una filogenia del haplogrupo A construida con 86 secuencias genómicas completas. El caso es más sorprendente si 
tenemos en cuenta que un criterio externo para evaluar la tasa mutacional de las posiciones como la escala de Soares y col. (2009) ubica a la posición 64 en el puesto 46, mientras que la posición 150, pese a ocupar el décimo lugar, no registra eventos mutacionales en las secuencias pertenecientes al haplogrupo A2 publicadas por Achilli y col. (2008) y se presenta como un sitio estable, permitiendo la definición de un linaje con coherencia geográfica, como se expuso anteriormente.

En el trabajo de Pereira y col. (2008) se propone que la formación de estructuras terciarias intracatenarias durante la replicación podría dar cuenta de la asimetría en cuanto a la tasa de mutación de ciertos sitios, ya que los que se encuentran formando el tallo de la estructura son más estables que los que se ubican en el lazo. Sin embargo, esta hipótesis no explica lo que ocurre con la posición 150 ya que no forma parte de ninguna de las estructuras identificadas en el citado trabajo, de modo que no puede atribuirse a la formación de dichas estructuras la relativa estabilidad que adquiere este sitio al interior del haplogrupo A2. Por otra parte, la inestabilidad de la posición 146 también observada para el haplogrupo A2 (Achilli y col. 2008) es coherente con la ubicación de esta posición en la parte correspondiente al lazo de la estructura (Figura 4.2). Sin embargo, existen otras posiciones que deberían ser del mismo modo inestables y este no es el caso. De modo que deben estar actuando otros factores que condicionan la estabilidad/inestabilidad de cada posición al interior de la Región Control, de los cuales aún no se tiene conocimiento. En el caso de la posición 64, ésta se encuentra formando el tallo de la estructura terciaria -1 (sensu Pereira y col. 2008); en un escenario en donde esta mutación fuese basal para el haplogrupo A2, es plausible la recurrencia de mutaciones hacia el estado ancestral debido al apareamiento con la posición 94 como base complementaria. Es interesante que en un linaje particular de A2, A2i (Achilli y col. 2008), ocurre la mutación G94A apoyando el modelo de mutaciones compensatorias en las bases ubicadas en la región del tallo (Figura 4.2).

En la SRCr

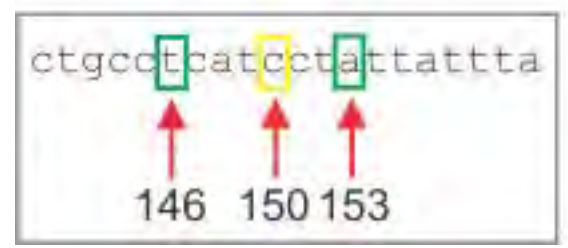

En el haplogrupo A2

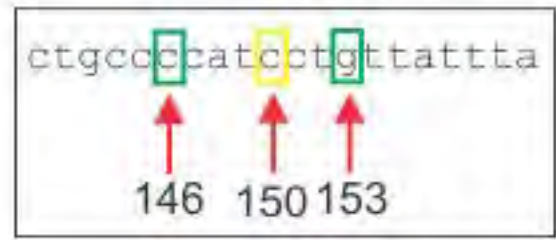

Figura 4.1. Secuencia de bases circundante a la posición 150. 


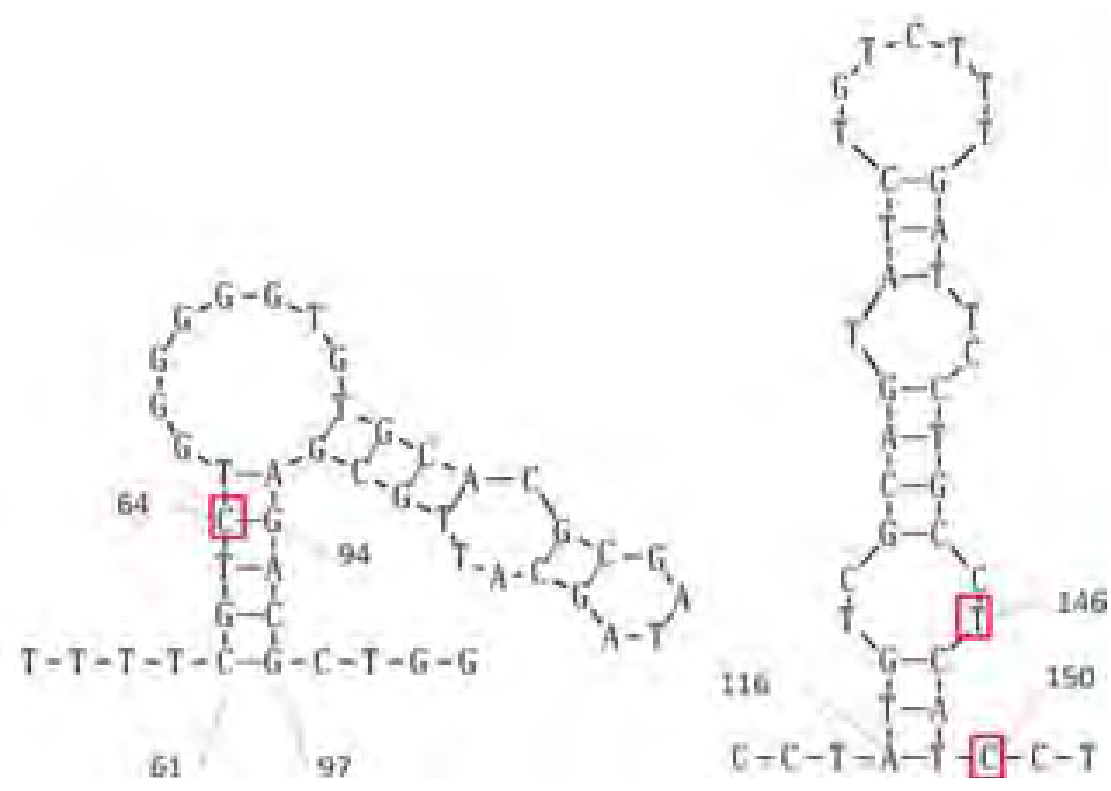

Figura 4.2. Estructuras I (izquierda) y J (derecha) identificadas por Pereira y col. (2008), indicando la ubicación de las posiciones 64, 94, 146 y 150.

\subsubsection{De CÓMO Un ÚNICO EVENTO MUTACIONAL PUEDE AFECTAR A MÁS DE UNA BASE}

En las aproximaciones metodológicas tradicionales, cada cambio de base es registrado como un evento independiente, sin embargo, existen eventos mutacionales que involucran a más de una base. Presentamos como ejemplo, la reestructuración en la región comprendida entre las posiciones 55 y 73; en este caso, una inserción en la posición 55 y dos inserciones en la posición 71 que extienden el homopolímero de seis guaninas a ocho, están asociadas a la deleción de tres timinas entre las posiciones 58 y 60 (Figura 4.3). Como consecuencia de la presencia de un homopolímero entre las posiciones 66 y 71, esta región presenta gran inestabilidad, registrándose numerosos casos de reticulaciones en las redes filogenéticas generadas por mutaciones en esta región, como sucede al interior de los linajes pertenecientes a B2 definidos, uno por 146-215- 455+T y otro por una transición en la posición 16188 donde son recurrentes las transiciones en 63, 64 y 66, incluso encontrándose transversiones en la posición 66.

En la SRCr

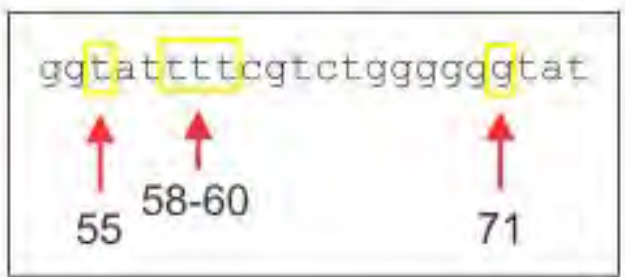

Ejemplo de reestructuración

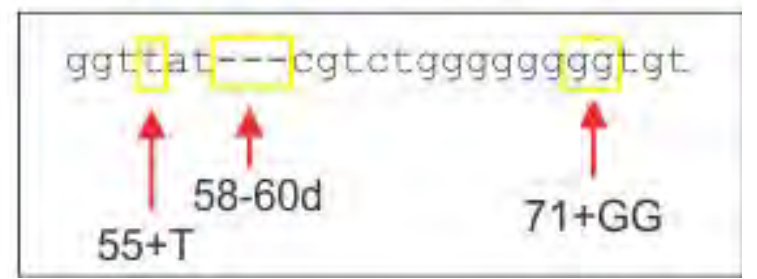

Figura 4.3. Reestructuración en la región 55-73. 


\subsubsection{COROLARIO}

A treinta años de la secuenciación en forma completa del ADNmt humano, el conocimiento acumulado acerca de las características de esta molécula, permite analizar en detalle el comportamiento mutacional de cada región y/o posición en particular. De estas observaciones surge la evidencia de que existe interdependencia de las tasas mutacionales entre sitios y es por eso que consideramos que la comparación directa de secuencias no es la alternativa más adecuada para realizar inferencias de afinidad interpoblacional. Así mismo, las mutaciones en la Región Control, propias de los macrohaplogrupos $\mathrm{M}$ y N por un lado, y de los haplogrupos A, B, C y D por otro, otorgan un peso decisivo en las comparaciones interpoblacionales, de modo que, en la mayoría de los casos, los análisis a nivel de secuencias que se basan en una comparación directa de las mismas, no son superadores de las comparaciones a nivel de frecuencias de haplogrupos. Proponemos en cambio, un análisis que incorpora criterios externos como la coherencia geográfica y el conocimiento del comportamiento mutacional de determinadas regiones de la molécula, para definir variables operacionales (linajes) cuya frecuencia constituya una medida más ajustada de la diferenciación poblacional.

La aproximación metodológica empleada en esta tesis ofrece como ventaja la utilización de variables que representan entidades reales: cada linaje definido es considerado un grupo monofilético de haplotipos cuyo ancestro común habría vivido en momentos posteriores al poblamiento americano y por lo tanto la historia de la que da cuenta, es aquella ocurrida en la región que nos interesa.

Por otro lado, somos conscientes de que la falta de secuenciación de la región codificante dificulta la identificación de linajes monofiléticos. Existen haplotipos que no presentan mutaciones diagnósticas en la Región Control, de modo que no es posible asignarlos a un linaje, aunque sabemos que seguramente existan relaciones de filiación que no hemos podido recuperar. En los últimos años se han publicado filogenias basadas en secuencias completas de algunos de los haplogrupos nativos americanos (Perego y col. 2009; Perego y col. 2010; Bodner y col. 2012) que dan sustento a algunos de los linajes definidos en esta tesis, mientras que otros conservan el carácter de preliminar. En algunos casos se ha considerado la presencia de mutaciones poco confiables, como 146 al interior del haplogrupo $\mathrm{C} 1 \mathrm{~b}$, como indicio de monofilia, sustentada por la coherencia geográfica de la distribución del linaje, sin embargo con este nivel de resolución no es posible afirmar conexiones a nivel extraregional.

\subsection{DIFERENCIACIÓN REGIONAL}

Hemos visto, a través de la identificación de barreras genéticas y del análisis de la distribución geográfica de los linajes, la existencia de regiones que se caracterizan por presentar una relativa homogeneidad en lo que respecta a la distribución de linajes maternos nativos. Esta homogeneidad es 
el reflejo de una historia biológica en común. Desde luego, estas regiones no se han mantenido aisladas y existen hoy en cada una de ellas, tanto linajes propios de otras regiones como linajes cuya adscripción geográfica no ha sido posible establecer a través de los métodos aquí empleados. Sin embargo, la presencia de linajes mayoritarios que muestran una coherencia regional, permite imaginar un escenario en el cual la historia poblacional y demográfica se habría desarrollado de manera independiente en cada una de estas regiones, al menos en determinados momentos del pasado. No hemos incluido aquí una aproximación metodológica que permita estimar los tiempos de coalescencia de los linajes descriptos, pero en un trabajo reciente (Bodner y col. 2012) se establecen los fechados para dos de los linajes aquí discutidos, D1j y D1g, los cuales corresponden a los primeros momentos de ocupación humana en la región según el conocimiento actual arqueológico. Teniendo en cuenta que la variabilidad interna de los linajes mayoritarios de cada región, es similar a la de estos dos, puede plantearse un escenario de diferenciación regional desde los primeros momentos de ocupación. La marca de esta diferenciación temprana estaría señalada por estos linajes mayoritarios, mientras que en la actualidad coexisten en cada región, numerosos linajes que darían cuenta del movimiento constante de los humanos, ya sea en forma individual o grupal.

Las regiones identificadas pueden resumirse en tres áreas principales: Puna (Región I), Centro (Región II) y Patagonia (no fue nombrada por no estar comprendida en el área de muestreo), con el agregado de una posible cuarta área correspondiente al sur de San Juan y norte de Mendoza (Región IV), la cual además de compartir características con la región central, presenta también linajes propios que soportarían un escenario de diferenciación independiente. En cuanto a la Región III, consideramos que ésta no constituye un área de diferenciación independiente, sino que queda definida por la extensión del área de influencia de la Región I y la presencia de linajes propios del Chaco y la Amazonia.

Es interesante destacar la particularidad de la localidad de Tartagal que se refleja en el Análisis de Componentes Principales, donde el segundo componente diferencia claramente a esta ciudad del resto. Entendemos que esta particularidad está asociada a la presencia de linajes propios del chaco y del litoral. En este caso la evidencia mitocondrial es coincidente con lo esperado según la evidencia etnográfica, lingüística e histórica que señala a la ciudad de Tartagal y sus alrededores como lugar de asentamiento de comunidades Tobas, Wichís, Chorotes, Chanés y Guaraníes, entre otros. Del mismo modo, las localidades de Maimará y La Quiaca muestran una clara diferenciación respecto de las restantes localidades en el Análisis de Componentes Principales. Desde una perspectiva arqueológica la región del norte de Jujuy se caracterizó por el estilo cerámico Yavi-Isla, que se mantuvo como estilo independiente aún en los momentos de expansión del estilo cerámico Aguada, esta diferenciación es interpretada como la existencia de dos esferas de acción independientes (Mandrini, 2008) y es coincidente con la evidencia mitocondrial que señala una marcada diferenciación entre ambas regiones. Sin embargo, es necesario recordar que no se trata de límites infranqueables, que las 
diferencias señaladas son diferencias en términos de frecuencias y que, como se señaló anteriormente, algunos de los linajes característicos de la Región I, se extienden hacia el sur, dando lugar a la definición de la Región III. Por otra parte, la amplia distribución de los linajes correspondientes a la Región II incluye a areas correspondientes a distintos grupos culturales, por lo que no puede hacerse una estricta asociación entre la diferenciación biológica y la diferenciación cultural.

La metodología empleada no es suficiente para discernir la profundidad temporal de los fenómenos de diferenciación regional observados. La información arqueológica disponible, tampoco puede afirmar o negar una continuidad biológica de los grupos humanos asentados en una misma región a lo largo de los milenios. Seguramente los procesos involucraron todas las posibilidades: supervivencia y continuidad en algunos casos, y extinción y reemplazo, en otros, así como también fusión y mestizaje. La respuesta a qué proceso primó en cada región sólo podrá ser abordada cuando se cuente con abundantes datos de calidad de ADN antiguo. Hasta tanto, la información referida a los linajes maternos nativos presentes entre la población actual, da cuenta de la existencia de focos de diferenciación poblacional que podrían remontarse a los primeros momentos de ocupación humana de la región. En este marco proponemos, a modo de hipótesis, un posible escenario de poblamiento regional.

\subsection{HIPÓTESIS DE POBLAMIENTO}

El intento de reconstruir el pasado a partir de la evidencia genética del presente ha sido denominado por Renfrew (2001) como -queogenética" y a ello nos dedicaremos en esta sección. Nos encontramos ante el panorama actual de distribución de linajes, una instantánea que nos ofrece un único plano temporal. Si lo pensamos en términos arqueológicos, podría decirse que carecemos de una estratigrafía que nos permita diferenciar las —apas" temporales, de modo que las mismas se nos presentan mezcladas en un palimpsesto. Para resolver este problema, contamos con un argumento de la filogeografía que propone que a mayor diversidad de un linaje, mayor antigüedad del mismo. Si bien un linaje no es equivalente a una población, puede considerarse la frecuencia y distribución de un linaje como indicio de una determinada historia poblacional. Otra hipótesis que asume la filogeografía es que el lugar donde actualmente se observa mayor variabilidad de un linaje, es el lugar de origen del mismo. Con estas herramientas, pasaremos a discutir posibles escenarios de poblamiento para el subcontinente sudamericano.

En Sudamérica los sitios arqueológicos más tempranos se localizan en la costa pacífica y dada la poca distancia temporal entre los sitios del norte y del sur, se propone un poblamiento rápido por vía pacífica como una de las hipótesis más aceptadas de poblamiento (Rothhammer y Dillehay, 2009 y bibliografía allí citada). En cuanto a la costa atlántica, el problema radica en que el ascenso del nivel del mar trasladó la línea de costa al interior del continente de modo que en caso de existir sitios 
tempranos, éstos se hallarían bajo el mar. Los sitios tempranos cercanos al Atlántico se encuentran en los cursos medios de los ríos, sugiriendo un ingreso a través del litoral fluvial (Miotti, 2006).

La forma de triángulo invertido que ofrece el continente sudamericano ubica a la Argentina en el punto de encuentro entre estas dos -eorrientes fundadoras" que acabamos de describir. Por un lado la cordillera de los Andes ofrece pasos naturales que son y han sido utilizados por habitantes a ambos lados del cordón montañoso como vía de comunicación e intercambio. Por otro lado, los ríos de la cuenca del Plata se vinculan con las redes fluviales de Bolivia, Paraguay y Brasil, actuando como vías de comunicación y desplazamiento, ofreciendo un ambiente similar en cuanto a la explotación de recursos.

Teniendo en cuenta la evidencia arqueológica y la evidencia mitocondrial, planteamos la existencia de focos de poblamiento, es decir poblaciones qua habrían permanecido aisladas o semiaisladas el tiempo suficiente para dar lugar a una diferenciación en las frecuencias de linajes maternos. La deriva génica habría tenido lugar en estas poblaciones, llevando a un aumento de frecuencia de determinadas variantes que serían características de cada región.

En cuanto al poblamiento inicial del noroeste y centro-oeste argentinos, los sitios arqueológicos más antiguos se hallan próximos a la cordillera y son levemente más modernos que los sitios chilenos (Tabla 1.1), indicando un sentido oeste-este para el poblamiento de la región. Por lo tanto el ingreso de los humanos en el territorio que nos ocupa, se habría dado a través de pasos intercordilleranos. La ubicación de los sitios señala al menos dos áreas principales de ingreso, una en la Puna y otra a la altura de Mendoza (Figura 1.5).

En la región del altiplano habría tenido lugar el establecimiento de un foco poblacional. A nivel arqueológico estos primeros asentamientos se reflejan en los sitios Salar de Punta Negra, San Lorenzo, Tuina, Huachichocana, Inca Cueva y Pintoscayoc (Rivero y Berberián 2007). En esta región se habría incrementado considerablemente la frecuencia de linajes B2, especialmente los linajes B2+16188 y B2+146-215-455+T, pero también linajes como D1+16527 y A2+16217. A través del tiempo, los pueblos de esta región se organizaron en sociedades estatales, lo que propició el aumento y la expansión demográfica, así como también el mantenimiento de redes de intercambio que facilitarían el flujo génico y el mantenimiento de la unidad en toda la región.

En las proximidades de la ciudad actual de Santiago de Chile se observa un conjunto de sitios con antigüedades mayores a 10.000 años AP como Quereo, Tagua-Tagua, Quebrada de Santa Julia y El Membrillo (Rivero y Berberián 2007; Jackson y col. 2007). Esta mayor densidad poblacional evidenciada a nivel arqueológico habría propiciado la incursión hacia nuevos territorios, produciéndose así el ingreso al actual territorio argentino que habría quedado registrado en sitios como Agua de la Cueva y Cueva del Indio en la provincia de Mendoza (Rivero y Berberián 2007). Como evidencia molecular de la existencia de un área refugio en los valles cuyanos podemos señalar la presencia de un linaje con mayor frecuencia y diversidad en el área, definido por la transición en la 
posición 150 dentro del haplogrupo A2, y también por la presencia de $\mathrm{C} 4 \mathrm{c}$, un linaje fundador descripto hasta el momento únicamente en América del Norte y en el norte de Colombia.

Además de los sitios en torno a la Puna y en los valles cuyanos, se registra la presencia humana temprana en las Sierras Centrales en el sitio El Alto 3, indicando el rápido ingreso al interior del continente. Si bien no puede descartarse la posibilidad de que los habitantes de este primer asentamiento provinieran de la región circumpuneña, o incluso de la región pampeana, la afinidad a nivel de las frecuencias de linajes mitocondriales entre la región central y la de los valles cuyanos, nos inclina en favor de esta ruta de ingreso hacia el interior del continente. A nivel de la evidencia mitocondrial pueden identificarse linajes que claramente presentan mayor frecuencia y diversidad en la región central y por eso lo proponemos como un foco poblacional independiente. En apoyo a este modelo, resalta por su importancia el linaje D1+152-16242-16311, denominado recientemente D1j por Bodner y col. (2012). Este linaje, cuyo carácter monofilético fue confirmado mediante la secuenciación completa del genoma mitocondrial en el citado trabajo, presenta mayor frecuencia en la región central de Argentina y entre las muestras analizadas en esta tesis es notable la correspondencia entre la mayor frecuencia y la mayor diversidad registrada en la localidad de La Rioja. En base a estos datos, discrepamos con la interpretación hecha en el trabajo de Bodner y col. (2012) según la cuál un solo foco poblacional habría dado origen a los linajes D1g y D1j. En su lugar, planteamos un foco poblacional independiente situado ya sea en las sierras centrales o en los valles riojanos, donde habría adquirido mayor frecuencia el linaje D1j. En apoyo de esta hipótesis, el tiempo de coalescencia estimado para D1j (13.900 años AP) es menor al estimado para D1g (18.300 años AP), señalando un establecimiento posterior de la población que habría dado origen al primero. Tal como es esperable teniendo en cuenta un poblamiento por costa pacífica que habría alcanzado en fechas más tempranas una mayor latitud, antes de atravesar la cordillera. Además de D1j, se distinguen por su mayor frecuencia y diversidad en la región del centro-oeste de Argentina, en claro contraste con los linajes típicamente patagónicos, los linajes definidos hasta el momento sólo por mutaciones en la Región Control, C1b+146, B2+16142, C1b+16192 y C1d+195; todos compartidos por la región de los valles cuyanos y por la región central, señalando el estrecho vínculo entre estos dos focos y el mantenimiento del flujo génico entre ambos.

La distribución a nivel sudamericano de estos tres últimos linajes plantea incertidumbres, ya que no puede establecerse fehacientemente un vínculo monofilético en ausencia de datos de la región codificante. Sin embargo, estos potenciales linajes refuerzan la hipótesis de un poblamiento por costa pacífica ya que se distribuyen en los países andinos (figuras 3.15, 3.17 y 3.19). Por otra parte, hacia los $40^{\circ}$ de latitud sur, las alturas de la cordillera decrecen y el traspaso del oeste hacia el este pudo haber sido aún más temprano. Este escenario es apoyado por la evidencia mitocondrial, ya que se observa una notable unidad de la Patagonia, tanto argentina como chilena por la presencia compartida de los linajes D1g, B2+470 y C1b+258. En particular el linaje D1g presenta gran diversidad interna como 
indicio de gran profundidad temporal por lo que se supone que pertenece a los primeros pobladores del área para los cuales se cuenta con un registro arqueológico. El sitio más temprano reconocido hasta el momento en Sudamérica, Monte Verde, se ubica a los $41^{\circ}$ de latitud sur, en la Región de los Lagos de Chile, consideramos que esta zona constituyó un foco de poblamiento, desde dónde se habría poblado la región patagónica a ambos lados de la cordillera. En este foco patagónico habrían adquirido preponderancia los linajes D1+16187 (D1g), C1b+258, y B2+470. Los linajes mitocondriales identificados para Tierra del Fuego, tanto entre la población actual como en restos arqueológicos, coinciden con los linajes patagónicos, con la presencia de D4h3a, C1b+258 y D1+16187 (García Bour y col. 2004; de Saint Pierre y col. 2012), señalando que el poblamiento del extremo sur habría ocurrido con posterioridad, luego de la incubación de los linajes patagónicos indicando en este caso una estructuración anidada entre el foco patagónico y el extremo sur insular.

La propuesta de la existencia de estos focos poblacionales se ve reforzada por la evidencia paleoclimática que señala que durante el Holoceno medio (7.000 a 5.000 AP) hubo fluctuaciones climáticas que aumentaron las condiciones de aridez en la región. A nivel arqueológico esto se refleja en una reducción en el número, e incluso la ausencia de sitios en los ambientes más frágiles (Barrientos, 1997; Núñez y col. 1999; Gil y col. 2005). Estas condiciones climáticas son compatibles con la fragmentación del paisaje y el consecuente aislamiento de los grupos humanos, que en ausencia de flujo génico y con un tamaño poblacional reducido habrían estado mayormente afectados por la deriva génica. Estas son las condiciones propicias para la diferenciación a nivel genético de cada población y de esta manera, en cada una de ellas se habrían perdido ciertos linajes al tiempo en que otros adquirieron preponderancia, generándose así linajes propios de cada región.

En cuanto al otro foco poblacional inicial ubicado en la actual costa atlántica de la provincia de Buenos Aires, señalado por la abundancia de sitios arqueológicos tempranos, no es posible hacer inferencias desde le punto de vista de la diversidad mitocondrial en el área, en primer lugar porque no existe un muestreo puntual en el área, pero aún en el caso de que lo hubiera, la dinámica poblacional de la región pampeana bonaerense ha sufrido mayormente el impacto de la inmigración europea de los siglos XVIII y XIX, y previamente el fenómeno conocido como —aucanización de las pampas" que consistió en el desplazamiento masivo de grupos mapuches provenientes de la Araucanía chilena. Estos procesos poblacionales recientes imposibilitan una estrategia metodológica similar a la empleada en esta tesis para acceder al conocimiento de los linajes maternos nativos. Sería muy difícil encontrar entre la población actual bonaerense descendientes de aquellos primeros pobladores.

En lo que respecta a la ruta de poblamiento que se desplazó hacia el este por la costa atlántica, uno de los linajes sobresalientes es D1+16142 (D1f sensu Kumar y col. 2011), cuyas mayores frecuencias se concentran en el norte de Brasil, y que alcanza el territorio argentino en la región del litoral, reforzando la idea de las vías fluviales como rutas de poblamiento (Figura 3.27g). 
La región muestreada en esta tesis se encuentra mayormente afectada por los procesos poblacionales andinos, pero en la Región III se distinguen linajes con un claro origen chaqueño o litoral, como A2+16051, B2+197-207-292 y D1f (Figuras 3.26 y 3.27). En las denominadas tierras bajas, se habrían constituido otros focos de diferenciación poblacional que también forman parte, aunque en menor medida, de la dinámica poblacional de la región en estudio.

Discutiremos a continuación los modelos propuestos desde una interpretación basada en medidas craneométricas en relación con el modelo planteado en base a la distribución de linajes mitocondriales.

Las investigaciones en morfología craneana se han centrado fundamentalmente en la discusión acerca del número de corrientes fundadoras u — -dadas migratorias” que poblaron Sudamérica (González-José, 2003; Neves y Hubbe, 2005; Pérez y col. 2007; Pérez y col. 2009). Este debate carece de asidero desde una perspectiva molecular, ya que se ha demostrado que todas las poblaciones americanas, incluso aquellas calificadas como -dictos" tales como las fueguinas, comparten los mismos subhaplogrupos que son derivados de clados de mayor jerarquía propios de Asia. Un trabajo reciente, basado en el análisis de polimorfismos en todo el genoma, comprueba que todos los pueblos americanos son el resultado de una única migración inicial, a la que posteriormente se habrían sucedido dos expansiones que no habrían alcanzado Sudamérica (Reich y col. 2012).

En cuanto a la diferenciación geográfica de las poblaciones en Argentina, Fabra y col. (2007) evalúan distintos modelos de poblamiento para el cono sur, a partir del análisis de 13 medidas craneanas en adultos varones, correspondientes a diez poblaciones del territorio argentino. Encuentran mayor afinidad entre las muestras del Litoral, las Sierras Centrales y Patagonia y proponen un poblamiento en sentido noreste suroeste. Esta interpretación, difiere rotundamente con el modelo de poblamiento propuesto en base al análisis de distribución de los linajes maternos en muestras actuales. Por el contrario, en esta tesis encontramos una mayor afinidad entre las Sierras Centrales y el Centro Oeste argentino, proponiendo una ruta de poblamiento por la costa pacífica, que habría ingresado en territorio argentino a través de los pasos cordilleranos ubicados a la altura de Mendoza y/o San Juan. Asimismo en el análisis de distribución de linajes a nivel sudamericano, no se han hallado en Patagonia, linajes compartidos con el Litoral. Los linajes patagónicos alcanzan su menor latitud en la región oeste, con la presencia de D1g en la provincia de Catamarca, indicando la existencia de flujo génico entre la Patagonia y el centro-oeste argentino.

Nuestros resultados son más próximos a los expuestos por Cocilovo y Di Rienzo (1984-1985), quienes basándose también en datos craneométricos, encuentran mayor afinidad entre las muestras de la Región Central (Córdoba y Santiago del Estero) respecto de las de Belén y a su vez entre ésta ultima y San Juan y Mendoza. Proponen una dirección de poblamiento norte-sur, que a partir de los valles Calchaquíes y a través de Belén, se habría bifurcado en dos rutas, una precordillerana y otra chacoserrana. En esta tesis, por el contrario proponemos que el poblamiento de la Región Central se habría 
dado desde la región de San Juan y Mendoza basándonos en la presencia compartida de linajes mitocondriales entre ambas regiones y en los fechados de los sitios arqueológicos tempranos próximos a la cordillera. Según nuestro análisis, Belén representa por un lado, el extremo sur de dispersión de linajes propios del sur de Bolivia y la Puna y por otro constituye un sector periférico de distribución de los linajes propios de la región centro-oeste. Más allá de las discusiones en torno al sentido de las rutas de poblamiento, coincidimos con el trabajo de Cocilovo y DiRenzo en el sentido de vincular a las poblaciones del NOA y CO-A como una entidad diferenciada respecto de las poblaciones del litoral.

El modelo de poblamiento, basado en la distribución actual de linajes maternos (Figura 4.4) es por supuesto, una propuesta que deberá ser contrastada con futuras investigaciones. En especial sería muy valioso contar con datos de ADN antiguo, ya que la distribución actual de los linajes puede estar enmascarando procesos poblacionales tempranos, tal vez algunas de las primeras ocupaciones territoriales fueron infructuosas y ya no existen linajes de aquellos primeros pobladores en la población actual, o existen en un reducido número y no han sido detectados por el muestreo. 


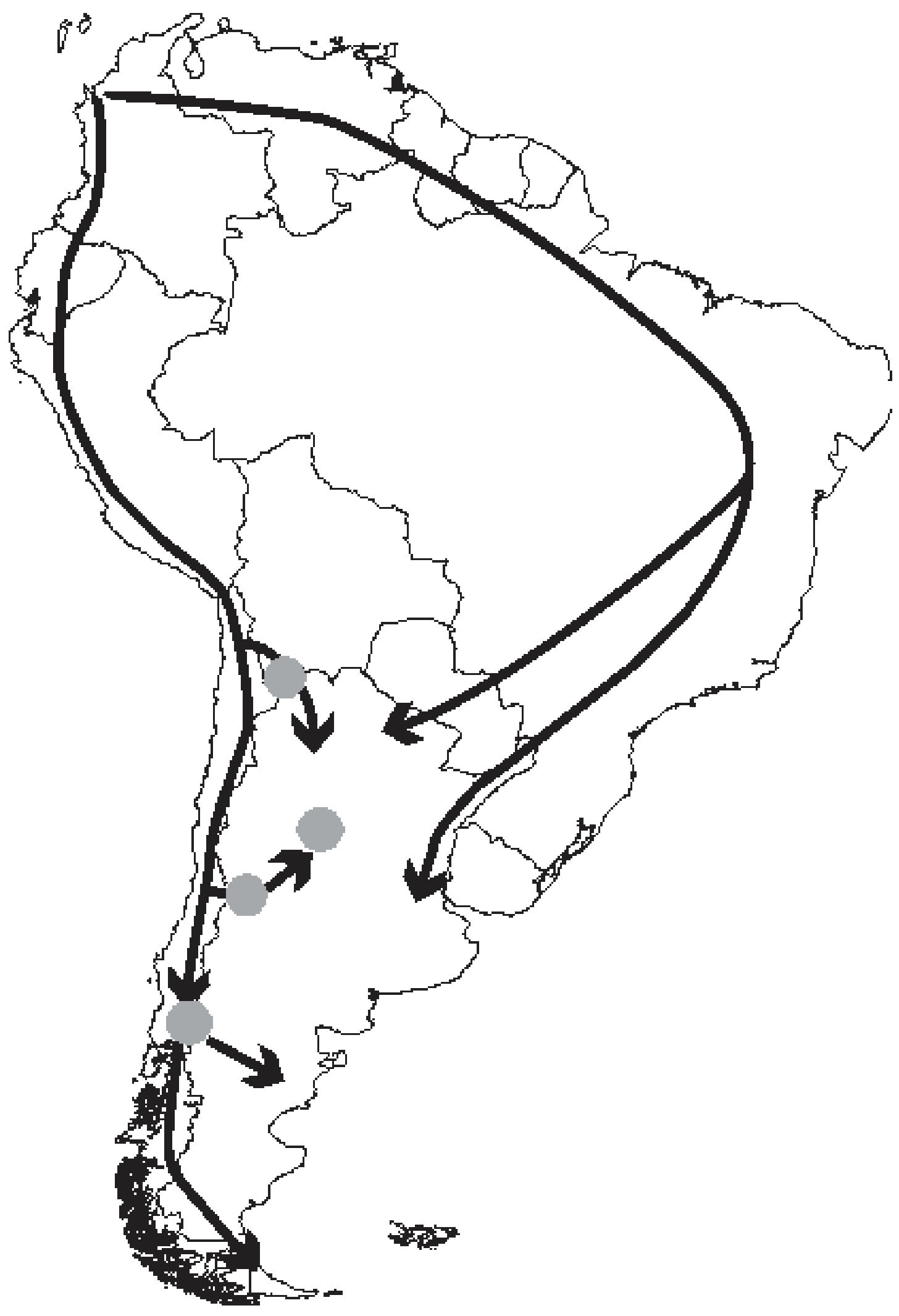

Figura 4.4. Modelo de poblamiento sudamericano propuesto en esta tesis. Se señalan los focos de poblamiento discutidos en el texto. 


\section{CAPÍTULO V: CONCLUSIONES}

- Se demostró la persistencia de un alto porcentaje de linajes maternos nativos en las regiones del Noroeste y Centro-oeste de Argentina.

- El análisis de la población actual constituye una alternativa válida de acceso al conocimiento de los linajes maternos nativos y su distribución espacial, siempre y cuando se considere la información histórica y genealógica como control de los efectos de las migraciones interregionales.

- La identificación de linajes monofiléticos al interior de cada haplogrupo permitió identificar diferencias regionales a nivel subcontinental y así refinar los estudios de afinidades y diferenciación poblacional.

- Se pudo comprobar una estructuración regional de los linajes maternos, identificándose la existencia de focos o centros de distribución de linajes que coinciden con la Puna, el Centro, los valles andinos del norte de Mendoza y sur de San Juan, el Chaco y la Patagonia.

- Mientras que en cada población coexisten múltiples linajes maternos, producto de distintos procesos de movilidad poblacional a lo largo del tiempo; pueden identificarse linajes que por su frecuencia y diversidad estarían asociados a momentos tempranos del poblamiento de la región. 


\section{CAPÍTULO VI: REFERENCIAS BIBLIOGRÁFICAS}

Achilli A, Rengo C, Magri C, Battaglia V, Olivieri A, Scozzari R, Cruciani F, Zeviani M, Briem E, Carelli V, Moral P, Dugoujon JM, Roostalu U, Loogvali EL, Kivisild T, Bandelt HJ, Richards M, Villems R, Santachiara-Benerecetti AS, Semino O, Torroni A. 2004. The molecular dissection of mtDNA haplogroup H confirms that the Franco-Cantabrian glacial refuge was a major source for the European gene pool. American Journal of Human Genetics; 75(5):910-8.

Achilli A, Perego UA, Bravi CM, Coble MD, Kong QP, Woodward SR, Salas A, Torroni A, Bandelt HJ. 2008. The phylogeny of the four pan-American MtDNA haplogroups: implications for evolutionary and disease studies. PLoS One; 3(3):e1764.

Afonso CH, Carvalho M, Lopes V, Balsa F, Bento A, Serra A, Andrade L, Anjos MJ, Vide MC, Pantoja S, Vieira DN, Corte-Real F. 2010. Mitochondrial DNA sequence analysis of a native Bolivian population. Journal of Forensic and Legal Medicine; 17(5):247-53.

Albeck E, Ruiz MS. 2003. El tardío en la puna de Jujuy: poblados, etnias y territorios. Cuadernos FHyCS-UNJu; 20:199-219.

Alvarez-Iglesias V, Jaime JC, Carracedo A, Salas A. 2007. Coding region mitochondrial DNA SNPs: targeting East Asian and Native American haplogroups. Forensic Science International Genetics; 1:44-55.

Alves-Silva J, da Silva Santos M, Guimarães PE, Ferreira ACS, Bandelt H-J, Pena SDJ, Ferreira Prado V. 2000. The ancestry of Brazilian mtDNA lineages. American Journal of Human Genetics; 67(2):444-61.

Anderson S, Bankier AT, Barrell BG, de Bruijn MH, Coulson AR, Drouin J, Eperon IC, Nierlich DP, Roe BA, Sanger F, Schreier PH, Smith AJ, Staden R, Young IG. 1981. Sequence and organization of the human mitochondrial genome. Nature; 290(5806):457-65.

Andrews RM, Kubacka I, Chinnery PF, Lightowlers RN, Turnbull DM, Howell N. 1999. Reanalysis and revision of the Cambridge reference sequence for human mitochondrial DNA. Nature Genetics; 23:147

Aris-Brosou S, Excoffier L. 1996. The impact of population expansion and mutation rate heterogeneity on DNA sequence polymorphism. Molecular Biology and Evolution; 13(3):494504.

Avena SA, Goicoechea AS, Dugoujon JM, Rey J, Dejean CB; Carnese FR. 2006. Mezcla génica en la Región Metropolitana de Buenos Aires. Revista Medicina 66:113-118.

Avena SA, Goicoechea A, Bartomioli M, Fernández V, Cabrera A, Dugoujon JM, Dejean C, Fabrykant G, Carnese FR. 2007. Mestizaje en el sur de la región pampeana (Argentina). Revista Argentina de Antropología Biológica; 9(2):59-76. 
Avena SA, Parolin ML, Dejean C, Ríos Part MC, Fabrikant G, Goicoechea AS, Dugoujon JM, Carnese FR. 2009. Mezcla génica y linajes uniparentales en Comodoro Rivadavia (porovincia de Chubut, Argentina). Revista Argentina de Antropología Biológica; 11(1):25-41.

Avena SA, Parolin ML, Boquet M, Dejean CB, Postillone MB, Alvarez Trentini Y, Di Fabio Rocca F, Mansilla F, Jones L, Dogoujon JM, Carnese FR. 2010. Mezcla génica y linajes uniparentales en Esquel (Pcia. de Chubut): Su comparación con otras muestras poblacionales argentinas. BAG. Journal of Basic and Applied Genetics; 21(1):01-14.

Ávila F. 2005. El estilo alfarero yavi y su relación con la construcción de entidades culturales. Theoria; 14(1):85-101.

Avise JC, Arnold J, Ball RM, Bermingham E, Lamb T, Neigel JE, Reeb CA, Saunders NC. 1987. Intraspecific phylogeography: the mitochondrial DNA bridge between population genetics and systematics. Annual review of ecology and systematics: 489-522.

Avise JC. 2000. Phylogeography: The history and formation of species. Harvard University Press, Londres.

Baeta M, Núñez C, González-Andrade F, Sosa C, Casalod Y, Bolea M, Zweynert S, Vacas Cruz OW, González-Solorzano J, Geppert M, Roewer L, Martínez-Jarreta B. 2009. Mitochondrial analysis revealed high homogeneity in the Waorani population-The last nomadic group of hunter-gatherers from Ecuador. Forensic Science International: Genetics Supplement Series; 2(1):313-4.

Bailliet G, Rothhammer F, Carnese FR, Bravi CM, Bianchi NO. 1994. Founder mitochondrial haplotypes in Amerindian populations. American Journal of Human Genetics; 27-33.

Bandelt HJ, Forster P, Sykes B, Richards M. 1995. Mitochondrial portraits of human populations using median networks. Genetics; 147:743-753.

Bandelt HJ, Herrnstadt C, Yao Y-G, Kong Q-P, Kivisild T, Rengo C, Scozzari R, Richards M, Villems R, Macaulay V, Howell N, Torroni A, Zhang Y-P. 2003. Identification of native american founder mtDNAs through the analysis of complete mtDNA sequences. Annals of Human Genetics; 1-13.

Bandelt HJ, Parson W. 2008. Consistent treatment of length variants in the human mtDNA control region: a reappraisal. International Journal of Legal Medicine; 122(1):11-21.

Barbieri C, Heggarty P, Castrì L, Luiselli D, Pettener D. 2011. Mitochondrial DNA variability in the Titicaca basin: Matches and mismatches with linguistics and ethnohistory. American journal of Human Biology : the official journal of the Human Biology Council; 23(1):89-99.

Barbosa ABG, da Silva LAF, Azevedo D a, Balbino VQ, Mauricio-da-Silva L. 2008. Mitochondrial DNA control region polymorphism in the population of Alagoas state, north-eastern Brazil. Journal of Forensic Sciences; 53(1):142-6. 
Barrientos G. 1997. Nutrición y dieta de las poblaciones aborígenes prehispánicas del sudeste de la región pampeana. Tesis Doctoral. La Plata, Facultad de Ciencias Naturales y Museo, Universidad Nacional de La Plata.

Behar DM, Villems R, Soodyall H, Blue-Smith J, Pereira L, Metspalu E, Scozzari R, Makkan H, Tzur S, Comas D, Bertranpetit J, Quintana-Murci L, Tyler-Smith C, Wells RS, Genographic Consortium. 2008. The dawn of human matrilineal diversity. The American Journal of Human Genetics; 82(5):1130-1140.

Benclowicz, J.D., 2011. Aportes para la Historia del Norte de Salta. Conformación y desarrollo de las localidades de Tartagal y General Mosconi durante la primera mitad del siglo XX. Andes 22, $0-0$.

Bert F, Corella A, Gene M. 2004. Mitochondrial DNA diversity in the Llanos de Moxos: Moxo , Movima and Yuracare Amerindian populations from Bolivia lowlands. Annals of Human Biology; 31(1):9-28.

Bobillo MC, Zimmermann B, Sala A, Huber G, Röck A, Bandelt H-J, Corach D, Parson W. 2010. Amerindian mitochondrial DNA haplogroups predominate in the population of Argentina: towards a first nationwide forensic mitochondrial DNA sequence database. International Journal of Legal Medicine; 124(4):263-268.

Bodner M, Perego U a, Huber G, Fendt L, Röck AW, Zimmermann B, Olivieri A, Gómez-Carballa A, Lancioni H, Angerhofer N, Bobillo MC, Corach D, Woodward SR, Salas A, Achilli A, Torroni A, Bandetlt H-J, Parson W. 2012. Rapid coastal spread of First Americans: Novel insights from South America's Southern Cone mitochondrial genomes. Genome research; en prensa.

Bonilla C, Bertoni B, Gonzalez S, Cardoso H, Brum-Zorrilla N, Sans M. 2004. Substantial Native American Female Contribution to the population of Tacuarembó, Uruguay, reveals past episodes of Sex-Biased gene flow. American Journal of Human Biology; 16:289-297

Bortolini MC, Araujo Da Silva Junior W, Castro de Guerra D, Remonatto G, Mirandola R, Hutz MH, Weimer TA, Silva MCBO, Zago MA, Salzano FM. 1999. African-derived South American populations : A history of symmetrical and asymmetrical matings according to sex revealed by bi- and uni-parental genetic markers. American Journal of Human Biology; 11: 551-63

Brandstätter A, Peterson CT, Irwin JA, Mpoke S, Koech DK, Parson W, Parsons TJ. 2004. Mitochondrial DNA control region sequences from Nairobi (Kenya): inferring phylogenetic parameters for the establishment of a forensic database. International Journal of Legal Medicine; 118(5):294-306 
Brandstätter A, Egyed B, Zimmermann B, Duftner N, Padar Z, Parson W. 2007. Migration rates and genetic structure of two hungarian ethnic groups in Transylvania, Romania. Annals of Human Genetics 71(Pt 6):791-803

Bryc K, Velez C, Karafet T, Moreno-Estrada A, Reynolds A, Auton A, Hammer M, Bustamante CD, Ostrer H. 2010. Colloquium paper: genome-wide patterns of population structure and admixture among Hispanic/Latino populations. Proceedings of the National Academy of Sciences of the United States of America; 107 Suppl :8954-61.

Cabana GS, Merriwether DA, Hunley KL, Demarchi D. 2006. Is the genetic structure of Gran Chaco populations unique? Interregional perspectives on Native South American mitochondrial DNA variation. American Journal of Physical Anthropology; 131 (1): 108-19.

Campaña H, Pawluk MS, López Camelo JS. 2010. Prevalencia al nacimiento de 27 anomalías congénitas seleccionadas, en 7 regiones geográficas de Argentina. Archivos Argentinos de Pediatría; 108(5):409-417.

Carnese FR, Mendisco F, Keyser C, Dejean CB, Dugoujon J-michel, Bravi CM, Ludes B, Crubézy E. 2010. Paleogenetical study of pre-columbian samples. American Journal of Physical Anthropology; 141(3): 452-62.

Carvajal-Carmona LG, Soto ID, Pineda N, Ortíz-Barrientos D, Duque C, Ospina-Duque J, McCarthy M, Montoya P, Alvarez VM, Bedoya G, Ruiz-Linares A. 2000. Strong Amerind/white sex bias and a possible Sephardic contribution among the founders of a population in northwest Colombia. The American Journal of Human Genetics; 67(5):1287-1295.

Carvalho BM, Bortolini MC, Batista dos Santos SE, Campos Ribeiro-dos-Santos AK. 2008. Mitochondrial DNA mapping of social-biological interactions in Brazilian Amazonian African-descendant populations. Genetics and Molecular Biology; 31 (1): 12-22.

Castro de Guerra D, Figuera Pérez C, Bravi CM, Sunier J, Scheible M, Irwin J, Coble MD. 2011. Sequence variation of mitochondrial DNA control region in North Central Venezuela. Forensic Science International Genetics. doi:10.1016/j.fsigen.2011.11.004

Catelli ML, Alvarez-Iglesias V, Gomez-Carballa A, Mosquera-Miguel A, Romanini C, Borosky A, Amigo J, Carracedo A, Vullo C, Salas A. 2011. The impact of modern migrations on presentday multi-ethnic Argentina as recorded on the mitochondrial DNA genome. BMC genetics; 12(1):77.

Censabella M. 1999. Las lenguas indígenas de la Argentina. Una mirada actual. Ed. Eudeba.

Cerezo M, Achilli A, Olivieri A, Perego UA, Gómez-Carballa A, Brisighelli F, Lancioni H, Woodward SR, López-Soto M, Carracedo A, Capelli C, Torroni A, Salas A. 2012. Reconstructing ancient mitochondrial DNA links between Africa and Europe. Genome Res; 22(5):821-6 
Cocilovo JA, Di Rienzo JA. 1984-1985. Un modelo biológico para el estudio del poblamiento prehispánico del territorio argentino. Correlación fenético-espacial. Relaciones de la Sociedad Argentina de Antropología; 15: 119-135

Corella A, Bert F, Pérez-Pérez A, Gené M, Turbón D. 2007. Mitochondrial DNA diversity of the Amerindian populations living in the Andean Piedmont of Bolivia: Chimane, Moseten, Aymara and Quechua. Annals of Human Biology; 34(1):34-55.

de Saint Pierre M, Bravi CM, Motti JMB, Fuku N, Tanaka M, Bonatto SL, Moraga M. 2012. An alternative model for the early peopling of southern South America revealed by analyses of three new mitochondrial DNA haplogroups. PlosOne, en prensa.

Diaz-Matallana M, Martinez-Cruzado JC. 2010. Estudios sobre ADN mitocondrial sugieren un linaje predominante en la cordillera Oriental de Colombia y un vínculo suramericano para los arcaicos de Puerto Rico. Universidad Médica de Bogotá; 51(3):241-72.

Dipierri JE, Alfaro E, Martínez-Marignac VL, Bailliet G, Bravi CM, Cejas S, Bianchi NO. 1998. Paternal directional mating in two Amerindian subpopulations located at different altitudes in northwestern Argentina. Human Biology; 70(6):1001-1010.

Dornelles CL, Battilana J, Fagundes NJR, Freitas LB, Bonatto SL. 2004. Mitochondrial DNA and Alu Insertions in a Genetically Peculiar Population: The Ayoreo Indians of Bolivia and Paraguay. American Journal of Human Biology; 16:479-88.

Dornelles CL, Bonatto SL, De Freitas LB, Salzano FM. 2005. Is haplogroup X present in extant South American Indians? American Journal of Physical Anthropology; 127(4):439-48.

Escolar D. 2001. Subjetividad y estatalidad: usos del pasado y pertenencias indígenas en Calingasta. En: Susana Bandieri coordinadora. Cruzando la cordillera... La frontera argentino-chilena como espacio social. CEHR. Universidad Nacional del Comahue. p 141-165.

Escolar D. 2007. Los dones étnicos de la nación: identificaciones huarpe y modos de producción de soberanía en Argentina. Ed. Prometeo. Buenos Aires.

Estrada-Cuzcano A, Sandoval J, Guevara-Fujita ML, Fujita R. 2006. Uso de la técnica SSCP para detectar mutaciones puntuales del ADN mitocondrial humano. Revista Peruana de Biología; 12(3):349-58.

Excoffier L, Laval LG, Schneider S. 2005. Arlequin ver. 3.0: An integrated software package for population genetics data analysis. Evolutionary Bioinformatics Online 1:47-50.

Fabra M, Laguens G, Demarchi DA. 2007. Human Colonization of the Central Territory of Argentina: Design Matrix Models and Craniometric Evidence. American Journal of Physical Anthropology; 133:1060-6.

Fagundes NJR, Kanitz R, Eckert R, Valls ACS, Bogo MR, Salzano FM, Glenn Smith D, Silva Jr. WA, Zago MA, Ribeiro-dos-Santos AK, Santos SEB, Petz-Erler ML, Bonatto SL. 2008. 
Mitochondrial population genomics supports a single pre-Clovis origin with a coastal route for the peopling of the Americas. Journal of Human Genetics; 82:583-92.

Fehren-Schmitz L, Reindel M, Cagigao ET, Hummel S, Herrmann B. 2009. Pre-Columbian population dynamics in coastal southern Peru: A diachronic investigation of mtDNA patterns in the Palpa region by ancient DNA analysis. American Journal of Physical Anthropology; 141(2):208-21.

Feio-Dos-Santos AC, Carvalho BM, Batista dos Santos SE, Ribeiro-dos-santos AK. 2006. Nucleotide variability of HV-I in admixed population of the Brazilian Amazon Region. Forensic Science International; 164(2-3):276-7.

Figueiro G, Hidalgo PC, Sans M. 2011. Control region variability of haplogroup C1d and the tempo of the peopling of the americas. PloS one; 6(6):e20978.

Forster P, Harding R, Torroni A, Bandelt HJ. 1996. Origin and evolution of Native American mtDNA variation: a reappraisal. American Journal of Human Genetics; 59(4):935-45.

Frazier TM. 1960. A note on race-specific congenital malformation rates. American Journal of Obstetrics and Gynecology; 80:184-185.

Fuselli S, Tarazona-santos E, Dupanloup I, Soto A, Luiselli D, Pettener D. 2003. Mitochondrial DNA diversity in South America and the genetic history of andean highlanders. Molecular Biology and Evolution; 20(10):1682-1691.

García A, Demarchi DA. 2009. Incidence and distribution of Native American mtDNA haplogroups in central Argentina. Human Biology; (1):59-69.

García-Bour J, Pérez-Pérez A, Alvarez S, Fernandez E, Lopez-Parra AM, Arroyo-Pardo E, Turbón D. 2004. Early population differentiation in extinct aborigines from Tierra del Fuego-Patagonia: ancient mtDNA sequences and Y-Chromosome STR characterization. American Journal of Physical Anthropology; 123: 361-70.

Gayà-Vidal M, Moral P, Saenz-Ruales N, Gerbault P, Tonasso L, Villena M, Vasquez R, Bravi CM, Dugoujon J-M. 2011. mtDNA and Y-chromosome diversity in Aymaras and Quechuas from Bolivia: Different stories and special genetic traits of the Andean Altiplano populations. American Journal of Physical Anthropology; en prensa

Ghose C, Perez-perez GI, Pride DT, Bravi CM, Blaser MJ. 2002. East Asian genotypes of Helicobacter pylori strains in Amerindians provide evidence for its ancient human carriage. Proceedings of the National Academy of Sciences; 99(23):15107-11.

Gil AF, Zárate M, Neme G. 2005. Mid-Holocene paleoenvironments and the archeological record of southern Mendoza, Argentina. Quaternary International; 132:81-94.

Gilbert MT, Willerslev E, Hansen AJ, Barnes I, Rudbeck L, Lynnerup N, Cooper A. 2003. Distribution patterns of postmortem damage in human mitochondrial DNA. American Journal of Human Genetics 72:32-47 
Ginther C, Corach D, Penacino GA, Rey JA, Carnese FR, Hutz MH, Anderson A, Just J, Salzano FM, King M-C. 1993. Genetic variation among the Mapuche Indians from the Patagonian region of Argentina: Mitochondrial DNA sequence variation and allele frequencies of several nuclear genes. En: Pena SDJ, Chakraborty R, Epplen JT, Jeffreys AJ, eds. DNA Fingerprinting: State of the Science, Birkhauser Verlag Basel, pp 211-219.

Golden Software, Inc. 2002. Surface Mapping System. Surfer v. 8.0. Golden, Colorado.

Gonçalves VF, Carvalho CMB, Bortolini MC, Bydlowski SP, Pena SDJ. 2008. The phylogeography of African Brazilians. Human Heredity; 65(1):23-32.

Gonçalves VF, Parra FC, Gonçalves-Dornelas H, Rodrigues-Carvalho C, Silva HP, Pena SDJ. 2010. Recovering mitochondrial DNA lineages of extinct Amerindian nations in extant homopatric Brazilian populations. Investigative genetics; 1(1):13.

González AR. 1960 La estratigrafía de la gruta de Intihuasi (Prov. de San Luis, R.A.) y sus relaciones con otros sitios precerámicos de Sudamérica. Revista del Instituto de Antropología; 1:5302 .

González AR. 1979. Dinámica Cultural del N. O. Argentino. Evolución e historia en las culturas del N. O. argentino. Antiquitas; 28-29: 1-15

González-José R. 2003. El poblamiento de la patagonia. Análisis de la variación craneofacial en el contexto del poblamiento americano. Tesis Doctoral. Universidad de Barcelona.

Goudet J. 1996. FSTAT A computer program to calculate F-statistics. Version 1.2. Jounal of Heredity; 86: 485-486

Grzybowski T, Malyarchuk BA, Derenko MV, Perkova MA, Bednarek J, Woźniak M. 2007. Complex interactions of the Eastern and Western Slavic populations with other European groups as revealed by mitochondrial DNA analysis. Forensic Science International Genetics; $1(2): 141-7$

Guerreiro-Junior V, Bisso-Machado R, Marrero AR, Hünemeier T, Salzano FM, Bortolini MC. 2009. Genetic signatures of parental contribution in black and white populations in Brazil. Genetics and Molecular Biology; 32(1):1-11.

Guzmán F. 2006. Africanos en la Argentina: Una reflexión desprevenida. Andes 17:197-238.

Haber M, Youhanna SC, Balanovsky O, Saade S, Martínez-Cruz B, Ghassibe-Sabbagh M, Shasha N, Osman R, el Bayeh H, Koshel S, Zaporozhchenko V, Balanovska E, Soria-Hernanz DF, Platt DE, Zalloua PA. 2012. mtDNA lineages reveal coronary artery disease-associated structures in the Lebanese population. Annals of Human Genetics; 76(1):1-8.

Helgason A, Pálsson G, Pedersen HS, Angulalik E, Gunnarsdóttir ED, Yngvadóttir B, Stefánsson K. 2006. mtDNA variation in Inuit populations of Greenland and Canada: migration history and population structure. American Journal of Physical Anthropology; 130(1):123-134. 
Hennig W. 1968. Elementos de una sistemática filogenética. EUDEBA, Buenos Aires

Horai S, Kondo R, Nakagawa-hattori Y, Hayashi S, Sonoda S, Tajima K. 1993. Peopling of the Americas, founded by four major lineages of mitochondrial DNA. Molecular Biology and Evolution; 10(1):23-47.

Howell N, Kubacka I, Mackey DA. How rapidly does the human mitochondrial genome evolve? 1996. American Journal of Human Genetics; 59(3):501-9.

Howell N, Smejkal CB, Mackey DA, Chinnery PF, Turnbull DM, Herrnstadt C. 2003. The pedigree rate of sequence divergence in the human mitochondrial genome: there is a difference between phylogenetic and pedigree rates. American Journal of Human Genetics; 72(3):659-70.

INDEC. 2001. Censo Nacional de Población, Hogares y Viviendas. www.indec.gov.ar

Ingman M, Kaessmann H, Paabo S, Gyllensten U. 2000. Mitochondrial genome variation and the origin of modern humans. Nature; 408(6813):708-13.

Ivanov PL, Wadhams MJ, Roby RK, Holland MM, Weedn VW, Parsons TJ. 1996. Mitochondrial DNA sequence heteroplasmy in the Grand Duke of Russia Georgij Romanov establishes the authenticity of the remains of Tsar Nicholas II. Nature Genetics; 12: 417-42

Jackson D, Mendez C, Seguel R, Maldonado A, Vargas G. 2007. Initial occupation of the Pacific coast of Chile during Late Pleistocene times. Current Anthropology; 48(5):725-31.

Kashani BH, Perego UA, Olivieri A, Angerhofer N, Gandini F, Carossa V, Lancioni H, Semino O, Woodward SR, Achilli A, Torroni A. 2012. Mitochondrial haplogroup C4c: A rare lineage entering America through the ice-free corridor? American Journal of Physical Anthropology; 147: $35-9$.

Kemp BM, Tung TA, Summar ML. 2009. Genetic continuity after the collapse of the Wari empire: mitochondrial DNA profiles from Wari and post-Wari populations in the ancient Andes. American Journal of Physical Anthropology; 140(1):80-91.

Kivisild T, Shen P, Wall DP, Do B, Sung R, Davis K, Passarino G, Underhill PA, Scharfe C, Torroni A, Scozzari R, Modiano D, Coppa A, de Knijff P, Feldman M, Cavalli-Sforza LL, Oefner P. 2006. The role of selection in the evolution of human mitochondrial genomes. Genetics; 172(1):373-87.

Kloss-Brandstaetter A, Pacher D, Schoenherr S, Weissensteiner H, Binna R, Specht G, Kronenberg F. 2010. HaploGrep: a fast and reliable algorithm for automatic classification of mitochondrial DNA haplogroups http://www.haplogrep.uibk.ac.at doi: 10.1002/humu.21382

Kocher TD, Wilson AC. 1991. Sequence evolution of mitochondrial DNA in humans and chimpanzees: control region and protein-coding regions, pp. 391-413 in Evolution of Life: Fossils, Molecules and Culture, edited by S. Osawa and T. Honio. Springer Verlag, Tokyo 
Kumar S, Bellis C, Zlojutro M, Melton PE, Blangero J, Curran JE. 2011. Large scale mitochondrial sequencing in Mexican Americans suggests a reappraisal of Native American origins. BMC evolutionary biology; 11(1):293.

Lagiglia H. 1976. La Cultura de Viluco del Centro Oeste Argentino. Actas y Memorias IV Congreso Nacional de Arqueología Argentina; 3 (1/4): 227-265 San Rafael, Mendoza

Lander N, Rojas MG, Chiurillo MA, Ramírez JL. 2008. Haplotype diversity in human mitochondrial DNA hypervariable regions I-III in the city of Caracas (Venezuela). Forensic Science International Genetics; 2(4):e61-4.

Lattes AE. 1973. Las migraciones en la Argentina entre mediados del siglo XIX y 1960. Desarrollo Económico; XII(48):1-20.

Lewis CM, Tito RY, Lizárraga B, Stone AC. 2005. Land, language, and loci: mtDNA in Native Americans and the genetic history of Peru. American Journal of Physical Anthropology; 127: 351-360.

Lewis CM, Lizárraga B, Tito RY, López PW, Iannacone GC, Medina A, Martínez R, Polo SI, De la Cruz AF, Cáceres AM, Stonne AC. 2007. Mitochondrial DNA and the peopling of South America. Human Biology; an international record of research; 79(2):159-78.

Lobos N. 2004. Para pensar la identidad cultural en el desierto de Lavalle. Revista Confluencia; 1(4): 1-20. Mendoza, Argentina.

Lorandi AM. 1998. Los Diaguitas y el Tawantinsuyu: una hipótesis de conflicto. En: La frontera del estado Inca. Dillehay y Netherty comps.

Macaulay V, Richards M, Forster P, Bendall K, Watson E, Sykes B, Bandelt H-J. mtDNA mutation rates-no need to panic. 1997. American Journal of Human Genetics; 61:983-986.

Malhi RS, Cybulski JS, Tito RY, Johnson J, Harry H, Dan C. 2010. Brief Communication: Mitochondrial Haplotype C4c Confirmed as a Founding Genome in the Americas. American Journal of Physical Anthropology; 141:494-7.

Mandrini R. 2008. La Argentina Aborigen. De los primeros pobladores a 1910. Buenos Aires: Siglo XXI Editores.

Manni F, Guérard E, Heyer E. 2004. Geographic patterns of (genetic, morphologic, linguistic) variation: how barriers can be detected by —Mnmonier's algorithm”. Human Biology; 76(2): 173-190.

Margulis L. 1967. On origin of mitosing cells. Journal of theoretical biology; 14 (3), 225-274.

Marinho AN do Rosário, de Moraes MR, Santos S, Ribeiro-Dos-Santos A. 2011. Human aging and somatic point mutations in mtDNA: A comparative study of generational differences (grandparents and grandchildren). Genetics and Molecular Biology; 34(1):31-4. 
Marrero AR, Das Neves Leite FP, De Almeida Carvalho B, Peres LM, Kommers TC, Da Cruz IM, Salzano FM, Ruiz-Linares A, Araujo Da Silva Junior W, Bortolini MC. 2005. Heterogeneity of the genome ancestry of individuals classified as White in the state of Rio Grande do Sul, Brazil. American journal of Human Biology: the official journal of the Human Biology Council; 17(4):496-506.

Marrero AR, Bravi CM, Stuart S, Long JC, Pereira das Neves Leite F, Kommers T, Carvalho CMB, Junho Pena SD, Ruiz-Linares A, Salzano FM, Bortolini MC. 2007. Pre- and post-Columbian gene and cultural continuity: the case of the Gaucho from southern Brazil. Human Heredity; 64(3):160-71.

Martínez H, Rodríguez-Larralde A, Izaguirre MH, Castro-de-Guerra D. 2007. Admixture estimates for Caracas, Venezuela, based on autosomal, Y-Chromosome, and mtDNA markers. Human Biology; 79(2):201-13.

Martínez-Marignac VL, Bravi CM, Lahitte HB, Bianchi NO. 1999. Estudio del ADN mitocondrial de una muestra de la ciudad de La Plata. Revista Argentina de Antropología Biológica; 2(1):281-300.

Mazières S. 2006. Le peuplement amerindien de la guyane française: apport des marqueurs moleculaires. Universite Toulouse III - paul sabatier U.F.R. SVT. Universidade Federal do Rio Grande do sul. Departamento de genetica.

Mendisco F, Keyser C, Hollard C, Seldes V, Nielsen AE, Crubézy E, Ludes B. 2011. Application of the iPLEX(TM) Gold SNP genotyping method for the analysis of Amerindian ancient DNA samples: Benefits for ancient population studies. Electrophoresis; en prensa.

Metspalu E, Mait, Bandelt H-J, Kivisild T, Richards MB, Villems R. 2006. The pioneer settlement of modern humans in Asia. En: Human Mitochondrial DNA and the Evolution of Homo Sapiens. Hans-Jürgen Bandelt, Vincent Macaulay y Martin Richards (Eds.)

Michieli CT. 1983. Los huarpes protohistóricos. San Juan, Instituto de Investigaciones Arqueológicas y Museo UNSJ.

Michieli CT. 1996. Realidad socioeconómica de los indígenas de San Juan en el Siglo XVII. Instituto de Investigaciones Arqueológicas y Museo Universidad Nacional de San Juan. San Juan, Argentina.

Michieli CT. 2000. La disolución de la categoría Jurídico-Social de "indio" en el siglo XVIII: El caso de San Juan (Región de Cuyo). Publicaciones 23 (nueva serie). Universidad Nacional de San Juan.

Miotti LL. 2006. La fachada atlántica, como puerta de ingreso alternativa de la colonización humana de América del Sur durante la transición Pleistoceno/Holoceno. En $2^{\circ}$ Simposio Internacional 
del Hombre Temprano en América (J. C. Jiménez López y col, eds.). Instituto Nacional de Antropología e Historia, México: 155-88.

Mishmar D, Ruiz-Pesini E, Golik P, Macaulay V, Clark AG, Hosseini S, Brandon M, Easley K, Chen E, Brown MD, Sukernik RI, Olckers A, Wallace DC. 2003. Natural selection shaped regional mtDNA variation in humans. Proceedings of the National Academy of Sciences of the United States of America; 100(1):171-6.

Moraga M, Rocco P, Miquel JF, Nervi F, Llop E, Chakraborty R, Rothhammer F, Carvallo P. 2000. Mitochondrial DNA polymorphisms in Chilean aboriginal populations: implications for the peopling of the southern cone of the continent. American Journal of Physical Anthropology; 113(1):19-29.

Motti JMB, Rodenak B, Bailliet G, Bravi CM. 2009. Tipificación de haplogrupos mitocondriales mediante multiplex PCR-AFLP. Novenas Jornadas Nacionales de Antropología Biológica. Puerto Madryn, Argentina.

Motti JMB. 2010. Detrás del consentimiento informado. International Journal of Bio-Anthropological Practice; $1: 15-18$.

Nei M. 1987. Molecular Evolutionary Genetics. Columbia Univ. Press, New York.

Neves WA, Hubbe M. 2005. Cranial morphology of early Americans from Lagoa Santa, Brazil: Implications for the settlement of the NewWorld. Procedings of the Natural Academy of Science USA; 102:18309-18314.

Núñez L, Grosjean M, Cartajena EL. 1999. Un ecorefugio oportunístico en la puna de Atacama durante eventos áridos del Holoceno Medio. Estudios Atacameños 17: 125-174.

Olivieri A, Achilli A, Pala M, Battaglia V, Fornarino S, Al-Zahery N, Scozzary R, Cruciani F, Behar DM, Dugoujon J-M, Coudray C, Santachiara-Benerecetti AS, Semino O, Bandelt H-J, Torroni A. 2006. The mtDNA legacy of the Levantine early Upper Palaeolithic in Africa. Science; 314(5806):1767-70.

Otero H. 2006. Estadística y Nación: una historia conceptual del pensamiento censal de la Argentina moderna 1869-1914. $1^{\mathrm{a}}$ ed. Buenos Aires. Prometeo.

Paäbo S. 1996. Mutational hot spots in the mitochondrial microcosm. American Journal of Human Genetics; 59(3):493-6.

Pagano S, Sans M, Pimenoff V, Cantera AM, Alvarez JC, Lorente JA, Peco JM, Mones P, Sajantila A. 2005. Assessment of HV1 and HV2 mtDNA variation for forensic purposes in an Uruguayan population sample. Journal of Forensic Sciences; 50(5):1239.

Palencia L, Valverde L, Alvarez A, Cainé LM, Cardoso S, Alfonso-Sánchez M, Pinheiro MF, de Pancorbo MM. 2010. Mitochondrial DNA diversity in a population from Santa Catarina (Brazil): predominance of the European input. International Journal of Legal Medicine; 124(4):331-6. 
Paredes A. 2004. Los inmigrantes en Mendoza. En: Roig A, Lacoste P y Saltari MC, compiladores. Mendoza a través de su historia. Caviar Bleu Editora.

Perego UA, Achilli A, Angerhofer N, Accetturo M, Pala M, Olivieri A, Kashani BH, Ritchie KH, Scozzari R, Kong K-P, Myres NM, Salas A, Semino O, Bandelt H-J, Woodward SR, Torroni A. 2009. Distinctive Paleo-Indian migration routes from Beringia marked by two rare mtDNA haplogroups. Current Biology; 19(1):1-8.

Perego UA, Angerhofer N, Pala M, Olivieri A, Lancioni H, Kashani BH, Carossa V, Ekins JE, Gómez-Carballa A, Huber G, Zimmermann B, Corach D, Baudri N, Panara F, Myres NM, Parson W, Semino O, Salas A, Woodward AR, Achilli A, Torroni A. 2010. The initial peopling of the Americas: A growing number of founding mitochondrial genomes from Beringia. Genome Research; 20(9):1174-9.

Pereira F, Soares P, Carneiro J, Pereira L, Richards MB, Samuels DC, Amorim A. 2008. Evidence for variable selective pressures at a large secondary structure of the human mitochondrial DNA control region. Molecular Biology and Evolution; 25(12):2759-70.

Pérez SI, Bernal V, Gonzalez PN. 2007. Morphological Differentiation of Aboriginal Human Populations From Tierra del Fuego ( Patagonia ): Implications for South American Peopling. American Journal of Physical Anthropology; 133:1067-79.

Pérez SI, Monteiro LR. 2009. Nonrandom factors in modern human morphological diversification: a study of craniofacial variation in southern South american populations. Evolution; 63(4):97893.

Politis G, Messineo PG, Kaufmann CA. 2004. El poblamiento temprano de las llanuras pampeanas de Argentina y Uruguay. Complutum; 15:207-24.

Politis G, Bonomo M. 2011. Nuevos datos sobre el "Hombre fósil" de Ameghino. En: Vida y obra de Florentino Ameghino. Publicación especial de la Asociación Paleontológica Argentina №12. Fernicola, Prieto y Lazo Editores.

Prieto L, Zimmermann B, Goios A, Rodriguez-Monge A, Paneto GG, Alves C, Alonso A, Fridman C, Cardoso S, Lima G, Anjos MJ, Whittle MR, Montesino M, Cicarelli RMB, Rocha AM, Albarrán C, de Pancorbo MM, Pinheiro MF, Carvalho M, Sumita DR. 2011. The GHEPEMPOP collaboration on mtDNA population data--A new resource for forensic casework. Forensic Science International. Genetics; 5(2):146-51.

Ramallo V, Mucci J, García A, Muzzio M, Motti JMB, Santos MR, Pérez ME, Alfaro EL, Dipierri JE, Demarchi DA, Bravi CM, Bailliet G. 2009. Comparison of Y-chromosome haplogroup frequencies in eight Provinces of Argentina. Forensic Science International: Genetics Supplement Series; 2:431-2.

Raymond M, Rousset F. 1995. An exact test for population differentiation. Evolution; 49:1280-1283 
Reich D, Patterson N, Campbell D, Tandon A, Mazieres S, Ray N, et al. 2012. Reconstructing Native American population history. Nature; en prensa

Reidla M, Kivisild T, Metspalu E, Kaldma K, Tambets K, Tolk H-V, Parik J, Loogväli E-L, Derenko M, Malyarchuk B, Bermisheva M, Zhadanov S, Pennarun E, Gubina M, Golubenko M, Damba L, Fedorova S, Gusar V, Grechanina E, Mikerezi I, Moisan J-P, Chaventré A, Khusnutdinova E, Osipova L, Stepanov V, Voevoda M, Achilli A, Rengo C, Rickards O, De Stefano GF, Papiha S, Beckman L, Janicijevic B, Rudan P, Anagnou N, Michalodimitrakis E, Koziel S, Usanga E, Geberhiwot T, Herrnstadt C, Howell N, Torroni A, Villems R. 2003. Origin and diffusion of mtDNA haplogroup X. American Journal of Human Genetics; 73(5):1178-90.

Renfrew C. 2001. From molecular genetics to archaeogenetics. Proceedings of the National Academy of Sciences of the United States of America; 98(9):4830-2.

Ribeiro-dos-santos AK, Guerreiro JF, Santos SE, Zago M. 2001. The split of the Arara population: comparison of genetic drift and founder effect. Human Heredity; 51(1-2):79-84.

Ribeiro-dos-santos AK, Carvalho BM, Feio-dos-Santos AC, Batista dos Santos SE. 2007. Announcement of population data nucleotide variability of HV-I in Afro-descendents populations of the Brazilian Amazon region. Forensic Science International; 167:77-80.

Rickards O, Martínez-Labraga C, Lum JK, De Stefano GF, Cann RL. 1999. mtDNA History of the Cayapa Amerinds of Ecuador: Detection of additional founding lineages for the Native American populations. Am J Hum. Genet; 65:519-30.

Rivero D, Roldán F. Initial peopling of the Córdoba mountains, Argentina : First evidence from El Alto 3. 2005. Current Research in the Pleistocene; 22:33-5.

Rivero D, Berberian E. 2008. El poblamiento de la región central del territorio argentino durante la transición Pleistoceno-Holoceno (12.000-9.000 AP). Revista Española de Antropología; 38:17-37.

Rohlf FJ. 2000. NTSYS-pc: Numerical Taxonomy and Multivariate Analysis System, version 2.11s. Exeter Software, Setauket, NY.

Rothhammer F, Dillehay TD. 2009. The late Pleistocene colonization of South America: an interdisciplinary perspective. Annals of Human Genetics; 73(5):540-9.

Rozas J, Sánchez-DelBarrio JC, Messeguer X, Rozas R. 2003. DnaSP, DNA polymorphism analyses by the coalescent and other methods. Bioinformatics; 19: 2496-2497.

Sala A, Argüelles CF, Marino ME, Bobillo MC, Fenocchio A, Corach D. 2010. Genetic analysis of six communities of Mbyá-Guaraní inhabiting Northeastern Argentina by means of nuclear and mitochondrial polymorphic markers. Human Biology; 82(4):433-56. 
Salas A, Richards M, Lareu M-V, Sobrino B, Silva S, Matamoros M, Macaulay V, Carracedo Á. 2005. Shipwrecks and founder effects: Divergent demographic histories reflected in Caribbean mtDNA. American Journal of Physical Anthropology; 128: 855-860.

Salas A, Jaime JC, Alvarez-Iglesias V. 2008. Gender bias in the multiethnic genetic composition of central Argentina. Journal of Human Genetics; 53(7):662-74.

Sandoval K, Buentello-Malo L, Peñaloza-Espinosa R, Avelino H, Salas A, Calafell F, Comas D. 2008. Linguistic and maternal genetic diversity are not correlated in Native Mexicans. Human Genetics; 126(4):521-31.

Sans M, Weimer TA, Franco MH, Salzano FM, Betancor N, Alvarez I, Bianchi NO, Chakraborty R. 2002. Unequal contributions of male and female gene pools from parental populations in the African descendants of the city of Melo, Uruguay. American Journal of Physical Anthropology; 18(1):33-44.

Sans M, Merriwether DA, Hidalgo PC, Bentancor N. 2006. Population structure and admixture in Cerro Largo, Uruguay, based on blood markers and mitochondrial DNA polymorphisms. American Journal of Human Biology; 524:513-524.

Sans M, Figueiro G, Ackermann E, Barreto I, Egaña a, Bertoni B, Poittevin-Glimet E, Maytia D, Hidalgo PC. 2011. Mitochondrial DNA in Basque descendants from the city of Trinidad, Uruguay: Uruguayan- or Basque-like population? Human Biology; an international record of research; 83(1):55-70.

Santos SE, Ribeiro-dos-Santos AK, Meyer D, Zago MA. 1996. Multiple founder haplotypes of mitochondrial DNA in Amerindians revealed by RFLP and sequencing. Annals of Human Genetics; 60:305-319.

Santos C, Montiel R, Sierra B, Bettencourt C, Fernandez E, Alvarez L, Lima M, Abade A, Aluja MP. 2005. Understanding differences between phylogenetic and pedigree-derived mtDNA mutation rate: a model using families from the Azores Islands (Portugal). Molecular Biology and Evolution; 22(6):1490-505.

Shinoda K-ichi, Adachi N, Guillen S, Shimada I. 2006. Mitochondrial DNA analysis of ancient peruvian highlanders. American Journal of Physical Anthropology; 131(1):98-107

Schmitt R, Bonatto SL, Freitas LB, Muschner V, Hill K, Hurtado AM, Salzano FM. 2004. Extremely limited mitochondrial DNA variability among the Aché Natives of Paraguay. Annals of Human Biology; 31(1):87-94.

Schwartz M, Vissing J. 2002. Paternal inheritance of mitochondrial DNA. New England Journal of Medicine; 347:576-80 
Silva WA, Bortolini MC, Schneider MPC, Marrero AR, Elion J, Krishnamoorthy R, Zago MA. 2006. MtDNA haplogroup analysis of black Brazilian and sub-Saharan populations: implications for the Atlantic slave trade. Human Biology; 78(1):29-41.

Soares P, Ermini L, Thomson N, Mormina M, Rito T, Röhl A, Salas A, Oppenheimer S, Macaulay V, Richards M. 2009. Correcting for purifying selection: an improved human mitochondrial molecular clock. Journal of Human Genetics; 84:740-759.

Steele J, Politis G. 2009. AMS 14C dating of early human occupation of southern South America. Journal of Archaeological Science; 36(2):419-29.

Stoneking M. 2000. Hypervariable sites in the mtDNA control region are mutational hotspots. American Journal of Human Genetics; 67:1029-32

Suárez R. 2011. Movilidad, acceso y uso de ágata traslucida por los cazadores-recolectores tempranos durante la transición Pleistoceno-Holoceno en el norte de Uruguay (ca. 11,000-8500 a.P.). Latin American Antiquity; 22(3):359-83.

Sutovsky P, Moreno RD, Ramalho-Santos J, Dominko T, Simerly C, Schatten G. 1999. Ubiquitin tag for sperm mitochondria. Nature; 402:371-72

Tercer Censo Nacional: Levantado el $1^{\circ}$ de junio de 1914. T2: Población. Buenos Aires, Argentina. Imprenta Rosso LJ. 1916-1917

Tamm E, Kivisild T, Reidla M, Smith DG, Metspalu M, Mulligan CJ, Bravi CM, Rickards O, Martinez-Labraga C, Khusnutdinova EK, Fedorova SA, Golubenko MV, Stepanov VA, Gubina MA, Zhadanov SI, Ossipova LP, Damba L, Voevoda MI, Dipierri JE, Villems R, Malhi R. 2007. Beringian standstill and spread of native American founders. PLoS One; 2(9):e829.

Tamura K, Nei M. 1993. Estimation of the number of nucleotide substitutions in the control region of mitochondrial DNA in humans and chimpanzees. Molecular Biology and Evolution; 10(3):512-26.

Tamura K, Dudley J, Nei M \& Kumar S (2007) MEGA4: Molecular Evolutionary Genetics Analysis (MEGA) software version 4.0. Molecular Biology and Evolution 24: 1596-1599.

Torres MM, Bravi CM, Bortolini MC, Duque C, Callegari-Jacques S, Ortiz D, Bedoya G, Groot de Restrepo H, Ruiz-Linares A. 2006. A revertant of the major founder Native American haplogroup $\mathrm{C}$ common in populations from northern South America. American Journal of Human Biology; 18(1):59-65.

Torroni A, Schurr TG, Cabell MF, Brown MD, Neel JV, Larsen M, Smith DG, Vullo CM, Wallace DC. 1993. Asian affinities and continental radiation of the four founding Native American mtDNAs. American Journal of Human Genetics; 53(3):563-90. 
Torroni A, Bandelt HJ, Macaulay V, Richards M, Cruciani F, Rengo C Martinez-Cabrera, Villems R, Kivisild T, Metspalu E, Parik J, Tolk HV, Tambets K, Forster P, Karger B, Francalacci P, Rudan P, Janicijevic B, Rickards O, Savontaus ML, Huoponen K, Laitinen V, Koivumäki S, Sykes B, Hickey E, Novelletto A, Moral P, Sellitto D, Coppa A, Al-Zaheri N, SantachiaraBenerecetti AS, Semino O, Scozzari R. 2001. A signal, from human mtDNA, of postglacial recolonization in Europe. American Journal of Human Genetics; 69(4):844-52.

Tully LA, Parsons TJ, Steighner RJ, Holland MM, Marino MA, Prenger VL. 2000. A sensitive denaturing gradient-gel electrophoresis assay reveals a high frequency of heteroplasmy in hypervariable region 1 of the human mtDNA control region. American Journal of Human Genetics 67:432-43

Umetsu K, Tanaka M, Yuasa I, Adachi N, Miyoshi A, Kashimura S, Sook Park K, Wei Y, Watanabe G, Osawa M. 2005. Multiplex amplified product-length polymorphism analysis of 36 mitochondrial single-nucleotide polymorphisms for haplogrouping of East Asian populations. Electrophoresis; 26:91-8.

Van Oven M, Kayser M. 2008. Updated comprehensive phylogenetic tree of global human mitochondrial DNA variation. Human Mutation; 386-394.

Vona G, Falchi A, Moral P, Calo CM, Varesi L. 2005. Mitochondrial sequence variation in the Guahibo Amerindian population from Venezuela. American Journal of Physical Anthropology; 369:361-9.

Ward RH, Salzano FM, Bonatto SL, Hutz MH, Coimbra CEA, Santos RV. 1996. Mitochondrial DNA polymorphism in three Brazilian Indian tribes. American Journal of Human Biology; 8: 317 323.

Williams SR, Chagnon NA, Spielman RS. 2002. Nuclear and mitochondrial genetic variation in the Yanomamo : a test case for ancient DNA studies of prehistoric populations. American Journal of Physical Anthropology; 259:246-59.

Wilson AS, Taylor T, Ceruti MC, Chavez JA, Reinhard J, Grimes V, Meier-Augenstein W, Cartmell L, Stern B, Richards MP, Worobey M, Barnes I, Gilbert TP. 2007. Stable isotope and DNA evidence for ritual sequences in Inca child sacrifice. Proceedings of the National Academy of Sciences of the United States of America; 104(42):16456-61.

Yang D, Oyaizu Y, Oyaizu H, Olsen GJ, Woese CR. 1985. Mitochondrial origins. Proceedings of the National Academy of Sciences of the United States of America; 82(13):4443-7.

Yang NN, Mazieres S, Bravi CM, Ray N, Wang S, Burley M-W, Bedoya G, Rojas W, Parra MV, Molina JA, Gallo C, Poletti G, Hill K, Hurtado AM, Petzl-Erler ML, Tsuneto LT, Klitz W, Barrantes R, Llop E, Rothhammer F, Labuda D, Salzano FM, Bortolini MC, Excoffier L, Dugoujon J-M, Ruiz-Linares A. 2010. Contrasting patterns of nuclear and mtDNA diversity in Native American populations. Annals of Human Genetics; 74(6):525-38. 
Yao Y-gang, Ogasawara Y, Kajigaya S, Molldrem JJ, Falcao RP, Pintao M, McCoy Jr JP, Rizzatti EG, Young NS. 2007. Mitochondrial DNA sequence variation in single cells from leukemia patients. Blood; 109(2):756-62. 


\section{ANEXOS}

\subsection{ANEXo MATERIAL Y MÉTODOS}

\subsubsection{ENCUESTA GENEALÓGICA}

El texto que se transcribe a continuación fue impreso en hoja tamaño oficio, lo cual permitió la inclusión de todo el documento en una sola carilla.

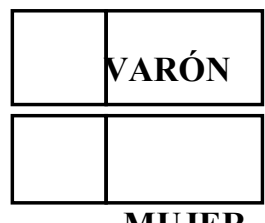

Muestra

$\mathrm{N}^{\circ}$

MUJER

DONANTE

Apellido y nombres (edad)

DONANTE Lugar de nacimiento (localidad o paraje / departamento / provincia / país)

1- PADRE Apellido y Nombres Lugar de nacimiento (localidad / departamento / provincia / país)

2- ABUElo PATERNO Apellido y Nombres Lugar de nacimiento (localidad / departamento / provincia / país)

3- ABUELA PATERNA Apellido y Nombres Lugar de nacimiento (localidad / departamento / provincia / país 
4- MADRE Apellido y Nombres Lugar de nacimiento (localidad / departamento / provincia / país)

5- ABUELO MATERNO Apellido y Nombres Lugar de nacimiento (localidad / departamento / provincia / país)

6- ABUELA MATERNA Apellido y Nombres Lugar de nacimiento (localidad / departamento / provincia / país)

Favor de preguntar al donante si sabe que alguno de sus padres/abuelos es/era descendiente de inmigrantes o perteneciente a alguna parcialidad socio-étnica (por ejemplo judío sefaradí, árabe, criollo, nativo, aborigen, etc.).

Cuando el donante desconoce el lugar de nacimiento de algún ancestro, favor de consignar el lugar de residencia habitual (e indicar en la encuesta con la leyenda +ive o vivía en") 


\title{
7.1.2 FORMULARIO DE CONSENTIMIENTO INFORMADO
}

El texto que se transcribe a continuación fue impreso en hoja tamaño oficio, lo cual permitió la inclusión de todo el documento en una sola carilla.

\section{Consentimiento Informado del Proyecto de Investigación}

"Aportes continentales diferenciales en la conformación de las poblaciones humanas

\author{
de América Latina"
}

Yo,

domicilio

DNI

$\mathrm{N}^{\circ}$ .con de la localidad de

calle. $\mathrm{N}^{\mathrm{o}}$ declaro que he sido informado sobre la

de la provincia de legal

en realización de un estudio genético para conocer el origen o procedencia de los antepasados de los habitantes actuales de América y averiguar qué proporción de ellos es originaria de este continente o bien llegó aquí desde Europa, Asia o África.

Manifiesto acceder voluntariamente a participar en este proyecto, del cual he sido informado a través de una entrevista con miembros del grupo de investigación (abajo firmantes), quienes me comunicaron ampliamente sobre las características y alcances del estudio y me entregaron una hoja de fnformación para el Participante" donde se detallan los objetivos, características genéticas a investigar, metodología, beneficios, riesgos y confidencialidad de los datos. Luego de leer esta hoja de información he podido realizar libremente cualquier pregunta relacionada con el proyecto.

Comprendo las características del trabajo y acepto libre y voluntariamente que me sea tomada una muestra de sangre o de saliva para ser utilizada en el presente estudio. Acepto además aportar datos sobre el origen o procedencia de mis padres, abuelos y bisabuelos para los fines indicados en la hoja de información. He comprendido que si lo deseo puedo retirarme de la investigación sin tener que dar explicaciones, como así también solicitar los datos obtenidos con mi muestra y reclamar la muestra sobrante del estudio.

La extracción de sangre o saliva (tachar lo que no corresponda) fue realizada por.

\section{Cargo}

DNI: 
La muestra es recibida por el investigador responsable quien la codifica y archiva el consentimiento informado en el Laboratorio de Bioantropología de la Universidad Nacional de Jujuy. La toma de la muestra y su codificación se realizó ante la presencia del/los testigos abajo firmantes.

Dado a los días del mes de. de $200 \ldots$

Firma del donante

Aclaración y DNI

Firma y cargo del entrevistador

Aclaración y DNI

Firma y cargo del extraccionista

Aclaración y DNI

Firma del testigo

Aclaración y DNI

\section{Investigadores Responsables: Dr. Claudio Bravi - Dra. Graciela Bailliet}

Instituto Multidisciplinario de Biología Celular (IMBICE), Calle 526 e/ 10 y 11, La Plata.

TeleFax: (0221) 421-0112 
- Etil-diamino-tetracético sal disódica (EDTA) 0,5M

Para 500ml

- $\quad 93,05$ grs de EDTA

- $\quad 480 \mathrm{ml}$ de $\mathrm{H} 2 \mathrm{O}$ destilada

- Llevar a pH 8 con $\mathrm{NaOH}$ (10grs aproximadamente)

- $\quad$ Completar con $\mathrm{H} 2 \mathrm{O}$ destilada hasta $500 \mathrm{ml}$

- $\quad$ Tris-Cloruro $1 \mathrm{M} \mathrm{pH} 8$ (Tris-Cl)

Para $500 \mathrm{ml}$
60,57grs de Tris
$400 \mathrm{ml}$ de $\mathrm{H} 2 \mathrm{O}$ destilada
Agregar $\mathrm{HCl}$ hasta alcanzar $\mathrm{pH}>7,8$
Completar con $\mathrm{H} 2 \mathrm{O}$ destilada hasta $500 \mathrm{ml}$

- $\quad$ Buffer Tris-Edta (TE)

Para $100 \mathrm{ml}$

$$
\begin{array}{ll}
\text { - } & 1 \mathrm{ml} \text { de Tris-Cl } 1 \mathrm{M} \\
\text { - } & 0,2 \mathrm{ml} \text { de EDTA } 0,5 \mathrm{M} \\
\text { - } & \text { Completar con } \mathrm{H} 2 \mathrm{O} \text { destilada hasta } 100 \mathrm{ml} \\
\text { - } \quad \text { Llevar a pH a } 8 \text { con } \mathrm{NaOH}
\end{array}
$$

- Buffer Tris-Borato-Edta (TBE)10x

Para $1000 \mathrm{ml}$

- $\quad$ 108grs de Tris

- $\quad 55$ grs de Acido Bórico

- $\quad 40 \mathrm{ml}$ de EDTA 0,5M pH8

- Completar con $\mathrm{H} 2 \mathrm{O}$ destilada hasta $1000 \mathrm{ml}$

- Acrilamida al 40\% (solución de stock)

Para $100 \mathrm{ml}$

$$
\begin{array}{ll}
\text { - } & \text { 38grs de Acrilamida } \\
\text { - } & \text { 2grs de Bisacrilamida } \\
\text { - } & \text { Completar con H2O destilada hasta } 100 \mathrm{ml}
\end{array}
$$

- Cloruro de Sodio (NaCl) 5,4M

Para $1000 \mathrm{ml}$

$$
\text { 315,57grs de } \mathrm{NaCl}
$$

Completar con $\mathrm{H} 2 \mathrm{O}$ destilada hasta $1000 \mathrm{ml}$

- Cloruro de Sodio $(\mathrm{NaCl}) 1 \mathrm{M}$ 
Para $1000 \mathrm{ml}$

- $\quad 58,44$ grs de $\mathrm{NaCl}$

- $\quad$ Completar con $\mathrm{H} 2 \mathrm{O}$ destilada hasta $1000 \mathrm{ml}$

- Detergente sodio duodecil sulfato (SDS) $20 \%$

Para 500ml

100grs de SDS

Completar con $\mathrm{H} 2 \mathrm{O}$ destilada hasta $500 \mathrm{ml}$

- Solución de lisis de glóbulos rojos (SLGR) 50x

Para $1000 \mathrm{ml}$

- $\quad 3,95$ grs de Bicarbonato de Amonio (NH4HCO3)

- $\quad 307,6$ grs de Cloruro de Amonio (NH4Cl)

Completar hasta $1000 \mathrm{ml}$ con $\mathrm{H} 2 \mathrm{O}$ destilada

En el campo, se lleva la solución a 1x mezclando 20ml de SLGR 50x en 980ml de H2O destilada.

- Solución de lisis de glóbulos blancos (SLGB)

Para $1000 \mathrm{ml}$

$100 \mathrm{ml}$ de Tris-Cl $1 \mathrm{M}$

$50 \mathrm{ml}$ de $\mathrm{NaCl} 1 \mathrm{M}$

$80 \mathrm{ml}$ de EDTA $0,5 \mathrm{M}$

0,5grs de Azida Sódica

$10 \mathrm{ml}$ de SDS al $20 \%$

Completar con $\mathrm{H} 2 \mathrm{O}$ destilada hasta $1000 \mathrm{ml}$ 


\subsection{Anexo Resultados}

7.2.1 LISTA DE MUESTRAS POR LOCALIDAD, INDICANDO EL HAPLOGRUPO, EL MÉTODO DE ASIGNACIÓN Y EL LUGAR DE NACIMIENTO DEL ÚLTIMO ANCESTRO MATERNO CONOCIDO.

\begin{tabular}{|c|c|c|c|c|c|}
\hline Rótulo & $\mathrm{Hg}$ & Método & RFLP info & UACM & Lugar de nacimiento \\
\hline \multicolumn{6}{|l|}{ BELEN } \\
\hline Be 001 & B2 & Sec. & & $A B U$ & ARG CAT BEL, Condorhuasi \\
\hline $\mathrm{Be} 002$ & B & AFLP & & $\mathrm{ABU}$ & ARG LRJ GBE, Olta \\
\hline Be 003 & B2 & Sec. & & $A B U$ & ARG CAT BEL, Puerta del Corral Quemado \\
\hline Be 004 & D1 & Sec. & & $A B U$ & ARG CAT BEL, La Toma (=ca. Pozo de Piedra) \\
\hline Be 005 & B2 & Sec. & & $A B U$ & ARG CAT ANT, Antofagasta de la Sa. \\
\hline Be 006 & $\mathrm{D}$ & AFLP & & $\mathrm{ABU}$ & ARG CAT BEL, Belén \\
\hline Be 007 & L1c1d & Sec. & & $\mathrm{ABU}$ & ARG CAT BEL, Hualfín \\
\hline Be 008 & $\mathrm{~A} 2$ & Sec. & & $A B U$ & ARG CAT BEL, Laguna Blanca \\
\hline Be 009 & B2 & Sec. & & $A B U$ & CHI? \\
\hline Be 010 & B & AFLP & & $A B U$ & ARG CAT BEL, Belén? \\
\hline Be 011 & D1 & Sec. & & $A B U$ & ARG CAT BEL, La Ciénaga \\
\hline Be 012 & B2 & Sec. & & $A B U$ & ARG CAT BEL, Azampay \\
\hline Be 013 & L3e1 & Sec. & & $A B U$ & ARG CAT BEL, Belén \\
\hline Be 014 & B & AFLP & & $A B U$ & ARG CAT BEL, Belén \\
\hline Be 015 & D & AFLP & & $A B U$ & ARG CAT BEL, Belén \\
\hline Be 016 & $\mathrm{~A} 2$ & Sec. & & $\mathrm{ABU}$ & ARG CAT BEL, Belén \\
\hline Be 017 & B2 & Sec. & & $A B U$ & ARG CAT BEL, Hualfín \\
\hline Be 018 & A & AFLP & & $A B U$ & ARG MZA LAV, Lavalle \\
\hline Be 019 & $\mathrm{~B}$ & AFLP & & $A B U$ & ARG CAT BEL, Belén \\
\hline Be 020 & B2 & Sec. & & $A B U$ & ARG CAT BEL, El Tolar (N.de Belén) \\
\hline Be 021 & D1 & Sec. & & $\mathrm{ABU}$ & ARG CAT BEL, Villa Vil \\
\hline Be 022 & D & AFLP & & $A B U$ & ARG CAT BEL, Belén \\
\hline Be 023 & D & AFLP & & $A B U$ & ARG CAT BEL, Belén \\
\hline Be 024 & B & AFLP & & $A B U$ & ARG CAT BEL, Belén \\
\hline Be 025 & $\mathrm{D}$ & AFLP & & $\mathrm{ABU}$ & ARG CAT BEL, Durán (será El Durazno?) \\
\hline Be 026 & C1b & Sec. & & $\mathrm{ABU}$ & ARG CAT AND, Andalgalá \\
\hline Be 027 & $\mathrm{~N}$ & AFLP & & $A B U$ & ARG BUE Bs As o ARG TUC Tafí Viejo? \\
\hline Be 028 & $\mathrm{~L}$ & Sec. & & $A B U$ & ITA Sicilia \\
\hline Be 029 & A & AFLP & & $A B U$ & ARG CAT BEL, Belén \\
\hline Be 030 & B2 & Sec. & & $\mathrm{ABU}$ & ARG CAT BEL, Puerta de Corral Quemado \\
\hline Be 031 & B2 & Sec. & & $A B U$ & ARG CAT SMA, Santa María \\
\hline Be 032 & C1c & Sec. & Alul 13262+ & $A B U$ & ARG CAT BEL, El Durazno (Norte Grande) \\
\hline Be 033 & A2 & Sec. & & $A B U$ & ARG CAT BEL, Piedra Larga (Norte Chico) \\
\hline Be 034 & $\mathrm{~L}$ & Sec. & & MA & ARG CAT BEL, Belén \\
\hline Be 035 & D1 & Sec. & & S/D & S/D \\
\hline Be 036 & C1b & Sec. & & $A B U$ & ARG CAT BEL, Jacipunco \\
\hline Be 037 & D1 & Sec. & & $A B U$ & ARG CAT BEL, algún lugar del "Norte" \\
\hline Be 038 & B2 & Sec. & & $A B U$ & ARG CAT BEL, Belén \\
\hline Be 039 & B2 & Sec. & & $\mathrm{ABU}$ & ARG CAT BEL, Belén \\
\hline Be 040 & B2 & Sec. & & $A B U$ & ARG CAT BEL, Belén \\
\hline Be 041 & B2 & Sec. & & $A B U$ & ARG CAT TIN, Tatón \\
\hline Be 042 & $\mathrm{D}$ & AFLP & & $A B U$ & ARG TUC \\
\hline Be 043 & B2 & Sec. & & $\mathrm{ABU}$ & ARG CAT BEL, Pozo de Piedra \\
\hline Be 044 & D1 & Sec. & & $A B U$ & ARG CAT BEL, Pozo de Piedra \\
\hline Be 045 & B2 & Sec. & & $A B U$ & ARG CAT BEL, Belén, $B^{\circ}$ La Puntilla \\
\hline Be 046 & C & AFLP & & $A B U$ & ARG CAT BEL, Londres \\
\hline Be 047 & B & AFLP & & MA & ARG CAT BEL, Hualfín \\
\hline Be 048 & D1 & Sec. & & $A B U$ & ARG CAT BEL, Los Morteritos \\
\hline Be 049 & $\mathrm{C}$ & AFLP & & $A B U$ & ARG CAT BEL, Belén \\
\hline Be 050 & B2 & Sec. & & $A B U$ & ARG CAT BEL, Villa Vil \\
\hline Be 051 & B & AFLP & & $A B U$ & BOL \\
\hline Be 052 & B2 & Sec. & & MA & ARG CAT BEL, Corral Quemado Cajón \\
\hline Be 053 & $\mathrm{C}$ & AFLP & & $\mathrm{ABU}$ & ARG CAT BEL, Belén \\
\hline Be 054 & B2 & Sec. & & $A B U$ & ARG CAT BEL, Jacipunco \\
\hline Be 055 & B2 & Sec. & & $A B U$ & ARG CAT BEL, Puerta de San José \\
\hline Be 056 & $\mathrm{~B}$ & AFLP & & MA & ARG CAT BEL, Belén \\
\hline Be 057 & A & AFLP & & MA & ARG CAT CAP, SFdV \\
\hline
\end{tabular}


Anexo

\begin{tabular}{|c|c|c|c|c|c|}
\hline Rótulo & $\mathrm{Hg}$ & Método & RFLP info & UACM & Lugar de nacimiento \\
\hline Be 058 & $\mathrm{~B}$ & AFLP & & $\mathrm{ABU}$ & ARG CAT BEL, Villa Vil \\
\hline Be 059 & B2 & Sec. & & $A B U$ & ARG CAT BEL, Ampujaco \\
\hline Be 060 & A2 & Sec. & & $A B U$ & ARG CAT BEL, Belén \\
\hline Be 061 & $\mathrm{D}$ & AFLP & & $A B U$ & ARG CAT BEL, Belén \\
\hline Be 062 & $\mathrm{C}$ & AFLP & & MA & ARG CAT BEL, Belén \\
\hline Be 063 & B2 & Sec. & & MA & ARG CAT BEL, Corral Quemado \\
\hline Be 064 & B2 & Sec. & & $A B U$ & ARG CAT AND, Andalgalá \\
\hline Be 065 & C & AFLP & & $A B U$ & ARG SAL? \\
\hline Be 066 & B2 & Sec. & & $A B U$ & ARG CAT BEL, Norte Chico \\
\hline Be 067 & $\mathrm{C} 1 \mathrm{~b}$ & Sec. & & $A B U$ & ARG CAT BEL, Belén \\
\hline Be 068 & B & AFLP & & $A B U$ & ARG SAL GSM, Embarcación \\
\hline Be 069 & B & AFLP & & $A B U$ & ARG CHB ESC, C. Rivadavia \\
\hline Be 070 & B2 & Sec. & & $A B U$ & ARG CAT BEL, Culampajá \\
\hline Be 071 & C & AFLP & & $A B U$ & BOL \\
\hline Be 072 & C & AFLP & & $A B U$ & ARG CAT BEL, Belén \\
\hline Be 073 & $B$ & AFLP & & $A B U$ & ARG CAT SMA, Santa María \\
\hline Be 074 & B2 & Sec. & & $A B U$ & ARG CAT BEL, Norte Chico \\
\hline Be 075 & $\mathrm{~N}$ & AFLP & & $A B U$ & ITA \\
\hline Be 076 & $\mathrm{D}$ & AFLP & & $A B U$ & ARG CAT BEL, Belén \\
\hline Be 077 & D1 & Sec. & & $A B U$ & ARG CAT BEL, Belén \\
\hline Be 078 & $\mathrm{C} 1 \mathrm{c}$ & Sec. & Alul 13262+ & $A B U$ & ARG CAT BEL, Azampay \\
\hline Be 079 & $\mathrm{C} 1 \mathrm{~b}$ & Sec. & & $A B U$ & ARG CAT BEL, Las Barrancas ( $\mathrm{N}$ chico) \\
\hline Be 080 & $\mathrm{C}$ & AFLP & & $A B U$ & ARG CAT BEL, Belén \\
\hline Be 081 & $\mathrm{D}$ & AFLP & & $A B U$ & ARG CAT SMA, Santa María \\
\hline Be 082 & C & AFLP & & $A B U$ & ARG CAT BEL, Belén \\
\hline Be 083 & B2 & Sec. & & $A B U$ & ARG CAT BEL, El Tolar \\
\hline Be 084 & B2 & Sec. & & $A B U$ & ARG CAT BEL, La Estancia (hacia Andalgalá) \\
\hline Be 085 & $\mathrm{C} 1 \mathrm{~b}$ & Sec. & & $A B U$ & ARG CAT BEL, Puerta del Corral Quemado \\
\hline Be 086 & B & AFLP & & MA & ARG CAT BEL, Puerta de Corral Quemado \\
\hline Be 087 & A2 & Sec. & & $A B U$ & ARG CAT BEL, Belén \\
\hline Be 088 & $\mathrm{C} 1 \mathrm{c}$ & Sec. & Alul $13262+$ & $A B U$ & ARG CAT BEL, El Durazno \\
\hline Be 089 & A & AFLP & & $A B U$ & ARG CAT BEL, Londres \\
\hline Be 090 & D1 & Sec. & & $A B U$ & ARG CAT BEL, Hualfín Los Nacimientos \\
\hline Be 091 & $\mathrm{C} 1 \mathrm{c}$ & Sec. & Alul $13262+$ & $A B U$ & ARG CAT BEL, Condorhuasi \\
\hline Be 092 & D1 & Sec. & & $A B U$ & ARG CAT BEL, Norte Grande \\
\hline Be 093 & $\mathrm{~L}$ & Sec. & & ABU & ARG CAT BEL, Belén \\
\hline Be 094 & $\mathrm{~A} 2$ & Sec. & & $A B U$ & ARG CAT TIN, Tinogasta / hija de chilenos \\
\hline Be 095 & D1 & Sec. & & $A B U$ & ARG CAT BEL, Belén \\
\hline Be 096 & C & AFLP & & $A B U$ & ARG CAT BEL, Belén \\
\hline Be 097 & $\mathrm{C} 1 \mathrm{~b}$ & Sec. & & $A B U$ & ARG CAT BEL, Ampujaco \\
\hline Be 098 & C & AFLP & & $A B U$ & ARG CAT BEL, Belén \\
\hline Be 099 & A & AFLP & & $A B U$ & ARG CAT BEL, Londres \\
\hline Be 100 & B2 & Sec. & & $A B U$ & ARG CAT BEL, Cóndorhuasi \\
\hline Be 101 & $\mathrm{D}$ & AFLP & & $A B U$ & ARG CAT BEL, Belén \\
\hline Be 102 & $\mathrm{D}$ & AFLP & & $A B U$ & ARG CAT BEL, Belén \\
\hline Be 103 & $\mathrm{C} 1 \mathrm{~b}$ & Sec. & & $A B U$ & ARG CAT BEL, Corral Quemado \\
\hline Be 104 & C & AFLP & & $A B U$ & ARG CAT BEL, Belén (viven en) \\
\hline Be 105 & $\mathrm{~N}$ & AFLP & & $A B U$ & ARG CAT BEL, Belén \\
\hline Be 106 & A & AFLP & & $A B U$ & ARG CAT BEL, Belén \\
\hline Be 107 & B & AFLP & & $A B U$ & ARG CAT BEL, Belén \\
\hline BeLo 01 & A & AFLP & & $A B U$ & ARG CAT BEL, Londres \\
\hline BeLo 02 & c & AFLP & & $A B U$ & ARG CAT TIN, Tinogasta \\
\hline BeLo 03 & $\mathrm{D}$ & AFLP & & $A B U$ & ARG TUC RIO, Santa Ana \\
\hline BeLo 04 & $\mathrm{~B}$ & AFLP & & ABU & ARG CAT BEL, La Ciénaga (N. Chico) \\
\hline BeLo 05 & $\mathrm{~N}$ & AFLP & & ABU & ARG CAT BEL, Londres \\
\hline BeLo 06 & $B$ & AFLP & & $A B U$ & ARG CAT BEL, Corral Quemado \\
\hline BeLo 07 & $\mathrm{D}$ & AFLP & & $S / D$ & S/D \\
\hline BeLo 08 & C & AFLP & & $A B U$ & ARG CAT BEL, Belén \\
\hline BeLo 09 & D & AFLP & & $A B U$ & ARG CAT BEL, Londres \\
\hline BeLo 10 & D & AFLP & & $A B U$ & ARG CAT BEL, Belén \\
\hline BeLo 11 & B & AFLP & & $A B U$ & ARG CAT BEL, Belén \\
\hline BeLo 12 & B & AFLP & & MA & ARG CAT BEL, Londres \\
\hline BeLo 13 & B & AFLP & & $A B U$ & ARG CAT BEL, Belén \\
\hline BeLo 14 & C & AFLP & & DO & ARG CAT BEL, Belén \\
\hline BeLo 15 & B & AFLP & & ABU & ARG CAT BEL, Londres \\
\hline BeLo 16 & B & AFLP & & DO & ARG CAT BEL, Belén \\
\hline BeLo 17 & A & AFLP & & MA & ARG CAT BEL, La Aguada \\
\hline BeLo 18 & C & AFLP & & DO & ARG CAT BEL, Londres \\
\hline BeLo 19 & B & AFLP & & $A B U$ & ARG CAT BEL, Londres? \\
\hline
\end{tabular}


Anexo

\begin{tabular}{|c|c|c|c|c|c|}
\hline Rótulo & $\mathrm{Hg}$ & Método & RFLP info & UACM & Lugar de nacimiento \\
\hline BeLo 20 & $\mathrm{~A}$ & AFLP & & MA & ARG CAT BEL, Belén \\
\hline BeLo 21 & A & AFLP & & MA & ARG CAT BEL, Londres? \\
\hline BeLo 22 & C & AFLP & & MA & ARG LRJ CAP, La Rioja ciudad \\
\hline BeLo 23 & $\mathrm{C}$ & AFLP & & $A B U$ & ARG CAT BEL, Londres \\
\hline BeLo 24 & $\mathrm{C}$ & AFLP & & DO & ARG CAT BEL, Belén \\
\hline BeLo 25 & $\mathrm{~L}$ & Sec. & & MA & ARG CAT BEL, Londres \\
\hline BeLo 26 & A & AFLP & & $A B U$ & ARG CAT BEL, Londres \\
\hline BeLo 27 & $\mathrm{~N}$ & AFLP & & $A B U$ & ARG CAT BEL, Londres \\
\hline BeLo 28 & $B$ & AFLP & & MA & ARG CAT BEL, Londres \\
\hline BeLo 29 & $\mathrm{D}$ & AFLP & & ABU & ARG CAT BEL, Londres \\
\hline BeLo 30 & $\mathrm{D}$ & AFLP & & $A B U$ & ARG CAT BEL, Londres \\
\hline BeLo 31 & C1c & Sec. & Alul 13262+ & $A B U$ & ARG CAT BEL, Laguna Blanca \\
\hline BeLo 32 & B & AFLP & & $A B U$ & ARG TUC CAP, SMdTucumán \\
\hline BeLo 33 & A & AFLP & & $A B U$ & ARG CAT BEL, Norte de Belén \\
\hline BeLo 34 & C & AFLP & & $A B U$ & ARG CAT TIN, Tinogasta \\
\hline BeP 001 & B & AFLP & & $A B U$ & ARG CAT BEL, Villa Vil \\
\hline BeP 002 & C & AFLP & & $A B U$ & ARG CAT BEL, Belén \\
\hline BeP 003 & C1b & Sec. & & $A B U$ & ARG CAT BEL, Corral Quemado \\
\hline BeP 004 & $\mathrm{~B}$ & AFLP & & $A B U$ & ARG CAT TIN, Fiambalá \\
\hline BeP 005 & $\mathrm{C}$ & AFLP & & $A B U$ & ARG CAT BEL, Belén \\
\hline BeP 006 & $\mathrm{~B}$ & AFLP & & $A B U$ & ARG CAT BEL, Belén \\
\hline BeP 007 & $\mathrm{D}$ & AFLP & & $A B U$ & ARG CAT BEL, Belén \\
\hline BeP 008 & $\mathrm{~A} 2$ & Sec. & & $A B U$ & ARG CAT TIN, EI Salado \\
\hline BeP 009 & $\mathrm{~A}$ & AFLP & & $A B U$ & ARG CAT BEL, Londres \\
\hline BeP 010 & $\mathrm{D}$ & AFLP & & $A B U$ & ARG CAT BEL, Belén \\
\hline BeP 011 & C & AFLP & & $A B U$ & ARG CAT BEL, Londres \\
\hline BeP 012 & $\mathrm{~N}$ & AFLP & & $A B U$ & ARG ERI VGY, Villaguay \\
\hline BeP 013 & B2 & Sec. & & $A B U$ & ARG CAT BEL, Corral Quemado \\
\hline BeP 014 & C & AFLP & & $A B U$ & ARG CAT BEL, Las Juntas (N. Chico) \\
\hline BeP 015 & $\mathrm{D}$ & AFLP & & $A B U$ & ARG CAT BEL, Londres \\
\hline BeP 016 & $\mathrm{D}$ & AFLP & & $A B U$ & ARG CAT BEL, Hualfín \\
\hline BeP 017 & D & AFLP & & $A B U$ & ARG CAT SFVdeCat \\
\hline BeP 018 & D & AFLP & & $A B U$ & ARG CAT AND, Andalgalá \\
\hline BeP 019 & B & AFLP & & $A B U$ & ARG CAT BEL, Villa Vil, Rodeo Gerbán \\
\hline BeP 020 & $\mathrm{~A} 2$ & Sec. & & $A B U$ & ARG CAT BEL, Hualfín \\
\hline \multicolumn{6}{|c|}{ CALINGASTA } \\
\hline CAL 01 & $\mathrm{~B} 2$ & Sec. & & $A B U$ & ARG SNJ CAL, Calingasta \\
\hline CAL 02 & $\mathrm{C} 1 \mathrm{~b}$ & Sec. & & $A B U$ & CHILE V, Valparaíso \\
\hline CAL 03 & D1 & Sec. & & MA & CHILE VIII, Concepción \\
\hline CAL 04 & $\mathrm{H}$ & Sec. & & $A B U$ & España \\
\hline CAL 05 & C1b & Sec. & & $A B U$ & ARG SNJ CAL, Calingasta \\
\hline CAL 06 & C1b & Sec. & & MA & ARG SNJ CAP, San Juan \\
\hline CAL 07 & $\mathrm{~A} 2$ & Sec. & & MA & CHILE IV, Andacollo \\
\hline CAL 08 & D1 & Sec. & & MA & ARG SNJ CAP, San Juan \\
\hline CAL 09 & D1 & Sec. & & ABU & ARG SNJ JAC, Jáchal_padres de CHI? \\
\hline CAL 10 & D1 & Sec. & & MA & ARG SNJ CAP, San Juan \\
\hline CAL 11 & B2 & Sec. & & $A B U$ & ARG SNJ CAL, Villa Corral \\
\hline CAL 12 & $\mathrm{~A} 2$ & Sec. & & $A B U$ & $\mathrm{CHI}$ \\
\hline CAL 13 & D1 & Sec. & & $A B U$ & ARG SNJ JAC, Jáchal \\
\hline CAL 14 & $\mathrm{C} 1 \mathrm{~b}$ & Sec. & & MA & ARG SNJ CAL, Calingasta \\
\hline CAL 15 & D1 & Sec. & & $A B U$ & $\mathrm{CHI}$ \\
\hline CAL 16 & B2 & Sec. & & $A B U$ & $\mathrm{CHI}$ \\
\hline CAL 17 & C1b & Sec. & & $A B U$ & ARG SNJ CAL, Calingasta \\
\hline CAL 18 & B2 & Sec. & & $A B U$ & ARG SNJ CAL, Calingasta \\
\hline CAL 19 & D1 & Sec. & & $A B U$ & CHILE IV, Andacollo \\
\hline CAL 20 & C1b & Sec. & & $A B U$ & ARG SNJ CAL, Calingasta \\
\hline CAL 21 & D1 & Sec. & & $A B U$ & ARG SNJ CAL, Barreal_madre CHI \\
\hline CAL 22 & D1 & Sec. & & $A B U$ & ARG SNJ_huarpe \\
\hline CAL 23 & $\mathrm{~A} 2$ & Sec. & & $A B U$ & ARG LRJ RVP, Mascasín \\
\hline CAL 24 & U6a & Sec. & & $A B U$ & ARG LRJ \\
\hline CAL 25 & C1b & Sec. & & $A B U$ & ARG SNJ CAL \\
\hline CAL 26 & $\mathrm{C} 1 \mathrm{~b}$ & Sec. & & $A B U$ & $\mathrm{CHI}$ \\
\hline CAL 27 & D1 & Sec. & & $A B U$ & ARG SNJ JAC, Jáchal \\
\hline CAL 28 & D1 & Sec. & & $A B U$ & $\mathrm{CHI}$ \\
\hline CAL 29 & D4h3 & Sec. & & $A B U$ & ARG SNJ CAL, Puchuzún \\
\hline CAL 30 & D1 & Sec. & & $A B U$ & CHILE IV, Carén \\
\hline CAL 31 & $\mathrm{~A} 2$ & Sec. & & MA & ARG SNJ CAL, Calingasta \\
\hline CAL 32 & $\mathrm{C} 1 \mathrm{~b}$ & Sec. & & $A B U$ & ARG SNJ CAL, Calingasta \\
\hline
\end{tabular}


Anexo

\begin{tabular}{|c|c|c|c|c|c|}
\hline Rótulo & $\mathrm{Hg}$ & Método & RFLP info & UACM & Lugar de nacimiento \\
\hline CAL 33 & $\mathrm{C} 1 \mathrm{~b}$ & Sec. & & $A B U$ & ARG SNJ CAL, Puchuzún_abu Campillay \\
\hline CAL 34 & $\mathrm{D} 1$ & Sec. & & $A B U$ & ARG SNJ CAL, Barreal \\
\hline CAL 35 & C1b & Sec. & & $A B U$ & ARG SNJ CAL \\
\hline CAL 36 & A2 & Sec. & & $A B U$ & ARG SNJ VFE, Sierras de Elizondo \\
\hline CAL 37 & C1b & Sec. & & $A B U$ & ARG SNJ CAL, Tamberías \\
\hline CAL 38 & C4c & Sec. & & MA & ARG SNJ CAP, San Juan \\
\hline CAL 39 & C1b & Sec. & & $A B U$ & ARG SNJ CAL, Tamberías abu Campillay \\
\hline CAL 40 & C1d & Sec. & & MA & CHILE IV, Ovalle \\
\hline CAL 41 & C1b & Sec. & & $A B U$ & $\mathrm{CHI}$ \\
\hline CAL 42 & B2 & Sec. & & $A B U$ & ARG SNJ JAC, Jáchal \\
\hline CAL 43 & $\mathrm{C} 1 \mathrm{~b}$ & Sec. & & $A B U$ & ARG SNJ CAL, Calingasta \\
\hline CAL 44 & C1d & Sec. & & $A B U$ & ARG SNJ CAL, Calingasta_abu Campillay \\
\hline CAL 45 & B2 & Sec. & & MA & $\mathrm{CHI}$ \\
\hline CAL 46 & L3d3 & Sec. & & $A B U$ & $\mathrm{CHI}$ \\
\hline CAL 47 & B2 & Sec. & & $A B U$ & $\mathrm{CHI}$ \\
\hline CAL 48 & C1d & Sec. & & MA & ARG SNJ CAL, Calingasta \\
\hline CAL 49 & $\mathrm{~A} 2$ & Sec. & & $A B U$ & $\mathrm{CHI}$ \\
\hline CAL 50 & D1 & Sec. & & $A B U$ & $\mathrm{CHI}$ \\
\hline CAL 51 & B2 & Sec. & & $A B U$ & ARG SNJ JAC, Huaco_abu Aballay \\
\hline CAL 52 & C1d & Sec. & & $A B U$ & ARG SNJ CAL, Calingasta \\
\hline CAL 53 & B2 & Sec. & & $A B U$ & $\mathrm{CHI}$ \\
\hline CAL 54 & D1 & Sec. & & $A B U$ & ARG SNJ CAL, Calingasta \\
\hline CAL 55 & A2 & Sec. & & $A B U$ & ARG SNJ ANG, Angaco \\
\hline CAL 56 & B2 & Sec. & & $A B U$ & $\mathrm{CHI}$ \\
\hline CAL 57 & A2 & Sec. & & $A B U$ & CHILE IV, Andacollo \\
\hline CAL 58 & B2 & Sec. & & $A B U$ & CHILE IV, La Serena? \\
\hline CAL 59 & C1b & Sec. & & $A B U$ & ARG SNJ CAL, Calingasta \\
\hline CAL 60 & $\mathrm{C} 1 \mathrm{~b}$ & Sec. & & $A B U$ & $\mathrm{CHI}$ \\
\hline CAL Sal 01 & LOa & Sec. & & $A B U$ & ARG SNJ \\
\hline CAL Sal 02 & $\mathrm{C} 1 \mathrm{~b}$ & Sec. & & $A B U$ & ARG SNJ CAL, Calingasta \\
\hline CAL Sal 03 & $\mathrm{C} 1 \mathrm{~b}$ & Sec. & & $A B U$ & ARG SNJ CAL, Calingasta \\
\hline CAL Sal 04 & $\mathrm{C} 1 \mathrm{~b}$ & Sec. & & $A B U$ & ARG SNJ CAL, Calingasta \\
\hline CAL Sal 05 & B2 & Sec. & & $A B U$ & ARG SNJ CAL, Calingasta \\
\hline CAL Sal 06 & B2 & Sec. & & $A B U$ & CHILE IV, Ovalle \\
\hline CAL Sal 07 & $\mathrm{C} 1 \mathrm{~b}$ & Sec. & & DO & ARG SNJ CAP, San Juan \\
\hline CAL Sal 08 & C1b & Sec. & & MA & ARG SNJ CAP, San Juan \\
\hline CAL Sal 09 & B2 & Sec. & & DO & ARG SNJ CAL, Barreal \\
\hline CAL Sal 10 & $\mathrm{C} 1 \mathrm{~b}$ & Sec. & & $A B U$ & $\mathrm{CHI}$ \\
\hline CAL Sal 11 & L3e1d & Sec. & & $A B U$ & ARG SNJ CAL, Barreal \\
\hline \multicolumn{6}{|l|}{ CHEPES } \\
\hline CHE 01 & $\mathrm{C} 1 \mathrm{~b}$ & Sec. & & $A B U$ & ARG CBA \\
\hline CHE 02 & C1b & Sec. & & $A B U$ & ARG LRJ RVP, Chepes \\
\hline CHE 03 & D1 & Sec. & & $A B U$ & ARG LRJ GSM, Ulapes \\
\hline CHE 04 & $\mathrm{C}$ & AFLP & & $A B U$ & ARG SNL? \\
\hline CHE 05 & C1b & Sec. & & $A B U$ & ARG LRJ RVP, Chepes \\
\hline CHE 06 & $\mathrm{Nx}(\mathrm{A}, \mathrm{B})$ & AFLP & & $A B U$ & ARG BS AS \\
\hline CHE 07 & D1 & Sec. & & $A B U$ & ARG LRJ RVP, Chelcos \\
\hline CHE 08 & D1 & Sec. & & $A B U$ & ARG SNJ, Caucete (o de la zona) \\
\hline CHE 09 & A2 & Sec. & & $A B U$ & ARG LRJ RVP, Ea. San Antonio (cerca de Chepes) \\
\hline CHE 10 & C1b & Sec. & & $A B U$ & ARG CBA, Chancaní \\
\hline CHE 11 & $\mathrm{H}$ & Sec. & & $A B U$ & ARG LRJ RVP, Chepes \\
\hline CHE 12 & $\mathrm{~A} 2$ & Sec. & & $A B U$ & ARG LRJ RVP, El Totoral ( o de la zona) \\
\hline CHE 13 & C1b & Sec. & & $A B U$ & ARG LRJ RVP, Chepes \\
\hline CHE 14 & $\mathrm{H}$ & Sec. & & $A B U$ & ARG LRJ GSM, Ulapes \\
\hline CHE 15 & B2 & Sec. & & $A B U$ & ARG CBA (cerca de Dean Funes) \\
\hline CHE 17 & D1 & Sec. & & $A B U$ & ARG LRJ RVP, La Aguada \\
\hline CHE 18 & C1b & Sec. & & ABU & ARG LRJ RVP, Sierra de los Argañaraz \\
\hline CHE 19 & A2 & Sec. & & $A B U$ & ARG LRJ RVP, La Calera \\
\hline CHE 20 & A & AFLP & & DO & ARG LRJ RVP, Agua de Aguirre \\
\hline CHE 21 & D1 & Sec. & & $A B U$ & ARG LRJ RVP, San Isidro \\
\hline CHE 22 & $\mathrm{C} 1 \mathrm{~b}$ & Sec. & & ABU & AEG SNJ, Caucete \\
\hline CHE 23 & A2 & Sec. & & $A B U$ & ARG LRJ RVP, Chepes \\
\hline CHE 24 & W1c & Sec. & & $A B U$ & ARG LRJ RVP, Chepes \\
\hline CHE 25 & $\mathrm{Nx}(\mathrm{A}, \mathrm{B})$ & AFLP & & ABU & ARG BS AS \\
\hline CHE 26 & B2 & Sec. & & $A B U$ & ARG LRJ RVP, Chepes (o en el campo) \\
\hline CHE 27 & A & AFLP & & $A B U$ & ARG SNJ, San Juan capital \\
\hline CHE 28 & D1 & Sec. & & $A B U$ & ARG LRJ RVP, Chepes \\
\hline CHE 29 & D1 & Sec. & & ABU & ARG LRJ RVP, Jarilla \\
\hline
\end{tabular}


Anexo

\begin{tabular}{|c|c|c|c|c|c|}
\hline Rótulo & $\mathrm{Hg}$ & Método & RFLP info & UACM & Lugar de nacimiento \\
\hline CHE 30 & C & AFLP & & MA & ARG CBA, Chancaní \\
\hline CHE 31 & $\mathrm{C} 1 \mathrm{~b}$ & Sec. & & $A B U$ & ARG SNJ, Valle Fértil \\
\hline CHE 32 & C & AFLP & & MA & ARG LRJ RVP, Las Toscas \\
\hline CHE 33 & $\mathrm{C} 1 \mathrm{~b}$ & Sec. & & $A B U$ & ARG LRJ RVP, Jarilla \\
\hline CHE 34 & $\mathrm{H}$ & Sec. & & $A B U$ & ARG LRJ GOO, Milagro \\
\hline CHE 35 & $\mathrm{~A} 2$ & Sec. & & $A B U$ & ARG LRJ \\
\hline CHE 36 & $\mathrm{C}$ & AFLP & & MA & ARG LRJ RVP, Chepes \\
\hline CHE 37 & $\mathrm{~A} 2$ & Sec. & & $\mathrm{ABU}$ & ARG LRJ RVP, Villa Casana \\
\hline CHE 38 & $\mathrm{D}$ & AFLP & & $A B U$ & ARG SNJ \\
\hline CHE 39 & $\mathrm{~A} 2$ & Sec. & & $A B U$ & ARG LRJ GSM, Ulapes? \\
\hline CHE 40 & $\mathrm{~A} 2$ & Sec. & & $A B U$ & ARG LRJ, La Rioja capital \\
\hline CHE 41 & $\mathrm{D}$ & AFLP & & $A B U$ & ARG SNJ \\
\hline CHE 42 & D1 & Sec. & & $A B U$ & ARG LRJ RVP, Chepes \\
\hline CHE 43 & $\mathrm{~A} 2$ & Sec. & & $A B U$ & ARG LRJ RVP \\
\hline CHE 44 & $\mathrm{C} 4 \mathrm{c}$ & Sec. & & $A B U$ & ARG LRJ GSM, Pozo Piedra \\
\hline CHE 45 & $\mathrm{C} 1 \mathrm{~b}$ & Sec. & & $A B U$ & ARG LRJ RVP, Chepes \\
\hline CHE 46 & D1 & Sec. & & $A B U$ & ARG CBA, San José de las Salinas \\
\hline CHE 47 & A & AFLP & & $A B U$ & ARG SNJ \\
\hline CHE 48 & $\mathrm{C} 4 \mathrm{c}$ & Sec. & & $A B U$ & ARG LRJ RVP, Chepes \\
\hline CHE 49 & $\mathrm{C}$ & AFLP & & $A B U$ & ARG SNJ, Jáchal \\
\hline CHE 50 & $\mathrm{C} 1 \mathrm{~b}$ & Sec. & & $A B U$ & ARG LRJ RVP, Chepes \\
\hline CHE 51 & $\mathrm{~B}$ & AFLP & & $A B U$ & ARG LRJ RVP, La Pintada \\
\hline CHE 52 & D1 & Sec. & & $A B U$ & ARG LRJ JFQ, Nacate \\
\hline CHE 53 & C1b & Sec. & & $A B U$ & ARG LRJ GSM, Corral de Isaac \\
\hline CHE 54 & $\mathrm{H}$ & Sec. & & $A B U$ & ARG LRJ RVP, Chepes \\
\hline CHE 55 & $A$ & AFLP & & MA & ARG LRJ RVP, Chepes \\
\hline CHE 56 & A & AFLP & & $A B U$ & ARG SNJ \\
\hline CHE 57 & $\mathrm{C} 1 \mathrm{~b}$ & Sec. & & $A B U$ & ARG SNJ, Jáchal \\
\hline CHE 58 & D1 & Sec. & & $A B U$ & ARG LRJ AVP, Huaja \\
\hline CHE 59 & $\mathrm{C}$ & AFLP & & MA & ARG FOR, Las Lomitas \\
\hline CHE 60 & D1 & Sec. & & $A B U$ & ARG LRJ RVP, Chepes \\
\hline CHE 61 & $\mathrm{~A} 2$ & Sec. & & $A B U$ & ARG CBA, Alta Gracia \\
\hline CHE 62 & $\mathrm{C}$ & AFLP & & $A B U$ & ARG CBA, Lafinure \\
\hline CHE 63 & D1 & Sec. & & $A B U$ & ARG LRJ RVP, Chepes \\
\hline CHE 64 & $\mathrm{C}$ & AFLP & & $A B U$ & ARG LRJ RVP, Agua del Alto de la Sierra \\
\hline CHE 65 & $\mathrm{H}$ & Sec. & & $A B U$ & ARG LRJ RVP, Chepes \\
\hline CHE 66 & D1 & Sec. & & $A B U$ & ARG LRJ JFQ, Malanzán \\
\hline CHE 67 & $\mathrm{C}$ & AFLP & & $A B U$ & ARG LARJ RVP, La Jarilla? \\
\hline CHE 68 & $\mathrm{~A} 2$ & Sec. & & $A B U$ & ARG LRJ GOO, Milagro \\
\hline CHE 70 & $\mathrm{Nx}(\mathrm{A}, \mathrm{B})$ & AFLP & & MA & ARG LRJ RVP, Chepes \\
\hline CHE 71 & $\mathrm{Nx}(\mathrm{A}, \mathrm{B})$ & AFLP & & $A B U$ & ITALIA \\
\hline CHE 72 & $\mathrm{~A} 2$ & Sec. & & $A B U$ & ARG LRJ RVP, Salana \\
\hline CHE 73 & A & AFLP & & MA & ARG LRJ JFQ, San Antonio \\
\hline CHE 75 & $\mathrm{C} 1 \mathrm{~b}$ & Sec. & & $A B U$ & ARG LRJ RVP, Chepes \\
\hline CHE 77 & $\mathrm{C}$ & AFLP & & MA & ARG LRJ RVP, Chepes \\
\hline \multicolumn{6}{|l|}{ JUJUY } \\
\hline Jujuy 01 & $\mathrm{C} 1 \mathrm{~b}$ & RFLP y Sec. & & $S / D$ & $S / D$ \\
\hline Jujuy 03 & $\mathrm{~B} 2$ & RFLP y Sec. & & $S / D$ & $S / D$ \\
\hline Jujuy 04 & $\mathrm{D}$ & RFLP & & $S / D$ & $S / D$ \\
\hline Jujuy 05 & $\mathrm{~A} 2$ & RFLP y Sec. & & $S / D$ & $S / D$ \\
\hline Jujuy 06 & C1d & RFLP y Sec. & & $S / D$ & $S / D$ \\
\hline Jujuy 07 & C1d & RFLP y Sec. & & $S / D$ & $S / D$ \\
\hline Jujuy 08 & $\mathrm{C} 1 \mathrm{~b}$ & RFLP y Sec. & & $S / D$ & $S / D$ \\
\hline Jujuy 09 & $\mathrm{~B}$ & RFLP & & $S / D$ & S/D \\
\hline Jujuy 10 & $\mathrm{~B} 2$ & RFLP y Sec. & & $S / D$ & $S / D$ \\
\hline Jujuy 11 & $\mathrm{~A} 2$ & RFLP y Sec. & & $S / D$ & $S / D$ \\
\hline Jujuy 12 & D1 & RFLP y Sec. & & $S / D$ & $S / D$ \\
\hline Jujuy 13 & $\mathrm{D}$ & RFLP & & $S / D$ & S/D \\
\hline Jujuy 14 & $\mathrm{C} 1 \mathrm{~b}$ & RFLP y Sec. & & $S / D$ & $S / D$ \\
\hline Jujuy 15 & $\mathrm{~A} 2$ & RFLP y Sec. & & $S / D$ & $S / D$ \\
\hline Jujuy 17 & $\mathrm{C}$ & RFLP & & $S / D$ & $S / D$ \\
\hline Jujuy 18 & $\mathrm{~A} 2$ & RFLP y Sec. & & $S / D$ & $S / D$ \\
\hline Jujuy 19 & $\mathrm{C}$ & RFLP & & $S / D$ & $S / D$ \\
\hline Jujuy 20 & B2 & RFLP y Sec. & & $S / D$ & $S / D$ \\
\hline Jujuy 21 & C1b & RFLP y Sec. & & $S / D$ & $S / D$ \\
\hline Jujuy 22 & B2 & RFLP y Sec. & & $S / D$ & $S / D$ \\
\hline Jujuy 24 & $\mathrm{~B} 2$ & RFLP y Sec. & & $S / D$ & $S / D$ \\
\hline Jujuy 28 & L3e1 & RFLP y Sec. & 9 pb del. & $S / D$ & $S / D$ \\
\hline
\end{tabular}


Anexo

\begin{tabular}{|c|c|c|c|c|c|}
\hline Rótulo & $\mathrm{Hg}$ & Método & RFLP info & UACM & Lugar de nacimiento \\
\hline Jujuy 31 & $\mathrm{D} 1$ & RFLP y Sec. & & S/D & S/D \\
\hline Jujuy 33 & A & RFLP & & S/D & S/D \\
\hline Jujuy 34 & B2 & RFLP y Sec. & & S/D & S/D \\
\hline Jujuy 35 & B2 & RFLP y Sec. & & S/D & S/D \\
\hline Jujuy 36 & $\mathrm{~A} 2$ & RFLP y Sec. & & S/D & S/D \\
\hline Jujuy 38 & B2 & RFLP y Sec. & & S/D & S/D \\
\hline Jujuy 39 & B2 & RFLP y Sec. & & S/D & S/D \\
\hline Jujuy 40 & C & RFLP & & S/D & S/D \\
\hline Jujuy 41 & D1 & RFLP y Sec. & & S/D & S/D \\
\hline Jujuy 42 & B2 & RFLP y Sec. & & S/D & S/D \\
\hline Jujuy 45 & B2 & RFLP y Sec. & & S/D & S/D \\
\hline Jujuy 47 & $\mathrm{C} 1 \mathrm{~b}$ & RFLP y Sec. & & S/D & S/D \\
\hline Jujuy 48 & B2 & RFLP y Sec. & & S/D & S/D \\
\hline Jujuy 49 & $\mathrm{~A} 2$ & RFLP y Sec. & & S/D & S/D \\
\hline Jujuy 50 & B2 & RFLP y Sec. & & S/D & S/D \\
\hline Jujuy 52 & B2 & RFLP y Sec. & & S/D & S/D \\
\hline Jujuy 55 & B2 & RFLP y Sec. & & S/D & S/D \\
\hline Jujuy 56 & B2 & RFLP y Sec. & & S/D & S/D \\
\hline Jujuy 57 & $\mathrm{D} 1$ & RFLP y Sec. & & S/D & S/D \\
\hline Jujuy 58 & $\mathrm{~A} 2$ & RFLP y Sec. & & S/D & S/D \\
\hline \multicolumn{6}{|c|}{ LA QUIACA } \\
\hline LQ 001 & A & AFLP y Sec. & & MA & ARG JUJ PAL, Palpalá \\
\hline LQ 002 & $\mathrm{C}$ & AFLP y Sec. & & $A B U$ & ARG JUJ YAV, Pumahuasi \\
\hline LQ 003 & $\mathrm{D}$ & AFLP y Sec. & & $A B U$ & ARG JUJ YAV, La Quiaca \\
\hline LQ 004 & $\mathrm{~B}$ & AFLP & & DO & ARG JUJ SCA, Cienaguillas \\
\hline LQ 005 & C & AFLP & & $A B U$ & $\mathrm{BOL}$ \\
\hline LQ 006 & $\mathrm{~B}$ & AFLP y Sec. & & MA & ARG JUJ YAV, La Quiaca \\
\hline LQ 007 & B & AFLP & & MA & $\mathrm{BOL}$ \\
\hline LQ 008 & B & AFLP y Sec. & & MA & ARG SAL SVI, Viscachañi \\
\hline LQ 009 & B & AFLP & & $A B U$ & $\mathrm{BOL}$ \\
\hline LQ 010 & $\mathrm{D}$ & AFLP y Sec. & & $A B U$ & BOL TAR, Tarija \\
\hline LQ 011 & A & AFLP & & MA & $\mathrm{BOL}$ \\
\hline LQ 012 & A & AFLP y Sec. & & $A B U$ & ARG JUJ YAV, Inti Cancha \\
\hline LQ 013 & A & AFLP y Sec. & & $A B U$ & ARG JUJ COC, Abra Pampa \\
\hline LQ 014 & B & AFLP y Sec. & & ABU & BOL POT, Yanalpa? (frente a Yavi Chico) \\
\hline LQ 015 & A & AFLP y Sec. & & MA & ARG JUJ YAV, La Quiaca \\
\hline LQ 016 & $\mathrm{~B}$ & AFLP y Sec. & & $A B U$ & ARG JUJ YAV, La Quiaca \\
\hline LQ 017 & $\mathrm{D}$ & AFLP y Sec. & & $A B U$ & BOL CHU, Sucre \\
\hline LQ 018 & C & AFLP y Sec. & & DO & BOL SCZ, Santa Cruz \\
\hline LQ 019 & B & AFLP y Sec. & & $A B U$ & BOL TAR, El Puente \\
\hline LQ 020 & A & AFLP y Sec. & & $A B U$ & ARG JUJ SCA, Santa Catalina \\
\hline LQ 021 & A & AFLP y Sec. & & $A B U$ & ARG JUJ YAV, Rodeo \\
\hline LQ 022 & $\mathrm{~B}$ & AFLP & & DO & ARG JUJ YAV, Ojo de Agua \\
\hline LQ 023 & A & AFLP y Sec. & & MA & ARG JUJ YAV, Caracara \\
\hline LQ 024 & C & AFLP y Sec. & & MA & ARG JUJ YAV, Corral Blanco \\
\hline LQ 025 & B & AFLP y Sec. & & $A B U$ & ARG JUJ YAV, Tafna \\
\hline LQ 026 & B & AFLP y Sec. & & $A B U$ & ARG SAL SVI, S.V. Oeste \\
\hline LQ 027 & B & AFLP y Sec. & & MA & ARG JUJ YAV, La Quiaca \\
\hline LQ 028 & $\mathrm{~L}$ & Sec. & & $A B U$ & BOL POT, Sajnasti \\
\hline LQ 029 & B & AFLP y Sec. & & MA & ARG JUJ HUM, Humahuaca \\
\hline LQ 030 & C & AFLP & & DO & ARG CBA TUL, Va. Rosario de Saladillo \\
\hline LQ 031 & B & AFLP y Sec. & & $A B U$ & BOL POT, Potosí \\
\hline LQ 032 & B & AFLP y Sec. & & $A B U$ & ARG JUJ YAV, Cerrillos \\
\hline LQ 033 & B & AFLP y Sec. & & ABU & BOL POT, Villazón \\
\hline LQ 034 & $B$ & AFLP y Sec. & & MA & BOL POT, Potosí \\
\hline LQ 035 & A & AFLP y Sec. & & MA & BOL POT, Potosí \\
\hline LQ 036 & B & AFLP y Sec. & & $A B U$ & ARG JUJ YAV, La Quiaca \\
\hline LQ 037 & B & AFLP y Sec. & & $A B U$ & ARG JUJ COC, Abra Pampa \\
\hline LQ 038 & $\mathrm{~N}$ & AFLP & & $A B U$ & ITALIA \\
\hline LQ 039 & $B$ & AFLP y Sec. & & $A B U$ & BOL POT, Talina \\
\hline LQ 040 & $B$ & AFLP y Sec. & & $A B U$ & BOL ORU, Oruro \\
\hline LQ 041 & $\mathrm{~B}$ & AFLP y Sec. & & $A B U$ & ARG JUJ SCA, Santa Catalina \\
\hline LQ 042 & $\mathrm{~B}$ & AFLP y Sec. & & $A B U$ & ARG JUJ SCA, San Juan de Oro \\
\hline LQ 043 & B & AFLP y Sec. & & $A B U$ & PERÚ, Arequipa \\
\hline LQ 044 & B & AFLP & & $A B U$ & $\mathrm{BOL}$ \\
\hline LQ 045 & B & AFLP y Sec. & & $A B U$ & $\mathrm{BOL}$ \\
\hline LQ 046 & B & AFLP y Sec. & & $A B U$ & $\mathrm{BOL}$ \\
\hline LQ 047 & B & AFLP & & $A B U$ & $\mathrm{BOL}$ \\
\hline
\end{tabular}


Anexo

\begin{tabular}{|c|c|c|c|c|c|}
\hline Rótulo & $\mathrm{Hg}$ & Método & RFLP info & UACM & Lugar de nacimiento \\
\hline LQ 048 & B & AFLP & & DO & ARG SAL SVI, San Francisco de Tuctuca \\
\hline LQ 049 & B & AFLP & & $A B U$ & BOL \\
\hline LQ 050 & B & AFLP y Sec. & & $A B U$ & BOL ORU, Oruro \\
\hline LQ 051 & $\mathrm{~B}$ & AFLP & & $A B U$ & ARG JUJ HUM, Uquía \\
\hline LQ 052 & $\mathrm{~B}$ & AFLP & & $A B U$ & BOL POT, Villazón \\
\hline LQ 053 & $\mathrm{~B}$ & AFLP y Sec. & & $A B U$ & BOL POT, Tupiza \\
\hline LQ 054 & B & AFLP y Sec. & & MA & ARG JUJ YAV, Colpayoc \\
\hline LQ 055 & B & AFLP & & MA & ARG SAL \\
\hline LQ 056 & B & AFLP y Sec. & & $A B U$ & ARG JUJ SCA, Casira \\
\hline LQ 057 & B & AFLP y Sec. & & MA & BOL POT, Potosí \\
\hline LQ 058 & B & AFLP y Sec. & & $A B U$ & BOL POT, Villazón \\
\hline LQ 059 & B & AFLP y Sec. & & $A B U$ & BOL TAR, Tarija \\
\hline LQ 060 & B & AFLP y Sec. & & $A B U$ & ARG JUJ HUM, Coraya \\
\hline LQ 061 & A & AFLP y Sec. & & MA & ARG JUJ YAV, Yavi Chico \\
\hline LQ 062 & A & AFLP y Sec. & & $A B U$ & ARG JUJ COC, San José de Miraflores? \\
\hline LQ 063 & B & AFLP y Sec. & & $A B U$ & ARG JUJ YAV, Castí \\
\hline LQ 064 & B & AFLP & & $A B U$ & BOL \\
\hline LQ 065 & A & AFLP y Sec. & & MA & BOL POT, Potosí \\
\hline LQ 066 & B & AFLP y Sec. & & ABU & BOL POT, Suipacha \\
\hline LQ 067 & $\mathrm{~B}$ & AFLP & & $A B U$ & $\mathrm{BOL}$ \\
\hline LQ 068 & $B$ & AFLP y Sec. & & $A B U$ & ARG JUJ SCA, Timón Cruz \\
\hline LQ 069 & C & AFLP y Sec. & & MA & ARG JUJ SPE?, La Mendieta \\
\hline LQ 070 & B & AFLP & & $A B U$ & BOL \\
\hline LQ 071 & $\mathrm{~B}$ & AFLP y Sec. & & $A B U$ & BOL TAR, Tarija \\
\hline LQ 072 & $\mathrm{~B}$ & AFLP & & $A B U$ & $\mathrm{BOL}$ \\
\hline LQ 073 & B & AFLP & & MA & $\mathrm{BOL}$ \\
\hline LQ 074 & B & AFLP y Sec. & & $A B U$ & $\mathrm{BOL}$ \\
\hline LQ 075 & $\mathrm{~B}$ & AFLP y Sec. & & $A B U$ & ARG JUJ YAV, Río Colorado \\
\hline LQ 076 & B & AFLP & & $A B U$ & BOL POT, Potosí \\
\hline LQ 077 & $\mathrm{~B}$ & AFLP y Sec. & & $A B U$ & BOL ORU, Oruro \\
\hline LQ 078 & B & AFLP & & $A B U$ & BOL \\
\hline LQ 079 & $\mathrm{D}$ & AFLP y Sec. & & $A B U$ & BOL TAR, Iscayachi \\
\hline LQ 080 & B & AFLP y Sec. & & $A B U$ & ARG JUJ COC, Abdón Castro Tolay \\
\hline LQ 081 & A & AFLP y Sec. & & MA & ARG JUJ YAV, La Quiaca \\
\hline LQ 082 & B & AFLP y Sec. & & $A B U$ & ARG JUJ SCA, Yoscaba \\
\hline LQ 083 & B & AFLP y Sec. & & $A B U$ & ARG SAL SVI, Nazareno \\
\hline LQ 084 & A & AFLP y Sec. & & $A B U$ & ARG JUJ YAV, Tafna \\
\hline LQ 085 & A & AFLP & & $A B U$ & ARG SAL \\
\hline LQ 086 & $B$ & AFLP y Sec. & & $A B U$ & BOL POT, Sajnasti \\
\hline LQ 087 & A & AFLP y Sec. & & $A B U$ & ARG JUJ YAV, EL Cóndor \\
\hline LQ 088 & B & AFLP & & DO & ARG JUJ YAV, Suripujio \\
\hline LQ 089 & B & AFLP y Sec. & & $A B U$ & BOL POT, Cuartos -cerca Villazón \\
\hline LQ 090 & $\mathrm{~B}$ & AFLP & & $A B U$ & $\mathrm{BOL}$ \\
\hline LQ 091 & $\mathrm{~B}$ & AFLP & & $A B U$ & ARG SAL CAP, Salta \\
\hline LQ 092 & B & AFLP & & MA & ARG JUJ, BEL SSJ \\
\hline LQ 093 & B & AFLP y Sec. & & $A B U$ & ARG JUJ YAV, La Quiaca \\
\hline LQ 094 & $B$ & AFLP y Sec. & & $A B U$ & ARG JUJ RIN, Quebraleña \\
\hline LQ 095 & B & AFLP y Sec. & & MA & BOL POT, Villazón \\
\hline LQ 096 & B & AFLP y Sec. & & MA & ARG JUJ YAV, La Quiaca \\
\hline LQ 097 & C & AFLP y Sec. & & $A B U$ & ARG JUJ COC, Abra Pampa \\
\hline LQ 098 & B & AFLP y Sec. & & $A B U$ & ARG SAL SVI, Viscachañi \\
\hline LQ 099 & B & AFLP y Sec. & & MA & ARG JUJ SCA, La Cruz \\
\hline LQ 100 & $\mathrm{D}$ & AFLP y Sec. & & $A B U$ & ARG SAL SVI, S.V. Oeste \\
\hline LQ 101 & D & AFLP y Sec. & & MA & ARG SAL SVI, San Marcos \\
\hline LQ 102 & C & AFLP & & MA & ARG TUC \\
\hline LQ 103 & B & AFLP y Sec. & & $A B U$ & BOL POT, Tupiza \\
\hline LQ 104 & $B$ & AFLP y Sec. & & $A B U$ & BOL POT, Villazón \\
\hline LQ 105 & $\mathrm{D}$ & AFLP y Sec. & & $A B U$ & BOL CHU, Sucre \\
\hline LQ 106 & B & AFLP y Sec. & & MA & ARG JUJ SCA, Mina Azul \\
\hline LQ 107 & B & AFLP y Sec. & & $A B U$ & BOL TAR, Tarija \\
\hline LQ 108 & $B$ & AFLP & & MA & ARG SAL \\
\hline LQ 109 & $B$ & AFLP y Sec. & & $A B U$ & BOL TAR, Tarija \\
\hline LQ 110 & $\mathrm{~B}$ & AFLP y Sec. & & $A B U$ & ARG JUJ TIL?, Tunalito \\
\hline LQ 111 & B & AFLP y Sec. & & MA & ARG JUJ YAV, Río Colorado \\
\hline LQ 112 & C & AFLP y Sec. & & MA & ARG SAL SVI, Nazareno \\
\hline LQ 114 & $\mathrm{D}$ & AFLP y Sec. & & ABU & BOL? POT?, Valle Rico \\
\hline LQ 115 & B & AFLP y Sec. & & $A B U$ & ARG JUJ YAV, La Quiaca \\
\hline LQ 116 & C & AFLP y Sec. & & MA & ARG SAL GSM, Madrejones \\
\hline LQ 117 & A & AFLP y Sec. & & $A B U$ & ARG JUJ YAV, Suripugio \\
\hline
\end{tabular}


Anexo

\begin{tabular}{|c|c|c|c|c|c|}
\hline Rótulo & $\mathrm{Hg}$ & Método & RFLP info & UACM & Lugar de nacimiento \\
\hline LQ 118 & $\mathrm{~B}$ & AFLP y Sec. & & ABU & BOL POT, Potosí \\
\hline LQ 119 & $\mathrm{~B}$ & AFLP y Sec. & & MA & ARG JUJ YAV, Cienaguillas \\
\hline LQ 120 & A & AFLP & & DO & ARG JUJ BEL, SSJ \\
\hline LQ 121 & A & AFLP y Sec. & & $A B U$ & ARG SAL SVI, Nazareno \\
\hline LQ 122 & $B$ & AFLP & & $A B U$ & BOL \\
\hline LQ 123 & B & $\mathrm{xSec}$ & & $A B U$ & BOL POT, Moraya \\
\hline LQ 124 & B & AFLP y Sec. & & $A B U$ & ARG JUJ SCA, Santa Catalina \\
\hline LQ 125 & $\mathrm{~N}$ & AFLP & & $A B U$ & ARG JUJ BEL, SSJ \\
\hline LQ 126 & A & AFLP y Sec. & & MA & ARG JUJ YAV, Río Colorado \\
\hline LQ 127 & B & AFLP y Sec. & & $A B U$ & ARG JUJ YAV, Sansana \\
\hline LQ 128 & $\mathrm{~B}$ & AFLP y Sec. & & $A B U$ & ARG JUJ SCA, Mina Azul \\
\hline LQ 129 & B & AFLP & & $A B U$ & BOL \\
\hline LQ 130 & B & AFLP y Sec. & & $A B U$ & BOL \\
\hline LQ 131 & B & AFLP y Sec. & & MA & ARG JUJ HUM, Humahuaca \\
\hline LQ 132 & A & AFLP y Sec. & & $A B U$ & CHILE \\
\hline LQ 133 & $\mathrm{C}$ & AFLP & & MA & ARG SAL \\
\hline LQ 134 & $\mathrm{~B}$ & AFLP y Sec. & & $A B U$ & ARG JUJ YAV, La Quiaca \\
\hline LQ 135 & $A$ & AFLP y Sec. & & $A B U$ & ARG JUJ YAV, Ojo de Agua \\
\hline LQ 136 & A & AFLP & & MA & ARG JUJ \\
\hline LQ 137 & $\mathrm{~B}$ & AFLP & & $A B U$ & $\mathrm{BOL}$ \\
\hline LQ 138 & A & AFLP & & MA & ARG JUJ BEL, SSJ \\
\hline LQ 139 & A & AFLP y Sec. & & MA & BOL POT, Mojo \\
\hline LQ 140 & $C$ & AFLP y Sec. & & $A B U$ & ARG JUJ TUM, Purmamarca \\
\hline LQ 141 & B & AFLP & & $A B U$ & ARG TUC \\
\hline LQ 142 & $\mathrm{C}$ & AFLP & & ABU & ARG JUJ BEL, SSJ \\
\hline LQ 143 & $\mathrm{D}$ & AFLP y Sec. & & $A B U$ & BOL POT, Tupiza \\
\hline LQ 144 & $\mathrm{D}$ & AFLP & & $A B U$ & ARG SAL \\
\hline LQ 145 & $\mathrm{D}$ & AFLP & & $A B U$ & $\mathrm{BOL}$ \\
\hline LQ 146 & B & AFLP y Sec. & & $A B U$ & BOL SCZ, Santa Cruz \\
\hline LQ 147 & $\mathrm{~B}$ & AFLP y Sec. & & $A B U$ & BOL ORU, Oruro \\
\hline LQ 148 & A & AFLP y Sec. & & MA & ARG JUJ TUM, Volcán \\
\hline LQ 149 & A & AFLP y Sec. & & $A B U$ & ARG JUJ YAV, Corral Blanco \\
\hline LQ 150 & A & AFLP & & MA & ARG JUJ BEL, SSJ \\
\hline LQ 151 & $\mathrm{~B}$ & AFLP y Sec. & & MA & BOL POT, Talina \\
\hline LQ 152 & A & AFLP y Sec. & & $A B U$ & ARG JUJ COC, Abra Pampa? \\
\hline LQ 153 & B & AFLP & & MA & BOL \\
\hline LQ 154 & $\mathrm{~B}$ & AFLP y Sec. & & $A B U$ & BOL POT, Cotagaita \\
\hline LQ 155 & $\mathrm{~B}$ & AFLP y Sec. & & $A B U$ & ARG JUJ YAV, Punta de Agua \\
\hline LQ 156 & $\mathrm{~B}$ & AFLP y Sec. & & MA & ARG JUJ YAV, Cerro Colorado \\
\hline LQ 157 & $B$ & AFLP y Sec. & & MA & ARG SAL SVI, S.V. Oeste \\
\hline LQ 158 & C & AFLP y Sec. & & MA & ARG JUJ YAV, Pumahuasi \\
\hline LQ 159 & B & AFLP y Sec. & & MA & BOL POT, Talina \\
\hline LQ 161 & B & AFLP y Sec. & & $A B U$ & BOL POT, Tupiza \\
\hline LQ 162 & $\mathrm{~N}$ & AFLP & & $A B U$ & ESPAÑA \\
\hline LQ 163 & B & AFLP y Sec. & & MA & ARG JUJ COC, Cochinoca \\
\hline LQ 164 & A & AFLP y Sec. & & $A B U$ & ARG SAL SVI, Nazareno \\
\hline LQ 165 & B & AFLP y Sec. & & MA & ARG SAL SVI, Nazareno \\
\hline LQ 166 & $\mathrm{D}$ & AFLP y Sec. & & MA & ARG JUJ SCA, Puesto Grande \\
\hline LQ 167 & $B$ & AFLP y Sec. & & $A B U$ & ARG JUJ YAV, Barrios \\
\hline LQ 168 & $B$ & AFLP y Sec. & & $A B U$ & ARG JUJ YAV, La Quiaca \\
\hline LQ 169 & B & AFLP y Sec. & & MA & ARG JUJ SBA, El Talar Ramal \\
\hline LQ BS 01 & $\mathrm{~B}$ & AFLP y Sec. & & MA & ARG JUJ SPE, San Pedro \\
\hline LQ BS 02 & $\mathrm{~B}$ & AFLP y Sec. & & MA & ARG SAL SVI, S.V. Oeste \\
\hline LQ Cie 01 & $\mathrm{~B}$ & AFLP & & $A B U$ & ARG JUJ SCA, Santa Catalina \\
\hline LQ Cie 02 & B & AFLP y Sec. & & $A B U$ & ARG JUJ ANT, Ceibal \\
\hline LQ Cie 03 & $\mathrm{~B}$ & AFLP y Sec. & & $A B U$ & BOL \\
\hline LQ Cie 04 & $B$ & AFLP y Sec. & & MA & ARG JUJ VGR, Valle Grande \\
\hline LQ Cie 05 & B & AFLP y Sec. & & $A B U$ & BOL LPZ, La Paz \\
\hline LQ Cie 06 & B & AFLP y Sec. & & $A B U$ & ARG JUJ RIN, Peñas Blancas \\
\hline LQ Cie 07 & B & AFLP y Sec. & & $A B U$ & ARG JUJ SCA, El Angosto \\
\hline LQ Cie 08 & $\mathrm{~B}$ & AFLP y Sec. & & $A B U$ & ARG JUJ SCA, La Ciénaga \\
\hline LQ Cie 09 & $\mathrm{~B}$ & AFLP y Sec. & & $A B U$ & ARG JUJ HUM, Humahuaca \\
\hline LQ Pr 01 & $\mathrm{~B}$ & AFLP y Sec. & & $A B U$ & ARG JUJ RIN, Rinconada \\
\hline LQ Pr 02 & $C$ & AFLP y Sec. & & $A B U$ & ARG JUJ YAV, Yavi \\
\hline LQ Pr 03 & B & AFLP y Sec. & & $A B U$ & BOL POT o TAR?, Sococha \\
\hline LQ Pr 04 & $\mathrm{~B}$ & AFLP y Sec. & & $A B U$ & BOL POT, Charaja -Suipacha \\
\hline LQ Pr 05 & $\mathrm{~B}$ & AFLP & & $A B U$ & BOL \\
\hline LQ Pr 06 & B & AFLP & & DO & ARG JUJ HUM, El Aguilar \\
\hline LQ Pr 07 & $\mathrm{~B}$ & AFLP & & $A B U$ & BOL \\
\hline
\end{tabular}


Anexo

\begin{tabular}{|c|c|c|c|c|c|}
\hline Rótulo & $\mathrm{Hg}$ & Método & RFLP info & UACM & Lugar de nacimiento \\
\hline LQ Pr 08 & $\mathrm{~B}$ & AFLP y Sec. & & $A B U$ & ARG JUJ?, Chariguamayoc \\
\hline LQ Pr 09 & B & AFLP y Sec. & & $A B U$ & BOL POT, Tupiza \\
\hline LQ Pr 10 & A & AFLP y Sec. & & MA & ARG JUJ SCA, Calahoyo \\
\hline LQ Pr 11 & C & AFLP & & $A B U$ & ARG SAL \\
\hline LQ Pr 12 & $\mathrm{~B}$ & AFLP y Sec. & & $A B U$ & ARG JUJ BEL, Ocloyas (León) \\
\hline LQ Pr 13 & $B$ & AFLP y Sec. & & $A B U$ & ARG JUJ YAV, Yavi Chico \\
\hline LQ Pr 14 & $B$ & AFLP y Sec. & & $A B U$ & BOL COC, Cochabamba \\
\hline LQ Pr 15 & $B$ & AFLP y Sec. & & $A B U$ & ARG JUJ SCA, Santa Catalina \\
\hline LQ Pr 16 & C & AFLP & & MA & BOL \\
\hline LQ Pr 17 & A & AFLP y Sec. & & $A B U$ & BOL POT, Palca de Higueras \\
\hline LQ $\operatorname{Pr} 18$ & A & AFLP & & $A B U$ & BOL \\
\hline LQ $\operatorname{Pr} 19$ & B & AFLP y Sec. & & $A B U$ & BOL POT, Tupiza \\
\hline LQ Pr 20 & B & AFLP & & MA & ARG SAL \\
\hline LQ $\operatorname{Pr} 21$ & B & AFLP y Sec. & & MA & ARG JUJ HUM, Miyuyoc \\
\hline LQ Pr 22 & C & AFLP y Sec. & & $A B U$ & BOL POT, Tupiza \\
\hline LQ Pr 23 & A & AFLP y Sec. & & $A B U$ & ARG JUJ COC, Cochinoca \\
\hline LQ Pr 24 & C & AFLP y Sec. & & $A B U$ & BOL POT, Tupiza \\
\hline LQ Pr 25 & $B$ & AFLP y Sec. & & $A B U$ & BOL POT, Potosí \\
\hline LQ Pr 26 & B & AFLP y Sec. & & ABU & ARG JUJ SCA, El Angosto \\
\hline LQ Pr 27 & $B$ & AFLP & & MA & ARG JUJ BEL, SSJ \\
\hline LQ Pr 28 & $B$ & AFLP y Sec. & & $A B U$ & ARG JUJ YAV, La Quiaca \\
\hline LQ Pr 29 & B & AFLP y Sec. & & MA & BOL POT, (puna) \\
\hline LQ Pr 30 & A & AFLP y Sec. & & $A B U$ & ARG JUJ CAR, Perico \\
\hline LQ Pr 31 & $B$ & AFLP y Sec. & & $A B U$ & BOL POT, Livi Livi \\
\hline LQ Pr 32 & C & AFLP y Sec. & & MA & BOL POT, Tupiza \\
\hline LQ Pr 33 & $B$ & AFLP y Sec. & & $A B U$ & BOL ORU, Oruro \\
\hline LQ Pr 34 & $B$ & AFLP y Sec. & & $A B U$ & ARG JUJ YAV, Barrios \\
\hline LQ Pr 35 & $\mathrm{C}$ & AFLP y Sec. & & $A B U$ & ARG JUJ YAV, Cangrejillos \\
\hline LQ Pr 36 & $\mathrm{D}$ & AFLP y Sec. & & MA & ARG JUJ SCA, Santa Catalina \\
\hline LQ Pr 37 & $\mathrm{~B}$ & AFLP y Sec. & & MA & ARG JUJ TIL, Maimará \\
\hline LQ Pr 38 & B & AFLP y Sec. & & $A B U$ & ARG JUJ TIL, Tilcara \\
\hline LQ Pr 39 & B & AFLP y Sec. & & $A B U$ & BOL CHU, Sucre \\
\hline LQ Pr 40 & B & AFLP y Sec. & & $A B U$ & BOL POT, Talina \\
\hline LQ Pr 41 & B & AFLP & & $A B U$ & ARG SNJ CAU, Caucete \\
\hline LQ SCA 01 & B & AFLP y Sec. & & $A B U$ & ARG JUJ SCA, San Francisco \\
\hline LQ SCA 02 & $B$ & AFLP y Sec. & & $A B U$ & ARG JUJ RIN, Mina Pirquitas \\
\hline LQ SCA 03 & A & AFLP y Sec. & & $A B U$ & ARG JUJ SCA, Mina Azul \\
\hline \multicolumn{6}{|l|}{ LA RIOJA } \\
\hline LR 001 & D1 & Sec. & & $A B U$ & ARG LRJ CHA, Chamical \\
\hline LR 003 & B & RFLP & & $A B U$ & ARG LRJ \\
\hline LR 004 & $\mathrm{H}$ & Sec. & & $A B U$ & ARG SNL \\
\hline LR 005 & C1b & Sec. & & $A B U$ & ARG LRJ, La Rioja capital \\
\hline LR 006 & $N(x A, B)$ & RFLP & & $A B U$ & ARG MZA, Junín \\
\hline LR 007 & A & RFLP & & $A B U$ & ARG CBA, Córdoba capital \\
\hline LR 009 & C & RFLP & & MA & ARG SFE, Las Toscas \\
\hline LR 010 & $B$ & RFLP & & MA & ARG CAT \\
\hline LR 011 & $\mathrm{D}$ & RFLP & & MA & ARG LRJ GBE, Olta \\
\hline LR 012 & C & RFLP & & $A B U$ & ARG TUC, Tacurrado \\
\hline LR 013 & D & RFLP & & $A B U$ & ARG LRJ, La Rioja capital \\
\hline LR 014 & $\mathrm{C} 1 \mathrm{~b}$ & Sec. & & $A B U$ & ARG LRJ SBL, Los Sauces \\
\hline LR 015 & B & RFLP & & $A B U$ & ARG CAT TIN \\
\hline LR 016 & D1 & Sec. & & $A B U$ & ARG LRJ CHI, Chilecito \\
\hline LR 017 & D & RFLP & & $A B U$ & ARG LRJ (interior) \\
\hline LR 019 & C & RFLP & & $A B U$ & ARG SNJ, San Ramón \\
\hline LR 020 & B & Sec. & & $A B U$ & ARG VIN, Va. San José \\
\hline LR 021 & $\mathrm{D} 1$ & Sec. & & $A B U$ & ARG LRJ, La Rioja capital \\
\hline LR 022 & $\mathrm{C} 1 \mathrm{~b}$ & Sec. & & $A B U$ & ARG LRJ FVA, Guandacol \\
\hline LR 023 & $\mathrm{D}$ & RFLP & & $A B U$ & ARG BS AS, Quilmes \\
\hline LR 024 & C & RFLP & & $A B U$ & ARG LRJ, La Rioja capital \\
\hline LR 025 & A & RFLP & & $A B U$ & ARG BS AS? \\
\hline LR 026 & C & RFLP & & $A B U$ & ARG LRJ, La Rioja capital \\
\hline LR 027 & $\mathrm{C} 1 \mathrm{~b}$ & Sec. & & MA & ARG LRJ CHI, Chilecito \\
\hline LR 028 & D1 & Sec. & & $A B U$ & ARG LRJ, La Rioja capital \\
\hline LR 029 & D1 & Sec. & & $A B U$ & ARG LRJ CAB, Anillaco \\
\hline LR 030 & $\mathrm{C} 1 \mathrm{~b}$ & Sec. & & $A B U$ & ARG LRJ LSC, Alpasinda \\
\hline LR 031 & D1 & Sec. & & $A B U$ & ARG LRJ CHI, Chilecito \\
\hline LR 032 & D1 & Sec. & & $A B U$ & ARG LRJ, La Rioja Capital \\
\hline LR 033 & D1 & Sec. & & MA & ARG RL FVA, Va. Unión \\
\hline
\end{tabular}


Anexo

\begin{tabular}{|c|c|c|c|c|c|}
\hline Rótulo & $\mathrm{Hg}$ & Método & RFLP info & UACM & Lugar de nacimiento \\
\hline LR 034 & $\mathrm{~A}$ & RFLP & & MA & ARG LRJ IND, La Torre \\
\hline LR 035 & $\mathrm{C} 1 \mathrm{~b}$ & Sec. & & $A B U$ & ARG LRJ CHA, Chamical \\
\hline LR 036 & $\mathrm{D}$ & RFLP & & $A B U$ & ARG CBA, Chancaní \\
\hline LR 037 & $\mathrm{~B}$ & Sec. & & $A B U$ & ARG SDE \\
\hline LR 038 & $\mathrm{D}$ & RFLP & & $A B U$ & ARG MZA, Godoy Cruz \\
\hline LR 039 & A & RFLP & & DO & ARG LRJ GBE, Chañar \\
\hline LR 040 & $\mathrm{C}$ & RFLP & & MA & ARG CBA, Córdoba capital \\
\hline LR 041 & $\mathrm{C} 1 \mathrm{~b}$ & Sec. & & ABU & ARG SNL, (del campo) \\
\hline LR 042 & C & RFLP & & ABU & ARG MZA, Mendoza Capital \\
\hline LR 043 & B & Sec. & & ABU & ARG LRJ FVA, Guandacol \\
\hline LR 044 & C & RFLP & & $A B U$ & ARG TUC, ¿capital? \\
\hline LR 046 & $\mathrm{C} 1 \mathrm{~b}$ & Sec. & & $A B U$ & ARG LRJ JFQ, Nacate \\
\hline LR 047 & $N(x A, B)$ & RFLP & & MA & ARG LRJ, La Rioja Capital \\
\hline LR 048 & D1 & Sec. & & $A B U$ & ARG LRJ, La Rioja Capital \\
\hline LR 049 & D1 & Sec. & & $A B U$ & ARG LRJ CHI, Chilecito \\
\hline LR 050 & $N(x A, B)$ & RFLP & & MA & ARG BS AS, Junín \\
\hline LR 051 & $\mathrm{D}$ & RFLP & & MA & ARG CBA, Cruz del eje \\
\hline LR 052 & A & Sec. & & $A B U$ & ARG LRJ GOO, (de la región de Milagro) \\
\hline LR 053 & $\mathrm{D} 1$ & Sec. & & $A B U$ & ARG TUC MON, Acheral \\
\hline LR 054 & $\mathrm{D}$ & RFLP & & MA & ARG CAT, Bazán \\
\hline LR 055 & C1d & Sec. & & $A B U$ & ARG LRJ, La Rioja Capital \\
\hline LR 056 & B & Sec. & & $A B U$ & ARG LRJ IND, Patquía \\
\hline LR 057 & $N(x A, B)$ & RFLP & & MA & ARG \\
\hline LR 058 & D1 & Sec. & & $A B U$ & ARG LRJ, La Rioja Capital \\
\hline LR 059 & $\mathrm{~B}$ & RFLP & & $A B U$ & ARG LRJ RVP, Ñoqueve \\
\hline LR 060 & $H$ ? & Sec. & & $A B U$ & ARG LRJ CHA, Chamical \\
\hline LR 061 & $N(x A, B)$ & RFLP & & $A B U$ & ARG LRJ GSM, Ulapes \\
\hline LR 063 & $\mathrm{C}$ & RFLP & & DO & ARG BS AS, Morón \\
\hline LR 064 & $N(x A, B)$ & RFLP & & $A B U$ & ARG LRJ, La Rioja Capital \\
\hline LR 065 & D1 & Sec. & & $A B U$ & ARG LRJ LSA, Los Sauces \\
\hline LR 066 & D1 & Sec. & & $A B U$ & ARG LRJ, La Rioja Capital \\
\hline LR 067 & C1d & Sec. & & $A B U$ & ARG LRJ IND, Patquía \\
\hline LR 068 & $\mathrm{D}$ & RFLP & & MA & ARG CBA, Cobituyo \\
\hline LR 069 & A & RFLP & & MA & ARG CAT, Gruta quinta paralela Norte \\
\hline LR 070 & B & RFLP & & $A B U$ & ARG CAT MFL \\
\hline LR 071 & L3e2b & Sec. & & ABU & ARG LRJ, La Rioja Capital \\
\hline LR 072 & $\mathrm{D}$ & RFLP & & MA & ARG LRJ, La Rioja Capital \\
\hline LR 073 & $\mathrm{D} 1$ & Sec. & & $A B U$ & ARG LRJ LSA, Los Sauces \\
\hline LR 074 & $\mathrm{C}$ & RFLP & & MA & ARG SNJ VFE \\
\hline LR 075 & $\mathrm{C} 1 \mathrm{~b}$ & Sec. & & $A B U$ & ARG LRJ IND, Patquía \\
\hline LR 076 & C & RFLP & & $A B U$ & ARG LRJ, La Rioja Capital \\
\hline LR 077 & $\mathrm{D} 1$ & Sec. & & $A B U$ & ARG LRJ, La Rioja Capital \\
\hline LR 078 & $\mathrm{C}$ & RFLP & & $A B U$ & ARG TUC \\
\hline LR 079 & $\mathrm{D}$ & RFLP & & MA & ARG LRJ, La Rioja Capital \\
\hline LR 080 & A & Sec. & & $A B U$ & ARG MIS CAP, Pto. Mineral \\
\hline LR 081 & $\mathrm{~N}(\mathrm{xA}, \mathrm{B})$ & RFLP & & $A B U$ & ARG LRJ, La Rioja Capital \\
\hline LR 082 & $\mathrm{~A}$ & RFLP & & $A B U$ & ARG CBA \\
\hline LR 083 & A & RFLP & & $A B U$ & ARG LRJ \\
\hline LR 084 & D1 & Sec. & & $A B U$ & ARG LRJ GOO, Las Playas \\
\hline LR 085 & D & RFLP & & $A B U$ & ARG LRJ \\
\hline LR 086 & D1 & Sec. & & $A B U$ & ARG LRJ LSA, Los Sauces \\
\hline LR 087 & $\mathrm{D}$ & RFLP & & $A B U$ & ARG LRJ, La Rioja Capital \\
\hline LR 088 & $\mathrm{D}$ & RFLP & & $A B U$ & ARG LRJ RVP, San Antonio \\
\hline LR 089 & $\mathrm{D}$ & RFLP & & $A B U$ & ARG LRJ, La Rioja Capital \\
\hline LR 090 & C1d & Sec. & & ABU & ARG LRJ CHI, Chilecito? (vivía) \\
\hline LR 091 & J1c1 & Sec. & & $A B U$ & ARG LRJ FAM, Famatina \\
\hline LR 092 & B & RFLP & & $A B U$ & ARG SNJ, San Juan Capital? (vivía) \\
\hline LR 093 & C & RFLP & & $A B U$ & ARG CBA, Alta Gracia \\
\hline LR 095 & C & RFLP & & $A B U$ & ARG LRJ RVP, La Chuña \\
\hline LR 096 & A & RFLP & & $A B U$ & ARG SNJ VFE, Las Sierras \\
\hline LR 097 & C & RFLP & & $A B U$ & ARG LRJ, La Rioja Capital? (vivia) \\
\hline LR 098 & $N(x A, B)$ & RFLP & & $A B U$ & ARG LRJ, La Rioja Capital \\
\hline LR 099 & C1d & Sec. & & $A B U$ & ARG LRJ SAN, Sanagasta \\
\hline LR 100 & D1 & Sec. & & $A B U$ & ARG LRJ, La Rioja Capital \\
\hline LR 101 & $\mathrm{D}$ & RFLP & & DO & ARG CAT, Saujil \\
\hline LR 102 & $N(x A, B)$ & RFLP & & $A B U$ & ARG CBA, Cerro de la Rosa \\
\hline LR 103 & D & RFLP & & $A B U$ & ARG LRJ \\
\hline LR 104 & A & RFLP & & $A B U$ & ARG SNJ, Valle Fértil \\
\hline LR 105 & D1 & Sec. & & $A B U$ & ARG LRJ VIN, Jagüe \\
\hline
\end{tabular}


Anexo

\begin{tabular}{|c|c|c|c|c|c|}
\hline Rótulo & $\mathrm{Hg}$ & Método & RFLP info & UACM & Lugar de nacimiento \\
\hline LR 106 & $\mathrm{D} 1$ & Sec. & & $A B U$ & ARG LRJ CBR, Pinchas \\
\hline LR 107 & $\mathrm{D}$ & RFLP & & $A B U$ & ARG LRJ, La Rioja Capital \\
\hline LR 108 & $L(X M, N)$ & RFLP & & $A B U$ & ARG CBA, Cruz del Eje \\
\hline LR 109 & D & RFLP & & MA & ARG LRJ \\
\hline LR 110 & $N(x A, B)$ & RFLP & & $A B U$ & ESPAÑA \\
\hline LR 111 & D1 & Sec. & & $A B U$ & ARG LRJ CHA, Chamical \\
\hline LR 112 & A & RFLP & & $A B U$ & ARG LRJ \\
\hline LR 113 & A & Sec. & & ABU & ARG LRJ CAP, Carranza \\
\hline LR 114 & $\mathrm{D}$ & RFLP & & $A B U$ & ARG LRJ ACO, Villa Mazán \\
\hline LR 115 & $\mathrm{D}$ & RFLP & & $A B U$ & ARG CBA, Córdoba capital \\
\hline LR 116 & $L(X M, N)$ & RFLP & & $A B U$ & ARG LRJ \\
\hline LR 117 & C & RFLP & & MA & ARG CAT, Catamarca capital \\
\hline LR 118 & D & RFLP & & MA & ARG LRJ CBR, Pinchas \\
\hline LR 119 & C1d & Sec. & & $A B U$ & ARG LRJ, La Rioja Capital \\
\hline LR 120 & C & RFLP & & $A B U$ & ARG FOR, Villa General Güemes \\
\hline LR 121 & D1 & Sec. & & $A B U$ & ARG LRJ CHI, Vichigasta \\
\hline LR 122 & $\mathrm{D}$ & RFLP & & MA & ARG LRJ FVA, Guandacol \\
\hline LR 123 & D1 & Sec. & & $A B U$ & ARG LRJ CHI, Chilecito \\
\hline LR 124 & $\mathrm{D}$ & RFLP & & ABU & ARG LRJ, La Rioja Capital \\
\hline LR 125 & A & RFLP & & $A B U$ & ARG LRJ, La Rioja Capital \\
\hline LR 126 & $\mathrm{D}$ & RFLP & & $A B U$ & ARG LRJ, La Rioja Capital \\
\hline LR 127 & $N(x A, B)$ & RFLP & & $A B U$ & ARG CBA, Cruz del eje \\
\hline LR 128 & D1 & Sec. & & ABU & ARG LRJ CHA, La Esperanza de los Cerrillos \\
\hline LR 129 & C & RFLP & & $A B U$ & ARG LRJ, La Rioja Capital (vive) \\
\hline LR 130 & $\mathrm{H}$ & Sec. & & $A B U$ & ARG LRJ GBE \\
\hline LR 131 & $\mathrm{D}$ & RFLP & & DO & ARG LRJ, La Rioja Capital \\
\hline LR 132 & $N(x A, B)$ & RFLP & & $A B U$ & ARG CBA, Córdoba Capital \\
\hline LR 133 & C & RFLP & & ABU & ARG FOR \\
\hline LR 134 & B & RFLP & & $A B U$ & ARG LRJ, La Rioja Capital \\
\hline LR 135 & A & RFLP & & MA & ARG LRJ, Salana \\
\hline LR 136 & A & RFLP & & $A B U$ & ARG LRJ, La Rioja Capital \\
\hline LR 137 & D1 & Sec. & & $A B U$ & ARG LRJ, La Rioja Capital \\
\hline LR 138 & C & RFLP & & $A B U$ & ARG BS AS \\
\hline LR 139 & $L(X M, N)$ & RFLP & & $A B U$ & ARG CBA, Chancaní \\
\hline LR 140 & D1 & Sec. & & $A B U$ & ARG LRJ CHI, Nonogasta \\
\hline LR 141 & D1 & Sec. & & $A B U$ & ARG LRJ \\
\hline LR 142 & $\mathrm{D}$ & RFLP & & $A B U$ & ARG LRJ, La Rioja Capital \\
\hline LR 143 & B & RFLP & & $A B U$ & ARG JUJ \\
\hline LR 144 & D1 & Sec. & & $A B U$ & ARG LRJ CHI, Chilecito \\
\hline LR 145 & $B$ & Sec. & & $A B U$ & ARG LRJ CAP, El Cantadero \\
\hline LR 146 & B & Sec. & & $A B U$ & ARG LRJ GOO, Milagro \\
\hline LR 147 & A & RFLP & & $A B U$ & ARG LRJ RVP, EL Agua de Aguirre \\
\hline LR 148 & B & RFLP & & $A B U$ & ARG CAT, Belén \\
\hline LR 149 & $\mathrm{C}$ & RFLP & & $A B U$ & ARG MZA, Gral. Alvear \\
\hline LR 150 & B & Sec. & & MA & ARG LRJ VIN, Jagüe \\
\hline LR 151 & B & RFLP & & MA & ARG CAT AND, Capillitas \\
\hline LR 152 & B & Sec. & & $A B U$ & ARG LRJ CBR, Anillaco \\
\hline LR 153 & C & RFLP & & $A B U$ & ARG CAT, Catamarca Capital. \\
\hline LR 154 & C & RFLP & & DO & ARG LRJ, La Rioja Capital \\
\hline LR 155 & $N(x A, B)$ & RFLP & & ABU & ARG LRJ, La Rioja Capital \\
\hline LR 156 & $\mathrm{D}$ & RFLP & & DO & ARG SDE ATA, Loreto \\
\hline LR 157 & $\mathrm{~N}(\mathrm{xA}, \mathrm{B})$ & RFLP & & $A B U$ & ARG LRJ, La Rioja Capital \\
\hline LR 158 & B & RFLP & & $A B U$ & ARG COR, Sauce \\
\hline LR 159 & B & RFLP & & $A B U$ & ARG, Capital Federal \\
\hline LR 160 & $\mathrm{D}$ & RFLP & & $A B U$ & ARG CBA, Córdoba Capital \\
\hline LR 161 & $L(X M, N)$ & RFLP & & $A B U$ & ARG LRJ, La Rioja Capital \\
\hline LR 162 & D & RFLP & & MA & ARG CBA, La Tacanita (El Chacho) \\
\hline LR 163 & D1 & Sec. & & $A B U$ & ARG LRJ JFQ, Portezuelo \\
\hline LR 164 & $\mathrm{~N}(\mathrm{xA}, \mathrm{B})$ & RFLP & & $A B U$ & ARG BS AS \\
\hline LR 165 & $N(x A, B)$ & RFLP & & $A B U$ & ARG CBA, Serrezuela \\
\hline LR 166 & $\mathrm{D}$ & RFLP & & $A B U$ & ARG LRJ, La Rioja Capital \\
\hline LR 167 & D1 & Sec. & & MA & ARG LRJ FVA, Guandacol \\
\hline LR 168 & $L(X M, N)$ & RFLP & & $A B U$ & ARG CBA, Cruz del eje \\
\hline LR 169 & D1 & Sec. & & ABU & ARG SDE, Santiago del E. capital \\
\hline LR 170 & C1b & Sec. & & ABU & CHI, Tarca \\
\hline LR 171 & C & RFLP & & $A B U$ & ARG TUC, Tucumán Capital \\
\hline LR 172 & A & Sec. & & $A B U$ & ARG LRJ, La Rioja Capital \\
\hline LR 174 & B & RFLP & & S/D & S/D \\
\hline LR 175 & D1 & Sec. & & $A B U$ & ARG LRJ, La Rioja Capital \\
\hline
\end{tabular}


Anexo

\begin{tabular}{|c|c|c|c|c|c|}
\hline Rótulo & $\mathrm{Hg}$ & Método & RFLP info & UACM & Lugar de nacimiento \\
\hline LR 176 & C & RFLP & & $A B U$ & ARG LRJ, La Rioja Capital \\
\hline LR 177 & D & RFLP & & $A B U$ & ARG LRJ, La Rioja Capital \\
\hline LR 178 & D & RFLP & & $A B U$ & ARG TUC, Tucumán Capital \\
\hline LR 179 & $\mathrm{~B}$ & Sec. & & ABU & ARG LRJ SAN, Sanagasta \\
\hline LR 180 & $\mathrm{D}$ & RFLP & & ABU & ARG CAT, Andalgalá \\
\hline LR 181 & A & RFLP & & ABU & ARG, Capital Federal \\
\hline LR 182 & A & RFLP & & MA & ARG LRJ, La Rioja Capital \\
\hline LR 184 & A & RFLP & & $A B U$ & ARG SNJ \\
\hline LR 185 & $N(x A, B)$ & RFLP & & $A B U$ & ARG LRJ, La Rioja Capital \\
\hline LR 186 & $\mathrm{C}$ & RFLP & & MA & ARG LRJ, La Rioja Capital \\
\hline LR 187 & $B$ & RFLP & & $A B U$ & BOL Cochabamba Prov. Esteban Arce Tarata \\
\hline LR 188 & $\mathrm{D}$ & RFLP & & $A B U$ & ARG JUJ \\
\hline LR 189 & C1d & Sec. & & $A B U$ & ARG LRJ GOO, Catuna \\
\hline LR 190 & $\mathrm{D}$ & RFLP & & MA & ARG SNL \\
\hline LR 191 & B & RFLP & & ABU & ARG MZA, Rivadavia \\
\hline LR 192 & L1c1a2 & Sec. & & $A B U$ & ARG LRJ FAM, Famatina Atocarrizal \\
\hline LR 193 & $\mathrm{~A}$ & Sec. & & $A B U$ & ARG LRJ GOO, Milagro \\
\hline LR 194 & A & RFLP & & $A B U$ & ARG LRJ, La Rioja Capital \\
\hline LR 195 & A & Sec. & & $A B U$ & ARG LRJ CHI, Chilecito \\
\hline LR 196 & A & RFLP & & MA & ARG SNJ, Rawson \\
\hline LR 197 & $L(X M, N)$ & RFLP & & $A B U$ & ARG CBA \\
\hline LR 198 & $\mathrm{~B}$ & RFLP & & $A B U$ & ARG FOR, Formosa Capital \\
\hline LR BS 01 & C1b & Sec. & & $A B U$ & ARG LRJ AVP, Tama \\
\hline LR BS 02 & B & Sec. & & $A B U$ & ARG LRJ FAM, Antinaco \\
\hline LR BS 03 & $\mathrm{D}$ & RFLP & & MA & ARG ¿LRJ o CAT?, Tucumanao \\
\hline LR BS 04 & $\mathrm{H} 5$ & Sec. & & $A B U$ & ARG LRJ CB, Aminga \\
\hline LR BS 05 & C1d & Sec. & & $A B U$ & ARG LRJ GLM, Va. Castelli \\
\hline LR BS 06 & B & Sec. & & $A B U$ & ARG LRJ CHI, Anguinan \\
\hline LR BS 07 & $\mathrm{C} 1 \mathrm{~b}$ & Sec. & & $A B U$ & ARG LRJ JFQ, Nacate \\
\hline LR BS 08 & $\mathrm{D}$ & RFLP & & $A B U$ & ARG LRJ, LA Rioja capital \\
\hline LR BS 09 & A & RFLP & & $A B U$ & ARG SFE, Sta. Fe Capital \\
\hline LR BS 10 & $\mathrm{~B}$ & RFLP & & MA & ARG LRJ GOO, Milagro \\
\hline LR BS 11 & A & Sec. & & $A B U$ & ARG LRJ FVA, Villa Unión \\
\hline LR BS 12 & D1 & Sec. & & $A B U$ & ARG LRJ GOO, Olpas \\
\hline LR BS 13 & $N(x A, B)$ & RFLP & & MA & ÁRG CBA \\
\hline LR BS 14 & $\mathrm{D}$ & RFLP & & $A B U$ & ARG LRJ CHA, Puesto de las Riberas \\
\hline LR BS 15 & L3e3 & Sec. & & $A B U$ & ARG LRJ CHI, Malligasta \\
\hline LR BS 16 & C & RFLP & & S/D & S/D \\
\hline LR BS 17 & $N(x A, B)$ & RFLP & & $A B U$ & ARG LRJ, LA Rioja capital \\
\hline LR BS 18 & $\mathrm{D}$ & RFLP & & $A B U$ & ARG TUC, Monteros \\
\hline LR BS 19 & $\mathrm{D}$ & RFLP & & $A B U$ & ARG CAT, Copacabana \\
\hline LR BS 20 & J1a'b'e & Sec. & & $A B U$ & ARG LRJ ACO, Aimogasta \\
\hline LR BS 21 & D1 & Sec. & & MA & ARG LRJ ACO, Aimogasta \\
\hline LR BS 22 & C & RFLP & & MA & ARG LRJ, La Rioja capital \\
\hline LR BS 23 & $\mathrm{D}$ & RFLP & & $A B U$ & ARG LRJ, La Rioja capital \\
\hline LR BS 24 & $\mathrm{D}$ & RFLP & & $A B U$ & ARG CBA \\
\hline LR BS 25 & A & RFLP & & MA & ARG LRJ, La Rioja capital \\
\hline LR BS 26 & $\mathrm{D}$ & RFLP & & $A B U$ & ARG LRJ, Chamical \\
\hline LR BS 27 & $N(x A, B)$ & RFLP & & $A B U$ & ARG CAT \\
\hline LR BS 28 & $\mathrm{D}$ & RFLP & & $A B U$ & ARG LRJ, La Rioja capital \\
\hline LR BS 29 & HVOb'c & Sec. & & $A B U$ & ARG LRJ FMA, Chañarmuyo \\
\hline LR BS 30 & D1 & Sec. & & $A B U$ & ARG LRJ, La Rioja capital \\
\hline LR BS 31 & D1 & Sec. & & $A B U$ & ARG LRJ LRC, Talamuyuna \\
\hline LR BS 32 & $N(x A, B)$ & RFLP & & $A B U$ & ITALIA \\
\hline LR BS 33 & C & RFLP & & $A B U$ & ARG LRJ, La Rioja capital \\
\hline LR BS 34 & $\mathrm{D}$ & RFLP & & $A B U$ & ARG CAT, Medanito \\
\hline LR BS 35 & $N(x A, B)$ & RFLP & & $A B U$ & ARG CBA \\
\hline LR BS 36 & D1 & Sec. & & $A B U$ & ARG LRJ VCH, Jagüé \\
\hline LR BS 37 & B & Sec. & & $A B U$ & ARG LRJ CHA (a $15 \mathrm{~km}$. De Chamical) \\
\hline LR BS 38 & D1 & Sec. & & MA & ARG LRJ, Chilecio \\
\hline LR BS 39 & B & RFLP & & $A B U$ & ARG SNJ, Jáchal \\
\hline LR BS 40 & C & RFLP & & $A B U$ & ARG LRJ, La Rioja capital \\
\hline LR BS 41 & D & RFLP & & MA & ARG LRJ, La Rioja capital \\
\hline LR BS 42 & $N(x A, B)$ & RFLP & & $A B U$ & ARG CAT \\
\hline LR BS 43 & B & Sec. & & $A B U$ & ARG LRJ, Chamical \\
\hline LR BS 44 & $N(x A, B)$ & RFLP & & $A B U$ & ARG ERI, Gualeguay \\
\hline LR BS 45 & $\mathrm{H} 5$ & Sec. & & $A B U$ & ARG LRJ, Cuesta de Miranda \\
\hline LR BS 46 & $N(x A, B)$ & RFLP & & $A B U$ & ARG CBA, Cruz del Eje \\
\hline
\end{tabular}


Anexo

\begin{tabular}{|c|c|c|c|c|c|}
\hline Rótulo & $\mathrm{Hg}$ & Método & RFLP info & UACM & Lugar de nacimiento \\
\hline \multicolumn{6}{|c|}{ MAIMARA } \\
\hline MM 001 & B & AFLP & & DO & ARG JUJ TIL, Maimará \\
\hline MM 002 & B & AFLP y sec. & & $A B U$ & ARG JUJ YAV, Pulpera \\
\hline MM 003 & $\mathrm{~B}$ & AFLP & & DO & ARG JUJ TIL, Tilcara \\
\hline MM 004 & $\mathrm{~B}$ & AFLP y sec. & & MA & ARG JUJ HUM, Hornaditas \\
\hline MM 005 & $B$ & AFLP & & DO & ARG JUJ TIL, Maimará \\
\hline MM 006 & A & AFLP & & MA & ARG SAL CAP, Salta Capital \\
\hline MM 007 & $\mathrm{~B}$ & AFLP y sec. & & ABU & ARG JUJ SUS, Huancar \\
\hline MM 009 & $B$ & AFLP y sec. & & $A B U$ & BOL \\
\hline MM 010 & B & AFLP y sec. & & ABU & ARG SAL IRU, Rodeo Colorado \\
\hline MM 011 & B & AFLP y sec. & & $A B U$ & BOL POT, Potosí \\
\hline MM 012 & B & AFLP y sec. & & MA & BOL COC, Cochabamba \\
\hline MM 013 & B & AFLP & & $A B U$ & ARG JUJ COC, Cochinoca \\
\hline MM 014 & B & AFLP y sec. & & $A B U$ & BOL TAR, Villazón San Marco \\
\hline MM 016 & B & AFLP y sec. & & $A B U$ & ARG JUJ TIL, Juella \\
\hline MM 017 & C & AFLP y sec. & & $A B U$ & BOL MISTE, Huanacuno \\
\hline MM 018 & $\mathrm{Nx}(\mathrm{A}, \mathrm{B})$ & AFLP & & $A B U$ & Siria \\
\hline MM 019 & $B$ & AFLP y sec. & & $A B U$ & ARG JUJ BEL, SSJ \\
\hline MM 020 & C & AFLP y sec. & & ABU & $\mathrm{BOL}$ \\
\hline MM 021 & $\mathrm{C}$ & AFLP y sec. & & $A B U$ & ARG JUJ TIL, Maimará \\
\hline MM 022 & $B$ & AFLP y sec. & & $A B U$ & ARG JUJ TIL, Maimará \\
\hline MM 023 & C & AFLP y sec. & & $A B U$ & ARG JUJ TIL, Las Ánimas \\
\hline MM 024 & B & AFLP y sec. & & $A B U$ & ARG JUJ TIL, Juella \\
\hline MM 025 & $\mathrm{D}$ & AFLP y sec. & & $A B U$ & ARG JUJ TIL, El Perchel \\
\hline MM 026 & $B$ & AFLP & & DO & ARG JUJ TIL, Maimará \\
\hline MM 027 & A & AFLP y sec. & & $A B U$ & ARG JUJ LED, Yuto \\
\hline MM 028 & $\mathrm{D}$ & AFLP y sec. & & $A B U$ & ARG JUJ TIL, Juella \\
\hline MM 029 & $\mathrm{~B}$ & AFLP y sec. & & $A B U$ & ARG JUJ TIL, Yacoraite \\
\hline MM 030 & B & AFLP & & MA & ARG SAL CAN?, El Zapallar \\
\hline MM 031 & $\mathrm{~B}$ & AFLP y sec. & & $A B U$ & BOL? \\
\hline MM 032 & B & AFLP y sec. & & $A B U$ & ARG JUJ YAV, Abra Colorada \\
\hline MM 033 & B & AFLP y sec. & & $A B U$ & ARG JUJ HUM, Mina El Aguilar (Portillo) \\
\hline MM 034 & B & AFLP y sec. & & MA & ARG JUJ TIL, Tilcara \\
\hline MM 035 & B & AFLP y sec. & & $A B U$ & ARG JUJ TIL, Maimará \\
\hline MM 036 & B & AFLP y sec. & & $A B U$ & ARG JUJ HUM, Rodero \\
\hline MM 037 & A & AFLP y sec. & & $A B U$ & ARG JUJ COC, Abra Pampa \\
\hline MM 038 & B & AFLP y sec. & & ABU & BOL? \\
\hline MM 039 & B & AFLP y sec. & & $A B U$ & ARG JUJ HUM, Mina El Aguilar \\
\hline MM 040 & B & AFLP & & $A B U$ & BOL TAR, Villazón San Marco \\
\hline MM 041 & $\mathrm{D}$ & AFLP y sec. & & $A B U$ & ARG JUJ SUS, Susques \\
\hline MM 042 & B & AFLP y sec. & & MA & ARG JUJ VGR, Caspalá \\
\hline MM 043 & B & AFLP y sec. & & MA & ARG SAL GUE, Güemes \\
\hline MM 044 & $B$ & AFLP y sec. & & $A B U$ & ARG SAL CAP, Salta \\
\hline MM 045 & $B$ & AFLP y sec. & & $A B U$ & BOL SCZ, Santa Cruz de la Sierra \\
\hline MM 046 & A & AFLP y sec. & & MA & ARG JUJ COC, Abra Pampa \\
\hline MM 047 & C & AFLP y sec. & & $A B U$ & BOL \\
\hline MM 048 & B & AFLP y sec. & & MA & ARG SAL SVI, Santa Victoria \\
\hline MM 049 & B & AFLP y sec. & & $A B U$ & ARG JUJ YAV, Tafna \\
\hline MM 050 & $\mathrm{~B}$ & AFLP y sec. & & $A B U$ & BOL, La Paz \\
\hline MM 051 & B & AFLP y sec. & & $A B U$ & ARG JUJ HUM, Mina El Aguilar \\
\hline MM 052 & B & AFLP y sec. & & $A B U$ & ARG JUJ TIL, Maimará \\
\hline MM 053 & C & AFLP y sec. & & $A B U$ & ARG JUJ CAR, Los Lapachos \\
\hline MM 054 & B & AFLP y sec. & & $A B U$ & ARG JUJ TIL, Tilcara \\
\hline MM 055 & $\mathrm{~B}$ & AFLP y sec. & & MA & ARG JUJ TIL, Juella \\
\hline MM 056 & B & AFLP y sec. & & ABU & ARG JUJ TIL, Maimará \\
\hline MM 057 & $\mathrm{~B}$ & AFLP y sec. & & $A B U$ & ARG JUJ TUM, San José del Chañi \\
\hline MM 058 & $B$ & AFLP y sec. & & $A B U$ & ARG JUJ TUM, Purmamarca \\
\hline MM 059 & $B$ & AFLP y sec. & & $A B U$ & ARG JUJ TUM, Purmamarca \\
\hline MM 060 & B & AFLP y sec. & & $A B U$ & BOL COC, Cochabamba \\
\hline MM 062 & B & AFLP y sec. & & $A B U$ & ARG JUJ TIL, Huichaira \\
\hline MM 063 & B & AFLP y sec. & & $A B U$ & ARG JUJ TIL, Abra Mayo \\
\hline MM 064 & C & AFLP y sec. & & MA & ARG JUJ COC, Aguas Chicas \\
\hline MM 065 & $B$ & AFLP y sec. & & $A B U$ & $\mathrm{BOL}$ \\
\hline MM 066 & $\mathrm{D}$ & AFLP y sec. & & $A B U$ & ARG JUJ TIL, Huichaira \\
\hline MM 067 & C & AFLP y sec. & & MA & ARG JUJ COC, Abra Pampa o ARG JUJ HUM, El Aguilar \\
\hline MM 068 & B & AFLP & & DO & ARG JUJ PED, Ingenio La Esperanza \\
\hline MM 069 & B & AFLP y sec. & & MA & ARG JUJ HUM, Humahuaca \\
\hline MM 071 & A & AFLP & & $A B U$ & ARG JUJ YAV, La Quiaca \\
\hline MM 072 & B & AFLP y sec. & & MA & ARG JUJ TUM, El Moreno \\
\hline
\end{tabular}


Anexo

\begin{tabular}{|c|c|c|c|c|c|}
\hline Rótulo & $\mathrm{Hg}$ & Método & RFLP info & UACM & Lugar de nacimiento \\
\hline MM 073 & $\mathrm{C}$ & AFLP y sec. & & MA & ARG JUJ TIL, Molulo \\
\hline MM 074 & B & AFLP & & MA & ARG JUJ HUM, Mina El Aguilar \\
\hline MM 075 & A & AFLP y sec. & & $A B U$ & ARG SAL RDL, El Palomar \\
\hline MM 076 & A & AFLP y sec. & & $A B U$ & ARG SAL SVI, Santa Victoria \\
\hline MM 077 & $\mathrm{~B}$ & AFLP y sec. & & $A B U$ & BOL? \\
\hline MM 078 & $B$ & AFLP y sec. & & $A B U$ & BOL? \\
\hline MM 079 & $\mathrm{C}$ & AFLP y sec. & & $A B U$ & ARG JUJ TIL, El Durazno \\
\hline MM 080 & B & AFLP y sec. & & MA & ARG JUJ YAV, Aguada (cerca de Cerrillos) \\
\hline MM 081 & B & AFLP y sec. & & MA & ARG JUJ HUM, Casa Grande \\
\hline MM 082 & $B$ & AFLP y sec. & & ABU & ARG JUJ SUS, Susques \\
\hline MM 083 & B & AFLP y sec. & & $A B U$ & ARG JUJ TIL, Tilcara_hija de BOL \\
\hline MM 084 & $\mathrm{D}$ & AFLP y sec. & & MA & ARG JUJ TIL, Juella \\
\hline MM 085 & B & AFLP y sec. & & MA & ARG JUJ TIL, El Durazno \\
\hline MM 086 & B & AFLP y sec. & & $A B U$ & ARG JUJ TIL, Juella \\
\hline MM 087 & B & AFLP & & $A B U$ & ARG CAT SMA, Santa María \\
\hline MM 088 & B & AFLP y sec. & & $A B U$ & ARG JUJ YAV, Pulpera \\
\hline MM 089 & B & AFLP y sec. & & $A B U$ & ARG JUJ COC, Quebraleña \\
\hline MM 090 & $B$ & AFLP y sec. & & $A B U$ & ARG JUJ TIL, Huichaira \\
\hline MM 091 & B & AFLP y sec. & & ABU & ARG SAL \\
\hline MM 092 & $B$ & AFLP y sec. & & $A B U$ & ARG JUJ TUM, El Moreno \\
\hline MM 093 & A & AFLP y sec. & & $A B U$ & ARG SAL IRU, Iruya \\
\hline MM 094 & B & AFLP y sec. & & MA & ARG JUJ HUM, Mina El Aguilar \\
\hline MM 095 & B & AFLP & & DO & ARG JUJ HUM, Mina El Aguilar \\
\hline MM 096 & A & AFLP y sec. & & $A B U$ & ARG JUJ HUM, Rodero \\
\hline MM 097 & $B$ & AFLP y sec. & & $A B U$ & ARG JUJ HUM, Azulpampa \\
\hline MM 098 & $B$ & AFLP y sec. & & $A B U$ & ARG JUJ HUM, Tres Cruces \\
\hline MM 099 & C & AFLP y sec. & & MA & BOL \\
\hline MM 100 & C & AFLP y sec. & & ABU & BOL TAR, Tarija \\
\hline MM 101 & $\mathrm{D}$ & AFLP & & DO & ARG JUJ HUM, Negra Muerta \\
\hline MM 102 & $\mathrm{~B}$ & AFLP y sec. & & MA & PAR, Mbarigüí \\
\hline MM 103 & A & AFLP y sec. & & $A B U$ & ARG JUJ TIL, Quebrada Amarilla \\
\hline MM 104 & $\mathrm{Nx}(\mathrm{A}, \mathrm{B})$ & AFLP & & $A B U$ & ITA, Piamonte \\
\hline MM 105 & B & AFLP y sec. & & $A B U$ & ARG JUJ COC, Casabindo \\
\hline MM 106 & B & AFLP & & DO & ARG JUJ TUM, Purmamarca \\
\hline MM 107 & C & AFLP & & $A B U$ & URU \\
\hline MM 108 & A & AFLP y sec. & & $A B U$ & ARG SAL RIV?, Morillos \\
\hline MM 109 & B & AFLP & & $A B U$ & $\mathrm{BOL}$ \\
\hline MM 110 & $B$ & AFLP y sec. & & $A B U$ & ARG JUJ TUM, Purmamarca \\
\hline MM 112 & A & AFLP y sec. & & $A B U$ & $\mathrm{BOL}$ \\
\hline MM 113 & B & AFLP & & DO & ARG JUJ TIL, Tilcara \\
\hline MM 114 & B & AFLP & & DO & ARG JUJ TIL, Maimará \\
\hline MM 115 & B & AFLP y sec. & & $A B U$ & ARG JUJ TIL, Juella \\
\hline MM 116 & $B$ & AFLP & & $A B U$ & ARG JUJ TUM, Sepultura \\
\hline MM 117 & $B$ & AFLP & & MA & ARG JUJ BEL, SSJ \\
\hline MM 118 & $\mathrm{D}$ & AFLP y sec. & & $A B U$ & $\mathrm{BOL}$ \\
\hline MM 119 & B & AFLP y sec. & & $A B U$ & ARG JUJ COC, Abra Pampa \\
\hline MM 120 & A & AFLP y sec. & & $A B U$ & ARG JUJ RIN, Mina Pirquitas \\
\hline MM 121 & B & AFLP & & DO & ARG JUJ TIL, Tilcara \\
\hline MM 122 & B & AFLP y sec. & & MA & ARG JUJ HUM, Humahuaca \\
\hline MM 123 & B & AFLP y sec. & & MA & ARG JUJ HUM, Humahuaca \\
\hline MM 124 & B & AFLP y sec. & & $A B U$ & ARG JUJ TUM, Rinconadilla \\
\hline MM 125 & B & AFLP y sec. & & $A B U$ & PER \\
\hline MM 126 & B & AFLP y sec. & & $A B U$ & BOL COC, Quillacoyo \\
\hline MM 127 & B & AFLP y sec. & & $A B U$ & ARG JUJ TIL, Maimará \\
\hline MM 128 & B & AFLP y sec. & & MA & BOL TAR, Tarija \\
\hline MM 129 & B & AFLP y sec. & & $A B U$ & ARG JUJ TUM, Volcán \\
\hline MM 130 & $B$ & AFLP y sec. & & $A B U$ & ARG JUJ TUM, Purmamarca \\
\hline MM 131 & $B$ & AFLP & & MA & ARG JUJ TIL, Maimará \\
\hline MM 132 & A & AFLP y sec. & & MA & ARG JUJ COC, Quera \\
\hline MM 133 & C & AFLP y sec. & & $A B U$ & ARG JUJ TUM, Purmamarca \\
\hline MM 134 & B & AFLP y sec. & & MA & ARG JUJ TUM, Purmamarca \\
\hline MM 135 & $B$ & AFLP y sec. & & $A B U$ & ARG JUJ TUM, Chañi Grande \\
\hline MM 136 & C & AFLP y sec. & & $A B U$ & $\mathrm{CHI}$ \\
\hline MM 137 & B & AFLP y sec. & & ABU & ARG JUJ HUM, Mina El Aguilar \\
\hline MM 138 & $\mathrm{~B}$ & AFLP y sec. & & ABU & ARG JUJ HUM, Mina El Aguilar \\
\hline MM 139 & B & AFLP y sec. & & MA & ARG JUJ TIL, Maimará \\
\hline MM 140 & $\mathrm{D}$ & AFLP & & DO & ARG JUJ TIL, Maimará \\
\hline MM 141 & B2 & Sec. & & $A B U$ & ARG JUJ HUM, Mina El Aguilar \\
\hline MM 142 & B & AFLP y sec. & & MA & ARG JUJ TUM, Cienaguillas \\
\hline
\end{tabular}


Anexo

\begin{tabular}{|c|c|c|c|c|c|}
\hline Rótulo & $\mathrm{Hg}$ & Método & RFLP info & UACM & Lugar de nacimiento \\
\hline MM 143 & A & AFLP y sec. & & MA & ARG JUJ COC, Queta \\
\hline MM Pur 01 & B & AFLP y sec. & & $A B U$ & ARG JUJ TUM, Lipán \\
\hline MM Pur 02 & A & AFLP y sec. & & $A B U$ & ARG JUJ TUM, El Moreno? \\
\hline MM Pur 03 & $\mathrm{~B}$ & AFLP y sec. & & $A B U$ & ARG JUJ TIL, Maimará \\
\hline MM Pur 04 & $\mathrm{~B}$ & AFLP y sec. & & MA & ARG JUJ RIN, Casa Colorada \\
\hline MM Pur 06 & B & AFLP y sec. & & $A B U$ & ARG JUJ TUM, Tucsa (cerca de Colorado) \\
\hline MM Pur 08 & $B$ & AFLP y sec. & & $A B U$ & ARG JUJ TUM, Purmamarca \\
\hline MM Pur 09 & B & AFLP y sec. & & ABU & ARG SAL \\
\hline MM Pur 10 & B & AFLP y sec. & & ABU & ARG JUJ COC, Vicuñayoc (cerca de El Aguilar) \\
\hline MM Pur 11 & B & AFLP y sec. & & $A B U$ & ARG JUJ COC, Tusaquía \\
\hline MM Pur 12 & B & AFLP y sec. & & $A B U$ & ARG JUJ TUM, La Ciénaga \\
\hline MM Pur 13 & B & AFLP y sec. & & $A B U$ & ARG JUJ TUM, Potrero Grande \\
\hline MM Pur 14 & A & AFLP y sec. & & MA & ARG JUJ TUM, Tumbaya \\
\hline MM Pur 15 & A & AFLP y sec. & & $A B U$ & ARG JUJ COC, Abra Pampa \\
\hline MM Pur 16 & C & AFLP y sec. & & $A B U$ & ARG JUJ TUM, Lipán \\
\hline MM Pur 17 & B & AFLP y sec. & & $A B U$ & BOL \\
\hline MM Pur 18 & A & AFLP y sec. & & $A B U$ & ARG JUJ TUM, Purmamarca \\
\hline MM Pur 20 & $\mathrm{~B}$ & AFLP y sec. & & $A B U$ & ARG JUJ TUM, Rinconadilla \\
\hline MM Pur 21 & B & AFLP y sec. & & $A B U$ & ARG JUJ TUM, El Moreno \\
\hline MM Pur 22 & B & AFLP & & MA & ARG JUJ BEL, SSJ \\
\hline MM Pur 25 & B & AFLP y sec. & & MA & ARG JUJ TUM, San José del Chañi \\
\hline MM Pur 26 & B & AFLP y sec. & & $A B U$ & ARG JUJ TUM, Moreno Chico \\
\hline MM Pur 27 & B & AFLP y sec. & & $A B U$ & ARG JUJ TUM, El Moreno \\
\hline MM Pur 28 & B & AFLP y sec. & & $A B U$ & ARG SAL LAN, Sansana \\
\hline MM Pur 29 & B & AFLP y sec. & & $A B U$ & ARG JUJ TUM, San José del Chañi \\
\hline MM Pur 30 & $B$ & AFLP y sec. & & $A B U$ & ARG JUJ TUM, Rinconadilla \\
\hline MM Pur 31 & A & AFLP y sec. & & $A B U$ & ARG JUJ TUM, San José del Chañi \\
\hline MM Pur 34 & B & AFLP y sec. & & MA & ARG JUJ TUM, Huachichocana \\
\hline MM Pur 35 & B & AFLP y sec. & & $A B U$ & ARG SAL IRU, San Juan (cerca de Iruya) \\
\hline MM Pur 36 & C & AFLP y sec. & & $A B U$ & ARG JUJ HUM, Humahuaca \\
\hline MM Pur 37 & B & AFLP & & MA & ARG JUJ BEL, SSJ \\
\hline MM Pur 38 & B & AFLP y sec. & & $A B U$ & ARG SAL SVI, Santa Victoria \\
\hline MM Pur 39 & C & AFLP y sec. & & $A B U$ & BOL SCZ, Santa Cruz de la Sierra \\
\hline MM Pur 40 & B & AFLP & & MA & ARG JUJ BEL, San Bernardo \\
\hline MM Pur 41 & B & AFLP y sec. & & $A B U$ & ARG JUJ TUM, Volcán \\
\hline MM Pur 42 & $B$ & AFLP & & DO & ARG JUJ TIL, Maimará \\
\hline MM Tum 01 & B & AFLP y sec. & & MA & ARG JUJ TIL, Maimará \\
\hline MM Tum 02 & B & AFLP y sec. & & MA & ARG JUJ TUM, Tumbaya Grande \\
\hline MM Tum 03 & B & AFLP y sec. & & $A B U$ & ARG JUJ TUM, Salvear (Tumbaya Grande) \\
\hline MM Tum 04 & B & AFLP y sec. & & MA & BOL TAR, Uyuni \\
\hline MM Tum 06 & B & AFLP y sec. & & $A B U$ & ARG JUJ TIL, Huacalera \\
\hline MM Tum 07 & B & AFLP y sec. & & $A B U$ & ARG JUJ TIL, Maimará \\
\hline MM Tum 08 & C & AFLP y sec. & & $A B U$ & ARG JUJ TUM, Tumbaya \\
\hline MM Tum 09 & C & AFLP y sec. & & MA & ARG JUJ TIL, Yala de Monte Carmelo \\
\hline MM Tum 10 & $\mathrm{D}$ & AFLP y sec. & & $A B U$ & ARG JUJ TUM, Punta Corral \\
\hline MM Tum 11 & A & AFLP y sec. & & $A B U$ & ARG JUJ TUM, Tumbaya Grande \\
\hline MM Tum 13 & A & AFLP y sec. & & $A B U$ & ARG JUJ TUM, Tunalito (cerca de Maimará) \\
\hline MM Tum 14 & C & AFLP y sec. & & MA & ARG JUJ TUM o BEL, Bárcena \\
\hline MM Tum 15 & B & AFLP y sec. & & MA & ARG JUJ TIL, Maimará \\
\hline MM Tum 20 & B & AFLP y sec. & & $A B U$ & ARG JUJ TUM, Punta Corral \\
\hline MM Tum 21 & B & AFLP y sec. & & $A B U$ & ARG JUJ TUM, Punta Corral \\
\hline MM Tum 22 & B & AFLP y sec. & & $A B U$ & ARG JUJ TUM, San Bernardo \\
\hline MM Tum 23 & B & AFLP y sec. & & $A B U$ & ARG JUJ TUM, Punta Corral \\
\hline \multicolumn{6}{|l|}{ MENDOZA } \\
\hline MZ 001 & $\mathrm{~N}(\mathrm{xAB})$ & RFLP & & $A B U$ & URUGUAY \\
\hline MZ 002 & $N(x A B)$ & RFLP & & MA & ARG MZA, Mendoza capital \\
\hline MZ 003 & D & RFLP & & DO & ARG MZA, Godoy Cruz \\
\hline MZ 004 & $N(x A B)$ & RFLP & & MA & ARG BS AS, Chavez \\
\hline MZ 005 & $\mathrm{C}$ & RFLP & & $A B U$ & ARG SJN \\
\hline MZ 006 & $\mathrm{~N}(\mathrm{xAB})$ & RFLP & & $A B U$ & ITALIA? \\
\hline MZ 007 & A & Sec. & & $A B U$ & ARG MZA \\
\hline MZ 008 & A & Sec. & & $A B U$ & ARG CBA \\
\hline MZ 010 & B & Sec. & & ABU & BOL TAR \\
\hline MZ 012 & D1 & Sec. & & DO & ARG MZA, Bermejo \\
\hline MZ 013 & D & RFLP & & MA & BOL \\
\hline MZ 015 & B & Sec. & & $A B U$ & BOL \\
\hline MZ 016 & C & RFLP & & MA & ARG SNJ, Pocitos \\
\hline MZ 017 & $\mathrm{C} 1 \mathrm{~b}$ & Sec. & & $A B U$ & ARG SAL GGM, General Güemes \\
\hline
\end{tabular}


Anexo

\begin{tabular}{|c|c|c|c|c|c|}
\hline Rótulo & $\mathrm{Hg}$ & Método & RFLP info & UACM & Lugar de nacimiento \\
\hline MZ 018 & $\mathrm{~B}$ & Sec. & & $A B U$ & ARG MZA \\
\hline MZ 019 & C1d & Sec. & & $A B U$ & ARG SDE, Herrera? \\
\hline $\mathrm{MZ} 020$ & $\mathrm{H}$ & Sec. & & S/D & S/D \\
\hline MZ 021 & D1 & Sec. & & $A B U$ & ARG SNJ \\
\hline MZ 022 & D1 & Sec. & & $A B U$ & ARG MZA \\
\hline MZ 023 & A & RFLP & & MA & ARG LRJ \\
\hline MZ 024 & $N(x A B)$ & RFLP & & $A B U$ & ITALIA, Sicilia \\
\hline MZ 025 & L3e2b & Sec. & & $A B U$ & ARG SNJ \\
\hline MZ 026 & $\mathrm{D}$ & RFLP & & MA & ARG MZA \\
\hline MZ 027 & A & Sec. & & $A B U$ & ARG MZA \\
\hline MZ 028 & L3f1b1 & Sec. & & $A B U$ & ITALIA \\
\hline MZ 029 & $N(x A B)$ & RFLP & & $A B U$ & ITALIA, Carrara \\
\hline MZ 030 & A & RFLP & & $A B U$ & ESPAÑA, Toledo \\
\hline MZ 031 & $\mathrm{D}$ & RFLP & & $A B U$ & ESPAÑA \\
\hline MZ 032 & $N(x A B)$ & Sec. & $\begin{array}{l}\text { Región V 9bp } \\
\text { por triplicado }\end{array}$ & $A B U$ & ESPAÑA \\
\hline MZ 033 & A & Sec. & & $A B U$ & ARG SNL? \\
\hline MZ 034 & B & Sec. & & $A B U$ & $\mathrm{BOL}$ \\
\hline MZ 035 & A & Sec. & & $A B U$ & Chi, Santiago \\
\hline MZ 036 & $N(x A B)$ & RFLP & & $A B U$ & ARG MZA, Mendoza capital \\
\hline MZ 037 & $B$ & Sec. & & $A B U$ & ARG MZA, San Martín \\
\hline MZ 038 & $N(x A B)$ & RFLP & & $A B U$ & ARG MZA \\
\hline MZ 039 & C1b & Sec. & & $A B U$ & ARG MZA, san Carlos \\
\hline MZ 040 & $\mathrm{C} 1 \mathrm{~b}$ & Sec. & & $A B U$ & ARG MZA \\
\hline MZ 041 & D1 & Sec. & & $A B U$ & ARG SNJ \\
\hline MZ 042 & L3e1 & Sec. & & $A B U$ & ARG, Cap. Fed. \\
\hline MZ 050 & B & Sec. & & $A B U$ & ARG MZA, Malrgüe \\
\hline MZ 051 & A & Sec. & & $A B U$ & ARG MZA, mendoza capital \\
\hline MZ 052 & D1 & Sec. & & $A B U$ & ARG SNL, Quines (al norte) \\
\hline MZ 053 & $N(x A B)$ & RFLP & & $A B U$ & ARG MZA \\
\hline MZ 054 & $\mathrm{D}$ & RFLP & & $A B U$ & ARG SNJ \\
\hline MZ 055 & B & Sec. & & $A B U$ & ARG MZA \\
\hline MZ 056 & C & RFLP & & MA & ARG MZA \\
\hline MZ 057 & $\mathrm{C} 1 \mathrm{~b}$ & Sec. & & $A B U$ & ARG MZA? \\
\hline MZ 058 & D1 & Sec. & & $A B U$ & ARG SNJ ¿de Astica o Valle fértil? \\
\hline MZ 059 & $\mathrm{H}$ & Sec. & & $A B U$ & ARG MZA \\
\hline MZ 060 & L2Ac1 & Sec. & & $A B U$ & ARG MZA, Luján de Cuyo \\
\hline MZ 061 & H5 & Sec. & & $A B U$ & ARG MZA \\
\hline MZ 062 & $N(x A B)$ & RFLP & & MA & ARG MZA \\
\hline MZ 063 & A & RFLP & & MA & ARG SNJ, San Juan Capital \\
\hline MZ 064 & C1b & Sec. & & $A B U$ & CHILE, Temuco \\
\hline MZ 065 & B & RFLP & & $A B U$ & ARG SAL \\
\hline MZ 066 & A & RFLP & & $A B U$ & ARG MZA \\
\hline MZ 067 & C & RFLP & & $A B U$ & ARG SNJ \\
\hline MZ 068 & C1b & Sec. & & $A B U$ & ARG SNL \\
\hline MZ 069 & A & RFLP & & MA & ARG MZA LAV \\
\hline MZ 070 & C & RFLP & & $A B U$ & ITALIA \\
\hline MZ 071 & C & RFLP & & MA & BOL \\
\hline MZ 073 & D1 & Sec. & & $A B U$ & ARG SNJ? \\
\hline MZ 074 & A & RFLP & & $A B U$ & ARG MZA \\
\hline MZ 075 & $\mathrm{C}$ & RFLP & & $A B U$ & URU, San josé \\
\hline MZ 076 & D1 & Sec. & & $A B U$ & ARG LPMP, Victorica \\
\hline MZ 077 & $\mathrm{H}$ & Sec. & & $A B U$ & ARG MZA, Las Heras \\
\hline MZ 078 & B & RFLP & & $A B U$ & ARG? \\
\hline MZ 079 & $\mathrm{~L} 3 \mathrm{~b}$ & Sec. & & $A B U$ & ARG MZA, Guaymallén \\
\hline MZ 080 & $N(x A B)$ & RFLP & & $A B U$ & ESPAÑA \\
\hline MZ 081 & $\mathrm{D}$ & RFLP & & $A B U$ & ARG MZA, Guaymallén \\
\hline MZ 082 & $N(x A B)$ & RFLP & & $A B U$ & ESPAÑA \\
\hline MZ 083 & $N(x A B)$ & RFLP & & $A B U$ & ARG MZA, Maipú \\
\hline MZ 084 & L3b & Sec. & & $A B U$ & ARG CBA RIO $2^{\circ}$ \\
\hline MZ 085 & L2a1 & Sec. & & MA & ARG MZA, Mendoza Capital \\
\hline MZ 086 & $B$ & RFLP & & $A B U$ & ARG SNJ, Caucete \\
\hline MZ 087 & C1b & Sec. & & $A B U$ & ARG MZA LUJ, Chacra de Coria \\
\hline MZ 088 & A & Sec. & & $A B U$ & ARG MZA \\
\hline MZ 089 & $N(x A B)$ & RFLP & & MA & ARG MZA, Mendoza Capital \\
\hline MZ 090 & D & RFLP & & $A B U$ & CHILE \\
\hline MZ 091 & A & Sec. & & MA & ARG MZA, Tunuyán \\
\hline MZ 092 & $N(x A B)$ & RFLP & & $A B U$ & ARG MZA \\
\hline MZ 093 & $B$ & RFLP & & $A B U$ & ARG SNJ \\
\hline
\end{tabular}


Anexo

\begin{tabular}{|c|c|c|c|c|c|}
\hline Rótulo & $\mathrm{Hg}$ & Método & RFLP info & UACM & Lugar de nacimiento \\
\hline MZ 094 & C & RFLP & & MA & ARG SNJ \\
\hline MZ 095 & K1b2 & Sec. & & $A B U$ & ITALIA \\
\hline MZ 096 & $N(x A B)$ & RFLP & & $A B U$ & ARG MZA \\
\hline MZ 097 & $N(x A B)$ & RFLP & & $A B U$ & ARG MZA \\
\hline MZ 098 & D & RFLP & & $A B U$ & ARG SNJ \\
\hline MZ 099 & B & RFLP & & $A B U$ & ARG SNJ \\
\hline MZ 100 & C & RFLP & & $A B U$ & ARG LRJ \\
\hline MZ 101 & A & Sec. & & ABU & ARG MZA, General Alvear \\
\hline MZ 102 & $B$ & RFLP & & $A B U$ & ARG SNJ, San Juan Capital \\
\hline MZ 103 & C & RFLP & & $A B U$ & ARG JUJ, San Salvador de Jujuy \\
\hline MZ 104 & C & RFLP & & MA & ARG MZA \\
\hline MZ 105 & D & RFLP & & $A B U$ & ARG MZA, Tunuyán \\
\hline MZ 106 & D1 & Sec. & & $A B U$ & $\mathrm{BOL}$ \\
\hline MZ 107 & D1 & Sec. & & $A B U$ & CHILE \\
\hline MZ 108 & A & RFLP & & $A B U$ & ARG SNJ, San Juan capital \\
\hline MZ 109 & $B$ & Sec. & & $A B U$ & ARG MZA, Las Heras \\
\hline MZ 110 & $B$ & RFLP & & $A B U$ & ARG MZA \\
\hline MZ 111 & C1b & Sec. & & $A B U$ & ARG SNJ BARRIAL \\
\hline MZ 112 & D1 & Sec. & & $A B U$ & ARG LRJ CHEPES \\
\hline MZ 114 & $\mathrm{C} 1 \mathrm{c}$ & Sec. & & $A B U$ & CHILE II REGION? \\
\hline MZ 115 & D1 & Sec. & & $A B U$ & ARG MZA, Mendoza Capital \\
\hline MZ 116 & C1d & Sec. & & $A B U$ & ARG MZA \\
\hline MZ 117 & $\mathrm{H}$ & Sec. & & $A B U$ & ARG MZA, Maipú \\
\hline MZ 118 & $\mathrm{D}$ & RFLP & $\begin{array}{l}\text { Región V } \\
\text { triplicada }\end{array}$ & MA & ARG MZA, San Rafael \\
\hline MZ 119 & A & Sec. & & $A B U$ & ARG MZA, San Rafael \\
\hline MZ 120 & A & RFLP & & $A B U$ & ARG MZA \\
\hline MZ 121 & B & RFLP & & DO & ARG MZA, Guaymallen \\
\hline MZ 123 & D & RFLP & & $A B U$ & ITALIA \\
\hline MZ 124 & B & RFLP & & S/D & S/D \\
\hline MZ 125 & D1 & Sec. & & $A B U$ & ARG SNL \\
\hline MZ 126 & A & Sec. & & $A B U$ & ARG MZA, San Rafael \\
\hline MZ 127 & $\mathrm{H}$ & Sec. & & $A B U$ & ARG MZA, San Rafael \\
\hline MZ 128 & L3e2b & Sec. & & $A B U$ & ARG MZA, Guaymallén \\
\hline MZ 130 & C1d & Sec. & & $A B U$ & ARG SNJ \\
\hline MZ 131 & D1 & Sec. & & $A B U$ & BOL \\
\hline MZ 132 & $N(x A B)$ & RFLP & & MA & ARG MZA \\
\hline MZ 133 & $N(x A B)$ & RFLP & & $A B U$ & ESPAÑA \\
\hline MZ 134 & C & RFLP & & $A B U$ & ARG SNJ \\
\hline MZ 135 & C & RFLP & & MA & ARG \\
\hline MZ 136 & $B$ & RFLP & & $A B U$ & ARG BS AS \\
\hline MZ 137 & $\mathrm{H}$ & Sec. & & $A B U$ & BRASIL \\
\hline MZ 138 & $N(x A B)$ & RFLP & & $A B U$ & ARG MZA \\
\hline MZ 139 & $\mathrm{D}$ & RFLP & & $A B U$ & ARG MZA, Junín \\
\hline MZ 140 & C1b & Sec. & & MA & ARG MZA, Malargüe \\
\hline MZ 141 & A & Sec. & & $A B U$ & ARG SDE \\
\hline MZ 142 & B & Sec. & & $A B U$ & ARG MZA \\
\hline MZ 143 & D1 & Sec. & & $A B U$ & ARG MZA, Rivadavia \\
\hline MZ 144 & $\mathrm{C} 1 \mathrm{~b}$ & Sec. & & $A B U$ & ARG SNL, Villa Mercedes \\
\hline MZ 145 & L3f1b1 & Sec. & & DO & ARG MZA, Mendoza capital \\
\hline MZ 146 & $\mathrm{C} 1 \mathrm{~b}$ & Sec. & & $A B U$ & ARG MZA, General Alvear \\
\hline MZ 147 & L3f1b1 & Sec. & & $A B U$ & ARG MZA JUNIN de CUYO, Medrano \\
\hline MZ 148 & A & RFLP & & $A B U$ & ARG MZA \\
\hline MZ 149 & B & RFLP & & $A B U$ & ARG MZA \\
\hline MZ 150 & D1 & Sec. & & $A B U$ & ARG MZA \\
\hline MZ Sal 02 & $\mathrm{C} 1 \mathrm{c}$ & RFLP y Sec. & 13263 rev. & $A B U$ & ARG MZA, Rivadavia \\
\hline MZ Sal 03 & A & RFLP y Sec. & & $A B U$ & Mza, Sta Rosa \\
\hline MZ Sal 15 & D1 & RFLP y Sec. & & $A B U$ & Mza, San Rafael, Las Malvinas \\
\hline MZ Sal 01 & B & RFLP & & $A B U$ & BOL \\
\hline MZ Sal 16 & & RFLP & & ABU & ARG RNE \\
\hline \multicolumn{6}{|l|}{ SAN JUAN } \\
\hline SJ JA 01 & $\mathrm{C} 1 \mathrm{~b}$ & Sec. & & $A B U$ & ARG SJN JAC, Jáchal \\
\hline SJ JA 02 & $\mathrm{C} 1 \mathrm{~b}$ & Sec. & & MA & ARG SJN JAC, Jáchal \\
\hline SJ JA 03 & B & Sec. & & DO & ARG SJN JAC, Jáchal \\
\hline SJ JA 04 & U6a & Sec. & & $A B U$ & CHILE \\
\hline SJ JA 05 & D1 & Sec. & & $A B U$ & ARG SJN JAC, Jáchal \\
\hline SJ JA 06 & $\mathrm{C} 1 \mathrm{~b}$ & Sec. & & $A B U$ & ARG SNJ IGL, Iglesia \\
\hline SJ JA 07 & A & Sec. & & $A B U$ & ARG SJN JAC, Jáchal \\
\hline
\end{tabular}


Anexo

\begin{tabular}{|c|c|c|c|c|c|}
\hline Rótulo & $\mathrm{Hg}$ & Método & RFLP info & UACM & Lugar de nacimiento \\
\hline SJ JA 08 & B & Sec. & & $A B U$ & ARG SJN JAC, Jáchal \\
\hline SJ JA 09 & B & Sec. & & DO & ARG SJN JAC, Jáchal \\
\hline SJ JA 10 & $\mathrm{D} 1$ & Sec. & & $A B U$ & ARG SJN JAC, Jáchal \\
\hline SJ JA 12 & C1d & Sec. & & ABU & ARG SJN JAC, Huaco \\
\hline SJ JA 13 & C1d & Sec. & & $A B U$ & ARG COR PDL, Paso de los Libres \\
\hline SJ JA 14 & U5a & Sec. & & $A B U$ & ARG SNJ CAP, San Juan \\
\hline SNJ 001 & $\mathrm{C} 1 \mathrm{~b}$ & Sec. & & $A B U$ & ARG SNJ POC, Pocito \\
\hline SNJ 002 & C4c & Sec. & & $A B U$ & ARG SNJ CAU, Caucete \\
\hline SNJ 003 & B2 & Sec. & & MA & ARG SNJ ULL \\
\hline SNJ 004 & B2 & Sec. & & MA & ARG SNJ CAP, San Juan \\
\hline SNJ 005 & D1 & Sec. & & $A B U$ & ARG SNJ VFE, Valle Fértil \\
\hline SNJ 006 & $\mathrm{Nx}(\mathrm{A}, \mathrm{B})$ & AFLP & & $A B U$ & ESPAÑA \\
\hline SNJ 008 & $\mathrm{~A} 2$ & Sec. & & $A B U$ & ARG SNJ RIV, La Bebida \\
\hline SNJ 009 & D4h3 & Sec. & & $A B U$ & ARG SNJ SAR, Va. Media Agua \\
\hline SNJ 010 & A2 & Sec. & & $A B U$ & ARG SNJ SAR, Va. Media Agua \\
\hline SNJ 011 & A2 & Sec. & & MA & ARG SNJ \\
\hline SNJ 012 & C4c & Sec. & & $A B U$ & ARG LRJ \\
\hline SNJ 013 & $\mathrm{D} 1$ & Sec. & & $A B U$ & ARG SNJ CAP, San Juan \\
\hline SNJ 014 & C1d & Sec. & & $A B U$ & ARG SNJ VFE, La Majadita \\
\hline SNJ 015 & $\mathrm{~B} 2$ & Sec. & & MA & ARG SNJ CAP, San Juan \\
\hline SNJ 016 & C1c & Sec. & Alul 13262+ & $A B U$ & ARG SNJ CAP, San Juan \\
\hline SNJ 017 & A2 & Sec. & & $A B U$ & ARG SNJ JAC, Jáchal \\
\hline SNJ 018 & $\mathrm{~A} 2$ & Sec. & & $A B U$ & ARG LRJ GBE, Bella Vista \\
\hline SNJ 019 & U6a & Sec. & & $A B U$ & ARG SNJ \\
\hline SNJ 020 & $\mathrm{x} 2 \mathrm{~b}$ & Sec. & & $A B U$ & ARG SNJ \\
\hline SNJ 021 & $\mathrm{~A} 2$ & Sec. & & $A B U$ & ARG SNJ CAP, San Juan \\
\hline SNJ 023 & $\mathrm{~A} 2$ & Sec. & & $A B U$ & ARG LRJ GBE, Bella Vista \\
\hline SNJ 024 & $\mathrm{C} 1 \mathrm{~b}$ & Sec. & & $A B U$ & ARG SNJ \\
\hline SNJ 025 & $\mathrm{C} 1 \mathrm{~b}$ & Sec. & & MA & ARG SNJ CAP, San Juan \\
\hline SNJ 026 & D1 & Sec. & & $A B U$ & CHILE \\
\hline SNJ 027 & B2 & Sec. & & $A B U$ & ARG SNJ CAL, Calingasta \\
\hline SNJ 028 & $\mathrm{~A} 2$ & Sec. & & $A B U$ & ARG SNL CAP, San Luis \\
\hline SNJ 029 & C1b & Sec. & & $A B U$ & ARG LRJ RVP, Chepes \\
\hline SNJ 030 & $\mathrm{~A} 2$ & Sec. & & MA & ARG SNJ \\
\hline SNJ 031 & $\mathrm{C} 1 \mathrm{~b}$ & Sec. & & $A B U$ & ARG SNJ VDM \\
\hline SNJ 032 & B2 & Sec. & & $A B U$ & ARG SNJ \\
\hline SNJ 033 & B2 & Sec. & & $A B U$ & ARG SNJ \\
\hline SNJ 034 & B2 & Sec. & & MA & ARG SNJ VFE, Valle Fértil \\
\hline SNJ 035 & L3e2 & Sec. & & $A B U$ & ARG SNJ VFE, Valle Fértil \\
\hline SNJ 037 & C1b & Sec. & & $A B U$ & ARG SNJ CAL, Calingasta \\
\hline SNJ 038 & B2 & Sec. & & MA & ARG SNJ CAP, San Juan \\
\hline SNJ 039 & A2 & Sec. & & $A B U$ & ARG SNJ CAP, San Juan \\
\hline SNJ 040 & B2 & Sec. & & $A B U$ & ARG SNJ CAL, Puchuzún \\
\hline SNJ 041 & D1 & Sec. & & $A B U$ & ARG MZA \\
\hline SNJ 042 & $\mathrm{C} 1 \mathrm{~b}$ & Sec. & & MA & ARG SNJ RAW, Rawson \\
\hline SNJ 043 & $\mathrm{C} 1 \mathrm{~b}$ & Sec. & & $A B U$ & ARG SNJ CAP, San Juan \\
\hline SNJ 044 & U4c1 & Sec. & & $A B U$ & ARG SNJ CAP, San Juan \\
\hline SNJ 047 & C1b & Sec. & & $A B U$ & ARG LRJ \\
\hline SNJ 048 & C1b & Sec. & & $A B U$ & ARG SNJ ALB, Albardón \\
\hline SNJ 049 & D1 & Sec. & & $A B U$ & ARG SNJ ULL \\
\hline SNJ 050 & C1d & Sec. & & $A B U$ & ARG LRJ \\
\hline SNJ 051 & $\mathrm{Nx}(\mathrm{A}, \mathrm{B})$ & AFLP & & $A B U$ & RUMANIA \\
\hline SNJ 052 & B2 & Sec. & & $A B U$ & ARG SNJ \\
\hline SNJ 053 & C1d & Sec. & & $A B U$ & ARG SNJ_abu mat apellido Casivar \\
\hline SNJ 054 & B2 & Sec. & & $A B U$ & ARG SNJ CAL, Calingasta \\
\hline SNJ 055 & D1 & Sec. & & $A B U$ & ARG SNJ POC, Pocitos \\
\hline SNJ 056 & C1d & Sec. & & $A B U$ & ARG SNJ CAP, San Juan? \\
\hline SNJ 057 & D1 & Sec. & & $A B U$ & ARG SNJ CAP, San Juan \\
\hline SNJ 058 & C1b & Sec. & & $A B U$ & ARG SNJ \\
\hline SNJ 059 & B2 & Sec. & & $A B U$ & ARG CHA CAP, Resistencia \\
\hline SNJ 060 & $\mathrm{C} 1 \mathrm{c}$ & Sec. & Alul 13262 - & $A B U$ & ARG SNJ \\
\hline SNJ 061 & $\mathrm{C} 1 \mathrm{~b}$ & Sec. & & MA & ARG SNJ CAP, San Juan \\
\hline SNJ 062 & $\mathrm{H}$ & Sec. & & MA & ARG MZA LAV, Laguna del Rosario \\
\hline SNJ 063 & B2 & Sec. & & MA & ARG SNJ \\
\hline SNJ 064 & L2a1 & Sec. & & MA & ARG LRJ \\
\hline SNJ 065 & B2 & Sec. & & ABU & ARG SNJ JAC, Jáchal \\
\hline SNJ 066 & D1 & Sec. & & MA & ARG SNJ CAP, San Juan \\
\hline SNJ 067 & C1b & Sec. & & MA & ARG SNJ CAP, San Juan \\
\hline SNJ 068 & B2 & Sec. & & $A B U$ & ARG SNJ JAC, Jáchal? \\
\hline
\end{tabular}


Anexo

\begin{tabular}{|c|c|c|c|c|c|}
\hline Rótulo & $\mathrm{Hg}$ & Método & RFLP info & UACM & Lugar de nacimiento \\
\hline SNJ 069 & $\mathrm{C} 1 \mathrm{~b}$ & Sec. & & MA & ARG SNJ CAP, San Juan \\
\hline SNJ 070 & D1 & Sec. & & $A B U$ & ARG SNJ JAC, Jáchal \\
\hline SNJ 071 & D1 & Sec. & & $A B U$ & ARG SNJ CAL, Calingasta \\
\hline SNJ 072 & $\mathrm{D} 1$ & Sec. & & $A B U$ & ARG SNJ CAP, San Juan \\
\hline SNJ 073 & J1c7 & Sec. & & $A B U$ & ARG SNJ CAP, San Juan \\
\hline SNJ 074 & C1d & Sec. & & $A B U$ & ARG SNJ IGL, Rodeo \\
\hline SNJ 075 & $\mathrm{H}$ & Sec. & & $A B U$ & ARG SNJ CAP, San Juan \\
\hline SNJ 076 & B2 & Sec. & & $A B U$ & ARG SNJ ANG \\
\hline SNJ 077 & D1 & Sec. & & $A B U$ & ARG SNJ ANG \\
\hline SNJ 078 & B2 & Sec. & & $A B U$ & ARG SNJ CAP, San Juan \\
\hline SNJ 079 & $\mathrm{~W}^{*}$ & Sec. & & $A B U$ & ARG SNJ CAP, San Juan \\
\hline SNJ 080 & B2 & Sec. & & $A B U$ & ARG SNJ CAP, San Juan \\
\hline SNJ 081 & $\mathrm{~A} 2$ & Sec. & & $A B U$ & ARG SNJ CAL, Barreal \\
\hline SNJ 082 & C1d & Sec. & & MA & CHI IIIRe, Chañaral Alto \\
\hline SNJ 083 & H5 & Sec. & & MA & ARG SNJ CAP, San Juan \\
\hline SNJ 084 & $\mathrm{C} 1 \mathrm{~b}$ & Sec. & & $A B U$ & ARG SNJ \\
\hline SNJ 085 & $\mathrm{~A} 2$ & Sec. & & $A B U$ & ARG SNJ CAP, San Juan \\
\hline SNJ 086 & L3e1a & Sec. & & $A B U$ & ARG SNJ CAP, San Juan \\
\hline SNJ 087 & $\mathrm{C} 1 \mathrm{~b}$ & Sec. & & MA & ARG SNJ CAP, San Juan \\
\hline SNJ 088 & $\mathrm{~A} 2$ & Sec. & & $A B U$ & ARG SNJ CAP, San Juan \\
\hline SNJ 089 & C1b & Sec. & & $A B U$ & ARG MZA, Guaymallén \\
\hline SNJ 091 & D1 & Sec. & & $A B U$ & ARG SNJ POC, Pocitos \\
\hline SNJ 092 & $\mathrm{C} 1 \mathrm{~b}$ & Sec. & & DO & ARG SNJ RAW, Rawson \\
\hline SNJ 093 & $\mathrm{D} 1$ & Sec. & & $A B U$ & ARG SNJ POC, Pocitos \\
\hline SNJ 094 & C1b & Sec. & & $A B U$ & ARG SNJ CAP, San Juan \\
\hline SNJ 095 & C1b & Sec. & & DO & ARG SNJ CAP, San Juan \\
\hline SNJ 096 & $\mathrm{Nx}(\mathrm{A}, \mathrm{B})$ & AFLP & & $A B U$ & ESPAÑA \\
\hline SNJ 097 & $\mathrm{Nx}(\mathrm{A}, \mathrm{B})$ & AFLP & & $A B U$ & ARG SNJ CAP, San Juan \\
\hline SNJ 098 & A & AFLP & & $A B U$ & ARG SNJ CAP, San Juan \\
\hline SNJ 099 & A2 & Sec. & & $A B U$ & ARG SNJ CAP, San Juan \\
\hline SNJ 100 & $\mathrm{~A} 2$ & Sec. & & MA & ARG SNJ CAP, San Juan \\
\hline SNJ 101 & D1 & Sec. & & MA & ARG SNJ CAP, San Juan \\
\hline SNJ 102 & $\mathrm{C} 1 \mathrm{~b}$ & Sec. & & $A B U$ & ARG TUC CAP, SMT? \\
\hline SNJ 103 & L3f1b1 & Sec. & & $A B U$ & ARG SNJ CAP, San Juan \\
\hline SNJ 104 & A2 & Sec. & & MA & ARG SNJ RAW, Rawson \\
\hline SNJ 105 & $\mathrm{Nx}(\mathrm{A}, \mathrm{B})$ & AFLP & & ABU & ESPAÑA \\
\hline SNJ 106 & D1 & Sec. & & $A B U$ & ARG SNJ CAP, San Juan \\
\hline SNJ 107 & B2 & Sec. & & $A B U$ & ARG SDE \\
\hline SNJ 108 & B2 & Sec. & & $A B U$ & ARG SNJ CAP, San Juan \\
\hline SNJ SLV 01 & C1d & Sec. & & $A B U$ & ARG SNJ JAC, Jáchal \\
\hline SNJ SLV 02 & J1c1 & Sec. & & $A B U$ & ARG SNJ ALB, Albardón \\
\hline SNJ SLV 03 & $\mathrm{D} 1$ & Sec. & & $A B U$ & ARG SNJ CAP, San Juan \\
\hline SNJ SLV 04 & D1 & Sec. & & $A B U$ & ARG TUC \\
\hline \multicolumn{6}{|c|}{ SANTA MARÍA } \\
\hline SJS 01 & B & AFLP & & MA & ARG BS AS, Maipú \\
\hline SJS 02 & B2 & Sec. & & $A B U$ & ARG CAT SMA, San José \\
\hline SJS 03 & B2 & Sec. & & $A B U$ & ARG CAT SMA, San José \\
\hline SJS 04 & $\mathrm{C} 1 \mathrm{~b}$ & Sec. & & $A B U$ & ARG CAT SMA, San José \\
\hline SJS 05 & B2 & Sec. & & $A B U$ & ARG CAT SMA, San José \\
\hline SJS 06 & C & AFLP & & DO & ARG CAT SMA, Santa María \\
\hline SJS 07 & $\mathrm{D}$ & AFLP & & $A B U$ & ARG CAT, San Fernando del V. de Catamarca \\
\hline SJS 08 & C1b & Sec. & & $A B U$ & ARG CAT SMA, Famatanca \\
\hline SJS 09 & D1 & Sec. & & $A B U$ & ARG CAT SMA, Punta de Balasto \\
\hline SJS 10 & D1 & Sec. & & MA & ARG CAT SMA, San José? \\
\hline SJS 11 & B2 & Sec. & & $A B U$ & ARG CAT SMA, Santa María en el cerro \\
\hline SJS 12 & D1 & Sec. & & $A B U$ & ARG CAT PAZ, San Antonio de La Paz \\
\hline SJS 13 & D1 & Sec. & & $A B U$ & ARG CAT SMA, San José \\
\hline SJS 14 & D1 & Sec. & & $A B U$ & ARG CAT BEL \\
\hline SJS 15 & $\mathrm{~L}$ & Sec. & & $A B U$ & ARG CAT BEL \\
\hline SJS 16 & A & AFLP & & MA & ARG CAT SMA, Agua Amarilla \\
\hline SJS 17 & B2 & Sec. & & $A B U$ & ARG CAT SMA, San José Andalhualá \\
\hline SJS 18 & A & AFLP & & $A B U$ & ARG CAT SMA, En el Cerro \\
\hline SJS 19 & B2 & Sec. & & $A B U$ & PERU LAM, Moncefú Chiclayo \\
\hline SJS 20 & A2 & Sec. & & $A B U$ & ARG CAT SMA, Punta de Balasto \\
\hline SJS 21 & B2 & Sec. & & MA & ARG SAL CAF \\
\hline SJS 22 & $\mathrm{C}$ & AFLP & & $A B U$ & ARG SAL, Abra Pampa ¿? \\
\hline SMA 001 & B2 & Sec. & & $A B U$ & ARG CAT SMA, Santa María \\
\hline
\end{tabular}


Anexo

\begin{tabular}{|c|c|c|c|c|c|}
\hline Rótulo & $\mathrm{Hg}$ & Método & RFLP info & UACM & Lugar de nacimiento \\
\hline SMA 002 & $\mathrm{~B}$ & AFLP & & $A B U$ & ARG SAL \\
\hline SMA 003 & $\mathrm{C} 1 \mathrm{~b}$ & Sec. & & $A B U$ & ARG CAT SMA, Palo Seco \\
\hline SMA 004 & B2 & Sec. & & $A B U$ & ARG TUC? \\
\hline SMA 005 & $\mathrm{~B}$ & AFLP & & $A B U$ & ARG CAT SMA, Santa María \\
\hline SMA 006 & $\mathrm{~B} 2$ & Sec. & & MA & ARG CAT SMA, LA Hoyada \\
\hline SMA 007 & $\mathrm{Nx}(\mathrm{A}, \mathrm{B})$ & AFLP & & $A B U$ & ARG CAT SMA \\
\hline SMA 008 & C & AFLP & & $A B U$ & ARG TUC \\
\hline SMA 009 & $\mathrm{~B}$ & AFLP & & $A B U$ & ARG TUC TAF, Amaicha del Valle \\
\hline SMA 010 & D1 & Sec. & & $A B U$ & ARG CAT SMA, Santa María \\
\hline SMA 011 & A2 & Sec. & & ABU & ARG CAT SMA, Santa María \\
\hline SMA 012 & B & AFLP & & $A B U$ & ARG BS AS \\
\hline SMA 013 & C & AFLP & & $A B U$ & ARG TUC \\
\hline SMA 014 & $\mathrm{Nx}(\mathrm{A}, \mathrm{B})$ & AFLP & & $A B U$ & LIBANO \\
\hline SMA 015 & $\mathrm{Nx}(\mathrm{A}, \mathrm{B})$ & AFLP & & $A B U$ & FRANCIA \\
\hline SMA 016 & B2 & Sec. & & $A B U$ & ARG CAT SMA, Palo Seco \\
\hline SMA 017 & $\mathrm{D}$ & AFLP & & MA & ARG CAT SMA, Santa María \\
\hline SMA 018 & C & AFLP & & MA & ARG CAT SMA, Santa María \\
\hline SMA 019 & C1b & Sec. & & $A B U$ & ARG FOR, Las Lomitas \\
\hline SMA 020 & $\mathrm{D}$ & AFLP & & $A B U$ & ARG TUC TAF, Amaicha del Valle \\
\hline SMA 021 & A & AFLP & & $A B U$ & ESPAÑA \\
\hline SMA 022 & $\mathrm{D}$ & AFLP & & $A B U$ & ARG TUC, Quilmes \\
\hline SMA 023 & B2 & Sec. & & $A B U$ & ARG CAT SMA, El Cajón \\
\hline SMA 024 & $\mathrm{C} 1 \mathrm{~b}$ & Sec. & & $A B U$ & ARG CAT SMA, Lorohuasi \\
\hline SMA 025 & B2 & Sec. & & $A B U$ & ARG SAL, Bodeguita \\
\hline SMA 026 & B2 & Sec. & & $A B U$ & ARG CAT SMA, Las Mojarras \\
\hline SMA 027 & $\mathrm{~A} 2$ & Sec. & & DO & ARG CAT SMA, San Antonio del Cajón \\
\hline SMA 028 & D1 & Sec. & & MA & ARG TUC CRU, Ranchillos \\
\hline SMA 029 & B2 & Sec. & & $A B U$ & ARG CAT SMA, Santa María \\
\hline SMA 030 & $\mathrm{C} 1 \mathrm{~b}$ & Sec. & & $A B U$ & ARG CAT SMA, Santa María \\
\hline SMA 031 & D1 & Sec. & & $A B U$ & ARG ERI, San José \\
\hline SMA 032 & $\mathrm{C} 1 \mathrm{~b}$ & Sec. & & DO & ARG CAT SMA, Santa María \\
\hline SMA 033 & D1 & Sec. & & MA & ARG CAT SMA \\
\hline SMA 034 & $\mathrm{Nx}(\mathrm{A}, \mathrm{B})$ & AFLP & & MA & ARG CAT SMA, Yapes \\
\hline SMA 035 & A & AFLP & & $A B U$ & ARG CAT SMA \\
\hline SMA 036 & B2 & Sec. & & MA & ARG CAT SMA, Lorohuasi \\
\hline SMA 037 & D1 & Sec. & & $A B U$ & ARG TUC TAF, Colalao del Valle \\
\hline SMA 038 & $\mathrm{Nx}(\mathrm{A}, \mathrm{B})$ & AFLP & & $A B U$ & ARG TUC \\
\hline SMA 039 & B2 & Sec. & & $A B U$ & ARG CAT FIAM, Tinogasta \\
\hline SMA 040 & C1b & Sec. & & $A B U$ & ARG CAT SMA, Santa María \\
\hline SMA 041 & C & AFLP & & MA & ARG TUC \\
\hline SMA 042 & C & AFLP & & $A B U$ & ARG BS AS TAN, Iraola \\
\hline SMA 043 & D1 & Sec. & & MA & ARG CAT SMA, Punta de Balasto \\
\hline SMA 044 & C1d & Sec. & & $A B U$ & ARG CAT SMA, San José \\
\hline SMA 045 & B & AFLP & & MA & ARG CAT SMA, Santa María \\
\hline SMA 046 & B & AFLP & & MA & ARG CAT SMA SNJ, Palo Seco \\
\hline SMA 047 & $\mathrm{Nx}(\mathrm{A}, \mathrm{B})$ & AFLP & & MA & ARG CAT SMA, San José \\
\hline SMA 048 & $B$ & AFLP & & $A B U$ & ARG CAT SMA, Santa María \\
\hline SMA 049 & $\mathrm{D}$ & AFLP & & $A B U$ & ARG LPM, Santa Rosa \\
\hline SMA 050 & $\mathrm{C} 1 \mathrm{~b}$ & Sec. & & $A B U$ & ARG CAT SMA, Ampajango \\
\hline SMA 051 & B & AFLP & & MA & ARG CAT SMA, Santa María \\
\hline SMA 052 & B2 & Sec. & & $A B U$ & ARG CAT SMA, Medanito \\
\hline SMA 053 & B2 & Sec. & & $A B U$ & ARG CAT SMA, Famatanca \\
\hline SMA 054 & B & AFLP & & $A B U$ & ARG CAT SMA, Santa María \\
\hline SMA 055 & B2 & Sec. & & $A B U$ & ARG TUC, El Bañado \\
\hline SMA 056 & $\mathrm{Nx}(\mathrm{A}, \mathrm{B})$ & AFLP & & $A B U$ & ARG CAT SMA, Santa María \\
\hline SMA 057 & D4h3 & Sec. & & $A B U$ & ARG CAT SMA, Famatanca \\
\hline SMA 058 & $\mathrm{~A}$ & AFLP & & $A B U$ & ARG CAT SMA, Santa María \\
\hline SMA 059 & B2 & Sec. & & MA & ARG TUC, Quilmes \\
\hline SMA 060 & D & AFLP & & $A B U$ & ARG CAT SMA, Santa María? \\
\hline SMA 061 & A2 & Sec. & & $A B U$ & ARG CAT SMA, Santa María \\
\hline SMA 062 & D1 & Sec. & & $A B U$ & ARG CAT SMA, Chiñocani? \\
\hline SMA 063 & B2 & Sec. & & $A B U$ & ARG CAT SMA, La Hoyada \\
\hline SMA 064 & D1 & Sec. & & $A B U$ & ARG TUC, Quilmes \\
\hline SMA 065 & $\mathrm{D}$ & AFLP & & $A B U$ & ARG CAT SMA, Santa María \\
\hline SMA 066 & D1 & Sec. & & $A B U$ & ARG CAT BEL, Andalgalá \\
\hline SMA 067 & C1d & Sec. & & $A B U$ & ARG TUC CON, Los Buchea \\
\hline SMA 068 & A2 & Sec. & & $A B U$ & ARG CAT TIN, Tinogasta \\
\hline SMA 069 & B2 & Sec. & & $A B U$ & ARG CAT SMA, Santa María \\
\hline SMA 070 & $\mathrm{C} 1 \mathrm{~b}$ & Sec. & & MA & ARG CAT SMA El Cajón San Antonio \\
\hline
\end{tabular}


Anexo

\begin{tabular}{|c|c|c|c|c|c|}
\hline Rótulo & $\mathrm{Hg}$ & Método & RFLP info & UACM & Lugar de nacimiento \\
\hline SMA 071 & $\mathrm{C}$ & AFLP & & DO & ARG CAT SMA (vive en Agua Amarilla) \\
\hline SMA 072 & B & AFLP & & $A B U$ & ARG CAT SMA, Santa María \\
\hline SMA 073 & B2 & Sec. & & $A B U$ & ARG CAT SMA, San José Yape \\
\hline SMA 074 & C1b & Sec. & & $A B U$ & ARG CAT SMA (en el cerro) \\
\hline SMA 075 & C1d & Sec. & & $A B U$ & ARG CAT SMA, Lorohuasi \\
\hline SMA 076 & $\mathrm{~A}$ & AFLP & & $A B U$ & ARG TUC, San Miguel de Tucumán \\
\hline SMA 077 & D1 & Sec. & & $A B U$ & ARG SDE, Santiago del Estero cap. ? \\
\hline SMA 078 & $\mathrm{C} 1 \mathrm{~b}$ & Sec. & & $A B U$ & ARG CAT SMA, Santa María \\
\hline SMA 079 & B & AFLP & & $A B U$ & ARG CAT SMA, Santa María \\
\hline SMA 080 & B2 & Sec. & & MA & ARG CAT SMA, LA Hoyada \\
\hline SMA 081 & B2 & Sec. & & $A B U$ & ARG TUC \\
\hline SMA 082 & A2 & Sec. & & MA & ARG CAT SMA, Santa María \\
\hline SMA 083 & $\mathrm{~L}$ & Sec. & & $A B U$ & ARG CAT SMA, Lorohuasi \\
\hline SMA 084 & D4h3 & Sec. & & $A B U$ & ARG CAT SMA, Santa María \\
\hline SMA 085 & B & AFLP & & $A B U$ & ARG CAT SMA, Santa María \\
\hline SMA 086 & $\mathrm{C} 1 \mathrm{~b}$ & Sec. & & $A B U$ & ARG CAT SMA, LA Puntilla \\
\hline SMA 087 & B2 & Sec. & & MA & ARG CAT SMA, Santa María \\
\hline SMA 088 & C1d & Sec. & & $A B U$ & ARG CAT SMA (en el cerro) \\
\hline SMA 089 & $\mathrm{D} 1$ & Sec. & & $A B U$ & ARG SAL ORA, Orán \\
\hline SMA 090 & B2 & Sec. & & $A B U$ & ARG CAT SMA, Punta de Balasto \\
\hline SMA 091 & $\mathrm{C} 1 \mathrm{~b}$ & Sec. & & $A B U$ & ARG CAT SMA, Lorohuasi \\
\hline SMA 092 & B2 & Sec. & & $A B U$ & ARG TUC, Quilmes \\
\hline SMA 093 & C & AFLP & & $A B U$ & ARG CAT SMA \\
\hline SMA 094 & D4h3 & Sec. & & $A B U$ & ARG CAT SMA, Lorohuasi \\
\hline SMA 095 & B2 & Sec. & & $A B U$ & ARG CAT BEL \\
\hline SMA 096 & A2 & Sec. & & MA & ARG CAT SMA, Santa María \\
\hline SMA 097 & $\mathrm{~B}$ & AFLP & & DO & ARG CAT SMA, Santa María \\
\hline SMA 099 & C & AFLP & & MA & ARG SAL, Salta cap. \\
\hline SMA 100 & B2 & Sec. & & MA & ARG TUC, Quilmes \\
\hline SMA 101 & $\mathrm{D}$ & AFLP & & DO & ARG CAT SMA, Santa María \\
\hline SMA 102 & $\mathrm{Nx}(\mathrm{A}, \mathrm{B})$ & AFLP & & $A B U$ & ARG CAT SMA, San José \\
\hline SMA 103 & A & AFLP & & MA & ARG CAT SMA, Las Abritas \\
\hline SMA 104 & D1 & Sec. & & $A B U$ & ARG TUC TAF, Ampimpa \\
\hline SMA 105 & B & AFLP & & DO & ARG CAT SMA, Santa María \\
\hline SMA 106 & B & AFLP & & DO & ARG CAT SMA, Lamparcito \\
\hline SMA 107 & B2 & Sec. & & $A B U$ & ARG CAT BEL, Nacimiento \\
\hline SMA 108 & $\mathrm{C} 1 \mathrm{c}$ & Sec. & & $A B U$ & ARG TUC RIO, Aguilares \\
\hline SMA 109 & B2 & Sec. & & $A B U$ & ARG CAT SMA, Medanito \\
\hline SMA 110 & C1d & Sec. & & $A B U$ & ARG CAT SMA, Santa María \\
\hline SMA 111 & B & AFLP & & $A B U$ & ARG SAL, Salta Cap. \\
\hline SMA 112 & B & AFLP & & $A B U$ & ARG CAT SMA, Santa María \\
\hline SMA 113 & B2 & Sec. & & $A B U$ & ARG CAT SMA, La Hoyada \\
\hline SMA 114 & D4h3 & Sec. & & MA & ARG CAT SMA, El Puesto \\
\hline SMA 115 & D1 & Sec. & & DO & ARG SDE, Pozo Hondo \\
\hline SMA 116 & C1b & Sec. & & $A B U$ & ARG CAT SMA, Santa María \\
\hline SMA 117 & C & AFLP & & $A B U$ & ARG CAT SMA, Santa María? \\
\hline SMA 118 & C1d & Sec. & & $A B U$ & ARG CAT SMA, Famatanca \\
\hline SMA 120 & $\mathrm{C} 1 \mathrm{c}$ & Sec. & & $A B U$ & ARG CAT SMA, LA Hoyada \\
\hline SMA 121 & D1 & Sec. & & $A B U$ & ARG CAT SMA, San José \\
\hline SMA 122 & B2 & Sec. & & $A B U$ & ARG CAT BEL, Los Nacimientos? \\
\hline SMA 124 & $\mathrm{~A} 2$ & Sec. & & $A B U$ & ARG CAT BEL \\
\hline SMA 125 & B & AFLP & & $A B U$ & ARG CAT SMA, Santa María \\
\hline SMA 126 & D4h3 & Sec. & & $A B U$ & ARG CAT SMA, Santa María \\
\hline SMA 127 & C1b & Sec. & & MA & ARG CAT SMA, Santa María \\
\hline SMA 128 & C & AFLP & & ABU & ARG CAT SMA, Santa María \\
\hline SMA 129 & A & AFLP & & $A B U$ & ARG CAT, San Fernando del V. de Catamarca \\
\hline SMA 131 & C1d & Sec. & & $A B U$ & ARG CAT SMA \\
\hline SMA 132 & $\mathrm{C} 1 \mathrm{~b}$ & Sec. & & $A B U$ & ARG CAT SMA, San José \\
\hline SMA 133 & D1 & Sec. & & DO & ARG CAT SMA, Santa María \\
\hline SMA 134 & B2 & Sec. & & $A B U$ & ARG CAT SMA, La Hoyada \\
\hline SMA 135 & $\mathrm{C} 1 \mathrm{~b}$ & Sec. & & $A B U$ & ARG CAT SMA, San José Banda \\
\hline SMA 136 & D4h3 & Sec. & & $A B U$ & ARG TUC TAF, Amaicha del Valle \\
\hline SMA 137 & $\mathrm{~B}$ & AFLP & & MA & ARG CAT SMA, Agua Amarilla \\
\hline SMA 138 & C1d & Sec. & & DO & ARG TUC TAF, Colalao del Valle \\
\hline SMA 139 & D1 & Sec. & & ABU & ARG CAT SMA, Mojarras \\
\hline SMA 140 & $\mathrm{D}$ & AFLP & & $A B U$ & ESPAÑA \\
\hline SMA 141 & A2 & Sec. & & $A B U$ & ARG TUC, San Miguel de Tucumán \\
\hline SMA 142 & B2 & Sec. & & $A B U$ & ARG CAT BEL, Las Cuevas Los Morteritos \\
\hline SMA 143 & B2 & Sec. & & $A B U$ & ARG TUC, Quilmes \\
\hline
\end{tabular}


Anexo

\begin{tabular}{|c|c|c|c|c|c|}
\hline Rótulo & $\mathrm{Hg}$ & Método & RFLP info & UACM & Lugar de nacimiento \\
\hline SMA 144 & $\mathrm{D}$ & AFLP & & $A B U$ & ARG CAT SMA, Santa María \\
\hline SMA 145 & $\mathrm{C} 1 \mathrm{~b}$ & Sec. & & $A B U$ & ARG TUC BUR, LA Cruz \\
\hline SMA 146 & $\mathrm{C} 1 \mathrm{~b}$ & Sec. & & $A B U$ & ARG CAT SMA, San José Andalhuala? \\
\hline SMA 147 & D1 & Sec. & & $A B U$ & ARG TUC, Quilmes \\
\hline SMA 148 & C1c & Sec. & & $A B U$ & ARG CAT SMA, En los cerros \\
\hline SMA 149 & B2 & Sec. & & $A B U$ & ARG CAT SMA, Santa María ? \\
\hline SMA 150 & C1d & Sec. & & $A B U$ & ARG CAT SMA, San José Banda \\
\hline SMA 151 & B2 & Sec. & & $A B U$ & ARG CAT SMA, Santa María \\
\hline SMA 152 & B2 & Sec. & & $A B U$ & ARG CAT SMA, Lamparcito \\
\hline \multicolumn{6}{|c|}{ TARTAGAL } \\
\hline TG 001 & C & RFLP & & $A B U$ & ARG SAL \\
\hline TG 002 & B & RFLP y Sec. & & $A B U$ & ARG SDE \\
\hline TG 003 & B & RFLP y Sec. & & MA & ARG SAL GSM, Tartagal \\
\hline TG 004 & A & RFLP y Sec. & & $A B U$ & ARG SAL GSM, Tartagal \\
\hline TG 005 & B & RFLP & & $A B U$ & ARG TUC \\
\hline TG 006 & $\mathrm{D}$ & RFLP y Sec. & & $A B U$ & ARG SAL MET, Metán \\
\hline TG 007 & $\mathrm{D}$ & RFLP y Sec. & & $A B U$ & PAR \\
\hline TG 008 & $\mathrm{C} 1 \mathrm{~b}$ & RFLP y Sec. & & $A B U$ & ARG FOR \\
\hline TG 009 & $\mathrm{~B}$ & RFLP & & $A B U$ & $\mathrm{BOL}$ \\
\hline TG 010 & B & RFLP y Sec. & & $A B U$ & ARG CRR, Monte Caseros \\
\hline TG 011 & B & RFLP y Sec. & & MA & ARG SAL GSM, Tartagal \\
\hline TG 012 & B & RFLP y Sec. & & $A B U$ & BOL TAR, Pocitos \\
\hline TG 013 & C & RFLP & & $A B U$ & $\mathrm{BOL}$ \\
\hline TG 014 & C1d & RFLP y Sec. & & $A B U$ & ARG SDE \\
\hline TG 015 & $\mathrm{D}$ & RFLP & & $A B U$ & BOL? \\
\hline TG 017 & C1c & RFLP y Sec. & & MA & ARG SAL GSM, Tartagal \\
\hline TG 018 & D4h3 & RFLP y Sec. & & ABU & BOL COCHAB, Cochabamba \\
\hline TG 019 & B & RFLP y Sec. & & MA & ARG SAL, Pilcomayo (chaco salteño) \\
\hline TG 020 & $\mathrm{~B}$ & RFLP y Sec. & & MA & ARG SDE \\
\hline TG 021 & B & RFLP & & MA & BOL, Crebos \\
\hline TG 022 & D & RFLP y Sec. & & $A B U$ & ARG SAL GSM, Traslado \\
\hline TG 023 & B & RFLP y Sec. & & $A B U$ & ARG SAL, Poza del Mulato \\
\hline TG 024 & B & RFLP & & DO & ARG SAL GSM, Acambuco \\
\hline TG 025 & $\mathrm{D}$ & RFLP y Sec. & & $A B U$ & PAR \\
\hline TG 026 & $B$ & RFLP & & MA & ARG TUC \\
\hline TG 028 & $\mathrm{D}$ & RFLP y Sec. & & ABU & ARG SAL GSM, Tartagal \\
\hline TG 029 & B & RFLP y Sec. & & MA & ARG SAL GSM, Tartagal \\
\hline TG 030 & B & RFLP y Sec. & & $A B U$ & ARG SAL GSM, Pocitos \\
\hline TG 031 & B & RFLP y Sec. & & MA & ARG SAL GSM, Tartagal \\
\hline TG 032 & $\mathrm{C} 1 \mathrm{~b}$ & RFLP y Sec. & & $A B U$ & ARG SAL GSM, Aguaray \\
\hline TG 033 & B & RFLP y Sec. & & $A B U$ & ARG SAL GSM, La Puntana \\
\hline TG 034 & c & RFLP & & DO & ARG SAL RBN, Sta Victoria E. \\
\hline TG 035 & B & RFLP y Sec. & & MA & ARG SAL GSM, Tartagal \\
\hline TG 036 & C & RFLP & & $A B U$ & chaco salteño? \\
\hline TG 039 & $\mathrm{C} 1 \mathrm{c}$ & RFLP y Sec. & & MA & ARG SAL GSM, Tartagal \\
\hline TG 040 & $\mathrm{C} 1 \mathrm{~b}$ & RFLP y Sec. & & $A B U$ & BOL TAR, Tarija? \\
\hline TG 041 & A & RFLP & & $A B U$ & $\mathrm{BOL}$ \\
\hline TG 042 & $\mathrm{D}$ & RFLP y Sec. & & DO & ARG SAL ORAN, Orán \\
\hline TG 043 & $\mathrm{D}$ & RFLP & & $A B U$ & ARG SAL O SDE? \\
\hline TG 044 & B & RFLP & & MA & ARG SAL GSM, Tartagal \\
\hline TG 045 & B & RFLP & & $A B U$ & chaco, cerca de BOL \\
\hline TG 046 & $\mathrm{D}$ & RFLP & & MA & chaco salteño? \\
\hline TG 047 & B & RFLP y Sec. & & $A B U$ & ARG SAL GSM, Dragones? \\
\hline TG 048 & B & RFLP & & DO & BOL TAR, Entre Ríos, Las Cuevas \\
\hline TG 049 & $\mathrm{D}$ & RFLP y Sec. & & $A B U$ & ARG SAL? Chaco salteño?, Puesto El Medio \\
\hline TG 050 & B & RFLP & & $A B U$ & $\mathrm{BOL}$ \\
\hline TG 051 & D & RFLP y Sec. & & $A B U$ & ARG SAL GSM, Tonono \\
\hline TG 052 & C & RFLP & & $A B U$ & BOL \\
\hline TG 053 & B & RFLP & & S/D & \\
\hline TG 054 & $\mathrm{D}$ & RFLP y Sec. & & MA & ARG SAL GSM, Mosconi \\
\hline TG 055 & $\mathrm{D}$ & RFLP y Sec. & & $A B U$ & ARG CHA, Resistencia \\
\hline TG 056 & C & RFLP & & $A B U$ & inmigrante de ultramar \\
\hline TG 057 & B & RFLP & & $A B U$ & ARG CAT \\
\hline TG 058 & $\mathrm{D}$ & RFLP & & MA & ARG JUJ, Abrapampa \\
\hline TG 059 & $\mathrm{D}$ & RFLP & & MA & BOL TAR, Yacuiba \\
\hline TG 060 & A & RFLP y Sec. & & $A B U$ & ARG FOR o Paraguay? \\
\hline TG 061 & B & RFLP y Sec. & & $A B U$ & ARG SAL GSM, Tartagal \\
\hline TG 062 & $\mathrm{C} 1 \mathrm{c}$ & RFLP & & $A B U$ & madre venía de Entre Ríos (BOL TAR) \\
\hline
\end{tabular}


Anexo

\begin{tabular}{|c|c|c|c|c|c|}
\hline Rótulo & $\mathrm{Hg}$ & Método & RFLP info & UACM & Lugar de nacimiento \\
\hline TG 063 & $\mathrm{~B}$ & RFLP y Sec. & & MA & ARG SAL GSM, Embarcación \\
\hline TG 064 & B & RFLP y Sec. & & MA & ARG SAL GSM, Tartagal \\
\hline TG 065 & B & RFLP y Sec. & & MA & ARG FOR \\
\hline TG 066 & A & RFLP y Sec. & & $A B U$ & BOL, La Paz \\
\hline TG 067 & $\mathrm{~B}$ & RFLP & & MA & BOL TAR, Entre Ríos \\
\hline TG 068 & B & RFLP y Sec. & & MA & ARG SAL GSM, Acambuco \\
\hline TG 069 & $B$ & RFLP y Sec. & & $A B U$ & BOL TAR, Tarija \\
\hline TG 070 & A & RFLP & & ABU & ARG SDE o BOL Sta. Cruz? \\
\hline TG 071 & $\mathrm{D}$ & RFLP y Sec. & & $A B U$ & BOL \\
\hline TG 072 & $\mathrm{D}$ & RFLP y Sec. & & MA & ARG SAL GSM, Acambuco \\
\hline TG 073 & C & RFLP & & $A B U$ & BOL \\
\hline TG 074 & B & RFLP y Sec. & & $A B U$ & BOL TAR, Tarija \\
\hline TG 075 & $\mathrm{C} 1 \mathrm{~b}$ & RFLP y Sec. & & $A B U$ & ARG TUC, Simoca \\
\hline TG 076 & D & RFLP & & $A B U$ & ARG TUC \\
\hline TG 077 & $\mathrm{D}$ & RFLP & & $A B U$ & ARG CAT \\
\hline TG 078 & $\mathrm{C} 1 \mathrm{~b}$ & RFLP y Sec. & & ABU & ARG SAL RIV, La Victoria \\
\hline TG 079 & B & RFLP & & $A B U$ & ARG CAT, Catamarca Capital? \\
\hline TG 080 & C1c & RFLP y Sec. & & $A B U$ & ARG SAL GSM, San Pedrito \\
\hline TG 085 & U5a & RFLP y Sec. & & $A B U$ & ARG SAL ORAN, Orán \\
\hline TG 086 & $\mathrm{~B}$ & RFLP & & DO & $\mathrm{BOL}$ \\
\hline TG 087 & $\mathrm{D}$ & RFLP y Sec. & & $A B U$ & ARG SAL GSM, El 46 \\
\hline TG 088 & B & RFLP & & $A B U$ & BOL? \\
\hline TG 090 & A & RFLP y Sec. & & MA & ARG SAL GSM, Aguaray \\
\hline TG 091 & A & RFLP y Sec. & & $A B U$ & ARG SAL GSM, Campo Largo \\
\hline TG 092 & $\mathrm{~B}$ & RFLP y Sec. & & MA & ARG SAL ORAN, La Ramadita (ca. Pichanal) \\
\hline TG 093 & $\mathrm{D}$ & RFLP & & MA & ARG SAL \\
\hline TG 094 & $\mathrm{D}$ & RFLP y Sec. & & $A B U$ & ARG SAL GSM, Tartagal \\
\hline TG 095 & $\mathrm{~B}$ & RFLP y Sec. & & ABU & ARG SAL GSM, Acambuco \\
\hline TG 096 & $\mathrm{C} 1 \mathrm{~b}$ & RFLP y Sec. & & $A B U$ & ARG JUJ? \\
\hline TG 097 & A & RFLP y Sec. & & $A B U$ & BOL TAR, Villa Montes \\
\hline TG 098 & B & RFLP y Sec. & & $A B U$ & BOL, Caixa \\
\hline TG 099 & $\mathrm{C} 1 \mathrm{~b}$ & RFLP y Sec. & & MA & ARG SDE \\
\hline TG 101 & B & RFLP y Sec. & & $A B U$ & ARG SAL, chaco salteño \\
\hline TG 102 & B & RFLP & & $A B U$ & BOL \\
\hline TG 103 & B & RFLP y Sec. & & $A B U$ & ARG SAL GUACHIPAS \\
\hline TG 104 & C1d & RFLP y Sec. & & $A B U$ & ARG SAL RIV, Morrillo \\
\hline TG 105 & $\mathrm{C} 1 \mathrm{~b}$ & RFLP y Sec. & & $A B U$ & ARG SAL RBN \\
\hline TG 106 & D4h3 & RFLP y Sec. & & $A B U$ & ARG JUJ \\
\hline TG 107 & $\mathrm{C} 1 \mathrm{~b}$ & RFLP y Sec. & & MA & ARG SAL RBN, paraje La Casa Vieja \\
\hline TG 109 & B & RFLP & & $A B U$ & ARG BUE \\
\hline TG 110 & A & RFLP y Sec. & & $A B U$ & ARG FOR, Pozo del Tigre \\
\hline TG 111 & $B$ & RFLP & & $A B U$ & $\mathrm{BOL}$ \\
\hline TG 113 & $B$ & RFLP y Sec. & & $A B U$ & ARG SAL RBN, Sta María \\
\hline TG 114 & $\mathrm{D}$ & RFLP y Sec. & & MA & ARG SAL ANT, Gral. Pizarro \\
\hline TG 115 & A & RFLP y Sec. & & ABU & ARG SAL, El Despunte \\
\hline TG 116 & $B$ & RFLP & & $A B U$ & BOL, chaco \\
\hline TG 117 & B & RFLP y Sec. & & $A B U$ & PAR \\
\hline TG 118 & $\mathrm{~B}$ & RFLP & & $A B U$ & ARG SDE? \\
\hline TG 119 & $\mathrm{D}$ & RFLP y Sec. & & DO & ARG SAL GSM, Km 6 (vive en Tonono) Wichí \\
\hline TG 120 & $\mathrm{D}$ & RFLP & & MA & ARG SAL \\
\hline TG 121 & $\mathrm{C} 1 \mathrm{~b}$ & RFLP y Sec. & & $A B U$ & ARG FOR, Puerto Bermejo \\
\hline TG 122 & L2a1 & RFLP y Sec. & & $A B U$ & ARG SAL, Lagunilla (cerca de Güemes) \\
\hline TG 123 & B & RFLP & & $A B U$ & BOL \\
\hline TG 124 & $\mathrm{D}$ & RFLP y Sec. & & MA & ARG SAL GSM, Tartagal \\
\hline TG 125 & B & RFLP y Sec. & & ABU & ARG SAL GSM, Acambuco \\
\hline TG 126 & A & RFLP y Sec. & 663 revertante & $A B U$ & BOL TAR, Villa Montes \\
\hline TG 127 & $B$ & RFLP y Sec. & & $A B U$ & BOL, Peña Colorada \\
\hline TG 128 & B & RFLP y Sec. & & $A B U$ & ARG SAL GUA, Guachipas \\
\hline TG 129 & B & RFLP y Sec. & & $A B U$ & ARG SAL ORAN, H.Yrigoyen \\
\hline TG 131 & B & RFLP & & $A B U$ & España \\
\hline TG 133 & B & RFLP y Sec. & & $A B U$ & ARG SAL RIV, Sta. Victoria, Banda Norte \\
\hline TG 134 & $B$ & RFLP y Sec. & & $A B U$ & ARG SAL GSM, Yacuicito \\
\hline TG 135 & B & RFLP y Sec. & & MA & ARG SAL GSM, Tartagal \\
\hline TG 136 & $\mathrm{C} 1 \mathrm{~b}$ & RFLP y Sec. & & ABU & ARG SAL GSM, Tartagal \\
\hline TG 137 & $\mathrm{~A}$ & RFLP y Sec. & & ABU & ARG SAL, misión La Puntana, Banda Norte \\
\hline TG 138 & $\mathrm{C} 1 \mathrm{c}$ & RFLP y Sec. & & $A B U$ & BOL SCZ, Gutierrez (cerca de Sta. Cruz) \\
\hline TG 139 & $\mathrm{D}$ & RFLP y Sec. & & $A B U$ & ARG JUJ, Huacalera (pasando Tilcara) \\
\hline TG 140 & C1d & RFLP y Sec. & & $A B U$ & ARG JUJ, Perico \\
\hline TG 142 & B & RFLP y Sec. & & $A B U$ & ARG SAL GSM, Tartagal \\
\hline
\end{tabular}


Anexo

\begin{tabular}{|c|c|c|c|c|c|}
\hline Rótulo & $\mathrm{Hg}$ & Método & RFLP info & UACM & Lugar de nacimiento \\
\hline TG 144 & $\mathrm{~B}$ & RFLP y Sec. & & MA & PAR, Macheretí \\
\hline TG 145 & D4h3 & RFLP y Sec. & & $A B U$ & BOL, Villamonte \\
\hline TG 146 & B & RFLP y Sec. & & $A B U$ & PAR, Lomitas \\
\hline TG 147 & $\mathrm{~B}$ & RFLP y Sec. & & $A B U$ & ARG SAL GSM, Aguaray \\
\hline TG AG 01 & A & RFLP & & MA & ARG SAL GSM, Macueta \\
\hline TG AG 02 & $\mathrm{~B}$ & RFLP & & MA & ARG SAL GSM, Aguaray \\
\hline TG AG 03 & $\mathrm{C}$ & RFLP & & MA & ARG SAL, El Sauzal (chaco) \\
\hline TG AG 04 & $\mathrm{D}$ & RFLP & & MA & ARG SAL GSM, Aguaray? \\
\hline TG AG 05 & $B$ & RFLP & & $A B U$ & BOL TAR, Entre Ríos \\
\hline TG AG 06 & B & RFLP & & $A B U$ & ARG SAL GSM, Aguaray \\
\hline TG AG 07 & B & RFLP & & $A B U$ & BOL? \\
\hline TG AG 08 & B & RFLP & & $A B U$ & BOL? \\
\hline TG AG 09 & B & RFLP & & $A B U$ & $\mathrm{BOL}$ \\
\hline TG AG 10 & C & RFLP & & $A B U$ & $\mathrm{BOL}$ \\
\hline TG AG 11 & B & RFLP & & MA & BOL \\
\hline TG AG 12 & C & RFLP & & $A B U$ & ARG SDE \\
\hline TG AG 13 & $B$ & RFLP & & $A B U$ & ARG CHA \\
\hline TG AG 14 & A & RFLP & & $A B U$ & $\mathrm{BOL}$ \\
\hline TG AG 16 & $\mathrm{~N}(\mathrm{xM}, \mathrm{N})$ & RFLP & & $A B U$ & ARF SFE \\
\hline TG AG 17 & $\mathrm{~B}$ & RFLP & & $A B U$ & BOL TAR, Yacuiba \\
\hline TG AG 18 & $\mathrm{~B}$ & RFLP & & $A B U$ & ARG SAL GSM, Campo Largo \\
\hline TG AG 20 & B & RFLP & & MA & ARG SAL GSM, Macueta \\
\hline TG AG 21 & B & RFLP & & $A B U$ & BOL TAR, Itaú \\
\hline TG AG 22 & B & RFLP & & $A B U$ & BOL TAR, Choza Tarija \\
\hline TG AG 23 & B & RFLP & & $A B U$ & $\mathrm{BOL}$ \\
\hline TG AG 24 & $B$ & RFLP & & $A B U$ & BOL TAR \\
\hline TG AG 25 & $B$ & RFLP & & DO & ARG SAL GSM, Macueta \\
\hline TG AG 26 & B & RFLP & & $A B U$ & $\mathrm{BOL}$ \\
\hline TG AG 27 & B & RFLP & & S/D & S/D \\
\hline TG AG 29 & C & RFLP & & $A B U$ & BOL, Caraparí \\
\hline TG AG 34 & B & RFLP & & $A B U$ & ARG SAL GSM, Macueta \\
\hline TG AG 36 & B & RFLP & & $A B U$ & ARG SAL GSM, Macueta \\
\hline TG AG 40 & A & RFLP & & $A B U$ & BOL SCZ \\
\hline TG AG 41 & A & RFLP & & MA & ARG FOR \\
\hline TG AG 42 & B & RFLP & & MA & ARG SAL GSM, Dragones \\
\hline TG AG 43 & C & RFLP & & ABU & ARG LRJ, Chepes \\
\hline TG AG 44 & C & RFLP & & ABU & ARG CBA, Sobremonte \\
\hline TG AG 45 & C & RFLP & & $A B U$ & ARG SAL GSM, Aguaray_Tobantirenda \\
\hline TG AG 46 & $\mathrm{C}$ & RFLP & & $A B U$ & ARG SAL METAN \\
\hline TG AG 47 & B & RFLP & & $A B U$ & $\mathrm{BOL}$ \\
\hline TG AG 48 & B & RFLP & & S/D & S/D \\
\hline TG AG 56 & C & RFLP & & $A B U$ & ARG SAL GSM, Campo Largo \\
\hline TG AG 57 & $\mathrm{D}$ & RFLP & & S/D & S/D \\
\hline TG AG 60 & $B$ & RFLP & & S/D & S/D \\
\hline TG AG 66 & B & RFLP & & DO & ARG SAL GSM, Acambuco \\
\hline TG AG 67 & B & RFLP & & DO & ARG SAL GSM, Tuyunti (comunidad Chané) \\
\hline TG AG 68 & C & RFLP & & $A B U$ & ARG SAL CERRILLOS, La Garza \\
\hline TG BS 01 & $\mathrm{~B}$ & RFLP & & $A B U$ & ARG SAL GSM, Tartagal \\
\hline TG BS 02 & B & RFLP & & $A B U$ & ARG SAL ORAN, Pichanal \\
\hline TG BS 03 & B & RFLP & & $A B U$ & ARG SAL ORAN, Urundel \\
\hline TG BS 04 & C & RFLP & & MA & ARG SAL GSM, Acambuco \\
\hline TG BS 05 & B & RFLP & & $A B U$ & ARG SAL ORAN \\
\hline TG BS 06 & C & RFLP & & $A B U$ & ARG SAL GSM, Tartagal \\
\hline TG BS 07 & B & RFLP & & ABU & ARG SAL GSM, Tartagal \\
\hline TG BS 08 & $\mathrm{D}$ & RFLP & & ABU & ARG SAL GSM, Aguaray? \\
\hline TG BS 09 & $\mathrm{D}$ & RFLP & & $A B U$ & ARG SAL GSM, Aguaray \\
\hline TG BS 10 & $B$ & RFLP & & $A B U$ & ARG SAL ORAN \\
\hline TG BS 11 & D & RFLP & & DO & ARG SAL GSM, Yacuy \\
\hline TG BS 12 & D & RFLP & & $A B U$ & BOL \\
\hline TG BS 13 & A & RFLP & & $A B U$ & PAR \\
\hline TG BS 14 & $\mathrm{D}$ & RFLP & & $A B U$ & ARG JUJ, Jujuy capital \\
\hline TG BS 16 & $B$ & RFLP & & $A B U$ & BOL TAR \\
\hline TG BS 17 & $\mathrm{C} 1 \mathrm{~b}$ & RFLP y Sec. & & $A B U$ & ARG SAL GSM, El Algarrobal \\
\hline TG BS 18 & C1b & RFLP y Sec. & & ABU & ARG SAL GSM, Tartagal \\
\hline TG BS 19 & $\mathrm{D}$ & RFLP y Sec. & & ABU & BOL SCZ, Charagua \\
\hline TG BS 20 & B & RFLP & & DO & ARG SAL RDL \\
\hline TG BS 21 & B & RFLP y Sec. & & $A B U$ & ARG SAL GSM, Tuyunti \\
\hline TG BS 22 & B & RFLP y Sec. & & DO & ARG SAL GSM, Coronel Cornejo \\
\hline TG BS 23 & B & RFLP & & $A B U$ & $\mathrm{BOL}$ \\
\hline
\end{tabular}


Anexo

\begin{tabular}{|c|c|c|c|c|c|}
\hline Rótulo & $\mathrm{Hg}$ & Método & RFLP info & UACM & Lugar de nacimiento \\
\hline TG BS 24 & A & RFLP y Sec. & 663 revertante & $A B U$ & ARG JUJ, San Pedro \\
\hline TG BS 25 & C & RFLP & & MA & ARG TUC \\
\hline TG BS 26 & $\mathrm{D}$ & RFLP y Sec. & & $A B U$ & ARG SAL GSM, Tartagal_La Curvita \\
\hline TG BS 27 & A & RFLP y Sec. & & $A B U$ & $\mathrm{BOL}$ \\
\hline TG BS 28 & C & RFLP & & $A B U$ & $\mathrm{BOL}$ \\
\hline TG BS 29 & $\mathrm{D}$ & RFLP y Sec. & & $A B U$ & ARG SAL RIV \\
\hline TG BS 30 & $B$ & RFLP & & $A B U$ & BOL \\
\hline TG BS 31 & C1b & RFLP y Sec. & & $A B U$ & ARG SAL RDF \\
\hline TG BS 32 & A & RFLP & & $A B U$ & BOL \\
\hline TG BS 33 & B & RFLP & & MA & ARG TUC \\
\hline TG BS 34 & C & RFLP & & $A B U$ & ARG SDE, Stgo. Del Estero capital \\
\hline TG BS 35 & B & RFLP & & $A B U$ & ARG SAL GSM, Tartagal \\
\hline TG BS 36 & A & RFLP & & $A B U$ & ARG SAL GSM, Capiasuti \\
\hline TG BS 37 & B & RFLP & & $A B U$ & BOL \\
\hline TG BS 38 & C & RFLP & & $A B U$ & ARG SAL (chaco) \\
\hline TG BS 39 & B & RFLP & & $A B U$ & BOL LPZ, La Paz \\
\hline TG BS 40 & B & RFLP & & $A B U$ & BOL, Chilcara \\
\hline TG BS 41 & $B$ & RFLP & & $A B U$ & ARG JUJ \\
\hline TG BS 42 & B & RFLP & & $A B U$ & $\mathrm{BOL}$ \\
\hline TG BS 43 & $\mathrm{D}$ & RFLP & & $A B U$ & BOL SCZ \\
\hline TG BS 44 & B & RFLP & & $A B U$ & ARG SAL GSM, Campamento Vespucio \\
\hline TG BS 45 & B & RFLP & & $A B U$ & BOL TAR, Entre Ríos \\
\hline TG BS 46 & B & RFLP & & DO & ARG SAL GSM, Tartagal \\
\hline TG BS 47 & $\mathrm{D}$ & RFLP & & MA & ARG SAL RIV, Misión Pozo del Tigre \\
\hline TG BS 48 & $\mathrm{D}$ & RFLP & & MA & ARG SAL GSM, Misión Chorote \\
\hline TG BS 49 & $B$ & RFLP & & MA & ARG TUC \\
\hline TG BS 50 & C & RFLP & & $A B U$ & ARG SDE \\
\hline TG BS 51 & $\mathrm{D}$ & RFLP & & MA & ARG SAL RIV (chaco) \\
\hline TG BS 52 & $\mathrm{D}$ & RFLP & & MA & ARG SAL GSM, Embarcación \\
\hline TG BS 53 & $\mathrm{~B}$ & RFLP & & $A B U$ & ARG SAL GSM, Embarcación \\
\hline TG BS 54 & B & RFLP & & $A B U$ & BOL, Gutierrez \\
\hline TG BS 55 & D & RFLP & & $A B U$ & ARG SAL RIV, Monte Carmelo \\
\hline TG EA 01 & B & Sec. & & $A B U$ & ARG SAL, Salta capital \\
\hline TG EA 02 & $\mathrm{~N}(\mathrm{xM}, \mathrm{N})$ & RFLP & & $A B U$ & ARG BS AS \\
\hline TG EA 03 & $\mathrm{~N}(\mathrm{xM}, \mathrm{N})$ & RFLP & & $A B U$ & ARG LPAM, General Pico \\
\hline TG EA 04 & B & RFLP & & $A B U$ & ARG SAL GSM, Ycuarenda \\
\hline TG EA 05 & B & RFLP & & MA & BOL TAR \\
\hline TG EA 06 & C & RFLP & & $A B U$ & ARG, Cap. Fed. \\
\hline TG EA 07 & $B$ & RFLP & & $A B U$ & ARG JUJ, La Quiaca \\
\hline TG EA 08 & B & RFLP & & MA & ARG JUJ, Tilcara \\
\hline TG EA 09 & B & RFLP & & $A B U$ & ARG JUJ TUMBAYA, Volcán \\
\hline TG EA 10 & A & RFLP & & $A B U$ & ARG CORR \\
\hline TG EA 11 & A & RFLP & & $A B U$ & PAR \\
\hline TG EA 12 & C & RFLP & & $A B U$ & ARG SAL GSM, Tartagal \\
\hline TG EA 13 & $\mathrm{C}$ & RFLP & & MA & ARG SAL, General Güemes \\
\hline TG EA 14 & $\mathrm{H}$ & Sec. & & $A B U$ & ARG BS AS \\
\hline TG EA 15 & A & RFLP & & $A B U$ & BOL \\
\hline TG EA 16 & $\mathrm{D}$ & RFLP & & $A B U$ & BOL TAR \\
\hline TG EA 17 & A & RFLP & & $A B U$ & ARG LR \\
\hline TG EA 18 & B & RFLP & & $A B U$ & ARG SAL RIV, Santa Victoria Este \\
\hline TG EA 19 & B & RFLP & & $A B U$ & ARG SAL ORAN, EI Chulque \\
\hline TG EA 20 & $L(x A, B)$ & RFLP & & $A B U$ & ARG SAL, Salta capital \\
\hline TG EA 21 & C & RFLP & & $A B U$ & ARG SDE, Campo Gallo \\
\hline TG EA 22 & A & RFLP & & ABU & ARG SAL ORAN \\
\hline TG EA 23 & A & RFLP & & ABU & ARG SAL CAFAYATE \\
\hline TG EA 24 & $\mathrm{D}$ & RFLP & & $A B U$ & ARG SAL CAFAYATE \\
\hline TG SAL 01 & $\mathrm{D}$ & RFLP & & $A B U$ & BOL? \\
\hline TG SAL 02 & B & RFLP & & $A B U$ & BOL SCZ \\
\hline TG SAL 03 & B & RFLP & & $A B U$ & BOL \\
\hline TG SAL 04 & B & RFLP & & $A B U$ & BOL, Tiwanaku \\
\hline TG SAL 05 & A & RFLP & & $A B U$ & $\mathrm{BOL}$ \\
\hline TG SAL 06 & $\mathrm{D}$ & RFLP & & $A B U$ & ARG SAL ORAN \\
\hline \multicolumn{6}{|c|}{ Villa Tulumaya } \\
\hline L 001 & A & Sec. & & ABU & ARG SJN \\
\hline L 002 & $B$ & Sec. & & $A B U$ & BOL, La Paz \\
\hline L 003 & $\mathrm{C} 1 \mathrm{~b}$ & Sec. & & $A B U$ & CHI, Puerto Mont \\
\hline L 004 & D1 & Sec. & & $A B U$ & ARG SJN \\
\hline L 005 & B & RFLP & & MA & ARG SNJ, Pocitos \\
\hline L 007 & A & Sec. & & $A B U$ & ARG SLS \\
\hline
\end{tabular}


Anexo

\begin{tabular}{|c|c|c|c|c|c|}
\hline Rótulo & $\mathrm{Hg}$ & Método & RFLP info & UACM & Lugar de nacimiento \\
\hline L 008 & $\mathrm{~B}$ & RFLP & & $A B U$ & ARG JUJ \\
\hline L 012 & L1b & Sec. & & $A B U$ & ARG MZA, Capital \\
\hline L013 & $B$ & Sec. & & $A B U$ & BOL, Sucre, Chirimayo \\
\hline Lo15 & B & Sec. & & ABU & ARG LAR \\
\hline L 016 & A & RFLP & & DO & ARG JUJ, Yavi \\
\hline L 017 & A & Sec. & & $A B U$ & ARG MZA, Maipú \\
\hline L 018 & $B$ & Sec. & & $A B U$ & ARG SJN \\
\hline L 019 & $B$ & Sec. & & $A B U$ & ARG SAL, Orán, San Andrés \\
\hline L 020 & B & RFLP & & $A B U$ & ARG MZA \\
\hline L 021 & $B$ & Sec. & & $A B U$ & ARG MZA, Lavalle \\
\hline L 022 & $B$ & Sec. & & $A B U$ & ARG MZA, Lavalle \\
\hline L 023 & $\mathrm{C} 1 \mathrm{~b}$ & Sec. & & ABU & ARG MZA, Luján \\
\hline L 025 & $\mathrm{C} 1 \mathrm{~b}$ & Sec. & & ABU & ARG MZA, Rivadavia \\
\hline L 026 & $\mathbf{H}$ & Sec. & & MA & ARG MZA, Carrizal \\
\hline L 027 & $\mathrm{C} 1 \mathrm{~b}$ & Sec. & & $A B U$ & ARG SJN \\
\hline L 029 & $\mathrm{C} 1 \mathrm{~b}$ & Sec. & & $A B U$ & ARG LAR, Vinchina \\
\hline L 030 & A & Sec. & & $A B U$ & ARG MZA, Capital \\
\hline L032 & D1 & Sec. & & $A B U$ & ARG MZA, Lavalle \\
\hline L033 & $\mathrm{N}(\mathrm{xA}, \mathrm{B})$ & RFLP & & MA & ARG CBA, Bellville \\
\hline L 034 & $\mathrm{~A}$ & Sec. & & $A B U$ & ARG SJN, Los Berros \\
\hline L035 & C & RFLP & & MA & ARG SAL \\
\hline L 036 & $N(x A, B)$ & RFLP & & $A B U$ & España \\
\hline L 037 & A & Sec. & & ABU & ARG MZA, Lavalle \\
\hline L039 & $\mathrm{N}(\mathrm{xA}, \mathrm{B})$ & RFLP & & $A B U$ & ARG SFE, Rosario? \\
\hline L 041 & D1 & Sec. & & $A B U$ & ARG SJN \\
\hline L 042 & ? & Sec. & & $A B U$ & PAR \\
\hline Lo43 & $B$ & RFLP & & MA & ARG MZA, Luján o Godoy Cruz \\
\hline L 044 & A & RFLP & & MA & ARG MZA, Capital \\
\hline Lo45 & $\mathrm{H}$ & Sec. & & $A B U$ & ARG MZA, Lavalle \\
\hline Lo46 & $\mathrm{C} 1 \mathrm{~b}$ & Sec. & & ABU & ARG MZA, Lavalle \\
\hline L 047 & $\mathrm{C} 1 \mathrm{~b}$ & Sec. & & ABU & ARG SJN \\
\hline L 048 & $\mathrm{C} 1 \mathrm{~b}$ & Sec. & & $A B U$ & ARG MZA, Lavalle \\
\hline L 049 & $N(x A, B)$ & RFLP & & $A B U$ & Italia \\
\hline L 050 & A & Sec. & & MA & ARG MZA, Lavalle \\
\hline L 051 & C1c & Sec. & Alul $13262+$ & $A B U$ & ARG MZA, Lavalle, Costa de Araujo \\
\hline Lo52 & $N(x A, B)$ & RFLP & & $A B U$ & España \\
\hline L 053 & $\mathrm{H}$ & Sec. & & $A B U$ & ARG MZA, 25 de Mayo, Corralito \\
\hline L 054 & D1 & Sec. & & $A B U$ & ARG MZA, Lavalle \\
\hline L055 & $\mathrm{H}$ & Sec. & & $A B U$ & ARG MZA, Godoy Cruz \\
\hline L 056 & A & Sec. & & ABU & ARG MZA, Lavalle \\
\hline L 057 & C1c & Sec. & Alul 13262+ & $A B U$ & ARG MZA, Junín de Cuyo \\
\hline L 058 & $\mathrm{~N}(\mathrm{xA}, \mathrm{B})$ & RFLP & & MA & ARG MZA, Junín de Cuyo \\
\hline L 059 & A & RFLP & & MA & ARG SJN \\
\hline L 060 & A & Sec. & & $A B U$ & ARG SJN \\
\hline L 060 & A & RFLP & & $A B U$ & ARG SJN \\
\hline L061 & U4a2 & Sec. & & $A B U$ & ARG SJN \\
\hline L062 & $\mathrm{C} 1 \mathrm{~b}$ & Sec. & & ABU & ARG MZA, San Carlos \\
\hline L063 & A & Sec. & & $A B U$ & ARG MZA, Lavalle, Costa de Araujo \\
\hline L 064 & A & Sec. & & MA & ARG SJN \\
\hline L 065 & A & Sec. & & MA & ARG MZA, Lavalle \\
\hline L 067 & $B$ & RFLP & & ABU & ARG MZA, Gral Alvear \\
\hline L 068 & $\mathrm{C}$ & RFLP & & MA & ARG SNJ, Pocitos \\
\hline L 069 & $B$ & Sec. & & $A B U$ & ARG MZA, Lavalle \\
\hline L 070 & A & RFLP & & MA & ARG SJN \\
\hline L 072 & $\mathrm{~A}$ & Sec. & & $A B U$ & ARG MZA, Capital \\
\hline L 073 & $\mathrm{C} 1 \mathrm{~b}$ & Sec. & & $A B U$ & ARG MZA, Lavalle \\
\hline L 075 & $\mathrm{C} 1 \mathrm{~b}$ & Sec. & & MA & ARG MZA, Lavalle \\
\hline L 075 & $\mathrm{C}$ & RFLP & & $A B U$ & ARG MZA, Lavalle \\
\hline L 076 & $\mathrm{~B}$ & Sec. & & $A B U$ & ARG SJN, (idem) \\
\hline L 077 & $\mathrm{~N}(\mathrm{xA}, \mathrm{B})$ & RFLP & & $A B U$ & Italia \\
\hline L 078 & L2a1 & Sec. & & $A B U$ & ARG MZA, Lavalle \\
\hline L 079 & D1 & Sec. & & $A B U$ & ARG MZA, Lavalle, Lags Rosario \\
\hline L 080 & H5 & Sec. & & MA & ARG LAR \\
\hline L 081 & $\mathrm{C} 1 \mathrm{~b}$ & Sec. & & ABU & $\mathrm{CHI}$ \\
\hline L082 & C1d & Sec. & & ABU & ARG TUC, Aguilar \\
\hline L 083 & A & Sec. & & $A B U$ & ARG MZA, Lavalle, Costa de Araujo \\
\hline L 084 & A & RFLP & & MA & ARG MZA \\
\hline L 085 & B & Sec. & & $A B U$ & BOL \\
\hline L086 & B & RFLP & & MA & BOL \\
\hline
\end{tabular}


Anexo

\begin{tabular}{|c|c|c|c|c|c|}
\hline Rótulo & $\mathrm{Hg}$ & Método & RFLP info & UACM & Lugar de nacimiento \\
\hline L 087 & A & Sec. & & $A B U$ & BOL, Tarija \\
\hline L 088 & L3f1b1 & Sec. & & $A B U$ & ARG SNJ \\
\hline L 089 & A & Sec. & & $A B U$ & ARG SJN, Jáchal \\
\hline L 090 & $\mathrm{D}$ & RFLP & & $A B U$ & ARG MZA LAV, Costa de Araujo \\
\hline L 091 & C1d & Sec. & & $A B U$ & ARG SJN, Caucete \\
\hline L 092 & A & Sec. & & $A B U$ & ARG MZA, Lavalle, Lags Rosario \\
\hline L 093 & $\mathrm{C} 4 \mathrm{c}$ & Sec. & & MA & ARG MZA, Lavalle, S. MigueLAVSauces \\
\hline L 094 & B & Sec. & & $A B U$ & BOL, Sucre \\
\hline L 095 & B & Sec. & & $A B U$ & ARG LAR, Vinchina \\
\hline L 096 & $\mathrm{H}$ & Sec. & & $A B U$ & ARG MZA, Lavalle \\
\hline L 098 & C1c & Sec. & Alul 13262- & $A B U$ & ARG MZA, San Martín \\
\hline L 099 & C1c & Sec. & Alul 13262+ & $A B U$ & ARG MZA, Lavalle \\
\hline L 100 & $\mathrm{~L} 1 \mathrm{~b}$ & Sec. & & $A B U$ & ARG MZA, Capital \\
\hline L 101 & L3f1b1 & Sec. & & $A B U$ & ARG MZA, San Martín, California \\
\hline L 102 & C1b & Sec. & & MA & ARG SLS \\
\hline L 103 & D1 & Sec. & & $A B U$ & ARG SJN, Sta Lucía \\
\hline L 104 & $\mathrm{~B}$ & RFLP & & MA & ARG MZA, San Carlos \\
\hline L 105 & A & Sec. & & $A B U$ & ARG SJN \\
\hline L 106 & $\mathrm{~B}$ & Sec. & & $A B U$ & ARG SJN \\
\hline L 107 & L1b & Sec. & & $A B U$ & ARG MZA, Lavalle \\
\hline SLV 04 & D1 & Sec. & & $A B U$ & ARG SLS, San Fco Monte de Oro \\
\hline SLV 05 & $\mathrm{C}$ & RFLP & & MA & ARG MZA, Lavalle \\
\hline SLV 07 & B & Sec. & & $A B U$ & ARG MZA, Lavalle \\
\hline SLV 08 & B & Sec. & & $A B U$ & ARG MZA, San Martín Palmira \\
\hline SLV 09 & B & Sec. & & $A B U$ & ARG MZA, Lavalle \\
\hline SLV 10 & C1b & Sec. & & $A B U$ & BOL \\
\hline SLV 11 & $\mathrm{C}$ & RFLP y AFLP & Alul 13262 - & MA & ARG SJN, Sta Lucía \\
\hline SLV 12 & U5 & Sec. & & $A B U$ & ARG SJN, Albardón \\
\hline SLV 14 & C1b & Sec. & & $A B U$ & ARG MZA, San Rafael \\
\hline
\end{tabular}


7.2.2 LiSTA DE MUESTRAS SECUENCIADAS POR LOCALIDAD, INDICANDO LAS MUTACIONES CON RESPECTO A LA SECUENCIA DE REFERENCIA DE CAMBRIDGE (SRC REVISADA), EL RANGO DE LECTURA Y LA UBICACIÓN EN LAS REDES DE HAPLOTIPOS.

\begin{tabular}{|c|c|c|c|c|c|}
\hline $\begin{array}{l}\text { ID en } \\
\text { la red }\end{array}$ & ID & $\mathrm{Hg}$ & Región Control 5' (+16000) & Región Control 3' & Rango de lectura \\
\hline 1.1 & CAL 31 & A2 & 111223290319362 & 064073146153235263 309+C 315+C 523dd & $15878-16569$ / 001-628 \\
\hline 1.1 & CHE 37 & A2 & 111223290319362 & $064073146153235263315+C$ 523dd & $15878-16569$ / 001-628 \\
\hline 1.1 & J36 & A2 & 111223290319362 & $064073146153235263315+C$.C 523dd & $15878-16569$ / 001-628 \\
\hline 1.1 & SJ 099 & A2 & 111223290319362 & $064073146153235263315+C$. 523dd & $15878-16569$ / 001-628 \\
\hline 1.1 & TG 066 & A2 & 111223290319362 & $064073146153235263309+C 315+C$ & $16024-16569$ / 001-576 \\
\hline 1.1 & L 030 & A2 & 111223290319362 & $064073146153235263315+C$ 523dd & $16024-16569$ / 001-576 \\
\hline 1.1 & LQ 023 & A2 & 111223290319362 & $064073146153235263315+C$ 523dd & $15991-16569$ / 001-628 \\
\hline 1.1 & MM 108 & A2 & 111223290319362 & 064073146153235263 309+C 315+C 523dd & 15991-16569/ 001-628 \\
\hline 1.1 & MM 120 & A2 & 111 179Y 223290319362 & 064073146153235263 309+CC 315+C 523dd & 15991-16569/001-628 \\
\hline 1.2 & SMA 011 & A2 & 15972111189223290319362 & $064073146153235263315+C$ 523dd & $15878-16569$ / 001-628 \\
\hline 1.2 & SMA 061 & A2 & 15972111189223290319362 & $064073146153235263315+C$ 523dd & $15878-16569$ / 001-628 \\
\hline 1.2 & L 007 & A2 & 15972111189223290319362 & $064073146153235263309+C$ 315+C 523dd & $15972-16569$ / 001-576 \\
\hline 1.2 & L 034 & A2 & 15972111189223290319362 & 064073146153 215R 235263 309+CC 315+C 523dd & 15972-16569 / 001-576 \\
\hline 1.3 & MZ 008 & A2 & 15972111189223290319362 & 064073146152153235263 309+C 315+C 523dd & $15972-16569$ / 001-576 \\
\hline 1.4 & MZ 007 & A2 & $15972111189193+C 193.2 C 223290319362$ & 064073146153235263 309+C 315+C 523dd & $15972-16569$ / 001-576 \\
\hline 1.4 & SJ 104 & A2 & $15972111189193+C C 223290319362$ & 064073146153235263 309+CC 315+C 523dd & $15878-16569$ / 001-628 \\
\hline 1.5 & CAL 12 & A2 & $111223243 Y 290319362$ & $064073146153235315+C$ 523dd & $15878-16569$ / 001-628 \\
\hline 1.5 & LR BS 11 & A2 & 111223290319362 & $064073146153235315+C$ 523dd & $15878-16569$ / 001-628 \\
\hline 1.5 & SJ 088 & A2 & 111223290319362 & $064073146153235315+C$ 523dd & $15878-16569$ / 001-628 \\
\hline 1.5 & SJ JA 07 & A2 & 111223290319362 & $064073146153235315+C$ 523dd & $15878-16569$ / 001-628 \\
\hline 1.6 & Be 016 & A2 & 111189209223290319362519 & $064073146235263315+C$ 523dd & $15878-16569$ / 001-628 \\
\hline 1.6 & SJ 011 & A2 & 111189209223290319362519 & $064073146235263309+C$ 315+C 523dd & $15878-16569$ / 001-628 \\
\hline 1.7 & LQ 035 & A2 & 111209223290319 & $064073146153235238263309+C$ 315+C 523dd & $15991-16569$ / 001-628 \\
\hline 1.8 & TG 126 & A2 & 111209223290301319 & $064073146153235238263309+C$ 315+C 523dd & $16024-16569$ / 001-576 \\
\hline
\end{tabular}

167 


\begin{tabular}{|c|c|c|c|c|c|}
\hline $\begin{array}{l}\text { ID en } \\
\text { la red }\end{array}$ & ID & $\mathrm{Hg}$ & Región Control 5' (+16000) & Región Control 3' & Rango de lectura \\
\hline 1.8 & TG BS 24 & A2 & 111209223290301319 & 064073146153235238263 315+C 523dd & $15878-16569$ / 001-628 \\
\hline 1.9 & SMA 068 & A2 & 209223290319362 & 064073146153235263 309+C 315+C 456 523dd & $15878-16569$ / 001-628 \\
\hline 1.10 & MZ 091 & A2 & 111192209223290319362 & 064073146153235263 315+C 523dd & $16024-16569 / 001-576$ \\
\hline 1.11 & $J 15$ & A2 & 111223290291319362465 & 010064073153235263 309+C 315+C 523dd & $15878-16569$ / 001-628 \\
\hline 1.11 & $J 49$ & A2 & 111223290291319362465 & 010064073153235263 315+C 523dd & $15878-16569$ / 001-628 \\
\hline 1.12 & L 087 & A2 & 111117223290319362465519 & 064073146153215235263 315+C 523dd & $15898-16569$ / 001-628 \\
\hline 1.13 & TG AG 41 & A2 & 111223266290319362 & 064073146153235263 315+C 523dd & $15878-16569$ / 001-628 \\
\hline 1.14 & TG BS 13 & A2 & 111223 239A 266290319362 & 064073146153207235263 309+C 315+C 523dd & $15878-16569$ / 001-628 \\
\hline 1.15 & LQ 152 & A2 & 111223266290319362437 & 073146153235263 309+CC 315+C 356+C 499 523dd & $15991-16569$ / 001-628 \\
\hline 1.16 & MM 027 & A2 & 111266290319362437 & 073146153235263 309+CC 315+C 356+C 499 523dd & $15991-16569 / 001-628$ \\
\hline 1.17 & $J 11$ & A2 & 111223290319362 & 064073146153235239263 309+C 315+C 523dd & $15878-16569$ / 001-628 \\
\hline 1.18 & TG EA 23 & A2 & 111290319350362 & 073103146153235239263 309+C 315+C 418 523dd & $15878-16569 / 001-628$ \\
\hline 1.19 & LQ 164 & A2 & 111223290362 & $064073146153235239263309+C$ 315+C 523dd & $15991-16569$ / 001-628 \\
\hline 1.20 & LQ 020 & A2 & 111223290319362 & 064073146153200235251263 309+C 315+C & $16009-16569$ / 001-600 \\
\hline 1.20 & LQ 087 & $A 2$ & 111223290319362 & $064073146153200235251263309+C 315+C$ & $15991-16569$ / 001-628 \\
\hline 1.20 & LQ 149 & A2 & 111223290319362 & $064073146153200235251263309+C 315+C$ & 15991-16569 / 001-628 \\
\hline 1.20 & LQ Pr 10 & A2 & 111223290319362 & $064073146153200235251263309+C 315+C$ & $15991-16569$ / 001-628 \\
\hline 1.20 & MM 093 & A2 & 111223290319362 & $064073146153200235251263309+C 315+C$ & 15991-16569/001-628 \\
\hline 1.21 & MM 008 & A2 & 097098111223260286290319362 & $064073146153235263309+C C$ 315+C 523dd & 15991-16569/ 001-628 \\
\hline 1.22 & TG BS 36 & A2 & 111223286290319362 & 061A 062064073146153 235R 263 315+C 523dd & $15878-16569$ / 001-628 \\
\hline 2.1 & Be 060 & $\mathrm{~A} 2$ & 111223290319362519 & 064073146153235263 309+C 315+C 523dd & $15878-16569$ / 001-628 \\
\hline 2.1 & SJ 010 & A2 & 111223290319362519 & $064073146153235263309+C$ 315+C 523dd & $15878-16569$ / 001-628 \\
\hline 2.1 & SJ 018 & A2 & 111223290319362519 & 064073146153235263 309+C 315+C 523dd & $15878-16569$ / 001-628 \\
\hline 2.1 & SJ 022 & A2 & 111223290319362519 & 064073146153235263 309+C 315+C 523dd & $15878-16569$ / 001-628 \\
\hline 2.1 & SJ 023 & A2 & 111223290319362519 & 064073146153235263 309+C 315+C 523dd & $15878-16569$ / 001-628 \\
\hline 2.1 & TG AG 67 & A2 & 111223290319362519 & 064073146153235263 309+CC 315+C 523dd & $15878-16569$ / 001-628 \\
\hline 2.1 & LQ 061 & A2 & 111223290319362519 & $064073146153235263315+C$ 523dd & 15991-16569 / 001-628 \\
\hline 2.1 & MM 132 & A2 & 111223290319362519 & $064073146153235263315+C$ 523dd & 15991-16569/001-628 \\
\hline 2.2 & LQ 021 & A2 & 111223290319362519 & 064073143146153235263310 315d 523dd & $15991-16569$ / 001-628 \\
\hline
\end{tabular}




\begin{tabular}{|c|c|c|c|c|c|}
\hline $\begin{array}{l}\text { ID en } \\
\text { la red }\end{array}$ & ID & $\mathrm{Hg}$ & Región Control 5’ (+16000) & Región Control 3' & Rango de lectura \\
\hline 2.3 & LQ Pr 30 & A2 & 111223290319356362519 & 064073143146153235263310 523dd & 15991-16569 / 001-628 \\
\hline 2.4 & LQ 132 & A2 & 111223290311319362463519 & 064073143146153235263 309+C 315+C 523dd & $15991-16569$ / 001-628 \\
\hline 2.5 & TG EA 10 & A2 & $111189193+C C 223290319320362519$ & 064073143146153235263 309d 315+C 345 523dd & $15878-16569$ / 001-628 \\
\hline 2.6 & $\mathrm{~J} 58$ & A2 & $111189193+$ +CC 223263290319362519 & 064073146153235263 309+CC 315+C 523dd & $15878-16569$ / 001-628 \\
\hline 2.7 & MZ 035 & $\mathrm{~A} 2$ & 111156223263290319362438519 & 064073146153235263 315+C 523dd 573A & $16024-16569$ / 001-576 \\
\hline 2.8 & LQ 081 & A2 & 092223 234A 256290319325362519 & $073146153235263315+C$ 523dd & 15991-16569 / 001-628 \\
\hline 2.9 & LQ SCA 03 & A2 & $092223234 G 256290319325362519$ & 073146153200235263 315+C 523dd & $15991-16569$ / 001-628 \\
\hline 2.10 & LQ 121 & A2 & $223234 G 256290319362519$ & $073146153235263309+C$ 315+C 523dd & 15991-16569 / 001-628 \\
\hline 2.10 & LQ 135 & A2 & 223 234G 256290319362519 & 073146153235263 309+CC 315+C 523dd & $15991-16569$ / 001-628 \\
\hline 2.10 & MM 112 & A2 & $223234 R 256290319362519$ & $073146153235263315+C$ 523dd & $15991-16569 / 001-628$ \\
\hline 2.10 & MM Pur 14 & A2 & $223234 G 256290319362519$ & 073146153235263 309+C 315+C 523dd & 15991-16569/ 001-628 \\
\hline 2.10 & MM Pur 18 & A2 & $223234 G 256290319362519$ & 073146153235263 309+C 315+C 523dd & 15991-16569/ 001-628 \\
\hline 2.11 & SMA 096 & A2 & 15946111223290319362519 & 064Y 073146152153194235263 315+C 523dd & $15878-16569$ / 001-628 \\
\hline 2.11 & LQ 062 & A2 & 111223290319362519 & 064073146152153194235263 315+C 523dd & $15991-16569$ / 001-628 \\
\hline 2.11 & LQ 126 & A2 & 111223290319362519 & 064073146152153194235263 315+C 523dd & 15991-16569 / 001-628 \\
\hline 2.11 & MM 046 & A2 & 111223290319362519 & 064073146152153194235263 315+C 523dd & 15991-16569/ 001-628 \\
\hline 2.11 & MM 075 & A2 & 111223290319362519 & 064073146152153194235263 315+C 523dd & 15991-16569/001-628 \\
\hline 2.11 & MM Pur 02 & A2 & 111223290319362519 & 064073146152153194235263 315+C 523dd & $15991-16569 / 001-628$ \\
\hline 2.12 & MM 076 & A2 & 223290319362519 & 064073146153182194195263 309+C 315+C 523dd & $15991-16569 / 001-628$ \\
\hline 2.12 & MM 096 & A2 & 223290319362519 & 064073146153182194195263 309+C 315+C 523dd & $15991-16569 / 001-628$ \\
\hline 2.12 & MM 103 & A2 & 223290319362519 & 064073146153182194195263 309+C 315+C 523dd & 15991-16569/ 001-628 \\
\hline 2.13 & TG 110 & A2 & 223290319362 & 064073146153235263 309+C 315+C 523dd & $16024-16569$ / 001-576 \\
\hline 2.14 & MM 061 & $\mathrm{~A} 2$ & 189223260288290319362 & 064073146153234235263 309+C 315+C 523dd & $16014-16569$ / 001-628 \\
\hline 2.14 & MM Pur 31 & A2 & 189223260288290319362 & 064073146153234235263 309+C 315+C 523dd & $16014-16569$ / 001-628 \\
\hline 2.15 & LQ 012 & A2 & 095111223290319362519 & 064073146153235263 315+C 523dd & $15991-16569$ / 001-628 \\
\hline 2.15 & LQ 117 & A2 & 095111223290319362519 & 064073146153235263 315+C 523dd & 15991-16569 / 001-628 \\
\hline 2.16 & CAL 55 & A2 & 111223290319362519 & 064073146153235263 309+CC 315+C 521dddd & $15878-16569$ / 001-628 \\
\hline 2.17 & LQ 065 & A2 & 111217223290319 343Т 362 & 064073146153235260263 315+C 523dd & $15991-16569$ / 001-628 \\
\hline 2.18 & MM 037 & A2 & 111217223290319362519 & 064073146153212215235249263 315+C 523dd & 15991-16569/ 001-628 \\
\hline
\end{tabular}

169 


\begin{tabular}{|c|c|c|c|c|c|}
\hline $\begin{array}{l}\text { ID en } \\
\text { la red }\end{array}$ & ID & $\mathrm{Hg}$ & Región Control 5' (+16000) & Región Control 3' & Rango de lectura \\
\hline 2.19 & LQ 084 & A2 & 111217223287290319362519 & 064073146153212215235263 315+C 523dd & 15991-16569 / 001-628 \\
\hline 2.20 & CHE 39 & A2 & 15927R 111223290319362519 & 064073146153210235263 315+C 523dd & $15878-16569$ / 001-628 \\
\hline 2.20 & SJ 085 & A2 & 111223290319362519 & 064073146153210235263 315+C 523dd & $15878-16569$ / 001-628 \\
\hline 2.20 & L 001 & A2 & 111223290319362519 & 064073146153210235263 315+C 523dd & $16024-16569$ / 001-576 \\
\hline 2.21 & SMA 027 & A2 & 111188223290319357362519 & 064073146153235263 309+C 315+C 523dd & $15878-16569$ / 001-628 \\
\hline 2.22 & SMA 141 & $\mathrm{~A} 2$ & 111 182M 183C 189 193+C 223290319356362519 & $064073146 Y 153235263$ 309+C 315+C 523dd & 15878-16569 / 001-628 \\
\hline 2.23 & CAL 07 & A2 & 111223290294319362519 & 064073146153235263 315+C 523dd & $15878-16569$ / 001-628 \\
\hline 2.23 & CAL 57 & A2 & 111223290294319362519 & 064073146153235263 315+C 523dd & $15878-16569$ / 001-628 \\
\hline 2.24 & TG 115 & A2 & $111186223290294319354 Y 362519$ & $064073146152153235263309+C$ 315+C 523dd & 16024-16569 / 001-576 \\
\hline 2.25 & Be 008 & A2 & 111223290319362519 & 064073146153155235263 309+C 315+C 523dd & $15878-16569$ / 001-628 \\
\hline 2.25 & Be 087 & A2 & 111223290319362519 & $064073146153155235263309+C$ 315+C 523dd & $15878-16569$ / 001-628 \\
\hline 2.25 & BeP 20 & A2 & 111223290319362519 & 064073146153155235263 309+C 315+C 523dd & $15878-16569$ / 001-628 \\
\hline 2.25 & SMA 082 & A2 & 111223290319362519 & 064073146153155235263 309+C 315+C 523dd & $15878-16569$ / 001-628 \\
\hline 2.25 & SMA 124 & A2 & 111223290319362519 & $064073146153155235263309+C$ 315+C 523dd & $15878-16569$ / 001-628 \\
\hline 2.25 & SJS 20 & A2 & 111223290319362519 & 064073146153155235263 309+C 315+C 523dd & $15878-16569$ / 001-628 \\
\hline 2.26 & LQ 001 & A2 & 111129223290319362 & $064073146153235263309+C$ 315+C 523dd & $16009-16569$ / 001-628 \\
\hline 2.27 & CHE 12 & A2 & 111129223290319362519 & 064073146153195235263 309+C 315+C 523dd & $15878-16569$ / 001-628 \\
\hline 2.27 & CHE 23 & A2 & 111129223290319362519 & 064073146153195235263 309+C 315+C 523dd & $15878-16569$ / 001-628 \\
\hline 2.27 & CHE 35 & A2 & 111129 216R 223290319362519 & 064073146 153R 195235263 309+C 315+C 523dd & $15878-16569$ / 001-628 \\
\hline 2.27 & LR172 & A2 & 111129223290319362519 & $064073146153195235263309+C$ 315+C 523dd & $15878-16569$ / 001-628 \\
\hline 2.27 & SJ 081 & A2 & 111129223290319362519 & 064073146153195235263 309+C 315+C 523dd & $15878-16569$ / 001-628 \\
\hline 2.27 & L 105 & A2 & 111129223290319362519 & 064073146153195235263 309+C 315+C 523dd & $15898-16569$ / 001-628 \\
\hline 3.1 & CHE 09 & A2 & 111223290319362 & $073146153235263315+C$ 523dd & $15878-16569$ / 001-628 \\
\hline 3.1 & CHE 19 & A2 & 111223290319362 & 073146153235263 309+C 315+C 523dd & $15878-16569$ / 001-628 \\
\hline 3.1 & CHE 40 & A2 & 111223290319362 & $073146153235263315+C$ 523dd & 15878-16569 / 001-628 \\
\hline 3.1 & CHE 72 & A2 & 111223290319362 & 073146153235263 309+C 315+C 523dd & $15878-16569$ / 001-628 \\
\hline 3.1 & LR052 & A2 & 111223290319362 & $073146153235263309+C C$ 315+C 523dd & $15878-16569$ / 001-628 \\
\hline 3.1 & LR080 & A2 & 111223290319362 & 073146153235263 309+C 315+C 523dd & $15878-16569$ / 001-628 \\
\hline 3.1 & LR193 & A2 & 111223290319362 & $073146153235263309+C$ 315+C 523dd & $15878-16569$ / 001-628 \\
\hline
\end{tabular}

170 


\begin{tabular}{|c|c|c|c|c|c|}
\hline $\begin{array}{l}\text { ID en } \\
\text { la red }\end{array}$ & ID & $\mathrm{Hg}$ & Región Control 5' (+16000) & Región Control 3' & Rango de lectura \\
\hline 3.1 & MZ 027 & $\mathrm{~A} 2$ & 111223290319362 & $073146153235263309+C$ 315+C 523dd & $16024-16569$ / 001-576 \\
\hline 3.1 & MZ 051 & $\mathrm{~A} 2$ & 111223290319362 & $073146153235263309+C$ 315+C 523dd & $16024-16569 / 001-576$ \\
\hline 3.1 & MZ 088 & A2 & 111223290319362 & 073146153235263 309+C 315+C 523dd & $16024-16569 / 001-576$ \\
\hline 3.1 & L 060 & A2 & 111223290319362 & $073146153235263309+C$ 315+C 523dd & $16024-16569$ / 001-576 \\
\hline 3.2 & SJ 021 & A2 & $111222 Y 223290319362$ & $073146153235263309+C$ 315+C 523dd 573+C & $15878-16569$ / 001-628 \\
\hline 3.3 & MM Pur 15 & A2 & 111223290319362512547 551+G & $073146153263309+C$ 315+C 523dd & $16009-16569$ / 001-628 \\
\hline 3.4 & TG AG 14 & A2 & $111184223290319362512547551+G$ & $073146153263309+C$ 315+C 523dd & $15878-16569$ / 001-628 \\
\hline 3.4 & LQ Pr 23 & $\mathrm{~A} 2$ & $111184223290319362512547551+G$ & $073146153263309+C$ 315+C 523dd & $16008-16569$ / 001-628 \\
\hline 3.4 & MM 143 & A2 & 111184223290319362512547 551+G & $073146153263309+C$ 315+C 523dd & 15991-16569/ 001-628 \\
\hline 3.5 & SJ 008 & A2 & $111290319325362512547551+G$ & $073146153263309+C C$ 315+C 523dd & $15878-16569 / 001-628$ \\
\hline 3.6 & MZ 126 & A2 & 111223290319362512547551 551+G & $073146153263309+C$ 315+C & 16024-16569 / 001-576 \\
\hline 3.7 & TG 097 & A2 & 111223290319362512547551 551+G & $073146153263309+C C$ 315+C 523dd & 16024-16569 / 001-576 \\
\hline 3.8 & Be 033 & A2 & 094111223290319362 & 073146153235263 309+C 315+C 523dd & $15878-16569$ / 001-628 \\
\hline 3.8 & BeP 08 & A2 & 094111223290319362 & $073146153235263309+C$ 315+C 523dd & 15878-16569 / 001-628 \\
\hline 3.9 & TG 060 & A2 & 104111290319362 & $073146153235263309+C$ 315+C 523dd & 16024-16569 / 001-576 \\
\hline 3.10 & TG 137 & A2 & 051111223290319362 & $073146153235263315+C$ 523dd & 16024-16569 / 001-576 \\
\hline 3.11 & TG AG 40 & A2 & 051111223290319362 & 057G 073146153235263 309+C 315+C 523dd & $15878-16569$ / 001-628 \\
\hline 3.12 & TG 004 & A2 & 051111223290319362 & 057G 073146153195215235263 309+C 315+C 523dd & $16024-16569$ / 001-576 \\
\hline 3.13 & $\mathrm{~J} 18$ & A2 & 051111290311319362 & 057G 064073146153185235263 309+C 315+C 455 523dd & $15878-16569 / 001-628$ \\
\hline 3.13 & LQ 139 & A2 & 051111290311319362 & 057G 064073146153185235263 309+C 315+C 455 523dd & $15991-16569$ / 001-628 \\
\hline 3.14 & TG 091 & A2 & 051111223290319362519 & $073146153235263309+C$ 315+C 523dd & $16024-16569$ / 001-576 \\
\hline 3.15 & J05 & A2 & 037051111223290319362519 & 073146153235263 315+C 372+T 523dd & $15878-16569$ / 001-628 \\
\hline 3.16 & TG 090 & A2 & 111223290319362 & 073 090C 098146152235263 315+C 523dd & $16024-16569$ / 001-576 \\
\hline 4.1 & CHE 43 & A2 & 111223290319362 & $064073146150153235263309+C$ 315+C 523dd & $15878-16569$ / 001-628 \\
\hline 4.1 & MZ 033 & A2 & 111223290319362 & 064073146150153235263 309+C 315+C 523dd & $16024-16569$ / 001-576 \\
\hline 4.1 & SJ 030 & A2 & 111223290319362 & $064073146150153235263309+C$ 315+C 523dd & $15878-16569$ / 001-628 \\
\hline 4.1 & SJ 100 & A2 & 111223290319362 & 064073146150153235263 315+C 523dd & $15878-16569$ / 001-628 \\
\hline 4.1 & L 017 & A2 & 111223290319362 & 064073146150153235263 309+C 315+C 523dd & 16024-16569 / 001-576 \\
\hline 4.2 & LR113 & A2 & 111188223290319362526 & $064073146150153235263309+C$ 315+C 523dd & $15878-16569 / 001-628$ \\
\hline
\end{tabular}




\begin{tabular}{|c|c|c|c|c|c|}
\hline $\begin{array}{l}\text { ID en } \\
\text { la red }\end{array}$ & ID & $\mathrm{Hg}$ & Región Control 5’ (+16000) & Región Control 3' & Rango de lectura \\
\hline 4.3 & Be 094 & A2 & 111172223290319362 & 064073146150153235263 309+C 315+C 523dd & $15878-16569$ / 001-628 \\
\hline 4.3 & CAL 49 & A2 & 111172223290319362 & 064073146150153235263 309+CC 315+C 523dd & $15878-16569$ / 001-628 \\
\hline 4.3 & SJ 017 & A2 & 111172223290319362 & 064073146150153235263 309+C 315+C 523dd & $15878-16569$ / 001-628 \\
\hline 4.3 & SJ 039 & A2 & 111172223290319362 & 064073146150153235263 309+CC 315+C 523dd & $15878-16569$ / 001-628 \\
\hline 4.3 & L 083 & $\mathrm{~A} 2$ & 111172223290319362 & 064073146150153235263 309+C 315+C 523dd & $16024-16569$ / 001-576 \\
\hline 4.4 & CAL 23 & A2 & $092 Y 111172218223290319362519$ & 064073146150153235263 309+C 315+C 523dd & $15878-16569$ / 001-628 \\
\hline 4.5 & CAL 36 & A2 & 111172223290293319362 & 064073146150152153235263 309+C 315+C 523dd & $15878-16569$ / 001-628 \\
\hline 4.6 & MZ Sal 03 & A2 & 111223290319362 & 064073146150153263 309+CC 315+C 523dd & $15878-16569$ / 001-628 \\
\hline 4.6 & L 056 & A2 & 111223290319362 & 064073146150153263 309+CC 315+C 523dd & $16024-16569$ / 001-576 \\
\hline 4.6 & L 072 & A2 & 111223290319362 & 064073146150153263 309+CC 315+C 523dd & $16024-16569 / 001-576$ \\
\hline 4.7 & CHE 68 & A2 & 111129223290319362 & 064073146150153235263 309+C 315+C 523dd & $15878-16569$ / 001-628 \\
\hline 4.8 & CHE 61 & A2 & 223290319362 & 064073146150153195235263 309+C 315+C 523dd & $15878-16569$ / 001-628 \\
\hline 4.9 & SJ 028 & A2 & 111223290319362445 & $064073146150153195235263309+C C$ 315+C 523dd & $15878-16569$ / 001-628 \\
\hline 4.9 & L 050 & A2 & 111223290319362445 & $064073146150153195235263309+C C$ 315+C 523dd & $16024-16569$ / 001-576 \\
\hline 4.9 & L 065 & A2 & 111223290319362445 & 064073146150153195235263 309+C 315+C 523dd & $16024-16569$ / 001-576 \\
\hline 4.10 & MZ 119 & A2 & 111223290297319 & 064073143146150153235263 309+CC 315+C 523dd 574 & $16024-16569$ / 001-576 \\
\hline 4.11 & L 064 & A2 & 111223290297311319362519 & 064073125127143146150153235263 309+CC 315+C 523dd & $16024-16569$ / 001-576 \\
\hline 4.12 & LR195 & A2 & 111223290319362493 & 064073109143146150153235263 309+CC 315+C 523dd & $15878-16569$ / 001-628 \\
\hline 4.12 & L 089 & A2 & 111223290319362493 & 064073109143146150153235263 309+CC 315+C 523dd & $16024-16569 / 001-576$ \\
\hline 4.13 & L 037 & A2 & 111162223290319362493 & 064073109143146150153235263 309+C 315+C 523dd & $16024-16569 / 001-576$ \\
\hline 4.13 & L 063 & A2 & 111162223290319362493 & 064073109143146150153235263 309+C 315+C 523dd & $16024-16569$ / 001-576 \\
\hline 4.13 & L 092 & A2 & 111162223290319362493 & 064073109143146150153235263 309+C 315+C 523dd & $16024-16569 / 001-576$ \\
\hline 4.14 & LQ 013 & $\mathrm{~A} 2$ & 111223290311319362 & 064073146150153235263 309+C 315+C 523dd & $15991-16569$ / 001-628 \\
\hline 5.1 & LQ 015 & A2 & 092111136223290319362 & 064073146153 189R 235263 315+C 523dd & 15991-16569 / 001-628 \\
\hline 5.2 & TG BS 27 & A2 & 092111223290319362 & 045064073146153235263 309+CC 315+C 523dd & $15878-16569$ / 001-628 \\
\hline 5.3 & TG BS sal 5 & A2 & 092111189223290319362 & 064073146153235263 309+CC 315+C 523dd & $15878-16569$ / 001-628 \\
\hline 5.4 & TG EA 11 & A2 & 092111223290319362468519 & 064073146153185235263 309+C 315+C 338 523dd 573+C & $15878-16569$ / 001-628 \\
\hline 5.5 & MZ 141 & A2 & 111223290311319362 & 064073146153185189235263 309+CC 315+C 523dd & $16024-16569$ / 001-576 \\
\hline 5.6 & MM Tum 11 & A2 & 111223319362 & $064073146 \mathrm{Y} 153235263$ 315+C 523dd & 15991-16569/ 001-628 \\
\hline
\end{tabular}




\begin{tabular}{|c|c|c|c|c|c|}
\hline $\begin{array}{l}\text { ID en } \\
\text { la red }\end{array}$ & ID & $\mathrm{Hg}$ & Región Control 5' (+16000) & Región Control 3' & Rango de lectura \\
\hline 5.7 & MM Tum 13 & A2 & 111223287290319362 & $064073146153235263315+C$ 523dd & $15991-16569 / 001-628$ \\
\hline 5.8 & LQ Pr 17 & A2 & 111223287290319 & 064Y 073146153235263 309+C 315+C 523dd & $15991-16569$ / 001-628 \\
\hline 5.9 & LQ 148 & A2 & 111223319 & $064073146235263315+C 484$ 523dd & $15991-16569$ / 001-628 \\
\hline 5.10 & TG EA 22 & A2 & 111176223290319362 & 036064073146152153183235263280 309+C 315+C 318 523dd & $15878-16569$ / 001-628 \\
\hline 5.11 & MZ 101 & A2 & 111223290319362 & $064073146152153235263315+C$ & $16024-16569$ / 001-576 \\
\hline 6.1 & SJ 076 & B2 & 183C $189193+C 217519$ & $073263315+C 499$ & $15878-16569$ / 001-628 \\
\hline 6.1 & SJ JA 03 & B2 & $183 C 189193+C 217519$ & $073263315+C 499$ & $15878-16569$ / 001-628 \\
\hline 6.1 & TG 092 & B2 & 182C 183C 189 193+C 217519 & $073263309+C 315+C 499$ & $16024-16569$ / 001-576 \\
\hline 6.1 & TG AG 09 & B2 & 183C 189 193+C 217519 & $073263309+C C 315+C 499$ & $15878-16569$ / 001-628 \\
\hline 6.1 & TG EA 08 & B2 & 183C 189 193+C 217519 & $073263309+C 315+C 499$ & 15878-16569 / 001-628 \\
\hline 6.1 & TG EA 19 & B2 & 183C $189193+C 217519$ & $073263309+C C 315+C 499$ & $15878-16569$ / 001-628 \\
\hline 6.1 & L 013 & B2 & 182C 183C 189 193+C 217519 & $073263309+C 315+C 499$ & $16024-16569$ / 001-576 \\
\hline 6.1 & LQ 083 & B2 & $183 C 189193+C 217519$ & $073263315+C 499$ & $16008-16569$ / 001-628 \\
\hline 6.1 & MM 016 & B2 & 182C 183C 189217519 & $073263309+C C 315+C 499$ & $16014-16569$ / 001-628 \\
\hline 6.1 & MM 035 & B2 & 183C $189193+C 217519$ & $073263309+C C C$ 315+C 499 & $16014-16569$ / 001-628 \\
\hline 6.1 & MM 044 & B2 & 183C $189193+C 217519$ & $073263315+C 499$ & 16014-16569 / 001-628 \\
\hline 6.1 & MM 049 & B2 & 183C 189 193+C 217519 & $073263315+C 499$ & $16014-16569$ / 001-628 \\
\hline 6.1 & MM 060 & $B 2$ & 183C $189193+C 217519$ & $073263315+C 499$ & 16014-16569 / 001-628 \\
\hline 6.1 & MM 115 & B2 & 183C $189193+C 217519$ & $073263315+C 499$ & $16014-16569$ / 001-628 \\
\hline 6.1 & MM 134 & B2 & 182C 183C 189217519 & $073263309+C C 315+C 499$ & $16014-16569$ / 001-628 \\
\hline 6.1 & MM 139 & B2 & $183 C 189193+C 217519$ & $073263315+C 499$ & $16014-16569$ / 001-628 \\
\hline 6.1 & L 085 & B2 & $182 C 183 C 189193+C 217519$ & 073 215R 263 309+CC 315+C 499 & $16024-16569$ / 001-576 \\
\hline 6.2 & LQ 160 & B2 & 182C 183C $189193+C 217519$ & $054073263309+C C 315+C 499$ & $16008-16569$ / 001-628 \\
\hline 6.2 & MM 094 & B2 & 182C 183C $189193+C 217519$ & $054073263309+C C 315+C 499$ & $16014-16569$ / 001-628 \\
\hline 6.3 & SMA 023 & B2 & $15940086183 C 189193+C 217220294519$ & 056d 058 059G 061+T 064 065G 073103200263 309+CC 315+C 499 & $15878-16569$ / 001-628 \\
\hline 6.4 & SMA 087 & B2 & $15940086183 C 189$ 193+C 217220294519 & $\begin{array}{l}\text { 056d 058 059G 061+T } 064 \text { 065G } 073103194200263 \text { 309+CC 315+C } \\
499\end{array}$ & $15878-16569$ / 001-628 \\
\hline 6.5 & TG EA 09 & B2 & $183 C 189193+C 217258357519$ & 073103263310 314d 315d 499 & $15878-16569$ / 001-628 \\
\hline 6.6 & TG BS 16 & B2 & 182C 183C 189217258357519 & 073103143263310 315d 499 & $15878-16569$ / 001-628 \\
\hline
\end{tabular}




\begin{tabular}{|c|c|c|c|c|c|}
\hline $\begin{array}{l}\text { ID en } \\
\text { la red }\end{array}$ & ID & $\mathrm{Hg}$ & Región Control 5' (+16000) & Región Control 3' & Rango de lectura \\
\hline 6.6 & MM Pur 03 & B2 & 183C 189 193+C 217258357519 & $073103143263310315 d 499$ & $16014-16569$ / 001-628 \\
\hline 6.7 & LQ Pr 12 & B2 & $182 C 183 C 189217258357519$ & 073103143228263310 315d 499 & $16008-16569$ / 001-628 \\
\hline 6.8 & $\mathrm{~J} 20$ & B2 & 182C 183C 189 193+C 217258357519 & 073103143228263310 314- 315- 499 & $15878-16569 / 001-628$ \\
\hline 6.8 & TG 127 & B2 & 182C 183C 189 193+C 217258357519 & 073103143228263310 314d 315d 499 & 16024-16569 / 001-576 \\
\hline 6.9 & Lo94 & B2 & 183C $189193+C 217258357519$ & 042073103143146263310 315d 499 & 16024-16569 / 001-576 \\
\hline 6.9 & MM Pur 10 & B2 & $183 C 189193+C 217258357519$ & 042073103143146263310 315d 499 & $16009-16569$ / 001-628 \\
\hline 6.10 & LQ 050 & B2 & 183C $189193+C 217258357519$ & 042073103143263310 314d 315d 499 & 16009-16569 / 001-628 \\
\hline 6.11 & LQ 031 & B2 & $017183 C 189$ 193+C 217359519 & $073103146151263309+C C$ 315+C 499 & $16009-16569$ / 001-628 \\
\hline 6.11 & MM 126 & B2 & $017183 C 189193+C 217359519$ & 073103146151263 309+C 315+C 499 & 16014-16569 / 001-628 \\
\hline 6.11 & MM Pur 17 & B2 & $017183 C 189$ 193+C 217359519 & $073103146151263309+C C$ 315+C 499 & $16009-16569$ / 001-628 \\
\hline 6.12 & TG 074 & B2 & $183 C 189193+C 217519$ & 073093143195263 309+C 315+C 499 & 16024-16569 / 001-576 \\
\hline 6.13 & TG 029 & B2 & $093183 C 189193+C 217519$ & $073093195263309+C$ 315+C 499 & 16024-16569 / 001-576 \\
\hline 6.13 & TG 098 & B2 & $093183 C 189193+C 217519$ & 073093195263 309+C 315+C 499 & 16024-16569 / 001-576 \\
\hline 6.13 & TG BS 01 & B2 & $093183 C 189193+C 217519$ & $073093195263309+C$ 315+C 499 & 15878-16569 / 001-628 \\
\hline 6.13 & TG BS 35 & B2 & $093183 C 189193+C 217519$ & $073093195263309+C$ 315+C 499 & $15878-16569$ / 001-628 \\
\hline 6.14 & LQ 109 & B2 & 182C 183C 189 193+C 217218278519 & $073127263309+C C 315+C 499$ & $16008-16569$ / 001-628 \\
\hline 6.15 & LQ Cie 07 & B2 & $146183 C 189193+C 217218519$ & $073127263309+C C 315+C 499$ & 16009-16569 / 001-628 \\
\hline 6.15 & LQ Pr 40 & B2 & $146183 C 189193+C 217218519$ & $073127263309+C C$ 315+C 499 & $16009-16569$ / 001-628 \\
\hline 6.16 & MM Pur 27 & B2 & 182C 183C 189217519 & 060+T 073263 309+CC 315+C 499513 523dd & $16014-16569$ / 001-628 \\
\hline 6.16 & MM Pur 29 & B2 & 182C 183C 189217519 & 060+T 073263 309+CC 315+C 499513 523dd & $16009-16569$ / 001-628 \\
\hline 6.17 & MM 081 & B2 & 182C 183C 189217256519 & 060+T 073263 309+CC 315+C 499513 523dd & 16014-16569 / 001-628 \\
\hline 6.18 & L 022 & B2 & 182C 183C 189217391519 & 057059 060+T073 195263 309- 315+C 499 & $16024-16569$ / 001-576 \\
\hline 6.19 & L 018 & B2 & $15968086182 C 183 C 189$ 193+C 217356362519 & 057059 060+T 073153263 309d 315+C 499 523dd & $15968-16569$ / 001-576 \\
\hline 6.20 & LQ 146 & B2 & 182C 183C 189217303519 & $073094204263315+C 499$ & $16008-16569$ / 001-628 \\
\hline 6.21 & TG BS 22 & B2 & 183C 189 193+C 217233356519 & 010073191192195198204263 309+C 315+C 499 & $15878-16569$ / 001-628 \\
\hline 6.22 & TG BS 05 & B2 & $183 C 189193+C 217519$ & $073204207263309+C C 315+C 499$ & $16024-16569$ / 001-628 \\
\hline 6.22 & MM 019 & B2 & $183 C 189193+C 217519$ & $073204207263309+C C$ 315+C 499 & 16014-16569 / 001-628 \\
\hline 6.23 & LQ 130 & B2 & $183 C 189193+C 217290519$ & $073204207263309+C$ 315+C 499 & $16008-16569$ / 001-628 \\
\hline 6.24 & TG AG 47 & B2 & 183C 189 193+C 217290519 & 073204207263294 309+C 315+C 499 & $15878-16569 / 001-628$ \\
\hline
\end{tabular}




\begin{tabular}{|c|c|c|c|c|c|}
\hline $\begin{array}{l}\text { ID en } \\
\text { la red }\end{array}$ & ID & $\mathrm{Hg}$ & Región Control 5' (+16000) & Región Control 3' & Rango de lectura \\
\hline 6.25 & TG AG 06 & B2 & 182C 183C 189217519 & $073203204263309+C$ 315+C 499 & $16024-16569$ / 001-576 \\
\hline 6.26 & SMA 025 & B2 & $137182 C 183 C 189193+C 217519$ & 073195203204228263 309+CC 315+C 499 & $15878-16569$ / 001-628 \\
\hline 6.26 & TG 103 & B2 & $137182 C 183 C 189$ 193+C 217519 & 073195203204228263 309+C 315+C 499 & 16024-16569 / 001-576 \\
\hline 6.26 & LQ 159 & B2 & $137182 C 183 C 189217519$ & 073195203204228263 309+C 315+C 499 & $16008-16569$ / 001-628 \\
\hline 6.27 & TG 128 & B2 & 182C 183C 189 193+C 217519 & 073163203204263 309+C 315+C 499 & 16024-16569 / 001-576 \\
\hline 6.27 & TG 147 & B2 & 182C 183C 189217519 & 073163203204263 309+C 315+C 499 & $16024-16569$ / 001-576 \\
\hline 6.28 & TG 020 & B2 & 182C 183C $189193+C 217519$ & 073197207263292 315+C 499 & $16024-16569$ / 001-576 \\
\hline 6.28 & TG 023 & B2 & 182C 183C $189193+C 217519$ & 073197207263292 315+C 499 & $16024-16569$ / 001-576 \\
\hline 6.28 & TG 033 & B2 & 182C 183C 189 193+C 217519 & 073197207263292 315+C 499 & 16024-16569 / 001-576 \\
\hline 6.29 & TG 019 & B2 & 093Y 182C 183C 189 193+C 217519 & 073197204207263292 315+C 499 & 16024-16569 / 001-576 \\
\hline 7.1 & MM 010 & B2 & 182C 183C 189217221519 & $073146207263315+C 499$ & 16014-16569 / 001-628 \\
\hline 7.1 & MM 083 & B2 & 182C 183C 189217221519 & $073146207263315+C 499$ & 16014-16569 / 001-628 \\
\hline 7.2 & LR056 & B2 & 182C 183C 189217519 & $073143146263315+C 499$ & $15878-16569$ / 001-628 \\
\hline 7.2 & MZ 109 & B2 & 182C 183C 189217519 & $073143146263315+C 499$ & 16024-16569 / 001-576 \\
\hline 7.3 & CAL 18 & B2 & 182C 183C 189217519 & $073143146165263315+C 499$ & $15878-16569$ / 001-628 \\
\hline 7.3 & CAL 45 & B2 & 183C $189193+C 217519$ & 073143146165263 315+C 499 & 15878-16569 / 001-628 \\
\hline 7.3 & CAL 47 & B2 & 183C $189193+C 217519$ & $073143146165263309+C C$ 315+C 499 & 16011-16569 / 001-628 \\
\hline 7.3 & CAL 58 & B2 & 182C 183C 189217519 & $073143146165263315+C 499$ & 15878-16569 / 001-628 \\
\hline 7.3 & CHE 26 & B2 & 182C 183C 189217519 & $073143146165263315+C 499$ & 15878-16569 / 001-628 \\
\hline 7.3 & SJ 108 & B2 & 182C 183C 189217519 & 073143146165263 315+C 499 & 15878-16569 / 001-628 \\
\hline 7.3 & TG 146 & B2 & 182C 183C $189193+C 217519$ & 073143146165263 315+C 499 & 16024-16569 / 001-576 \\
\hline 7.3 & L 076 & B2 & 182C 183C 189217519 & 073143146165263 315+C 499 & 16024-16569 / 001-576 \\
\hline 7.3 & L 106 & B2 & 182C 183C 189217519 & 073143146165263 315+C 499 & 15898-16569 / 001-628 \\
\hline 7.3 & L sal 07 & B2 & 182C 183C 189217519 & $073143146165263315+C 499$ & $15898-16569$ / 001-628 \\
\hline 7.3 & L sal 09 & B2 & 182C 183C 189217519 & 073143146165263 315+C 499 & 15898-16569 / 001-628 \\
\hline 7.4 & SJ 003 & B2 & 182C 183C 189217519 & $073143146152165263315+C 499$ & $15878-16569$ / 001-628 \\
\hline 7.4 & SMA 081 & B2 & 182C 183C 189217519 & $073143146152165263315+C 499$ & 15878-16569 / 001-628 \\
\hline 7.5 & J56 & B2 & $183 C 189193+C 217519$ & $073195215263309+C$ 315+C 499 & 15878-16569 / 001-576 \\
\hline 7.6 & J34 & B2 & $086182 C$ 183C 189 193+C 217454455519 & 073215263 309+CC 315+C 499 & $15878-16569$ / 001-628 \\
\hline
\end{tabular}




\begin{tabular}{|c|c|c|c|c|c|}
\hline $\begin{array}{l}\text { ID en } \\
\text { la red }\end{array}$ & ID & $\mathrm{Hg}$ & Región Control 5' (+16000) & Región Control 3' & Rango de lectura \\
\hline 7.6 & $J 50$ & B2 & 086 182C 183C 189 193+C 217454455519 & $073215263309+C C 315+C 499$ & $15878-16569$ / 001-628 \\
\hline 7.6 & LQ Pr 26 & B2 & 086 182C 183C 189 193+C 217454455519 & $073215263309+C C 315+C 499$ & $16009-16569$ / 001-628 \\
\hline 7.6 & LQ Pr 28 & B2 & 086 182C 183C 189 193+C 217454455519 & $073215263309+C C 315+C 499$ & 16009-16569 / 001-628 \\
\hline 7.6 & MM 123 & B2 & $086182 C 183 C 189$ 193+C 217454455519 & $073215263309+C 315+C 499$ & $16014-16569$ / 001-628 \\
\hline 7.6 & MM Pur 35 & B2 & 086 182C 183C 189 193+C 217454455519 & $073215263309+C C 315+C 499$ & 16014-16569 / 001-628 \\
\hline 7.7 & TG 012 & B2 & $182 C 183 C 189193+C 217519$ & $073247263309+C C 315+C 499$ & $16024-16569$ / 001-576 \\
\hline 7.7 & TG 047 & B2 & $182 C 183 C 189193+C 217519$ & $073247263309+C C 315+C 499$ & 16024-16569 / 001-576 \\
\hline 7.8 & SMA 052 & B2 & $093183 C 189193+C 217316519$ & $073152247263309+C 315+C 499$ & $15878-16569$ / 001-628 \\
\hline 7.8 & SMA 109 & B2 & $093183 C 189$ 193+C 217316519 & $073152247263309+C$ 315+C 499 & $15878-16569$ / 001-628 \\
\hline 7.9 & TG 095 & B2 & $182 C 183 C 189$ 193+C 217519 & $073143247263309+$ +CCC 315+C 499 & 16024-16569 / 001-576 \\
\hline 7.9 & TG 113 & B2 & $182 C 183 C 189193+C 217519$ & $073143247263309+C C$ 315+C 499 & 16024-16569 / 001-576 \\
\hline 7.9 & TG 135 & B2 & $182 C 183 C 189193+C 217519$ & $073143247263309+C C$ 315+C 499 & 16024-16569 / 001-576 \\
\hline 7.9 & TG AG 18 & B2 & 182C 183C 189217519 & $073143247263309+C C$ 315+C 499 & $15878-16569$ / 001-628 \\
\hline 7.9 & TG BS sal 3 & B2 & 182C 183C 189217519 & $073143247263309+C C$ 315+C 499 & 15878-16569 / 001-628 \\
\hline 7.10 & TG 117 & B2 & $148182 C 183 C 188189217519$ & $073143247263309+C 315+C 499$ & 16024-16569 / 001-576 \\
\hline 8.1 & LQ Pr 04 & B2 & $183 C 189193+C 217519$ & $073143226263309+C C$ 315+C 499 & $16008-16569$ / 001-628 \\
\hline 8.2 & SJ 038 & B2 & $093183 C 189$ 193+C 217304519 & 073199225226263 315+C 438+C 499 523dd 573+CCCC & $15878-16569$ / 001-628 \\
\hline 8.3 & TG BS sal 4 & B2 & $183 C 189193+C 217519$ & 065 071d 073143226263 309+CC 315+C 499 & $15878-16569$ / 001-628 \\
\hline 8.4 & MM Tum 07 & B2 & $167183 C 189193+C 217309519$ & $073263292309+C C 315+C 499$ & $16009-16569$ / 001-628 \\
\hline 8.5 & SMA 026 & B2 & $129183 C 189193+C 217309519$ & $073143263309+C 315+C 499$ & $15878-16569$ / 001-628 \\
\hline 8.5 & LQ 156 & B2 & $129183 C 189193+C 217309519$ & $073143263309+C 315+C 499$ & $16008-16569$ / 001-628 \\
\hline 8.5 & MM 072 & B2 & $129183 C 189193+C 217309519$ & $073143263315+C 499$ & $16014-16569$ / 001-628 \\
\hline 8.5 & MM 135 & B2 & $129183 C 189193+C 217309519$ & $073143263315+C 499$ & $16014-16569$ / 001-628 \\
\hline 8.5 & MM 137 & B2 & $129183 C 189193+C 217309519$ & $073143263309+C 315+C 499$ & $16014-16569$ / 001-628 \\
\hline 8.5 & MM Pur 25 & B2 & $129183 C 189193+C 217309519$ & $073143263315+C 499$ & $16014-16569$ / 001-628 \\
\hline 8.5 & MM Pur 26 & B2 & $129183 C 189193+C 217309519$ & $073143263315+C 499$ & $16014-16569$ / 001-628 \\
\hline 8.6 & MM 090 & B2 & $129183 C 189193+C 217309519$ & $073143227263309+C$ 315+C 499 & 16014-16569 / 001-628 \\
\hline 8.7 & Be 031 & B2 & 183C $189193+C 217309519$ & 073143195263 309+C 315+C 499 & 15878-16569 / 001-628 \\
\hline 8.7 & SMA 134 & B2 & 183C 189 193+C 217309519 & $073143195263309+C$ 315+C 499 & $15878-16569$ / 001-628 \\
\hline
\end{tabular}




\begin{tabular}{|c|c|c|c|c|c|}
\hline $\begin{array}{l}\text { ID en } \\
\text { la red }\end{array}$ & ID & $\mathrm{Hg}$ & Región Control 5' (+16000) & Región Control 3' & Rango de lectura \\
\hline 8.7 & SMA 142 & B2 & 183C 189 193+C 217309519 & 073143195263 309+C 315+C 499 & $15878-16569$ / 001-628 \\
\hline 8.8 & LQ 118 & B2 & 129R 183C 189 193+C 217289519 & $073143263309+C 315+C 499$ & $16008-16569$ / 001-628 \\
\hline 8.8 & MM Pur 04 & B2 & 183C $189193+C 217289519$ & $073143263309+C C 315+C 499$ & 16014-16569 / 001-628 \\
\hline 8.9 & MM 007 & B2 & 183C $189193+C 217289519$ & $073143204263309+C C$ 315+C 499 & 16014-16569 / 001-628 \\
\hline 8.10 & MM 029 & B2 & 183C 189 193+C 217286289519 & 073143146199263 309+C 315+C 499 & 16014-16569 / 001-628 \\
\hline 8.10 & MM 055 & B2 & 183C 189 193+C 217286289519 & 073143146199263 309+C 315+C 499 & $16014-16569$ / 001-628 \\
\hline 8.10 & MM 062 & B2 & 183C $189193+C 217286289519$ & 073143146199263 309+C 315+C 499 & 16014-16569 / 001-628 \\
\hline 8.10 & MM 141 & B2 & 183C 189 193+C 217286289519 & 073143146199263 309+C 315+C 499 & $16014-16569$ / 001-628 \\
\hline 8.10 & MM Tum 06 & B2 & 183C 189 193+C 217286289519 & 073143146199263 309+C 315+C 499 & 16009-16569 / 001-628 \\
\hline 8.11 & MM 069 & B2 & $086183 C 189$ 193+C 217286289519 & 073143199263 309+C 315+C 499 & $16014-16569$ / 001-628 \\
\hline 8.12 & LR150 & B2 & $066183 C 185189$ 193d 217519 & 042073143210263 309+C 315+C 499 & $15878-16569$ / 001-628 \\
\hline 8.12 & LR BS 06 & B2 & $066183 C 185189$ 193d 217519 & $042073143210263309+C$ 315+C 499 & $15878-16569$ / 001-628 \\
\hline 8.13 & $\mathrm{~J} 55$ & B2 & $066183 C 185189217519$ & $042073143210263315+C 499$ & $15878-16569$ / 001-628 \\
\hline 8.14 & MM 110 & B2 & $066183 C 185189$ 193d 217519 & $073143210263309+C 315+C 499$ & 15991-16569/001-628 \\
\hline 8.15 & LQ 086 & B2 & 183C 185189 193d 217320519 & 042073143150210263 315+C 499 & $15991-16569 / 001-628$ \\
\hline 8.16 & LR037 & B2 & 043T $066183 C 185189$ 193d 217519 & 042073143210263 309+C 315+C 499 & $15878-16569$ / 001-628 \\
\hline 8.17 & MZ 055 & B2 & $183 C 185189$ 193d 217519 & $073263309+C 315+C 499573+C C C$ & $16024-16569$ / 001-576 \\
\hline 9.1 & TG AG 05 & B2 & $183 C 189193+C 217519$ & 073146215263 309+CC 315+C 455+T 499 & $16024-16569$ / 001-576 \\
\hline 9.1 & LQ 034 & B2 & $183 C 189193+C 217519$ & $073146215263315+C 455+T 499$ & $16009-16569$ / 001-628 \\
\hline 9.1 & LQ 096 & B2 & $183 C 189193+C 217519$ & $073146215263315+C 455+T 499$ & $16008-16569$ / 001-628 \\
\hline 9.1 & LQ 119 & B2 & $183 C 189193+C 217519$ & 073146215263 309+CC 315+C 455+T 499 & $16008-16569$ / 001-628 \\
\hline 9.1 & MM 052 & B2 & $183 C 189193+C 217519$ & $073146215263315+C 455+T 499$ & $16014-16569$ / 001-628 \\
\hline 9.1 & MM 056 & B2 & $183 C 189217519$ & $073146215263315+C 455+T 499$ & $16014-16569 / 001-628$ \\
\hline 9.2 & LQ 093 & B2 & 182C 183C 189217240519 & $073146215263315+C$ 455+T 499 & $16008-16569$ / 001-628 \\
\hline 9.3 & LQ Pr 25 & B2 & $183 C 189193+C 217519$ & 073146215263 309+CC 315+C 455+T 499 573+CC & $16009-16569$ / 001-603 \\
\hline 9.4 & LQ 026 & B2 & $183 C 189193+C 217519$ & 073143146215263 309+CC 315+C 455+T 499 & $16009-16569$ / 001-628 \\
\hline 9.4 & LQ 043 & B2 & 183C $189193+C 217519$ & $073143146215263309+C C$ 315+C 455+T 499 & $16009-16569$ / 001-628 \\
\hline 9.4 & MM Pur 01 & B2 & 183C $189193+C 217519$ & $073143146215263309+C$ 315+C 455+T 499 & $16009-16569$ / 001-628 \\
\hline 9.5 & Be 041 & B2 & $183 C 189217519$ & 073143146215263 309+C 315+C 414G 455+T 499 & $15878-16569 / 001-628$ \\
\hline
\end{tabular}




\begin{tabular}{|c|c|c|c|c|c|}
\hline $\begin{array}{l}\text { ID en } \\
\text { la red }\end{array}$ & ID & $\mathrm{Hg}$ & Región Control 5' (+16000) & Región Control 3' & Rango de lectura \\
\hline 9.6 & Be 009 & B2 & $183 C 189193+C 217519$ & 064073146215263 309+CC 315+C 455+T 499 & $15878-16569$ / 001-628 \\
\hline 9.6 & Be 050 & B2 & $183 C 189193+C 217519$ & 064073146215263 309+CC 315+C 455+T 499 & $15878-16569$ / 001-628 \\
\hline 9.6 & Be 054 & B2 & $183 C 189193+C 217519$ & $064073146215263309+C$ 315+C 455+T 499 & $15878-16569 / 001-628$ \\
\hline 9.6 & Be 074 & B2 & 183C $189193+C 217519$ & $064073146215263309+C$ 315+C 455+T 499 & $16014-16569$ / 001-628 \\
\hline 9.6 & SMA 113 & B2 & $183 C 189193+C 217519$ & 064073146215263 309+C 315+C 455+T 499 & $15878-16569$ / 001-628 \\
\hline 9.6 & SJS 05 & B2 & $183 C 189193+C 217519$ & 064073146215263 309+CC 315+C 455+T 499 & $15878-16569$ / 001-628 \\
\hline 9.7 & Be 020 & B2 & $129183 C 189193+C 217519$ & $064073146215263309+C$ 315+C 455+T 499 & 16006-16569 / 001-628 \\
\hline 9.7 & Be 030 & B2 & $129183 C 189193+C 217519$ & $064073146215263309+C$ 315+C 455+T 499 & $15878-16569$ / 001-628 \\
\hline 9.7 & Be 039 & B2 & $129183 C 189193+C 217519$ & $064073146215263309+C$ 315+C 455+T 499 & $15878-16569$ / 001-628 \\
\hline 9.7 & Be 083 & B2 & $129183 C 189193+C 217519$ & $064073146215263309+C$ 315+C 455+T 499 & $15878-16569 / 001-628$ \\
\hline 9.8 & SMA 107 & B2 & $183 C 189193+C 217519$ & 064073146215263310 312-318d 321 455+T 499 & 16009-16569 / 001-628 \\
\hline 9.9 & MM Tum 15 & B2 & 093Y 183C $189193+C 217519$ & 064073146215263 310-315d 455+T 499 & 16014-16569 / 001-628 \\
\hline 9.10 & MM 042 & B2 & $093183 C 189193+C 217519$ & $064073146215263309+C$ 315+C 455+T 499 & $16014-16569$ / 001-628 \\
\hline 9.10 & MM Pur 06 & B2 & $093183 C 189193+C 217519$ & 064073146215263 309+CC 315+C 455+T 499 & 16009-16569 / 001-628 \\
\hline 9.11 & Be 001 & B2 & $183 C 189193+C 217519$ & 063064073146215263 309+CC 315+C 455+T 499 & $15878-16569$ / 001-628 \\
\hline 9.11 & Be 005 & B2 & $183 C 189193+C 217519$ & 063064073146215263 309+CC 315+C 455+T 499 & $15878-16569$ / 001-628 \\
\hline 9.11 & Be 012 & B2 & $183 C 189193+C 217519$ & 063064073146215263 309+CC 315+C 455+T 499 & $15878-16569$ / 001-628 \\
\hline 9.11 & Be 017 & B2 & $183 C 189193+C 217519$ & 063064073146215263 309+CC 315+C 455+T 499 & $15878-16569$ / 001-628 \\
\hline 9.11 & Be 040 & B2 & $183 C 189193+C 217519$ & 063064073146215263 309+CC 315+C 455+T 499 & $15878-16569 / 001-628$ \\
\hline 9.11 & Be 066 & B2 & $183 C 189193+C 217519$ & 063064073146215263 309+CC 315+C 455+T 499 & $15878-16569$ / 001-628 \\
\hline 9.11 & Be 100 & B2 & $183 C 189193+C 217519$ & 063064073146215263 309+CC 315+C 455+T 499 & $16008-16569$ / 001-628 \\
\hline 9.11 & $\mathrm{~J} 42$ & B2 & 136Y 183C $189193+C 217519$ & 063064073146215263 309+C 315+C 455+T 499 & $15878-16569$ / 001-628 \\
\hline 9.11 & MZ 010 & B2 & 183C $189193+C 217519$ & 063064073146215263 309+CC 315+C 455+T 499 & $16024-16569$ / 001-576 \\
\hline 9.11 & SMA 006 & B2 & 183C $189193+C 217519$ & 063064073146215263 309+CC 315+C 455+T 499 & $15878-16569$ / 001-628 \\
\hline 9.11 & SMA 016 & B2 & 183C $189193+C 217519$ & 063064073146215263 309+C 315+C 455+T 499 & $15878-16569$ / 001-628 \\
\hline 9.11 & SMA 059 & B2 & $183 C 189193+C 217519$ & 063064073146215263 309+C 315+C 455+T 499 & $15878-16569 / 001-628$ \\
\hline 9.11 & SMA 063 & B2 & $183 C 189193+C 217519$ & 063064073146215263 309+C 315+C 455+T 499 & $15878-16569$ / 001-628 \\
\hline 9.11 & SMA 122 & B2 & $183 C 189193+C 217519$ & 063064073146215263 309+CC 315+C 455+T 499 & $15878-16569$ / 001-628 \\
\hline 9.11 & SMA 143 & B2 & $183 C 189193+C 217519$ & 063064073146215263 309+C 315+C 455+T 499 & $15878-16569 / 001-628$ \\
\hline
\end{tabular}

178 


\begin{tabular}{|c|c|c|c|c|c|}
\hline $\begin{array}{l}\text { ID en } \\
\text { la red }\end{array}$ & ID & $\mathrm{Hg}$ & Región Control 5' (+16000) & Región Control 3' & Rango de lectura \\
\hline 9.11 & SMA 144 & B2 & $183 C 189193+C 217519$ & 063064073146215263 309+C 315+C 455+T 499 & $15878-16569$ / 001-628 \\
\hline 9.11 & SJS 03 & B2 & $183 C 189193+C 217519$ & $063064073146189 R 215263$ 309+C 315+C 455+T 499 & $15878-16569$ / 001-628 \\
\hline 9.11 & SJS 21 & B2 & $183 C 189193+C 217519$ & 063064073146215263 309+CC 315+C 455+T 499 & $15878-16569$ / 001-628 \\
\hline 9.11 & TG 065 & B2 & $183 C 189193+C 217519$ & 063064073146215263 309+C 315+C 455+T 499 & $16024-16569$ / 001-576 \\
\hline 9.11 & LQ 046 & B2 & $183 C 189193+C 217519$ & 063064073146215263 309+CC 315+C 455+T 499 & $16009-16569$ / 001-628 \\
\hline 9.11 & LQ 074 & B2 & $183 C 189193+C 217519$ & $063064073146215263309+C C$ 315+C 455+T 499 & $16008-16569$ / 001-628 \\
\hline 9.11 & MM 014 & B2 & 182C 183C 189217519 & $063064073146215263309+C$ 315+C 455+T 499 & $16014-16569$ / 001-628 \\
\hline 9.11 & MM 043 & B2 & $183 C 189193+C 217519$ & 063064073146215263 309+CC 315+C 455+T 499 & $16014-16569$ / 001-628 \\
\hline 9.11 & MM Pur 09 & B2 & $183 C 189193+C 217311 Y 519$ & 063064073146215263 309+C 315+C 455+T 499 & 16009-16569 / 001-628 \\
\hline 9.11 & MM Pur 12 & B2 & $183 C 189193+C 217519$ & 063064073146215263 309+C 315+C 455+T 499 & $16009-16569$ / 001-628 \\
\hline 9.12 & LQ 014 & B2 & $183 C 189193+C 217519$ & 063064073146203215263 309+CC 315+C 455+T 499 & $16009-16569$ / 001-628 \\
\hline 9.12 & LQ Pr 38 & B2 & $183 C 189193+C 217519$ & $063064073146203215263309+C C$ 315+C 455+T 499 & $16009-16569$ / 001-628 \\
\hline 9.12 & MM 048 & B2 & $183 C 189193+C 217519$ & 063064073146203215263 309+CC 315+C 455+T 499 & $16014-16569$ / 001-628 \\
\hline 9.12 & MM Pur 38 & B2 & 093Y 183C 189 193+C 217519 & $063064073146203215263309+C C$ 315+C 455+T 499 & 16014-16569 / 001-628 \\
\hline 9.13 & SMA 080 & B2 & $183 C 189193+C 217519$ & 063064073093146215263 309+CC 315+C 455+T 499 & $15878-16569$ / 001-628 \\
\hline 9.14 & MM Tum 21 & B2 & $183 C 189193+C 217519$ & 063064073146183215263 309+CC 315+C 455+T 499 & 16009-16569 / 001-628 \\
\hline 9.15 & Be 070 & B2 & 183C $189193+C 217311519$ & $063064073146215263309+C$ 315+C 455+T 499 & $15878-16569$ / 001-628 \\
\hline 9.16 & MM 082 & B2 & $183 C 189193+C 217519$ & $063064066073146152215263309+C 315+C 455+T 499$ & 16014-16569 / 001-628 \\
\hline 9.17 & MM 002 & B2 & 183C 184A 189217519 & $063064066073146152215263315+C 455+T 499$ 523dd & $16014-16569$ / 001-628 \\
\hline 9.18 & LQ 027 & B2 & 183C 184A 189217519 & $063064073146152215263315+C 455+T 499$ 523dd & $16009-16569$ / 001-628 \\
\hline 9.19 & Be 063 & B2 & 183C $189193+C 217294519$ & $063064066073146215263309+C C$ 315+C 455+T 499 & 15878-16569 / 001-628 \\
\hline 9.19 & SMA 069 & B2 & 183C 189 193+C 217294519 & 063064066073146215263 309+CC 315+C 455+T 499 & $15878-16569$ / 001-628 \\
\hline 9.19 & SMA 090 & B2 & 183C $189193+C 217294519$ & $063064066073146215263309+C C$ 315+C 455+T 499 & $15878-16569 / 001-628$ \\
\hline 9.20 & Be 003 & B2 & 183C $189193+C 217294519$ & 005063064066073146215263 309+CC 315+C 455+T 499 & $15878-16569$ / 001-628 \\
\hline 9.20 & Be 043 & B2 & 183C $189193+C 217294519$ & 0050636466073146215263 309+CC 315+C 455+T 499 & $15878-16569$ / 001-628 \\
\hline 9.20 & SMA 001 & B2 & 183C $189193+C 217294519$ & $005063064066073146215263309+C C$ 315+C 455+T 499 & $15878-16569 / 001-628$ \\
\hline 9.21 & LQ 104 & B2 & 183C $189193+C 217294519$ & $063064066 \mathrm{~T} 073146215263$ 309+C 315+C 455+T 499 & $16008-16569$ / 001-628 \\
\hline 9.21 & MM 127 & B2 & 183C $189193+C 217294519$ & $063064066 T 073146215263309+C$ 315+C 455+T 499 & $16014-16569$ / 001-628 \\
\hline 9.22 & LQ 169 & B2 & $183 C 189193+C 217519$ & $063064066073146203215263309+C C$ 315+C 455+T 499 & $16008-16569$ / 001-628 \\
\hline
\end{tabular}

179 


\begin{tabular}{|c|c|c|c|c|c|}
\hline $\begin{array}{l}\text { ID en } \\
\text { la red }\end{array}$ & ID & $\mathrm{Hg}$ & Región Control 5' (+16000) & Región Control 3' & Rango de lectura \\
\hline 10.1 & MM 022 & B2 & $037182 C 183 C 189217311357519$ & $073182235263315+C 499$ 524+AC & $16014-16569$ / 001-628 \\
\hline 10.2 & LQ 029 & B2 & $126183 C 189193+C 217519$ & 066T $073235263309+C C 315+C 499$ & $16009-16569$ / 001-628 \\
\hline 10.3 & MM 057 & B2 & $126183 C 189193+C 217311519$ & $063064066 T 073235263$ 309+CCC 315+C 499 & $16014-16569$ / 001-628 \\
\hline 10.4 & MM 091 & B2 & $051183 C 189$ 193+C 217519 & $073153263315+C 499$ & $16014-16569$ / 001-628 \\
\hline 10.5 & LQ Pr 19 & B2 & $051183 C 189$ 193+C 217519 & $073263309+C C 315+C 499524+A C$ & $16008-16569$ / 001-628 \\
\hline 10.6 & $\mathrm{~J} 38$ & B2 & $051183 C 189$ 193+C 217360519 & $073152263309+C C 315+C 499$ 523dd & $15878-16569$ / 001-628 \\
\hline 10.6 & $J 48$ & B2 & $051183 C 189193+C 217360519$ & 041Y 073152263 309+C 315+C 499 523dd & $15878-16569$ / 001-628 \\
\hline 10.6 & TG 063 & B2 & $051183 C 189193+C 217360519$ & $073152263309+C C 315+C 499$ 523dd & $16024-16569$ / 001-576 \\
\hline 10.6 & TG BS 53 & B2 & $051183 C 189$ 193+C 217360519 & $073152263309+C C$ 315+C 499 523dd & $15878-16569$ / 001-628 \\
\hline 10.6 & LQ 134 & B2 & $051183 C 189193+C 217360519$ & 073152263 309+CC 315+C 499 523dd & $16008-16569$ / 001-628 \\
\hline 10.7 & LQ Pr 09 & B2 & $111183 C 189$ 193+C 217519 & $073143263309+C 315+C 499$ & $16008-16569$ / 001-628 \\
\hline 10.8 & LQ Pr 33 & B2 & $\begin{array}{l}111183 C 189193+C 217224449451455493497 \\
519\end{array}$ & $073263309+C C 315+C 499$ & $16009-16569 / 001-628$ \\
\hline 10.9 & MM 015 & B2 & 111 183C 189 193+C 217512519 & $073185263309+C 315+C 499$ & $16014-16569$ / 001-628 \\
\hline 10.9 & MM 105 & B2 & 111 183C 189 193+C 217512519 & $073185263309+C 315+C 499$ & $16014-16569$ / 001-628 \\
\hline 10.9 & MM 130 & B2 & $111183 C 189$ 193+C 217512519 & 073185263 309+CC 315+C 499 & $16014-16569$ / 001-628 \\
\hline 10.9 & MM Tum 01 & B2 & 111 183C 189 193+C 217512519 & $073185263309+C 315+C 499$ & $16009-16569$ / 001-628 \\
\hline 10.10 & MM Tum 22 & B2 & $111183 C 189193+C 217512519$ & $073185189263309+C$ 315+C 499 & $16009-16569$ / 001-628 \\
\hline 10.11 & TG 061 & B2 & 183C $189193+C 217519$ & $073228 T 263309+C C$ 315+C 499 & $16024-16569$ / 001-576 \\
\hline 10.11 & LQ 154 & B2 & $183 C 189193+C 217519$ & $073228 T 263309+C 315+C 499$ & $16008-16569$ / 001-628 \\
\hline 10.12 & CAL 51 & B2 & 183C $189193+C 217519$ & $073207263309+C C 315+C 470499$ & $15878-16569$ / 001-628 \\
\hline 10.12 & SJ 032 & B2 & 183C $189193+C 217519$ & $073207263309+C C$ 315+C 470499 & $15878-16569$ / 001-628 \\
\hline 10.13 & CAL 53 & B2 & $183 C 189$ 193+C 217294519 & $073207263309+C 315+C 470499$ & $15878-16569$ / 001-628 \\
\hline 10.13 & SJ 054 & B2 & 182C 183C 189 193+C 217294519 & 073207263 309+CC 315+C 470499 & $15878-16569$ / 001-628 \\
\hline 10.14 & CAL Sal 05 & B2 & 182M 183C 189 193+C 217234519 & $073207263309+C 315+C 470499$ & $15878-16569$ / 001-628 \\
\hline 10.14 & CAL Sal 06 & B2 & 183C 189 193+C 217234519 & 073207263 309+C 315+C 470499 & $15878-16569 / 001-576$ \\
\hline 10.15 & CAL 11 & B2 & 182C 183C 189207217519 & $073263309+C 315+C 470499$ & $15878-16569$ / 001-628 \\
\hline 10.15 & TG AG 23 & B2 & 182C 183C 189207217519 & 073263 309+CC 315+C 470499 & $15878-16569$ / 001-628 \\
\hline 10.16 & CAL 16 & B2 & 182C 183C 189207217290519 & $073263309+C 315+C 470499$ & $15878-16569$ / 001-628 \\
\hline
\end{tabular}




\begin{tabular}{|c|c|c|c|c|c|}
\hline $\begin{array}{l}\text { ID en } \\
\text { la red }\end{array}$ & ID & $\mathrm{Hg}$ & Región Control 5' (+16000) & Región Control 3' & Rango de lectura \\
\hline 10.17 & CAL 42 & B2 & 183C 189 193+C 207217291519 & 073263 309+CC 315+C 470499 & $15878-16569$ / 001-628 \\
\hline 10.17 & MZ 050 & B2 & $183 C 189$ 193+C 207217291519 & $073263309+C 315+C 470499$ & $16024-16569$ / 001-576 \\
\hline 10.17 & SJ 027 & B2 & 183C 189 193+C 207217291519 & $073263309+C C 315+C 470499$ & 15878-16569 / 001-628 \\
\hline 10.17 & SJ 040 & B2 & 183C 189 193+C 207217291519 & $073263309+C C$ 315+C 470499 & $15878-16569$ / 001-628 \\
\hline 10.18 & L015 & B2 & 183C 189 193+C 207217291519 & $073151263309+C C$ 315+C 470499 & 16024-16569 / 001-576 \\
\hline 10.19 & LQ 053 & B2 & 096T 183C 189 193+C 217519 & $073263315+C 499$ & $16009-16569$ / 001-628 \\
\hline 10.19 & LQ 103 & B2 & 096T 183C 189 193+C 217519 & $073263315+C 499$ & $16008-16569$ / 001-628 \\
\hline 10.20 & LQ SCA 01 & B2 & $183 C 189193+C 217519$ & $073263309+C 315+C 479480499$ & $16009-16569$ / 001-628 \\
\hline 10.21 & SMA 100 & B2 & 182C 183C 189217519 & $073263309+C$ 315+C 479480499 524+AC & $15878-16569$ / 001-628 \\
\hline 10.21 & MM 129 & B2 & $183 C 189193+C 217519$ & 073263 309+C 315+C 479480499 524+AC & $16014-16569$ / 001-628 \\
\hline 10.22 & LQ Cie 03 & B2 & $183 C 189193+C 217519$ & $073263309+C 315+C 479480499$ 524+ACAC & 16009-16569 / 001-603 \\
\hline 10.23 & Be 045 & B2 & $092126182 C 183 C 189$ 193+C 214217 355A 519 & $073152309+C C 315+C 499$ & $15878-16569$ / 001-628 \\
\hline 10.23 & CAL Sal 09 & B2 & $092126182 C 183 C 189214217$ 355A 519 & $073152309+C C 315+C 499$ & $15878-16569$ / 001-576 \\
\hline 10.23 & $J 52$ & B2 & $092126182 C 183 C 189214217$ 355A 519 & $073152309+C 315+C 499$ & $15878-16569$ / 001-628 \\
\hline 10.23 & SJ 015 & B2 & 092Y 126 182C 183C 189 193+C 214217 355A 519 & $073152309+C C 315+C 499$ & $15878-16569$ / 001-628 \\
\hline 10.23 & SJ 033 & B2 & $092126182 C 183 C 189$ 193+C 214217 355A 519 & $073152309+C 315+C 499$ & $15878-16569$ / 001-628 \\
\hline 10.23 & SJ 063 & B2 & 092126 182C 183C 189 193+C 214217 355A 519 & $073152309+C C 315+C 499$ & $15878-16569$ / 001-628 \\
\hline 10.23 & TG 129 & B2 & $092126182 C 183 C 189$ 193+C 214217 355A 519 & $073152309+C 315+C 499$ & $16024-16569$ / 001-576 \\
\hline 10.23 & Lo95 & B2 & $092126182 C 183 C 189$ 193+C 214217 355A 519 & $073152309+C C 315+C 499$ & $16024-16569$ / 001-576 \\
\hline 10.24 & SMA 095 & B2 & $092126182 C$ 183C 189 193+C 214217 355A 519 & $073152310+$ CCT 315+C 499 & $15878-16569$ / 001-628 \\
\hline 11.1 & SJ 107 & B2 & $178183 C 189193+C 217519$ & $073263315+C 499$ & $15878-16569$ / 001-628 \\
\hline 11.2 & LQ 058 & B2 & 178 182C 183C 189 193+CC 217519 & 073152263 309d 315+C 499 & $16009-16569$ / 001-628 \\
\hline 11.3 & TG 010 & B2 & $178183 C 189193+C 217352357519$ & $073146 Y 152252263315+C 499$ & $16024-16569$ / 001-576 \\
\hline 11.4 & MM Tum 04 & B2 & 038R 129178 182C 183C 189 193+C 217519527 & 055057073112173217263 307-309d 315+C 499 & $16009-16569$ / 001-628 \\
\hline 11.5 & $\mathrm{~J} 10$ & B2 & $145183 C 189193+C 217362519$ & $073263315+C 499$ 523dd & $15878-16569$ / 001-628 \\
\hline 11.5 & TG 064 & B2 & $145183 C 189193+C 217362519$ & $073263315+C 499$ 523dd & 16024-16569 / 001-576 \\
\hline 11.5 & TG 144 & B2 & $145183 C 189193+C 217362519$ & $073263315+C 499$ 523dd & 16024-16569 / 001-576 \\
\hline 11.6 & Be 059 & B2 & $145156157183 C 189$ 193+C 217519 & $073263309+C 315+C 499$ & 15878-16569 / 001-628 \\
\hline 11.6 & $J 45$ & B2 & $145156157183 C 189$ 193+C 217519 & $073263309+C C 315+C 499$ & $16008-16569$ / 001-628 \\
\hline
\end{tabular}




\begin{tabular}{|c|c|c|c|c|c|}
\hline $\begin{array}{l}\text { ID en } \\
\text { la red }\end{array}$ & ID & $\mathrm{Hg}$ & Región Control 5' (+16000) & Región Control 3' & Rango de lectura \\
\hline 11.6 & LQ 032 & B2 & $145156157183 C 189$ 193+C 217519 & $073263309+C C 315+C 499$ & $16009-16569$ / 001-628 \\
\hline 11.6 & LQ Pr 37 & B2 & 145156157 182M 183C 189 193+C 217519 & $073263309+C 315+C 499$ & $16009-16569$ / 001-628 \\
\hline 11.6 & MM 039 & B2 & $145156157183 C 189193+C 217519$ & $073263309+C 315+C 499$ & $16014-16569$ / 001-628 \\
\hline 11.6 & MM 089 & B2 & $145156157183 C 189$ 193+C 217519 & $073263309+C C 315+C 499$ & $16014-16569$ / 001-628 \\
\hline 11.6 & MM Pur 28 & B2 & $145156157183 C 189193+C 217519$ & $073263309+C 315+C 499$ & 16014-16569 / 001-628 \\
\hline 11.7 & LR152 & B2 & $145156157183 C 189193+C 217$ & $073263315+C 499513$ & $16008-16569$ / 001-628 \\
\hline 11.7 & LR BS 37 & B2 & $145156157183 C 189$ 193+C 217 & $073263315+C 499513$ & $16008-16569$ / 001-628 \\
\hline 11.8 & Be 052 & B2 & $156183 C 189193+C 217519$ & $073263309+C 315+C 499$ & $15878-16569$ / 001-628 \\
\hline 11.8 & LR BS 02 & B2 & $156183 C 189$ 193+C 217519 & $073263309+C 315+C 499$ & $15878-16569$ / 001-628 \\
\hline 11.9 & SJS 19 & B2 & $15924140183 C 189$ 193+C 217519 & $073263309+C C 315+C 499$ & 15878-16569 / 001-628 \\
\hline 11.10 & MM 125 & B2 & $140183 C 189193+C 217301 Y 519$ & $073131263309+C 315+C 499$ & $16014-16569$ / 001-628 \\
\hline 11.11 & LQ Cie 02 & B2 & $140183 C 189193+C 217437519$ & $073263315+C 499$ & 16009-16569 / 001-628 \\
\hline 11.12 & TG BS 40 & B2 & 093Y $140183 C 189$ 193+C 217437519 & $073263315+C 499$ & 15878-16569 / 001-628 \\
\hline 11.12 & TG EA 04 & B2 & $093140183 C 189$ 193+C 217437519 & $073263315+C 499$ & $15878-16569$ / 001-628 \\
\hline 11.13 & TG 069 & B2 & 182T 183C $189193+C 217519$ & $073263309+C 315+C 499$ & $16024-16569$ / 001-576 \\
\hline 11.13 & TG BS 10 & B2 & 182T 183C $189193+C 217519$ & $073263309+C 315+C$ 390R 499 & $15878-16569$ / 001-628 \\
\hline 11.14 & TG 031 & B2 & 182T 183C 189 193+C $217259291 Y 519$ & $073263315+C 499$ & $16024-16569$ / 001-576 \\
\hline 11.15 & L 021 & B2 & $168183 C 189193+C 217519$ & $073263309+C C 315+C 499$ & $16024-16569$ / 001-576 \\
\hline 11.15 & MM 034 & B2 & $168183 C 189$ 193+C 217519 & $073263309+C 315+C 499$ & 16014-16569 / 001-628 \\
\hline 11.15 & MM 092 & B2 & $168183 C 189193+C 217519$ & $073263309+C C 315+C 499$ & $16014-16569$ / 001-628 \\
\hline 11.16 & MM Pur 21 & B2 & $093168183 C 189193+C 217519$ & $073263309+C C 315+C 499$ & 16014-16569 / 001-628 \\
\hline 11.17 & LQ 059 & B2 & $168182 C 183 C 189193+C 217519$ & 073263 309d 315+C 499 523dd & $16009-16569$ / 001-628 \\
\hline 11.18 & LQ 147 & B2 & 093Y $168183 C 189$ 193+C 217519 & $073185263315+C 499$ & $16008-16569$ / 001-628 \\
\hline 11.19 & L 002 & B2 & $168183 C 189193+C 217519$ & $073185195263309+C 315+C 499$ & $16024-16569$ / 001-576 \\
\hline 11.20 & MM 102 & B2 & $168182 C 183 C 189217249312519$ & $073152263271309+C C 315+C 499$ & $16014-16569$ / 001-628 \\
\hline 11.21 & SMA 036 & B2 & 182C 183C $189193+C 217249519$ & $073146195263309+C C 315+C 499$ & $15878-16569$ / 001-628 \\
\hline 11.21 & TG AG 22 & B2 & 182C 183C 189217249519 & $073146195263309+C C 315+C 499$ & $15878-16569$ / 001-628 \\
\hline 11.21 & LQ BS 01 & B2 & 182C 183C 189 193+C 217249519 & $073146195263309+C C$ 315+C 499 & $16008-16569$ / 001-628 \\
\hline 11.21 & MM 138 & B2 & 182C 183C 189 193+C 217249519 & $073146195263309+C C 315+C 499$ & $16014-16569$ / 001-628 \\
\hline
\end{tabular}




\begin{tabular}{|c|c|c|c|c|c|}
\hline $\begin{array}{l}\text { ID en } \\
\text { la red }\end{array}$ & ID & $\mathrm{Hg}$ & Región Control 5' (+16000) & Región Control 3' & Rango de lectura \\
\hline 11.22 & MM 080 & B2 & 182C 183C 189217235242291519 & $073263315+C 499$ & $16014-16569$ / 001-600 \\
\hline 11.23 & LQ 033 & B2 & 182C 183C 189 193+C 217235242291519 & $073263309+C 315+C 499$ 524+ACAC & $16009-16569$ / 001-579 \\
\hline 11.23 & LQ 163 & B2 & 182C 183C 189217235242291519 & $073263315+C 499524+A C A C$ & $16008-16569 / 001-600$ \\
\hline 11.24 & LQ 077 & B2 & $182 C 183 C 189217242324519$ & $073146215263309+C C 315+C 499$ & 15991-16569/001-628 \\
\hline 11.25 & MM 038 & B2 & 125 182C 183C 189 193+C 217242284324389519 & $073146215263309+C C 315+C 499$ & $16014-16569$ / 001-628 \\
\hline 11.26 & LQ 054 & B2 & 182C 183C 189 193+C 217242519 & $073146153263309+C C 315+C 499$ & $16009-16569$ / 001-628 \\
\hline 12.1 & J39 & B2 & 183C 188189217519 & $263309+C C 315+C 499$ & $15878-16569$ / 001-628 \\
\hline 12.1 & MZ 018 & B2 & 183C 188189217519 & $263309+C 315+C 499$ & 16024-16569 / 001-576 \\
\hline 12.1 & L 019 & B2 & 183C 188189217519 & $263309+C C 315+C 499$ & 16024-16569 / 001-576 \\
\hline 12.1 & LQ 040 & B2 & 183C 188189217519 & $263309+C C 315+C 499$ & 16009-16569 / 001-628 \\
\hline 12.1 & LQ 057 & B2 & 183C 188189217519 & $263309+C C 315+C 499$ & 15991-16569/ 001-628 \\
\hline 12.1 & LQ 060 & B2 & 183C 188189217519 & $263309+C C 315+C 499$ & 15991-16569/ 001-628 \\
\hline 12.1 & LQ 080 & B2 & 183C 188189217519 & $263315+C 499$ & 15991-16569/ 001-628 \\
\hline 12.1 & LQ 165 & B2 & 183C 188189217519 & $263309+C C 315+C 499$ & 15991-16569/ 001-628 \\
\hline 12.1 & LQ SCA 02 & B2 & 183C 188189217519 & $263309+C C 315+C 499$ & 15991-16569/001-628 \\
\hline 12.1 & MM 012 & B2 & 183C 188189217519 & 263 309+CC 315+C 408W 499 & 15991-16569/ 001-628 \\
\hline 12.1 & MM 024 & B2 & 183C $188189217362 Y 519$ & $263309+C C 315+C 499$ & 15991-16569/ 001-628 \\
\hline 12.1 & MM 054 & B2 & 183C 188189217519 & $263309+C C 315+C 499$ & 15991-16569/ 001-628 \\
\hline 12.1 & MM 086 & B2 & 183C 188189217519 & $263309+C C 315+C 499$ & 15991-16569/ 001-628 \\
\hline 12.1 & MM 122 & B2 & 183C 188189217519 & $263309+C 315+C 499$ & 15991-16569/ 001-628 \\
\hline 12.1 & MM Pur 20 & B2 & 183C 188189217519 & $263309+C 315+C 499$ & 15991-16569/ 001-628 \\
\hline 12.2 & LQ 019 & B2 & 183C 188189217519 & $093215263309+C$ 315+C 499 & $16009-16569$ / 001-628 \\
\hline 12.2 & LQ Cie 08 & B2 & 183C 188189217519 & $093215263309+C$ 315+C 499 & 15991-16569/ 001-628 \\
\hline 12.3 & LQ 052 & B2 & 183C 188189217519 & $152263309+C C$ 315+C 499 & 15991-16569/001-628 \\
\hline 12.4 & LQ 131 & B2 & $129183 C 188189217519$ & $063263309+C C 315+C 499$ & 15991-16569 / 001-628 \\
\hline 12.5 & LQ 110 & B2 & 183C 188189 193d 217519 & $063263309+C C \quad 315+C 499$ & 15991-16569/ 001-628 \\
\hline 12.5 & MM Tum 03 & B2 & 183C 188189 193d 217519 & $063263309+C C 315+C 499$ & 15991-16569/ 001-628 \\
\hline 12.6 & LQ Pr 39 & B2 & 183C 188189217519 & $063064146263315+C 499$ & 15991-16569/ 001-628 \\
\hline 12.7 & MM Pur 11 & B2 & 183C 188189217519 & $063064066 T 263$ 309+C 315+C 499 & 15991-16569/ 001-628 \\
\hline
\end{tabular}




\begin{tabular}{|c|c|c|c|c|c|}
\hline $\begin{array}{l}\text { ID en } \\
\text { la red }\end{array}$ & ID & $\mathrm{Hg}$ & Región Control 5' (+16000) & Región Control 3' & Rango de lectura \\
\hline 12.8 & LQ 042 & B2 & 183C 188189217519 & $064073263315+C 499$ & 15991-16569/001-628 \\
\hline 12.9 & LQ 039 & B2 & 183C 188189217519 & $063064073263315+C 499$ & $16009-16569$ / 001-628 \\
\hline 12.9 & MM 031 & B2 & 183C 188189217519 & $063064073263309+C 315+C 499$ & 15991-16569/001-628 \\
\hline 12.9 & MM 050 & B2 & 183C 188189217519 & $063064073263309+C 315+C 499$ & 15991-16569/ 001-628 \\
\hline 12.10 & LQ 025 & B2 & 183C 188189217519 & 063064073 146Y $185234 R 263$ 309+C 315+C 499 & 15991-16569/ 001-628 \\
\hline 12.11 & LQ Pr 14 & B2 & $183 C 188189217218519$ & $063064073185263309+C 315+C 499$ & $16008-16569$ / 001-628 \\
\hline 12.12 & SMA 053 & B2 & 183C 188189217519 & 063064066073185263 309+C 315+C 499 & $15878-16569$ / 001-628 \\
\hline 12.12 & MM 058 & B2 & 183C 188189217519 & $063064066073185204 Y 263$ 309+C 315+C 499 & 15991-16569/001-628 \\
\hline 12.12 & MM Pur 08 & B2 & 183C 188189217519 & 063064066073185263 309+C 315+C 499 & 15991-16569/ 001-628 \\
\hline 12.12 & MM Pur 13 & B2 & 183C 188189217519 & 063064066073185263 309+C 315+C 499 & 15991-16569/ 001-628 \\
\hline 12.13 & MM 059 & B2 & 183C 188189217223519 & 063064066073185263 309+CC 315+C 499 & 15991-16569/ 001-628 \\
\hline 12.14 & MM 124 & B2 & 183C 188189217519 & 063064066073 235R 263 309+C 315+C 499 & 15991-16569/ 001-628 \\
\hline 12.15 & MM 098 & B2 & 183C 188189217464519 & $063064073263309+C 315+C 499$ & $15991-16569 / 001-628$ \\
\hline 12.15 & MM Pur 34 & B2 & 183C 188189217464519 & $063064073263309+C C 315+C 499$ & 15991-16569/ 001-628 \\
\hline 12.16 & $J 24$ & B2 & 183C 188189217519 & $063064073146263309+C 315+C 499$ & $15878-16569$ / 001-628 \\
\hline 12.17 & SJ 052 & B2 & 183C 188189217319519 & $064073263309+C$ 315+C 499 & $15878-16569$ / 001-628 \\
\hline 12.18 & MM 119 & B2 & 051R 172 183C 188189217519 & $073263315+C 499$ & 15991-16569/ 001-628 \\
\hline 12.19 & TG 035 & B2 & 183C 188189217519 & $073186263309+C$ 315+C 499 & $16024-16569$ / 001-576 \\
\hline 12.19 & TG AG 24 & B2 & 183C 188189217519 & $073186263309+C$ 315+C 499 & $15878-16569$ / 001-628 \\
\hline 12.20 & LQ Cie 05 & B2 & $172183 C 188189217295519$ & $073186263309+C$ 315+C 499 & 15991-16569 / 001-628 \\
\hline 12.21 & LQ 128 & B2 & 183C 188189217354519 & $073186263309+C$ 315+C 499 & 15991-16569/ 001-628 \\
\hline 12.21 & LQ Pr 15 & B2 & 183C 188189217354519 & $073186263309+C$ 315+C 499 & $16008-16569$ / 001-628 \\
\hline 12.22 & TG 068 & B2 & 183C 188189217354519 & 073186263 309+CC 315+C 373499 & 16024-16569 / 001-576 \\
\hline 12.22 & TG 101 & B2 & 183C 188189217354519 & 073186263 309+CC 315+C 373499 & $16024-16569$ / 001-576 \\
\hline 12.23 & $\mathrm{~J} 03$ & B2 & 183C 188189217354519 & $073146186263315+C 499$ & $15878-16569$ / 001-628 \\
\hline 12.24 & LQ 063 & B2 & 183C 188189217266519 & $073186204 Y 263309+C 315+C 499$ & 15991-16569/ 001-628 \\
\hline 12.24 & LQ 168 & B2 & 183C 188189217266519 & $073186263309+C$ 315+C 499 & $16008-16569$ / 001-628 \\
\hline 12.25 & LQ 099 & B2 & 183C 188189217 & $073186263309+C C$ 315+C 499 & 15991-16569/ 001-628 \\
\hline 12.25 & LQ 106 & B2 & 183C 188189217 & 073186263 309+CC 315+C 499 & 15991-16569/ 001-628 \\
\hline
\end{tabular}




\begin{tabular}{|c|c|c|c|c|c|}
\hline $\begin{array}{l}\text { ID en } \\
\text { la red }\end{array}$ & ID & $\mathrm{Hg}$ & Región Control 5' (+16000) & Región Control 3' & Rango de lectura \\
\hline 12.26 & LQ 095 & B2 & 183C 188189217519 & $073186263309+C 315+C 316499$ & 15991-16569/001-587 \\
\hline 12.27 & LQ 075 & B2 & $183 C 188189217223519$ & $073186263309+C 315+C 316499$ & 15991-16569/001-628 \\
\hline 12.27 & LQ 111 & B2 & 183C 188189217223519 & $073186263309+C 315+C 316499$ & 15991-16569/001-628 \\
\hline 12.28 & LQ 155 & B2 & 183C 188189217519 & $073143186263315+C 449499$ & 15991-16569/001-628 \\
\hline 12.28 & MM 032 & B2 & 183C 188189217519 & $073143186263309+C 315+C 449499$ & 15991-16569/001-628 \\
\hline 12.29 & Be 064 & B2 & 183C 188189217519 & $073143263309+C 315+C 449499$ & $15878-16569$ / 001-628 \\
\hline 12.30 & TG BS 07 & B2 & $183 C 188189217362519$ & $073152186204 Y 263$ 309+C 315+C 499 & $15878-16569$ / 001-628 \\
\hline 12.31 & LR179 & B2 & 183C 188189217362519 & $073152186195263315+C 499$ & $15878-16569$ / 001-628 \\
\hline 12.32 & LQ 107 & B2 & $148183 C 188189217362519524$ & $073186263309+C$ 315+C 499 & 15991-16569 / 001-628 \\
\hline 12.33 & SMA 004 & B2 & 183C 188189217519 & $073241263309+C$ 315+C 499 & $15878-16569 / 001-628$ \\
\hline 12.33 & SMA 055 & B2 & 183C 188189217519 & $073241263309+C 315+C 499$ & $15878-16569$ / 001-628 \\
\hline 12.33 & SMA 092 & B2 & 183C 188189217519 & $073241263309+C$ 315+C 499 & $15878-16569 / 001-628$ \\
\hline 12.34 & MM Tum 20 & B2 & 183C 188189 193d 217428465519 & $073263309+C 315+C 499$ & 15991-16569/001-628 \\
\hline 12.35 & LQ 161 & B2 & 093Y 183C 188189217299465519 & $073146234 R 263309+C 315+C 499$ & 15991-16569 / 001-628 \\
\hline 13.1 & MZ 034 & B2 & 183C $189193+C 217381519$ & $073263309+C C C 315+C 499$ & $16024-16569$ / 001-576 \\
\hline 13.1 & TG AG 36 & B2 & $183 C 189193+C 217381519$ & $073263315+C 499$ & $15878-16569$ / 001-628 \\
\hline 13.1 & LQ 068 & B2 & $183 C 189193+C 217381519$ & 073263 309+CC 315+C 499 & $16009-16569 / 001-628$ \\
\hline 13.1 & MM 033 & B2 & $183 C 189193+C 217381519$ & $073263309+C C 315+C 499$ & $16014-16569$ / 001-628 \\
\hline 13.1 & MM 077 & B2 & $183 C 189193+C 217381519$ & 073263 309+CC $315+C 499$ & $16014-16569$ / 001-628 \\
\hline 13.1 & MM Pur 30 & B2 & $183 C 189193+C 217381519$ & $073263309+C 315+C 499$ & $16009-16569$ / 001-628 \\
\hline 13.1 & MM Pur 41 & B2 & $183 C 189193+C 217381519$ & $073263309+C C 315+C 499$ & $16009-16569$ / 001-628 \\
\hline 13.2 & TG AG 34 & B2 & 183C 189 193+C 217381474519 & $073263309+C 315+C 499$ & $15878-16569$ / 001-628 \\
\hline 13.3 & LQ 082 & B2 & $183 C 189193+C 217456519$ & 073199 227R 263 309+CC 315+C 499 & $16008-16569$ / 001-628 \\
\hline 13.3 & LQ Cie 04 & B2 & $183 C 189193+C 217456519$ & $073199227263309+C$ 315+C 499 & $16009-16569 / 001-580$ \\
\hline 13.3 & MM 036 & B2 & $183 C 189193+C 217456519$ & $073199227263309+C 315+C 499$ & $16014-16569$ / 001-628 \\
\hline 13.4 & TG BS 39 & B2 & 183C 189 193+C 217270278456519 & $073228263309+C 315+C 499$ & $15878-16569$ / 001-628 \\
\hline 13.5 & TG BS 44 & B2 & 183C 189 193+C 217311390519 & $073263309+C C 315+C 499$ & $15878-16569$ / 001-628 \\
\hline 13.6 & LQ Pr 31 & B2 & 182C 183C 189217390519 & $073207257263309+C 315+C 499606$ & $16009-16569$ / 001-628 \\
\hline 13.6 & MM 078 & B2 & 182M 183C 189 193+C 217390519 & $073207257263309+C 315+C 499606$ & $16014-16569$ / 001-628 \\
\hline
\end{tabular}




\begin{tabular}{|c|c|c|c|c|c|}
\hline $\begin{array}{l}\text { ID en } \\
\text { la red }\end{array}$ & ID & $\mathrm{Hg}$ & Región Control 5' (+16000) & Región Control 3' & Rango de lectura \\
\hline 13.6 & MM 128 & B2 & 183C $189193+C 217390519$ & 073207257263 309+C 315+C 499606 & 16014-16569 / 001-628 \\
\hline 13.7 & SJ 078 & B2 & 182C 183C 189 193+C 217390519 & $073227263309+C C 315+C 499$ & 15878-16569 / 001-628 \\
\hline 13.8 & SMA 029 & B2 & $183 C 189193+C 217292519$ & $063064066 T 073263309+C 315+C 499$ & 15878-16569 / 001-628 \\
\hline 13.8 & SMA 073 & B2 & $183 C 189193+C 217292519$ & $063064066 T 073263309+C 315+C 499$ & 15878-16569 / 001-628 \\
\hline 13.9 & MM 011 & B2 & $176182 C 183 C 189$ 193+C 217256356362519 & 073215263 309d 315+C 499 523dd & 16014-16569 / 001-628 \\
\hline 13.10 & $\mathrm{~J} 35$ & B2 & $183 C 189193+C 217256288519$ & $073185263309+C C 315+C 499$ & 15878-16569 / 001-628 \\
\hline 13.10 & TG EA 07 & B2 & $183 C 189193+C 217256288519$ & $073185263309+C 315+C 499$ & 15878-16569 / 001-628 \\
\hline 13.10 & LQ 036 & B2 & $183 C 189193+C 217256288519$ & $073185263309+C C 315+C 499$ & 16009-16569 / 001-628 \\
\hline 13.10 & LQ 056 & B2 & $183 C 189193+C 217256288519$ & $073185263309+C C 315+C 499$ & $16009-16569$ / 001-628 \\
\hline 13.10 & LQ Cie 06 & B2 & $183 C 189193+C 217256288519$ & $073185263309+C C 315+C 499$ & 16009-16569 / 001-628 \\
\hline 13.10 & MM 045 & B2 & $183 C 189193+C 217256288519$ & $073185263309+C C 315+C 499$ & 16014-16569 / 001-628 \\
\hline 13.10 & MM 088 & B2 & $183 C 189193+C 217256288519$ & $073185263309+C C 315+C 499$ & 16014-16569 / 001-628 \\
\hline 13.11 & TG BS 45 & B2 & $000179183 T 189217256290519527$ & 073146150189194263310 315d 499 & 15878-16569 / 001-628 \\
\hline 14.1 & TG 030 & B2 & $183 C 189193+C 217316519$ & 041092097 106-111d 263 309+CC 315+C 499 523dd & 16024-16569 / 001-576 \\
\hline 14.1 & LQ 066 & B2 & 183C $189193+C 217316519$ & 041092097 106-111d 263 309+CC 315+C 499 523dd & $16009-16569$ / 001-628 \\
\hline 14.2 & TG AG 17 & B2 & $182 C 183 C 189217316519$ & 057G 073260263 309+CC 315+C 499 523dd 549619 & $16024-16569$ / 001-628 \\
\hline 14.2 & TG AG 26 & B2 & 182C 183C $189193+C 217316519$ & 057G 073260263 309+CC 315+C 499 523dd 549619 & 15878-16569 / 001-628 \\
\hline 14.3 & TG 142 & B2 & 182C 183C $189193+C 217316519$ & $073151260263309+C 315+C 499523 d d$ & $16024-16569$ / 001-576 \\
\hline 14.4 & TG 134 & B2 & 182C 183C 189217316519 & $073151228260263309+C$ 315+C 499 523dd & 16024-16569 / 001-576 \\
\hline 14.5 & LQ 037 & B2 & $182 C 183 C 189193+C 217316512519542 G$ & 057G 073151152260263310 315-318d 499 523dd & $16009-16569$ / 001-628 \\
\hline 14.5 & LQ 071 & B2 & 182C 183C 189 193+C $217316512519542 G$ & 057G 073151152260263310 315-318d 499 523dd & 16009-16569 / 001-628 \\
\hline 14.6 & LQ 041 & B2 & 183C $189193+C 217316519$ & 042+G 57G 073151263293 309+CC 315+C 499 523dd & $16009-16569$ / 001-628 \\
\hline 14.6 & LQ 124 & B2 & $183 C 189193+C 217316519$ & 042+G 57G 073151263293 309+CC 315+C 499 523dd & $16008-16569$ / 001-628 \\
\hline 14.7 & SJ 059 & B2 & $093183 C 189193+C 2173360519$ & 057G 073151152207211263 309+CC 315+C 499 523dd & 15878-16569 / 001-628 \\
\hline 15.1 & LQ 089 & B2 & 181 182C 183C 189217261311519 & $073114258263309+C C 315+C 499$ 523dd & $16008-16569$ / 001-628 \\
\hline 15.2 & CAL 01 & B2 & $183 C 189193+C 217261319519$ & 071+G 073075263 309+C 315+C 340499 & 15878-16569 / 001-628 \\
\hline 15.2 & CAL 56 & B2 & $183 C 189193+C 217261319519$ & 071+G 073075263 309+C 315+C 340499 & 15878-16569 / 001-628 \\
\hline 15.2 & LQ 167 & B2 & 183C $189193+C 217261319519$ & 071+G $073075263309+C 315+C 340499$ & 16008-16569 / 001-628 \\
\hline 15.2 & LQ Pr 29 & B2 & 183C $189193+C 217261319519$ & 071+G $073075263315+C 340499$ & $16009-16569$ / 001-628 \\
\hline
\end{tabular}




\begin{tabular}{|c|c|c|c|c|c|}
\hline $\begin{array}{l}\text { ID en } \\
\text { la red }\end{array}$ & ID & $\mathrm{Hg}$ & Región Control 5' (+16000) & Región Control 3' & Rango de lectura \\
\hline 15.3 & LQ 008 & B2 & 183C $189193+C 217261319362519$ & 071+G 073263 309+CC 315+C 499 & $16009-16569$ / 001-628 \\
\hline 15.3 & LQ 098 & B2 & $183 C 189193+C 217261319362519$ & 071+G 073263 309+CC 315+C 499 & $16008-16569$ / 001-628 \\
\hline 15.3 & LQ BS 02 & B2 & 183C $189193+C 217261319362519$ & 071+G 073263 309+CC 315+C 499 & $16008-16569$ / 001-628 \\
\hline 15.4 & LQ Pr 01 & B2 & 183C $189193+C 217261319362519$ & 071+G 073189263 309+CC 315+C 499 & $16008-16569$ / 001-628 \\
\hline 15.5 & CHE 15 & B2 & $183 C 189193+C 212217261270319519$ & 071+G 073094 146Y 263 309+CC 315+C 499 & $15878-16569$ / 001-628 \\
\hline 15.6 & LQ 045 & B2 & 183C 189 193+C 212217261319519 & 065G 073263 309+CC 315+C 499 & $16009-16569$ / 001-628 \\
\hline 15.7 & $\mathrm{~J} 22$ & B2 & $182 C 183 C 189212217261319335519$ & 065G $073263309+C 315+C 499$ & $15878-16569$ / 001-628 \\
\hline 15.8 & LQ 157 & B2 & $182 C 183 C 189212217261319335519$ & 065G 073 195Y 263 309+C 315+C 499 & $16008-16569$ / 001-628 \\
\hline 15.8 & LQ Pr 08 & B2 & $182 C 183 C 189212217261319335519$ & 065G 073195263 309+C 315+C 499 & $16008-16569$ / 001-628 \\
\hline 15.9 & LQ 016 & B2 & 182C 183C 189212217261319335519520 & 065G 073195263 309+C 315+C 499 & $16009-16569$ / 001-628 \\
\hline 15.10 & MM 142 & B2 & 183C 189 193+C 21725926151959 & $073263315+C 499$ & $16014-16569$ / 001-628 \\
\hline 15.11 & MZ 037 & B2 & $142183 C 189193+C 217261519$ & $073263309+C 315+C 499$ & $16024-16569$ / 001-576 \\
\hline 15.11 & SJ 004 & B2 & $142182 C 183 C 189217261519$ & $073263309+C 315+C 499$ & $15878-16569$ / 001-628 \\
\hline 15.11 & L 069 & B2 & $142183 C 189193+C 217261519$ & $073263309+C 315+C 499$ & $16024-16569$ / 001-576 \\
\hline 15.12 & MZ 142 & B2 & $142183 C 189193+C 217519$ & $073263309+C 315+C 499$ & $16024-16569$ / 001-576 \\
\hline 15.13 & SJ 068 & B2 & $142183 C 189193+C 217519$ & $073152263309+C 315+C 499$ & $15878-16569$ / 001-628 \\
\hline 15.14 & TG EA 18 & B2 & $142183 C 189193+C 217304519$ & $073263309+C 315+C 499$ & $15878-16569$ / 001-628 \\
\hline 15.15 & SMA 151 & B2 & $142182 C 183 C 189193+C 217325519$ & $073195263309+C C 315+C 499$ & $15878-16569$ / 001-628 \\
\hline 15.15 & SMA 152 & B2 & $142182 C 183 C 189217325519$ & $073195263309+C C 315+C 499$ & 15878-16569 / 001-628 \\
\hline 15.16 & SJ 080 & B2 & $142182 C 183 C 189$ 193+C 217325519 & 073195263 309+CC 315+C 499523 & $15878-16569$ / 001-628 \\
\hline 15.17 & Be 038 & B2 & 142 182C 183C 189 193+C 217222293519 & 073195247263310 314- 315- 499 & $15878-16569$ / 001-628 \\
\hline 15.17 & SJ 034 & B2 & $142182 C 183 C 189193+C 217222293519$ & 073195247263310 314- 315- 499 & 15878-16569 / 001-628 \\
\hline 15.17 & L sal 08 & B2 & 142 182C 183C 189 193+C 217222293519 & 073195247263310 314d 315d 499 & $15898-16569$ / 001-628 \\
\hline 15.18 & LR020 & B2 & $142183 C 189193+C 217222293319519$ & 073195247263310 314d 315d 499 & $15878-16569$ / 001-628 \\
\hline 15.18 & LR043 & B2 & $142183 C 189193+C 217222293319519$ & 073195247263310 314d 315d 499 & $15878-16569$ / 001-628 \\
\hline 15.18 & SJ 065 & B2 & $142183 C 189193+C 217222293319519$ & 073195247263310 314- 315- 499 & $15878-16569$ / 001-628 \\
\hline 15.18 & SMA 039 & B2 & $142183 C 189193+C 217222293319519$ & 073195247263310 314d 315d 499 & $15878-16569$ / 001-628 \\
\hline 15.18 & SJS 11 & B2 & $142183 C 189193+C 217222293319519$ & 073195247263310 314d 315d 499 & $15878-16569$ / 001-628 \\
\hline 15.18 & SJS 17 & B2 & $142183 C 189193+C 217222293319519$ & 073195247263310 314d 315d 499 & $15878-16569$ / 001-628 \\
\hline
\end{tabular}

187 


\begin{tabular}{|c|c|c|c|c|c|}
\hline $\begin{array}{l}\text { ID en } \\
\text { la red }\end{array}$ & ID & $\mathrm{Hg}$ & Región Control 5' (+16000) & Región Control 3' & Rango de lectura \\
\hline 15.18 & TG 133 & B2 & $142182 C 183 C 189193+C 217222293319519$ & 073195247263310 314d 315d 499 & $16024-16569$ / 001-576 \\
\hline 15.18 & LQ Cie 09 & B2 & $142182 C 183 C 189193+C 217222293319519$ & 073195247263310 314-315d 499 & $16009-16569$ / 001-628 \\
\hline 15.19 & LR145 & B2 & $142183 C 189193+C 217222293319519$ & 073195247263310 315d 499 & $15878-16569$ / 001-628 \\
\hline 15.19 & SJ JA 09 & B2 & $142183 C 189193+C 217222293319519$ & $073195247263310315-499$ & $15878-16569$ / 001-628 \\
\hline 15.19 & SMA 149 & B2 & $142183 C 189193+C 217222293319519$ & 073195247263310 315d 499 & $15878-16569$ / 001-628 \\
\hline 15.19 & LQ Pr 34 & B2 & $142183 C 189193+C 217222293319519$ & 073195247263310 315d 499 & $16009-16569$ / 001-628 \\
\hline 15.20 & SJ JA 08 & B2 & $142183 C 189193+C 217519$ & $073195263309+C C 315+C 499573+C$ & $15878-16569$ / 001-628 \\
\hline 15.21 & LR146 & B2 & $142183 C 189193+C 217519$ & $073195263309+C C 315+C 499573+C C C$ & $15878-16569 / 001-576$ \\
\hline 15.22 & LR BS 43 & B2 & $142183 C 189193+C 217519$ & 073195263 309+CC 315+C 499 573+CCCCC & $15878-16569$ / 001-576 \\
\hline 15.23 & Be 055 & B2 & $092142183 C 189193+C 217519$ & 073146198263 309+C 315+C 499 & $15878-16569 / 001-628$ \\
\hline 16.1 & LQ Pr 03 & B2 & $129183 C 189193+C 217519$ & 073146263 309+CCC 315+C 499545 & $16008-16569$ / 001-628 \\
\hline 16.2 & MM 063 & B2 & $129183 C 189193+C 217519$ & $073143263315+C 499523 d d$ & $16014-16569 / 001-628$ \\
\hline 16.3 & Be 084 & B2 & 183C $189193+C 217519$ & $073152263315+C 499$ & $15878-16569$ / 001-628 \\
\hline 16.4 & TG 011 & B2 & $153183 C 189193+C 217519$ & $073152263309+C 315+C 499$ & $16024-16569$ / 001-576 \\
\hline 16.5 & LQ Pr 21 & B2 & $183 C 189193+C 217519$ & 073195263 309+CC 315+C 499 & $16008-16569$ / 001-628 \\
\hline 16.5 & MM 085 & B2 & $183 C 189193+C 217519$ & $073195263309+C C 315+C 499$ & $16014-16569$ / 001-628 \\
\hline 16.5 & MM Tum 02 & B2 & 182M 183C 189 193+C 217519 & $073195263309+C 315+C 499$ & $16009-16569 / 001-628$ \\
\hline 16.6 & MM 097 & B2 & 183C $189193+C 217519$ & $073150195263309+$ +CCC 315+C 499 & $16014-16569$ / 001-628 \\
\hline 16.7 & TG BS 54 & B2 & 182C 183C 189217519 & $046073146263309+C C$ 309.3C 315+C 499 & $15878-16569$ / 001-628 \\
\hline 16.8 & MM 051 & B2 & $183 C 189193+C 217519$ & 046G 073146152189195263 315+C 499 595A & $16014-16569$ / 001-628 \\
\hline 16.9 & TG AG 01 & B2 & 183C $189193+C 217319360519$ & $073146263309+C 315+C 499$ & $15930-15569 / 001-576$ \\
\hline 16.10 & SJS 02 & B2 & $172182 C 183 C 189217380519$ & 061A 062064073146263 315+C 499 & $15878-16569$ / 001-628 \\
\hline 16.11 & TG 125 & B2 & 182C 183C 189217294519 & $073263309+C 315+C 499573+C$ & $16024-16569$ / 001-576 \\
\hline 16.12 & MM 004 & B2 & $093183 C 189193+C 217519$ & $073263315+C 499$ & $16014-16569$ / 001-628 \\
\hline 16.13 & TG AG 21 & B2 & $092183 C 189193+C 217519$ & $073263309+C 315+C 499$ & $15878-16569$ / 001-628 \\
\hline 16.14 & TG 002 & B2 & 183C $189193+C 217519$ & $073263315+C 499524+A C$ & $16024-16569$ / 001-576 \\
\hline 16.15 & LQ Pr 13 & B2 & $183 C 189193+C 217519$ & $073214263309+C 315+C 499573+C C C 573.4 C$ & $16008-16569$ / 001-604 \\
\hline 16.16 & LQ 006 & B2 & $172183 C 189193+C 217310519$ & $073139263309+C C 315+C 499$ & $16009-16569$ / 001-628 \\
\hline 16.17 & BeP 13 & B2 & $15952183 C 189193+C 217311519$ & $073263315+C 499$ & $15878-16569$ / 001-628 \\
\hline
\end{tabular}




\begin{tabular}{|c|c|c|c|c|c|}
\hline $\begin{array}{l}\text { ID en } \\
\text { la red }\end{array}$ & ID & $\mathrm{Hg}$ & Región Control 5' (+16000) & Región Control 3' & Rango de lectura \\
\hline 16.17 & TG 003 & B2 & 15952 183C 189 193+C 217311519 & $064 Y 073263315+C 499$ & 15878-16569 / 001-576 \\
\hline 16.17 & TG BS 03 & B2 & $15952183 C 189$ 193+C 217311519 & $073263315+C 499$ & 15878-16569 / 001-628 \\
\hline 16.17 & LQ 094 & B2 & 183C 189 193+C 217311519 & $073263315+C 499$ & 16008-16569 / 001-608 \\
\hline 16.17 & LQ 115 & B2 & 183C 189 193+C 217311519 & $073263315+C 499$ & 16008-16569 / 001-628 \\
\hline 16.17 & LQ 127 & B2 & 183C 189 193+C 217311519 & $073263315+C 499$ & 16008-16569 / 001-628 \\
\hline 16.17 & LQ 151 & B2 & $183 C 189193+C 217311519$ & $073263315+C 499$ & 16008-16569 / 001-628 \\
\hline 16.17 & MM 009 & B2 & 183C 189 193+C 217311519 & $073263315+C 499$ & 16014-16569 / 001-628 \\
\hline 16.17 & MM 065 & B2 & 183C 189 193+C 217311519 & $073263315+C 499$ & 16014-16569 / 001-628 \\
\hline 16.18 & TG BS 21 & B2 & 179A 183C 189 193+C 217311519 & $073263309+C 315+C 430485499524+A C$ & 15878-16569 / 001-628 \\
\hline 16.19 & MZ 015 & B2 & 183C 189 193+C 217266519 & $073186263309+C C 315+C 499$ & 16024-16569 / 001-576 \\
\hline 16.20 & LQ 123 & B2 & 182C 183C $189193+C 217519$ & 073263310 314d 315d 499 573+CCC & 16008-16569 / 001-604 \\
\hline 17.1 & Be 067 & C1b & 223298325327 & 073 249d 263 290dd 309+C 315+C 489493 523dd & 15878-16569 / 001-628 \\
\hline 17.1 & J47 & C1b & 223298325327 & 073 249d 263 290dd 315+C 489493 523dd & 15878-16569 / 001-628 \\
\hline 17.1 & LR170 & C1b & 223298325327 & 073 249d 263 290dd 315+C 489493 523dd & 15878-16569 / 001-628 \\
\hline 17.1 & MZ 146 & $\mathrm{C} 1 \mathrm{~b}$ & 223298325327 & 073 249d 263 290dd 315+C 489493 523dd & 16024-16569 / 001-576 \\
\hline 17.1 & SMA 146 & C1b & 223298325327 & 073 249d 263 290dd 309+C 315+C 489493 523dd & 15878-16569 / 001-628 \\
\hline 17.1 & TG 096 & $\mathrm{C} 1 \mathrm{~b}$ & 223298325327 & 073 249d 263 290dd 315+C 489493 523dd & 16024-16569 / 001-576 \\
\hline 17.1 & L 046 & C1b & 223298325327 & 073 249d 263 290dd 315+C 489493 523dd & $16024-16569$ / 001-576 \\
\hline 17.1 & L 048 & C1b & 223298325327 & 073 249d 263 290dd 315+C 489493 523dd & $16024-16569$ / 001-576 \\
\hline 17.1 & L 073 & C1b & 223298325327 & 073 249d 263 290dd 315+C 489493 523dd & $16024-16569$ / 001-576 \\
\hline 17.1 & LQ 097 & C1b & 223298325327 & 073 249d 263 290dd 315+C 489493 523dd & 15991-16569/001-628 \\
\hline 17.2 & SMA 030 & C1b & 223298325327 & 073204207 249d 263 290dd 309+C 315+C 489493 523dd & 15878-16569 / 001-628 \\
\hline 17.3 & CHE 01 & C1b & 223298325327519 & 073150207 249d 263 290dd 309+C 315+C 489493 523dd & 15878-16569 / 001-628 \\
\hline 17.3 & CHE 10 & $\mathrm{C} 1 \mathrm{~b}$ & 223298325327519 & 073150207 249d 263 290dd 309+CC 315+C 489493 523dd & 15878-16569 / 001-628 \\
\hline 17.4 & TG BS 18 & C1b & 223260261298311325327519 & 073207 249d 263 290dd 315+C 489493 523dd & $15878-16569$ / 001-628 \\
\hline 17.5 & MM 020 & C1b & 000209223243298325327362519 & 073 249d 263 290dd 309+C 315+C 489493 523dd & 15991-16569/001-628 \\
\hline 17.6 & SMA 032 & C1b & 000209223243298325362519 & 073 249d 263 290dd 315+C 489493 523dd & 15878-16569 / 001-628 \\
\hline 17.7 & MM 067 & C1b & 157209223298325327 & 073 249d 263 290dd 309+C 315+C 489493 523dd & 15991-16569/001-628 \\
\hline 17.7 & MM Tum 14 & C1b & 157209223298325327 & 073 249d 263 290dd 309+C 315+C 489493 523dd & 15991-16569/001-628 \\
\hline
\end{tabular}

189 


\begin{tabular}{|c|c|c|c|c|c|}
\hline $\begin{array}{l}\text { ID en } \\
\text { la red }\end{array}$ & ID & $\mathrm{Hg}$ & Región Control 5' (+16000) & Región Control 3' & Rango de lectura \\
\hline 17.8 & TG 032 & $\mathrm{C} 1 \mathrm{~b}$ & 223270298325327 & 073214 249d 263 290dd 309+C 315+C 489493 523dd & $16024-16569$ / 001-576 \\
\hline 17.9 & LR BS 01 & $\mathrm{C} 1 \mathrm{~b}$ & 223270298325327527 & 073146214 249d 263 290dd 309+C 315+C 489493 523dd & $15878-16569$ / 001-628 \\
\hline 17.9 & SJ 047 & $\mathrm{C} 1 \mathrm{~b}$ & 223270298325327527 & 073146214 249d 263 290dd 309+C 315+C 489493 523dd & $15878-16569$ / 001-628 \\
\hline 17.10 & CAL 02 & $\mathrm{C} 1 \mathrm{~b}$ & 223298325327 & 073 249d 258263 290dd 309+C 315+C 489493 523dd & $15878-16569 / 001-628$ \\
\hline 17.10 & CAL 26 & $\mathrm{C} 1 \mathrm{~b}$ & 223298325327 & 073 249d 258263 290dd 309+C 315+C 489493 523dd & $15878-16569$ / 001-628 \\
\hline 17.10 & CAL 41 & $\mathrm{C} 1 \mathrm{~b}$ & 223298325327 & 073 249d 258263 290dd 309+C 315+C 489493 523dd & $15878-16569$ / 001-628 \\
\hline 17.10 & CAL 60 & $\mathrm{C} 1 \mathrm{~b}$ & 223298325327 & 073 249d 258263 290dd 309+C 315+C 489493 523dd & $15878-16569$ / 001-628 \\
\hline 17.10 & LR035 & $\mathrm{C} 1 \mathrm{~b}$ & 223298325327 & 073 249d 258263 290dd 309+C 315+C 489493 523dd & $15878-16569$ / 001-628 \\
\hline 17.10 & MZ 039 & $\mathrm{C} 1 \mathrm{~b}$ & 223298325327 & 073 249d 258263 290dd 315+C 489493 523dd & $16024-16569$ / 001-576 \\
\hline 17.10 & L sal 14 & $\mathrm{C} 1 \mathrm{~b}$ & 223298325327 & 073 249d 258263 290dd 309+C 315+C 489493 523dd & $15898-16569$ / 001-628 \\
\hline 17.11 & CAL 20 & $\mathrm{C} 1 \mathrm{~b}$ & 223298325327 & 073 249d 258263 290dd 309+CC 315+C 489493 & $15878-16569$ / 001-628 \\
\hline 17.11 & CAL 35 & $\mathrm{C} 1 \mathrm{~b}$ & 223298325327 & 073 249d 258263 290dd 309+CC 315+C 489493 & $15878-16569$ / 001-628 \\
\hline 17.11 & SJ 001 & $\mathrm{C} 1 \mathrm{~b}$ & 223298325327 & 073 249d 258263 290dd 309+C 315+C 489493 & $15878-16569$ / 001-628 \\
\hline 17.12 & CHE 02 & $\mathrm{C} 1 \mathrm{~b}$ & 223294298325327 & 073 249d 258263 290dd 309+C 315+C 489493 & $15878-16569$ / 001-628 \\
\hline 17.12 & MM 136 & $\mathrm{C} 1 \mathrm{~b}$ & 223294298325327 & 073 249d 258263 290dd 309+CC 315+C 489493 & 15991-16569/ 001-628 \\
\hline 17.13 & MZ 064 & $\mathrm{C} 1 \mathrm{~b}$ & 051223298325327 & 073 249d 258263 290dd 315+C 489493 523dd & $16024-16569$ / 001-576 \\
\hline 17.14 & MZ 111 & $\mathrm{C} 1 \mathrm{~b}$ & 223298311325327 & 073 249d 258263 290dd 309+C 315+C 489493 523dd & 16024-16569 / 001-576 \\
\hline 17.14 & LO 023 & $\mathrm{C} 1 \mathrm{~b}$ & 223298311325327 & 073 249d 258263 290dd 309+C 315+C 489493 523dd & $16024-16569$ / 001-576 \\
\hline 17.15 & L075 & $\mathrm{C} 1 \mathrm{~b}$ & 223298325327335 & 073 249d 258263 290dd 315+C 489493 523dd & 16024-16569 / 001-576 \\
\hline 17.16 & BeP 03 & $\mathrm{C} 1 \mathrm{~b}$ & $183 C 189193+C 223298311325327519$ & 073 249d 263 290dd 315+C 489493 523dd & $15878-16569$ / 001-628 \\
\hline 17.16 & SMA 050 & $\mathrm{C} 1 \mathrm{~b}$ & $183 C 189193+C 223298311325327519$ & 064Y 073 249d 263 290dd 315+C 489493 523dd & $15878-16569$ / 001-628 \\
\hline 17.16 & SMA 070 & $\mathrm{C} 1 \mathrm{~b}$ & $183 C 189193+C 223298311325327519$ & 073 249d 263 290dd 315+C 489493 523dd & $15878-16569$ / 001-628 \\
\hline 17.16 & SMA 074 & $\mathrm{C} 1 \mathrm{~b}$ & $183 C 189193+C 223298311325327519$ & 073 249d 263 290dd 315+C 489493 523dd & $15878-16569$ / 001-628 \\
\hline 17.16 & LQ 158 & $\mathrm{C} 1 \mathrm{~b}$ & $183 C 189193+C 223298311325327519$ & 073 249d 263 290dd 309+CC 315+C 489493 523dd & $16008-16569$ / 001-628 \\
\hline 17.16 & MM 017 & $\mathrm{C} 1 \mathrm{~b}$ & $183 C 189193+C 223298311325327519$ & 073 249d 263 290dd 309+C 315+C 489493 523dd & $16014-16569$ / 001-628 \\
\hline 17.16 & MM Tum 08 & $\mathrm{C} 1 \mathrm{~b}$ & 182M 183C 189 193+C 223298311325327519 & 073 249d 263 290dd 309+CC 315+C 489493 523dd & $16014-16569$ / 001-628 \\
\hline 17.17 & SMA 135 & $\mathrm{C} 1 \mathrm{~b}$ & $182183 C 189193+C 223298311325327519$ & 073 249d 263 290dd 315+C 489493 523dd & $15878-16569$ / 001-628 \\
\hline 17.18 & J14 & $\mathrm{C} 1 \mathrm{~b}$ & 092223298325327 & 073 249d 263 290dd 315+C 489493 523dd & $15878-16569$ / 001-628 \\
\hline 17.18 & MZ 057 & $\mathrm{C} 1 \mathrm{~b}$ & 092223298325327 & 073 249d 263 290dd 315+C 489493 523dd & $16024-16569 / 001-576$ \\
\hline
\end{tabular}

190 


\begin{tabular}{|c|c|c|c|c|c|}
\hline $\begin{array}{l}\text { ID en } \\
\text { la red }\end{array}$ & ID & $\mathrm{Hg}$ & Región Control 5' (+16000) & Región Control 3' & Rango de lectura \\
\hline 17.18 & SMA 091 & $\mathrm{C} 1 \mathrm{~b}$ & 092223298325327 & 073 249d 263 290dd 309+C 315+C 489493 523dd & $15878-16569$ / 001-628 \\
\hline 17.19 & SMA 116 & $\mathrm{C} 1 \mathrm{~b}$ & 086092223298325327 & 073 249d 263 290dd 315+C 489493 523dd & $15878-16569$ / 001-628 \\
\hline 17.19 & SJS 04 & $\mathrm{C} 1 \mathrm{~b}$ & 086092223298325327 & 073 249d 263 290dd 309+C 315+C 489493 523dd & $15878-16569$ / 001-628 \\
\hline 17.20 & MM 099 & $\mathrm{C} 1 \mathrm{~b}$ & 092223298325327400463519 & 046G 059A 061 062T 073 249d 263 290dd 315+C 489493 523dd 593 & $15991-16569 / 001-628$ \\
\hline 17.21 & SJ 089 & $\mathrm{C} 1 \mathrm{~b}$ & 092223298325327526 & 073 249d 263 290dd 309+C 315+C 489493 523dd & $15878-16569$ / 001-628 \\
\hline 17.22 & L 102 & $\mathrm{C} 1 \mathrm{~b}$ & 092223298325327526 & 073146 249d 263 290dd 309+CC 315+C 489493 523dd & $16024-16569$ / 001-576 \\
\hline 17.23 & CHE 45 & $\mathrm{C} 1 \mathrm{~b}$ & 223298325327 & 073194 249d 263 290dd 309+C 315+C 489493 523dd & $15878-16569$ / 001-628 \\
\hline 17.23 & CHE 53 & $\mathrm{C} 1 \mathrm{~b}$ & 223298325327 & 073194 249d 263 290dd 309+C 315+C 489493 523dd & $15878-16569$ / 001-628 \\
\hline 17.23 & LR046 & $\mathrm{C} 1 \mathrm{~b}$ & 223298325327 & 073194 249d 263 290dd 309+C 315+C 489493 523dd & $15878-16569$ / 001-628 \\
\hline 17.23 & LR BS 07 & $\mathrm{C} 1 \mathrm{~b}$ & 223298325327 & 073194 249d 263 290dd 309+C 315+C 489493 523dd & $15878-16569$ / 001-628 \\
\hline 17.23 & MZ 144 & $\mathrm{C} 1 \mathrm{~b}$ & 223298325327 & 073194 249d 263 290dd 309+C 315+C 489493 523dd & $16024-16569$ / 001-576 \\
\hline 17.24 & TG BS 34 & $\mathrm{C} 1 \mathrm{~b}$ & 223298325327390 & 073150194 249d 263 290dd 309+C 315+C 489493 & $15878-16569$ / 001-628 \\
\hline 17.24 & L 081 & $\mathrm{C} 1 \mathrm{~b}$ & 223298325327390 & 073150194 249d 263 290dd 309+C 315+C 489493 & $16024-16569$ / 001-576 \\
\hline 18.1 & Be 026 & $\mathrm{C} 1 \mathrm{~b}$ & 223298325327 & 073146 249d 263 290dd 309+C 315+C 489493 523dd & $15878-16569$ / 001-628 \\
\hline 18.1 & CHE 57 & $\mathrm{C} 1 \mathrm{~b}$ & 223298325327 & 073146 249d 263 290dd 315+C 489493 523dd & $15878-16569$ / 001-628 \\
\hline 18.1 & LR022 & $\mathrm{C} 1 \mathrm{~b}$ & 223298325327 & 073146 249d 263 290dd 309+C 315+C 489493 523dd & $15878-16569$ / 001-628 \\
\hline 18.1 & SJ 048 & $\mathrm{C} 1 \mathrm{~b}$ & 223298325327 & 073146 249d 263 290dd 309+C 315+C 489493 523dd & $15878-16569$ / 001-628 \\
\hline 18.1 & SJ 058 & $\mathrm{C} 1 \mathrm{~b}$ & 223298325327 & 073146 249d 263 290dd 309+C 315+C 489493 523dd & $15878-16569$ / 001-628 \\
\hline 18.2 & CAL Sal 07 & $\mathrm{C} 1 \mathrm{~b}$ & 15924156223298325327 & 073146207 249d 263 290dd 309+C 315+C 489493 523dd & $15878-16569$ / 001-628 \\
\hline 18.3 & Be 036 & $\mathrm{C} 1 \mathrm{~b}$ & 223298325327519 & 073146 249d 263 290dd 309+C 315+C 489493 523dd & $15878-16569$ / 001-628 \\
\hline 18.3 & Be 097 & $\mathrm{C} 1 \mathrm{~b}$ & 223298325327519 & 073146 249d 263 290dd 309+C 315+C 489493 523dd & $15878-16569$ / 001-628 \\
\hline 18.3 & CHE 75 & $\mathrm{C} 1 \mathrm{~b}$ & 223298325327519 & 073146 249d 263 290dd 309+C 315+C 489493 523dd & $15878-16569$ / 001-628 \\
\hline 18.3 & J08 & $\mathrm{C} 1 \mathrm{~b}$ & 223298325327519 & 073146 249d 263 290dd 309+CC 315+C 489493 523dd & $15878-16569$ / 001-576 \\
\hline 18.3 & LR014 & $\mathrm{C} 1 \mathrm{~b}$ & 223298325327519 & 073146 249d 263 290dd 309+C 315+C 489493 523dd & $15878-16569$ / 001-628 \\
\hline 18.3 & MZ 068 & $\mathrm{C} 1 \mathrm{~b}$ & 223298325327519 & 073146 249d 263 290dd 315+C 489493 523dd & $16024-16569$ / 001-576 \\
\hline 18.3 & MZ 087 & $\mathrm{C} 1 \mathrm{~b}$ & 223298325327519 & 073146 249d 263 290dd 309+C 315+C 489493 523dd & $16024-16569$ / 001-576 \\
\hline 18.3 & SMA 019 & $\mathrm{C} 1 \mathrm{~b}$ & 223298325327519 & 073146 249d 263 290dd 309+C 315+C 489493 523dd & $15878-16569$ / 001-628 \\
\hline 18.3 & SMA 145 & $\mathrm{C} 1 \mathrm{~b}$ & 223298325327519 & 073146 249d 263 290dd 309+C 315+C 489493 523dd & $15878-16569$ / 001-628 \\
\hline 18.3 & TG 008 & $\mathrm{C} 1 \mathrm{~b}$ & 223298325327519 & 073146 249d 263 290dd 309+CC 315+C 489493 523dd & $16024-16569$ / 001-576 \\
\hline
\end{tabular}

191 


\begin{tabular}{|c|c|c|c|c|c|}
\hline $\begin{array}{l}\text { ID en } \\
\text { la red }\end{array}$ & ID & $\mathrm{Hg}$ & Región Control 5' (+16000) & Región Control 3' & Rango de lectura \\
\hline 18.3 & TG 075 & $\mathrm{C} 1 \mathrm{~b}$ & 223298325327519 & 073146 249d 263 290dd 309+C 315+C 489493 523dd & 16024-16569 / 001-576 \\
\hline 18.3 & TG 107 & $\mathrm{C} 1 \mathrm{~b}$ & 223298325327519 & 073146 249d 263 290dd 309+C 315+C 489493 523dd & 16024-16569 / 001-576 \\
\hline 18.3 & TG BS 31 & $\mathrm{C} 1 \mathrm{~b}$ & 223298325327519 & 073146 249d 263 290dd 309+CC 315+C 489493 523dd & $15878-16569$ / 001-628 \\
\hline 18.3 & TG EA 13 & $\mathrm{C} 1 \mathrm{~b}$ & 223298325327519 & 073146 249d 263 290dd 309+C 315+C 489493 523dd & 15878-16569 / 001-628 \\
\hline 18.3 & L sal 10 & $\mathrm{C} 1 \mathrm{~b}$ & 223298325327519 & 073146 249d 263 290dd 315+C 489493 523dd & 15898-16569 / 001-628 \\
\hline 18.3 & MM 021 & $\mathrm{C} 1 \mathrm{~b}$ & 223298325327519 & 073146 249d 263 290dd 309+C 315+C 489493 523dd & $15991-16569 / 001-628$ \\
\hline 18.3 & MM 100 & $\mathrm{C} 1 \mathrm{~b}$ & 223298325327519 & 073146 249d 263 290dd 309+C 315+C 489493 523dd & 15991-16569/001-628 \\
\hline 18.4 & LR027 & $\mathrm{C} 1 \mathrm{~b}$ & 223235298325327519 & 073146 249d 263 290dd 309+C 315+C 489493 523dd & 15878-16569 / 001-628 \\
\hline 18.5 & SJ 094 & $\mathrm{C} 1 \mathrm{~b}$ & 223298325327519 & 073146152 249d 263 290dd 315+C 489493 523dd & $15878-16569$ / 001-628 \\
\hline 18.6 & CHE 31 & $\mathrm{C} 1 \mathrm{~b}$ & 136223298325327519 & 073146 249d 263 290dd 309+C 315+C 489493 523dd & 15878-16569 / 001-628 \\
\hline 18.6 & J01 & $\mathrm{C} 1 \mathrm{~b}$ & 136223298325327519 & 073146 249d 263 290dd 309+C 315+C 489493 523dd & 15878-16569 / 001-628 \\
\hline 18.6 & MZ 017 & $\mathrm{C} 1 \mathrm{~b}$ & 136223298325327519 & 073146 249d 263 290dd 309+C 315+C 489493 523dd & 16024-16569 / 001-576 \\
\hline 18.6 & SJ 029 & $\mathrm{C} 1 \mathrm{~b}$ & 136223298325327519 & 073146 249d 263 290dd 309+C 315+C 489493 523dd & 15878-16569 / 001-628 \\
\hline 18.7 & LR041 & $\mathrm{C} 1 \mathrm{~b}$ & 136223298325327519 & 073146152 249d 263 290dd 309+C 315+C 489493 523dd & $15878-16569$ / 001-628 \\
\hline 18.8 & TG 136 & $\mathrm{C} 1 \mathrm{~b}$ & 136223298325327519 & 073146150 249d 263 290dd 309+C 315+C 489493 523dd & $16024-16569$ / 001-576 \\
\hline 18.9 & SJ 067 & $\mathrm{C} 1 \mathrm{~b}$ & 136223298311325327519 & 073146150 249d 263 290dd 309+C 315+C 489493 523dd & 15878-16569 / 001-628 \\
\hline 18.9 & SJ 069 & $\mathrm{C} 1 \mathrm{~b}$ & 136223298311325327519 & 073146150 249d 263 290dd 309+C 315+C 489493 523dd & 15878-16569 / 001-628 \\
\hline 18.10 & CHE 05 & $\mathrm{C} 1 \mathrm{~b}$ & 136223256298325327519 & 073146153 249d 263 290dd 309+C 315+C 489493 523dd 549 & $15878-16569$ / 001-628 \\
\hline 18.10 & CHE 50 & $\mathrm{C} 1 \mathrm{~b}$ & 136223256298325327519 & 073146153 249d 263 290dd 309+C 315+C 489493 523dd 549 & 15878-16569 / 001-628 \\
\hline 18.10 & LR030 & $\mathrm{C} 1 \mathrm{~b}$ & 136223256298325327519 & 073146153 249d 263 290dd 309+C 315+C 489493 523dd 549 & $15878-16569$ / 001-628 \\
\hline 18.10 & LR075 & $\mathrm{C} 1 \mathrm{~b}$ & 136223256298325327519 & 073146153 249d 263 290dd 309+C 315+C 489493 523dd 549 & 15878-16569 / 001-628 \\
\hline 18.10 & SJ 024 & $\mathrm{C} 1 \mathrm{~b}$ & 136223256298325327519 & 073146153 249d 263 290dd 309+C 315+C 489493 523dd 549 & 15878-16569 / 001-628 \\
\hline 18.10 & SJ 031 & $\mathrm{C} 1 \mathrm{~b}$ & 136223256298325327519 & 073146153 249d 263 290dd 309+C 315+C 489493 523dd 549 & $15878-16569$ / 001-628 \\
\hline 18.10 & TG 105 & $\mathrm{C} 1 \mathrm{~b}$ & 136223256298325327519 & 073146153 249d 263 290dd 309+C 315+C 489493 523dd 549 & $16024-16569$ / 001-576 \\
\hline 18.10 & TG BS 17 & $\mathrm{C} 1 \mathrm{~b}$ & 136223256298325327519 & 073146153 249d 263 290dd 309+C 315+C 489493 523dd 549 & $15878-16569$ / 001-628 \\
\hline 18.11 & TG AG 44 & $\mathrm{C} 1 \mathrm{~b}$ & 223298325327519 & 073146 249d 263 290dd 309+C 315+C 489493 523dd 574 & $15878-16569$ / 001-628 \\
\hline 18.12 & TG 078 & $\mathrm{C} 1 \mathrm{~b}$ & 223298325327344519 & 062068073146194 249d 263 290dd 309+C 315+C 489493 523dd & $16024-16569$ / 001-576 \\
\hline 18.13 & SJ 102 & $\mathrm{C} 1 \mathrm{~b}$ & 223298325327519 & 073146214 249d 263 290dd 309+C 315+C 489493 523dd & $15878-16569 / 001-628$ \\
\hline 18.14 & L 047 & C1b & $183 C 189193+C 223298325327$ & 073146235 249d 263 290dd 315+C 489493 523dd & $16024-16569$ / 001-576 \\
\hline
\end{tabular}

192 


\begin{tabular}{|c|c|c|c|c|c|}
\hline $\begin{array}{l}\text { ID en } \\
\text { la red }\end{array}$ & ID & $\mathrm{Hg}$ & Región Control 5' (+16000) & Región Control 3' & Rango de lectura \\
\hline 18.15 & LQ Pr 24 & $\mathrm{C} 1 \mathrm{~b}$ & 189223298325327 & 073146183235 249d 263 290dd 315+C 489493 523dd & $16008-16569$ / 001-628 \\
\hline 18.16 & L 027 & $\mathrm{C} 1 \mathrm{~b}$ & $129183 C 189193+C 223298325327$ & 073146235 249d 263 290dd 315+C 489493 523dd & $16024-16569$ / 001-576 \\
\hline 19.1 & CHE 18 & $\mathrm{C} 1 \mathrm{~b}$ & 145192223298325327519 & 073214 249d 263 290dd 309+C 315+C 489493 523dd & $15878-16569 / 001-628$ \\
\hline 19.1 & CHE 33 & $\mathrm{C} 1 \mathrm{~b}$ & 145192223298325327519 & 073214 249d 263 290dd 309+C 315+C 489493 523dd & $15878-16569 / 001-628$ \\
\hline 19.1 & LR005 & $\mathrm{C} 1 \mathrm{~b}$ & $145192223264 Y 298325327519$ & 073214 249d 263 290dd 309+C 315+C 489493 523dd & $15878-16569$ / 001-628 \\
\hline 19.2 & LQ Pr 32 & $\mathrm{C} 1 \mathrm{~b}$ & 145192218223298325327519 & 073214 249d 263 290dd 309+CC 315+C 489493 523dd & 15991-16569 / 001-615 \\
\hline 19.2 & MM 053 & $\mathrm{C} 1 \mathrm{~b}$ & 145192218223298325327519 & 073214 249d 263 290dd 309+CC 315+C 489493 523dd & 15991-16569/001-628 \\
\hline 19.3 & LQ 116 & $\mathrm{C} 1 \mathrm{~b}$ & 145223298311325327519 & 073214 249d 263 290dd 309+C 315+C 489493 523dd & $15991-16569 / 001-628$ \\
\hline 19.4 & TG 099 & $\mathrm{C} 1 \mathrm{~b}$ & 173192223298325327346519 & 073204 249d 263 290dd 309+C 315+C 489493 523dd & $16024-16569$ / 001-576 \\
\hline 19.5 & SJ 084 & $\mathrm{C} 1 \mathrm{~b}$ & 144192223291298325327362 & 073 249d 263 290dd 315+C 489493 523dd & 15878-16569 / 001-628 \\
\hline 19.5 & L 062 & $\mathrm{C} 1 \mathrm{~b}$ & 144 189Y 192223291298325327362 & 073 249d 263 290dd 315+C 489493 523dd & $16024-16569$ / 001-576 \\
\hline 19.6 & SJ 087 & $\mathrm{C} 1 \mathrm{~b}$ & $192223298311 Y 325327356$ & 073207 249d 263 290dd 315+C 489493 523dd & $15878-16569$ / 001-628 \\
\hline 19.7 & SJ 042 & $\mathrm{C} 1 \mathrm{~b}$ & 15977192209223274298311325327 & 073201 249d 263 290dd 309+C 315+C 489493 523dd & $15878-16569$ / 001-628 \\
\hline 19.8 & Be 079 & $\mathrm{C} 1 \mathrm{~b}$ & 093192223298325327 & 073201 249d 263 290dd 309+C 315+C 489493 523dd & $15878-16569$ / 001-628 \\
\hline 19.8 & CAL 05 & $\mathrm{C} 1 \mathrm{~b}$ & 093192223298325327 & 073201 249d 263 290dd 309+C 315+C 489493 523dd & $15878-16569$ / 001-628 \\
\hline 19.8 & CAL 14 & $\mathrm{C} 1 \mathrm{~b}$ & 093192223298325327 & 073201 249d 263 290dd 309+C 315+C 489493 523dd & $15878-16569$ / 001-628 \\
\hline 19.8 & CAL 17 & $\mathrm{C} 1 \mathrm{~b}$ & 093192223298325327 & 073201 249d 263 290dd 309+C 315+C 489493 523dd & $15878-16569$ / 001-628 \\
\hline 19.8 & CAL 25 & $\mathrm{C} 1 \mathrm{~b}$ & 093Y 192223298325327 & 073201 249d 263 290dd 309+C 315+C 489493 523dd & $15878-16569$ / 001-628 \\
\hline 19.8 & CAL 32 & $\mathrm{C} 1 \mathrm{~b}$ & 093192223298325327 & 073201 249d 263 290dd 309+C 315+C 489493 523dd & $15878-16569$ / 001-628 \\
\hline 19.8 & CAL 33 & $\mathrm{C} 1 \mathrm{~b}$ & 093192223298325327 & 073201 249d 263 290dd 309+C 315+C 489493 523dd & $15878-16569$ / 001-628 \\
\hline 19.8 & CAL 37 & $\mathrm{C} 1 \mathrm{~b}$ & $093192 Y 223298325327$ & 073201 249d 263 290dd 309+C 315+C 489493 523dd & $15878-16569$ / 001-628 \\
\hline 19.8 & CAL 39 & $\mathrm{C} 1 \mathrm{~b}$ & 093192223298325327 & 073201 249d 263 290dd 309+C 315+C 489493 523dd & 15878-16569 / 001-628 \\
\hline 19.8 & CAL 43 & $\mathrm{C} 1 \mathrm{~b}$ & 093192223298325327 & 073201 249d 263 290dd 309+C 315+C 489493 523dd & $15878-16569$ / 001-576 \\
\hline 19.8 & CAL 59 & $\mathrm{C} 1 \mathrm{~b}$ & 093192223298325327 & 073201 249d 263 290dd 309+C 315+C 489493 523dd & $15878-16569$ / 001-628 \\
\hline 19.8 & CAL Sal 03 & $\mathrm{C} 1 \mathrm{~b}$ & 093192223298325327 & 073201 249d 263 290dd 309+C 315+C 489493 523dd & $15878-16569$ / 001-628 \\
\hline 19.8 & CAL Sal 04 & $\mathrm{C} 1 \mathrm{~b}$ & 093192223298325327 & 073201 249d 263 290dd 309+C 315+C 489493 523dd & $15878-16569 / 001-576$ \\
\hline 19.8 & CAL Sal 08 & $\mathrm{C} 1 \mathrm{~b}$ & 093192223298325327 & 073201 249d 263 290dd 309+C 315+C 489493 523dd & $15878-16569$ / 001-628 \\
\hline 19.8 & CHE 13 & $\mathrm{C} 1 \mathrm{~b}$ & 093192223298325327 & 073201 249d 263 290dd 309+C 315+C 489493 523dd & $15878-16569$ / 001-628 \\
\hline 19.8 & CHE 22 & $\mathrm{C} 1 \mathrm{~b}$ & 093192223298325327 & 073201 249d 263 290dd 309+C 315+C 489493 523dd & $15878-16569$ / 001-628 \\
\hline
\end{tabular}

193 


\begin{tabular}{|c|c|c|c|c|c|}
\hline $\begin{array}{l}\text { ID en } \\
\text { la red }\end{array}$ & ID & $\mathrm{Hg}$ & Región Control 5' (+16000) & Región Control 3' & Rango de lectura \\
\hline 19.8 & SJ 025 & $\mathrm{C} 1 \mathrm{~b}$ & 093192223298325327 & 073201 249d 263 290dd 309+C 315+C 489493 523dd & $15878-16569 / 001-628$ \\
\hline 19.8 & SJ 037 & $\mathrm{C} 1 \mathrm{~b}$ & 093192223298325327 & 073201 249d 263 290dd 309+C 315+C 489493 523dd & $15878-16569$ / 001-628 \\
\hline 19.8 & SJ 043 & $\mathrm{C} 1 \mathrm{~b}$ & 093192223298325327 & 073201 249d 263 290dd 309+C 315+C 489493 523dd & $15878-16569$ / 001-628 \\
\hline 19.8 & SJ 061 & $\mathrm{C} 1 \mathrm{~b}$ & 093192223298325327 & 073201 249d 263 290dd 309+C 315+C 489493 523dd & $15878-16569 / 001-628$ \\
\hline 19.8 & SJ 092 & $\mathrm{C} 1 \mathrm{~b}$ & 093192223298325327 & 073201 249d 263 290dd 309+C 315+C 489493 523dd & $15878-16569$ / 001-628 \\
\hline 19.8 & SJ 095 & $\mathrm{C} 1 \mathrm{~b}$ & 093192223298325327 & 073201 249d 263 290dd 315+C 489493 523dd & $15878-16569$ / 001-628 \\
\hline 19.8 & SJ JA 01 & $\mathrm{C} 1 \mathrm{~b}$ & 093192223298325327 & 073201 249d 263 290dd 309+C 315+C 489493 523dd & $15878-16569$ / 001-628 \\
\hline 19.8 & SJ JA 02 & $\mathrm{C} 1 \mathrm{~b}$ & 093192223298325327 & 073201 249d 263 290dd 309+C 315+C 489493 523dd & $15878-16569$ / 001-628 \\
\hline 19.8 & SJ JA 06 & $\mathrm{C} 1 \mathrm{~b}$ & 093192223298325327 & 073201 249d 263 290dd 309+C 315+C 489493 523dd & $15878-16569$ / 001-628 \\
\hline 19.8 & SMA 003 & $\mathrm{C} 1 \mathrm{~b}$ & 093192223298325327 & 073201 249d 263 290dd 309+C 315+C 489493 523dd & $15878-16569$ / 001-628 \\
\hline 19.8 & SMA 024 & $\mathrm{C} 1 \mathrm{~b}$ & 093Y 192223298325327 & 073201 249d 263 290dd 309+C 315+C 489493 523dd & $15878-16569$ / 001-628 \\
\hline 19.8 & SMA 040 & $\mathrm{C} 1 \mathrm{~b}$ & 093192223298325327 & 073201 249d 263 290dd 309+C 315+C 489493 523dd & $15878-16569$ / 001-628 \\
\hline 19.8 & SMA 078 & $\mathrm{C} 1 \mathrm{~b}$ & 093192223298325327 & 073201 249d 263 290dd 309+C 315+C 489493 523dd & $15878-16569$ / 001-628 \\
\hline 19.8 & SMA 086 & $\mathrm{C} 1 \mathrm{~b}$ & 093192223298325327 & 073201 249d 263 290dd 309+C 315+C 489493 523dd & $15878-16569$ / 001-628 \\
\hline 19.8 & SMA 127 & $\mathrm{C} 1 \mathrm{~b}$ & 093192223298325327 & 073201 249d 263 290dd 309+C 315+C 489493 523dd & $15878-16569$ / 001-628 \\
\hline 19.8 & SJS 08 & $\mathrm{C} 1 \mathrm{~b}$ & 093192223298325327 & 073201 249d 263 290dd 309+C 315+C 489493 523dd & $15878-16569$ / 001-628 \\
\hline 19.8 & L 029 & $\mathrm{C} 1 \mathrm{~b}$ & 093192223298325327 & 073201 249d 263 290dd 309+C 315+C 489493 523dd & 16024-16569 / 001-576 \\
\hline 19.8 & MM Tum 09 & $\mathrm{C} 1 \mathrm{~b}$ & 093192223298325327 & 073201 249d 263 290dd 309+C 315+C 489493 523dd & $15991-16569 / 001-628$ \\
\hline 19.9 & MM Pur 36 & $\mathrm{C} 1 \mathrm{~b}$ & 093192223298325327 & 073198201 249d 263 290dd 309+C 315+C 489493 523dd & 15991-16569/ 001-628 \\
\hline 19.10 & SMA 132 & $\mathrm{C} 1 \mathrm{~b}$ & 093189192223298325327 & 073201 249d 263 290dd 309+C 315+C 489493 523dd & $15878-16569$ / 001-628 \\
\hline 20.1 & LQ 002 & $\mathrm{C} 1 \mathrm{~b}$ & 223298325327354356 & 073 249d 263 290dd 309+C 315+C 489493 523dd & 15991-16569/ 001-628 \\
\hline 20.2 & LQ 018 & $\mathrm{C} 1 \mathrm{~b}$ & 223298325327 & 060073 249d 263 290dd 309+C 315+C 489493 523dd & $16009-16569$ / 001-628 \\
\hline 20.3 & LQ 069 & $\mathrm{C} 1 \mathrm{~b}$ & 150169223298325327 & 073143 249d 263 290dd 309+C 315+C 489493 523dd & 15991-16569/ 001-628 \\
\hline 20.4 & MM 047 & $\mathrm{C} 1 \mathrm{~b}$ & 179223298325327381 & 073143200 249d 263 290dd 315+C 316489493 523dd & 15991-16569/ 001-628 \\
\hline 20.5 & CAL 06 & $\mathrm{C} 1 \mathrm{~b}$ & 15924086223325327519 & 073143152 249d 263 290dd 315+C 489493 523dd & $15878-16569$ / 001-628 \\
\hline 20.6 & CAL Sal 10 & $\mathrm{C} 1 \mathrm{~b}$ & 223298325327 & 073152 249d 263 290dd 309+CC 315+C 489493 523dd & $15878-16569$ / 001-628 \\
\hline 20.7 & $J 21$ & $\mathrm{C} 1 \mathrm{~b}$ & 111223298325327368 & 018073152 249d 263 290dd 309+C 315+C 489493 523dd & $15878-16569$ / 001-576 \\
\hline 20.8 & TG AG 29 & $\mathrm{C} 1 \mathrm{~b}$ & 223298325327399 & 073195 249d 263 290dd 309+C 315+C 489493 523dd & $15878-16569$ / 001-628 \\
\hline 20.9 & L 025 & $\mathrm{C} 1 \mathrm{~b}$ & 223239298325327 & 073195 249d 263 290dd 315+C 489493 523dd & $16024-16569 / 001-576$ \\
\hline
\end{tabular}

194 


\begin{tabular}{|c|c|c|c|c|c|}
\hline $\begin{array}{l}\text { ID en } \\
\text { la red }\end{array}$ & ID & $\mathrm{Hg}$ & Región Control 5' (+16000) & Región Control 3' & Rango de lectura \\
\hline 20.10 & TG 121 & $\mathrm{C} 1 \mathrm{~b}$ & 193223298325327 & 073150 249d 263 290dd 315+C 489493 523dd & $16024-16569$ / 001-576 \\
\hline 20.11 & L 003 & $\mathrm{C} 1 \mathrm{~b}$ & 171223298325327 & 073 249d 263 290dd 309+C 315+C 489493 523dd & $15898-16569$ / 001-628 \\
\hline 20.12 & Be 085 & $\mathrm{C} 1 \mathrm{~b}$ & 129223298325327 & 073 249d 263 290dd 315+C 489493 523dd & $15878-16569$ / 001-628 \\
\hline 20.12 & Be 103 & $\mathrm{C} 1 \mathrm{~b}$ & 129223298325327 & 073 249d 263 290dd 315+C 489493 523dd & $15878-16569$ / 001-628 \\
\hline 20.13 & MZ 140 & $\mathrm{C} 1 \mathrm{~b}$ & 093129223298300325327362 & 073242 249d 263 290dd 309+C 315+C 489493 523dd & $16024-16569$ / 001-576 \\
\hline 20.14 & MZ 040 & $\mathrm{C} 1 \mathrm{~b}$ & 15904223297298325327362 & 073 228T 249d 263 290dd 309+C 315+C 489493 523dd & 15904-16569 / 001-576 \\
\hline 20.15 & TG 040 & $\mathrm{C} 1 \mathrm{~b}$ & 223298325327384 & 073 249d 263 290dd 309+C 315+C 489493 523dd & 16024-16569 / 001-576 \\
\hline 21.1 & TG 062 & C1c & 15930223298325327526 & 073146195 249d 263 290dd 309+C 315+C 489 & 15930-15969 / 001- 576 \\
\hline 21.2 & LQ Pr 22 & $\mathrm{C} 1 \mathrm{c}$ & 126223298325327483 & 073143 249d 263 290dd 309+CC 315+C 489 & $16008-16569$ / 001-628 \\
\hline 21.3 & L 051 & C1c & 15930223298311325327368390 & 073151152 249d 263 290dd 309+C 315+C 489 & $15930-16569 / 001-576$ \\
\hline 21.3 & L 057 & C1c & 15930223298311325327368390 & 073151152 249d 263 290dd 309+C 315+C 489 & $15930-16569$ / 001-576 \\
\hline 21.3 & L 099 & $\mathrm{C} 1 \mathrm{c}$ & 15930223298311325327368390 & 073151152 249d 263 290dd 315+C 489 & 15930-16569 / 001-576 \\
\hline 21.4 & TG AG 03 & $\mathrm{C} 1 \mathrm{c}$ & 15930071092223298311325327368390 & 073151152 249d 263 290dd 309+C 315+C 489 & 15930-15969 / 001- 576 \\
\hline 21.4 & TG AG 12 & C1c & 15930071092223298311325327368390 & 073151152 249d 263 290dd 309+C 315+C 489 & $15878-16569$ / 001-628 \\
\hline 21.5 & Be 032 & $\mathrm{C} 1 \mathrm{c}$ & 15930223298311325327 & 073215228 249d 263 290dd 294 309+C 315+C 489 & $15878-16569$ / 001-628 \\
\hline 21.5 & Be 078 & $\mathrm{C} 1 \mathrm{c}$ & 15930223298311325327 & 073215228 249d 263 290dd 294 309+C 315+C 489 & 15878-16569 / 001-628 \\
\hline 21.5 & Be 088 & C1c & 15930223298311325327 & 073215228 249d 263 290dd 294 309+C 315+C 489 & $15878-16569$ / 001-628 \\
\hline 21.5 & Be 091 & $\mathrm{C} 1 \mathrm{c}$ & 15930223298311325327 & 073215228 249d 263 290dd $294309+C$ 315+C 489 & $15878-16569$ / 001-628 \\
\hline 21.6 & SJ 016 & C1c & 15930223298325327 & 073 249d 263 290dd 315+C 489 523dd & $15878-16569$ / 001-628 \\
\hline 21.6 & TG AG 43 & $\mathrm{C} 1 \mathrm{c}$ & 15930223298325327 & 073 249d 263 290dd 315+C 489 523dd & $15878-16569$ / 001-628 \\
\hline 21.7 & MZ Sal 02 & $\mathrm{C} 1 \mathrm{c}$ & 15930223298325327 & 073 249d 263 290dd 309+C 315+C 489 523dd & 15878-16569 / 001-628 \\
\hline 21.7 & SJ 060 & $\mathrm{C} 1 \mathrm{c}$ & 15930223298325327 & 073 249d 263 290dd 309+C 315+C 489 523dd & $15878-16569$ / 001-628 \\
\hline 21.7 & L 098 & $\mathrm{C} 1 \mathrm{c}$ & 15930223298325327 & 073 249d 263 290dd 309+C 315+C 489 523dd & 15930-16569 / 001-576 \\
\hline 21.8 & TG AG 46 & $\mathrm{C} 1 \mathrm{c}$ & 15930223298325327519 & 073207 249d 263 290dd 309+C 315+C 462489 & $15878-16569$ / 001-628 \\
\hline 21.9 & LQ Pr 35 & $\mathrm{C} 1 \mathrm{c}$ & 223304325327400519 & 073 249d 263 290dd 309+CC 315+C 489 & 15991-16569/ 001-628 \\
\hline 21.9 & MM 073 & $\mathrm{C} 1 \mathrm{c}$ & 223304325327400519 & 073 249d 263 290dd 309+CC 315+C 489 & $15991-16569 / 001-628$ \\
\hline 21.9 & MM 079 & $\mathrm{C} 1 \mathrm{c}$ & 223304325327400519 & 073 249d 263 290dd 309+CC 315+C 489 & 15991-16569/ 001-628 \\
\hline 21.10 & LQ 112 & $\mathrm{C} 1 \mathrm{c}$ & 189223298304325327519 & 073152195 249d 263 290dd 315+C 489 & $16008-16569$ / 001-628 \\
\hline 21.10 & LQ 140 & C1c & 189223298304325327519 & 073152195 249d 263 290dd 315+C 489 & $16008-16569$ / 001-628 \\
\hline
\end{tabular}

195 


\begin{tabular}{|c|c|c|c|c|c|}
\hline $\begin{array}{l}\text { ID en } \\
\text { la red }\end{array}$ & ID & $\mathrm{Hg}$ & Región Control 5' (+16000) & Región Control 3' & Rango de lectura \\
\hline 21.10 & MM 133 & $\mathrm{C} 1 \mathrm{c}$ & 189223298304325327519 & 073152195 249d 263 290dd 315+C 489 & $16014-16569$ / 001-628 \\
\hline 21.10 & MM Pur 16 & $\mathrm{C} 1 \mathrm{c}$ & 189223298304325327519 & 073152195 249d 263 290dd 315+C 489 & $16009-16569$ / 001-628 \\
\hline 21.11 & SMA 108 & C1c & 15930145169223298325327519 & 073 249d 263 290dd 309+C 315+C 489 & $15878-16569$ / 001-628 \\
\hline 21.12 & BeLo 31 & $\mathrm{C} 1 \mathrm{c}$ & 15930145169223298325327519 & 042+A 073 249d 263 290dd 315+C 489 & $15878-16569$ / 001-628 \\
\hline 21.12 & SMA 120 & C1c & 15930145169223298325327519 & 042+A 073 249d 263 290dd 315+C 489 & $15878-16569$ / 001-628 \\
\hline 21.12 & SMA 148 & $\mathrm{C} 1 \mathrm{c}$ & 15930145169223298325327519 & 042+A 073 249d 263 290dd 315+C 489 & 15878-16569 / 001-628 \\
\hline 21.13 & TG AG 56 & $\mathrm{C} 1 \mathrm{c}$ & $15930093 Y 145169223274298325327519$ & 073 249d 263 290dd 309+CC 315+C 489 & $15878-16569$ / 001-628 \\
\hline 21.14 & TG 017 & C1c & $15930169192 A 209223298325327519$ & 073 249d 263 290dd 309+C 315+C 489 & 15930-15969 / 001- 576 \\
\hline 21.14 & TG 039 & $\mathrm{C} 1 \mathrm{c}$ & $15930169192 A 209223298325327519$ & 073 249d 263 290dd 309+C 315+C 489 & 15930-15969 / 001- 576 \\
\hline 21.14 & TG BS 06 & C1c & 15930 129R 169 192A 209223298325327519 & 073 249d 263 290dd 309+C 315+C 489 & 15930-15969 / 001- 576 \\
\hline 21.15 & TG AG 45 & C1c & $15930169189192 A 209223298325327519$ & 073 249d 263 290dd 309+CC 315+C 489 & $15878-16569$ / 001-628 \\
\hline 21.16 & TG 138 & $\mathrm{C} 1 \mathrm{c}$ & 15930 15944d 169 192A 209223298325327519 & 073196 249d 263 290dd 309+CC 315+C 489 & 15930-15969 / 001- 576 \\
\hline 21.16 & MM Pur 39 & $\mathrm{C} 1 \mathrm{c}$ & 169 192A 209223298325327519 & 073196 249d 263 290dd 309+C 315+C 489 & 15991-16569/001-628 \\
\hline 21.17 & MZ 114 & C1c & 15930129223261298325327519 & 073152 249d 263 290dd 309+C 315+C 489 & 15930-16569 / 001-576 \\
\hline 21.18 & TG 080 & $\mathrm{C} 1 \mathrm{c}$ & 15930189223298325327519 & 073195 249d 263 290dd 315+C 489 & 15930-15969 / 001- 576 \\
\hline 22.1 & CAL 44 & C1d & 051223298325327 & 073194195 249d 263 290dd 315+C 489 523dd & 15878-16569 / 001-628 \\
\hline 22.1 & CAL 48 & C1d & 051223298325327 & 073194195 249d 263 290dd 315+C 489 523dd & $15878-16569$ / 001-628 \\
\hline 22.1 & CAL 52 & C1d & 051223298325327 & 073194195 249d 263 290dd 315+C 489 523dd & $15878-16569$ / 001-628 \\
\hline 22.1 & LR055 & C1d & 051223298325327 & 073194195 249d 263 290dd 309+C 315+C 489 523dd & $15878-16569$ / 001-628 \\
\hline 22.1 & LRO99 & C1d & 051223298325327 & 073194195 249d 263 290dd 309+C 315+C 489 523dd & $15878-16569$ / 001-628 \\
\hline 22.1 & LR189 & C1d & 051223298325327 & 073194195 249d 263 290dd 309+C 315+C 489 523dd & 15878-16569 / 001-628 \\
\hline 22.1 & MZ 019 & C1d & 051223298325327 & 073194195 249d 263 290dd 309+C 315+C 489 523dd & $16024-16569$ / 001-576 \\
\hline 22.1 & MZ 116 & C1d & 051223298325327 & 073194195 249d 263 290dd 315+C 489 523dd & 16024-16569 / 001-576 \\
\hline 22.1 & SJ 014 & C1d & 051223298325327 & 073194195 249d 263 290dd 309+C 315+C 489 523dd & $15878-16569$ / 001-628 \\
\hline 22.1 & SJ 050 & C1d & 051223298325327 & 073194195 249d 263 290dd 309+C 315+C 489 523dd & $15878-16569$ / 001-628 \\
\hline 22.1 & SJ 053 & C1d & 051223298325327 & 073194195 249d 263 290dd 309+C 315+C 489 523dd & $15878-16569$ / 001-628 \\
\hline 22.1 & SJ JA 12 & C1d & 051223298325327 & 073194195 249d 263 290dd 315+C 489 523dd & $15878-16569$ / 001-628 \\
\hline 22.1 & SMA 110 & C1d & 051223298325327 & $073194 Y 195$ 249d 263 290dd 315+C 489 523dd & $15878-16569$ / 001-628 \\
\hline 22.1 & SMA 138 & C1d & 051223298325327 & 073194195 249d 263 290dd 309+C 315+C 489 523dd & $15878-16569 / 001-628$ \\
\hline
\end{tabular}

196 


\begin{tabular}{|c|c|c|c|c|c|}
\hline $\begin{array}{l}\text { ID en } \\
\text { la red }\end{array}$ & ID & $\mathrm{Hg}$ & Región Control 5' (+16000) & Región Control 3' & Rango de lectura \\
\hline 22.2 & J06 & C1d & 051298325327 & 073194195 249d 263 290dd 309+C 315+C 489 523dd & 15878-16569 / 001-628 \\
\hline 22.2 & LR090 & C1d & 051298325327 & 073194195 249d 263 290dd 309+C 315+C 489 523dd & 15878-16569 / 001-628 \\
\hline 22.2 & LR BS 05 & C1d & 051298325327 & 073194195 249d 263 290dd 309+C 315+C 489 523dd & 15878-16569 / 001-628 \\
\hline 22.2 & SJ sal 1 & C1d & $051093 Y 298325327$ & 073194195 249d 263 290dd 309+C 315+C 489 523dd & 15878-16569 / 001-628 \\
\hline 22.2 & SMA 044 & C1d & 051298325327 & 073 189R 194195 249d 263 290dd 315+C 489 523dd & 15878-16569 / 001-628 \\
\hline 22.2 & TG 140 & C1d & 051298325327 & 073194195 249d 263 290dd 309+C 315+C 489 523dd & $16024-16569$ / 001-576 \\
\hline 22.3 & TG 104 & C1d & 051223259271298311325327 & 073194195 249d 263 290dd 315+C 489 523dd & $16024-16569$ / 001-576 \\
\hline 22.3 & LQ Pr 02 & C1d1b & 051223259271298311325327 & 073194195 249d 263 290dd 315+C 489 523dd & $16008-16569$ / 001-628 \\
\hline 22.3 & MM 064 & C1d1b & 051223259271298311325327 & 073194195 249d 263 290dd 315+C 489 523dd & 15991-16569/001-628 \\
\hline 22.4 & SJ 056 & C1d & 051223298325327 & 073194195204 249d 263 290dd 309+C 315+C 489 523dd & 15878-16569 / 001-628 \\
\hline 22.4 & SMA 075 & C1d & 051223298325327 & 073194195204 249d 263 290dd 309+C 315+C 489 523dd & 15878-16569 / 001-628 \\
\hline 22.4 & SMA 088 & C1d & 051223298325327 & 073194195204 249d 263 290dd 315+C 489 523dd & 15878-16569 / 001-628 \\
\hline 22.4 & SMA 118 & C1d & 051223298325327 & 073194195204 249d 263 290dd 315+C 489 523dd & 15878-16569 / 001-628 \\
\hline 22.4 & SMA 131 & C1d & 051223298325327 & 073194195204 249d 263 290dd 315+C 489 523dd & 15878-16569 / 001-628 \\
\hline 22.4 & SMA 150 & C1d & 051223298325327 & 073194195204 249d 263 290dd 309+CC 315+C 489 523dd & $15878-16569$ / 001-628 \\
\hline 22.4 & TG 014 & C1d & 051223298325327 & 073194195204 249d 263 290dd 309+C 315+C 489 523dd & $16024-16569$ / 001-576 \\
\hline 22.5 & J07 & C1d & 051223298325327 & 073150194195204 249d 263 290dd 309+C 315+C 489 523dd & $15878-16569$ / 001-628 \\
\hline 22.5 & TG EA 21 & C1d & 051223298325327 & 073150194195204 249d 263 290dd 309+C 315+C 489 523dd & 15878-16569 / 001-628 \\
\hline 22.6 & SJ 074 & C1d & 051223298325327 & 073195204 249d 263 290dd 309+C 315+C 489 523dd & $15878-16569$ / 001-628 \\
\hline 22.7 & MZ 130 & C1d & 051223298325327 & 073152195204 249d 263 290dd 309+C 315+C 478489 523dd & 16024-16569 / 001-576 \\
\hline 22.8 & LR067 & C1d & 051223298325327 & 073194195 249d 263 290dd 309+C 315+C 489 523dd 573+CC & 15878-16569 / 001-576 \\
\hline 22.8 & LR119 & C1d & 051223298325327 & 073194195 249d 263 290dd 309+C 315+C 489 523dd 573+CC & 15878-16569 / 001-576 \\
\hline 22.9 & SMA 067 & C1d & 051223298325327519 & 073194195 249d 263 290dd 309+C 315+C 489 523dd 573+CC & 15878-16569 / 001-628 \\
\hline 22.10 & L 091 & C1d & 051223298325327 & 073195200 249d 263 290dd 309+C 315+C 489 523dd & 16024-16569 / 001-576 \\
\hline 22.11 & CAL 40 & C1d & 051223249298325327 & 073194199 249d 263 290dd 309+C 315+C 489 523dd & 15878-16569 / 001-628 \\
\hline 22.11 & SJ 082 & C1d & 051223249298325327 & 073194199 249d 263 290dd 309+C 315+C 489 523dd & $15878-16569$ / 001-628 \\
\hline 22.12 & SJ JA 13 & C1d & 051172223298325327 & 073194 249d 263 290dd 309+CC 315+C 489 523dd & 15878-16569 / 001-628 \\
\hline 22.13 & L 082 & C1d & $15924051223298320325327344519 Y$ & 073152 234R 249d 263 290dd 309+C 315+C 489 523dd & $15898-16569$ / 001-628 \\
\hline 22.14 & LQ 024 & C1d & 051086170223298325327 & 055+T 057059073 249d 263 290dd 309+C 315+C 489 523dd & $16009-16569$ / 001-578 \\
\hline
\end{tabular}

197 


\begin{tabular}{|c|c|c|c|c|c|}
\hline $\begin{array}{l}\text { ID en } \\
\text { la red }\end{array}$ & ID & $\mathrm{Hg}$ & Región Control 5' (+16000) & Región Control 3' & Rango de lectura \\
\hline 22.14 & MM 023 & C1d & 051086170223298325327 & 055+T 057059073 249d 263 290dd 309+C 315+C 489 523dd & 15991-16569/001-628 \\
\hline 23.1 & CHE 44 & C4c & 223291298327468519 & $053054 C 073$ 249d 263 309+C 315+C 489 & 15878-16569 / 001-628 \\
\hline 23.1 & L 093 & C4c & 223291298327468519 & 053 054C 073 249d 263 309+C 315+C 489 & 16024-16569 / 001-576 \\
\hline 23.2 & CAL 38 & C4c & 160223291298327468519 & $053054 C 073$ 249d 263 309+C 315+C 489 & 15878-16569 / 001-628 \\
\hline 23.2 & CHE 48 & C4c & 160223291298327468519 & $053054 C 073$ 249d $263309+C 315+C 489$ & 15878-16569 / 001-628 \\
\hline 23.2 & SJ 002 & C4c & 160223291298327468519 & $053054 C 073$ 249d 263 309+C 315+C 489 & 15878-16569 / 001-628 \\
\hline 23.3 & SJ 012 & C4c & 160223291298320327468519 & $053054 C 073$ 249d 263 309+C 315+C 489 & 15878-16569 / 001-628 \\
\hline 24.1 & TG 124 & D1 & 223325362 & $073263309+C 315+C 489$ & $16024-16569$ / 001-576 \\
\hline 24.2 & Be 021 & D1 & 190223325362 & $073263309+C 315+C 489$ & 15878-16569 / 001-628 \\
\hline 24.2 & Be 092 & D1 & 190223325362 & $073263309+C 315+C 489$ & 15878-16569 / 001-628 \\
\hline 24.3 & TG 006 & D1 & 172190223234325362 & $073263309+C C 315+C 489$ & 16024-16569 / 001-576 \\
\hline 24.4 & CAL 15 & D1 & 126223325362 & $010055056064073263279309+C 315+C 489$ & 15878-16569 / 001-628 \\
\hline 24.4 & CAL 30 & D1 & 126223325362 & $010055056064073263279309+C 315+C 489$ & 15878-16569 / 001-628 \\
\hline 24.4 & CAL 54 & D1 & 126223325362 & $010055056064073263279309+C 315+C 489$ & 15878-16569 / 001-628 \\
\hline 24.5 & SJ 055 & D1 & 126165223325362 & $010055056064073263279309+C 315+C 489$ & 15878-16569 / 001-628 \\
\hline 24.6 & MZ 106 & D1 & 223293325362519 & 073097 106-111d 195263 315+C 489 523dd & 16024-16569 / 001-576 \\
\hline 24.6 & MM 118 & D1 & 223293325362519 & 073097 106-111d 195263 315+C 489 523dd & 15991-16569/001-628 \\
\hline 24.7 & LQ 143 & D1 & 213223293325362519 & 073092 093+T 097 106-111d 263 315+C 489 523dd & 15991-16569/001-628 \\
\hline 24.8 & SMA 033 & D1 & 223325362519527 & $073263315+C 489$ & 15878-16569 / 001-628 \\
\hline 24.8 & SMA 043 & D1 & 15924223325362519527 & $073263315+C 489$ & 15878-16569 / 001-628 \\
\hline 24.8 & TG 051 & D1 & 223325362519527 & $073263309+C 315+C 489$ & 16024-16569 / 001-576 \\
\hline 24.8 & LQ 003 & D1 & 223325362519527 & $073263315+C 481 Y 489$ & 16009-16569 / 001-628 \\
\hline 24.8 & LQ 017 & D1 & 223325362519527 & $073263315+C 489$ & 16009-16569 / 001-628 \\
\hline 24.8 & LQ 100 & D1 & 223325362519527 & $073263315+C 489$ & 15991-16569/001-628 \\
\hline 24.8 & LQ 101 & D1 & 223325362519527 & $073263315+C 489$ & 15991-16569/ 001-628 \\
\hline 24.8 & LQ 114 & D1 & 223325362519527 & $073263309+C C 315+C 489$ & 15991-16569/001-628 \\
\hline 24.8 & MM 025 & D1 & 223325362519527 & $073263309+C 315+C 489$ & 15991-16569/001-628 \\
\hline 24.9 & SJ 041 & D1 & 223325362519527 & $073263315+C 489$ 524+ACAC & 15878-16569 / 001-628 \\
\hline 24.10 & SMA 133 & D1 & 223295325362519527 & $073263315+C 489$ & 15878-16569 / 001-628 \\
\hline
\end{tabular}

198 


\begin{tabular}{|c|c|c|c|c|c|}
\hline $\begin{array}{l}\text { ID en } \\
\text { la red }\end{array}$ & ID & $\mathrm{Hg}$ & Región Control 5' (+16000) & Región Control 3' & Rango de lectura \\
\hline 24.11 & LQ 166 & D1 & 223292325362519527 & $073263309+C 315+C 489$ & 15991-16569/001-628 \\
\hline 24.12 & TG 139 & D1 & 15924223325342362519527 & $073263315+C 489$ & 15878-15969 / 001- 576 \\
\hline 24.12 & MM 028 & D1 & 223325342362519527 & $073263315+C 489$ & 15991-16569/ 001-628 \\
\hline 24.12 & MM 084 & D1 & 223325342362519527 & $073263315+C 489$ & 15991-16569/ 001-628 \\
\hline 24.13 & TG BS 19 & D1 & 223311325362519 & $073263309+C 315+C 489$ & 15878-16569 / 001-628 \\
\hline 24.14 & SJ JA 10 & D1 & 223311325362 & $073152263309+C C 315+C 489$ & 15878-16569 / 001-628 \\
\hline 24.14 & SMA 062 & D1 & 223311325362 & $073152263309+C 315+C 489$ & 15878-16569 / 001-628 \\
\hline 24.15 & MM 066 & D1 & 093223263311325362 & $073143263315+C 489$ & 15991-16569/001-628 \\
\hline 24.16 & SJ sal 4 & D1 & $223 Y 325362$ & $073207263309+C 315+C 489$ & 15878-16569 / 001-628 \\
\hline 24.17 & TG 054 & D1 & 174223263325361362390 & $073146207263309+C$ 315+C 489 & 16024-16569 / 001-576 \\
\hline 24.17 & TG 071 & D1 & 174223263325361362390 & $073146207263309+C C 315+C 489$ & 16024-16569 / 001-576 \\
\hline 24.17 & TG 119 & D1 & 174223263325361362390 & $073146207263309+C C 315+C 489$ & 16024-16569 / 001-576 \\
\hline 24.17 & TG BS 47 & D1 & 174223263325361362390 & $073146207263309+C C 315+C 489$ & 15878-16569 / 001-628 \\
\hline 24.17 & TG BS 52 & D1 & 174223263325361362390 & $073146207263309+C$ 315+C 489 & 15878-16569 / 001-628 \\
\hline 24.17 & TG BS 55 & D1 & 174223263325361362390 & $073146207263309+C C 315+C 489$ & 15878-16569 / 001-628 \\
\hline 24.18 & TG 022 & D1 & 174223263325361362390 & $073146204207263315+C 489$ & 16024-16569 / 001-576 \\
\hline 24.19 & LR053 & D1 & 223325362 & 073119143152263 315+C 489 & 15878-16569 / 001-628 \\
\hline 24.19 & LQ 010 & D1 & 223325362 & $073119143152263309+C 315+C 489$ & 15991-16569 / 001-600 \\
\hline 24.20 & TG BS sal 1 & D1 & 223291362 & $073309+C C$ 315+C 489 & 15878-16569 / 001-628 \\
\hline 24.20 & TG BS sal 6 & D1 & 223291362 & $073309+C C 315+C 489$ & 15878-16569 / 001-628 \\
\hline 24.20 & TG BS 08 & D1 & 223291362 & $073309+C 315+C 489$ & 15878-16569 / 001-628 \\
\hline 24.20 & TG BS 09 & D1 & 223291362 & $073309+C C 315+C 489$ & 15878-16569 / 001-628 \\
\hline 24.20 & TG BS 11 & D1 & 223291362 & $073309+C C 315+C 489$ & 15878-16569 / 001-628 \\
\hline 24.21 & TG 025 & D1 & 223291362 & $073185263315+C 489$ & 16024-16569 / 001-576 \\
\hline 24.21 & TG 028 & D1 & 223291362 & $073185263315+C 489$ & 16024-16569 / 001-576 \\
\hline 24.22 & TG BS 26 & D1 & 223291362 & $073143263315+C 489$ & 15878-16569 / 001-628 \\
\hline 24.23 & TG 042 & D1 & 092142 166d 223325362519 & $073093146263309+C$ 315+C 489 523dd 593 & 16024-16569 / 001-576 \\
\hline 24.24 & LQ 079 & D1 & 142148223278325356362519 & $073146228263309+C$ 315+C 489 & 15991-16569/001-628 \\
\hline 25.1 & SJ 072 & D1 & 187223325362 & $073263315+C 489$ & 15878-16569 / 001-628 \\
\hline
\end{tabular}

199 


\begin{tabular}{|c|c|c|c|c|c|}
\hline $\begin{array}{l}\text { ID en } \\
\text { la red }\end{array}$ & ID & $\mathrm{Hg}$ & Región Control 5' (+16000) & Región Control 3' & Rango de lectura \\
\hline 25.1 & TG 072 & D1 & 187223325362 & $073263315+C 489$ & $16024-16569$ / 001-576 \\
\hline 25.2 & SJ 026 & D1 & 187223245325362390 & $073146152263315+C 489$ & $15878-16569$ / 001-628 \\
\hline 25.3 & CAL 28 & D1 & 15924187223290325362 & $073204245263315+C 489$ & $15878-16569$ / 001-628 \\
\hline 25.3 & CAL 50 & D1 & 15924187223290325362 & $073204245263315+C 489$ & $15878-16569$ / 001-628 \\
\hline 25.4 & MZ 076 & D1 & 15965178187223325362 & $073150199263315+C 374489$ & 15965-16569 / 001-576 \\
\hline 25.5 & CAL 21 & D1 & $093 Y 187223249325362519$ & $070073199263315+C 489$ & $15878-16569$ / 001-628 \\
\hline 25.5 & CAL 34 & D1 & 093Y 187223249325362519 & $070073199263315+C 489$ & 15878-16569 / 001-628 \\
\hline 25.6 & MZ 107 & D1 & 172187223325362 & $073263309+C 315+C 489$ & 16024-16569 / 001-576 \\
\hline 25.7 & MZ 041 & D1 & $187223325362371 R 519$ & $073263309+C 315+C 489573+C C C$ & 16024-16569 / 001-576 \\
\hline 25.7 & SJ 057 & D1 & 187223325362519 & $073263309+C 315+C 489573+C C C$ & 15878-16569 / 001-628 \\
\hline 25.8 & CAL 22 & D1 & 187189209223325362 & $055056073263315+C 489$ & $15878-16569$ / 001-628 \\
\hline 25.8 & LR065 & D1 & 187189209223325362 & $055056073263309+C 315+C 489$ & $15878-16569$ / 001-628 \\
\hline 25.8 & MZ 150 & D1 & 187189209223325362 & $055056073263315+C 489$ & 16024-16569 / 001-576 \\
\hline 25.8 & L sal 04 & D1 & 187189209223325362 & $055056073263315+C 489$ & 15898-16569 / 001-628 \\
\hline 25.9 & LR066 & D1 & 187189209223325362 & $055056073185263309+C 315+C 489499$ & $15878-16569$ / 001-628 \\
\hline 25.9 & LR141 & D1 & $086 Y 187189209223325362$ & $055056073185263315+C 489499$ & $15878-16569$ / 001-628 \\
\hline 25.9 & MZ 021 & D1 & 187189209223325362 & $055056073185263315+C 489499$ & 16024-16569 / 001-576 \\
\hline 25.9 & MZ 125 & D1 & 187189209223325362 & $055056073185263315+C 489499$ & $15878-16569$ / 001-628 \\
\hline 25.10 & MZ 073 & D1 & 092187189209223325362 & $055056073263309+C 315+C 489499$ & $16024-16569$ / 001-576 \\
\hline 25.10 & SJ 005 & D1 & 092187189209223325362 & $055056073263309+C 315+C 489499$ & $15878-16569$ / 001-628 \\
\hline 25.10 & SJ 101 & D1 & 092187189209223325362 & $055056073263309+C$ 315+C 489499 & 15878-16569 / 001-628 \\
\hline 25.10 & L 032 & D1 & 092187189209223325362 & $055056073263309+C 315+C 489499$ & 16024-16569 / 001-576 \\
\hline 25.10 & L 041 & D1 & 092187189209223325362 & $055056073263309+C$ 315+C 489499 & 16024-16569 / 001-576 \\
\hline 25.10 & L 103 & D1 & 092187189209223325362 & $055056073263309+C 315+C 489499$ & 15898-16569 / 001-628 \\
\hline 25.11 & CAL 03 & D1 & 15930092187189223362 & $073143263315+C 489$ & $15878-16569$ / 001-628 \\
\hline 25.11 & CAL 19 & D1 & 15930092187189223362 & $073143263315+C 489$ & $15878-16569$ / 001-628 \\
\hline 25.11 & MZ 012 & D1 & 15930187189223362 & $073143263309+C 315+C 489$ & 15930-16569 / 001-576 \\
\hline 25.11 & MZ 143 & D1 & 15930092187189223362 & $073143263315+C 489$ & 15930-16569 / 001-576 \\
\hline 25.12 & SMA 121 & D1 & 187223254291325362519 & $073263309+C C 315+C 489$ & $15878-16569 / 001-628$ \\
\hline
\end{tabular}




\begin{tabular}{|c|c|c|c|c|c|}
\hline $\begin{array}{l}\text { ID en } \\
\text { la red }\end{array}$ & ID & $\mathrm{Hg}$ & Región Control 5' (+16000) & Región Control 3' & Rango de lectura \\
\hline 26.1 & CAL 08 & D1 & 223242311325362 & $073152263309+C 315+C 489$ & $15878-16569$ / 001-628 \\
\hline 26.1 & CAL 27 & D1 & 223242311325362 & $073152263315+C 489$ & $15878-16569$ / 001-628 \\
\hline 26.1 & CHE 03 & $\mathrm{D} 1$ & 223242311325362 & $073152263309+C 315+C 489$ & 15878-16569 / 001-628 \\
\hline 26.1 & LR001 & D1 & 223242311325362 & $073152263309+C 315+C 489$ & $15878-16569$ / 001-628 \\
\hline 26.1 & LR028 & D1 & 223242311325362 & $073152263309+C C$ 315+C 489 & 15878-16569 / 001-576 \\
\hline 26.1 & LR032 & D1 & 223242311325362 & $073152263309+C C$ 315+C 489 & $15878-16569$ / 001-628 \\
\hline 26.1 & LR048 & D1 & 223242311325362 & $073152263309+C 315+C 489$ & 15878-16569 / 001-628 \\
\hline 26.1 & LR073 & D1 & 223242311325362 & $073152263309+C 315+C 489$ & 15878-16569 / 001-628 \\
\hline 26.1 & LR077 & D1 & 223242311325362 & $073152263315+C 489$ & 15878-16569 / 001-628 \\
\hline 26.1 & LR086 & D1 & 223242311325362 & $073152263309+C 315+C 4891$ & $15878-16569 / 001-628$ \\
\hline 26.1 & LR100 & D1 & 223242311325362 & $073152263309+C 315+C 489$ & 15878-16569 / 001-628 \\
\hline 26.1 & LR140 & D1 & 223242311325362 & $073152263309+C C$ 315+C 489 & 15878-16569 / 001-628 \\
\hline 26.1 & LR144 & D1 & 223242311325362 & $073152263309+C 315+C 489$ & 15878-16569 / 001-628 \\
\hline 26.1 & LR169 & D1 & 223242311325362 & $073152263315+C 489$ & 15878-16569 / 001-628 \\
\hline 26.1 & LR175 & D1 & 223242311325362 & $073152263309+C C$ 315+C 489 & 15878-16569 / 001-628 \\
\hline 26.1 & LR BS 31 & D1 & 223242311325362 & $073152263309+C 315+C 489$ & 15878-16569 / 001-628 \\
\hline 26.1 & MZ 052 & D1 & 223242311325362 & $073152263309+C 315+C 489$ & 16024-16569 / 001-576 \\
\hline 26.1 & SJ 013 & D1 & 223242311325362 & $073152263309+C C$ 315+C 489 & $15878-16569$ / 001-628 \\
\hline 26.1 & SJ 049 & D1 & 223242311325362 & $073152263309+C C$ 315+C 489 & $15878-16569$ / 001-628 \\
\hline 26.1 & SJ 066 & D1 & 223242311325362 & $073152263309+C C$ 315+C 489 & $15878-16569$ / 001-628 \\
\hline 26.1 & SJ 091 & D1 & 223242311325362 & $073152263309+C 315+C 489$ & 15878-16569 / 001-628 \\
\hline 26.1 & SJ 093 & D1 & 223242311325362 & $073152263309+C 315+C 489$ & 15878-16569 / 001-628 \\
\hline 26.1 & SJ 106 & D1 & 223242311325362 & $073152263309+C 315+C 489$ & $15878-16569$ / 001-628 \\
\hline 26.1 & SMA 089 & D1 & 223242311325362 & $073152263309+C 315+C 489$ & 15878-16569 / 001-628 \\
\hline 26.1 & SMA 115 & D1 & 223242311325362 & $073152263309+C C$ 315+C 489 & $15878-16569$ / 001-628 \\
\hline 26.1 & SJS 09 & D1 & 223242311325362 & $073152263309+C 315+C 489$ & 15878-16569 / 001-628 \\
\hline 26.1 & SJS 12 & D1 & 223242311325362 & $073152263309+C 315+C 489$ & 15878-16569 / 001-628 \\
\hline 26.1 & SJS 13 & D1 & 223242311325362 & $073152263309+C 315+C 489$ & 15878-16569 / 001-628 \\
\hline 26.1 & L 004 & D1 & 223242311325362 & $073152263309+C 315+C 489$ & 16024-16569 / 001-576 \\
\hline
\end{tabular}




\begin{tabular}{|c|c|c|c|c|c|}
\hline $\begin{array}{l}\text { ID en } \\
\text { la red }\end{array}$ & ID & $\mathrm{Hg}$ & Región Control 5' (+16000) & Región Control 3' & Rango de lectura \\
\hline 26.2 & TG 087 & D1 & 223242311325362 & $073152263309+C C 315+C 489538 C$ & $16024-16569$ / 001-576 \\
\hline 26.2 & TG 094 & D1 & 223242311325362 & $073152263309+C C 315+C 489538 C$ & $16024-16569$ / 001-576 \\
\hline 26.2 & TG BS 29 & $\mathrm{D} 1$ & 223242311325362 & $073152263309+C C$ 315+C $489538 C$ & 15878-16569 / 001-628 \\
\hline 26.3 & $\mathrm{~J} 12$ & D1 & 223242311325362 & $073204 Y 263$ 309+C 315+C 489 538C & $15878-16569 / 001-628$ \\
\hline 26.3 & TG EA 24 & D1 & 223242311325362 & $073263309+C 315+C 489538 C$ & 15878-16569 / 001-576 \\
\hline 26.4 & LR058 & D1 & 157223242311325362 & $073152263309+C 315+C 489$ & $15878-16569$ / 001-628 \\
\hline 26.4 & MZ 112 & D1 & 157223242311325362 & $073152263309+C 315+C 489$ & 16024-16569 / 001-576 \\
\hline 26.4 & SMA 064 & D1 & 157223242311325362 & $073152204 Y 263315+C 489$ & $15878-16569$ / 001-628 \\
\hline 26.4 & SMA 139 & D1 & 145R 157223242311325362 & $073152263315+C 489$ & $15878-16569$ / 001-628 \\
\hline 26.4 & SMA 147 & D1 & $157223242311325362527 Y$ & $073152263315+C 489$ & $15878-16569 / 001-628$ \\
\hline 26.5 & Be 077 & D1 & 223242311325362519 & $073152263309+C 315+C 489$ & 15878-16569 / 001-628 \\
\hline 26.5 & CHE 52 & D1 & 223242311325362519 & $073152263309+C 315+C 489$ & 15878-16569 / 001-628 \\
\hline 26.5 & LR084 & D1 & 223242311325362519 & $073152263309+C 315+C 489$ & 15878-16569 / 001-628 \\
\hline 26.5 & LR111 & D1 & 223242311325362519 & $073152263309+C 315+C 489$ & 15878-16569 / 001-628 \\
\hline 26.5 & LR163 & D1 & 223242311325362519 & $073152263309+C 315+C 489$ & 15878-16569 / 001-628 \\
\hline 26.5 & LR BS 12 & D1 & 223242311325362519 & $073152263309+C 315+C 489$ & 15878-16569 / 001-628 \\
\hline 26.5 & LR BS 36 & D1 & 223242311325362519 & $073152263309+C 315+C 489$ & 15878-16569 / 001-628 \\
\hline 26.5 & MZ Sal 15 & D1 & 223242311325362519 & $073152263309+C 315+C 489$ & $15878-16569$ / 001-628 \\
\hline 26.5 & SJ 071 & D1 & $223 Y 242311325362519$ & $073152263309+C 315+C 489$ & $15878-16569$ / 001-628 \\
\hline 26.5 & SMA 010 & D1 & 223242311325362519 & $073152263309+C 315+C 489$ & $15878-16569$ / 001-628 \\
\hline 26.5 & SMA 104 & D1 & 223242311325362519 & $073152263309+C 315+C 489$ & 15878-16569 / 001-628 \\
\hline 26.6 & SMA 031 & D1 & 223242311325362 & 055+T 058d 059d 060d 071+GG 073152263 309+C 315+C 489 523dd & $15878-16569$ / 001-628 \\
\hline 26.6 & MM Tum 10 & D1 & 223242311325362 & 055+T 059d 060d 071+G 073152263 309+C 315+C 489 523dd & 15991-16569/ 001-628 \\
\hline 26.7 & CHE 46 & D1 & 223242311325362 & $073152235263315+C 489$ & $15878-16569$ / 001-628 \\
\hline 26.7 & $\mathrm{~J} 57$ & D1 & 223242311325362 & $073152235263315+C 489$ & $15878-16569$ / 001-628 \\
\hline 26.7 & LR121 & D1 & 223242311325362 & $073152235263309+C 315+C 489$ & $15878-16569 / 001-628$ \\
\hline 26.7 & SJ 077 & D1 & 223242311325362 & $073152235263309+C 315+C 489$ & $15878-16569$ / 001-628 \\
\hline 26.7 & SMA 028 & D1 & 223242311325362 & $073152235263309+C$ 315+C 489 & 15878-16569 / 001-628 \\
\hline 26.7 & SMA 077 & D1 & 223242311325362 & $073152235263315+C 489$ & $15878-16569$ / 001-628 \\
\hline
\end{tabular}




\begin{tabular}{|c|c|c|c|c|c|}
\hline $\begin{array}{l}\text { ID en } \\
\text { la red }\end{array}$ & ID & $\mathrm{Hg}$ & Región Control 5' (+16000) & Región Control 3' & Rango de lectura \\
\hline 26.8 & Be 037 & D1 & 223242311325362 & $073152263309+C 315+C 489$ 524+AC & 15878-16569 / 001-628 \\
\hline 26.8 & CAL 09 & D1 & 223242311325362 & $073152263309+C 315+C 489$ 524+AC & 15878-16569 / 001-628 \\
\hline 26.8 & CAL 10 & D1 & 223242311325362 & $073152263309+C 315+C 489524+A C$ & 15878-16569 / 001-628 \\
\hline 26.8 & CAL 13 & D1 & 223242311325362 & 073152263 309+CC 315+C 489 524+AC & 15878-16569 / 001-628 \\
\hline 26.8 & CHE 08 & D1 & 223242311325362 & $073152263315+C 489$ 524+AC & 15878-16569 / 001-628 \\
\hline 26.8 & CHE 28 & D1 & 223242311325362 & $073152263315+C 489524+A C$ & 15878-16569 / 001-628 \\
\hline 26.8 & CHE 60 & D1 & 223242311325362 & $073152263315+C 489$ 524+AC & 15878-16569 / 001-628 \\
\hline 26.8 & LR016 & D1 & 129R 223242311325362 & $073152263315+C 489$ 524+AC & 15878-16569 / 001-628 \\
\hline 26.8 & LR021 & D1 & 223242311325362 & $073152263315+C 489$ 524+AC & 15878-16569 / 001-628 \\
\hline 26.8 & LR029 & D1 & 223242311325362 & $073152263309+C 315+C 489$ 524+AC & 15878-16569 / 001-576 \\
\hline 26.8 & LR049 & D1 & 223242311325362 & $073152263309+C 315+C 489524+A C$ & 15878-16569 / 001-628 \\
\hline 26.8 & LR105 & D1 & 223242311325362 & $073152263309+C 315+C 489524+A C$ & 15878-16569 / 001-628 \\
\hline 26.8 & LR167 & D1 & 223242311325362 & $073152263315+C 489524+A C$ & 15878-16569 / 001-628 \\
\hline 26.8 & LR BS 21 & D1 & 223242311325362 & $073152263309+C 315+C 489$ 524+AC & 15878-16569 / 001-628 \\
\hline 26.8 & LR BS 38 & D1 & 223242311325362 & $073152263309+C 315+C 489524+A C$ & 15878-16569 / 001-628 \\
\hline 26.8 & MZ 058 & D1 & 223242311325362 & $073152263309+C C$ 315+C 489 524+AC & 16024-16569 / 001-576 \\
\hline 26.8 & MZ 115 & D1 & 223242311325362 & $073152263315+C 489$ 524+AC & 16024-16569 / 001-576 \\
\hline 26.8 & SJ sal 3 & D1 & 223242311325362 & $073152263309+C 315+C 489524+A C$ & 15878-16569 / 001-628 \\
\hline 26.8 & SJ JA 05 & D1 & 223242311325362 & $073152263315+C 489524+A C$ & 15878-16569 / 001-628 \\
\hline 26.8 & SMA 037 & D1 & 223242311325362 & $073152263315+C 489524+A C$ & $15878-16569$ / 001-628 \\
\hline 26.8 & SMA 066 & D1 & 223242311325362 & $073152263309+C 315+C 489524+A C$ & 15878-16569 / 001-628 \\
\hline 26.8 & TG 114 & D1 & 223242311325362 & $073152263309+C C$ 315+C 489 524+AC & 16024-16569 / 001-576 \\
\hline 26.9 & Be 090 & D1 & 223242311325362 & $055073152263309+C$ 315+C 489 524+AC & 15878-16569 / 001-628 \\
\hline 26.9 & CHE 63 & D1 & 223242311325362 & $055073152263309+C$ 315+C 489 524+AC & 15878-16569 / 001-628 \\
\hline 26.9 & LR128 & D1 & 223242311325362 & $055073152263309+C$ 315+C 489 524+AC & 15878-16569 / 001-576 \\
\hline 26.10 & LR031 & D1 & 223242311325362 & 055056073152263 309+C 315+C 489 524+AC & 15878-16569 / 001-576 \\
\hline 26.10 & LR106 & D1 & 223242311325362 & $055056073152263309+C C$ 315+C 489 524+AC & 15878-16569 / 001-628 \\
\hline 26.11 & LR137 & D1 & 223242311325362 & 055057073152263 309+CC 315+C 489 524+AC & 15878-16569 / 001-628 \\
\hline 26.12 & CHE 07 & D1 & 242 260Y 263311325362 & $073152263315+C 489$ 524+AC & 15878-16569 / 001-628 \\
\hline
\end{tabular}




\begin{tabular}{|c|c|c|c|c|c|}
\hline $\begin{array}{l}\text { ID en } \\
\text { la red }\end{array}$ & ID & $\mathrm{Hg}$ & Región Control 5' (+16000) & Región Control 3' & Rango de lectura \\
\hline 26.12 & CHE 17 & D1 & 242263311325362 & $073152263309+C 315+C 489$ 524+AC & $15878-16569$ / 001-628 \\
\hline 26.12 & CHE 42 & D1 & 242263311325362 & $073152263309+C 315+C 489524+A C$ & $15878-16569$ / 001-628 \\
\hline 26.13 & CHE 21 & $\mathrm{D} 1$ & 223242311325362 & $053073152263309+C$ 315+C 489 524+AC & 15878-16569 / 001-628 \\
\hline 26.14 & CHE 29 & D1 & 223242311325362 & $073146152263315+C 489$ & $15878-16569$ / 001-628 \\
\hline 26.14 & LR033 & D1 & 223242311325362 & $073146152263309+C$ 315+C 489 & $15878-16569$ / 001-628 \\
\hline 26.15 & CHE 66 & D1 & 223242311325362 & $073150152263309+C$ 315+C 489 & $15878-16569$ / 001-628 \\
\hline 26.15 & LR BS 30 & D1 & 223242311325362 & $073150152263309+C$ 315+C 489 & $15878-16569$ / 001-628 \\
\hline 26.15 & MZ 022 & D1 & 223242311325362 & $073150152263309+C$ 315+C 489 & $15878-16569$ / 001-628 \\
\hline 26.15 & SJ 070 & D1 & 223242311325362 & $073150152263309+C 315+C 489$ & $15878-16569$ / 001-628 \\
\hline 26.15 & L 079 & D1 & 223242311325362 & $073150152263309+C$ 315+C 489 & $16024-16569 / 001-576$ \\
\hline 26.16 & L 054 & D1 & $102223242301 Y 311325362$ & $073150152263309+C 315+C 489$ & $16024-16569$ / 001-576 \\
\hline 26.17 & TG 055 & D1 & 223242311325362 & 073 106-111d 114152212263 309+CC 315+C 489 & 16024-16569 / 001-576 \\
\hline 26.18 & Be 035 & D1 & 093214223242311325362 & $073152263309+C 315+C 489$ & $15878-16569$ / 001-628 \\
\hline 26.19 & Be 095 & D1 & 172223242311325362 & $073152263309+C 315+C 489$ & $15878-16569$ / 001-628 \\
\hline 26.19 & LR123 & D1 & 172223242311325362 & $073152263309+C 315+C 489$ & $15878-16569$ / 001-628 \\
\hline 26.20 & Be 004 & D1 & 223242311325362 & $073263309+C 315+C 489$ & $15878-16569$ / 001-628 \\
\hline 26.20 & Be 011 & D1 & 223242311325362 & $073263309+C 315+C 489$ & 15878-16569 / 001-628 \\
\hline 26.20 & Be 044 & D1 & 223242311325362 & $073263309+C 315+C 489$ & $15878-16569$ / 001-628 \\
\hline 26.20 & $\mathrm{~J} 41$ & D1 & 223242 300R 311325362 & $073263309+C 315+C 489$ & $15878-16569$ / 001-628 \\
\hline 27.1 & LQ Pr 36 & D1 & 223304325362 & $073195263309+C 315+C 489$ & 15991-16569/001-628 \\
\hline 27.2 & CHE 58 & D1 & 189223325342362519 & $073195263297315+C 489$ & 15878-16569 / 001-628 \\
\hline 27.3 & TG 049 & D1 & 223325362566 & $073153195214263309+C C$ 315+C 489 & 16024-16569 / 001-576 \\
\hline 27.4 & TG BS 43 & D1 & 223325362 & 073 204A 263 309+C 315+C 489 573+C & $15878-16569$ / 001-628 \\
\hline 27.5 & MM 041 & D1 & 223325362519 & $073152234263309+C 315+C 489573+C$ & 15991-16569/ 001-628 \\
\hline 27.6 & MZ 131 & D1 & 15924189223325362 & $073146263309+C 315+C 489$ & $15924-16569$ / 001-576 \\
\hline 27.7 & TG 007 & D1 & 223325362519 & $073143146263315+C 489$ & 16024-16569 / 001-576 \\
\hline 27.8 & $\mathrm{~J} 31$ & D1 & 172223325362 & 064A 065G 073263 315+C 489 & 15878-16569 / 001-628 \\
\hline 27.9 & Be 048 & D1 & 223325362 & $073150263309+C 315+C 489$ & 15878-16569 / 001-628 \\
\hline 27.9 & SJS 10 & D1 & 223325362 & $073150263309+C 315+C 489$ & 15878-16569 / 001-628 \\
\hline
\end{tabular}




\begin{tabular}{|c|c|c|c|c|c|}
\hline $\begin{array}{l}\text { ID en } \\
\text { la red }\end{array}$ & ID & $\mathrm{Hg}$ & Región Control 5' (+16000) & Región Control 3' & Rango de lectura \\
\hline 27.9 & SJS 14 & D1 & 223325362 & $073150263309+C 315+C 489$ & $15878-16569$ / 001-628 \\
\hline 28.1 & CAL 29 & D4h3a & 223241301342362 & $073152263315+C 489$ & $15878-16569$ / 001-628 \\
\hline 28.2 & TG 145 & D4h3a & 223241255301342362519 & $073150152263309+C C$ 315+C 489520545 & 16024-16569 / 001-576 \\
\hline 28.3 & SJ 009 & D4h3a & 223241298301342362519 & 073146152 208A 263 309+C 315+C 489 573+CCC & $15878-16569$ / 001-628 \\
\hline 28.4 & SMA 057 & D4h3a & 223241271292294301342362 & $073152263309+C 315+C 489573+C C C C$ & $15878-16569$ / 001-628 \\
\hline 28.4 & SMA 084 & D4h3a & 223241271292294301342362 & $073152263309+C 315+C 489$ 573+CCCCC & $15878-16569$ / 001-628 \\
\hline 28.4 & SMA 094 & D4h3a & 223241271292294301342362 & $073152263309+C 315+C 489573+C C C C$ & $15878-16569$ / 001-628 \\
\hline 28.4 & SMA 114 & D4h3a & 223241271292294301342362 & $073152263309+C 315+C 489573+C C C C C$ & $15878-16569$ / 001-628 \\
\hline 28.4 & SMA 126 & D4h3a & 223241271292294301342362 & $073152263309+C$ 315+C 489 573+CCCCC & $15878-16569$ / 001-628 \\
\hline 28.4 & SMA 136 & D4h3a & 223241271292294301342362 & $073152263309+C 315+C 489573+C C C C$ & $15878-16569 / 001-628$ \\
\hline 28.4 & LQ 105 & D4h3a & 223241271292294301342362 & $073152263309+C 315+C 489573+C C C$ & 15991-16569 / 001-604 \\
\hline 28.5 & TG 018 & D4h3a & 075223241260294301342362462533 & 073094125127152195263 309+C 315+C 489 & 16024-16569 / 001-576 \\
\hline \multirow[t]{17}{*}{28.6} & TG 106 & D4h3a & 189223241278301316362 & $073152263309+C 315+C 489$ & $16024-16569$ / 001-576 \\
\hline & L 042 & $?$ & $129173183 C 189193+C 519$ & 055+T $057059073263309+C C C 315+C$ & 16024-16569 / 001-576 \\
\hline & CHE 11 & $\mathrm{H}$ & 189519 & $152263315+C$ & $15878-16569$ / 001-628 \\
\hline & CHE 14 & $\mathrm{H}$ & 189519 & $152263315+C$ & $15878-16569$ / 001-628 \\
\hline & CHE 34 & $\mathrm{H}$ & 189519 & $152263315+C$ & 15878-16569 / 001-628 \\
\hline & CHE 54 & $\mathrm{H}$ & 189519 & $152263315+C$ & 15878-16569 / 001-628 \\
\hline & CHE 65 & $\mathrm{H}$ & 189519 & $152263315+C$ & $15878-16569$ / 001-628 \\
\hline & LRO04 & $\mathrm{H}$ & 519 & $152263315+C$ & $15878-16569$ / 001-628 \\
\hline & LR130 & $\mathrm{H}$ & OOOR 189519 & $152263315+C$ & 15878-16569 / 001-628 \\
\hline & SMA 123 & $\mathrm{H}$ & 519 & $263309+C 315+C$ & 15878-16569 / 001-628 \\
\hline & L053 & $\mathrm{H}$ & 519 & $263315+C$ & 16024-16569 / 001-576 \\
\hline & L 096 & $\mathrm{H}$ & 519 & $263309+C C 315+C$ 523dd & 16024-16569 / 001-576 \\
\hline & MZ 059 & $\mathrm{H}$ & 129311519 & $151152263315+C 437$ & 16024-16569 / 001-576 \\
\hline & CAL 04 & $\mathrm{H}$ & 519 & $263292309+C 315+C$ & 15878-16569 / 001-628 \\
\hline & LR060 & $\mathrm{H}$ & 189519 & $152263315+C$ & 15878-16569 / 001-628 \\
\hline & MZ 020 & $\mathrm{H}$ & 189519 & $152263315+C$ & 16024-16569 / 001-576 \\
\hline & MZ 077 & $\mathrm{H}$ & 189519 & $152263315+C$ & 16024-16569 / 001-576 \\
\hline
\end{tabular}




\begin{tabular}{|c|c|c|c|c|c|}
\hline $\begin{array}{l}\text { ID en } \\
\text { la red }\end{array}$ & ID & $\mathrm{Hg}$ & Región Control 5' (+16000) & Región Control 3' & Rango de lectura \\
\hline & MZ 117 & $\mathrm{H}$ & $183 C 189193+C 519$ & $152263309+C 315+C 489$ & 16024-16569 / 001-576 \\
\hline & MZ 127 & $\mathrm{H}$ & 357519 & $263309+C C 315+C 453$ & 16024-16569 / 001-576 \\
\hline & SJ 062 & $\mathrm{H}$ & 294519 & $263309+C 315+C$ & $15878-16569$ / 001-628 \\
\hline & SJ 075 & $\mathrm{H}$ & 311 & $263309+C 315+C$ & $15878-16569$ / 001-628 \\
\hline & Lo45 & $\mathrm{H}$ & 240519 & $152263309+C 315+C$ & $16024-16569$ / 001-576 \\
\hline & LO55 & $\mathrm{H}$ & 171266519 & $263293315+C$ & 16024-16569 / 001-576 \\
\hline & LR BS 04 & H5 & 304 & $263309+C C 315+C 456573+C$ & $15878-16569$ / 001-628 \\
\hline & LR BS 45 & H5 & 304 & $263309+C 315+C 456573+C$ & 15878-16569 / 001-576 \\
\hline & MZ 061 & H5 & 304 & $263309+C 315+C 456573+C C C C$ & 16024-16569 / 001-576 \\
\hline & SJ 083 & H5 & 294304320 & $146263315+C 456$ & $15878-16569$ / 001-628 \\
\hline & L 080 & H5 & 304 & $263309+C 315+C 456573+C$ & 16024-16569 / 001-576 \\
\hline & TG EA 03 & $\mathrm{H} 8$ & 068288362 & $146195263309+C 315+C$ & 15878-16569 / 001-628 \\
\hline & LR BS 29 & HVOb'c & 298311 & $072195263309+C C$ 315+C & $15878-16569$ / 001-628 \\
\hline & LR094 & J1a'b'e & 069126145222256261278 & $073199263295315+C 462489574 T$ & 15878-16569 / 001-628 \\
\hline & LR BS 20 & J1a'b'e & 069126145222256261278 & $073199263295315+C 462489574 T$ & $15878-16569$ / 001-628 \\
\hline & LR091 & J1c1 & 069126278366519 & 073185188228263295 315+C 462489 523dd & 15878-16569 / 001-628 \\
\hline & SJ sal 2 & J1c1 & 0691263360519 & $073185188228263295315+C 462489$ & $15878-16569$ / 001-628 \\
\hline & SJ 073 & $\mathrm{J1 \textrm {c } 7}$ & 069092126261 & $073185228263295315+C 462489$ & $15878-16569$ / 001-628 \\
\hline & SMA 056 & K1a & 224311519 & $073195263309+C 315+C 374497524+A C$ & $15878-16569$ / 001-628 \\
\hline & SMA 047 & $\mathrm{~T} 2 \mathrm{~b}$ & 15928126294296304519 & $073263309+C 315+C$ & $15878-16569$ / 001-628 \\
\hline & SMA 007 & T2c & 15928126278292294296422438519 & $073089146263315+C$ 523dd & 15878-16569 / 001-628 \\
\hline & L 061 & U4a & 356519 & 073152195235263310499 524+ACACAC & $15898-16569$ / 001-576 \\
\hline & SJ 044 & U4c1 & 179356519 & $073195263309+C 315+C 499$ & 15878-16569 / 001-628 \\
\hline & L sal 12 & U5 & 192270 & $073150263315+C 533$ & $15898-16569$ / 001-628 \\
\hline & SJ JA 14 & U5a & 114A 192256270294526 & $073263309+C 315+C$ & $15878-16569$ / 001-628 \\
\hline & SMA 034 & U5a & 256270304327526 & $073263309+C$ 315+C 523dd & $15878-16569$ / 001-628 \\
\hline & TG 085 & U5b1 & 189192270 & $073150152263309+C$ 315+C & 16024-16569 / 001-576 \\
\hline & CAL 24 & U6a & $093172183 C 189193+C 219278368$ & $073185263315+C$ & $15878-16569$ / 001-628 \\
\hline & SJ 019 & U6a & 172219235261278519 & $073263315+C$ & $15878-16569$ / 001-628 \\
\hline
\end{tabular}




\begin{tabular}{|c|c|c|c|c|c|}
\hline $\begin{array}{l}\text { ID en } \\
\text { la red }\end{array}$ & ID & $\mathrm{Hg}$ & Región Control 5' (+16000) & Región Control 3' & Rango de lectura \\
\hline & SJ JA 04 & U6a & 172219235261278519 & $073263315+C$ & $15878-16569$ / 001-628 \\
\hline & SJ 079 & $\mathrm{~W}^{*}$ & 223292295519 & $073152189195204207263315+C$ & $15878-16569$ / 001-628 \\
\hline & CHE 24 & W1c & $223 Y 292320519$ & 073119143189195204207263 309+C 315+C & $15878-16569$ / 001-628 \\
\hline & SJ 020 & $\mathrm{x} 2 \mathrm{~b}$ & 15927179188189203223278519 & $073153195225226263309+C$ 315+C & $15878-16569$ / 001-628 \\
\hline & CAL Sal 01 & LOa & $148172187188 G 189223230311320519$ & $064093152189236247263315+C$ 523dd & $15878-16569$ / 001-628 \\
\hline & L 012 & L1b & 126187189223264270278311519 & $073151152182185 T 189195247263$ 309+C 315+C 357 523dd & $16024-16569 / 001-576$ \\
\hline & L 100 & L1b & 126187189223264278293311519 & $073151152182185 T 195247263$ 315+C 357 523dd & $16024-16569$ / 001-576 \\
\hline & L 107 & L1b & 126187189223264278311519 & $073151152185 T 195247263$ 315+C 357 523dd & $15898-16569$ / 001-628 \\
\hline & LR192 & L1c1a & $\begin{array}{l}129183 C 189193+C 223274278293294311360 \\
519\end{array}$ & $\begin{array}{l}073076089093095 \mathrm{C} 152182 \text { 186A 189C } 236247263297309+C \\
315+C \quad 316523 \mathrm{dd}\end{array}$ & $15878-16569 / 001-628$ \\
\hline & Be 007 & L1c1d & 038187189223278293294311360519 & 073151152182 186A 189C 195198247263297 315+C 316 523dd & $15878-16569$ / 001-628 \\
\hline & SJ 064 & L2a1 & 223224234263278291309390519 & $073146 Y 152182263315+C 511$ & $15878-16569 / 001-628$ \\
\hline & TG 122 & L2a1 & $189193+$ CC 223278294296309390519 & 073146152195263 309+CC 315+C & $16024-16569$ / 001-576 \\
\hline & MZ 060 & L2a1c1 & 086223278294309390 & $073143146152195198263315+C$ & $16024-16569$ / 001-576 \\
\hline & MZ 079 & L3b & 15944d 124223278311362519 & $073263315+C$ 521d 522d 523dd & 15930-16569 / 001-576 \\
\hline & MZ 084 & L3b & 15944d 093124223278362519 & $073263315+C$ 523dd & $15930-16569$ / 001-576 \\
\hline & CAL 46 & L3d3 & 111124223519 & $073152199263309+C$ 315+C 523dd & $15878-16569$ / 001-628 \\
\hline & Be 013 & L3e1 & 15942223327 & $073150189200263315+C$ & $15878-16569$ / 001-628 \\
\hline & $\mathrm{J} 28$ & L3e1 & $15942183 C 189$ 193+C 223260327 & 073150189200263 309+C 315+C 523dd & 15878-16569 / 001-628 \\
\hline & SJS 15 & L3e1 & 15942223327 & 073150 189R 200263 309+C 315+C & $15878-16569$ / 001-628 \\
\hline & SJ 086 & L3e1a & 15942185223327519 & 073150189200263 309+CC 315+C 523dd & $15878-16569$ / 001-628 \\
\hline & CAL Sal 11 & L3e1d & 15942176223256327 & $073150152200263315+C$ & $15878-16569$ / 001-628 \\
\hline & SJ 035 & L3e2 & 223320399519 & $073150152195198263315+C 499$ & $15878-16569$ / 001-628 \\
\hline & SJ 036 & L3e2 & 223320399519 & $073150152195198263315+C 499$ & $15878-16569$ / 001-628 \\
\hline & LR071 & L3e2b & 172189223320519 & $073150152195263315+C$ & $15878-16569$ / 001-628 \\
\hline & MZ 128 & L3e2b & $172183 C 189193+C 223320519$ & $073150195263309+C 315+C$ & $16024-16569$ / 001-576 \\
\hline & SMA 083 & L3e2b & $172183 C 189$ 193+C 223320519 & $073150152 Y 195263$ 309+C 315+C 508 & $15878-16569$ / 001-628 \\
\hline & LR BS 15 & L3e3 & $223265 T 519$ & $073150195263309+C$ 315+C 523dd & 15878-16569 / 001-628 \\
\hline & MZ 147 & L3f1b1 & 15944d 129209223292295311519 & $073189200263309+C$ 315+C & 15930-16569 / 001-576 \\
\hline
\end{tabular}




\begin{tabular}{|l|l|l|l|l|l|}
\hline $\begin{array}{l}\text { ID en } \\
\text { la red }\end{array}$ & ID & Hg & Región Control 5' (+16000) & Región Control 3' & Rango de lectura \\
\hline & SJ 103 & L3f1b1 & 15944d 129 209 223292 295311 519 & $073189200263309+C \mathrm{CC} 315+\mathrm{C}$ & $15878-16569 / 001-628$ \\
\hline & L101 & L3f1b1 & 15944d 129209223292 295311 519 & $073189200263309+\mathrm{CC} 315+\mathrm{C}$ & $15930-16569 / 001-576$ \\
\hline
\end{tabular}




\subsubsection{HiPÓTESIS FILOGENÉTICAS: REDES DE HAPLOTIPOS}

La mayoría de los ciclos fueron eliminados a fin de privilegiar una lectura simple, los caracteres que constituyen un paralelismo están subrayados, indicando su carácter homoplásico. El signo@ indica reversión. Todas las mutaciones representan transiciones a menos que se indique lo contrario. Las mutaciones señaladas en naranja son las que forman parte de la definición de un linaje o subhaplogrupo. Al pie de cada red, se exponen los argumentos por los cuales se optó por privilegiar una hipótesis filogenética cuando existen otras alternativas.

Los haplotipos indicados en gris no fueron asignados a ningún subhaplogrupo. Los números en azul representan el código de identificación del haplotipo para ubicarlo en la tabla del Anexo 7.3.2; cada haplotipo consta de una identificación binaria que incluye el número de figura al que corresponde la red y el número interno a cada red. El haplotipo nodal se señala en rojo. 


\subsubsection{Haplogrupo A2}

Se privilegió a la mutación que consiste en una reversión en la posición 16111 por sobre la 16519 y 064 por la probada inestabilidad de estas dos últimas y por la coherencia geográfica local del cluster definido por dicha mutación. Salvo este caso y a pesar de la inestabilidad de 16519 y 064, pueden distinguirse dos clusters dentro de A2 que originalmente se caracterizarían por cambios en dichas posiciones. Sin embargo, la rápida velocidad de mutación genera frecuentes reversiones que impiden una clasificación en base a estas posiciones.

Mutaciones del nodal respecto de la SRCr en RC: 6473146153235263 315+C 522-523d 1611116223162901631916362.

Figura 1. Red de haplotipos correspondientes al cuerpo principal de A2*.

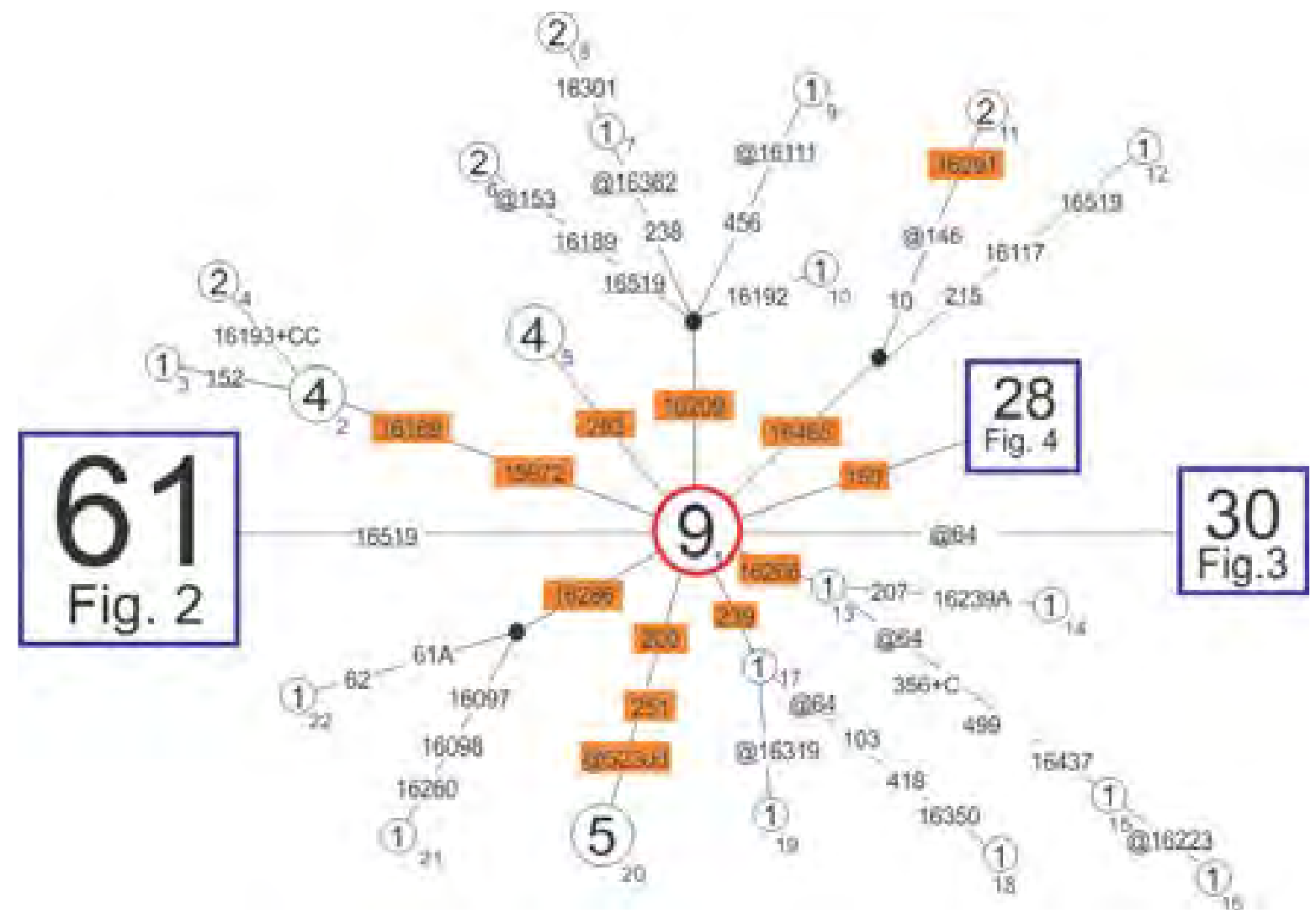

La posición 15972 no fue analizada para las muestras de Maimará y La Quiaca.

En esta red no están incluidos los haplotipos no asignados a un linaje, los cuales se muestran en la figura 
Figura 2. Red de haplotipos correspondientes a A2 + 16519

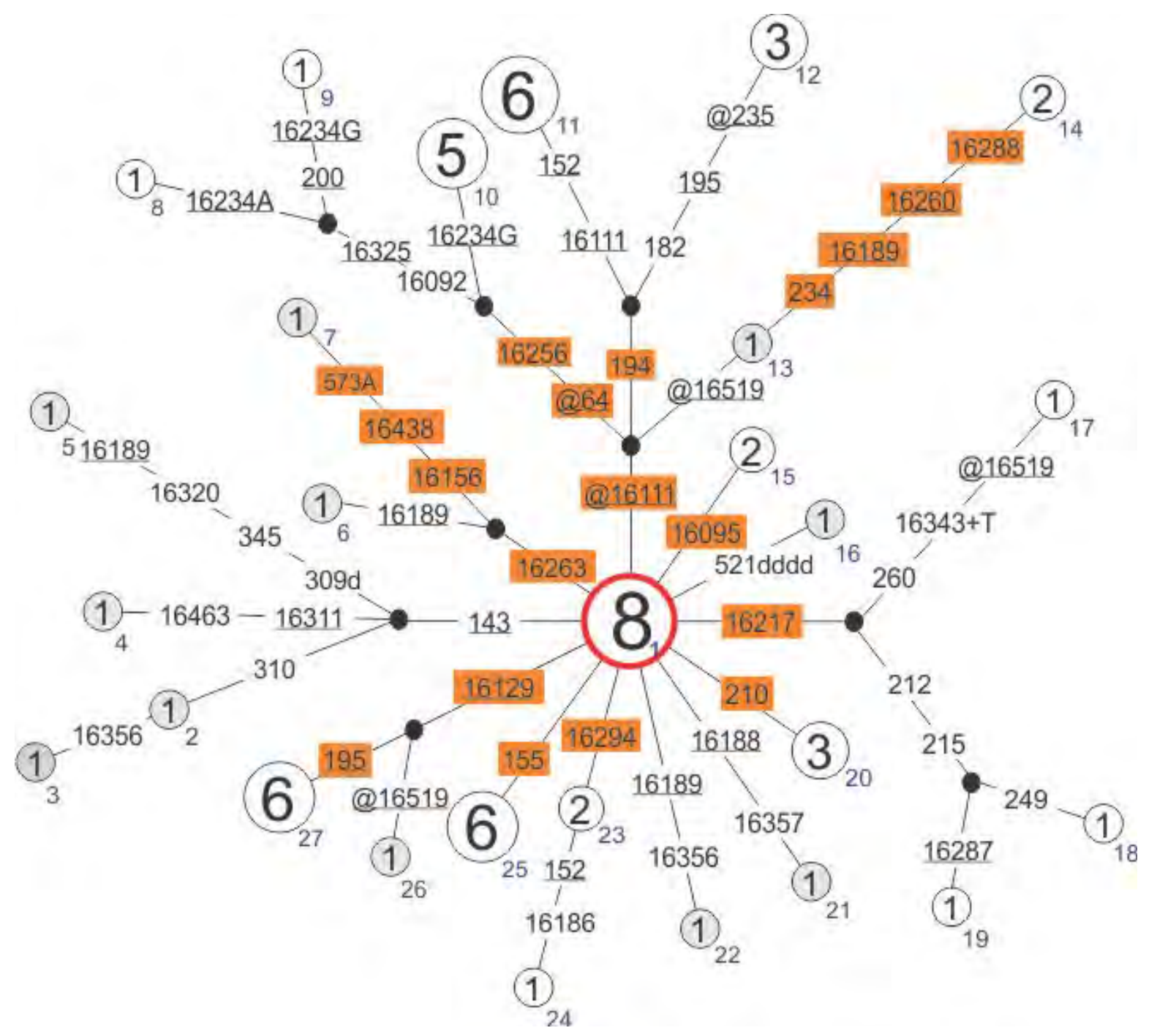

Los haplotipos 6 y 7 no fueron reunidos como parte de un mismo linaje, ya que las mutaciones 161561626316438 y 573A describen un linaje con clara distribución en Patagonia. 
Figura 3. Red de haplotipos correspondientes a A2 + @64.

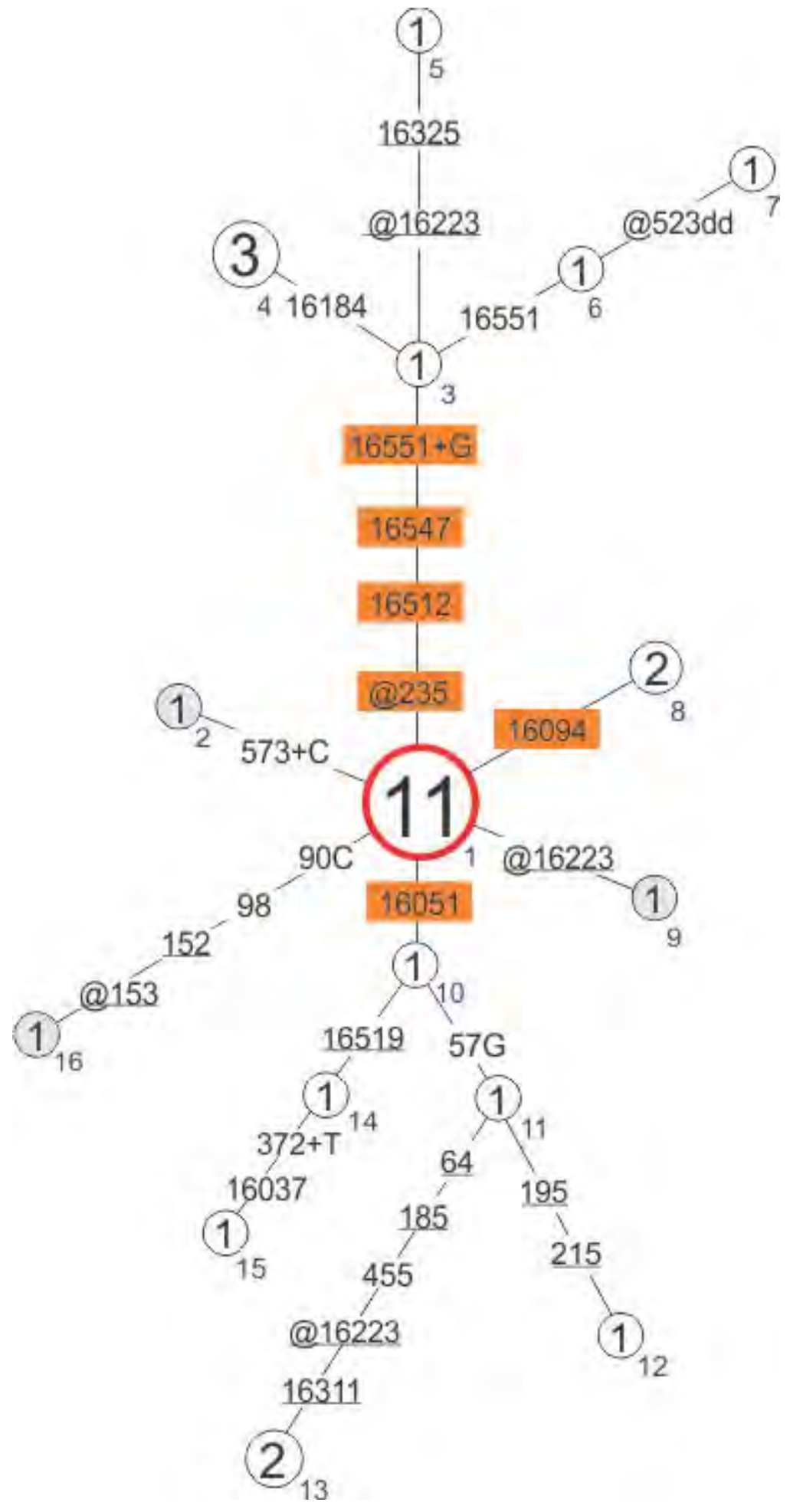


Figura 4. Red de haplotipos correspondientes a A2 + 150 .

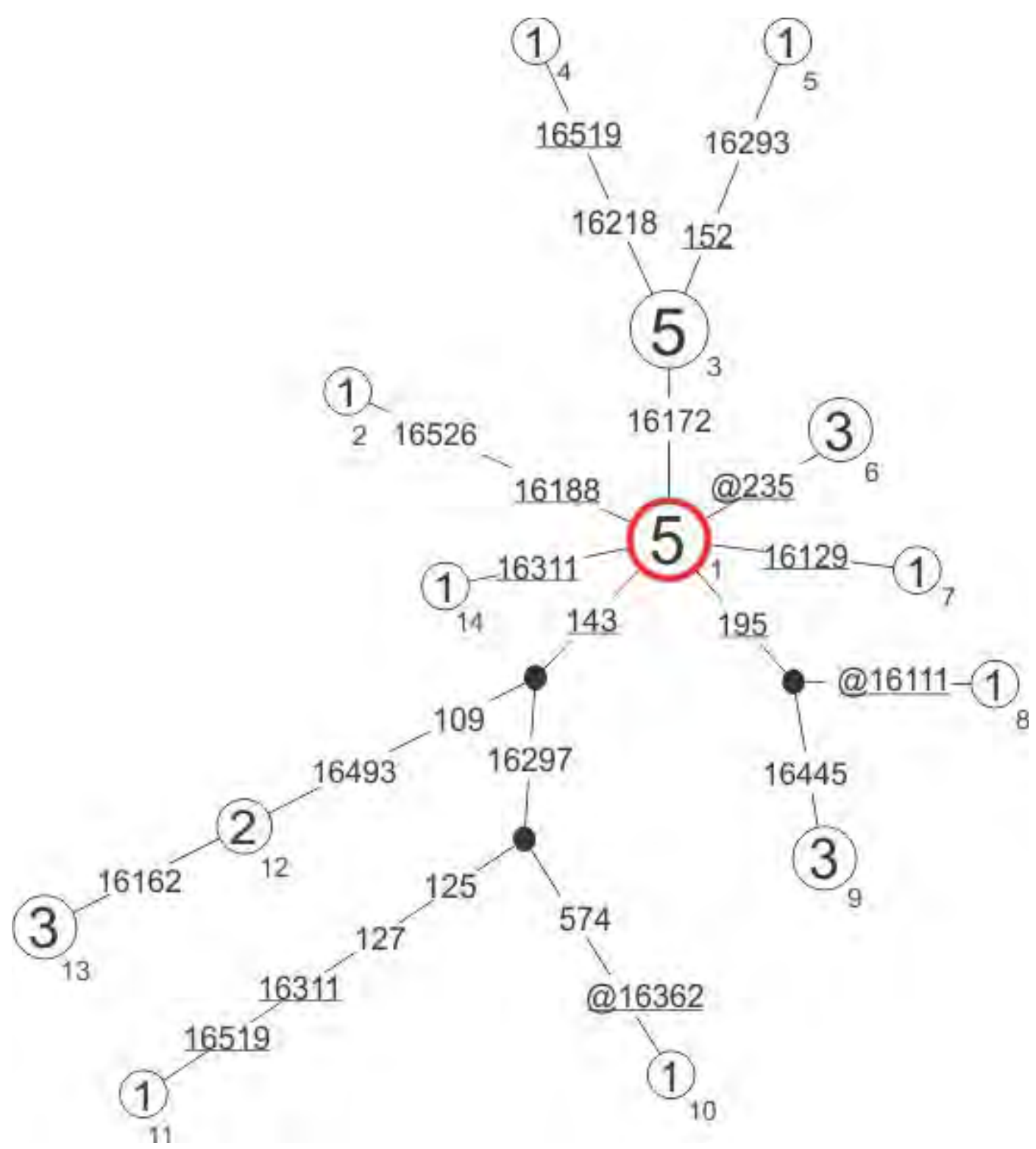


Figura 5. Red de haplotipos correspondientes a A2 no asignados.

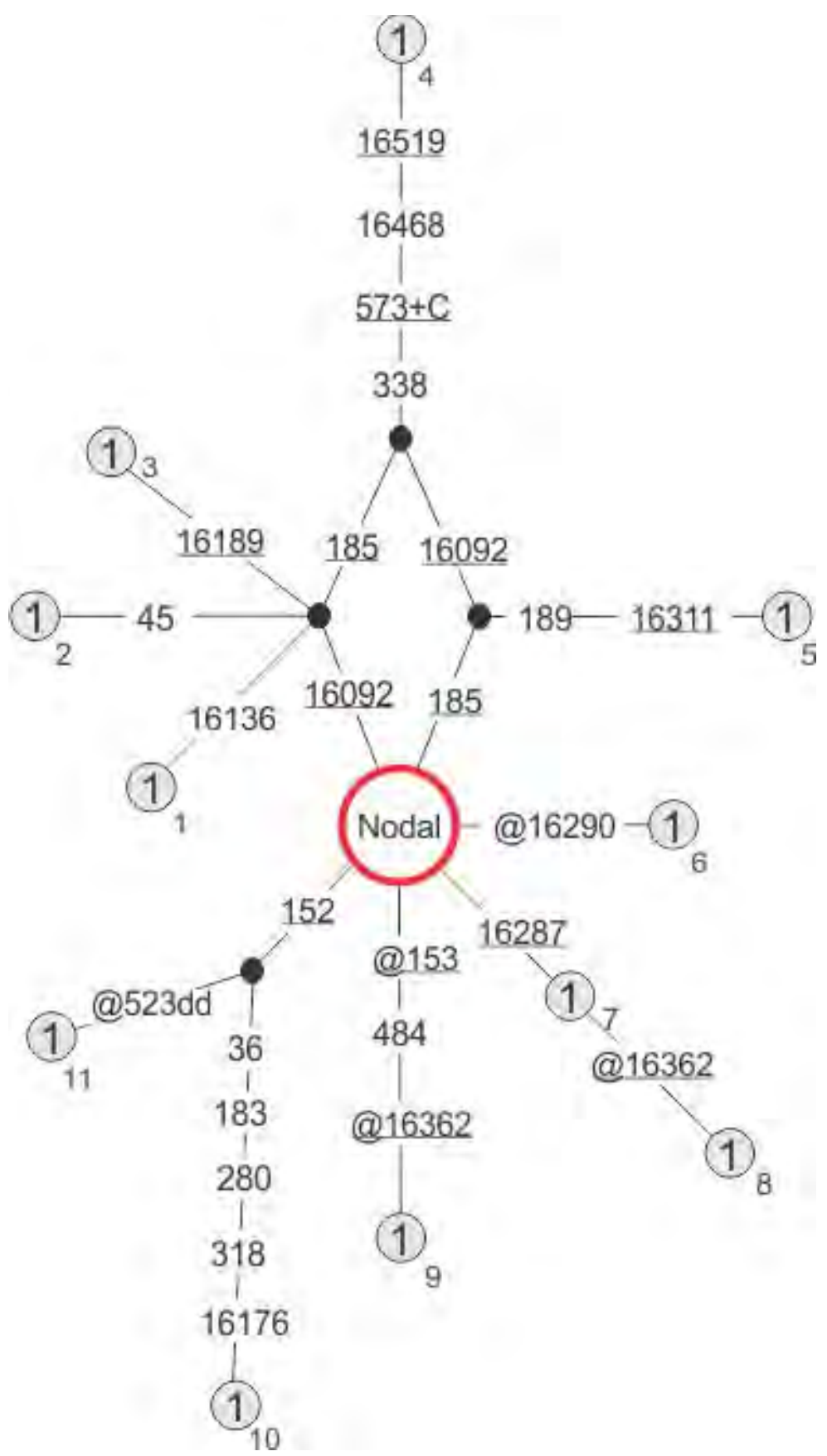




\subsubsection{Haplogrupo B2}

Debido a la gran cantidad de secuencias disponibles para este haplogrupo, no ha sido posible representar la variabilidad existente en una sola imagen. Las figuras han sido ordenadas siguiendo la numeración de las mutaciones que definen a los linajes, salvo en caso de que la necesidad de graficar el conflicto entre dos o más mutaciones por medio de ciclos o cubos impidiera respetar el orden numérico. La mutación 16182C no fue considerada en la construcción de las redes.

Mutaciones del nodal respecto de la SRCr en RC: 73263 315+C 499 16183C 161891621716519. 
Figura 6. Red de haplotipos correspondientes a B2 cuerpo 1.

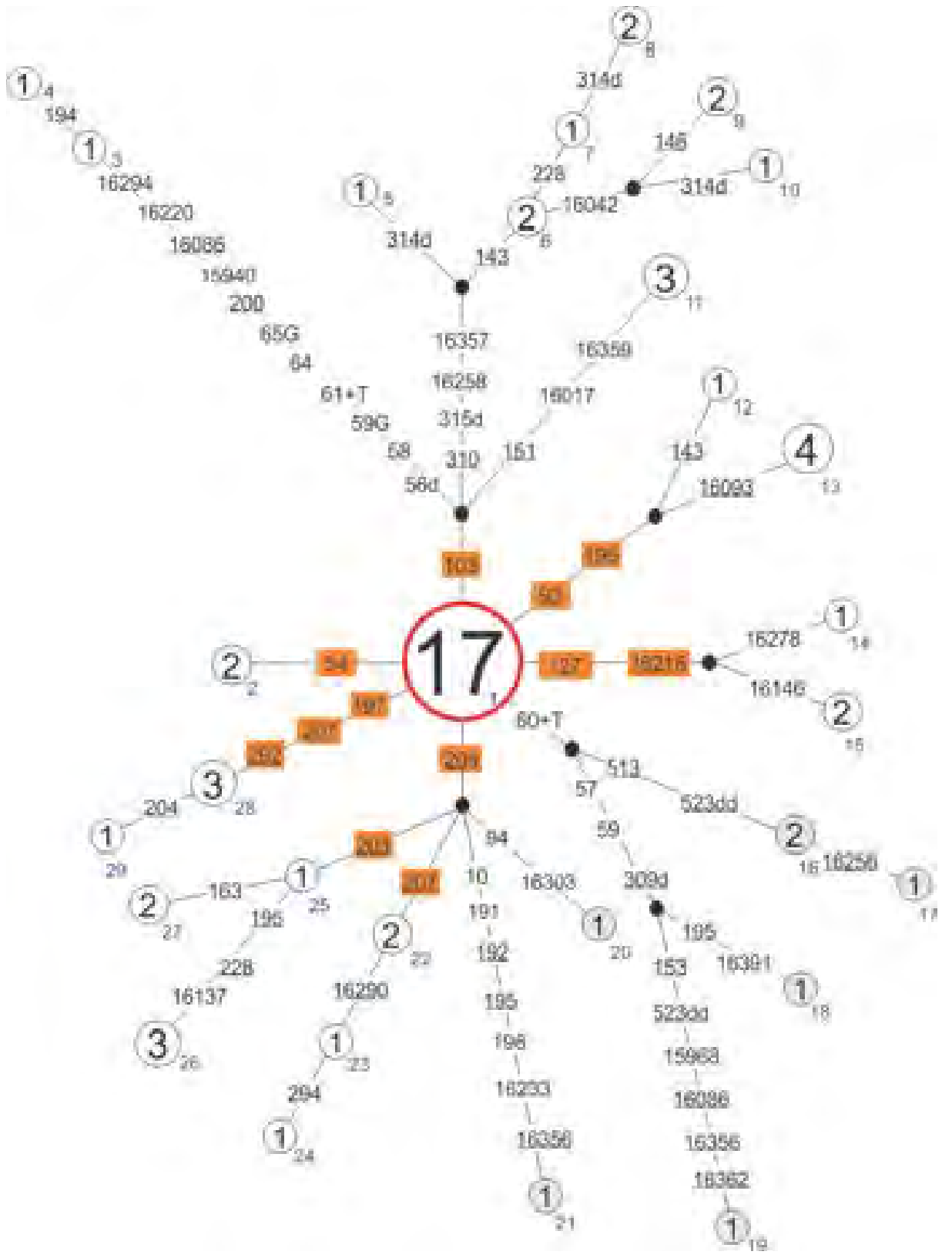

A pesar de que la inserción de una $\mathrm{T}$ en la posición 60 aparece en una rama basal, ésta mutación no es considerada para la definición de un linaje dada la inestabilidad de esa región en todo el haplogrupo B.

La posición de los haplotipos 28 y 29 podría estar asociada al haplotipo 22 pero, existe un linaje definido por 197207292 en el que se comprueba que la mutación 204 es posterior y cuya distribución geográfica está claramente asociada a la región chaqueña.

El linaje definido por la transición en 103 presenta gran diversidad interna que podría dar lugar a la definición de distintos sublinajes internos. Sin embargo, la distribución geográfica de los haplotipos que poseen 103 es coincidente, reforzando la hipótesis de ancestralidad común. 
Figura 7. Red de haplotipos correspondientes a B2 cuerpo 2.

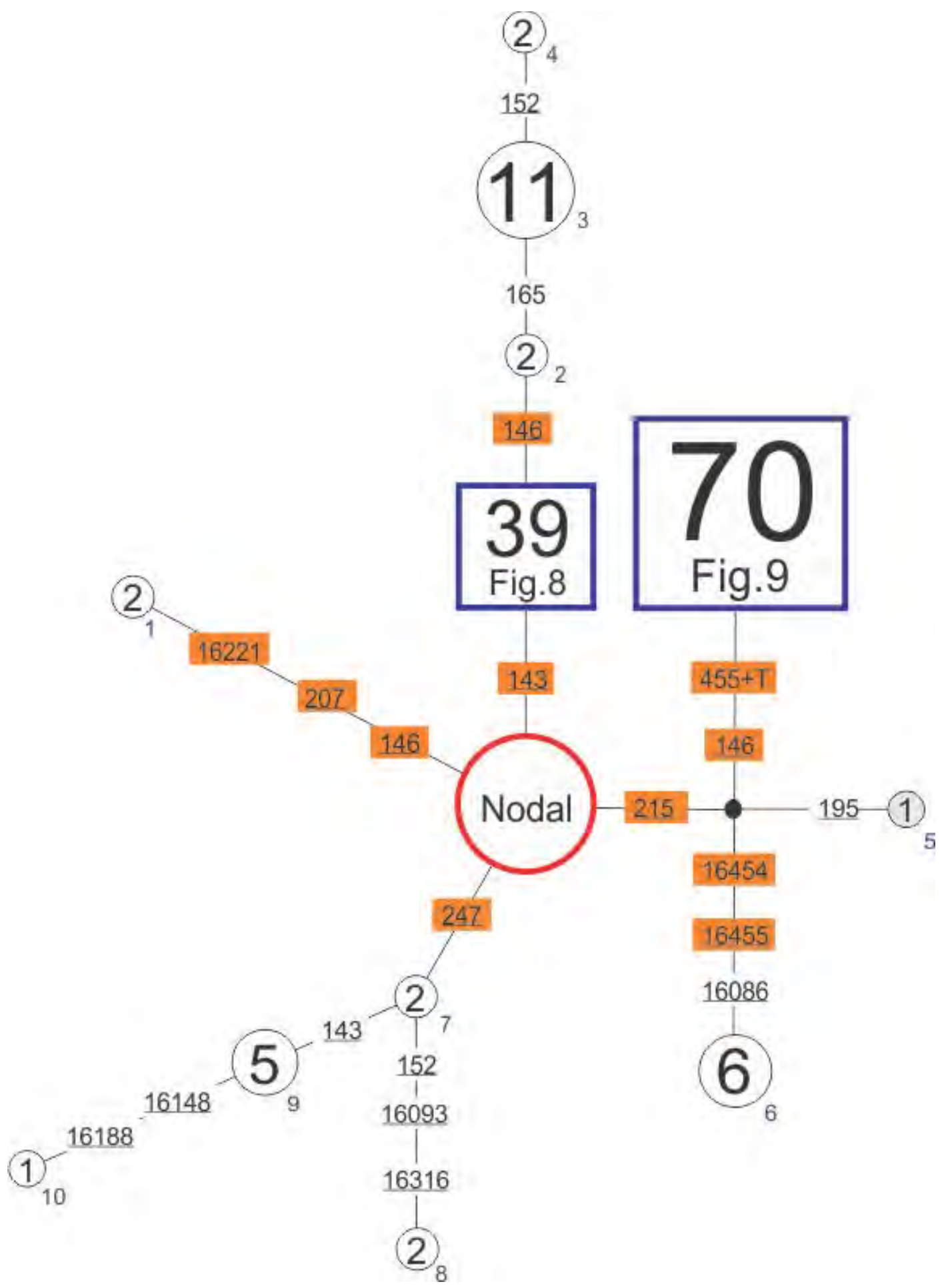


Figura 8. Red de haplotipos correspondientes a B2 + 143 .

(1) 2 16304 16093 $573+\operatorname{CccC}$ 523dd
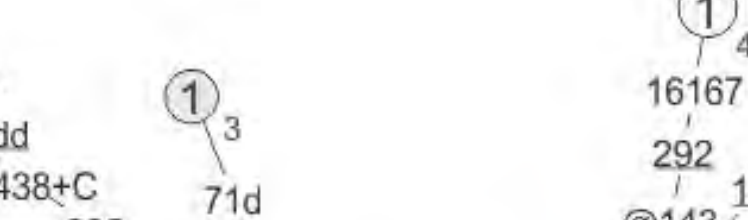
16167 292 225 19965 @143<smiles></smiles>
226 16309 Q143 16129

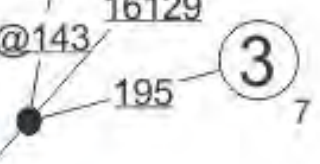

\section{9}

\section{5}

$16193 d$

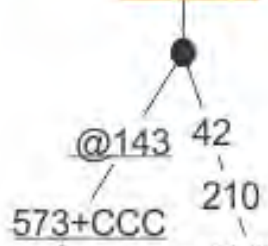

(1) 16066@16193d

(1) 13

12 (2) @42-(1) $16043 T^{150}$
(1) 6

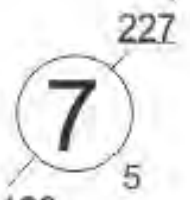


Figura 9. Red de haplotipos correspondientes a B2 + 146215 455+T.

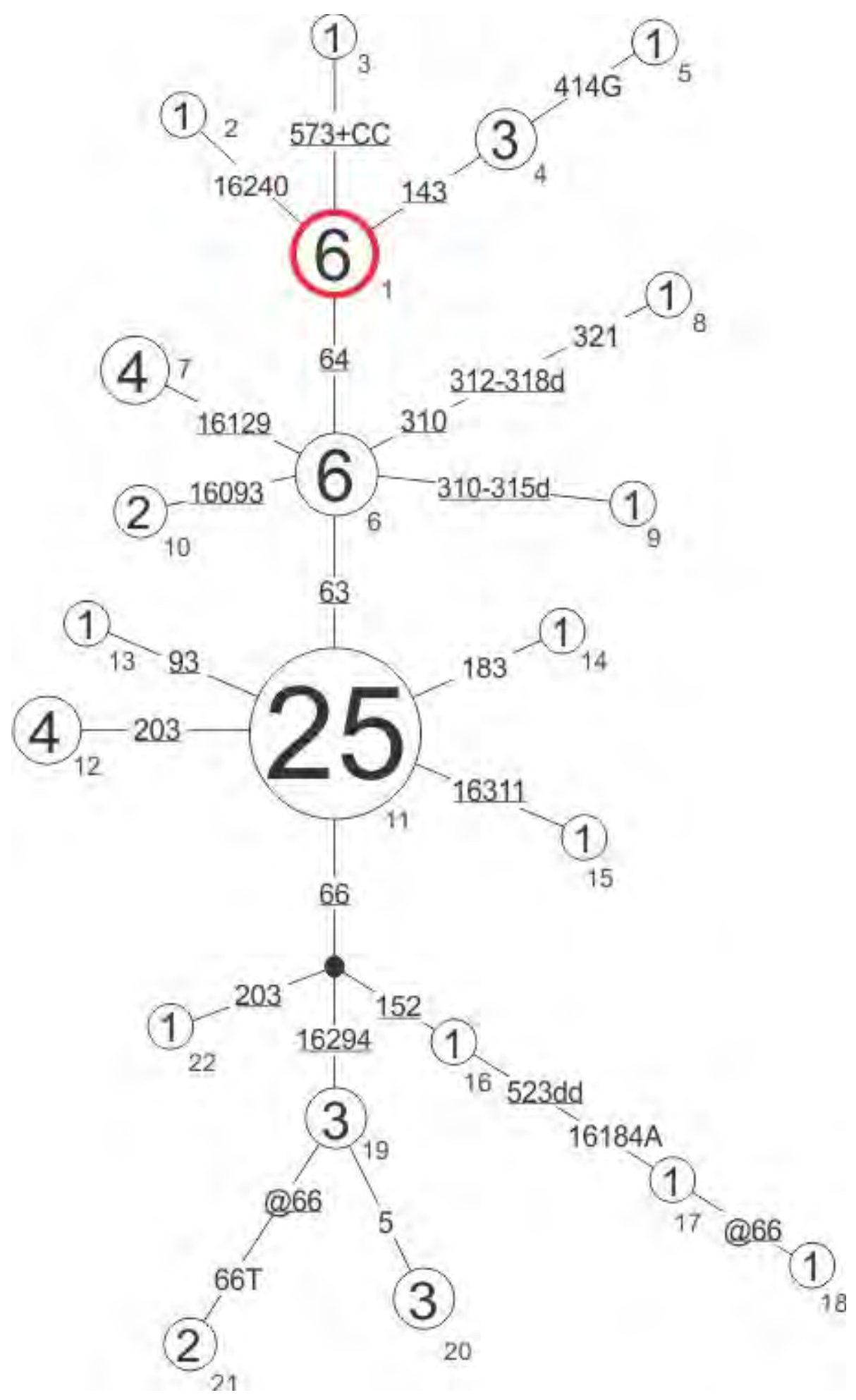


Figura 10. Red de haplotipos correspondientes a B2 cuerpo 3.

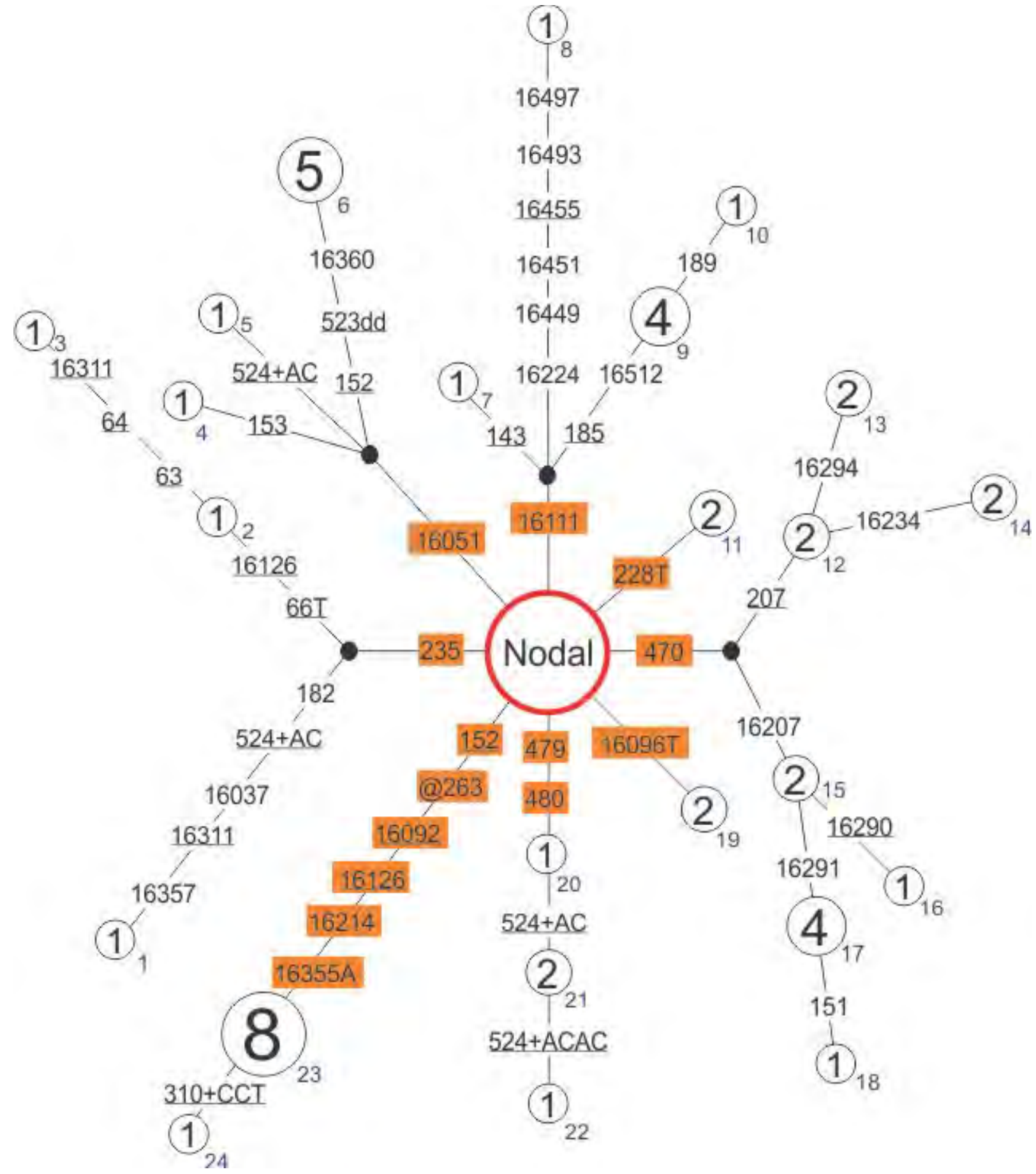

En el caso del linaje 10.23, por la información disponible de otras secuencias sudamericanas, se sabe que 16126 fue una mutación posterior a todas las otras que sostienen la rama, así que no debe considerársela en la definición del linaje. 
Figura 11. Red de haplotipos correspondientes a B2 cuerpo 4.

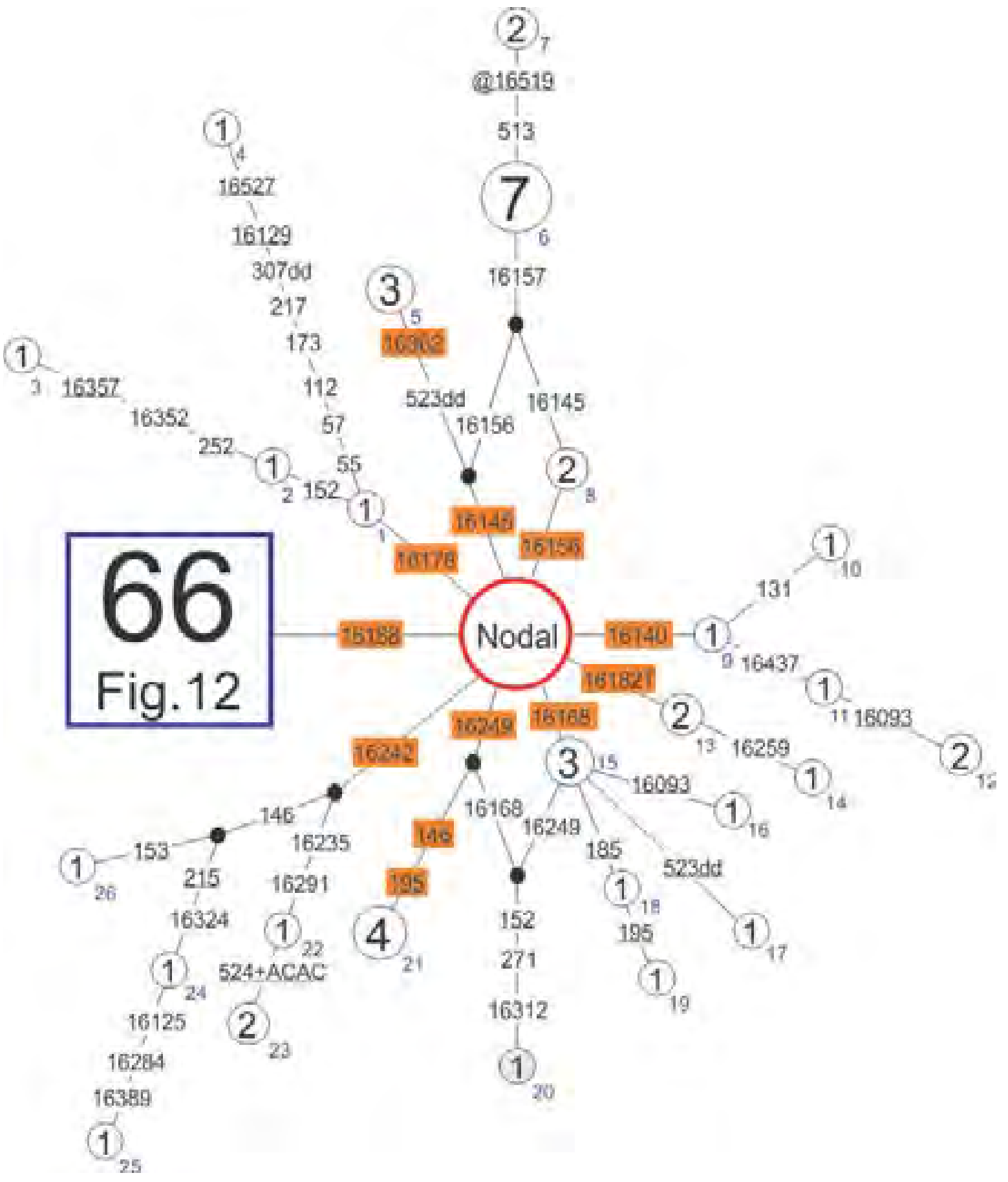

El haplotipo 20 pertenece a un linaje amazónico. 
Figura 12. Red de haplotipos correspondientes a B2 + 16188 .

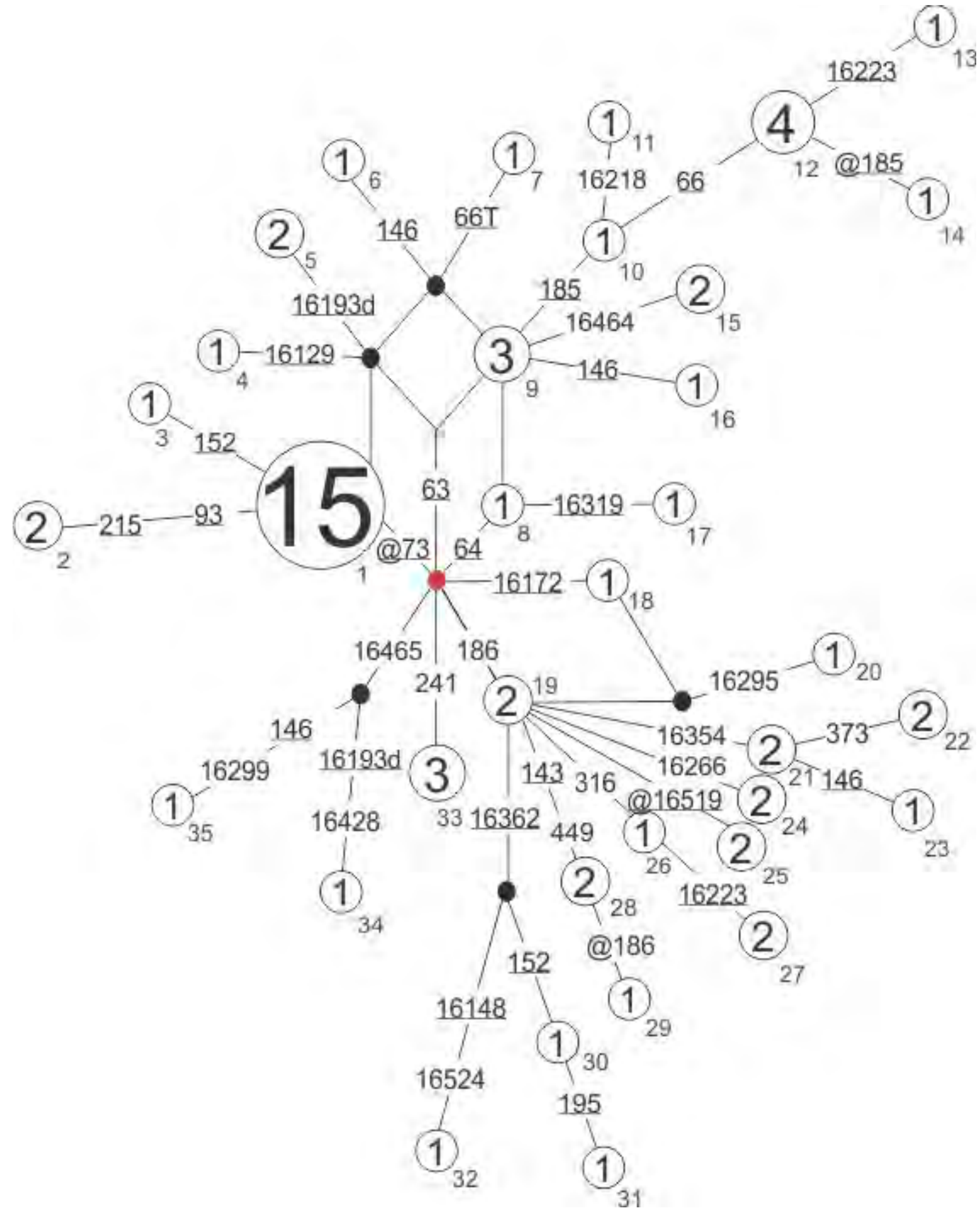

El haplotipo 12.32 comparte las mutaciones 16188 y 16148 con el haplotipo 7.10, pero por un criterio geográfico se privilegió la presencia compartida de las mutaciones $143+247$ en Tartagal. 
Figura 13. Red de haplotipos correspondientes a B2 cuerpo 5.

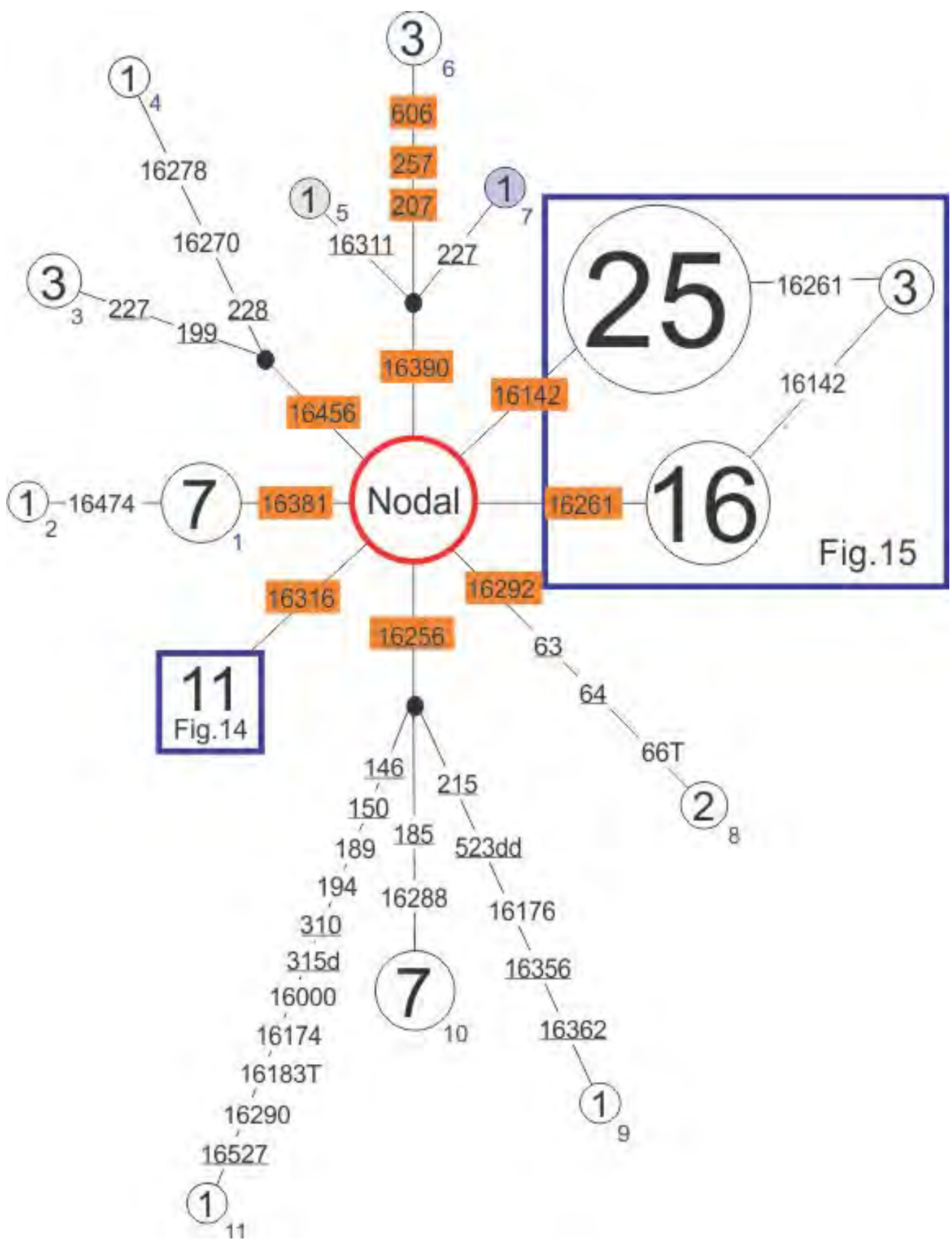

La mutación 16390 en contexto sudamericano está asociada a 470, 16142, 16454, 16168 y también a la mutación 6755 que define a un linaje amazónico en Región Control.

La pertenencia de los haplotipos 9 y 11 a 16256 está sustentada por información de secuencias completas. 
Figura 14. Red de haplotipos correspondientes a B2 +16316 .

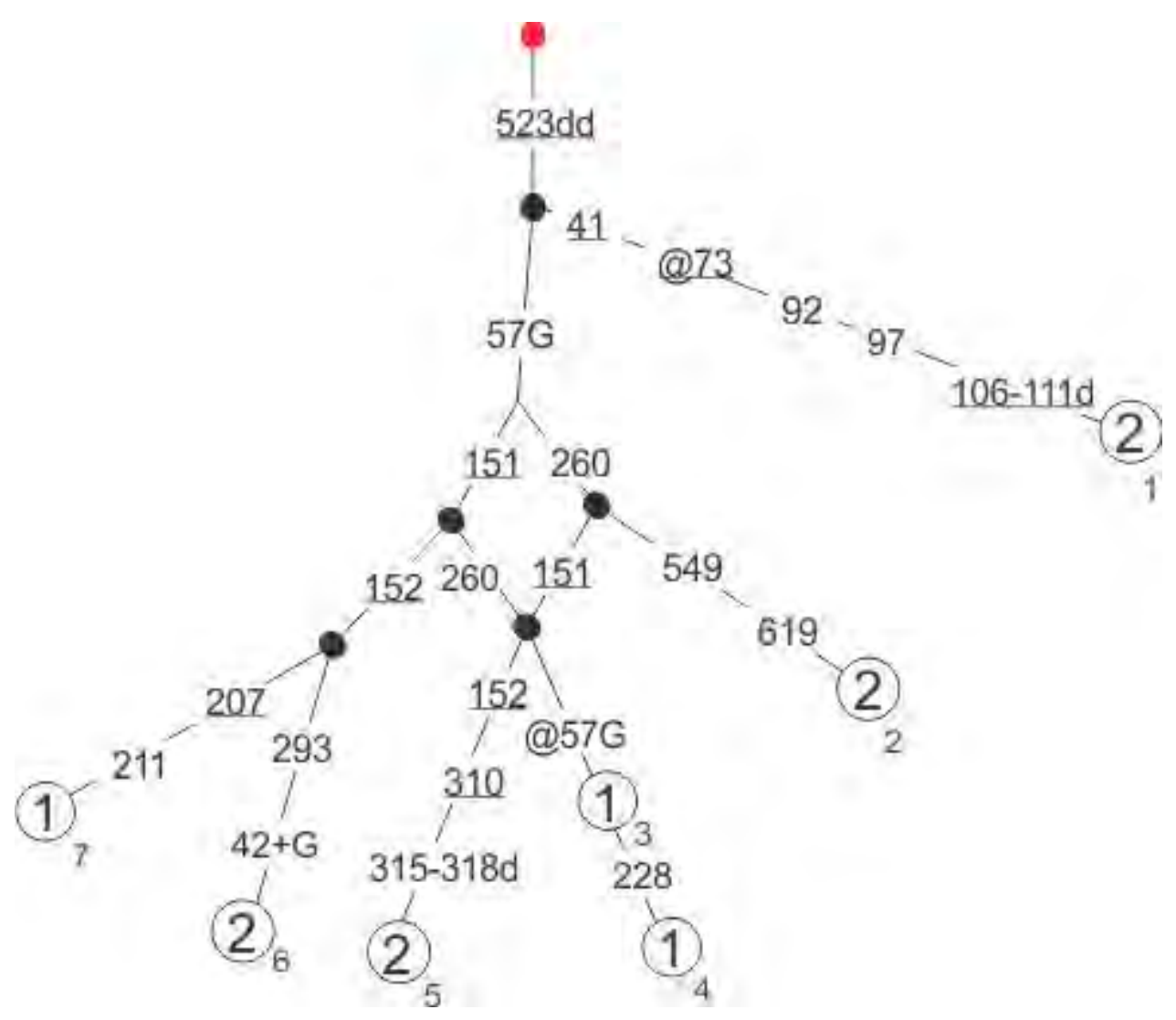


Figura 15. Red de haplotipos correspondientes a B2 + 16142 y 16261.

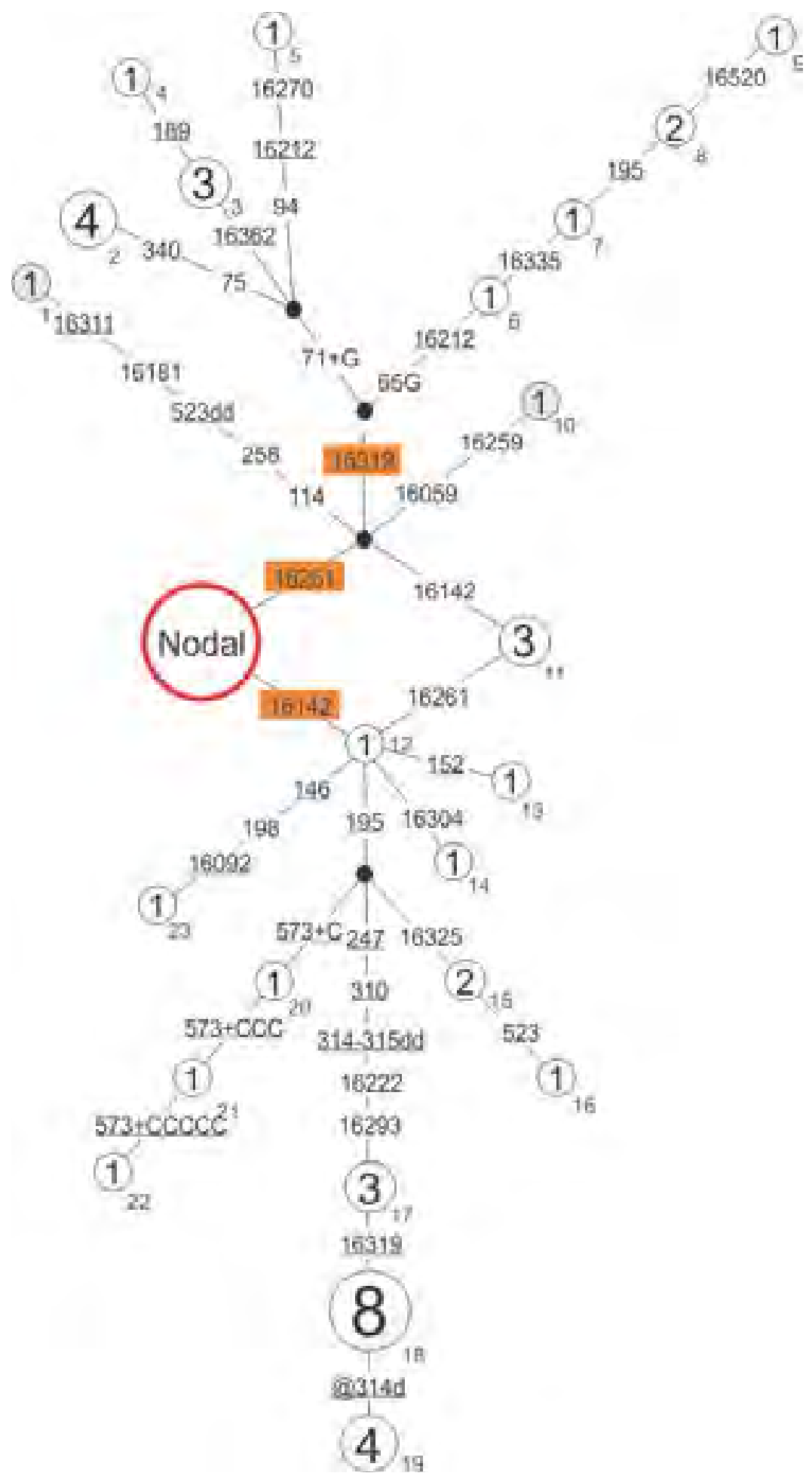

El haplotipo 11 es considerado perteneciente al linaje definido por la mutación 16142 por la coherencia geográfica del clado definido por dicha mutación. 
Figura 16. Red de haplotipos correspondientes a B2 no asignados.

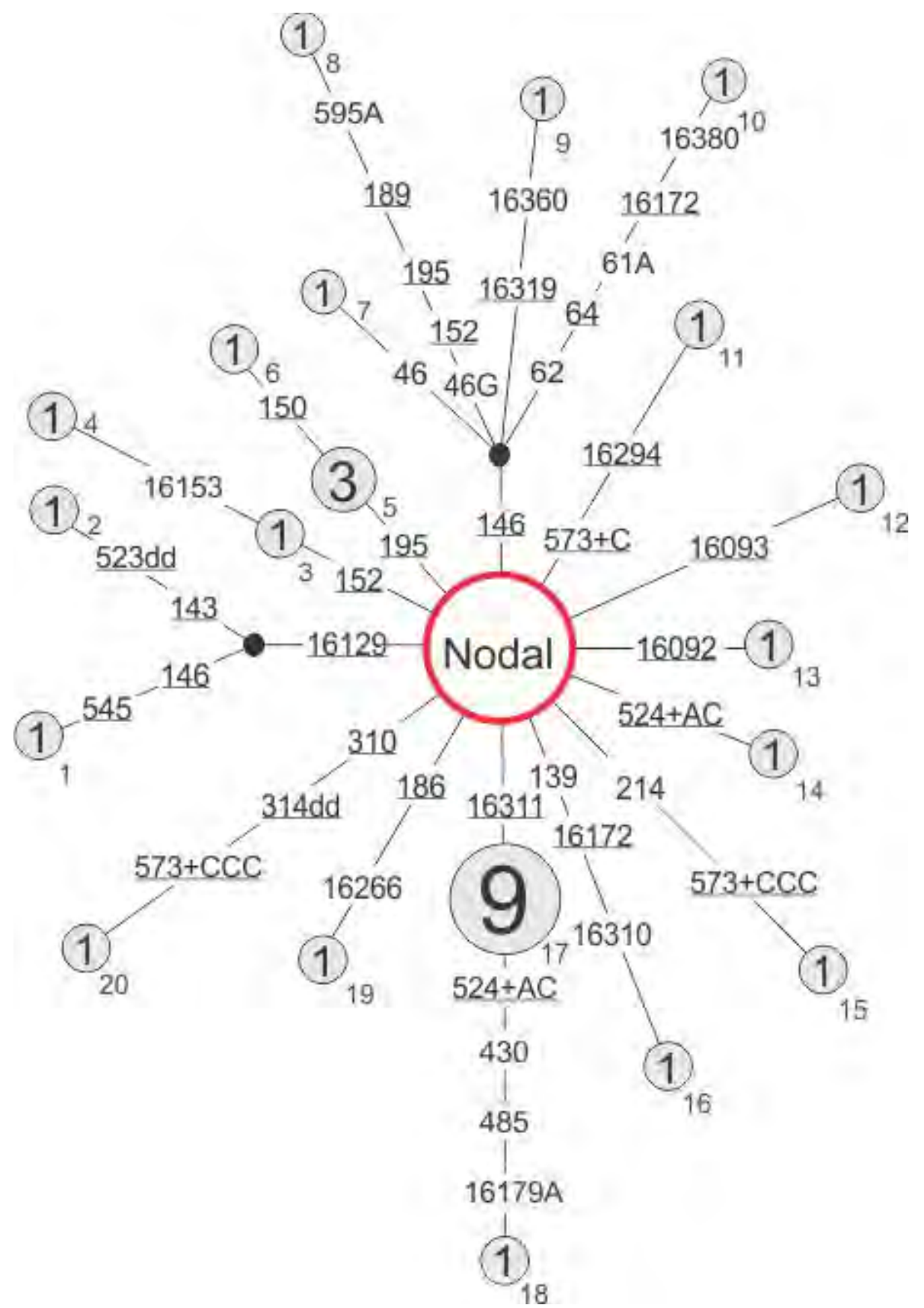




\subsubsection{Haplogrupo C1b}

Mutaciones del nodal respecto de la SRCr en RC: 73 249d 263 290-291d 315+C 489493 522-523d 16223162981632516327

Figura 17. Red de haplotipos correspondientes a C1b cuerpo.

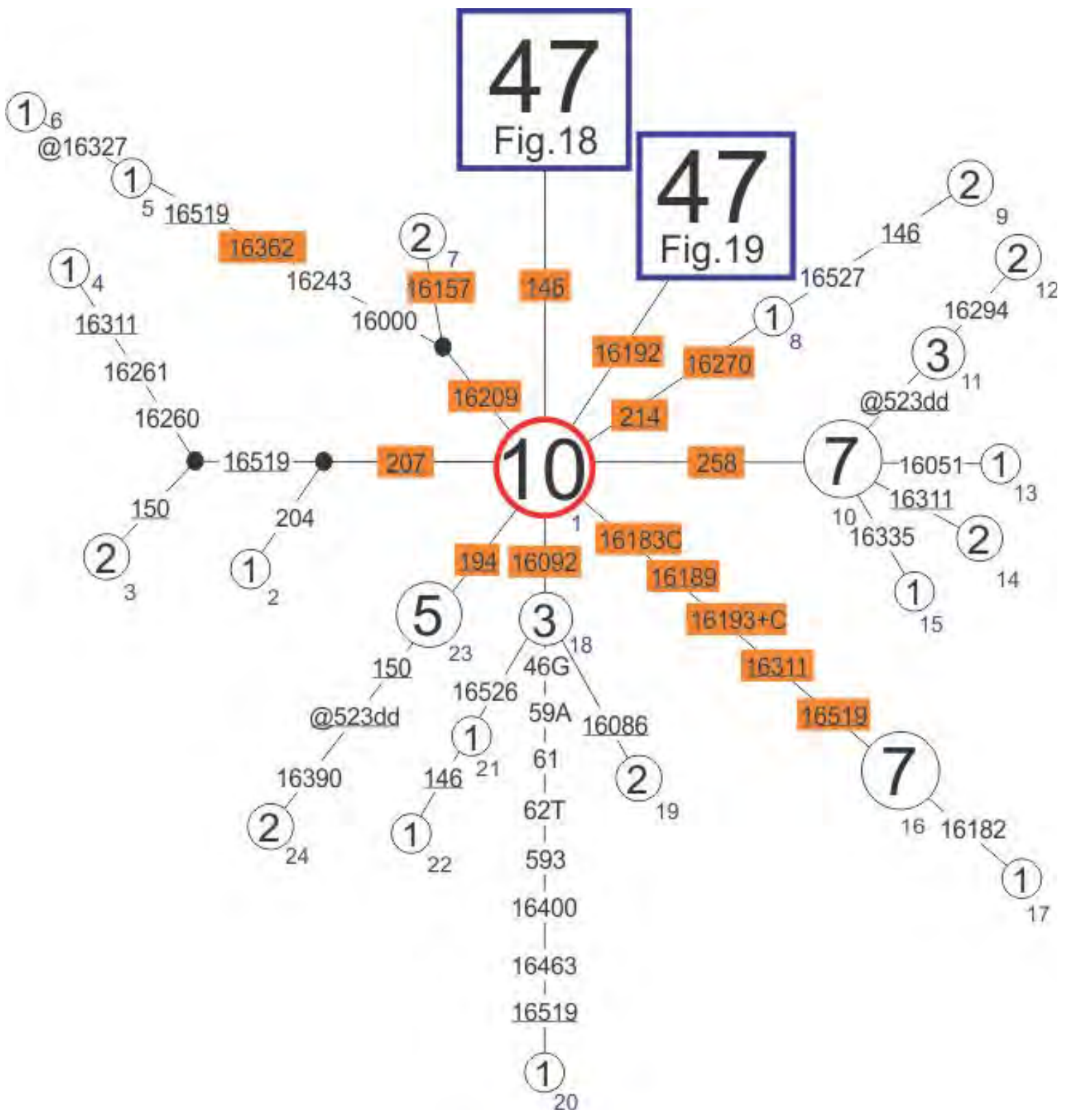

En esta red no están incluidos los haplotipos no asignados a un linaje, los cuales se muestran en la figura 20. 
Figura 18. Red de haplotipos correspondientes a C1b +146 .

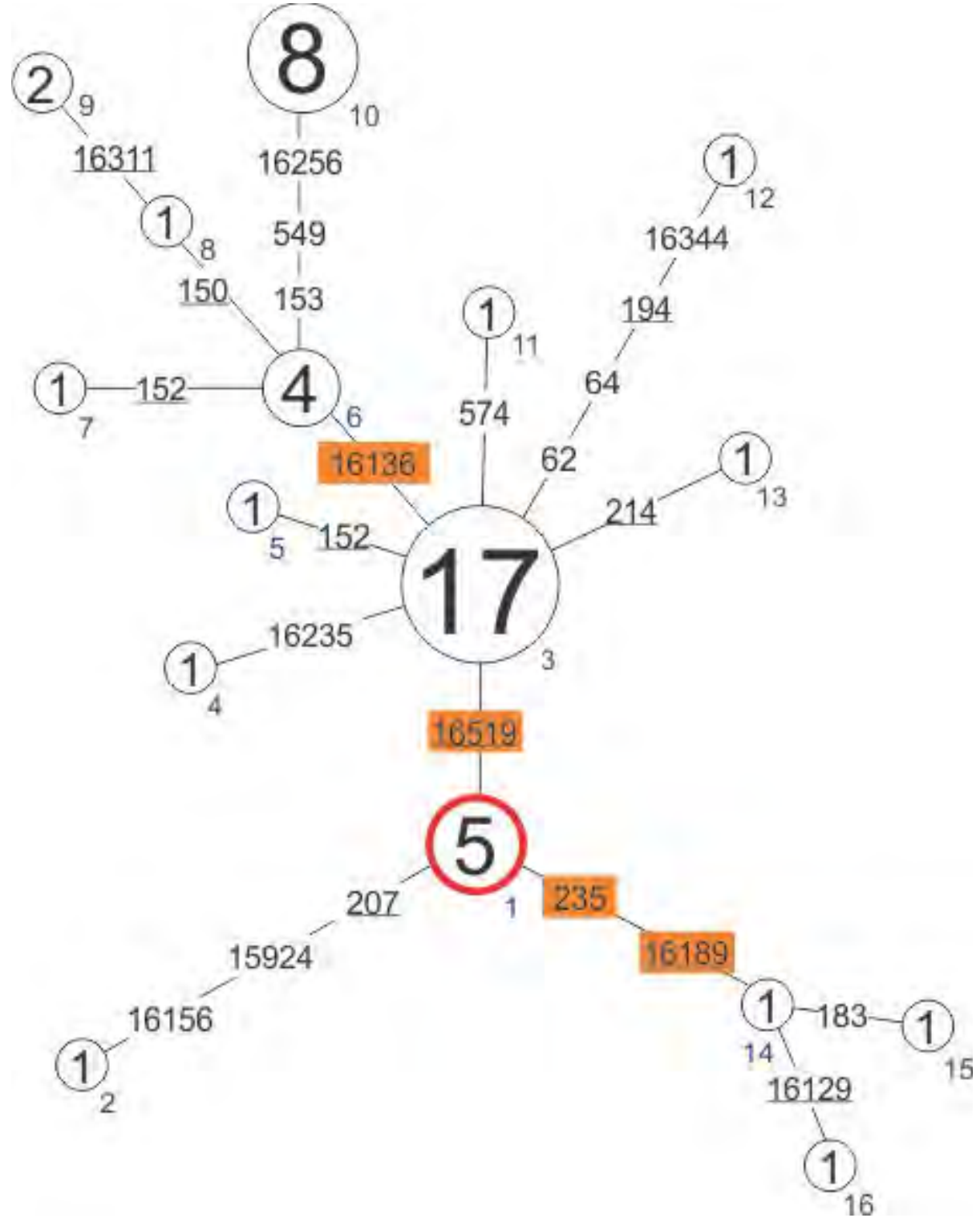


Figura 19. Red de haplotipos correspondientes a C1b +16192.

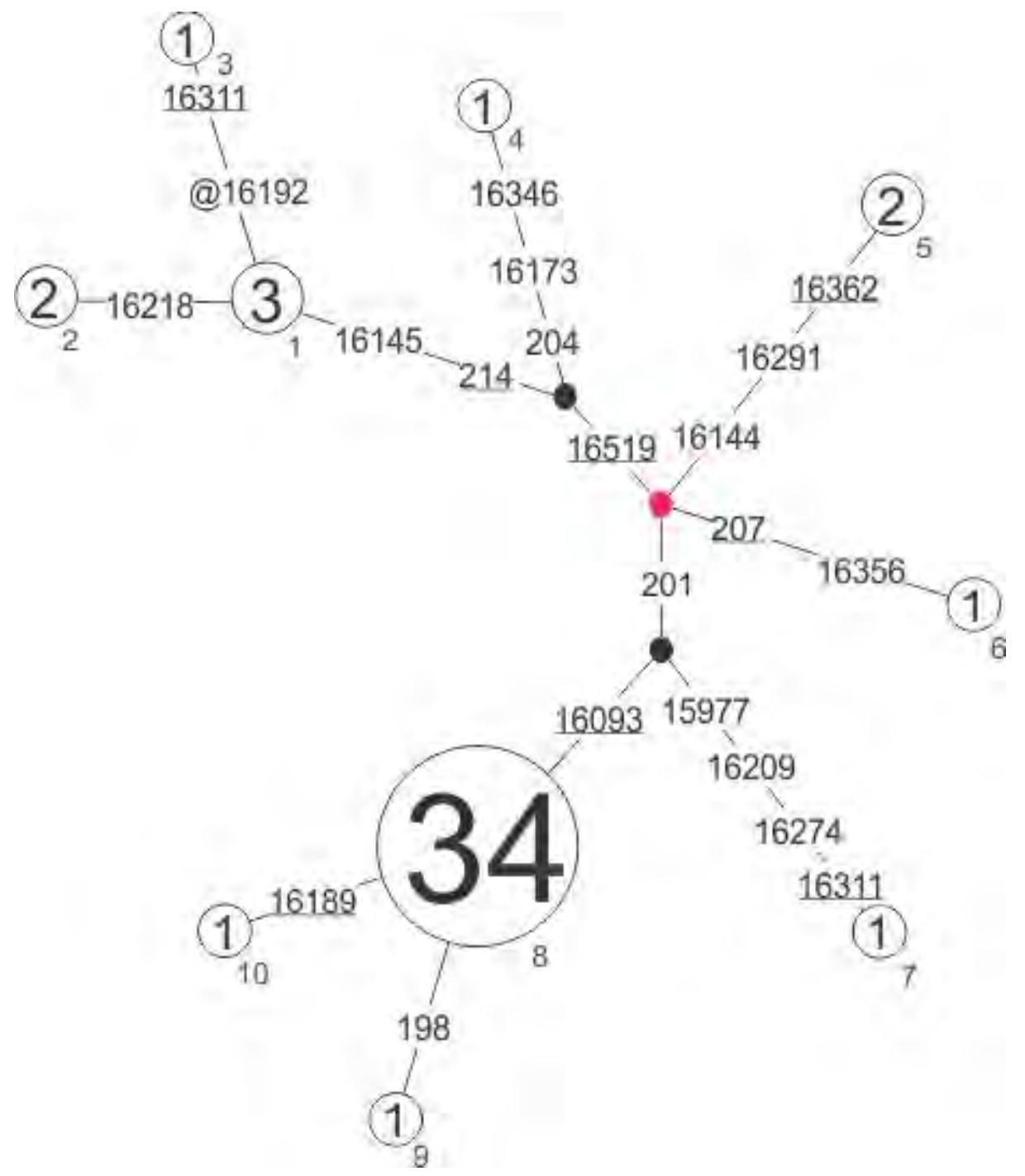


Figura 20. Red de haplotipos correspondientes a C1b No asignados.

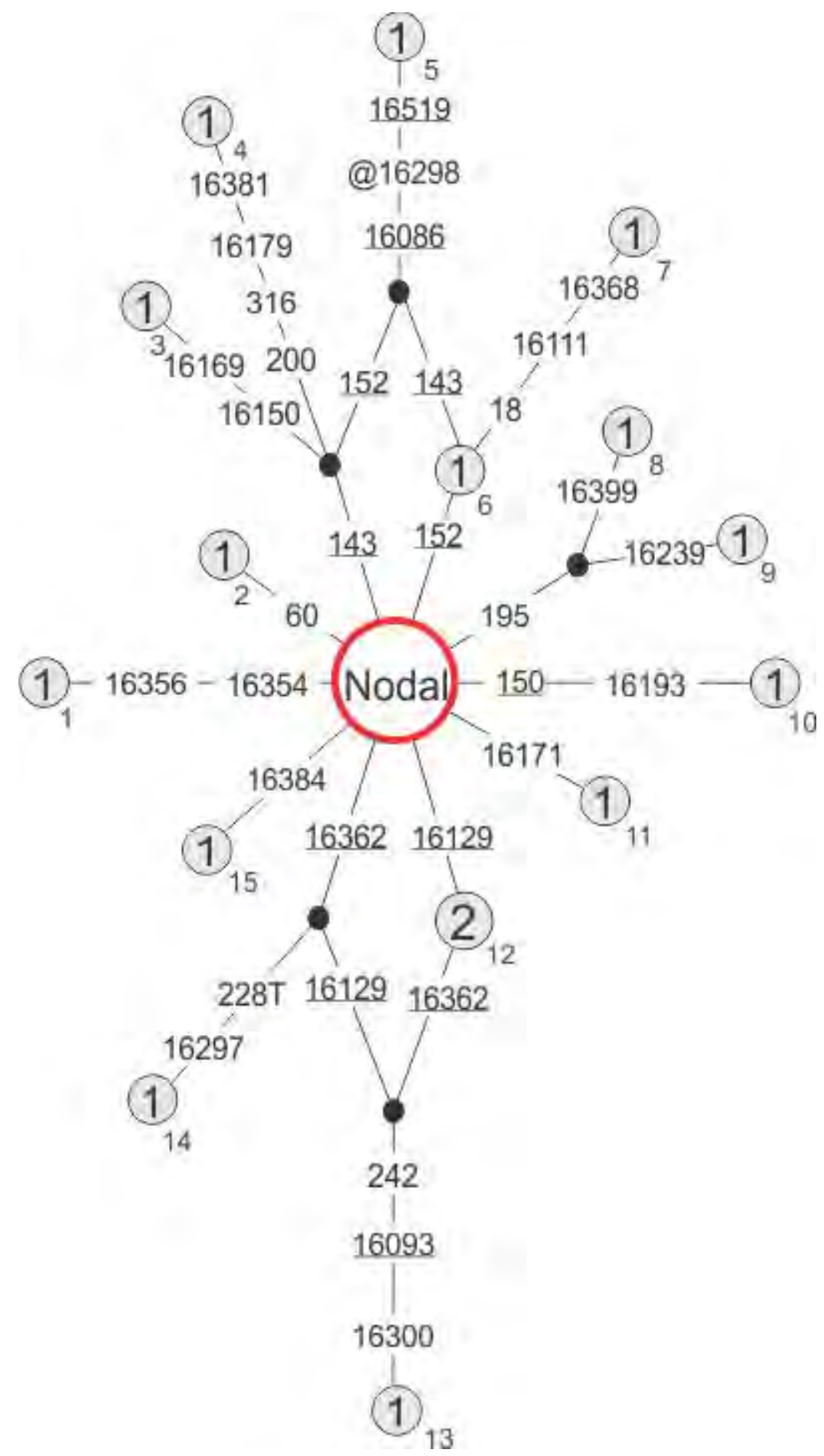




\subsubsection{Haplogrupo C1c}

Mutaciones del nodal respecto de la SRCr en RC: 73 249d 263 290-291d 315+C 489 (15930) 16223 162981632516327

Figura 21. Red de haplotipos correspondientes a C1c.

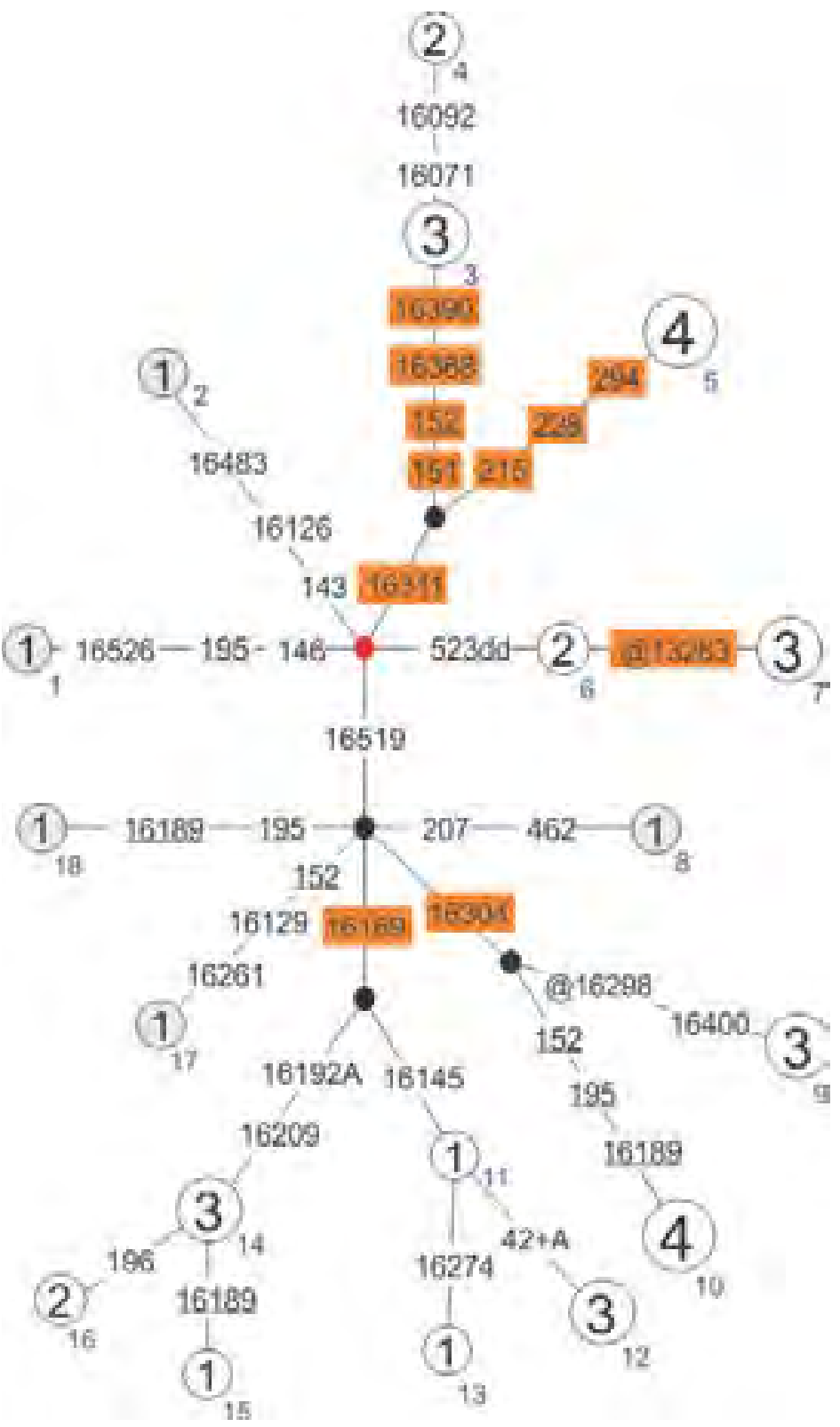

El subhaplogrupo definido por 16304 fue identificado en muestras de Maimará y de La Quiaca, donde no fue secuenciada la posición 15930, de modo que la asignación a C1c está basada en la ausencia de 16051 y 493. 


\subsubsection{Haplogrupo C1d}

Mutaciones del nodal respecto de la SRCr en RC: 73194 249d 263 290-291d 315+C 489 522-523d 1605116223162981632516327

Figura 22. Red de haplotipos correspondientes a C1d.

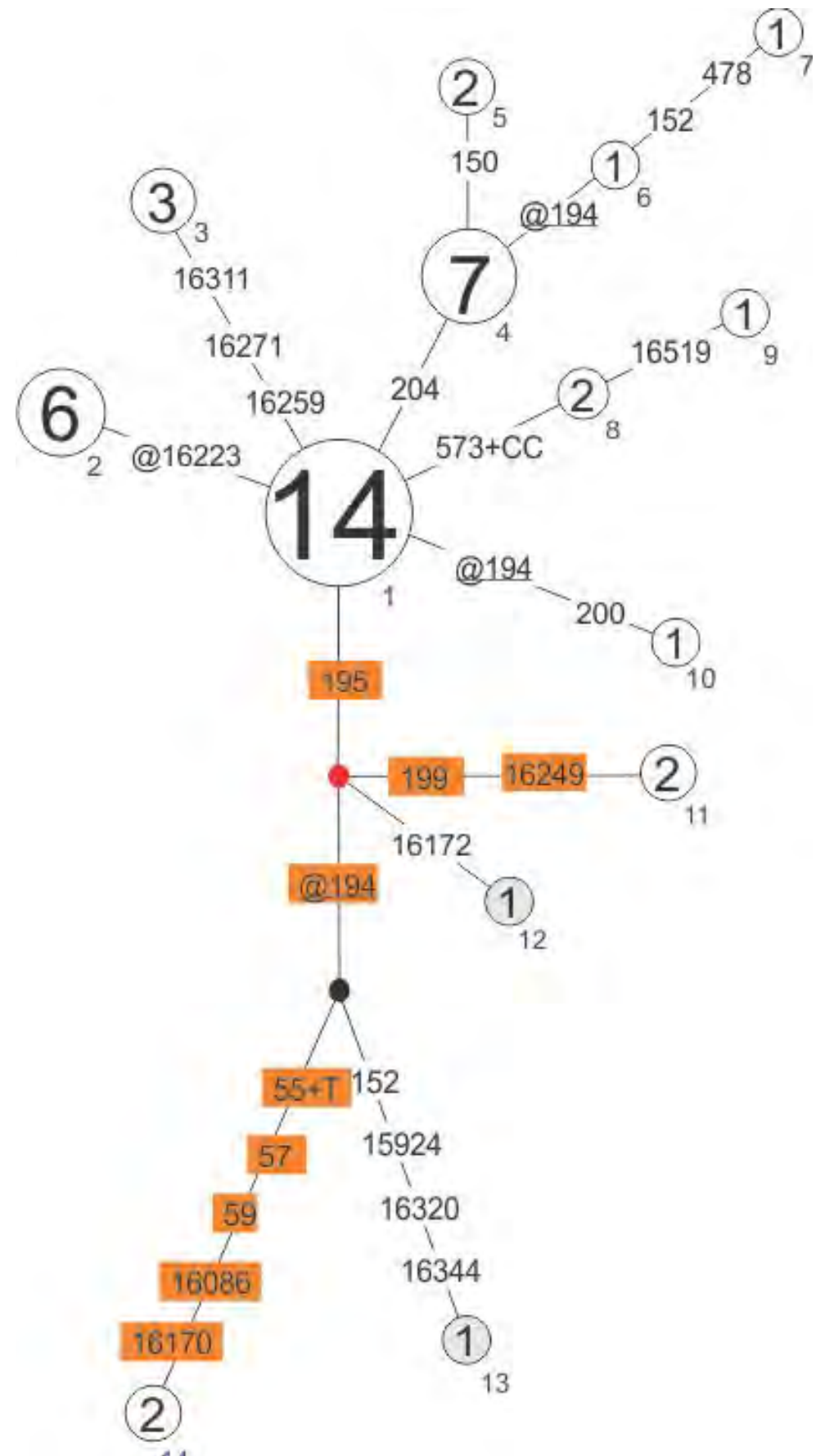




\subsubsection{Haplogrupo C4c}

Mutaciones del nodal respecto de la SRCr en RC: 73 249d 263 315+C 489162231629816327

Figura 23. Red de haplotipos correspondientes a C4c.

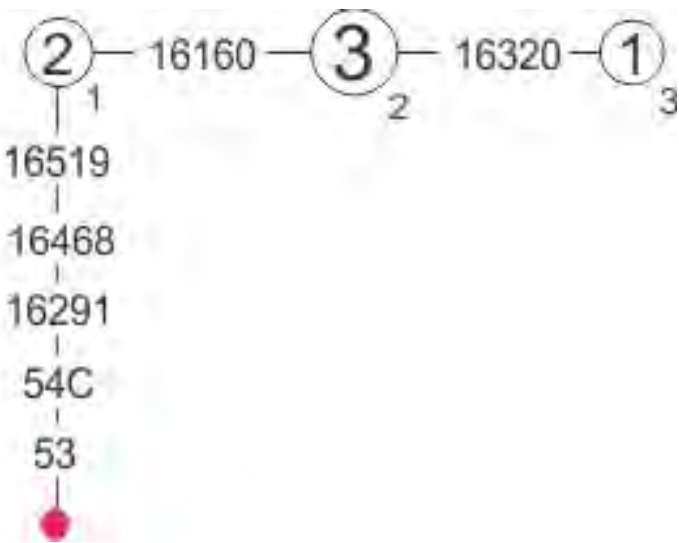




\subsubsection{Haplogrupo D1}

Mutaciones del nodal respecto de la SRCr en RC: 73263 315+C 489162231632516362

Figura 24. Red de haplotipos correspondientes a D1 cuerpo.

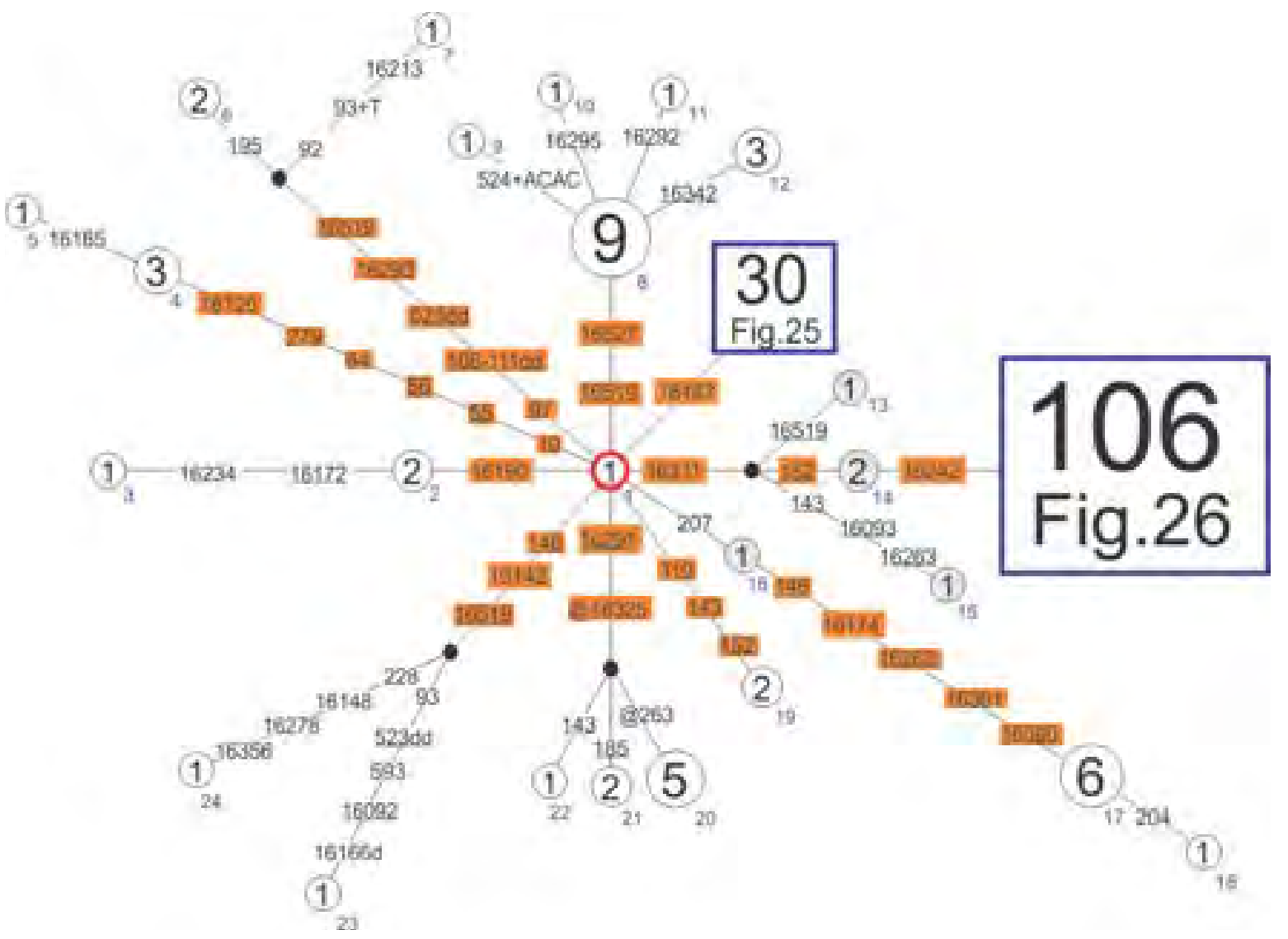

En esta red no están incluidos los haplotipos no asignados, los cuales se muestran en la figura 27. 
Figura 25. Red de haplotipos correspondientes a D1 + 16187 .

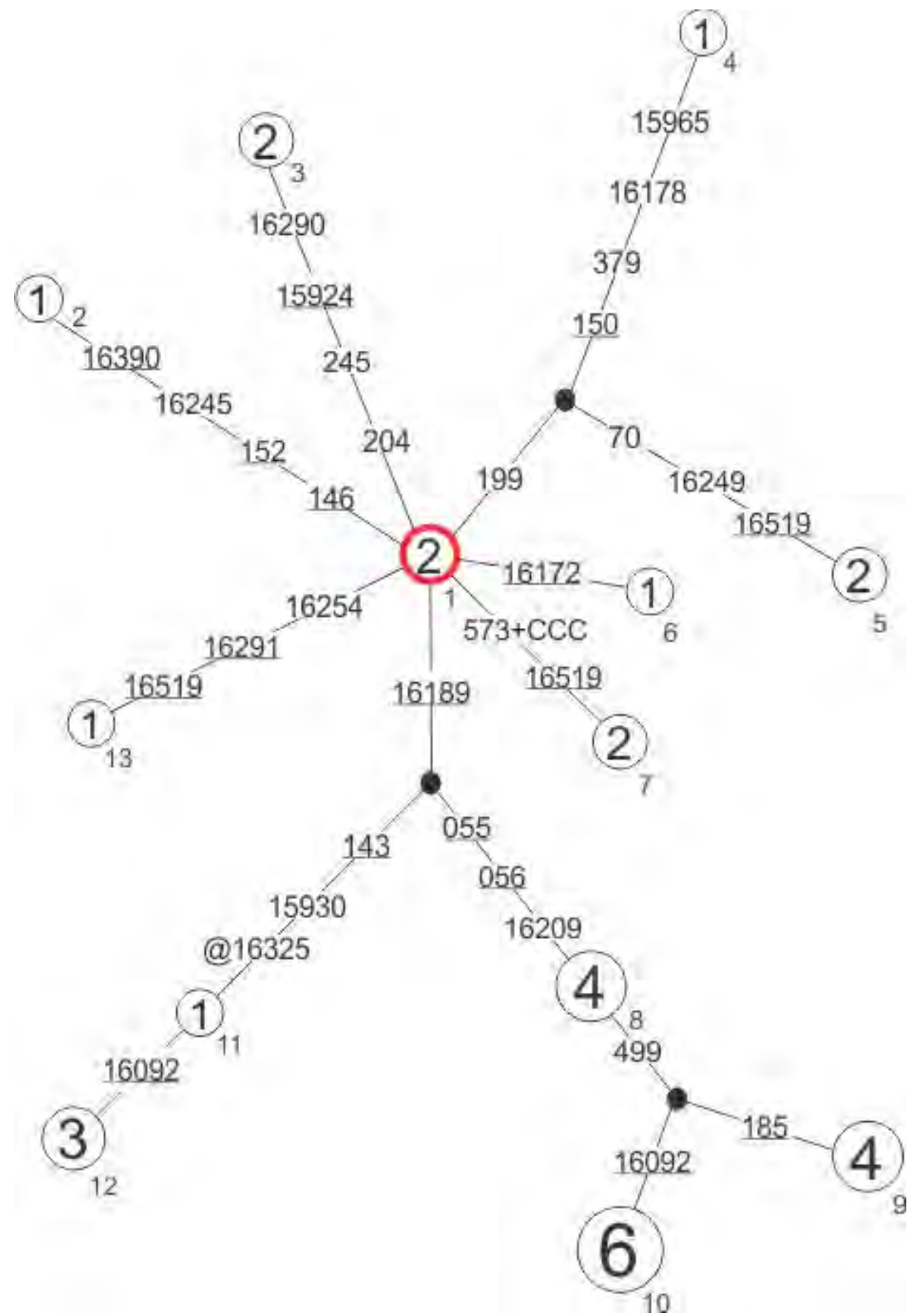


Figura 26. Red de haplotipos correspondientes a D1 + 1521624216311.

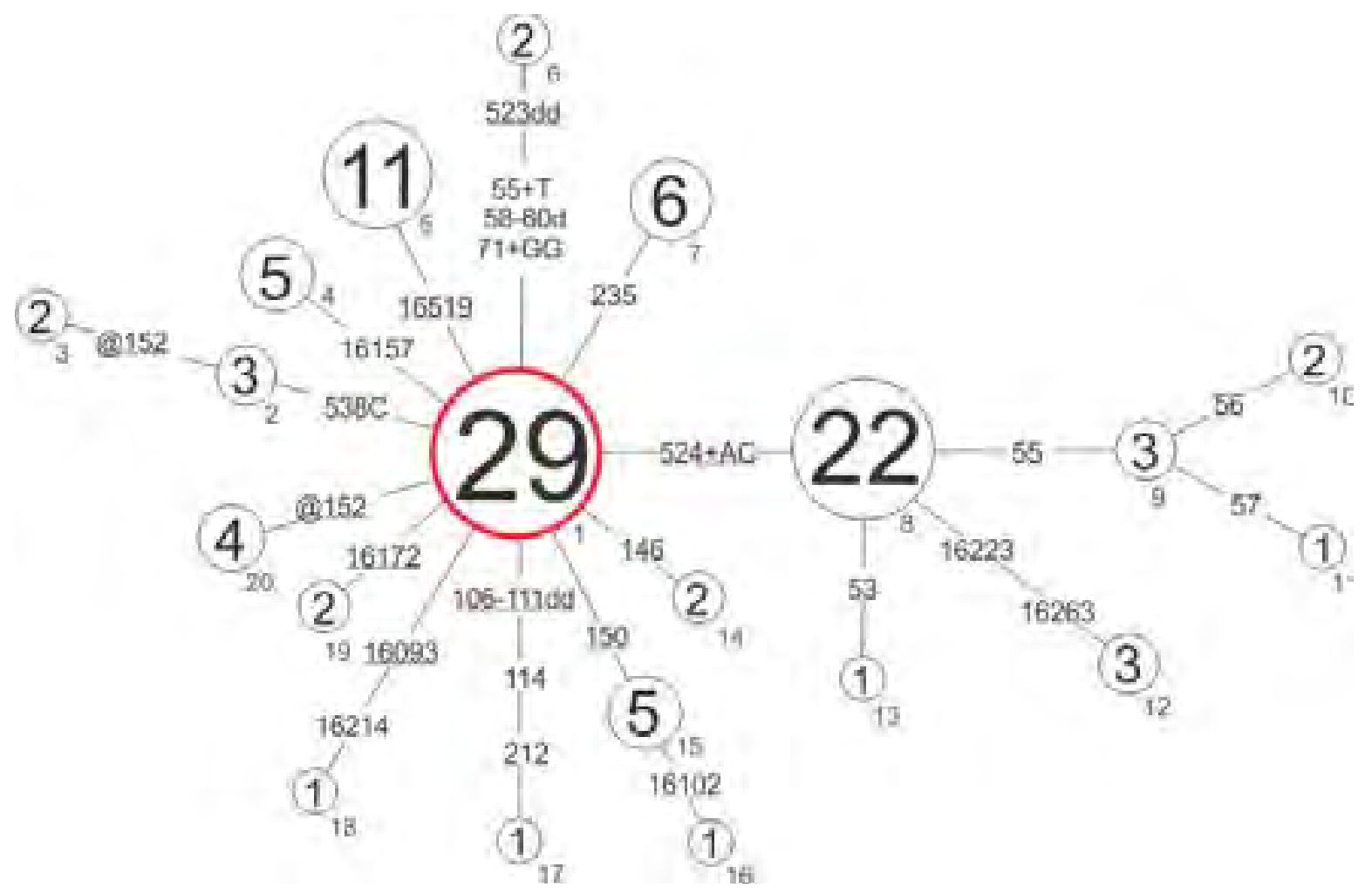


Figura 27. Red de haplotipos correspondientes a D1 No asignados.

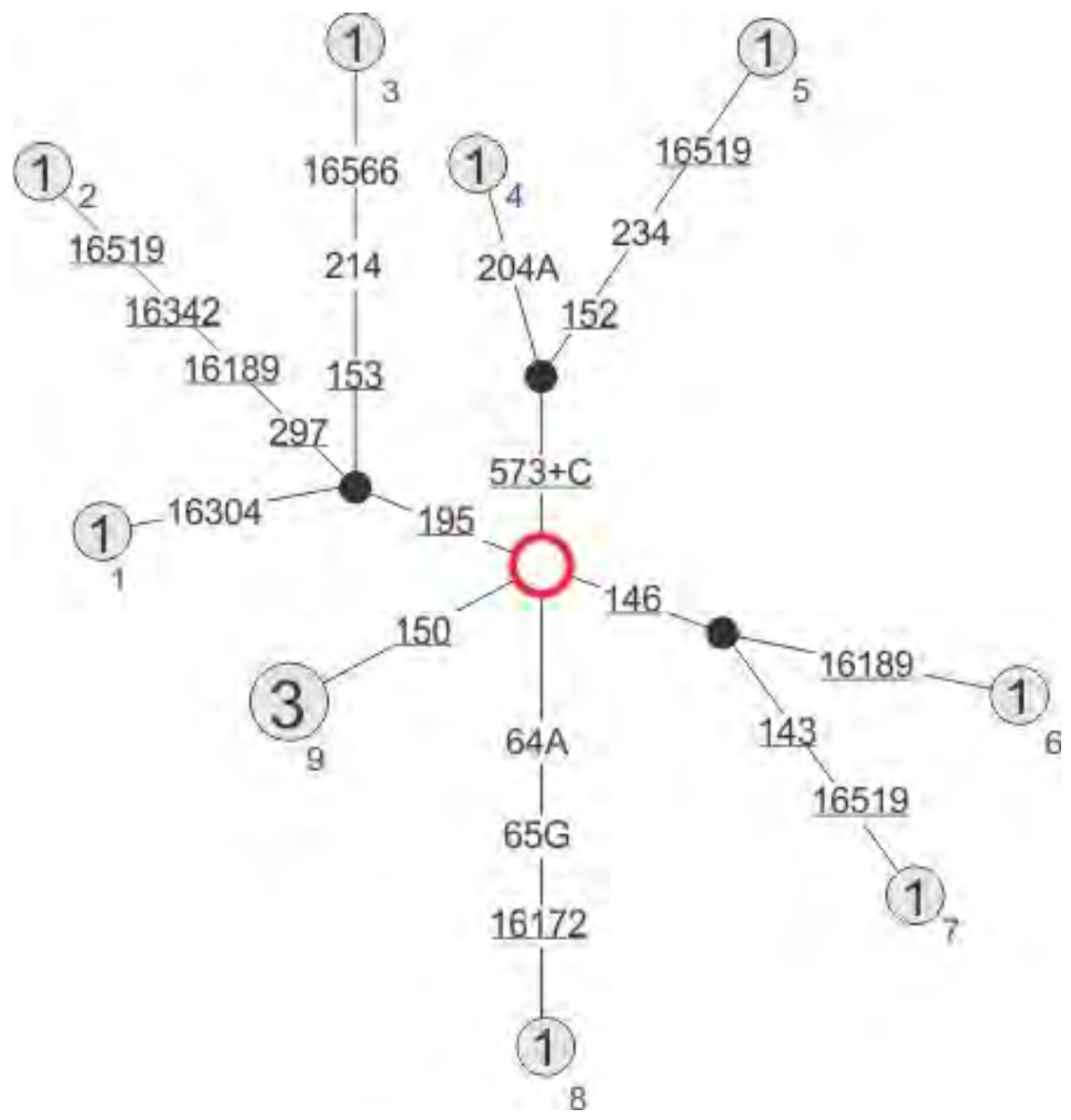




\subsubsection{Haplogrupo D4h3a}

Mutaciones del nodal respecto de la SRCr en RC: 73152263 315+C 48916223162411630116342 16362

Figura 28. Red de haplotipos correspondientes a D4h3a.

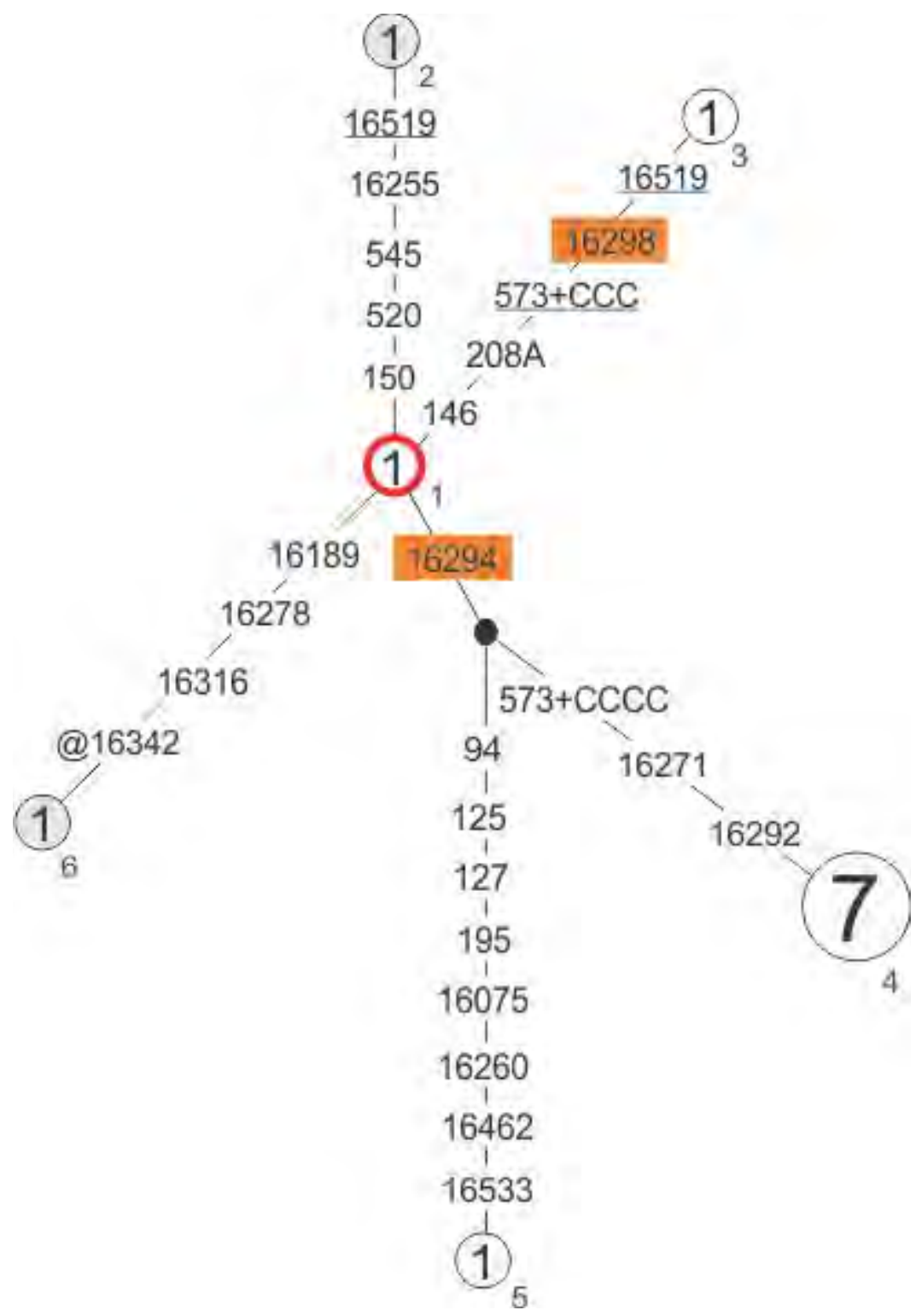


7.2.4. FRECUENCIA DE CLADOS POR POBLACIÓN.

\begin{tabular}{|c|c|c|c|c|c|c|c|c|c|c|c|c|c|c|c|c|c|c|c|c|c|c|c|c|}
\hline 는 & 文 & $\boldsymbol{N}$ & $\mathbf{N}$ & $\mid \boldsymbol{\infty}$ & 0 & $\sigma$ & $m$ & \begin{tabular}{|l|}
$\ln$ \\
\end{tabular} & $\theta$ & $m$ & $N$ & $N$ & $\mathbf{N}$ & $\mathbf{N}$ & \begin{tabular}{|l|}
$N \mid$ \\
\end{tabular} & $N$ & \begin{tabular}{l|l}
$m$ & 1
\end{tabular} & $\begin{array}{lll}0 & 0\end{array}$ & \begin{tabular}{l|l} 
& 6
\end{tabular} & \begin{tabular}{l|l} 
& $N$
\end{tabular} & \begin{tabular}{l|l|}
$\mathbf{v}$ & $m$
\end{tabular} & $|m|$ & $N$ & $\stackrel{+}{\sim}$ \\
\hline ơ & $N$ & (n) & $N$ & -1 & 0 & $N$ & 0 & \begin{tabular}{|l|}
+ \\
\end{tabular} & 0 & $F$ & 0 & न & 0 & $\sim$ & \begin{tabular}{|l|}
0 \\
\end{tabular} & \begin{tabular}{l|l}
+1 \\
\end{tabular} & $\mathrm{~N}=$ & $\begin{array}{lll}4 \\
\end{array}$ & \begin{tabular}{l|l}
0 & 1
\end{tabular} & $\begin{array}{lll}-10 \\
\end{array}$ & 50 & 0 & 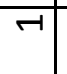 & ని \\
\hline$\stackrel{\circlearrowleft}{E}$ & $N$ & $\infty$ & 0 & 0 & 0 & 0 & 0 & 0 & 0 & 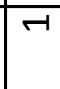 & 0 & $\nabla$ & 0 & 0 & \begin{tabular}{|l|}
0 \\
\end{tabular} & $v$ & $0 / 6$ & $0 / 6$ & \begin{tabular}{l|l}
0 & 1
\end{tabular} & \begin{tabular}{l|l}
$N$ \\
\end{tabular} & \begin{tabular}{l|l|}
-1 & -1
\end{tabular} & 0 & $\sim$ & $\tilde{N}$ \\
\hline$\sum_{\Sigma}$ & $m$ & $N$ & 0 & 0 & 0 & 6 & 0 & \begin{tabular}{|l|}
-1 \\
\end{tabular} & 0 & 0 & 0 & 0 & 0 & 0 & \begin{tabular}{|l|}
0 \\
\end{tabular} & $\begin{array}{ll}0 \\
\end{array}$ & \begin{tabular}{l|l}
${ }^{2}$ & 1
\end{tabular} & \begin{tabular}{l|l}
$\mathrm{r}$ \\
\end{tabular} & \begin{tabular}{l|l}
$N$ &
\end{tabular} & \begin{tabular}{l|l} 
\\
\end{tabular} & \begin{tabular}{l|l}
-1 & 0
\end{tabular} & 0 & $N$ & $\tilde{N}$ \\
\hline$\supseteq$ & 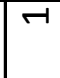 & 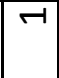 & 0 & 0 & 0 & 0 & 0 & 0 & 0 & $F$ & 0 & $N$ & 0 & 0 & \begin{tabular}{|l|}
0 \\
\end{tabular} & 0 & 016 & 010 & 010 & \begin{tabular}{l|l}
0 \\
\end{tabular} & 50 & $|v|$ & 0 & $\pi$ \\
\hline$\sum_{n}^{\pi}$ & 0 & $N$ & 0 & 0 & $m$ & $r$ & 0 & \begin{tabular}{|l|}
0 \\
\end{tabular} & 0 & 0 & 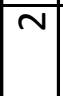 & 0 & 0 & 0 & \begin{tabular}{|l|}
0 \\
\end{tabular} & \begin{tabular}{l|l|}
+1 \\
\end{tabular} & 016 & 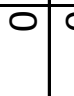 & \begin{tabular}{l|l}
0 \\
\end{tabular} & \begin{tabular}{l|l}
0 & 0
\end{tabular} & 50 & 0 & \begin{tabular}{|l|}
0 \\
\end{tabular} & a \\
\hline 亗 & 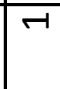 & 0 & 0 & 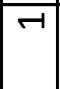 & $m$ & 0 & 0 & 0 & 0 & 0 & 0 & 0 & $\sim$ & 0 & \begin{tabular}{|l|}
0 \\
\end{tabular} & \begin{tabular}{l|l}
\multicolumn{1}{|c|}{} \\
\end{tabular} & 016 & $\begin{array}{lll}0 \\
\end{array}$ & \begin{tabular}{l|l}
0 \\
\end{tabular} & \begin{tabular}{l|l}
0 & 0
\end{tabular} & 50 & 0 & 0 & $\infty$ \\
\hline$\stackrel{\mathscr{c}}{\underline{I}}$ & $m$ & 0 & 0 & $N$ & 0 & 0 & 0 & \begin{tabular}{|l|l|}
0 \\
\end{tabular} & \begin{tabular}{|l|}
$|r|$ \\
\end{tabular} & 10 & 0 & 0 & 0 & 0 & \begin{tabular}{|l|}
+1 \\
\end{tabular} & 0 & 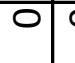 & \begin{tabular}{l|c}
10 \\
\end{tabular} & 010 & \begin{tabular}{l|l}
0 \\
\end{tabular} & 50 & 10 & 0 & $\pi$ \\
\hline 饪 & 10 & 0 & 0 & $N$ & 0 & 0 & 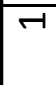 & \begin{tabular}{|l|l|}
0 \\
\end{tabular} & 0 & 0 & 0 & 0 & 0 & 0 & $\sigma$ & 0 & 016 & 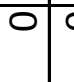 & $\begin{array}{lll}0 \\
\end{array}$ & \begin{tabular}{l|l}
0 & 0
\end{tabular} & 50 & 0 & 0 & F \\
\hline $\overrightarrow{\mathbb{S}}$ & 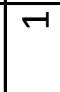 & -1 & 0 & $m$ & 0 & 0 & 0 & \begin{tabular}{|l|l|}
0 \\
\end{tabular} & -1 & 0 & 0 & 0 & 0 & 0 & 0 & 0 & 016 & 0 & $0 / 0$ & 00 & \begin{tabular}{l|l} 
\\
\end{tabular} & 0 & 0 & $\infty$ \\
\hline$\frac{z}{n}$ & 10 & \begin{tabular}{|l|}
$|r|$ \\
\end{tabular} & 0 & in & 0 & 0 & 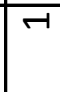 & \begin{tabular}{|l|l|}
0 \\
\end{tabular} & $N$ & 0 & \begin{tabular}{|l|}
-1 \\
\end{tabular} & 0 & 0 & 0 & \begin{tabular}{|l|} 
\\
\end{tabular} & $r$ & 0 & 0 & 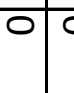 & 00 & 0 & o & - & $\stackrel{\infty}{\rightarrow}$ \\
\hline ? & $N$ & 0 & 0 & $ت$ & 0 & 0 & 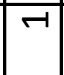 & 0 & 0 & 0 & $N$ & 0 & 0 & 0 & 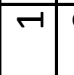 & 0 & 016 & $\begin{array}{lll}0 \\
\end{array}$ & \begin{tabular}{l|l|l}
0 \\
\end{tabular} & \begin{tabular}{l|l}
0 & 0
\end{tabular} & $\begin{array}{l}5 \\
\end{array}$ & 71 & 0 & $\underset{\sim}{\infty}$ \\
\hline$\underset{\Sigma}{\mathbb{Z}}$ & $m$ & $m$ & 0 & $m$ & 0 & 0 & 0 & \begin{tabular}{|l|l}
0 \\
\end{tabular} & 0 & 0 & 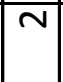 & 0 & 0 & 0 & $\begin{array}{ll}0 \\
\end{array}$ & $\begin{array}{ll}1 \\
\end{array}$ & 010 & 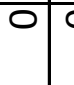 & 010 & \begin{tabular}{l|l}
0 \\
\end{tabular} & 50 & 0 & \begin{tabular}{|c|}
$|r|$ \\
\end{tabular} & $\vec{m}$ \\
\hline $\begin{array}{l}\frac{0}{0} \\
\frac{\pi}{0}\end{array}$ & 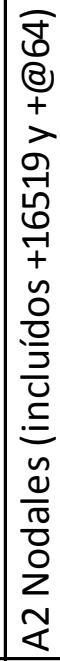 & 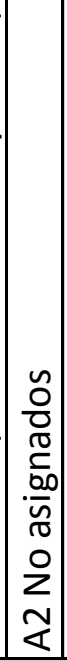 & 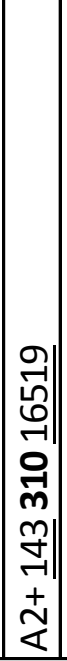 & 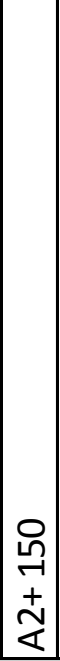 & 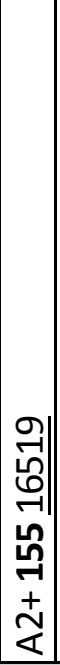 & 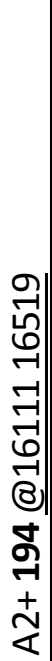 & 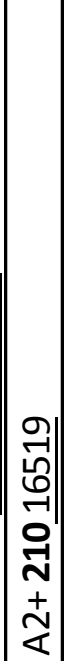 & 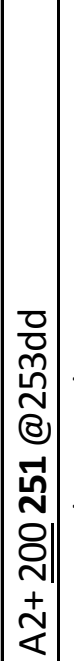 & 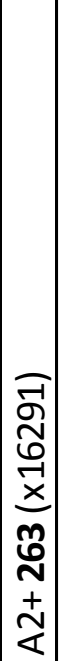 & 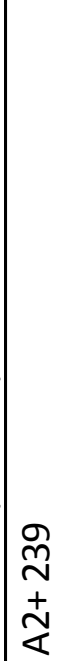 & 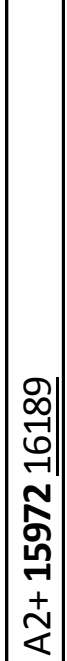 & 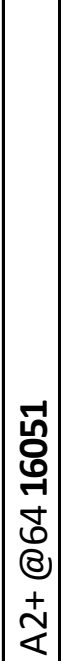 & 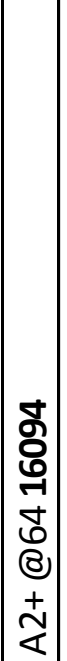 & 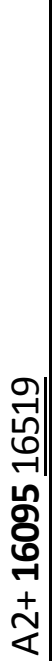 & 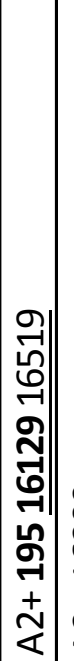 & 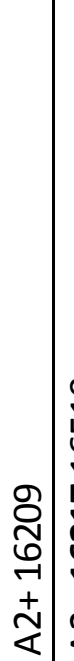 & 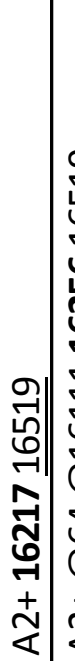 & 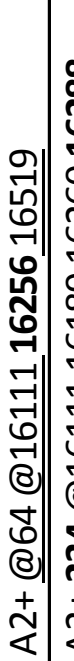 & 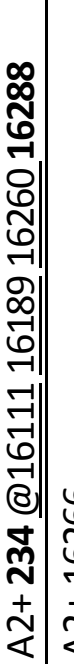 & 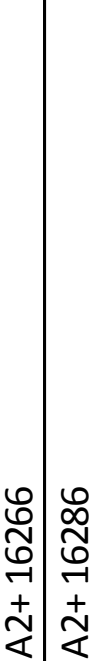 & 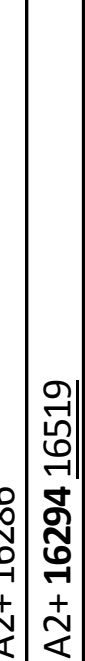 & 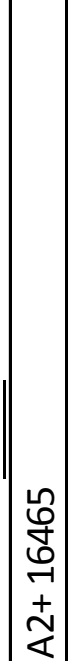 & 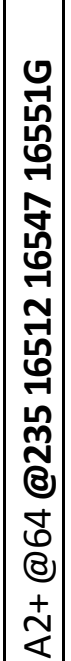 & $\begin{array}{l}\frac{1}{5} \\
\frac{1}{5} \\
\frac{5}{6}\end{array}$ \\
\hline ㅁop & & & & & & & & & & & & & & & & & & & & & & & & \\
\hline
\end{tabular}




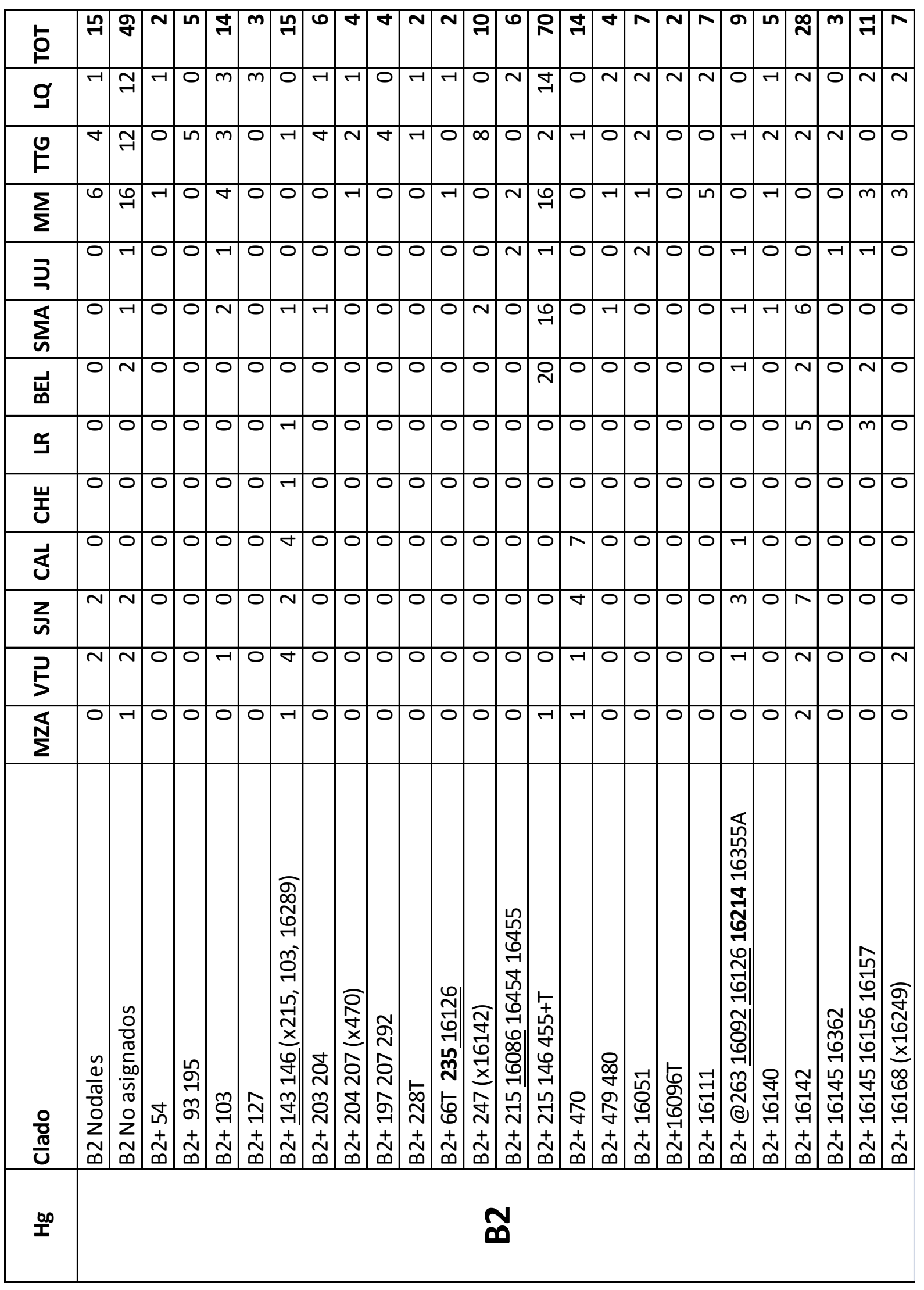




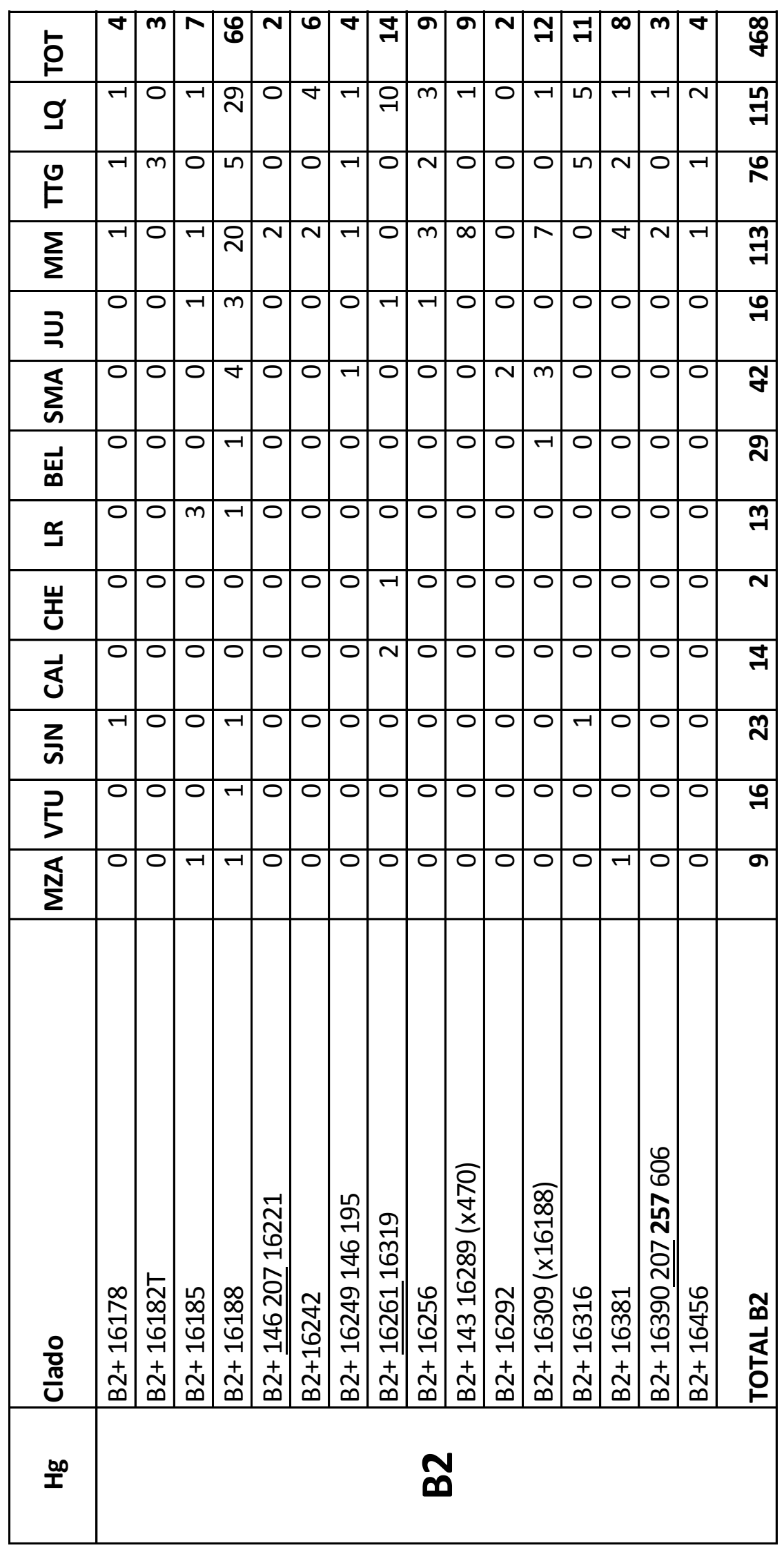




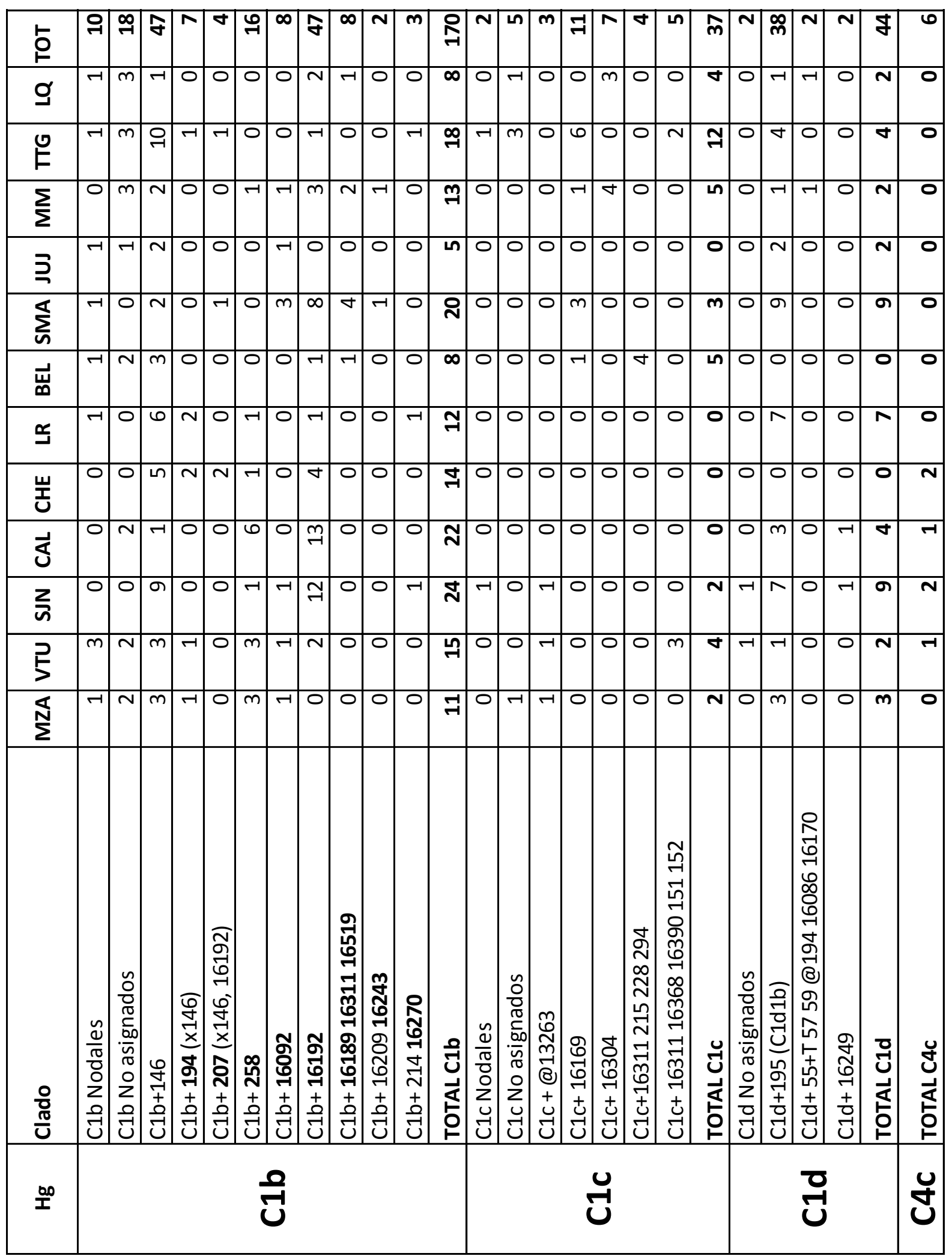




\begin{tabular}{|c|c|c|c|c|c|c|c|c|c|c|c|c|c|c|c|c|c|c|}
\hline$\stackrel{\circ}{\circ}$ & -1 & $\begin{array}{l} \\
\end{array}$ & $\mathbf{N}$ & $\mathbf{N}$ & $\mathbf{N}$ & 이 & $m$ & 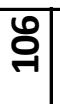 & 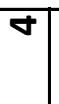 & $\infty$ & $m$ & П & नิㄱ & 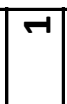 & m & $\infty$ & $\mathcal{F}$ & $\underset{ }{\infty}$ \\
\hline ơ & 0 & $r 1$ & 71 & -1 & 01 & 0 & 0 & 0 & 0 & 0 & $r 1$ & 6 & 욱 & 0 & 0 & न & $F$ & $\underset{ }{8}$ \\
\hline 它 & $न$ & + & 0 & 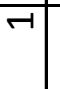 & $N^{\prime}$ & $\begin{array}{ll}-1 \\
\end{array}$ & -7 & 6 & 0 & $\infty$ & 0 & $v$ & $\bar{m}$ & 0 & 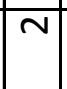 & - & $m$ & $\underset{7}{6}$ \\
\hline$\sum_{\Sigma}$ & 0 & $\sim$ & 0 & 0 & 010 & 0 & 0 & $r 1$ & 0 & 0 & नI & $m$ & $N$ & 0 & 0 & 0 & 0 & $\widetilde{్}$ \\
\hline$\supseteq$ & 0 & न1 & 0 & 0 & 010 & 0 & 0 & $m$ & 0 & 0 & 0 & 0 & $\theta$ & 0 & 0 & 0 & 0 & m \\
\hline$\sum_{n}^{\mathbb{s}}$ & 0 & $m$ & 0 & 0 & 015 & $\begin{array}{ll}71 \\
\end{array}$ & 0 & 뇨 & 0 & 0 & 0 & $m$ & $\boldsymbol{N}$ & 0 & 0 & \begin{tabular}{|l|}
6 \\
\end{tabular} & 6 & $\exists$ \\
\hline 岗 & 0 & $r$ & 0 & 0 & 010 & 0 & $N$ & $\infty$ & 0 & 0 & 0 & 0 & $\exists$ & 0 & 0 & 0 & 0 & 항 \\
\hline 咨 & 0 & 0 & 71 & 0 & 010 & $m$ & 0 & $\stackrel{n}{m}$ & 0 & 0 & 0 & 0 & m & 0 & 0 & 0 & 0 & $\infty$ \\
\hline 岌 & 0 & $r \mid$ & 0 & 0 & 010 & 0 & 0 & $\stackrel{m}{r}$ & 0 & 0 & 0 & 0 & $\vec{A}$ & 0 & 0 & 0 & 0 & 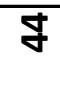 \\
\hline $\overrightarrow{\mathbb{S}}$ & 0 & 0 & 0 & 0 & 011 & 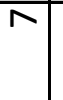 & 0 & n & $m$ & 0 & 0 & 0 & $\stackrel{2}{7}$ & 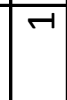 & 0 & 0 & 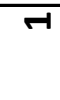 & 10 \\
\hline$\frac{z}{n}$ & 0 & $\sim$ & 0 & 0 & 014 & n) & 0 & $\vec{F}$ & -1 & 0 & 0 & -1 & 尺े & 0 & $\mid-1$ & 0 & 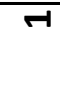 & ன \\
\hline 2 & 0 & 0 & 0 & 0 & 01 & + & 0 & $m$ & 0 & 0 & 0 & 0 & $\pi$ & 10 & 0 & 10 & 0 & ஜூ \\
\hline$\stackrel{\mathbb{N}}{\Sigma}$ & 0 & $r$ & 0 & 0 & 010 & का & 0 & 6 & 0 & 0 & न1 & 0 & $F$ & 0 & 0 & 0 & 0 & L \\
\hline $\begin{array}{l}\frac{0}{0} \\
\frac{\pi}{U}\end{array}$ & $\begin{array}{l}\frac{\tilde{a}}{0} \\
\frac{\pi}{0} \\
0 \\
z \\
\dot{0} \\
0\end{array}$ & $\begin{array}{l}\tilde{0} \\
\frac{0}{0} \\
\frac{\pi}{5} \\
\frac{50}{50} \\
\bar{n} \\
0 \\
z \\
-1 \\
\overline{0}\end{array}$ & 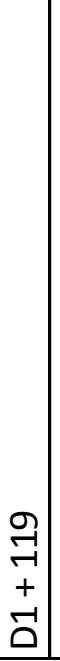 & 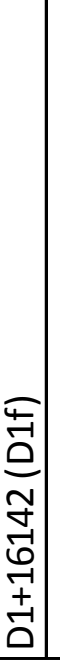 & 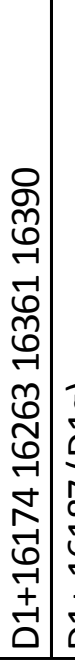 & 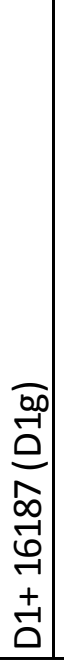 & $\begin{array}{c}8 \\
\stackrel{9}{-1} \\
-1 \\
+ \\
\stackrel{-1}{0}\end{array}$ & 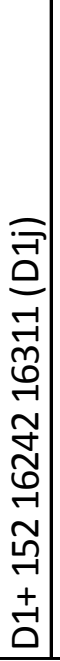 & 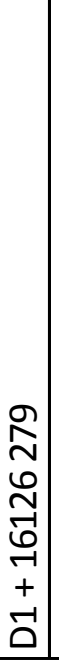 & 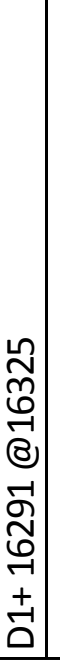 & 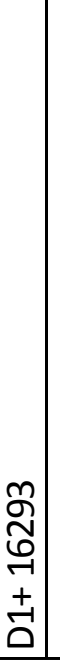 & 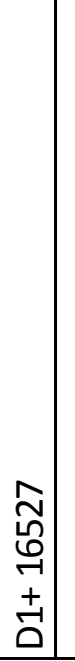 & $\frac{1}{2}$ & 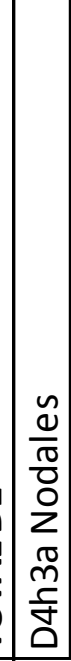 & 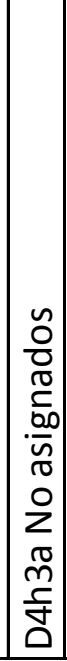 & 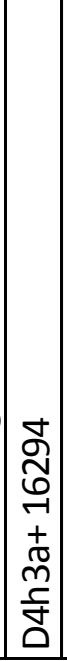 & 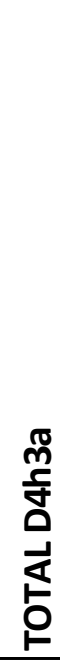 & 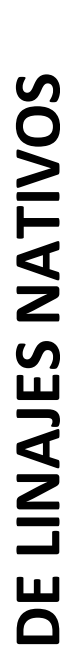 \\
\hline ㅁo & & & & & & & б & & & & & & & & & 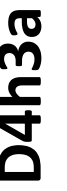 & & $\frac{1}{0}$ \\
\hline
\end{tabular}


7.2.5 PUNTOS GEOGRÁFICOS DEFINIDOS PARA LA INTERPOLACIÓN DE FRECUENCIAS DE CLADOS

7.2.5.1 Puntos geográficos definidos para polimorfismos en la RHVI

\begin{tabular}{|c|c|c|c|c|c|}
\hline Fuente & Población & Localidad & N A-D & Punto geográfico & N A-D \\
\hline Este trabajo & Urbana & ARG CAT BEL, Belén & 61 & ARG Belén & 61 \\
\hline Bobillo 2009 & Urbana & ARG BUE & 89 & $\triangle B G R s \Delta s$ & 141 \\
\hline Catelli 2011 & Urbana & ARG BUE & 52 & ATV DS & 141 \\
\hline Este trabajo & Urbana & ARG SNJ CAL, Calingasta & 65 & ARG Calingasta & 65 \\
\hline Tamm 2007 & Urbana & ARG CAT, SFV de Cat & 25 & ARG Catamarca & 27 \\
\hline Catelli 2011 & Urbana & ARG CAT & 2 & 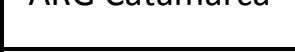 & 3 \\
\hline Cabana 2006 & Toba & ARG CHA & 43 & & \\
\hline Cabana 2006 & Wichí & ARG CHA & 32 & & \\
\hline Torroni 1993 & Wichí & ARG CHA El Sauzalito & 3 & ARG Chaco & 84 \\
\hline Catelli 2011 & Urbana & ARG CHA & 2 & & \\
\hline Bobillo 2009 & Urbana & ARG CHA & 4 & & \\
\hline Este trabajo & Urbana & ARG LRJ RVP, Chepes & 44 & ARG Chepes & 44 \\
\hline Salas 2008 & Urbana & ARG, Córdoba & 42 & & \\
\hline Catelli 2011 & Urbana & ARG CBA & 63 & ARG Córdoba & 119 \\
\hline IMBICE, Inédito & Urbana & ARG CBA, Pampa de Achala & 14 & & \\
\hline IMBICE, Inédito & Urbana & ARG CRR CUA, Curuzú Cuatiá & 140 & & \\
\hline Catelli 2011 & Urbana & ARG CRR & 5 & ARG Corrientes & 168 \\
\hline Bobillo 2009 & Urbana & ARG CRR & 23 & & \\
\hline Cabana 2006 & Pilaga & ARG FOR & 40 & & \\
\hline Cabana 2006 & Toba & ARG FOR & 24 & & \\
\hline Cabana 2006 & Wichí & ARG FOR & 70 & ARG Formosa & 150 \\
\hline Catelli 2011 & Urbana & ARG FOR & 1 & & \\
\hline Bobillo 2009 & Urbana & ARG FOR & 15 & & \\
\hline IMBICE, Inédito & Urbana & ARG & 115 & $\begin{array}{c}\text { ARG } \\
\text { Gualeguaychú }\end{array}$ & 115 \\
\hline IMBICE, Inédito & Cochinoca & ARG JUJ, Cochinoca & 17 & & \\
\hline IMBICE, Inédito & Rinconada & ARG JUJ, Rinconada & 20 & ARG Jujuy oeste & 59 \\
\hline IMBICE, Inédito & Susques & ARG JUJ, Susques & 22 & & \\
\hline Este trabajo & Urbana & ARG JUJ SSJ & 34 & ARG SS de Jujuy & 34 \\
\hline IMBICE, Inédito & Urbana & ARG ERI LPZ, La Paz & 56 & ARG La Paz & 56 \\
\hline Este trabajo & Urbana & ARG & 169 & ARG La Quiaca & 169 \\
\hline Este trabajo & Urbana & ARG LRI, La Rioja & 78 & ARG La Rioja & 78 \\
\hline Este trabajo & Urbana & ARG, Maimará & 115 & & \\
\hline Este trabajo & Urbana & ARG, Purmamarca & 31 & ARG Maimará & 162 \\
\hline Este trabajo & Urbana & ARG, Tumbaya & 16 & & \\
\hline
\end{tabular}


Anexo

\begin{tabular}{|c|c|c|c|c|c|}
\hline Fuente & Población & Localidad & N A-D & Punto geográfico & N A-D \\
\hline IMBICE, Inédito & Urbana & ARG, Malargüe & 117 & ARG Malargüe & 117 \\
\hline Este trabajo & Urbana & ARG MZA, Mendoza & 55 & ARG Mendoza & 55 \\
\hline Bobillo 2009 & Urbana & ARG MIS & 22 & & \\
\hline Catelli 2011 & Urbana & ARG MIS & 2 & ARG Misiones & 145 \\
\hline Sala 2010 & Mbyá & ARG MIS & 121 & & \\
\hline IMBICE, Inédito & Tehuelches & ARG CHU, Loma Redonda & 6 & & \\
\hline IMBICE, inédito & Tehuelches & ARG CHU, El Chalía & 17 & & \\
\hline Bobillo 2009 & Urbana & ARG CHU & 1 & & \\
\hline IMBICE, Inédito & Urbana & ARG CHU & 15 & & \\
\hline Catelli 2011 & Urbana & ARG CHU & 1 & ARG Patagonia & 61 \\
\hline IMBICE, Inédito & Tehuelches & ARG SCR & 5 & & \\
\hline Moraga 2000 & Yahgan & $\begin{array}{l}\text { Chile XII, Antartica, Isla } \\
\text { Navarino Puerto Williams }\end{array}$ & 15 & & \\
\hline Catelli 2011 & Urbana & ARG SCR & 1 & & \\
\hline IMBICE, Inédito & Mapuches & ARG RNE & 51 & & \\
\hline Bobillo 2009 & Urbana & ARG RNE & 30 & & \\
\hline IMBICE, Inédito & Urbana & ARG RNE, Bariloche & 27 & ARG Río Negro & 216 \\
\hline IMBICE, Inédito & Urbana & ARG RNE, El Bolsón & 69 & & \\
\hline Ginther 1993 & Mapuche & ARG RNE PIL, Anecón Grande & 39 & & \\
\hline Tamm 2007 & Urbana & ARG SAL, Salta & 18 & & \\
\hline $\begin{array}{l}\text { Alvarez-Iglesias } \\
2007\end{array}$ & & & 59 & ARG Salta & 77 \\
\hline Este trabajo & Urbana & ARG SNJ CAP, San Juan & 99 & ARG San Juan & 99 \\
\hline IMBICE, Inédito & Urbana & ARG SFE GOB, Reconquista & 79 & & \\
\hline Tamm 2007 & Mocovi & ARG SFE JUS, Gob.Crespo & 5 & anta Fe & 91 \\
\hline Catelli 2011 & Urbana & ARG SFE & 3 & ARG santa re & \\
\hline Bobillo 2009 & Urbana & ARG SFE & 4 & & \\
\hline Este trabajo & Urbana & \begin{tabular}{|l|} 
ARG CAT SMA, Santa María y \\
San José \\
\end{tabular} & 111 & ARG Santa María & 111 \\
\hline IMBICE, Inédito & Tobas & ARG SAL RBN SVE & 9 & & \\
\hline IMBICE, Inédito & Chaqueños indet & ARG SAL RBN SVE & 20 & ARG Sta. Victoria & 115 \\
\hline IMBICE, Inédito & Chorote & ARG SAL RBN SVE & 25 & Este & 115 \\
\hline IMBICE, Inédito & Wichi & ARG SAL RBN SVE & 61 & & \\
\hline Este trabajo & Urbana & ARG SAL, Tartagal & 167 & ARG Tartagal & 167 \\
\hline Este trabajo & Urbana & ARG MZA LAV, Villa Tulumaya & 63 & ARG V. Tulumaya & 63 \\
\hline
\end{tabular}


Anexo

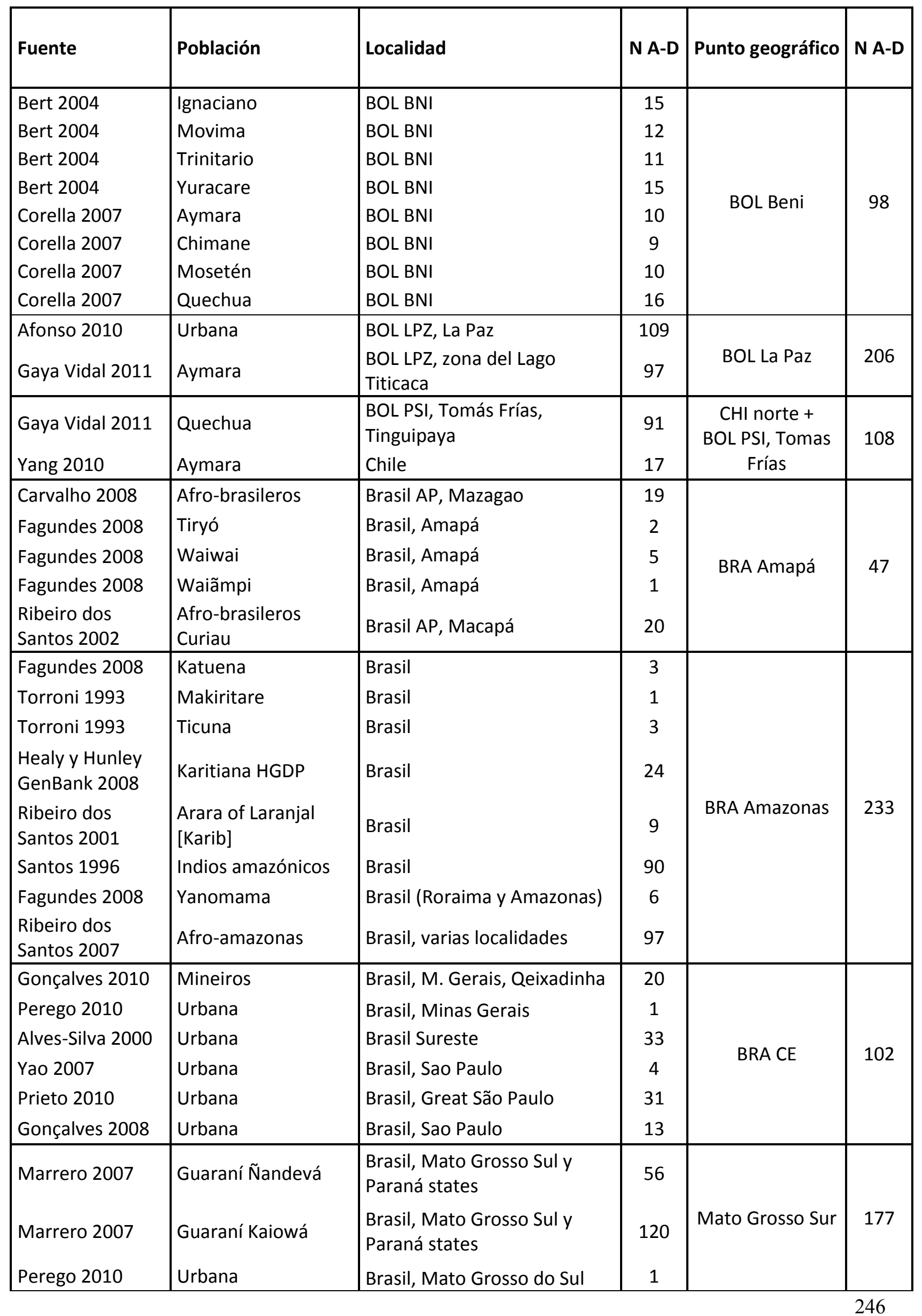


Anexo

\begin{tabular}{|c|c|c|c|c|c|}
\hline Fuente & Población & Localidad & N A-D & Punto geográfico & N A-D \\
\hline Ward 1996 & Xavante (Gé) & Brasil, Mato Groso & 25 & \multirow{7}{*}{$\begin{array}{l}\text { BRA Mato } \\
\text { Grosso y } \\
\text { Rondonia }\end{array}$} & \multirow{7}{*}{111} \\
\hline Ward 1996 & $\begin{array}{l}\text { Gaviao (Tupí- } \\
\text { Mondé) }\end{array}$ & Brasil, Rondonia & 27 & & \\
\hline $\begin{array}{l}\text { Healy y Hunley } \\
\text { GenBank } 2008\end{array}$ & Surui HGDP & Brasil & 21 & & \\
\hline Fagundes 2008 & Suruí & Brasil, Rondonia & 2 & & \\
\hline Fagundes 2008 & Xavante & Brasil, Mato grosso & 2 & & \\
\hline Fagundes 2008 & Zoró & $\begin{array}{l}\text { Brasil, Mato grosso y } \\
\text { Rondonia }\end{array}$ & 4 & & \\
\hline Ward 1996 & Zoró (Tupí-Mondé) & Brasil, Mato Groso & 30 & & \\
\hline Barbosa 2008 & Urbana & Brasil NE, Alagoas & 55 & \multirow{4}{*}{ BRA NE } & \multirow{4}{*}{84} \\
\hline Carvalho 2008 & Afro-brasileros & Brasil Maranhao, Tamauari & 17 & & \\
\hline Bortolini 1999 & Afro-brasileros & Brasil Salvador & 1 & & \\
\hline Alves-Silva 2000 & Brasileros blancos & Brasil Noreste(Pernambuco) & 11 & & \\
\hline Carvalho 2008 & Afro-brasileros & Brasil Pará, Trombetas & 14 & \multirow{17}{*}{ BRA Pará } & \multirow{17}{*}{288} \\
\hline Carvalho 2008 & Afro-brasileros & Brasil Pará, Marajó & 15 & & \\
\hline Carvalho 2008 & Afro-brasileros & Brasil Pará, Pitimandeuá & 9 & & \\
\hline Alves-Silva 2000 & Brasileros blancos & $\begin{array}{l}\text { Brasil North (AZ, PR, RN, } \\
\text { Acre) }\end{array}$ & 26 & & \\
\hline Silva 2006 & Afro-Brasilian & Brasil N, Pará, Cametá & 10 & & \\
\hline Marinho 2011 & Urbana & Brasil, Pará, Belem & 19 & & \\
\hline SIBI database & Urbana & Brasil, Santa Flor & 12 & & \\
\hline $\begin{array}{l}\text { Ribeiro dos } \\
\text { Santos } 2001\end{array}$ & Arara of Iriri [Karib] & Brasil, Pará, Iriri River & 28 & & \\
\hline Mazieres (2006) & Apalaí [Carib] & Brasil, Pará & 102 & & \\
\hline Torroni 1993 & Yanomama & Brasil & 3 & & \\
\hline Torroni 1993 & Kraho & Brasil & 1 & & \\
\hline Fagundes 2008 & $\begin{array}{l}\text { Arara/Arara do } \\
\text { Laranjal }\end{array}$ & Brasil & 1 & & \\
\hline Fagundes 2008 & Kayapó/Kriketun & Brasil, Pará o Matto Grosso & 2 & & \\
\hline Fagundes 2008 & Kayapó/Kubemkokre & Brasil, Pará o Matto Grosso & 2 & & \\
\hline Fagundes 2008 & Gavião & Brasil, Pará & 3 & & \\
\hline Fagundes 2008 & Poturujara & Brasil, Pará & 3 & & \\
\hline $\begin{array}{l}\text { Feio-dos-Santos } \\
2006\end{array}$ & Urbana & Brasil, Para, Santarem & 38 & & \\
\hline Marrero 2007 & Guaraní Mbyá & Brasil, Paraná state & 24 & \multirow{6}{*}{$\begin{array}{l}\text { BRA Paraná y } \\
\text { Santa Catalina }\end{array}$} & \multirow{6}{*}{76} \\
\hline Yang 2010 & Guaraní & Brasil & 8 & & \\
\hline Yang 2010 & Kaingang & Brasil & 2 & & \\
\hline Marrero 2007 & Kaingang Paraná & Brasil, Paraná state & 21 & & \\
\hline Fagundes 2008 & $\begin{array}{l}\text { Guarani/Rio das } \\
\text { Cobras }\end{array}$ & Brasil, Paraná & 4 & & \\
\hline Palencia 2010 & Urbana & Brasil, Santa Catarina & 17 & & \\
\hline
\end{tabular}


Anexo

\begin{tabular}{|c|c|c|c|c|c|}
\hline Fuente & Población & Localidad & N A-D & Punto geográfico & N A-D \\
\hline Marrero 2005 & Urbana & Brasil RS & 11 & \multirow{10}{*}{ BRA RGS } & \multirow{10}{*}{203} \\
\hline Alves-Silva 2000 & Brasileros blancos & Brasil sur (PA, SC, RGS) & 11 & & \\
\hline Marrero 2007 & Kaingang & Brasil, RGS state & 53 & & \\
\hline Marrero 2007 & Gaúchos & Brasil, RGS, Pampa region & 54 & & \\
\hline Guerreiro 2009 & Brasileros blancos & Brasil, RGS, Porto Alegre & 35 & & \\
\hline Guerreiro 2009 & Afro- brasileros & Brasil, RGS, Porto Alegre & 16 & & \\
\hline Perego 2010 & Urbana & Brasil, Rio Grande do Sul & 2 & & \\
\hline Prieto 2010 & Urbana & Brasil, SW & 14 & & \\
\hline Bortolini 1999 & Afro- brasileros & Brasil POA y SAL & 4 & & \\
\hline Marrero 2005 & urbana & Brasil RS, Veranópolis & 3 & & \\
\hline Yang 2010 & Huilliche & Chile & 20 & \multirow{4}{*}{$\mathrm{CHI}$ centro } & \multirow{4}{*}{122} \\
\hline Horai 1993 & Urbana & Chile [Chiloé y IX Región] & 44 & & \\
\hline Moraga 2000 & Pehuenche & Chile VIII & 24 & & \\
\hline Moraga 2000 & Mapuche & Chile X, Valdivia, Isla Huapi & 34 & & \\
\hline Torres 2006 & Amerindios & $\mathrm{COL}$ & 64 & \multirow{5}{*}{$\begin{array}{c}\mathrm{COL} \\
\text { indeterminado }\end{array}$} & \multirow{5}{*}{112} \\
\hline Bryc 2010 & Urbana & $\mathrm{COL}$ & 20 & & \\
\hline Family Tree & Urbana & $\mathrm{COL}$ & 1 & & \\
\hline Horai 1993 & Amerindios & $\mathrm{COL}$ & 20 & & \\
\hline Perego 2010 & Urbana & COL Mestizos & 7 & & \\
\hline Tamm 2007 & Coreguaje & $\mathrm{COL}$ & 27 & \multirow{4}{*}{ COL Amazonia } & \multirow{4}{*}{74} \\
\hline Tamm 2007 & Vaupes & $\mathrm{COL}$ & 22 & & \\
\hline Yang 2010 & Ticuna & $\mathrm{COL}$ & 12 & & \\
\hline $\begin{array}{l}\text { Healy y Hunley } \\
\text { GenBank } 2008\end{array}$ & $\begin{array}{l}\text { Curripaco/Piapoco } \\
\text { HGDP }\end{array}$ & $\mathrm{COL}$ & 13 & & \\
\hline Salas 2008 & Afro-Colombianos & $\begin{array}{l}\text { COL (Cauca+Valle de } \\
\text { Cauca+Nariño) }\end{array}$ & 23 & \multirow{5}{*}{ COL Andes sur } & \multirow{5}{*}{114} \\
\hline Salas 2008 & Mestizos & $\begin{array}{l}\text { COL (Cauca+Valle de } \\
\text { Cauca+Nariño) }\end{array}$ & 64 & & \\
\hline Salas 2008 & Mulatos & $\begin{array}{l}\text { COL (Cauca+Valle de } \\
\text { Cauca+Nariño) }\end{array}$ & 1 & & \\
\hline Yang 2010 & Inga & COL, ¿Pasto? & 16 & & \\
\hline Salas 2008 & Paez & $\begin{array}{l}\text { COL (Cauca+Valle de } \\
\text { Cauca+Nariño) }\end{array}$ & 10 & & \\
\hline Perego 2010 & Urbana & COL, Boyaca & 1 & \multirow{3}{*}{ COL centro } & \multirow{3}{*}{36} \\
\hline $\begin{array}{l}\text { Díaz-Matallana } \\
2010\end{array}$ & Urbana & COL, Boyacá, Villa de Leyva & $11^{*}$ & & \\
\hline $\begin{array}{l}\text { Díaz-Matallana } \\
2010\end{array}$ & Urbana & COL, Cundinamarca, Bogotá & $24^{*}$ & & \\
\hline
\end{tabular}

*En las muestras correspondientes al haplogrupo B, sólo se reportan polimorfismos a partir de la posición 16129 
Anexo

\begin{tabular}{|c|c|c|c|c|c|}
\hline Fuente & Población & Localidad & N A-D & Punto geográfico & N A-D \\
\hline $\begin{array}{l}\text { Tamm } 2007 \\
\text { Yang } 2010 \\
\text { Yang } 2010 \\
\text { Yang } 2010 \\
\text { Díaz-Matallana } \\
2010 \\
\text { Díaz-Matallana } \\
2010 \\
\text { Yang } 2010 \\
\text { Tamm } 2007 \\
\text { Tamm } 2007 \\
\text { Tamm } 2007\end{array}$ & $\begin{array}{l}\text { Wayuu } \\
\text { Wayuu } \\
\text { Arhuaco or ljka } \\
\text { Kogi } \\
\text { Urbana } \\
\text { Urbana } \\
\text { Zenu } \\
\text { Arsario } \\
\text { ljka } \\
\text { Kogui }\end{array}$ & $\begin{array}{l}\text { COL, Guajira } \\
\text { COL, La Guajira } \\
\text { COL, Magdalena, Santa Marta } \\
\text { COL, Magdalena, Santa Marta } \\
\text { COL, Magdalena, Santa Marta } \\
\text { COL, Atlántico, Barranquilla } \\
\text { COL, ¿Cordoba o Sucre? } \\
\text { COL, Sa. Nevada } \\
\text { COL, Sa. Nevada } \\
\text { COL, Sa. Nevada }\end{array}$ & $\begin{array}{l}42 \\
18 \\
16 \\
16 \\
10 \\
2 \\
15 \\
15 \\
47 \\
29 \\
48\end{array}$ & COL norte & 243 \\
\hline $\begin{array}{l}\text { Tamm } 2007 \\
\text { Tamm } 2007 \\
\text { Yang } 2010 \\
\text { Yang } 2010 \\
\text { Salas } 2005 \\
\text { Tamm } 2007\end{array}$ & $\begin{array}{l}\text { Embera } \\
\text { Waunana } \\
\text { Waunana } \\
\text { Embera } \\
\text { Afro-Chocó } \\
\text { Ngobë }\end{array}$ & $\begin{array}{l}\text { COL y Panama } \\
\text { COL y Panama } \\
\text { COL, Chocó } \\
\text { COL } \\
\text { COL } \\
\text { COL/Panamá }\end{array}$ & $\begin{array}{c}39 \\
57 \\
18 \\
9 \\
49 \\
1\end{array}$ & COL Pacífico & 173 \\
\hline $\begin{array}{l}\text { Tamm } 2007 \\
\text { Tamm } 2007 \\
\text { Tamm } 2007 \\
\text { Bryc } 2010 \\
\text { Rickards } 1999 \\
\text { Rickards } 1999 \\
\text { Baeta } 2009 \\
\text { Cardoso } 2009 \\
\text { Cardoso } 2009 \\
\text { IMBICE, Inédito } \\
\text { Perego } 2010\end{array}$ & $\begin{array}{l}\text { Cofan } \\
\text { Secoya } \\
\text { Siona } \\
\text { Urbana } \\
\text { Cayapas HVS-I + } \\
\text { HVS-II } \\
\text { Cayapas HVS-I } \\
\text { Waorani } \\
\text { Waorani } \\
\text { Waorani } \\
\text { Urbana } \\
\text { Urbana }\end{array}$ & $\begin{array}{l}\text { ECU } \\
\text { ECU } \\
\text { ECU } \\
\text { ECU } \\
\text { ECU, Esmeraldas } \\
\text { ECU, Esmeraldas } \\
\text { ECU, Orellana, Toñampari y } \\
\text { Bameno } \\
\text { ECU } \\
\text { ECU } \\
\text { ECU } \\
\text { ECU, Imbabura }\end{array}$ & $\begin{array}{c}4 \\
10 \\
2 \\
19 \\
30 \\
120 \\
111 \\
11 \\
24 \\
103 \\
1\end{array}$ & ECU & 435 \\
\hline $\begin{array}{l}\text { Mazieres (2006), } \\
\text { Ph Diss } \\
\text { Mazieres (2006), } \\
\text { Ph Diss } \\
\text { Mazieres (2006), } \\
\text { Ph Diss } \\
\text { Mazieres (2006), } \\
\text { Ph Diss }\end{array}$ & $\begin{array}{l}\text { Kaliña (=Galibi) } \\
\text { [Carib] } \\
\text { Emerillon [Tupí- } \\
\text { Guaraní] } \\
\text { Palikur [Arawak] } \\
\text { Wayampi [Tupí] }\end{array}$ & $\begin{array}{l}\text { Guayana Francesa } \\
\text { Guayana Francesa } \\
\text { Guayana Francesa } \\
\text { Guayana Francesa }\end{array}$ & $\begin{array}{l}29 \\
30 \\
48\end{array}$ & Guyana Francesa & 161 \\
\hline $\begin{array}{l}\text { Schmitt } 2004 \\
\text { Fagundes } 2008 \\
\text { Yang } 2010\end{array}$ & $\begin{array}{l}\text { Aché (=Guayakí) } \\
\text { Ache } \\
\text { Aché }\end{array}$ & $\begin{array}{l}\text { Paraguay } \\
\text { Paraguay } \\
\text { Paraguay }\end{array}$ & $\begin{array}{c}63 \\
2 \\
11\end{array}$ & PAR este & 76 \\
\hline
\end{tabular}


Anexo

\begin{tabular}{|c|c|c|c|c|c|}
\hline Fuente & Población & Localidad & N A-D & Punto geográfico & N A-D \\
\hline $\begin{array}{l}\text { IMBICE, Inédito } \\
\text { IMBICE, Inédito }\end{array}$ & $\begin{array}{l}\text { Ayoreo } \\
\text { Lengua }\end{array}$ & $\begin{array}{l}\text { Paraguay } \\
\text { Paraguay }\end{array}$ & $\begin{array}{l}16 \\
17\end{array}$ & PAR Filadelfia & 33 \\
\hline Dornelles 2004 & Ayoreo (=Moro) & Paraguay Bolivia & 91 & PAR oeste & 91 \\
\hline $\begin{array}{l}\text { Perego } 2010 \\
\text { Perego } 2010 \\
\text { Perego } 2010 \\
\text { Perego } 2010 \\
\text { Fuselli } 2003\end{array}$ & $\begin{array}{l}\text { Urbana } \\
\text { Urbana } \\
\text { Urbana } \\
\text { Urbana } \\
\text { Quechua + } \\
\text { Nomatsiguenga }\end{array}$ & $\begin{array}{l}\text { Peru, Loreto } \\
\text { Peru, Loreto } \\
\text { Peru, Cajamarca } \\
\text { Peru, Piura } \\
\text { Peru, San Martin Dept. }\end{array}$ & $\begin{array}{c}1 \\
1 \\
1 \\
1 \\
22\end{array}$ & PERÚ norte & 26 \\
\hline \begin{tabular}{|l|} 
Lewis 2007 \\
Perego 2010 \\
Estrada-Cuzcano \\
2005 \\
Lewis 2007 \\
Lewis Jr. 2005 \\
Perego 2010 \\
Perego 2010 \\
Fuselli 2003
\end{tabular} & $\begin{array}{l}\text { Jaqaru parlantes } \\
\text { Urbana } \\
\text { Urbana } \\
\text { Yungay Quechua } \\
\text { Urbana } \\
\text { Urbana } \\
\text { Urbana } \\
\text { Tayacaja Quechua }\end{array}$ & $\begin{array}{l}\text { Peru, Lima, Yauyos, Tupe } \\
\text { Peru, Lima } \\
\text { Perú } \\
\text { Peru, Ancash, Yungay } \\
\text { Peru, Ancash } \\
\text { Peru, Huanucu } \\
\text { Peru, Huancavelica } \\
\text { Peru, Huancavelica Dept. }\end{array}$ & $\begin{array}{c}16 \\
8 \\
1 \\
36 \\
33 \\
1 \\
1 \\
61\end{array}$ & PERÚ centro & 157 \\
\hline \begin{tabular}{|l} 
Fuselli 2003 \\
Lewis 2007 \\
Lewis 2007 \\
Yang 2010 \\
Estrada-Cuzcano \\
2005 \\
Sandoval 2009 \\
Barbieri 2010 \\
Barbieri 2010 \\
Barbieri 2010 \\
\end{tabular} & $\begin{array}{l}\text { Arequipa Quechua } \\
\text { Puno Quechua } \\
\text { Puno Aymara } \\
\text { Quechua } \\
\text { Urbana } \\
\text { Quechua } \\
\text { Aymaras } \\
\text { Uros } \\
\text { Quechuas } \\
\end{array}$ & $\begin{array}{l}\text { Peru, Arequipa Dept. } \\
\text { Peru, Puno } \\
\text { Peru, Puno } \\
\text { Perú } \\
\text { Perú } \\
\text { Peru } \\
\text { Peru, Puno, Chimú } \\
\text { Peru, Puno, Lake Titicaca, } \\
\text { Puma Uta island } \\
\text { Peru, Puno, Pucachupa } \\
\end{array}$ & $\begin{array}{l}22 \\
30 \\
14 \\
18 \\
1 \\
22 \\
20 \\
7 \\
3 \\
\end{array}$ & PERÚ sur Andes & 171 \\
\hline \begin{tabular}{|l} 
Mazieres (2006), \\
Ph Diss
\end{tabular} & \begin{tabular}{|l} 
Matsiguenga \\
[Arawak]
\end{tabular} & Perú & 38 & $\begin{array}{c}\text { PERU sur } \\
\text { Amazonas }\end{array}$ & 38 \\
\hline \begin{tabular}{|l} 
Bonilla 2004 \\
Pagano2005 \\
Sans 2006 \\
Perego 2010 \\
Sans 2011 \\
Perego 2010
\end{tabular} & $\begin{array}{l}\text { Urbana } \\
\text { Urbana } \\
\text { Urbana } \\
\text { Urbana } \\
\text { Urbana } \\
\text { Urbana }\end{array}$ & $\begin{array}{l}\text { URU Tacuarembó, } \\
\text { Tacuarermbó } \\
\text { Uruguay } \\
\text { Uruguay Cerro Largo Dept. } \\
\text { Uruguay } \\
\text { Uruguay, Flores, Trinidad } \\
\text { Uruguay, Flores }\end{array}$ & $\begin{array}{c}15 \\
37 \\
13 \\
1 \\
11 \\
1\end{array}$ & URUGUAY & 78 \\
\hline
\end{tabular}


Anexo

\begin{tabular}{|c|c|c|c|c|c|}
\hline Fuente & Población & Localidad & N A-D & Punto geográfico & N A-D \\
\hline $\begin{array}{l}\text { Ghose } 2002 \\
\text { Lander FSI Genet } \\
2008 \\
\text { Castro de Guerra } \\
2011 \\
\end{array}$ & $\begin{array}{l}\text { Urbana } \\
\text { Urbana } \\
\text { Urbana }\end{array}$ & $\begin{array}{l}\text { Venezuela, Caracas } \\
\text { Venezuela, Caracas } \\
\text { Venezuela, Caracas }\end{array}$ & $\begin{array}{c}8 \\
67 \\
67\end{array}$ & VEN Caracas & 142 \\
\hline $\begin{array}{l}\text { Ingman } 2000 \\
\text { Ghose } 2002 \\
\text { Ghose } 2002 \\
\text { Vona } 2005\end{array}$ & $\begin{array}{l}\text { Warao } \\
\text { Guahibo } \\
\text { Piaroa } \\
\text { Guahibo }\end{array}$ & $\begin{array}{l}\text { Venezuela, Orinoco Delta } \\
\text { Venezuela, Puerto Ayacucho } \\
\text { Venezuela, Puerto Ayacucho } \\
\text { Venezuela AMA, Puerto } \\
\text { Ayacucho }\end{array}$ & $\begin{array}{c}2 \\
3 \\
15 \\
59\end{array}$ & $\begin{array}{l}\text { VEN Pto. } \\
\text { Ayacucho }\end{array}$ & 79 \\
\hline Williams 2002 & $\begin{array}{l}\text { Yanomame, grupo } \\
\text { Shimitari }\end{array}$ & Venezuela (Amazonas) & 155 & VEN Amazonas & 155 \\
\hline
\end{tabular}


7.2.5.2 Puntos geográficos para polimorfismos en la RHVI y RHVII

\begin{tabular}{|c|c|c|c|c|c|}
\hline Fuente & Población & Localidad & N A-D & Punto geográfico & N A-D \\
\hline Este trabajo & Urbana & ARG CAT BEL, Belén & 61 & ARG Belén & 61 \\
\hline Bobillo 2009 & Urbana & ARG BUE & 89 & \multirow{2}{*}{ ARG Bs As } & \multirow{2}{*}{141} \\
\hline Catelli 2011 & Urbana & ARG BUE & 52 & & \\
\hline Este trabajo & Urbana & ARG SNJ CAL, Calingasta & 65 & ARG Calingasta & 65 \\
\hline Tamm 2007 & Urbana & ARG CAT, SFV de Cat & 25 & AR Catamarca & \\
\hline Catelli 2011 & Urbana & ARG CAT & 2 & Anu Calamaled & 21 \\
\hline Cabana 2006 & Toba & ARG CHA & 43 & \multirow{4}{*}{ ARG Chaco } & \multirow{4}{*}{81} \\
\hline Cabana 2006 & Wichí & ARG CHA & 32 & & \\
\hline Catelli 2011 & Urbana & ARG CHA & 2 & & \\
\hline Bobillo 2009 & Urbana & ARG CHA & 4 & & \\
\hline Este trabajo & Urbana & ARG LRJ RVP, Chepes & 44 & ARG Chepes & 44 \\
\hline Catelli 2011 & Urbana & ARG CBA & 63 & \multirow[b]{2}{*}{ ARG Córdoba } & \multirow[b]{2}{*}{77} \\
\hline IMBICE, Inédito & & $\begin{array}{l}\text { ARG CBA, Pampa de } \\
\text { Achala }\end{array}$ & 14 & & \\
\hline & & $\begin{array}{l}\text { ARG CRR CUA, Curuzú } \\
\text { Cuatiá }\end{array}$ & 140 & \multirow{3}{*}{ ARG Corrientes } & \multirow{3}{*}{168} \\
\hline Catelli 2011 & Urbana & ARG CRR & 5 & & \\
\hline Bobillo 2009 & Urbana & ARG CRR & 23 & & \\
\hline Cabana 2006 & Pilaga & ARG FOR & 40 & \multirow{5}{*}{ ARG Formosa } & \multirow{5}{*}{150} \\
\hline Cabana 2006 & Toba & ARG FOR & 24 & & \\
\hline Cabana 2006 & Wichí & ARG FOR & 70 & & \\
\hline Catelli 2011 & Urbana & ARG FOR & 1 & & \\
\hline Bobillo 2009 & Urbana & ARG FOR & 15 & & \\
\hline IMBICE, Inédito & Urbana & ARG & 115 & ARG Gualeguaychú & 115 \\
\hline IMBICE, Inédito & Cochinoca & ARG JUJ, Cochinoca & 17 & \multirow{3}{*}{ ARG Jujuy oeste } & \multirow{3}{*}{59} \\
\hline IMBICE, Inédito & Rinconada & ARG JUJ, Rinconada & 20 & & \\
\hline IMBICE, Inédito & Susques & ARG JUJ, Susques & 22 & & \\
\hline Este trabajo & Urbana & ARG JUJ SSJ & 34 & ARG SS de Jujuy & 34 \\
\hline IMBICE, Inédito & Urbana & ARG ERI LPZ, La Paz & 56 & ARG La Paz & 56 \\
\hline Este trabajo & Urbana & ARG & 169 & ARG La Quiaca & 169 \\
\hline Este trabajo & Urbana & ARG LRI, La Rioja & 78 & ARG La Rioja & 78 \\
\hline Este trabajo & Urbana & ARG, Maimará & 115 & \multirow{3}{*}{ ARG Maimará } & \multirow{3}{*}{162} \\
\hline Este trabajo & Urbana & ARG, Purmamarca & 31 & & \\
\hline Este trabajo & Urbana & ARG, Tumbaya & 16 & & \\
\hline IMBICE, Inédito & Urbana & ARG, Malargüe & 117 & ARG Malargüe & 117 \\
\hline Este trabajo & Urbana & ARG MZA, Mendoza & 55 & ARG Mendoza & 55 \\
\hline Bobillo 2009 & Urbana & ARG MIS & 22 & \multirow{3}{*}{ ARG Misiones } & \multirow{3}{*}{145} \\
\hline Catelli 2011 & Urbana & ARG MIS & 2 & & \\
\hline Sala 2010 & Mbyá & ARG MIS & 121 & & \\
\hline
\end{tabular}




\begin{tabular}{|c|c|c|c|c|c|}
\hline Fuente & Población & Localidad & N A-D & Punto geográfico & N A-D \\
\hline IMBICE, Inédito & Tehuelches & $\begin{array}{l}\text { ARG CHU, Loma } \\
\text { Redonda }\end{array}$ & 6 & \multirow{8}{*}{ ARG Patagonia sur } & \multirow{8}{*}{61} \\
\hline IMBICE, inédito & Tehuelches & ARG CHU, El Chalía & 17 & & \\
\hline Bobillo 2009 & Urbana & ARG CHU & 1 & & \\
\hline IMBICE, Inédito & Urbana & ARG CHU & 15 & & \\
\hline Catelli 2011 & Urbana & ARG CHU & 1 & & \\
\hline IMBICE, Inédito & Tehuelches & ARG SCR & 5 & & \\
\hline Moraga 2000 & Yahgan & $\begin{array}{l}\text { Chile XII, Antartica, Isla } \\
\text { Navarino Puerto } \\
\text { Williams }\end{array}$ & 15 & & \\
\hline Catelli 2011 & Urbana & ARG SCR & 1 & & \\
\hline IMBICE, Inédito & Mapuches & ARG RNE & 51 & \multirow{5}{*}{ ARG Río Negro } & \multirow{5}{*}{216} \\
\hline Bobillo 2009 & Urbana & ARG RNE & 30 & & \\
\hline IMBICE, Inédito & Urbana & ARG RNE, Bariloche & 27 & & \\
\hline IMBICE, Inédito & Urbana & ARG RNE, El Bolsón & 69 & & \\
\hline Ginther 1993 & Mapuche & $\begin{array}{l}\text { ARG RNE PIL, Anecón } \\
\text { Grande }\end{array}$ & 39 & & \\
\hline Tamm 2007 & Urbana & ARG SAL, Salta & 18 & & \\
\hline $\begin{array}{l}\text { Alvarez-Iglesias } \\
2007\end{array}$ & Coyas & ARG SAL+JUJ & 59 & ARG Salta & 77 \\
\hline Este trabajo & Urbana & ARG SNJ CAP, San Juan & 99 & ARG San Juan & 99 \\
\hline IMBICE, Inédito & Urbana & ARG SFE ,Reconquista & 79 & \multirow{4}{*}{ ARG Santa Fe } & \multirow{4}{*}{91} \\
\hline Tamm 2007 & Mocovi & ARG SFE JUS, Gob.Crespo & 5 & & \\
\hline Catelli 2011 & Urbana & ARG SFE & 3 & & \\
\hline Bobillo 2009 & Urbana & ARG SFE & 4 & & \\
\hline Este trabajo & Urbana & $\begin{array}{l}\text { ARG CAT SMA, Santa } \\
\text { María y San José }\end{array}$ & 111 & ARG Santa María & 111 \\
\hline IMBICE, Inédito & Tobas & ARG SAL RBN SVE & 9 & \multirow{4}{*}{$\begin{array}{c}\text { ARG Sta. Victoria } \\
\text { Este }\end{array}$} & \multirow{4}{*}{115} \\
\hline IMBICE, Inédito & $\begin{array}{l}\text { Chaqueños } \\
\text { indet }\end{array}$ & ARG SAL RBN SVE & 20 & & \\
\hline IMBICE, Inédito & Chorote & ARG SAL RBN SVE & 25 & & \\
\hline IMBICE, Inédito & Wichi & ARG SAL RBN SVE & 61 & & \\
\hline Este trabajo & Urbana & ARG SAL, Tartagal & 167 & ARG Tartagal & 167 \\
\hline Este trabajo & Urbana & $\begin{array}{l}\text { ARG MZA LAV, Villa } \\
\text { Tulumaya }\end{array}$ & 63 & ARG V. Tulumaya & 63 \\
\hline $\begin{array}{l}\text { Afonso } 2010 \\
\text { Gaya Vidal } 2011\end{array}$ & $\begin{array}{l}\text { Urbana } \\
\text { Aymara }\end{array}$ & $\begin{array}{l}\text { BOL LPZ, La Paz } \\
\text { BOL LPZ, zona del Lago } \\
\text { Titicaca }\end{array}$ & $\begin{array}{l}109 \\
97 *\end{array}$ & BOL La Paz & 206 \\
\hline $\begin{array}{l}\text { Gaya Vidal } 2011 \\
\text { Yang } 2010\end{array}$ & $\begin{array}{l}\text { Quechua } \\
\text { Aymara }\end{array}$ & $\begin{array}{l}\text { BOL PSI, Tomás Frías, } \\
\text { Tinguipaya } \\
\text { Chile }\end{array}$ & $\begin{array}{l}91^{*} \\
17\end{array}$ & $\begin{array}{l}\text { CHI norte + } \\
\text { BOL PSI, Tomas } \\
\text { Frías }\end{array}$ & 108 \\
\hline
\end{tabular}

* El rango de lectura alcanza hasta la posición 250 


\begin{tabular}{|c|c|c|c|c|c|}
\hline Fuente & Población & Localidad & N A-D & Punto geográfico & N A-D \\
\hline Fagundes 2008 & Katuena & Brasil & 3 & \multirow{3}{*}{ BRA Amazonas } & \multirow{3}{*}{33} \\
\hline $\begin{array}{l}\text { Healy y Hunley } \\
\text { GenBank } 2008\end{array}$ & Karitiana HGDP & Brasil & 24 & & \\
\hline Fagundes 2008 & Yanomama & $\begin{array}{l}\text { Brasil (Roraima y } \\
\text { Amazonas) }\end{array}$ & 6 & & \\
\hline Perego 2010 & Urbana & Brasil, Minas Gerais & 1 & \multirow{3}{*}{ BRA Centro este } & \multirow{3}{*}{36} \\
\hline Yao 2007 & Urbana & Brasil, Sao Paulo & 4 & & \\
\hline Prieto 2010 & Urbana & Brasil, Great São Paulo & 31 & & \\
\hline $\begin{array}{l}\text { Healy y Hunley } \\
\text { GenBank } 2008\end{array}$ & Surui HGDP & Brasil & 21 & \multirow{4}{*}{$\begin{array}{l}\text { BRA Mato Grosso y } \\
\text { Rondonia }\end{array}$} & \multirow{4}{*}{29} \\
\hline Fagundes 2008 & Suruí & Brasil, Rondonia & 2 & & \\
\hline Fagundes 2008 & Xavante & Brasil, Mato grosso & 2 & & \\
\hline Fagundes 2008 & Zoró & $\begin{array}{l}\text { Brasil, Mato grosso y } \\
\text { Rondonia }\end{array}$ & 4 & & \\
\hline Barbosa 2008 & Urbana & Brasil NE, Alagoas & 55 & BRA NE & 55 \\
\hline Fagundes 2008 & Arara/Arara do & Brasil & 1 & \multirow{8}{*}{ BRA Pará y Amapá } & \multirow{8}{*}{19} \\
\hline Fagundes 2008 & $\begin{array}{l}\text { Kayapó/Kriketu } \\
\text { n }\end{array}$ & $\begin{array}{l}\text { Brasil, Pará o Matto } \\
\text { Grosso }\end{array}$ & 2 & & \\
\hline Fagundes 2008 & $\begin{array}{l}\text { Kayapó/Kubem } \\
\text { kokre }\end{array}$ & Brasil, Pará o Matto & 2 & & \\
\hline Fagundes 2008 & Gavião & Brasil, Pará & 3 & & \\
\hline Fagundes 2008 & Poturujara & Brasil, Pará & 3 & & \\
\hline Fagundes 2008 & Tiryó & Brasil, Amapá & 2 & & \\
\hline Fagundes 2008 & Waiwai & Brasil, Amapá & 5 & & \\
\hline Fagundes 2008 & Waiãmpi & Brasil, Amapá & 1 & & \\
\hline Yang 2010 & Guaraní & Brasil & 8 & \multirow{4}{*}{$\begin{array}{l}\text { BRA Paraná y } \\
\text { Santa Catalina }\end{array}$} & \multirow{4}{*}{31} \\
\hline Yang 2010 & Kaingang & Brasil & 2 & & \\
\hline Fagundes 2008 & $\begin{array}{l}\text { Guarani/Rio } \\
\text { das Cobras }\end{array}$ & Brasil, Paraná & 4 & & \\
\hline Palencia 2010 & Urbana & Brasil, Santa Catarina & 17 & & \\
\hline $\begin{array}{l}\text { Perego } 2010 \\
\text { Prieto } 2010\end{array}$ & $\begin{array}{l}\text { Urbana } \\
\text { Urbana }\end{array}$ & $\begin{array}{l}\text { Brasil, Rio Grande do Sul } \\
\text { Brasil, SW }\end{array}$ & $\begin{array}{c}2 \\
14\end{array}$ & BRA RGS & 16 \\
\hline Yang 2010 & Huilliche & Chile & 20 & \multirow{3}{*}{$\mathrm{CHI}$ centro } & \multirow{3}{*}{78} \\
\hline Moraga 2000 & Pehuenche & $\begin{array}{l}\text { Chile VIII, Bío-Bío, Trapa- } \\
\text { Trapa }\end{array}$ & 24 & & \\
\hline Moraga 2000 & Mapuche & $\begin{array}{l}\text { Chile X, Valdivia, Isla } \\
\text { Huapi }\end{array}$ & 34 & & \\
\hline Torres 2006 & Amerindios & $\mathrm{COL}$ & 64 & \multirow{3}{*}{$\begin{array}{c}\mathrm{COL} \\
\text { indeterminado }\end{array}$} & \multirow{3}{*}{72} \\
\hline $\begin{array}{l}\text { Family Tree } \\
\text { GenBank }\end{array}$ & Urbana & $\mathrm{COL}$ & 1 & & \\
\hline Perego 2010 & Urbana & COL Mestizos & 7 & & \\
\hline
\end{tabular}




\begin{tabular}{|c|c|c|c|c|c|}
\hline Fuente & Población & Localidad & N A-D & Punto geográfico & N A-D \\
\hline Tamm 2007 & Coreguaje & $\mathrm{COL}$ & 27 & \multirow{4}{*}{ COL Amazonia } & \multirow{4}{*}{74} \\
\hline Tamm 2007 & Vaupes & $\mathrm{COL}$ & 22 & & \\
\hline Yang 2010 & Ticuna & $\mathrm{COL}$ & 12 & & \\
\hline $\begin{array}{l}\text { Healy y Hunley } \\
\text { GenBank } 2008\end{array}$ & $\begin{array}{l}\text { Curripaco/Piap } \\
\text { oco HGDP }\end{array}$ & $\mathrm{COL}$ & 13 & & \\
\hline Salas 2008 & Afro-COLnos & $\begin{array}{l}\text { COL (Cauca+Valle de } \\
\text { Cauca+Nariño) }\end{array}$ & 23 & \multirow{5}{*}{ COL Andes sur } & \multirow{5}{*}{114} \\
\hline Salas 2008 & Mestizos & $\begin{array}{l}\text { COL (Cauca+Valle de } \\
\text { Cauca+Nariño) }\end{array}$ & 64 & & \\
\hline Salas 2008 & Mulatos & $\begin{array}{l}\text { COL (Cauca+Valle de } \\
\text { Cauca+Nariño) }\end{array}$ & 1 & & \\
\hline Yang 2010 & Inga & COL, ¿'Pasto? & 16 & & \\
\hline Salas 2008 & Paez & $\begin{array}{l}\text { COL (Cauca+Valle de } \\
\text { Cauca+Nariño) }\end{array}$ & 10 & & \\
\hline Perego 2010 & Urbana & COL, Boyaca & 1 & \multirow{3}{*}{ COL centro } & \multirow{3}{*}{36} \\
\hline Díaz-Matallana 2010 & Urbana & $\begin{array}{l}\text { COL, Boyacá, Villa de } \\
\text { Leyva }\end{array}$ & 11 & & \\
\hline Díaz-Matallana 2010 & Urbana & $\begin{array}{l}\text { COL, Cundinamarca, } \\
\text { Bogotá }\end{array}$ & 24 & & \\
\hline Tamm 2007 & Wayuu & COL, Guajira & 42 & \multirow{10}{*}{ COL norte } & \multirow{10}{*}{243} \\
\hline Yang 2010 & Wayuu & COL, La Guajira & 18 & & \\
\hline Yang 2010 & Arhuaco or ljka & $\begin{array}{l}\text { COL, Magdalena, Santa } \\
\text { Marta }\end{array}$ & 16 & & \\
\hline Yang 2010 & Kogi & $\begin{array}{l}\text { COL, Magdalena, Santa } \\
\text { Marta }\end{array}$ & 16 & & \\
\hline Díaz-Matallana 2010 & Urbana & $\begin{array}{l}\text { COL, Magdalena, Santa } \\
\text { Marta }\end{array}$ & 10 & & \\
\hline Díaz-Matallana 2010 & Urbana & $\begin{array}{l}\text { COL, Atlántico, } \\
\text { Barranquilla }\end{array}$ & 2 & & \\
\hline Yang 2010 & Zenu & COL, ¿Cordoba o Sucre? & 15 & & \\
\hline Tamm 2007 & Arsario & COL, Sa. Nevada & 47 & & \\
\hline Tamm 2007 & ljka & COL, Sa. Nevada & 29 & & \\
\hline Tamm 2007 & Kogui & COL, Sa. Nevada & 48 & & \\
\hline Tamm 2007 & Embera & COL y Panama & 39 & \multirow{6}{*}{ COL Pacífico } & \multirow{6}{*}{173} \\
\hline Tamm 2007 & Waunana & COL y Panama & 57 & & \\
\hline Yang 2010 & Waunana & COL, Chocó & 18 & & \\
\hline Yang 2010 & Embera & $\mathrm{COL}$ & 9 & & \\
\hline Salas 2005 & Afro-Chocó & $\mathrm{COL}$ & 49 & & \\
\hline Tamm 2007 & Ngobë & COL/Panamá? & 1 & & \\
\hline
\end{tabular}




\begin{tabular}{|c|c|c|c|c|c|}
\hline Fuente & Población & Localidad & N A-D & Punto geográfico & N A-D \\
\hline Tamm 2007 & Cofan & ECU & 4 & \multirow{9}{*}{ Ecuador } & \multirow{9}{*}{296} \\
\hline Tamm 2007 & Secoya & ECU & 10 & & \\
\hline Tamm 2007 & Siona & ECU & 2 & & \\
\hline Rickards 1999 & Cayapas & ECU, Esmeraldas & 30 & & \\
\hline Baeta 2009 & Waorani & $\begin{array}{l}\text { ECU, Orellana, } \\
\text { Toñampari y Bameno }\end{array}$ & 111 & & \\
\hline Cardoso 2009 & Waorani & ECU & 11 & & \\
\hline Cardoso 2009 & Waorani & ECU & 24 & & \\
\hline IMBICE, Inédito & Urbana & ECU & 103 & & \\
\hline Perego 2010 & Urbana & ECU, Imbabura & 1 & & \\
\hline IMBICE, Inédito & Emerillon & Guayana Francesa & 7 & \multirow{4}{*}{ Guyana Francesa } & \multirow{4}{*}{52} \\
\hline IMBICE, Inédito & Kaliña & Guayana Francesa & 14 & & \\
\hline IMBICE, Inédito & Palikur & Guayana Francesa & 14 & & \\
\hline IMBICE, Inédito & Wayampi & Guayana Francesa & 17 & & \\
\hline $\begin{array}{l}\text { Fagundes } 2008 \\
\text { Yang } 2010\end{array}$ & $\begin{array}{l}\text { Ache } \\
\text { Aché }\end{array}$ & $\begin{array}{l}\text { Paraguay } \\
\text { Paraguay }\end{array}$ & $\begin{array}{c}2 \\
11\end{array}$ & PAR este & 13 \\
\hline $\begin{array}{l}\text { IMBICE, Inédito } \\
\text { IMBICE, Inédito }\end{array}$ & $\begin{array}{l}\text { Ayoreo } \\
\text { Lengua }\end{array}$ & $\begin{array}{l}\text { Paraguay } \\
\text { Paraguay }\end{array}$ & $\begin{array}{l}16 \\
17 \\
\end{array}$ & PAR Filadelfia & 33 \\
\hline $\begin{array}{l}\text { Perego } 2010 \\
\text { Perego } 2010 \\
\text { Perego } 2010 \\
\text { Perego } 2010 \\
\text { Perego } 2010 \\
\text { Perego } 2010 \\
\text { Perego } 2010 \\
\text { Yang } 2010 \\
\end{array}$ & $\begin{array}{l}\text { Urbana } \\
\text { Urbana } \\
\text { Urbana } \\
\text { Urbana } \\
\text { Urbana } \\
\text { Urbana } \\
\text { Urbana } \\
\text { Quechua }\end{array}$ & $\begin{array}{l}\text { Peru, Loreto } \\
\text { Peru, Loreto } \\
\text { Peru, Cajamarca } \\
\text { Peru, Piura } \\
\text { Peru, Lima } \\
\text { Peru, Huanucu } \\
\text { Peru, Huancavelica } \\
\text { Perú }\end{array}$ & $\begin{array}{c}1 \\
1 \\
1 \\
1 \\
8 \\
1 \\
1 \\
18 \\
\end{array}$ & PERÚ & 32 \\
\hline $\begin{array}{l}\text { Pagano2005 } \\
\text { Perego } 2010 \\
\text { Perego } 2010\end{array}$ & $\begin{array}{l}\text { Urbana } \\
\text { Urbana } \\
\text { Urbana }\end{array}$ & $\begin{array}{l}\text { Uruguay } \\
\text { Uruguay } \\
\text { Uruguay, Flores }\end{array}$ & $\begin{array}{c}37 \\
1 \\
1 \\
\end{array}$ & Uruguay & 39 \\
\hline $\begin{array}{l}\text { Lander FSI Genet } \\
2008 \\
\text { Castro de Guerra } \\
2011\end{array}$ & $\begin{array}{l}\text { Urbana } \\
\text { Urbana }\end{array}$ & $\begin{array}{l}\text { Venezuela, Caracas } \\
\text { Venezuela, Caracas }\end{array}$ & $\begin{array}{l}67 \\
67\end{array}$ & VEN Caracas & 134 \\
\hline $\begin{array}{l}\text { Ingman } 2000 \\
\text { Vona } 2005\end{array}$ & $\begin{array}{l}\text { Warao } \\
\text { Guahibo }\end{array}$ & $\begin{array}{l}\text { Venezuela, Orinoco Delta } \\
\text { Venezuela AMA, Puerto } \\
\text { Ayacucho }\end{array}$ & $\begin{array}{c}2 \\
59\end{array}$ & VEN Pto. Ayacucho & 61 \\
\hline OTAL & & & & & 4787 \\
\hline
\end{tabular}


7.2.5.3 Puntos geográficos para polimorfismos en la Región Control (por fuera de las RHVI y RHVII)

\begin{tabular}{|c|c|c|c|c|c|}
\hline Fuente & Población & Localidad & N A-D & $\begin{array}{c}\text { Punto } \\
\text { geográfico }\end{array}$ & N A-D \\
\hline Este trabajo & Urbana & ARG CAT BEL, Belén & 61 & ARG Belén & 61 \\
\hline Bobillo 2009 & Urbana & ARG BUE & 89 & ARG Bs As & 89 \\
\hline Este trabajo & Urbana & ARG SNJ CAL, Calingasta & 65 & ARG Calingasta & 65 \\
\hline Cabana 2006 & Toba & ARG CHA & $43^{*}$ & & \\
\hline Cabana 2006 & Wichí & ARG CHA & $32 *$ & ARG Chaco & 79 \\
\hline Bobillo 2009 & Urbana & ARG CHA & 4 & & \\
\hline Este trabajo & Urbana & ARG LRJ RVP, Chepes & 44 & ARG Chepes & 44 \\
\hline IMBICE, Inédito & Urbana & ARG CBA, Pampa de Achala & 14 & ARG Córdoba & 14 \\
\hline $\begin{array}{l}\text { IMBICE, Inédito } \\
\text { Bobillo } 2009\end{array}$ & $\begin{array}{l}\text { Urbana } \\
\text { Urbana }\end{array}$ & $\begin{array}{l}\text { ARG CRR, Curuzú Cuatiá } \\
\text { ARG CRR }\end{array}$ & $\begin{array}{c}140 \\
23\end{array}$ & ARG Corrientes & 163 \\
\hline $\begin{array}{l}\text { Cabana } 2006 \\
\text { Cabana } 2006 \\
\text { Cabana } 2006 \\
\text { Bobillo } 2009 \\
\end{array}$ & \begin{tabular}{|l|} 
Pilaga \\
Toba \\
Wichí \\
Urbana \\
\end{tabular} & $\begin{array}{l}\text { ARG FOR } \\
\text { ARG FOR } \\
\text { ARG FOR } \\
\text { ARG FOR }\end{array}$ & $\begin{array}{c}40^{*} \\
24 * \\
70^{*} \\
15 \\
\end{array}$ & ARG Formosa & 15 \\
\hline IMBICE, Inédito & Urbana & ARG & 115 & $\begin{array}{c}\text { ARG } \\
\text { Gualeguaychú }\end{array}$ & 115 \\
\hline $\begin{array}{l}\text { IMBICE, Inédito } \\
\text { IMBICE, Inédito } \\
\text { IMBICE, Inédito }\end{array}$ & $\begin{array}{l}\text { Cochinoca } \\
\text { Rinconada } \\
\text { Susques } \\
\end{array}$ & $\begin{array}{l}\text { ARG JUJ, Cochinoca } \\
\text { ARG JUJ, Rinconada } \\
\text { ARG JUJ, Susques }\end{array}$ & $\begin{array}{l}17 \\
20 \\
22\end{array}$ & $\begin{array}{l}\text { ARG Jujuy } \\
\text { oeste }\end{array}$ & 59 \\
\hline Este trabajo & Urbana & ARG JUJ SSJ & 34 & ARG SS de Jujuy & 34 \\
\hline IMBICE, Inédito & Urbana & ARG ERI LPZ, La Paz & 56 & ARG La Paz & 56 \\
\hline Este trabajo & Urbana & ARG & 169 & ARG La Quiaca & 169 \\
\hline Este trabajo & Urbana & ARG LRI, La Rioja & 78 & ARG La Rioja & 78 \\
\hline Este trabajo & Urbana & ARG, Maimará & 115 & & \\
\hline Este trabajo & Urbana & ARG, Purmamarca & 31 & ARG Maimará & 162 \\
\hline Este trabajo & Urbana & ARG, Tumbaya & 16 & & \\
\hline IMBICE, Inédito & Urbana & ARG, Malargüe & 117 & ARG Malargüe & 117 \\
\hline Este trabajo & Urbana & ARG MZA, Mendoza & 55 & ARG Mendoza & 55 \\
\hline Bobillo 2009 & Urbana & ARG MIS & 22 & ARG Misiones & 22 \\
\hline $\begin{array}{l}\text { IMBICE, Inédito } \\
\text { IMBICE, inédito } \\
\text { Bobillo } 2009 \\
\text { IMBICE, Inédito } \\
\text { IMBICE, Inédito }\end{array}$ & $\begin{array}{l}\text { Tehuelches } \\
\text { Tehuelches } \\
\text { Urbana } \\
\text { Urbana } \\
\text { Tehuelches }\end{array}$ & $\begin{array}{l}\text { ARG CHU, Loma Redonda } \\
\text { ARG CHU, El Chalía } \\
\text { ARG CHU } \\
\text { ARG CHU } \\
\text { ARG SCR }\end{array}$ & $\begin{array}{c}6 \\
17 \\
1 \\
15 \\
5\end{array}$ & $\begin{array}{c}\text { ARG Patagonia } \\
\text { sur }\end{array}$ & 44 \\
\hline
\end{tabular}

* El rango de lectura alcanza hasta la posición 338 
Anexo

\begin{tabular}{|c|c|c|c|c|c|}
\hline Fuente & Población & Localidad & N A-D & $\begin{array}{c}\text { Punto } \\
\text { geográfico }\end{array}$ & N A-D \\
\hline IMBICE, Inédito & Mapuches & ARG RNE & 51 & & \\
\hline Bobillo 2009 & Urbana & ARG RNE & 30 & & \\
\hline IMBICE, Inédito & Urbana & ARG RNE, Bariloche & 27 & ARG RIO Negro & $1 / 1$ \\
\hline IMBICE, Inédito & Urbana & ARG RNE, El Bolsón & 69 & & \\
\hline \begin{tabular}{|l|} 
Alvarez-Iglesias \\
2007 \\
\end{tabular} & Coyas & ARG SAL+JUJ & 59 & ARG Salta & 59 \\
\hline Este trabajo & Urbana & ARG SNJ CAP, San Juan & 99 & ARG San Juan & 99 \\
\hline $\begin{array}{l}\text { IMBICE, Inédito } \\
\text { Bobillo } 2009\end{array}$ & $\begin{array}{l}\text { Urbana } \\
\text { Urbana }\end{array}$ & $\begin{array}{l}\text { ARG SFE GOB, Reconquista } \\
\text { ARG SFE }\end{array}$ & $\begin{array}{c}79 \\
4 \\
\end{array}$ & ARG Santa Fe & 83 \\
\hline Este trabajo & Urbana & $\begin{array}{l}\text { ARG CAT SMA, Santa María } \\
\text { y San José }\end{array}$ & 111 & $\begin{array}{l}\text { ARG Santa } \\
\text { María }\end{array}$ & 111 \\
\hline IMBICE, Inédito & Tobas & ARG SAL RBN SVE & 9 & & \\
\hline IMBICE, Inédito & Chaqueños indet & ARG SAL RBN SVE & 20 & ARG Sta. & \\
\hline IMBICE, Inédito & Chorote & ARG SAL RBN SVE & 25 & Victoria Este & 115 \\
\hline IMBICE, Inédito & Wichi & ARG SAL RBN SVE & 61 & & \\
\hline Este trabajo & Urbana & ARG SAL, Tartagal & 167 & ARG Tartagal & 167 \\
\hline Este trabajo & Urbana & $\begin{array}{l}\text { ARG MZA LAV, Villa } \\
\text { Tulumaya } \\
\end{array}$ & 63 & $\begin{array}{l}\text { ARG V. } \\
\text { Tulumaya }\end{array}$ & 63 \\
\hline Gaya Vidal 2011 & Aymara & $\begin{array}{l}\text { BOL LPZ, zona del Lago } \\
\text { Titicaca } \\
\end{array}$ & $97^{* \prime}$ & BOL La Paz & 97 \\
\hline $\begin{array}{l}\text { Gaya Vidal } 2011 \\
\text { Yang } 2010\end{array}$ & $\begin{array}{l}\text { Quechua } \\
\text { Aymara }\end{array}$ & $\begin{array}{l}\text { BOL PSI, Tomás Frías, } \\
\text { Tinguipaya } \\
\text { Chile }\end{array}$ & $\begin{array}{l}91^{*} \\
17\end{array}$ & $\begin{array}{c}\text { CHI norte }+ \\
\text { BOL PSI, Tomas } \\
\text { Frías }\end{array}$ & 108 \\
\hline Fagundes 2008 & Katuena & Brasil & 3 & & \\
\hline $\begin{array}{l}\text { Healy y Hunley } \\
\text { GenBank } 2008\end{array}$ & Karitiana HGDP & 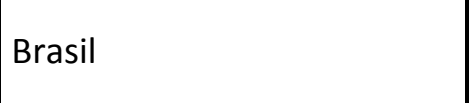 & 24 & BRA Amazonas & 33 \\
\hline Fagundes 2008 & Yanomama & Brasil (Roraima y Amazonas) & 6 & & \\
\hline \begin{tabular}{|l|} 
Perego 2010 \\
Yao 2007 \\
Prieto 2010 \\
\end{tabular} & $\begin{array}{l}\text { Urbana } \\
\text { Urbana } \\
\text { Urbana } \\
\end{array}$ & $\begin{array}{l}\text { Brasil, Minas Gerais } \\
\text { Brasil, Sao Paulo } \\
\text { Brasil, Great São Paulo }\end{array}$ & $\begin{array}{c}1 \\
4 \\
31 \\
\end{array}$ & $\begin{array}{l}\text { BRA Centro } \\
\text { este }\end{array}$ & 36 \\
\hline \begin{tabular}{|l} 
Healy y Hunley \\
GenBank 2008 \\
Fagundes 2008 \\
Fagundes 2008 \\
Fagundes 2008
\end{tabular} & $\begin{array}{l}\text { Surui HGDP } \\
\text { Suruí } \\
\text { Xavante } \\
\text { Zoró }\end{array}$ & $\begin{array}{l}\text { Brasil } \\
\text { Brasil, Rondonia } \\
\text { Brasil, Mato grosso } \\
\text { Brasil, Mato grosso y } \\
\text { Rondonia }\end{array}$ & $\begin{array}{l}21 \\
2 \\
2 \\
4\end{array}$ & $\begin{array}{l}\text { BRA Mato } \\
\text { Grosso y } \\
\text { Rondonia }\end{array}$ & 29 \\
\hline
\end{tabular}

*' El rango de lectura alcanza hasta la posición 250 
Anexo

\begin{tabular}{|c|c|c|c|c|c|}
\hline Fuente & Población & Localidad & N A-D & $\begin{array}{c}\text { Punto } \\
\text { geográfico }\end{array}$ & N A-D \\
\hline Fagundes 2008 & $\begin{array}{l}\text { Arara/Arara do } \\
\text { Laranjal }\end{array}$ & Brasil & 1 & \multirow{8}{*}{$\begin{array}{l}\text { BRA Pará y } \\
\text { Amapá }\end{array}$} & \multirow{8}{*}{19} \\
\hline Fagundes 2008 & Kayapó/Kriketun & Brasil, Pará o Matto Grosso & 2 & & \\
\hline Fagundes 2008 & $\begin{array}{l}\text { Kayapó/Kubemk } \\
\text { okre }\end{array}$ & Brasil, Pará o Matto Grosso & 2 & & \\
\hline Fagundes 2008 & Gavião & Brasil, Pará & 3 & & \\
\hline Fagundes 2008 & Poturujara & Brasil, Pará & 3 & & \\
\hline Fagundes 2008 & Tiryó & Brasil, Amapá & 2 & & \\
\hline Fagundes 2008 & Waiwai & Brasil, Amapá & 5 & & \\
\hline Fagundes 2008 & Waiãmpi & Brasil, Amapá & 1 & & \\
\hline Yang 2010 & Guaraní & Brasil & 8 & \multirow{4}{*}{$\begin{array}{l}\text { BRA Paraná y } \\
\text { Santa Catalina }\end{array}$} & \multirow{4}{*}{31} \\
\hline Yang 2010 & Kaingang & Brasil & 2 & & \\
\hline Fagundes 2008 & $\begin{array}{l}\text { Guarani/Rio das } \\
\text { Cobras }\end{array}$ & Brasil, Paraná & 4 & & \\
\hline Palencia 2010 & Urbana & Brasil, Santa Catarina & 17 & & \\
\hline $\begin{array}{l}\text { Perego } 2010 \\
\text { Prieto } 2010\end{array}$ & $\begin{array}{l}\text { Urbana } \\
\text { Urbana }\end{array}$ & $\begin{array}{l}\text { Brasil, Rio Grande do Sul } \\
\text { Brasil, SW }\end{array}$ & $\begin{array}{c}2 \\
14\end{array}$ & BRA RGS & 16 \\
\hline Yang 2010 & Huilliche & Chile & 20 & $\mathrm{CHI}$ centro & 20 \\
\hline Yang 2010 & Ticuna & $\mathrm{COL}$ & 12 & \multirow[b]{2}{*}{ COL Amazonia } & \multirow[b]{2}{*}{25} \\
\hline $\begin{array}{l}\text { Healy y Hunley } \\
\text { GenBank } 2008\end{array}$ & $\begin{array}{l}\text { Curripaco/Piapoc } \\
\text { o HGDP }\end{array}$ & $\mathrm{COL}$ & 13 & & \\
\hline Salas 2008 & Afro-COLnos & $\begin{array}{l}\text { COL (Cauca+Valle de } \\
\text { Cauca+Nariño) }\end{array}$ & 23 & \multirow{5}{*}{ COL Andes sur } & \multirow{5}{*}{114} \\
\hline Salas 2008 & Mestizos & $\begin{array}{l}\text { COL (Cauca+Valle de } \\
\text { Cauca+Nariño) }\end{array}$ & 64 & & \\
\hline Salas 2008 & Mulatos & $\begin{array}{l}\text { COL (Cauca+Valle de } \\
\text { Cauca+Nariño) }\end{array}$ & 1 & & \\
\hline Yang 2010 & Inga & COL, ¿Pasto? & 16 & & \\
\hline Salas 2008 & Paez & $\begin{array}{l}\text { COL (Cauca+Valle de } \\
\text { Cauca+Nariño) }\end{array}$ & 10 & & \\
\hline Yang 2010 & Wayuu & COL, La Guajira & 18 & \multirow{6}{*}{ COL norte } & \multirow{6}{*}{77} \\
\hline Yang 2010 & Arhuaco or ljka & $\begin{array}{l}\text { COL, Magdalena, Santa } \\
\text { Marta }\end{array}$ & 16 & & \\
\hline Yang 2010 & Kogi & $\begin{array}{l}\text { COL, Magdalena, Santa } \\
\text { Marta }\end{array}$ & 16 & & \\
\hline $\begin{array}{l}\text { Díaz-Matallana } \\
2010\end{array}$ & Urbana & $\begin{array}{l}\text { COL, Magdalena, Santa } \\
\text { Marta }\end{array}$ & 10 & & \\
\hline $\begin{array}{l}\text { Díaz-Matallana } \\
2010\end{array}$ & Urbana & COL, Atlántico, Barranquilla & 2 & & \\
\hline Yang 2010 & Zenu & COL, ¿Cordoba o Sucre? & 15 & & \\
\hline Yang 2010 & Waunana & COL, Chocó & 18 & \multirow{3}{*}{ COL pacífico } & \multirow{3}{*}{76} \\
\hline Yang 2010 & Embera & COL & 9 & & \\
\hline Salas 2005 & Afro-Chocó & COL & 49 & & \\
\hline
\end{tabular}


Anexo

\begin{tabular}{|c|c|c|c|c|c|}
\hline Fuente & Población & Localidad & N A-D & $\begin{array}{c}\text { Punto } \\
\text { geográfico }\end{array}$ & N A-D \\
\hline $\begin{array}{l}\text { Cardoso GenBank } \\
2009 \\
\text { Cardoso GenBank } \\
2009 \\
\text { IMBICE, Inédito } \\
\text { Perego } 2010\end{array}$ & $\begin{array}{l}\text { Waorani } \\
\text { Waorani } \\
\text { Urbana } \\
\text { Urbana }\end{array}$ & $\begin{array}{l}\text { ECU } \\
\text { ECU } \\
\text { ECU } \\
\text { ECU, Imbabura }\end{array}$ & $\begin{array}{c}11 \\
24 \\
103 \\
1\end{array}$ & Ecuador & 139 \\
\hline $\begin{array}{l}\text { Fagundes } 2008 \\
\text { Yang } 2010\end{array}$ & $\begin{array}{l}\text { Ache } \\
\text { Aché } \\
\end{array}$ & \begin{tabular}{|l} 
Paraguay \\
Paraguay \\
\end{tabular} & $\begin{array}{c}2 \\
11 \\
\end{array}$ & PAR este & 13 \\
\hline $\begin{array}{l}\text { IMBICE, Inédito } \\
\text { IMBICE, Inédito }\end{array}$ & $\begin{array}{l}\text { Ayoreo } \\
\text { Lengua } \\
\end{array}$ & $\begin{array}{l}\text { Paraguay } \\
\text { Paraguay }\end{array}$ & $\begin{array}{l}16 \\
17 \\
\end{array}$ & PAR Filadelfia & 33 \\
\hline $\begin{array}{l}\text { Perego } 2010 \\
\text { Perego } 2010 \\
\text { Perego } 2010 \\
\text { Perego } 2010 \\
\text { Perego } 2010 \\
\text { Perego } 2010 \\
\text { Perego } 2010 \\
\text { Yang } 2010\end{array}$ & $\begin{array}{l}\text { Urbana } \\
\text { Urbana } \\
\text { Urbana } \\
\text { Urbana } \\
\text { Urbana } \\
\text { Urbana } \\
\text { Urbana } \\
\text { Quechua }\end{array}$ & $\begin{array}{l}\text { Peru, Loreto } \\
\text { Peru, Loreto } \\
\text { Peru, Cajamarca } \\
\text { Peru, Piura } \\
\text { Peru, Lima } \\
\text { Peru, Huanucu } \\
\text { Peru, Huancavelica } \\
\text { Perú }\end{array}$ & $\begin{array}{c}1 \\
1 \\
1 \\
1 \\
8 \\
1 \\
1 \\
18\end{array}$ & PERÚ & 32 \\
\hline $\begin{array}{l}\text { Lander FSI Genet } \\
2008\end{array}$ & Urbana & Venezuela, Caracas & 67 & VEN Caracas & 67 \\
\hline TOTAL & & & & & 3075 \\
\hline
\end{tabular}


7.2.6 FRECUENCIAS POBLACIONALES UTILIZADAS PARA CONFECCIONAR LOS MAPAS DE DISTRIBUCIÓN GEOGRÁFICA DE LINAJES.

\subsubsection{Linajes definidos por mutaciones en la RHVI.}

\begin{tabular}{|c|c|c|c|c|c|c|c|c|c|c|c|c|c|c|c|c|c|c|c|c|c|c|c|c|}
\hline & 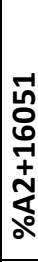 & 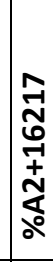 & 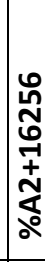 & & & & & 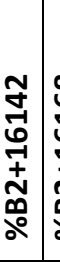 & 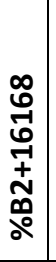 & 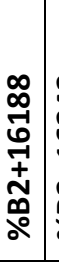 & 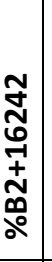 & 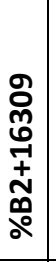 & 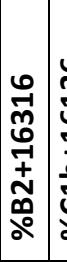 & 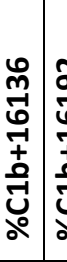 & 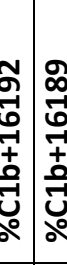 & 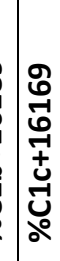 & 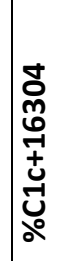 & 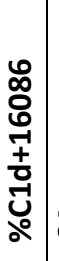 & 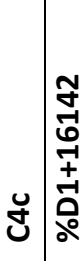 & $\begin{array}{l}0 \\
0 \\
-1 \\
0 \\
+ \\
+ \\
0 \\
0 \\
0\end{array}$ & 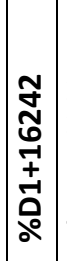 & 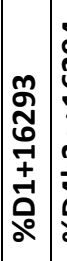 & 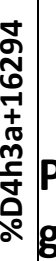 & $\begin{array}{l}\text { Punto } \\
\text { geográfico }\end{array}$ \\
\hline & & & & & & & & $\underset{\sim}{\stackrel{\infty}{m}}$ & & 总 & & $\underset{+}{+}$ & & 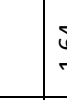 & 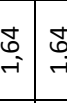 & i & & & & & \begin{tabular}{|l|}
$\overrightarrow{7}$ \\
$\overrightarrow{9}$ \\
\end{tabular} & & & ARG Belén \\
\hline & $\overbrace{}^{-1}$ & & & & & & & $\begin{array}{l}\mathbb{D} \\
\underset{\sim}{\infty}\end{array}$ & $\begin{array}{l}\Omega \\
0 \\
0\end{array}$ & $\stackrel{m}{i}$ & & & & $\begin{array}{ll}2 & \vdots \\
\vdots & 2\end{array}$ & & $\underset{\pi}{2}$ & & & & $\stackrel{m}{i}$ & $\stackrel{\vec{\infty}}{\sim}$ & & $\begin{array}{c}2 \\
\delta \\
0\end{array}$ & ARG Buenos Aires \\
\hline & & & & & & & & & & & & & & $£$ & & & & & 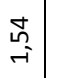 & $\begin{array}{l}\Omega \\
-\end{array}$ & 兽 & & & ARG Calingasta \\
\hline & & & & & & & & & & & & & & 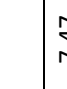 & & & & & & 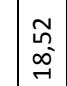 & $\begin{array}{l}\text { ma } \\
\text { ș }\end{array}$ & & & ARG Catamarca \\
\hline 8 & $\begin{array}{l}\infty \\
g \\
g \\
g\end{array}$ & & & & & & & & & & & & 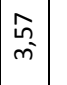 & $\vdots$ & & & & & & & & & & ARG Chaco \\
\hline & & & & & & & & & & & & & & 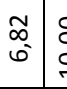 & \& & & & & $\begin{array}{l}\stackrel{n}{n} \\
\sim\end{array}$ & & $\begin{array}{l}\text { 坥 } \\
\text { ล }\end{array}$ & & & ARG Chepes \\
\hline 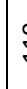 & $\begin{array}{c}\vdots \\
\infty \\
0 \\
0\end{array}$ & & & & & & & 志 & & & & & $\begin{array}{c}b_{0} \\
\infty \\
0 \\
0\end{array}$ & o & 离 & $\begin{array}{c}\dot{1} \\
0 \\
0 \\
0\end{array}$ & & & & 年 & 竝 & & & ARG Córdoba \\
\hline g & $\stackrel{8}{\circ}$ & & & & & & & & & $\stackrel{\circ}{:}$ & & & 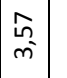 & 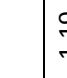 & $\stackrel{9}{-}$ & 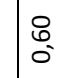 & & & $\underset{m}{\sim}$ & & $\because 8$ & & & ARG Corrientes \\
\hline st & $\begin{array}{l}8 \\
\infty\end{array}$ & & & $\stackrel{m}{m}$ & & & & ô. & & $\underset{i}{8}$ & $\begin{array}{l}\hat{0} \\
0\end{array}$ & $\underset{i}{8}$ & & $\underset{\substack{0 \\
i}}{8}$ & $\hat{0}$ & $\underset{\sim}{\stackrel{\sim}{-}}$ & & & & & $\underset{i}{\stackrel{i}{i}}$ & & & ARG Formosa \\
\hline 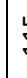 & 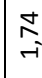 & & & $\begin{array}{c}\infty \\
0 \\
0\end{array}$ & $a$ & & & 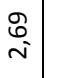 & & & & & & i & i & & & & $\begin{array}{l}\infty \\
\infty_{0} \\
0^{\prime}\end{array}$ & & $\mid \begin{array}{c}\stackrel{n}{\sim} \\
\sim \\
\sim\end{array}$ & & & ARG Gualeguaychi \\
\hline 5 & & $\underset{m}{m}$ & & & & & : & & 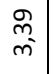 & & $\underset{m}{m}$ & 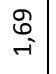 & & & & & & & & & & o & : & ARG Jujuy Oeste \\
\hline s & $\begin{array}{l}\infty \\
\infty \\
\text { in } \\
\text { in }\end{array}$ & & & & $\underset{\alpha}{\alpha}$ & & & & & $\underset{\substack{\infty \\
\infty \\
\infty}}{\substack{\infty \\
-}}$ & & & & 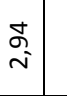 & & & & & & & 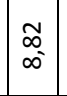 & & & $\begin{array}{l}\text { ARG Jujuy San } \\
\text { Salvador }\end{array}$ \\
\hline & 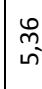 & & & & s & & & & & & & & $\begin{array}{c}g \\
-1 \\
-1\end{array}$ & \begin{tabular}{l|l}
9 \\
$-i$
\end{tabular} & ז & & & & 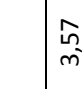 & & $\underset{-}{9}$ & & & ARG La Paz \\
\hline g & 온 & $\stackrel{\infty}{-}$ & 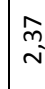 & भु & $\frac{\alpha}{7}$ & $\stackrel{\infty}{-}$ & $\begin{array}{lll}\infty & \\
\rightarrow & \vdots\end{array}$ & $\begin{array}{l}\infty \\
\rightarrow \\
\rightarrow\end{array}$ & $\begin{array}{l}\infty \\
-1 \\
-\end{array}$ & 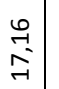 & $\underset{\substack{m \\
i}}{\mid}$ & 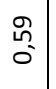 & $\stackrel{\substack{\infty \\
i}}{i}$ & 过 & 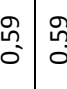 & & $\stackrel{\infty}{=}$ & 贻 & 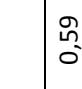 & & & 员 & 今̊. & ARG La Quiaca \\
\hline 9 & & & & & & & & $\begin{array}{l}7 \\
\text { f } \\
\text { to }\end{array}$ & & $\stackrel{\infty}{\rightarrow}$ & & & & 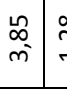 & $\stackrel{\infty}{-}$ & & & & & $\begin{array}{l}\infty \\
\infty \\
m \\
\end{array}$ & \begin{tabular}{l}
$\hat{\infty}$ \\
\multirow{j}{f}{}
\end{tabular} & & & ARG La Rioja \\
\hline 乌 & & O. & 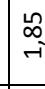 & o & 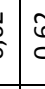 & & 离 & & $\stackrel{\stackrel{L}{\infty}}{\rightarrow}$ & 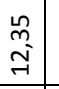 & $\underset{\sim}{\stackrel{n}{\sim}}$ & $\underset{m}{m} \underset{\sim}{m}$ & & L & 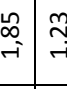 & 0 & $\underset{f}{\mathfrak{i}}$ & : & & & $\begin{array}{l}0 \\
6 \\
0 \\
0\end{array}$ & $\stackrel{\tilde{0}}{0}$ & & ARG Maimará \\
\hline 5 & & & & & & & & 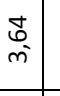 & & $\underset{\sim}{\infty}$ & & & & $\stackrel{\substack{\infty \\
-}}{-i}$ & & & & & & $\begin{array}{l}0 \\
0 \\
0 \\
-1 \\
\end{array}$ & $\underset{i}{\stackrel{i}{i}}$ & $\underset{\substack{\infty \\
\rightarrow+}}{\sim}$ & & ARG Mendoza \\
\hline & & & & & & & & $\stackrel{9}{-i}$ & & 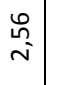 & & $\stackrel{\substack{n \\
i}}{i}$ & & 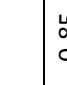 & $\begin{array}{l}\infty \\
\infty \\
0 \\
0\end{array}$ & & & & & 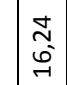 & $\underset{\mathcal{n}}{\mathcal{z}}$ & & & ARG Malargüe \\
\hline
\end{tabular}




\begin{tabular}{|c|c|c|c|c|c|c|c|c|c|c|c|c|c|c|c|c|c|c|c|c|}
\hline 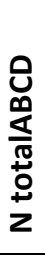 & 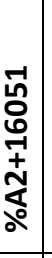 & 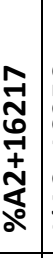 & 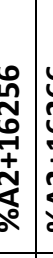 & & 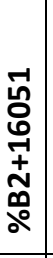 & 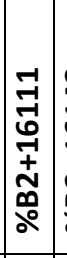 & & 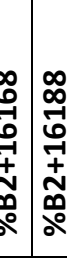 & 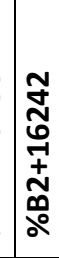 & 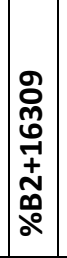 & & 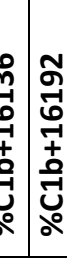 & 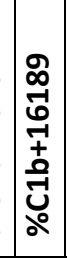 & 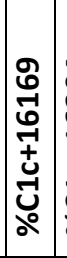 & 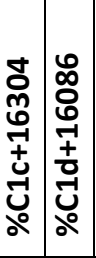 & & 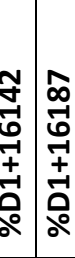 & 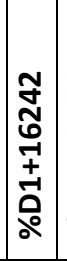 & & 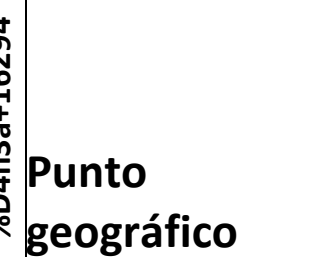 \\
\hline$\stackrel{\text { 守 }}{\sim}$ & & & & & & & & & & & & & & 皇 & & $\overbrace{}^{2}$ & - & & & ARG Misiones \\
\hline 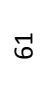 & & & & & & & & & & & & & & & & & $\begin{array}{l}\infty \\
\omega \\
\text { ஸे } \\
\text { in }\end{array}$ & & & ARG Patagonia sur \\
\hline$\stackrel{\oplus}{\sim}$ & $\begin{array}{l}0 \\
0 \\
0 \\
0\end{array}$ & & & & & & 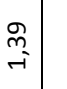 & & & & & & $\begin{array}{l}0 \\
+ \\
0 \\
0\end{array}$ & & & & $\begin{array}{l}0 \\
\text { ì } \\
\text { ì }\end{array}$ & $\vec{w}$ & $\stackrel{0}{0}$ & ARG Río Negro \\
\hline$\curvearrowright$ & & & i & & $\underset{m}{\stackrel{m}{\rightarrow}}$ & $\begin{array}{l}\dot{8} \\
i \\
i\end{array}$ & s & \begin{tabular}{ll}
0 \\
\hdashline \\
$-m$ & $g$ \\
\end{tabular} & $\underset{m}{\stackrel{m}{i}}$ & $\underset{m}{\substack{n \\
i}}$ & $\vdots$ & $\begin{array}{ll}\stackrel{p}{n} \\
-i \\
m\end{array}$ & $\begin{array}{l}0 \\
0 \\
i\end{array}$ & $\mid \begin{array}{l}\stackrel{0}{0} \\
i \\
i\end{array}$ & $\stackrel{\substack{m \\
\rightarrow}}{\rightarrow}$ & & & 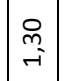 & $\stackrel{\circ}{m}$ & ARG Salta \\
\hline g & & & & & & & $\stackrel{\infty}{=}$ & $\vec{z}$ & & & $\underset{F}{ت}$ & 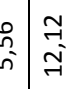 & & & & $\underset{\sim}{\tilde{N}}$ & 占 & $\begin{array}{l}\vec{z} \\
\vec{z}\end{array}$ & & ARG San Juan \\
\hline न & 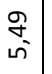 & & & & & & & & & & & & & $\underset{\rightarrow}{\stackrel{g}{\rightarrow}}$ & & & \begin{tabular}{l|l}
$\stackrel{9}{*}$ \\
$\&$
\end{tabular} & $\underset{-}{\stackrel{g}{-}}$ & & ARG Santa Fe \\
\hline$\exists$ & & & & & & & 乱 & $\stackrel{+}{\dot{m}}$ & & $\stackrel{m}{i}$ & 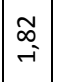 & $\stackrel{\sim}{N}$ & $\begin{array}{l}\dot{b} \\
\dot{m} \\
\dot{m}\end{array}$ & $\stackrel{m}{i}$ & & & $\underset{-i}{8}$ & 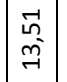 & f & f ARG Santa María \\
\hline 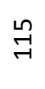 & $\begin{array}{l}\text { \&̊ } \\
6\end{array}$ & & & & $\begin{array}{c}\hat{\infty} \\
0_{0}^{-}\end{array}$ & & & & & & & & & $\underset{5}{\stackrel{4}{4}}$ & $\begin{array}{l}1 \\
\infty \\
0 \\
0\end{array}$ & & & & & $\begin{array}{l}\text { ARG Sta. Victoria } \\
\text { Este }\end{array}$ \\
\hline 包 & $\stackrel{\substack{q \\
i}}{i}$ & & & $\underset{\substack{i \\
\text { i }}}{ }$ & $\underset{i}{\stackrel{i}{\rightarrow}}$ & & $\stackrel{\substack{7 \\
i}}{1}$ & $\stackrel{g}{i}$ & & & 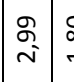 & $\begin{array}{lll}0 \\
\infty\end{array}$ & & 员 & & & \begin{tabular}{l|l}
0 \\
$:$
\end{tabular} & 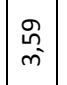 & $\stackrel{0}{\circ}$ & ARG Tartagal \\
\hline 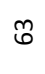 & & & & & & & 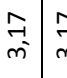 & f & & & & $\stackrel{f}{m}$ & & & & 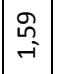 & 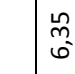 & $\underset{\substack{f \\
\leftarrow}}{\mathscr{f}}$ & & ARG Villa Tulumaya \\
\hline$\stackrel{\infty}{\circ}$ & & & & $\stackrel{\infty}{i}$ & & & $\stackrel{5}{g}$ & 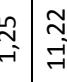 & & & & 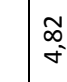 & & & & & & & $\stackrel{\infty}{\sim}$ & BOL Beni \\
\hline$\stackrel{N}{\circ}$ & & à & & gृ & \begin{tabular}{l}
$\infty$ \\
\hdashline \\
0
\end{tabular} & 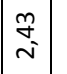 & $\bar{s}^{2}$ & 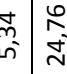 & & & & $\stackrel{+}{\rightarrow}$ & & & & & & & \begin{tabular}{l|l}
$g$ & $\infty$ \\
0 & 0
\end{tabular} & BOL La Paz \\
\hline$\stackrel{\infty}{\rightarrow}$ & $\stackrel{\infty}{\stackrel{\infty}{i}}$ & $\stackrel{\infty}{i}$ & & 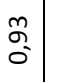 & & & s & \begin{tabular}{l|l}
$\Delta$ \\
Na
\end{tabular} & m. & & & ח. & & & & & $\begin{array}{l}n \\
\text { g. } \\
\text { o }\end{array}$ & $\begin{array}{l}\text { ma } \\
\text { â. }\end{array}$ & & BOL PSI + CHI norte \\
\hline f & & & & $\stackrel{m}{i}$ & & & & & & & & & & & & \begin{tabular}{l|l}
$\stackrel{n}{a}$ & $j$ \\
$i$ & $n$ \\
$i$
\end{tabular} & a & & & BRA Amapá \\
\hline$\prod_{\sim}^{\infty}$ & & & & $\stackrel{\infty}{\sim}$ & & & & & & $\underset{\sim}{\stackrel{9}{\sim}}$ & $\underset{\sim}{\stackrel{N}{N}}$ & & & & & \begin{tabular}{|l|l|} 
& \\
$\infty$ & $\vdots$ \\
0 & 0
\end{tabular} & $\stackrel{m}{\sigma}$ & & $\underset{m}{q}$ & BRA Amazonas \\
\hline م્ન & & & & $\stackrel{\text { s. }}{\text { s. }}$ & & \begin{tabular}{l}
$\infty$ \\
\multirow{2}{0}{} \\
0
\end{tabular} & & & \begin{tabular}{l}
$\infty$ \\
\multirow{\sigma}{o}{} \\
-
\end{tabular} & & $\begin{array}{l}\infty \\
0 \\
0 \\
0\end{array}$ & & & & & & 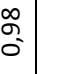 & & & BRA CE \\
\hline 今 & & & & 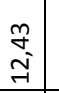 & & & & & & & & & & & & & & & & $\begin{array}{c}\text { BRA Mato Groso } \\
\text { sul }\end{array}$ \\
\hline$\exists$ & & & & i & & & & & & & $\underset{i}{8}$ & & & & & & & & & $\begin{array}{c}\text { BRA Mato Groso y } \\
\text { Rondonia }\end{array}$ \\
\hline
\end{tabular}




\begin{tabular}{|c|c|c|c|c|c|c|c|c|c|c|c|c|c|c|c|c|c|c|c|c|c|}
\hline 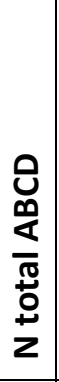 & 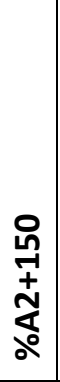 & 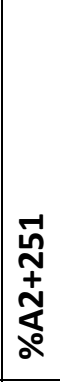 & 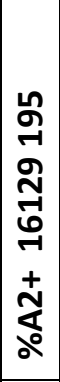 & 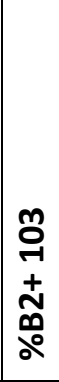 & 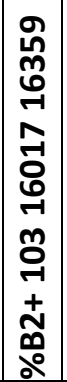 & 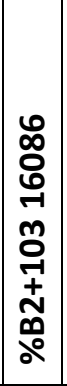 & 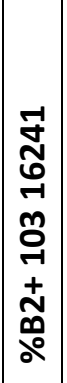 & 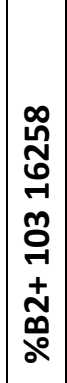 & 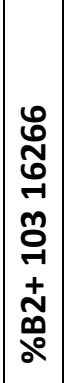 & 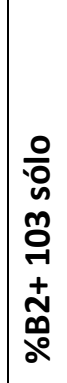 & 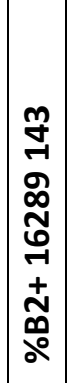 & 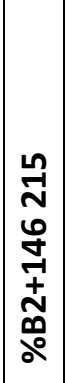 & 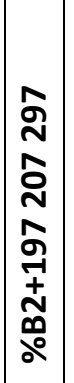 & 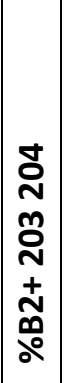 & 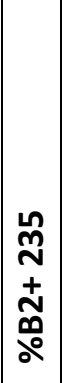 & $\mid \begin{array}{l}\hat{n} \\
\mathbf{N} \\
\mathbf{N} \\
\tilde{0} \\
\text { of }\end{array}$ & 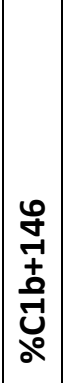 & 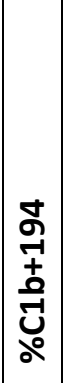 & 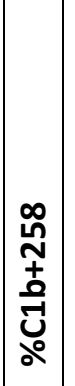 & 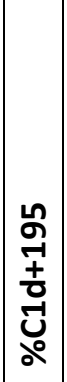 & $\begin{array}{c}\text { Punto } \\
\text { geográfico }\end{array}$ \\
\hline $\overrightarrow{6}$ & $\begin{array}{l}\Delta \\
\stackrel{i}{0}\end{array}$ & & & & & & & & & & & \begin{tabular}{|l|} 
\\
$\hat{j}$ \\
$\tilde{m}$ \\
\end{tabular} & & & & & 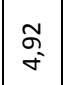 & & & & ARG Belén \\
\hline$\underset{\exists}{\vec{G}}$ & $\begin{array}{l}\mathfrak{m}_{0}^{\infty} \\
\omega^{-}\end{array}$ & & & $\stackrel{m}{\stackrel{m}{i}}$ & & & $\underset{i}{\mathcal{F}}$ & & & $\mid \begin{array}{l}\Omega \\
\tilde{0} \\
0\end{array}$ & & $\mid \begin{array}{l}\mathfrak{\Omega} \\
\hat{0}\end{array}$ & & & & & $\stackrel{m}{\stackrel{m}{i}}$ & & $\stackrel{\substack{\infty \\
\sim}}{ }$ & 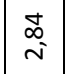 & ARG Buenos Aires \\
\hline$\tilde{6}$ & $\begin{array}{l}\tilde{\tilde{\sigma}} \\
\dot{\sigma}\end{array}$ & & & & & & & & & & & & & & & & 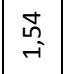 & & $\underset{\sigma}{\stackrel{J}{\sigma}}$ & 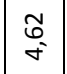 & ARG Calingasta \\
\hline$\grave{\sim}$ & $\begin{array}{c}\Delta \\
m^{-}\end{array}$ & & & $\frac{d}{\stackrel{d}{m}}$ & & & & & & $\mid \begin{array}{l}\Delta \\
\hat{n}\end{array}$ & & $\mid$\begin{tabular}{c}
\multirow{2}{*}{} \\
$\dot{m}$
\end{tabular} & & & & & 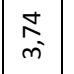 & & $\underset{\dot{m}}{\stackrel{t}{*}}$ & 亲 & ARG Catamarca \\
\hline$\vec{\infty}$ & & & & & & & & & & & & & $\begin{array}{l}\tilde{N} \\
\tilde{N}\end{array}$ & & & & f & & & & ARG Chaco \\
\hline$F$ & $\begin{array}{l}0 \\
\tilde{o}^{-}\end{array}$ & & $\mid \begin{array}{c}0 \\
\infty \\
\sigma^{\prime}\end{array}$ & & & & & & & & & & & & & & $\begin{array}{l}0 \\
\stackrel{n}{7} \\
\overrightarrow{7}\end{array}$ & $\stackrel{\stackrel{\sim}{\sim}}{\stackrel{\sim}{\sim}}$ & $\underset{\sim}{N}$ & & ARG Chepes \\
\hline$\approx$ & $\underset{m}{\stackrel{8}{m}}$ & & $\begin{array}{l}8 \\
0 \\
i\end{array}$ & & & & & & & & & & $\underset{\sim}{\stackrel{m}{-}}$ & & & & $\stackrel{g}{\stackrel{2}{n}}$ & $\begin{array}{l}0 \\
0 \\
i\end{array}$ & 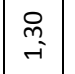 & 衤 & ARG Córdoba \\
\hline $\begin{array}{l}\infty \\
\stackrel{\sim}{-}\end{array}$ & $\begin{array}{l}: \\
: \\
0\end{array}$ & & & $\begin{array}{l}\infty \\
\infty \\
i \\
i\end{array}$ & & & 文 & & & & & & & & & & $0_{0}^{\circ}$ & & & $\underset{\sim}{\stackrel{9}{\rightarrow}}$ & ARG Corrientes \\
\hline 号 & & & & $\hat{b}_{0}^{\circ}$ & & & & 它 & & & & & \begin{tabular}{|l} 
O \\
d
\end{tabular} & & & & 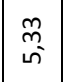 & $\stackrel{m}{\rightarrow}$ & & $\begin{array}{l}\stackrel{8}{0} \\
\therefore\end{array}$ & ARG Formosa \\
\hline$\stackrel{n}{\rightarrow}$ & 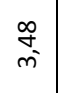 & & & $\begin{array}{l}\mathscr{2} \\
\text { o. } \\
\end{array}$ & & & 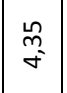 & & & $\begin{array}{l}\underset{i}{0} \\
\stackrel{\sim}{i}\end{array}$ & & & $\mid \begin{array}{l}\hat{\infty} \\
0 \\
0\end{array}$ & & & & $\stackrel{0}{0}$ & & & $\underset{t}{\stackrel{4}{4}}$ & $\begin{array}{c}\text { ARG } \\
\text { Gualeguaychú }\end{array}$ \\
\hline ถึ่ & & & & $\begin{array}{l}0 \\
0 \\
-1\end{array}$ & & & & & & O̊ & $\underset{-}{0}$ & $\mid \begin{array}{l} \pm \\
0 \\
0 \\
\sim\end{array}$ & & $\begin{array}{l}0 \\
0 \\
-1\end{array}$ & & & & & & & ARG Jujuy Oeste \\
\hline$\stackrel{+}{m}$ & & & & ఫ & & & & $\underset{\substack{a \\
d}}{a}$ & & & & $\underset{\substack{S \\
\sim}}{\mathrm{N}}$ & & & & & $\begin{array}{l}\infty \\
\infty \\
\infty \\
\text { in }\end{array}$ & & & $\begin{array}{l}\infty \\
\infty \\
i n \\
i n\end{array}$ & $\begin{array}{c}\text { ARG Jujuy San } \\
\text { Salvador }\end{array}$ \\
\hline i̊ & & & & $\underset{i}{\stackrel{9}{i}}$ & & & $\begin{array}{l}\stackrel{g}{i} \\
\rightarrow\end{array}$ & & & & & & & & & & $\stackrel{\hat{n}}{n}$ & 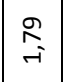 & & & ARG La Paz \\
\hline$\stackrel{0}{\rightarrow}$ & $\begin{array}{l}\stackrel{\leftrightarrow}{\leftrightarrow} \\
\text { c. }\end{array}$ & $\mid \begin{array}{c}n \\
i \\
i\end{array}$ & & $\stackrel{\infty}{\stackrel{\infty}{\sim}}$ & 吕 & & & 亦 & & & 员 & \begin{tabular}{|c|c}
$\infty$ \\
$\infty$ \\
$\infty$
\end{tabular} & & $\begin{array}{l}\text { 员 } \\
\text { o. }\end{array}$ & 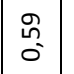 & 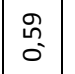 & 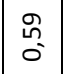 & & & 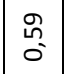 & ARG La Quiaca \\
\hline$\stackrel{\infty}{\wedge}$ & $\begin{array}{l}\stackrel{0}{\leftrightarrow} \\
\stackrel{i}{n}\end{array}$ & & $\underset{\sim}{\stackrel{\infty}{\sim}}$ & & & & & & & & & & & & & & $\begin{array}{l}\hat{a} \\
\infty \\
\infty\end{array}$ & 足 & $\stackrel{\infty}{\sim} \underset{\sim}{-\infty}$ & $\mid \begin{array}{l}0 \\
\infty \\
\infty\end{array}$ & ARG La Rioja \\
\hline
\end{tabular}




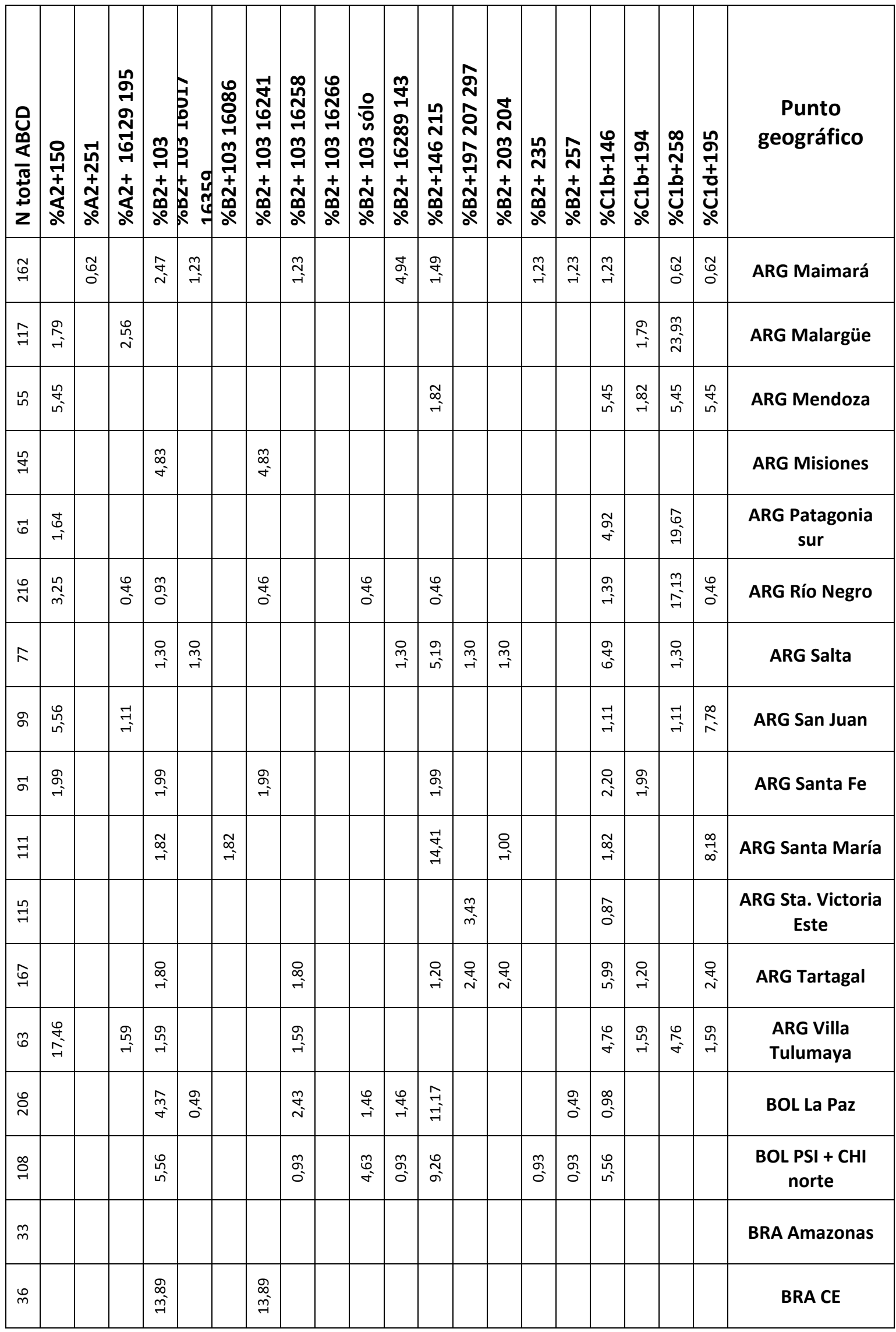




\begin{tabular}{|c|c|c|c|c|c|c|c|c|c|c|c|c|c|c|c|c|c|c|c|c|c|}
\hline 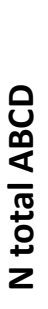 & 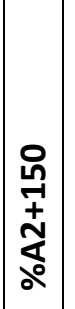 & 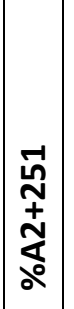 & 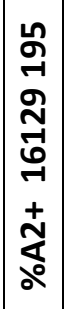 & 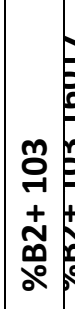 & 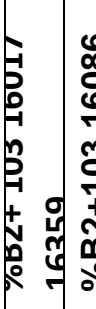 & 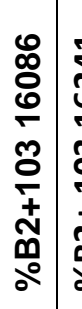 & 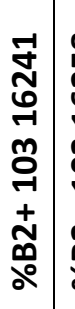 & 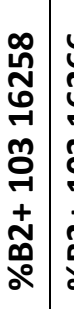 & 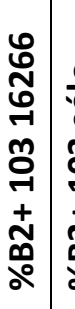 & 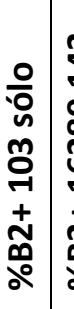 & 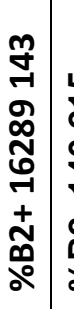 & 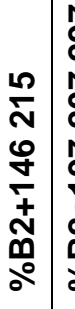 & 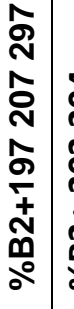 & 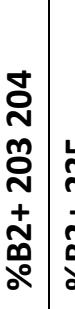 & 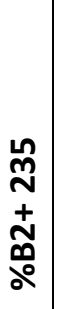 & 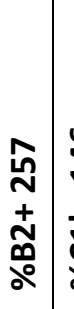 & 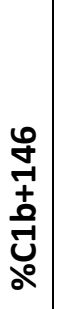 & 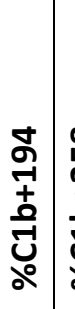 & $\begin{array}{c}\text { 足 } \\
\text { N } \\
\pm \\
\text { - } \\
\text { d }\end{array}$ & 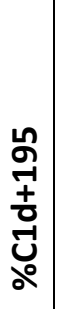 & $\begin{array}{c}\text { Punto } \\
\text { geográfico }\end{array}$ \\
\hline ล & & & & $\stackrel{\stackrel{n}{q}}{m}$ & & & $\stackrel{\text { fq }}{\text { r }}$ & & & & & & & & & & & & & & $\begin{array}{c}\text { BRA Mato Groso } \\
\text { y Rondonia }\end{array}$ \\
\hline 出 & & & & & & & & & & & & & & & & & & & & & BRA NE \\
\hline 9 & & & & & & & & & & & & & & & & & & & & & BRA Pará \\
\hline f & & & & $\underset{\sim}{\mathscr{f}}$ & & & $\underset{\sim}{\stackrel{\sim}{\sim}}$ & & & & & & & & & & & & & & BRA sur \\
\hline$\stackrel{\infty}{\curvearrowright}$ & & & & & & & & & & & & & & & & & & & $\begin{array}{l}\stackrel{\sim}{\sim} \\
\stackrel{\infty}{N}\end{array}$ & & $\mathrm{CHI}$ centro \\
\hline t & & & & & & & & & & & & & & & & & 译 & & & & COL Amazonía \\
\hline 焉 & & & & & & & & & & & & & & & & & & & & & COL Andes sur \\
\hline$\stackrel{m}{m}$ & & & $\frac{2}{n}$ & & & & & & & & & & & & & & & $\stackrel{\infty}{\sim}$ & & & $\begin{array}{l}\text { COL Centro } \\
\text { (Bogota) }\end{array}$ \\
\hline$\stackrel{m}{\sim}$ & & & $\begin{array}{l}-1 \\
0 \\
0\end{array}$ & & & & & & & & & & & & & & & & & & $\begin{array}{l}\text { COL norte } \\
\text { (Caribe) }\end{array}$ \\
\hline$\stackrel{M}{\rightarrow}$ & & & & & & & & & & & & & & & & & & & & & COL Pacífico \\
\hline ఫి & & & & 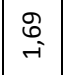 & & & & & $\stackrel{8}{\stackrel{8}{-}}$ & & & & & & & & & ্ָ & & & Ecuador \\
\hline กี & & & & & & & & & & & & & & & & & & & & & Guyana F \\
\hline $\mathscr{f}$ & & & & & & & & & & & & & & & & & & & & & PAR este \\
\hline$\tilde{m}$ & & & & & & & & & & & & & & & & & $\stackrel{m}{m}$ & & & & Perú \\
\hline gे & & & & & & & & & & & & & & & & & $\stackrel{\mathscr{n}}{\sim}$ & $\stackrel{m}{\text { nิ }}$ & & 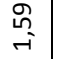 & Uruguay \\
\hline$\stackrel{m}{\rightarrow}$ & & & & & & & & & & & & & & & & & $\begin{array}{l}n \\
\stackrel{n}{0}\end{array}$ & & & $\stackrel{n}{\stackrel{n}{o}}$ & $\begin{array}{l}\text { Venezuela } \\
\text { Caracas }\end{array}$ \\
\hline $\overrightarrow{6}$ & & & & & & & & & & & & & & & & & & & & & $\begin{array}{c}\text { Venezuela Pto } \\
\text { Ayacucho }\end{array}$ \\
\hline
\end{tabular}


7.2.6.3 Linajes definidos por mutaciones en la Región Control (por fuera de las RHV I y II)

\begin{tabular}{|c|c|c|c|c|c|}
\hline 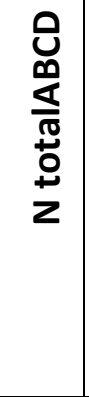 & 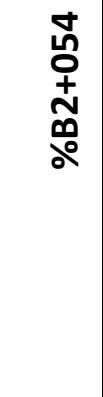 & 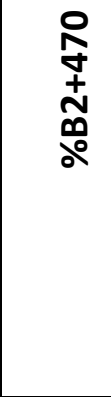 & 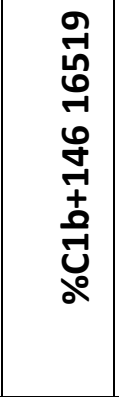 & $\begin{array}{l}\hat{N} \\
\text { } \\
0 \\
+1 \\
+ \\
0 \\
0 \\
0\end{array}$ & Punto geográfico \\
\hline 61 & & & 3,28 & & ARG Belén \\
\hline 89 & & & 1,12 & 2,25 & ARG Buenos Aires \\
\hline 65 & & 1,77 & & & ARG Calingasta \\
\hline 27 & & & & & ARG Catamarca \\
\hline 79 & & & 1,27 & & ARG Chaco \\
\hline 44 & & & 10,00 & & ARG Chepes \\
\hline 14 & & & 7,14 & & ARG Córdoba \\
\hline 163 & & & 0,61 & & ARG Corrientes \\
\hline 149 & & & 5,37 & & ARG Formosa \\
\hline 115 & & & 0,87 & & ARG Gualeguaychú \\
\hline 59 & & & & 1,69 & ARG Jujuy Oeste \\
\hline 34 & & & 5,88 & & ARG Jujuy San Salvador \\
\hline 56 & & & 1,79 & & ARG La Paz \\
\hline 169 & 0,59 & & & 3,55 & ARG La Quiaca \\
\hline 78 & & & 6,41 & & ARG La Rioja \\
\hline 162 & 0,62 & & 1,23 & 1,85 & ARG Maimará \\
\hline 117 & & 13,68 & & 1,79 & ARG Malargüe \\
\hline 55 & & 1,82 & 5,45 & & ARG Mendoza \\
\hline 22 & & & & & ARG Misiones \\
\hline 44 & & 25,00 & 6,82 & & ARG Patagonia sur \\
\hline 177 & & 2,94 & 0,56 & & ARG Río Negro \\
\hline 59 & & & 5,85 & 1,69 & ARG Salta \\
\hline 99 & & 4,44 & 7,78 & 1,11 & ARG San Juan \\
\hline 83 & & & 2,50 & & ARG Santa Fe \\
\hline 111 & & & 1,82 & 2,73 & ARG Santa María \\
\hline 115 & & & 0,87 & & ARG Sta. Victoria Este \\
\hline 167 & & 0,60 & 5,99 & 1,20 & ARG Tartagal \\
\hline 63 & & 1,59 & 1,59 & & ARG Villa Tulumaya \\
\hline 97 & 1,39 & S/D & & 3,93 & BOL La Paz \\
\hline 108 & & S/D & 5,56 & 1,85 & BOL PSI + CHI norte \\
\hline 33 & & & & & BRA Amazonas \\
\hline
\end{tabular}




\begin{tabular}{|c|c|c|c|c|c|}
\hline 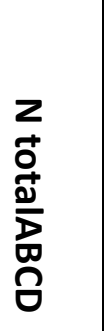 & $\begin{array}{l}\text { 怘 } \\
\text { 足 } \\
\text { 喜 }\end{array}$ & $\begin{array}{l}\text { ১̊ } \\
\text { 品 } \\
+ \\
+ \\
\text { ป }\end{array}$ & 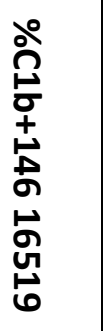 & 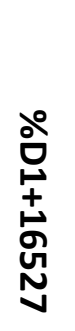 & Punto geográfico \\
\hline 36 & & & & & BRA CE \\
\hline 29 & & & & & BRA Mato Groso y Rondonia \\
\hline 19 & & & & & BRA Pará \\
\hline 47 & & & & & BRA Paraná y Sta Catalina \\
\hline 20 & & 1,00 & & & CHI centro \\
\hline 25 & & & & & COL Amazonía \\
\hline 114 & & & & & COL Andes sur \\
\hline 77 & & & & & COL norte (Caribe) \\
\hline 76 & & & & & COL Pacífico \\
\hline 139 & & & & & Ecuador \\
\hline 46 & & & & & PAR este \\
\hline 32 & & & & & Perú Centro \\
\hline 67 & & & 1,49 & & Venezuela Caracas \\
\hline
\end{tabular}




\subsection{Lista DE ABREVIATURAS}

ABR: Dos de Abril

ADN: Acido Desoxirribonucleico

ADNmt: ADN Mitocondrial

ADO: Adolfo Alsina

APLP: Polimorfismos de longitud de los productos de amplificación

AG: Aguaray

AGU: Aguirre

ALB (en SDE): Alberdi

ALB (en SNJ): Albardón

ALM: Almirante Brown

ALU: Aluminé

AMB: Ambato

ANC: Ancasti

AND: Andalgalá

ANG Angaco

ANT (en CAT): Antofagasta de la Sierra

ANT (en JUJ): San Antonio

ANT (en Salta): Anta

AÑE: Añelo

AP: Antes del Presente

APO: Apóstoles

ARA: Arauco

ARG: Argentina

ATA: Atamisqui

ATR: Atreucó

AVE: Avellaneda

AVP: Angel Vera Peñaloza

AYA: Ayacucho

BAN: Banda

BAR: Bariloche

BEL (en CAT): Belén

BEL (en JUJ): Dr Manuel Belgrano

BEL (en SDE, SFE y SLS): Belgrano

BER: Bermejo

BOL: Bolivia

BRA: Brasil

Bs As: Buenos Aires

BUR: Burruyacú

BVI: Bella Vista

CAB (en CHA): Sargento Cabral

CAB (en LRJ): Castro Barros

CAC: Cachi

CAF: Cafayate

CAI (en MIS): Cainguás

CAI (en SCZ): Corpen Aike

CAL (en CBA): Calamuchita

CAL (en LPM): Caleu Caleu

CAL (en SJN): Calingasta

CAN: Candelaria
CAP: Capital

CAR: El Carmen

CAT (en LPM): Catriló

CAT (en NQN): Catán Lil

CAT: Catamarca

CAU: Caucete

CBA: Córdoba

CCU: Collón Curá

CDE: Cruz del Eje

CE: Centro este

CER: Cerrillos

CFE: Comandante Fernández

CHA (en LRJ): Chamical

CHA (en SLS y en CHA): Chacabuco

CHA: Chaco

CHE: Chepes

CHI (en LPM): Chical Co

CHI (en LRJ): Chilecito

CHI (en SAL): Chicoana

CHI (en SCZ): Río Chico

CHI (en SNJ): Chimbas

CHI (en TUC): Chicligasta

CHI: Chile

CHL: Chalileo

CHO (en NQN): Chos Malal

CHO (en SDE): Choya

CHP: Chapaleufú

CHU: Chubut

COA: Centro oeste argentino

COC: Cochinoca

COL: Colombia

COL: Colón

CON (en CRR y MIS): Concepción

CON (en ERI): Concordia

CON (en LPM): Conhelo

CON (en NQN): Confluencia

CON (en RNE): Conesa

CON (en SFE): Constitución

COP: Copo

COS: San Cosme

CPY: Capayán

CRR: Corrientes

CRU: Cruz Alta

CSR: Caseros

CST: Castellanos

CUA (en CBA): Río Cuarto

CUA (en CRR): Curuzú Cuatiá

CUR: Curacó

CUY: El Cuy

DES: Deseado

DIA: Diamante

DUP: Gobernador Dupuy

EA: Ejército Argentino 
ECU: Ecuador

ELA: El Alto

ELD; Eldorado

EMP: Empedrado

ERI: Entre Ríos

ESP: España

ESQ: Esquina

FAM (en LRJ): Famatina

FAM (en TUC): Famaillá

FDL: Federal

FEL: San José de Feliciano

FIG: Figueroa

FMA: Fray Mamerto Esquiú

FON: Mayor Luis Jorge Fontana

FOR: Formosa

FRN: Federación

FVA: General FelipeVarela

GAI: Güer Aike

GAL: General Alvear

GAR: Garay

GBE: General Belgrano

GDO: General Donovan

GGU: Gualeguaychú

GLO: General López

GLY: Gualeguay

GMB: General Manuel Belgrano

GOB: General Obligado

GOD: Godoy Cruz

GOY: Goya

GPA: General Paz

GPE: General Pedernera

GRA: Graneros

GRO: General Roca

GRO: General Roca

GSM: General San Martín

GTA: General Taboada

GUA (en LPM): Guatraché

GUA (en MIS): Guaraní

GUA (en MZA): Guaymallén

GUA (en SAL): Guachipas

GUA (en SDE): Guasayán

GÜE: General Güemes

HIG: O'Higgins

HUC: Hucal

HUI: Huiliches

HUM: Humahuaca

IBA: Juan Felipe Ibarra

IBY: Islas del Ibicuy

IGL: Iglesia

IGU: Iguazú

IND: Independencia

IRI: Iriondo

IRU: Iruya

ISC: Ischilín
ITA: Itatí

IZO: Ituzaingó

JAC: Jáchal

JAV: San Javier

JBA: Juan Bautista Alberdi

JCE: Juárez Celman

JER: San Jerónimo

JFQ: General J.F. Quiroga

JIM: Jiménez

JUJ: Jujuy

JUL: Nueve de Julio

JUN: Junín

JUS: San Justo

LAC: La Cocha

LAC: Lácar

LAF: La Frontera

LAI: Laishi

LAM: Lambayeque

LAM: General Lamadrid

LAN: Los Andes

LAR: Lago Argentino

LAV: Lavalle

LBU: Lago Buenos Aires

LCA: La Caldera

LCO: Las Colonias

LEA (en MIS): Leandro N. Alem

LEA (en TUC): Leales

LED: Ledesma

LHE: Las Heras

LIB: Libertad

LIH: Lihuel Calel

LIM: Limay

LLA: Los Lagos

LON: Loncopué

LOR: Loreto

LOV: Loventué

LPA: La Paz

LPM: La Pampa

LPO: La Poma

LPZ: La Paz

LQ: La Quiaca

LRJ: La Rioja

LUJ: Luján de Cuyo

LUL; Lules

LVI: La Viña

MAG: Magallanes

MAI: Maipú

MAL: Malargüe

MAR: Maracó

MAT: Matacos

MAY: Veinticinco de Mayo

MBU: Mburucuyá

MCA: Monte Caseros

MER: Mercedes 
MIG: San Miguel

MIN: Minas

MIS: Misiones

MIT: Mitre

MJU: Marcos Juárez

MM: Maimará

MOL: Molinos

MON (en MIS): Montecarlo

MON (en TUC): Monteros

MZA: Mendoza

NDJ: Nueve de Julio

NOA: Noroeste argentino

NOG Nogoyá

NQN: Neuquén

ÑOR: Ñorquín

ÑOR: Norquincó

OBE: Oberá

OCA: General Ocampo

OCT: Doce de Octubre

OJO: Ojo de Agua

ORA: Orán

ORO Fray Justo Santa María de Oro

PAC: Paclín

PAL (en CRR): San Luis del Palmar

PAL (en JUJ): Palpalá

PAR: Paraguay

PAR: Paraná

PAT: Patiño

PAZ: La Paz

PCM: Pilcomayo

PCR: Reacción en cadena de la polomerasa

PED: San Pedro

PEH: Pehuenches

PEL: Pellegrini

PEÑ: Pte. Roque Sáenz Peña

PIC: Picunches

PIL: Pilcaniyeu

PIR: Pirané

PLA: Presidencia de la Plaza

PLE: Picún Leufú

PLG: Pilagás

PMA: Pichi Mahuida

POC (en CBA): Pocho

POC (en SNJ): Pocitos

POM: Pomán

PRI (en CBA): Río Primero

PRI (en CHA): Primero de Mayo

PRI (en SLS): Coronel Pringles

PSI: Potosí

PUE: Puelén

PUN: Punilla

Pur: Purmamarca

QUE: Quebrachos

QUI: Quitilipi
RAM: Ramón Lista

RAN: Rancul

RAW: Rawson

RBN: Rivadavia Banda Norte

RBS: Rivadavia Banda Sur

RC: Región Control

RDL: Rosario de Lerma

REA: Realicó

RFLP: Polimorfismos de longitud de los fragmentos de restricción

RIN: Rinconada

RIO (en SCZ): Río Chico

RIO (en SDE): Río Hondo

RIV: Rivadavia

RNE: Río Negro

ROB: Robles

ROS: Rosario

RVP: Rosario Vera Peñaloza

SAL (en CBA): San Alberto

SAL (en CRR): Saladas

SAL (en SDE): Salavina

SAL: Salta

SAN en (ERI): San Salvador

SAN en RNE): San Antonio

SAR: Sarmiento

SAU: Sauce

SBA: Santa Bárbara

SBS: San Blas de los Sauces

SCA (en JUJ): Santa Catalina

SCA (en MZA y SAL): San Carlos

SCR: San Cristóbal

SCZ: Santa Cruz

SDE: Santiago del Estero

SEC: Río Seco

SFE (en CHA): San Fernando

SFE: Santa Fe

SIG: San Ignacio

SIL: Silípica

SIM: Simoca

SJA: San Javier

SJN: San Juan

SJU: San Justo

SLO: San Lorenzo

SLS: San Luis

SLU: Santa Lucía

SMA (en CAT y CBA): Santa María

SMA (en CRR, SDE, SJN, MZA y SFE): San Martín

SOB: Sobremonte

SPE: San Pedro

SRA: San Rafael

SRO (en CAT y MZA): Santa Rosa

SRO (en CRR): San Roque

STO: Santo Tomé 
SUS: Susques

SVI: Santa Victoria

TAL: Tala

TAP: Tapenagá

TAR: Tarija

TER: Tercero Arriba

TIL: Tilcara

TIN: Tinogasta

TOA: Toay

TOT: Totoral

TRA: Trancas

TRE: Trenel

TTG: Tartagal

TUC: Tucumán

TUL: Tulumba

Tum: Tumbaya

TUM: Tumbaya

TUP: Tupungato

TVA: Tafí del Valle

TVI: Tafí Viejo

UACM: Último Ancestro Conocido por vía Materna

UACP: Último ancestro Conocido por vía Paterna

ULL: Ullum

UNI: Unión

URU: Uruguay

UTR: Utracán

VAL: Valcheta

VAV: Valle Viejo

VDM: 25 de Mayo

VEN: Venezuela

VER (en CHA): Bermejo

VER (en CRR): Berón de Astrada

VER (en SFE): Vera

VGR: Valle Grande

VIC: Victoria

VIN: Vinchina

VTU: Villa Tulumaya

YAV: Yavi

ZAP: Zapala

ZON: Zonda 